\title{
Nghiên cứu hiện trạng giao thông xe máy Việt Nam
}

\author{
Nguyễn Hữu Đức \\ Takagi Michimasa \\ Bùi Huynh Long \\ Nguyễn Thị Lệ Hằng \\ Nguyễn Bích Ngọc \\ Lưu Thị Thủy \\ Nguyễn Thùy Dung \\ Trần Minh Tú
}

April 1, 2019

JAPAN-ASEAN INTEGRATION FUND 


\section{Bộ GIAO THÔNG VậN TẢI}

CHỦ DƯ ÁN: VỤ AN TOÀN GIAO THÔNG

QUẢN LÝ DỰ ÁN: BAN QUẢN LÝ DỤ ÁN 2

Dự ÁN:

XÂY DỰNG CHIẾN LƯợC AN TOÀN GIAO THÔNG ĐỐI VỚI XE MÁY VÀ KẾ HOẠCH HÀNH ĐộNG: MộT KHỞI ĐÂU CỦA VIẸTT NAM

Code: TRN/FAC/12/006/REG

\section{BÁO CÁO CUỐI KỲ - TẬP 1 Nghiên cứu hiện trạng giao thông xe máy Việt Nam}

Hà Nội - 2019 



\section{Bộ GIAO THÔNG VậN TẢI}

CHỦ DƯ ÁN: VỤ AN TOÀN GIAO THÔNG

QUẢN LÝ DỰ ÁN: BAN QUẢN LÝ DỤ ÁN 2

Dư Án:

XÂY DỰNG CHIẾN LƯợC AN TOÀN GIAO THÔNG ĐỐI VỚI XE MÁY VÀ KẾ HOẠCH HÀNH ĐộNG: MộT KHỞI ĐẦU CỦA VIỆT NAM

Code: TRN/FAC/12/006/REG

\section{BÁO CÁO CUỐI KỲ - TậP 1 \\ Nghiên cứu hiện trạng giao thông xe máy Việt Nam}

Hà Nội - 2019 


\section{Soạn thảo: Đoàn tư vấn}

TS. Nguyễn Hữu Đức - Giám đốc dự án Ông Takagi Michimasa

Ông Bùi Huynh Long

Bà Nguyễn Thị Lệ Hằng

Bà Nguyễn Bích Ngọc

Bà Lưu Thị Thủy

Bà Nguyễn Thùy Dung

Với sự tham gia của TS. Trần Minh Tú trong Chương 4. 
Kính gửi: - Vụ An toàn giao thông

- Ban Quản lý dự án 2 (PMU2)

\section{THƯ ĐÊ TRÌNH BÁO CÁO CUỐI KỲ}

Dự án "Xây dựng Chiến lược an toàn giao thông đối với xe máy và Kế hoạch hành động: Một khởi đầu của Việt Nam"

Kính thưa ông / bà,

Tư vấn dự án hân hạnh gửi đến Quý cơ quan bàn Báo cáo cuối kỳ gồm 03 tập.

Đây là sản phẩm đầu ra của dự án, nhằm:

- Xây dựng Chiến lược phát triển an toàn giao thông xe máy trong hạn dài - đến năm 2025 và tầm nhìn 2030 ; và

- Chuẩn bị một Kế hoạch hành động 3 năm quản lý xe máy một cách hiệu quả cho Việt Nam.

Với sản phẩm này, nhóm tư vấn đã thực hiện đầy đủ nhiệm vụ nêu trong Quyết định của Bộ Giao thông vận tải số 2113/QĐ-BGTVT ngày 19/07/2017 phể duyệt Dự án và số 3270/QĐBGTVT ngày 27/11/2017 phê duyệt Điều khoản tham chiếu và Dự toán dự án, đồng thời đáp ứng tất cả các yêu cầu đặt ra trong Văn kiện dự án (ASEAN Cooperation Project Document bản đã thống nhất với nhà tài trợ).

Để có thể đạt được kết quả này sau 12 tháng thực hiện dự án, bên cạnh nỗ lực của toàn thể Đoàn tư vấn, chúng tôi không thể không nhắc tới một yếu tố quan trọng là sự quan tâm giúp đỡ và hợp tác hiệu quả của Vụ An toàn giao thông và Ban Quản lý dự án 2. Nhân dịp này, Tư vấn xin gửi lời chân thành cám ơn tới các cấp lãnh đạo và cán bộ nhân viên quý cơ quan.

Trân trọng!

Kính thư,

TS. NGUYẼ̃N HŨ்U ĐỨC

Giám đốc dụ án 



\section{LÒ̀I NÓI ĐẦU}

Dự án có nhiều nhiệm vụ, nhưng sản phẩm cuối cùng, quan trọng nhất là:

- Xây dựng Chiến lược phát triển an toàn giao thông xe máy trong hạn dài - đến năm 2025 và tầm nhìn 2030, (gọi tắt là Chiến lược); và

- Chuẩn bị Kế hoạch hành động 3 năm quản lý xe máy một cách hiệu quả cho Việt Nam giai đoạn 2019-2021 (gọi tắt là Kế hoạch).

Báo cáo cuối kỳ này tổng hợp những kết quả của dự án và bao gồm 03 tập.

Tập 1 có nội dung đánh giá, phân tích hiện trạng giao thông xe máy, rút ra các bài học kinh nghiệm, các quy luật để xây dựng Chiến lược và Kế hoạch và gồm 4 chương. Giao thông xe máy gắn liền với điều kiện kinh tế - xã hội. Vì vậy Chương 1 tổng hợp các điều kiện kinh tế xã hội này, đồng thời xem xét chung vấn đề xe máy ở Việt Nam. Chương 2 và Chương 3 có nhiều nội dung nghiên cứu đánh giá sâu. Nội dung đầu tiên là xem xét, đánh giá nguyên nhân vì sao có chủ trương, chính sách được thực hiện rất tốt, có hiệu quả nhưng vẫn có không ít trường hợp không được như vậy. Bài học rút ra từ đây sẽ giúp cho việc hoạch định các đầu ra khác của dự án mang tính thực tiễn cao. Tiếp theo, việc nghiên cứu hiện trạng giao thông xe máy theo hai cách: đánh giá trên cơ sở phân tích dữ liệu và tổng hợp một số kết luận từ các công trình khoa học đã công bố. Việc tìm và phân tích dữ liệu không chỉ đưa ra một bức tranh rõ ràng về hiện trạng, đặc biệt hơn, còn làm sáng tỏ một số quy luật trong giao thông xe máy. Cho đến nay, rất ít thông tin về những quy luật này vì chúng gần đây mới được phát hiện. Những quy luật khách quan này được tìm trên cơ sở phân tích các dữ liệu và có giá trị không nhỏ đối với việc hoạch định chủ trương, chính sách liên quan. Chương 4 dành cho nghiên cứu một cách tương đối đầy đủ kinh nghiệm quốc tế, nhất là đối với các nước ASEAN, đặc biệt, cung cấp thông tin gợi mở cho việc đề xuất các giải pháp bảo đảm trật tự, an toàn giao thông xe máy Việt Nam.

Tập 2 trình bầy Chiến lược phát triển an toàn giao thông xe máy trong hạn dài - đến năm 2025 và tầm nhìn 2030. Chiến lược này được xây dựng trên cơ sở thực trạng và dự báo giao thông xe máy theo cách tiếp cận 05 trụ cột của Liên Hợp Quốc, gồm 06 Chương trình với những giải pháp chọn lọc. Hai nội dung chủ yếu là tăng cường an toàn giao thông và kiềm chế mức tăng trưởng xe máy.

Tập 3 trình bầy Kế hoạch hành động 3 năm quản lý xe máy một cách hiệu quả cho Việt Nam. Kế hoạch này nhằm thực hiện Chiến lược trong giai đoạn đầu với các nhiệm vụ chính sau đây:

1. Giảm TNGT, ùn tắc giao thông liên quan đến xe máy,

2. Chuẩn bị kỹ các điều kiện cho một bước đột phá mới về an toàn giao thông,

3. Chuẩn bị kỹ các điều kiện để đưa công tác quản lý giao thông xe máy lên một bước phát triển mới.

Tư vấn dự án xin gửi đến quý vị bản Báo cáo này và rất hân hạnh nhận được sự quan tâm và ý kiến đóng góp của quý vị.

Hà Nội, ngày 01 tháng 04 năm 2019

TS. Nguyễn Hữu Đức

Giám đốc dự án 
MỤC LỤC

\section{VI TRÍ ĐỊA LÝ, KHÍ HẬU, DÂN SỐ, PHÁT TRIỂN KINH TẾ VÀ NHỬNG VẤN ĐỀ} XE MÁY Ở VIÊT NAM

1.1. Vị trí địa lý, khí hậu, dân số và phát triển kinh tế của Việt Nam.............................1-1

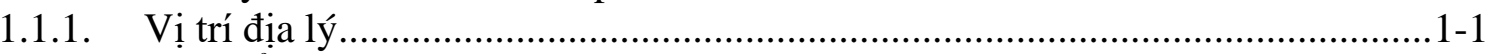

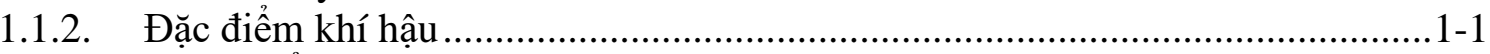

1.1.3. Nhân khẩu học Việt Nam ............................................................................1-3

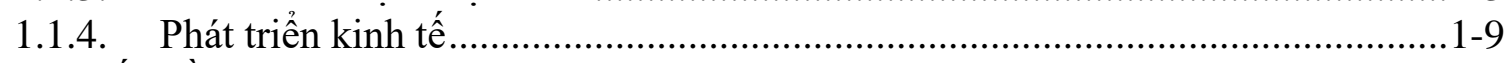

1.2. Vấn đề xe máy ở Việt Nam...........................................................................1-13

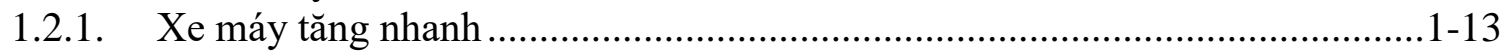

1.2.2. Những đặc điểm của xe máy ở Việt Nam......................................................1-18

1.2.3. Những điều kiện phù hợp để xe máy phát triển nhanh..................................1-23

1.2.4. Những tác động tiêu cực do phát triển xe máy quá mức ................................1-24

2. CHÍNH SÁCH, VĂN BẢN PHÁP LUẬT VỀ HẠN CHẾ TAI NẠN GIAO THÔNG XE

MÁY VÀ QUẢN LÝ XE MÁY...............................................................................2-27

2.1. Văn bản pháp luật về an toàn giao thông xe máy và quản lý xe máy ....................2-27

2.1.1. Văn bản pháp luật trật tự an toàn giao thông đường bộ trước khi ban hành Luật

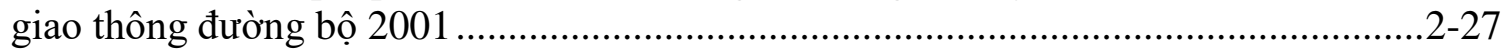

2.1.2. Luật Giao thông đường bộ 2001 …..............................................................2-30

2.1.3. Luật Giao thông đường bộ 2008 ….............................................................2-31

2.1.4. Nghị định của Chính phủ............................................................................2-2-33

2.1.5. Nghị quyết của Chính phủ về bảo đảm trật tự an toàn giao thông đường bộ..2-35

2.1.6. Văn bản quy định về đăng ký xe ....................................................................2-42

2.1.7. Văn bản kiểm tra chất lượng an toàn kỹ thuật và bảo vệ môi trường xe máy .2-42

2.1.8. Văn bản về đào tạo, sát hạch cấp giấy phép lái xe máy ..................................2-43

2.1.9. Văn bản về tuần tra, kiểm soát xử lý vi phạm ...............................................2-2-44

2.1.10. Văn bản về thống kê phân tích tai nạn giao thông đường bộ........................2-46

2.1.11. Văn bản về vận tải ................................................................................2-47

2.1.12. Văn bản về ứng phó sau tai nạn giao thông ..............................................2-2-48

2.2. Những thành công và chưa thành công của các chính sách về an toàn giao thông và quản lý đối với xe máy ..............................................................................................2-50

2.2.1. Quan điểm của Chính phủ về bảo đảm an toàn giao thông .............................2-51

2.2.2. Những thành công và chưa thành công của các chính sách về an toàn giao thông

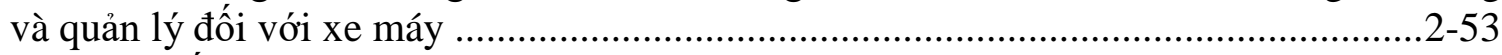

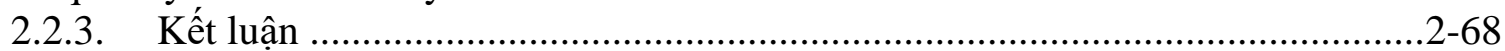

2.3. Chính sách phát triển vận tải hành khách công cộng đô thị ..................................2-68

2.4. Thực hiện Quy định bắt buộc đội mũ bảo hiểm khi đi xe máy ở Việt Nam ...........2-91

2.5. Công tác tuyên truyền, phổ biến, giáo dục pháp luật trật tự an toàn giao thông ..2-104

3. GIAO THÔNG XE MÁY: PHÂN TÍCH DỬ LIẸU VÀ TỔNG HỢP KÊTT QUẢ NGHIÊN CÚU KHOA HỌC

3.1 Dữ liệu xe máy trong sở hữu và lưu thông $\left(\mathrm{M}_{\mathrm{cir}}\right)$.................................................3-118

3.1.1 Số lượng xe máy theo đăng ký $\left(\mathrm{M}_{\mathrm{reg}}\right)$.........................................................3-119

3.1.2 Hiệu chỉnh số liệu năm 2017 ...................................................................3-119

3.1.3 Xe máy điện............................................................................................. $3-120$

3.1.4 Giao thông xe máy qua dữ liệu về số lượng xe trong lưu thông $\mathrm{M}_{\text {cir ..............3-123 }}$

3.2 Nghiên cứu về tai nạn giao thông do xe máy........................................................3-134

3.2.1 Xe máy như một loại phương tiện gây TNGT: nhiều nhất, nhưng không phải nguy hiểm nhất 
3.2.2 Xe máy-phương tiện liên quan với TNGT

3-135

3.3 Hành vi vi phạm hành chính trên đường của người sử dụng xe máy..................... 3-139

3.3.1 Dữ liệu xử lý vi phạm giao thông xe máy................................................... 3-139

3.3.2 Vi phạm giao thông của người sử dụng xe máy cả giai đoạn 2012-2017 .... 3-143

3.4 Nghiên cứu dữ liệu Giấy phép lái xe (GPLX) ................................................. 3-145

3.4.1 Vi phạm liên quan đến GPLX của xe máy................................................... 3-145

3.4.2 Số lượng GPLX của người lái xe máy còn sống và tình hình thực hiện quy định về GPLX ........................................................................................ 3-146

3.4.3 Tổng số người lái xe gắn máy $\left(\mathrm{M}_{\text {user }}\right)$ và số người (trung bình) dùng chung một

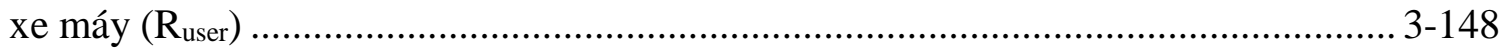

3.5 Nghiên cứu hành vi Văn hóa giao thông của người điều khiển xe máy............... 3-150

3.5.1 Điều tra bằng phương pháp bảng hỏi ..................................................... 3-150

3.5.2 Các ghi nhận trực tiếp trên đường qua phương pháp dùng camera ghi lại hình ảnh tại các nút giao thông .................................................................................... 3-162

3.5.3 Kết luận và kiến nghị ........................................................................... 3-167

3.6 Quản lý xe máy: nhìn theo quan điểm Lý thuyết Hệ thống ................................ 3-168

3.6.1 Việc quản lý xe máy: nhiều chính sách, giải pháp không thành công ............3-168

3.6.2 Nghiên cứu so sánh khuôn khổ thể chế quản lý xe máy và khuôn khổ thể chế quản

lý quản lý ô tô hiện nay ..................................................................................... 3-170

3.6.3 Kinh nghiệm từ các quốc gia khác: Các công cụ thể chế hình thành một hệ thống

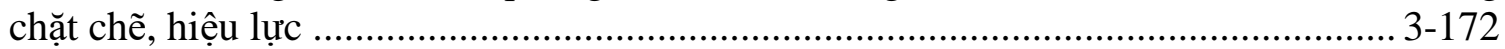

3.6.4 Tăng cường, bổ sung các công cụ thể chế quản lý xe máy ở Việt Nam ....... 3-172

3.7 Quy luật về tác động của các điều kiện kinh tế-xã hội đối với sự phát triển của xe máy 3-173

4. KINH NGHIỆM QUỐC TÊ VỀ ĐẢM BẢO AN TOÀN GIAO THÔNG XE MÁY 4-191

4.1 Tình hình tai nạn giao thông xe máy....

4.1.1 Tỷ lệ người đi xe máy chết ở Đông Nam Á

4.1.2 Tỷ lệ người đi xe máy chết ở Đông Á

4.2 Tổng quan về Kế hoạch An toàn Giao thông Dường bộ 4-192

4.2.1 Các hướng tiếp cận khác nhau trong chiến lược an toàn giao thông 4-192

4.2.2 Hướng tiếp cận hiện tại trong Kế hoạch an toàn giao thông của các nước ASEAN 4-197

4.3 Các chính sách cấm xe máy và hạn chế ô tô trên thế giới. 4-208

4.3.1 Các chính sách cấm và hạn chế xe máy của Trung Quốc ................................. 4-208

4.3.2 Chính sách hạn chế sở hữu phương tiện tại thành phố Bắc Kinh .................. 4-212

4.3.3 Chính sách cấm xe máy ở Yangon (Myanmar) ........................................... 4-215

4.4 Tổ chức giao thông cho xe máy và xe đạp điện ở Châu Á.................................... 4-216

4.4.1 Các biện pháp tổ chức giao thông liên quan tới xe máy .................................. 4-217

4.4.2 Các biện pháp tổ chức giao thông liên quan tới xe đạp điện ........................ 4-225

4.5 Kiểm tra độ tỉnh táo của người lái xe máy ....................................................... 4-228

4.5.1 Tổng quan về kiểm tra độ tỉnh táo ............................................................ 4-228

4.5.2 Bài học kinh nghiệm từ Hoa Kỳ ............................................................ 4-232

4.5.3 Thực tế kiểm tra độ tỉnh táo ở châu Á ….................................................... 4-238

4.6 Một số công cụ thể chế quản lý xe máy trên thế giới .......................................... 4-241

4.7 Bài học kinh nghiệm.............................................................................. 4-244 


\section{DANH MỤC BẢNG}

Bảng 1-1 Dân số, dân số phân theo giới tính, phân theo nông thôn và thành thị ................. 1-3

Bảng 1-2 Tỷ lệ tăng dân số 2005 - 2017 .......................................................................... 1-5

Bảng 1-3 Tuổi thọ trung bình 2005 -2017 ..................................................................... 1-6

Bảng 1-4 Cấu trúc tuổi - giới tính của dân số đã điều chỉnh, Việt Nam 2014 ........................ 1-7

Bảng 1-5 Thu nhập quốc dân GDP giai đoạn 1975-1982 ..................................................... 1-9

Bảng 1-6 Số lượng xe máy đăng ký 1990-2018 .............................................................. 1-14

Bảng 1-7 Số xe máy trên 100 dân 1995-2018.................................................................... 1-16

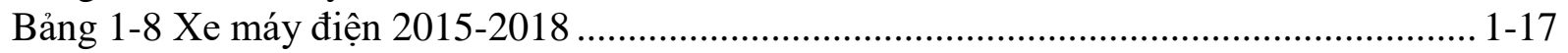

Bảng 1-9 Xe máy tính trên 1000 dân các địa phương....................................................... 1-19

Bảng 1-10 Xe máy tính trên 1.000 dân theo khu vực năm 2017 .......................................... 1-21

Bảng 2-1 Phương tiện cơ giới đường bộ 1990-1996.......................................................... 2-28

Bảng 2-2 Tai nạn giao thông 1990-1996 ....................................................................... 2-28

Bảng 2-3 Tai nạn giao thông đường bộ 1999-2002 ............................................................ 2-30

Bảng 2-4 Các Nghị định xử lý vi phạm hành chính được ban hành từ năm 1995 đến 2018 2-34

Bảng 2-5 Một số thay đổi mức phạt đối với hành vi vi phạm trong giao thông đường bộ (người

điều khiển xe máy) .................................................................................................. 2-34

Bảng 2-6 Số lượng ô tô và xe máy của Hà Nội 2005 - 2018 ............................................... 2-73

Bảng 2-7 Tổng hợp chỉ tiêu VTHKCC bằng xe buýt 2000-2017 ...................................... 2-74

Bảng 2-8 Tổng hợp trợ giá cho xe buýt của Hà Nội .......................................................... 2-75

Bảng 2-9 Dân số, sản lượng vận chuyển hành khách đường bộ và sản lượng vận chuyển hành khách bằng xe buýt của Hà Nội ...................................................................................... 2-78

Bảng 2-10 Số lượng phương tiện giao thông trên địa bàn TP. Hồ Chí Minh giai đoạn 2011 -

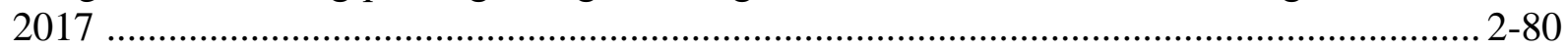

Bảng 2-11 Tổng hợp chỉ tiêu VTHKCC bằng xe buýt của thành phố Hồ Chí Minh giai đoạn

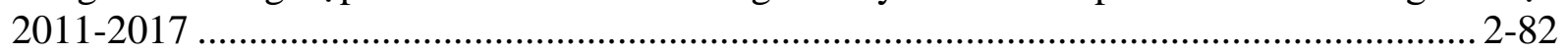

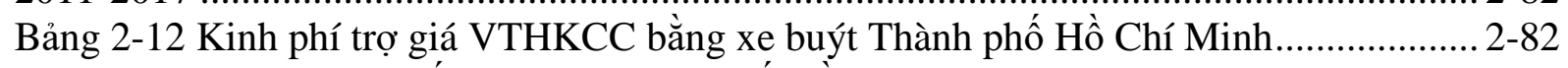

Bảng 2-13 Khảo sát chỉ số hài lòng Thành phố Hồ Chí Minh............................................. 2-84

Bảng 2-14 Tỷ lệ tăng dân số, VTHK bằng đường bộ, xe máy và sản lượng VTHKCC bằng xe

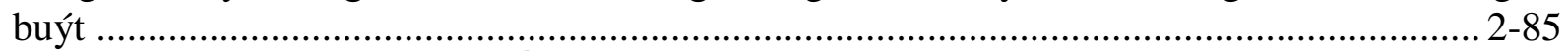

Bảng 2-15 Quy hoạch đường sắt đô thị Hà Nội ................................................................ 2-87

Bảng 2-16 Quy hoạch xe buýt nhanh (BRT) Hà Nội......................................................... 2-88

Bảng 2-17 Quy hoạch đường sắt đô thị Thành phố Hồ Chí Minh ......................................... 2-88

Bảng 2-18 Quy hoạch tuyến Tramway, Monorail Thành phố Hồ Chí Minh........................ 2-89

Bảng 2-19 Quy hoạch xe buýt nhanh (BRT) Thành phố Hồ Chí Minh............................... 2-89

Bảng 2-20 Tai nạn giao thông đường bộ 1990 - 2000 ........................................................... 2-93

Bảng 2-21 Tai nạn giao thông đường bộ 1999-2007 ................................................................ 2-94

Bảng 3-1 So sánh hai số liệu tăng hàng năm khác nhau của xe máy..................................... 3-119

Bảng 3-2 So sánh độ tương quan của 3 giá trị $\mathrm{M}_{\mathrm{reg}}$ (2017) với các năm trước.................... 3-120

Bảng 3-3 Số liệu phương tiện giao thông đường bộ 2015-2018 ....................................... 3-121

Bảng 3-4 Dữ liệu TNGT đường bộ và số lượng xe cơ giới theo đăng ký ........................... 3-122

Bảng 3-5 Số lượng xe máy toàn quốc theo đăng ký $\left(\mathrm{M}_{\mathrm{reg}}\right)$ và trong lưu thông $\left(\mathrm{M}_{\mathrm{cir}}\right)$........... 3-123

Bảng 3-6 Số xe máy không còn lưu thông và tuổi thọ......................................................... 3-124

Bảng 3-7 Tốc độ tăng đều của xe máy và một số chỉ tiêu kinh tế-xã hội trong hạn dài ..... 3-125

Bảng 3-8 Dữ liệu xe máy trong lưu thông ở khu vực thành thị và nông thôn toàn quốc (2006-

2017)

Bảng 3-9 So sánh tốc độ tăng đều xe máy ở khu vực nông thôn và thành thị ..................... 3-127

Bảng 3-10 Phân bố xe máy trong lưu thông giai đoạn 2006-2017 theo năm nhóm thu nhập .. 3128 
Bảng 3-11 Phân bố xe máy trong lưu thông theo 06 vùng kinh tế-xã hội

Bảng 3-12 Phân bố xe máy ở 63 tình, thành phố năm 2017 xếp theo 6 vùng kinh tế-xã hội....3131

Bảng 3-13 Các tỉnh/thành phố xếp theo số lượng xe máy trong lưu thông $\mathrm{M}_{\text {cir }}$

Bảng 3-14 Các tỉnh/thành phố xếp theo số lượng xe máy trong lưu thông tính theo 100 dân

$\mathrm{M}_{\text {cir100. }}$

3-133

Bảng 3-15 So sánh khả năng gây TNGT giữa xe máy và ô tô

3-135

Bảng 3-16 Phân tích TNGT liên quan xe máy về loại phương tiện ...................................3-136

Bảng 3-17 Phân tích nguyên nhân TNGT liên quan đến xe máy .......................................3-136

Bảng 3-18 Phân tích tổng hợp các yếu tố liên quan tới TNGT xe máy .............................3-137

Bảng 3-19 Số liệu tuần tra, kiểm soát của CSGT ...............................................................3-140

Bảng 3-20 Phân tích số liệu vi phạm 2017 và 2018 ..........................................................3-141

Bảng 3-21 So sánh tỷ lệ một số lối vi phạm giữa ô tô và xe máy .......................................3-142

Bảng 3-22 Vi phạm đáng ra cần xử lý nhưng không có quy định đối với xe máy...............3-143

Bảng 3-23 Tốp 10 vi pham giao thông xử lý nhiều nhất...................................................3-143

Bảng 3-24 Tốp 10 địa phương xử lý số lượng vi phạm giao thông cao nhất .......................3-144

Bảng 3-25 Tốp 10 địa phương có tỷ lệ xử lý vi phạm giao thông /1000 dân cao nhất ........3-144

Bảng 3-26 Tốp 10 địa phương có tỷ lệ xử lý vi phạm không đội mũ bảo hiểm $(\mathrm{MBH})$ cao nhất

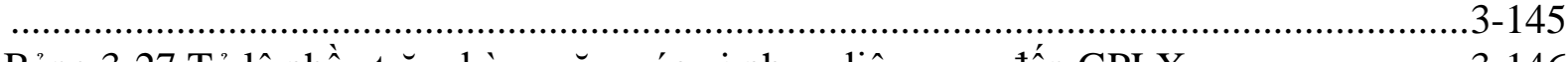

Bảng 3-27 Tỷ lệ phần trăm hàng năm các vi phạm liên quan đến GPLX ..........................3-146

Bảng 3-28 Số lượng GPLX của người dùng xe máy còn sống $\left(\mathrm{M}_{\mathrm{liv}}\right)$..................................

Bảng 3-29 Tổng số người lái xe gắn máy $\left(\mathrm{M}_{\text {user }}\right)$ và số người (trung bình) dùng chung một xe

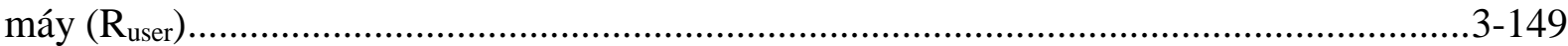

Bảng 3-30 Tổng số GPLX của người còn sống và số lượng xe máy đang lưu hành ..........3-149

Bảng 3-31 Số phiếu điều tra phân theo địa phương ......................................................... $3-151$

Bảng 3-32 Thông tin về người trả lời phỏng vấn văn hóa giao thông xe máy .....................3-153

Bảng 3-33 Số phương tiện trên 100 hộ gia đình...............................................................3-154

Bảng 3-34 Về một số thói quen không tốt.....................................................................3-160

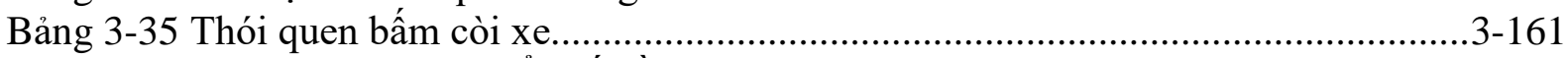

Bảng 3-36 So sánh quy định thể chế về quản lý xe ô tô và quản lý xe máy .........................3-170

Bảng 3-37 So sánh hiệu quả công tác quản lý xe ô tô và quản lý xe máy............................3-171

Bảng 3-38 P1-Dữ liệu TNGTĐB và số lượng xe cơ giới theo đăng ký (1990-2018) .........3-176

Bảng 3-39 P2-Tổng hợp số liệu xe máy và các chỉ số kinh tê-xã hội các năm 2003-2018 và dự

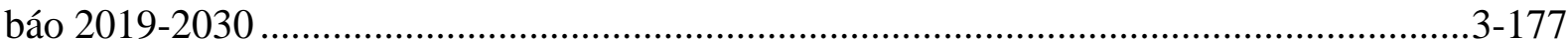

Bảng 3-40 P3-Xe máy điện từ 2015 và dự báo tổng số xe máy theo đăng ký đến năm 2030..3178

Bảng 3-41 P4-Tỷ lệ tăng đều hàng năm

Bảng 3-42 P5-Phân bố xe máy trong lưu thông giai đọ̣n 2006-2017 ................................3-180

Bảng 3-43 P6-Phân bố xe máy trong lưu thông giai đoạn 2006-2017 giữa năm nhóm thu nhập

3-181

Bảng 3-44 P7- Phân bố xe máy trong lưu thông giai đoạn 2006-2017

$3-182$

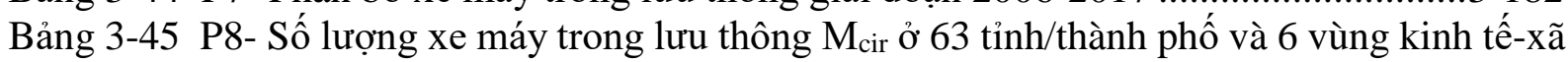
hội năm 2017

Bảng 3-46 P9-Các tỉnh/thành phố xếp theo số lượng xe máy trong lưu thông $\mathrm{M}_{\text {cir }}$ năm 20173 185

Bảng 3-47 P10-Các tỉnh/thành phố xếp theo số lượng xe máy trong lưu thông cho 100 người

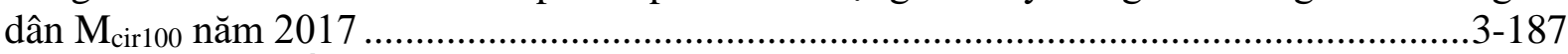

Bảng 3-48 P11-Số liệu phương tiện Hà Nội 2015-2018 .................................................3-189

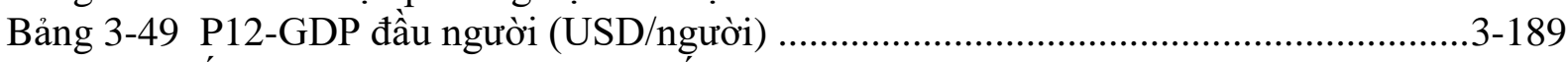

Bảng 4-1 Kế hoạch an toàn đường bộ quốc gia của các nước ASEAN .............................4-198 
Bảng 4-2 Kết quả cuối cùng và kết quả giữa kỳ của RSPM 2014-2020.

Bảng 4-3 Chương trình an toàn giao thông đường bộ theo các trụ cột của RSPM 2014 -20204200

Bảng 4-4 Các hoạt động/chương trình an toàn giao thông đường bộ thuộc 8 trụ cột của CNRSP 2020 4-202

Bảng 4-5 Chương trình và các bên liên quan của CNRSP 2020 4-204

Bảng 4-6 Các chương trình và các bên liên quan của INRSP 2011-2035 .......................... 4-206

Bảng 4-7 Cấm/hạn chế xe máy ở một số đô thị của Trung Quốc 4-209

Bảng 4-8 Quá trình thực hiện chính sách cấm xe máy ở Quảng Châu và Thượng Hải 4-210

Bảng 4-9 Tổng hợp các bài kiểm tra độ tỉnh táo tại hiện trường

Bảng 4-10 Tổng hợp dấu hiệu người đi xe máy bị suy nhược.

Bảng 4-11 Dấu hiệu điều tra đặc trưng đối với lái xe khi thẩm vấn

Bảng 4-12 Tổng hợp các kỹ thuật thẩm vấn

Bảng 4-13 Ngưỡng BAC cho phép tại Đông Nam Á và Đông Á

Bảng 4-14 Kiểm tra khí thở ngẫu nhiên và các điểm kiểm tra ở Đông Nam Á, Đông Á... 4-240

Bảng 4-15 Quy chế đối với xe máy dưới 50cc ở một số quốc gia

Bảng 4-16 Hệ thống phí lưu hành phương tiện.

Bảng 4-17 Phí lưu hành phương tiện ở Thái Lan và Nhật Bản 4-243 


\section{DANH MỤC HÌNH}

Hình 1-1 Phân vùng khí hậu Việt Nam............................................................................ 1-2

Hình 1-2 Biểu đồ dân số Việt Nam 2005 - 2017 ................................................................. 1-4

Hình 1-3 Biểu đồ dân số phân theo giới tính ................................................................... 1-4

Hình 1-4 Biểu đồ dân số phân theo thành thị và nông thôn.................................................... 1-5

Hình 1-5 Tỷ lệ tăng dân số 2005 - 2017 ........................................................................... 1-5

Hình 1-6 Cơ cấu dân số Việt Nam theo nhóm tuổi $(\%)$........................................................ 1-7

Hình 1-7 Tháp dân số Việt Nam năm 2014 ....................................................................... 1-8

Hình 1-8 Phương tiện cá nhân thời kỳ bao cấp phổ biến là xe đạp .................................. 1-10

Hình 1-9 GDP Việt Nam 2000 - 2017 .......................................................................... 1-11

Hình 1-10 Bình quân GDP trên đầu người năm và số xe máy tăng năm 2000 đến 2017 .... 1-12

Hình 1-11 Quan hệ tỷ lệ sở hữu xe máy với GDP/đầu người và với tỷ lệ đô thị hóa ........... 1-12

Hình 1-12 Số lượng xe máy 1990 - 2018 ........................................................................ 1-15

Hình 1-13 Số xe máy tăng hàng năm so với năm liền trước............................................. 1-15

Hình 1-14 Số xe máy bình quân trên 100 dân 1995 - 2018.............................................. 1-17

Hình 1-15 Số xe máy điện và gia tăng xe máy điện hàng năm từ 2015-2018 ......................... 1-17

Hình 1-16 Số lượng xe máy trong tồng số phương tiện cơ giới đường bộ các nước............... 1-18

Hình 1-17 Bình quân số lượng xe máy trên 100 dân các nước ASEAN, ............................. 1-18

Hình 1-18 Biểu đồ số xe máy trên 1.000 dân các địa phương ............................................ 1-21

Hình 1-19 Số xe máy tăng và số người bị chết vì tai nạn giao thông 1990 - 2007 .............. 1-25

Hình 1-20 Tỷ lệ vụ tai nạn giao thông xe máy trong tổng số vụ TNGT đường bộ ............... 1-25

Hình 2-1 Tác động của chính sách đển tai nạn giao thông .................................................. 2-55

Hình 2-2 Tác động của chính sách đến hạn chế gia tăng xe máy 1998-2018 ...................... 2-65

Hình 2-3 Biểu đồ gia tăng ô tô của Hà Nội 2005 - 2018 …............................................... 2-74

Hình 2-4 Biểu đồ gia tăng xe máy của Hà Nội 2005 - 2018 ............................................ 2-74

Hình 2-5 Tỷ lệ tăng trưởng dân số Hà Nội 2005 - 2016 (\%) ............................................... 2-78

Hình 2-6 Tỷ lệ tăng trưởng vận chuyển hành khách bằng đường bộ 2008 - $2015(\%)$........ 2-79

Hình 2-7 Tỷ lệ tăng trưởng sản lượng xe buýt Hà Nội 2009-2017 (\%) ................................ 2-79

Hình 2-8 Tỷ lệ tăng trưởng xe máy Hà Nội 2005 - 2018 ................................................... 2-79

Hình 2-9 Tăng trưởng phương tiện giao thông cơ giới đường bộ......................................... 2-80

Hình 2-10 Lý do không sử dụng xe buýt ở Thành phố Hồ Chí Minh.................................. 2-84

Hình 2-11 Tỷ lệ tăng dân số Thành phố Hồ Chí Minh $2005-2015$....................................... 2-85

Hình 2-12 Tỷ lệ tăng vận tải hành khách đường bộ Thành phố Hồ Chí Minh 2005 - 2015 2-86

Hình 2-13 Tỷ lệ tăng trưởng sản lượng xe buýt Thành phố Hồ Chí Minh 2005 - 2015 ...... 2-86

Hình 2-14 Tỷ lệ tăng trưởng xe máy Thành phố Hồ Chí Minh 2005 - 2017 ....................... 2-86

Hình 2-15 Tai nạn giao thông đường bộ năm 1990 - 2000 ................................................ 2-93

Hình 2-16 Tai nạn giao thông đường bộ năm 1999 -2007 .................................................... 2-94

Hình 2-17 Biển thông báo đoạn đường bắt buộc đội mũ bảo hiểmđối với người ngồi trên xe

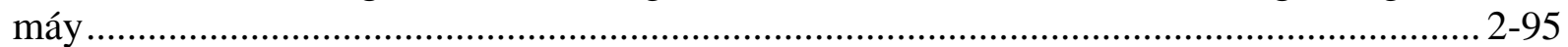

Hình 3-1 Tỷ lệ xe máy trong dòng giao thông hỗn hợp................................................. 3-122

Hình 3-2 Thay đổi về tỷ lệ xe máy lưu thông ở nông thôn và thành thị hàng năm (2006-2017)

Hình 3-3 Phân bố xe máy trong lưu thông giai đoạn 2006-2017 theo năm nhóm thu nhập3-128

Hình 3-4 Phân bố xe máy trong lưu thông giai đoạn 2006-2017 theo sáu (06) vùng kinh tế-xã

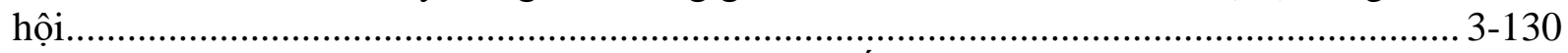

Hình 3-5 Phân tích nguyên nhân TNGT liên quan đến xe máy ............................................. 3-137

Hình 3-6 Các lối vi phạm chính ............................................................................. 3-141

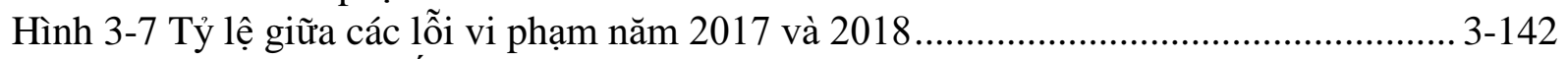

Hình 4-1 Tỷ lệ người chết vì tai nạn giao thông đường bộ theo loại phương tiện.............. 4-191 
Hình 4-2 Tỷ lệ tử vong của người đi xe máy tại các quốc gia ASEAN 4-192

Hình 4-3 Tỷ lệ người đi xe máy tử vong ở khu vực Đông Á

Hình 4-4 Hướng dẫn Hướng tiếp cận $3 \mathrm{E}$ về an toàn giao thông ở Nhật Bản 4-193

Hình 4-5 Hướng tiếp cận hệ thống an toàn đảm bảo an toàn giao thông đường bộ 4-195

Hình 4-6 Hướng tiếp cận 5 trụ cột đảm bảo an toàn giao thông đường bộ 4-197

Hình 4-7 Các bên liên quan tới RSPM 2014-2020 ...........................................................4-201

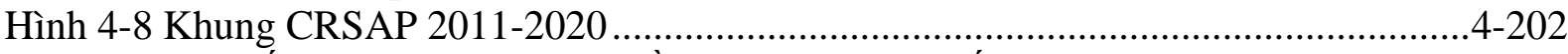

Hình 4-9 Sự phối hợp giữa 5 trụ cột nhằm đạt mục tiêu quốc gia của In-đô-nê-xia ...........4-206

Hình 4-10 Làn cấm xe máy (MBL) và Làn ưu tiên xe máy (MPL) ..................................4-218

Hình 4-11 Làn dành riêng cho xe máy (EMCL) .........................................................4-219

Hình 4-12 Làn ưu tiên xe máy (NEMCL) ......................................................................4-219

Hình 4-13 Cơ chế chuyển hướng 2 bước ở Đài Loan......................................................4-221

Hình 4-14 Ô chờ rẽ trái cho xe máy ...........................................................................4-222

Hình 4-15 Minh hoạ quy trình rẽ phải theo hai bước ở Nhật Bản......................................4-223

Hình 4-16 Khu vực xe máy chờ (MWZ) ở Đài Loan .....................................................4-224

Hình 4-17 Các cách bố trí làn xe máy ............................................................................4-225

Hình 4-18 Hai loại mái che mưa nắng cơ bản ở Trung Quốc ............................................4-226

Hình 4-19 Làn xe đạp điện ở Trung Quốc..........................................................................4-227

Hình 4-20 Các loại hình kiểm tra độ tỉnh táo .....................................................................4-230

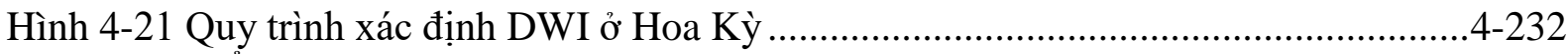

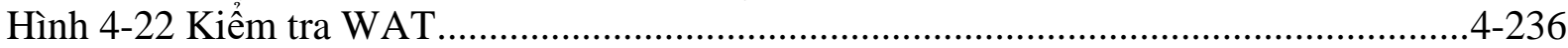

Hình 4-23 Tem chứng nhận cho xe máy ..........................................................................4-244 


\section{VI TRÍ ĐIA LÝ, KHÍ HẬU, DÂN SỐ, PHÁT TRIỂN KINH TẾ VÀ NHŨ̃NG VẤN ĐỀ XE MÁY Ở VIẸTT NAM}

\subsection{Vị trí địa lý, khí hậu, dân số và phát triển kinh tế của Việt Nam}

Khoảng từ năm 2000 xe máy ở Việt Nam tăng rất nhanh và xe máy đang là phương tiện giao thông có tỷ lệ tai nạn giao thông cao, gây ùn tắc giao thông và ô nhiễm môi trường. Vấn đề gia tăng xe máy quá nhanh ở Việt Nam liên quan ít nhiều đến: vị trí địa lý, khí hậu, nhân khẩu học, phát triển kinh tế, văn hóa ...

\subsubsection{Vị trí địa lý}

Việt Nam là một quốc gia nằm trên bán đảo Đông Dương, khu vực Đông Nam Á, ven biển Thái Bình Dương. Việt Nam có đường biên giới trên đất liền dài $4.550 \mathrm{~km}$ tiếp giáp với Trung Quốc ở phía Bắc, với Lào và Cam-pu-chia ở phía Tây; phía Đông giáp biển Đông. Trên bản đồ, dải đất liền Việt Nam mang hình chữ $\mathrm{S}$, kéo dài từ vĩ độ $23^{\circ} 23^{\prime}$ Bắc đến $8^{\circ} 27^{\prime}$ Bắc, dài $1.650 \mathrm{~km}$ theo hướng bắc nam, phần rộng nhất trên đất liền khoảng $500 \mathrm{~km}$; nơi hẹp nhất gần $50 \mathrm{~km}$.

Do vị trí địa lí, Việt Nam có 5 đặc điểm và những đặc điểm này chi phối toàn bộ các lợi ích và thách thức đối với sự hình thành vị thế của Việt Nam ở khu vực và thế giới, đó là:

- Việt Nam nằm hoàn toàn trong vành đai nhiệt đới, thuộc địa ô nhiệt đới gió mùa Đông Nam Á;

- Việt Nam nằm trong các đai sinh khoáng Tây Thái Bình Dương và Địa Trung Hải, nằm trong vùng chịu ảnh hưởng của các vòng cung núi lửa và động đất, cũng là nơi chuyển tiếp của thế giới sinh vật với nhiều khu hệ khác nhau;

- Việt Nam có phần đất liền nằm ở phía Đông bán đảo Trung Án, thuộc góc Đông Nam của lục địa Á-Âu; có phần biển gồm hai quần đảo Hoàng Sa và Trường Sa nằm ở trung tâm Biển Đông, nối liền Thái Bình Dương với Ấn Độ Dương;

- Việt Nam nằm sát Trung Quốc, là một quốc gia lớn, đang phát triển kinh tế mạnh mẽ và có quan hệ văn hóa-lịch sử rất lâu đời;

- Việt Nam nằm ở trung tâm khu vực Đông Nam Á, đồng thời ở trung tâm khu vực của các quốc gia phát triển năng động và mới nổi, gồm có Đông Á, Nam Á và châu Úc.

Trong đó, 2 đặc điểm đầu tiên có thể là điểm chung của nhiều quốc gia trong khu vực; nhưng 3 đặc điểm sau mang tính đặc thù cho Việt Nam, có thể khái quát ngắn gọn thành 3 đặc điểm: vừa mang tính lục địa vừa mang tính biển, tiếp giáp với Trung Quốc và nằm gần các trung tâm phát triển lớn. ${ }^{1}$

\subsection{2. Đặc điểm khí hậu}

Do vị trí địa lí Việt Nam nhận được một lượng nhiệt mặt trời lớn, vì vậy nhiệt độ cao quanh năm, trung bình trên $2^{\circ} \mathrm{C}$ và tăng dần từ Bắc vào $\mathrm{Nam}$, lượng mưa lớn $(1.500-2.000 \mathrm{~mm} / \mathrm{năm})$ và độ ẩm không khí trên $80 \%$. So với các nước trong cùng vĩ độ, Việt Nam có một mùa đông lạnh hơn và một mùa hạ mát hơn. Bình quân $1 \mathrm{~m}^{2}$ nhận được trên 1 triệu kilocalo nhiệt năng, số giờ nắng đạt từ 1400 - 3000 giờ/ năm.

\footnotetext{
1 Tác động của vị trí địa lý đến hội nhập khu vực của Việt Nam - ThS. Lê Hồng Ngọc, Viện Địa lý nhân văn
} 


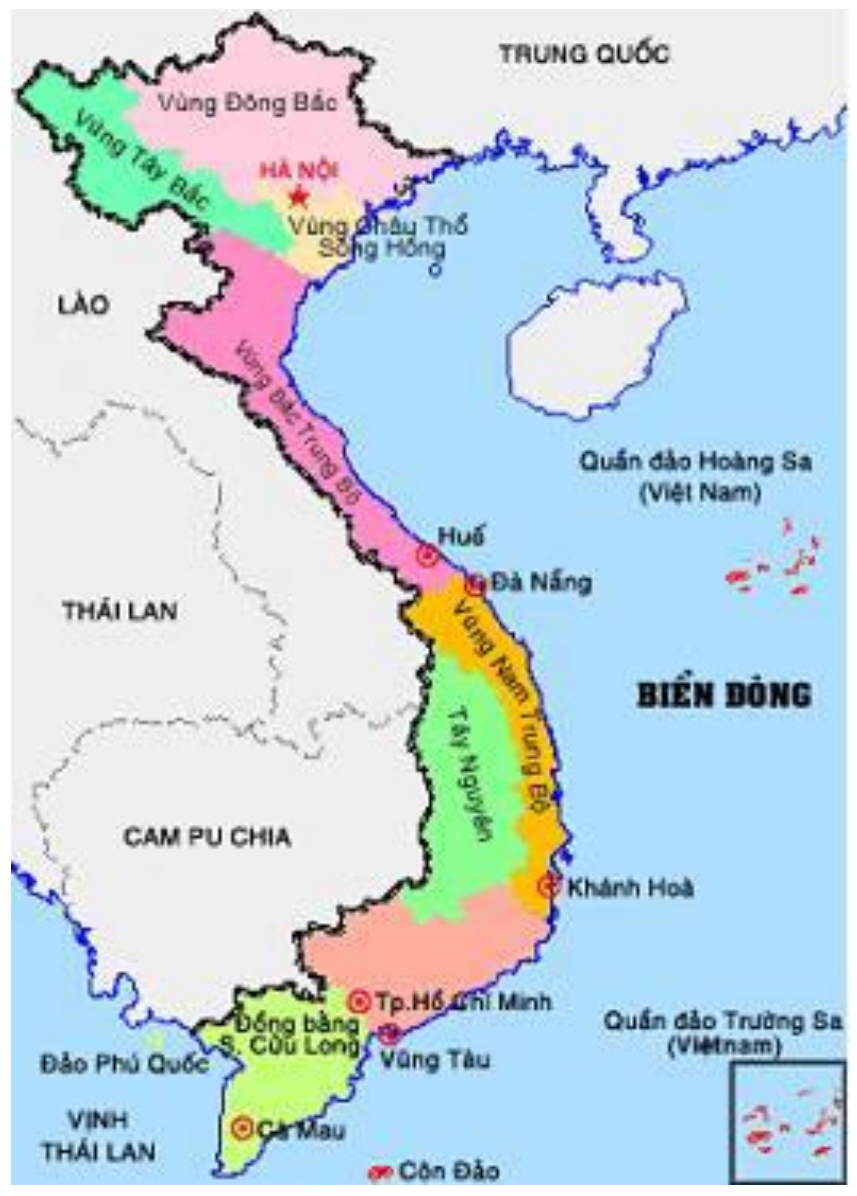

Hình 1-1 Phân vùng khí hậu Việt Nam

Khí hậu Việt Nam có đặc điểm lớn nhất là khí hậu vùng, người ta chia các vùng khí hậu của Việt Nam như sau:

- Miền khí hậu phía Bắc: bao gồm khí hậu vùng Đông Bắc Bộ, vùng Tây Bắc Bộ

- Miền khí hậu Trường Sơn: bao gồm vùng khí hậu Bắc Trung bộ, vùng Duyên hải Nam Trung bộ

- Miền khí hậu Phía Nam: bao gồm vùng khí hậu đồng bằng Nam Bộ và vùng khí hậu cao nguyên Nam Trung bộ (Tây Nguyên)

Có 8 nhân tố tác động nên sự hình thành khí hậu của Việt Nam là:

1. Nền bức xạ cao

2. Ảnh hưởng của Biển Đông

3. Ảnh hưởng của gió mùa

4. Phân hóa theo mùa

5. Khí hậu phân hóa từ Bắc vào Nam

6. Khí hậu phân hóa theo độ cao

7. Khí hậu thất thường

8. Khắc nghiệt nhiều thiên tai

Nhiệt độ trung bình tại Việt Nam dao động từ $21^{\circ} \mathrm{C}$ dến $27^{\circ} \mathrm{C}$ và tăng dần từ Bắc vào Nam. Mùa hè, nhiệt độ trung bình trên cả nước là $25^{\circ} \mathrm{C}$ (Hà Nội $23^{\circ} \mathrm{C}$, Huế $25^{\circ} \mathrm{C}$, thành phố Hồ Chí Minh $26^{\circ} \mathrm{C}$ ). Mùa đông ở miền Bắc, nhiệt độ xuống thấp nhất vào các tháng Mười Hai và tháng Giêng. 
Ở vùng núi phía Bắc, như Sa Pa, Tam Đảo, Hoàng Liên Sơn, nhiệt độ có thể xuống tới $0^{\circ} \mathrm{C}$, có tuyết rơi, xong thường chỉ kéo dài vài ngày.

Nhìn chung với khí hậu của Việt Nam, người dân có thể sử dụng xe máy quanh năm.

\subsubsection{Nhân khẩu học Việt Nam}

\subsubsection{Dân số, tỷ lệ tăng dân số}

Năm 2017 dân số Việt Nam đã đạt mức 93,7 triệu dân. Dân số Việt Nam từ năm 2005 đến năm 2017 tăng 11,281 triệu người, bình quân mỗi năm tăng 940.000 người, tỷ lệ tăng dân số tương đối ổn định, tỷ lệ bình quân tăng dân số từ năm 2005 đến 2017 là $1,08 \%$, thấp hơn tỷ lệ tăng dân số bình quân của khu vực ASEAN (1,3\%); mật độ dân số 383 người $/ \mathrm{km}^{2}$, tổng tỷ suất sinh năm 2017 đạt 2,04 con/phụ nữ, tiếp tục duy trì ở mức sinh thay thế. Tỷ số giới tính của trẻ em mới sinh là 112,1 bé trai/100 bé gái.

Bảng 1-1 Dân số, dân số phân theo giới tính, phân theo nông thôn và thành thị

\begin{tabular}{|l|l|l|l|r|r|}
\hline \multirow{2}{*}{ Năm } & \multirow{2}{*}{ Dân số } & \multicolumn{2}{|c|}{ Phân theo giới tính } & \multicolumn{2}{c|}{$\begin{array}{c}\text { Phân theo thành thị } \\
\text { Nông thôn }\end{array}$} \\
\cline { 3 - 6 } & & Nam & Nũ & Thành thị & Nông thôn \\
\hline 2005 & $82.392,1$ & $40.521,5$ & $41.870,6$ & $22.322,0$ & $60.060,1$ \\
\hline 2006 & $83.311,2$ & $40.999,0$ & $42.312,2$ & $23.045,8$ & $60.265,4$ \\
\hline 2007 & $84.218,5$ & $41.447,3$ & $42.771,2$ & $23.746,3$ & $60.472,2$ \\
\hline 2008 & $85.118,7$ & $41.956,1$ & $43.162,6$ & $24.673,1$ & $60.445,6$ \\
\hline 2009 & $86.025,0$ & $42.523,4$ & $43.501,6$ & $25.584,7$ & $60.440,3$ \\
\hline 2010 & $86.947,4$ & $42.993,5$ & $43.953,9$ & $26.515,9$ & $60.431,5$ \\
\hline 2011 & $87.860,4$ & $43.446,8$ & $44.413,6$ & $27.719,3$ & $60.141,1$ \\
\hline 2012 & $88.809,3$ & $43.908,2$ & $44.901,4$ & $28.269,2$ & $60.540,1$ \\
\hline 2013 & $89.759,5$ & $44.364,9$ & $45.394,6$ & $28.874,9$ & $60.884,6$ \\
\hline 2014 & $90.728,9$ & $44.758,1$ & $45.970,8$ & $30.035,4$ & $60.693,5$ \\
\hline 2015 & $91.709,8$ & $45.224,0$ & $46.485,8$ & $31.067,5$ & $60.642,3$ \\
\hline 2016 & $92.692,2$ & $45.753,4$ & $46.938,8$ & $31.926,3$ & $60.765,9$ \\
\hline 2017 & $93.671,6$ & $46,253,0$ & $47.418,6$ & $32.813,4$ & $60.858,2$ \\
\hline
\end{tabular}

Nguồn: Tổng cục Thống kê 
Đơn vị: nghìn người

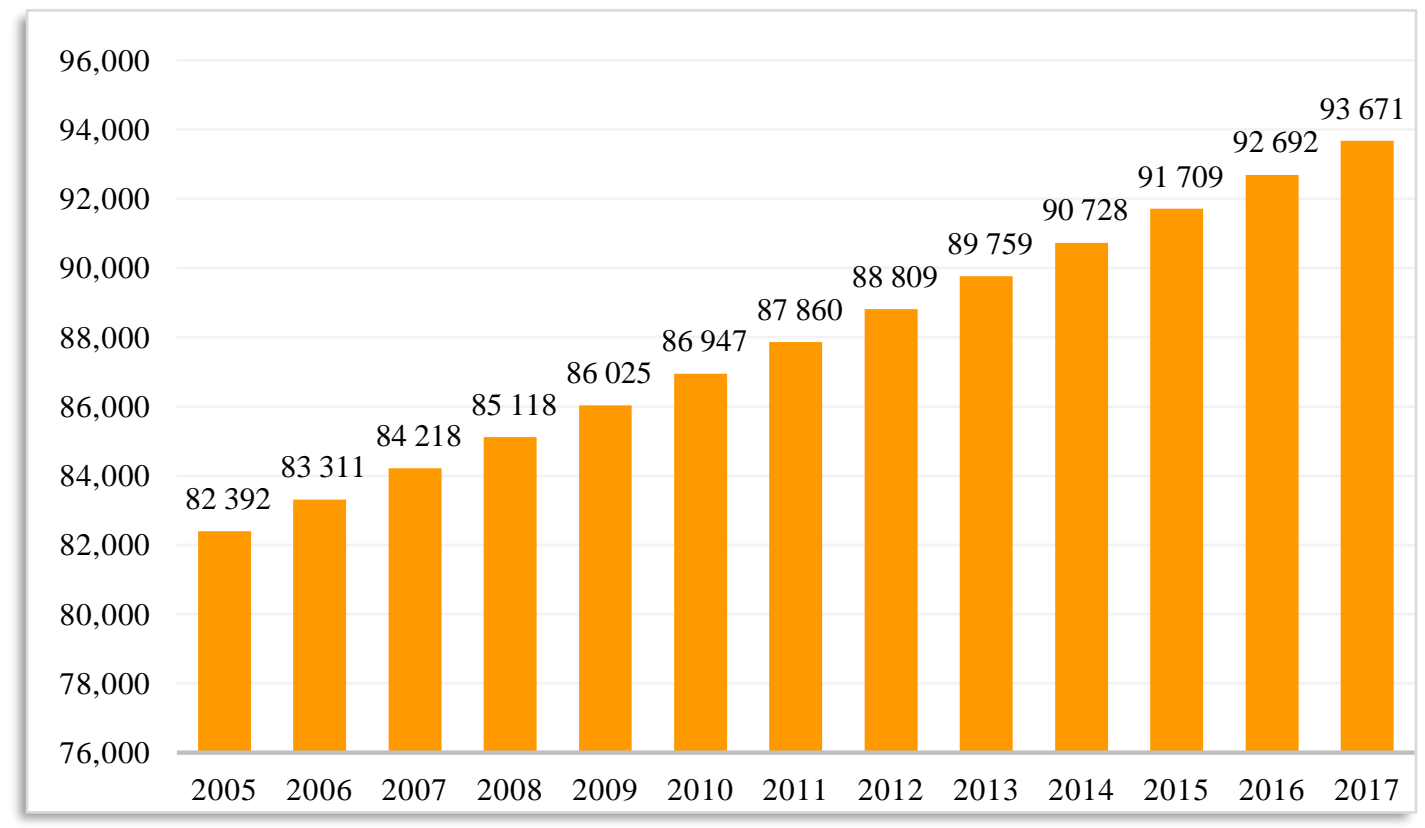

Hình 1-2 Biểu đồ dân số Việt Nam 2005 - 2017

Đơn vị: nghìn người

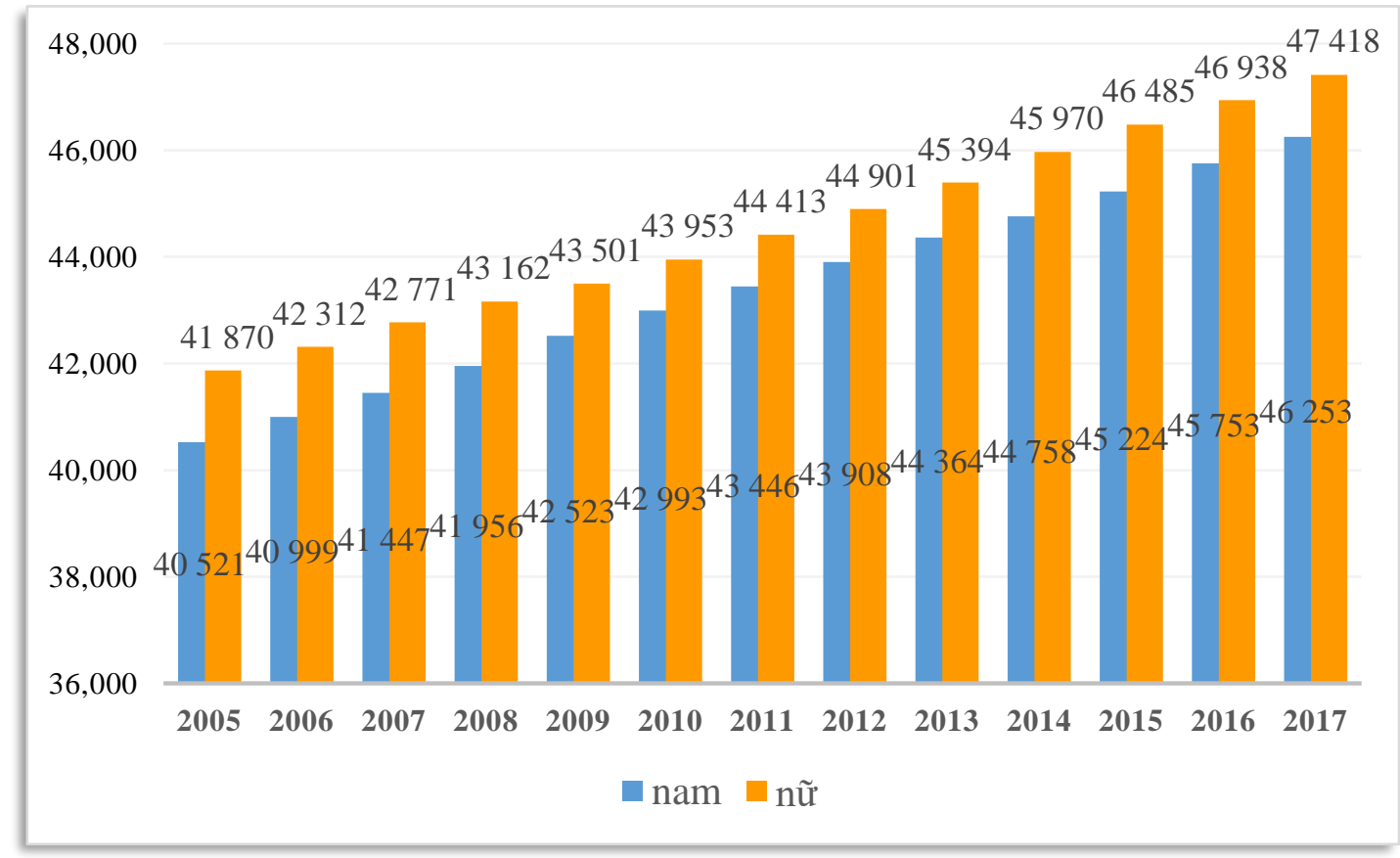

Hình 1-3 Biểu đồ dân số phân theo giới tính 


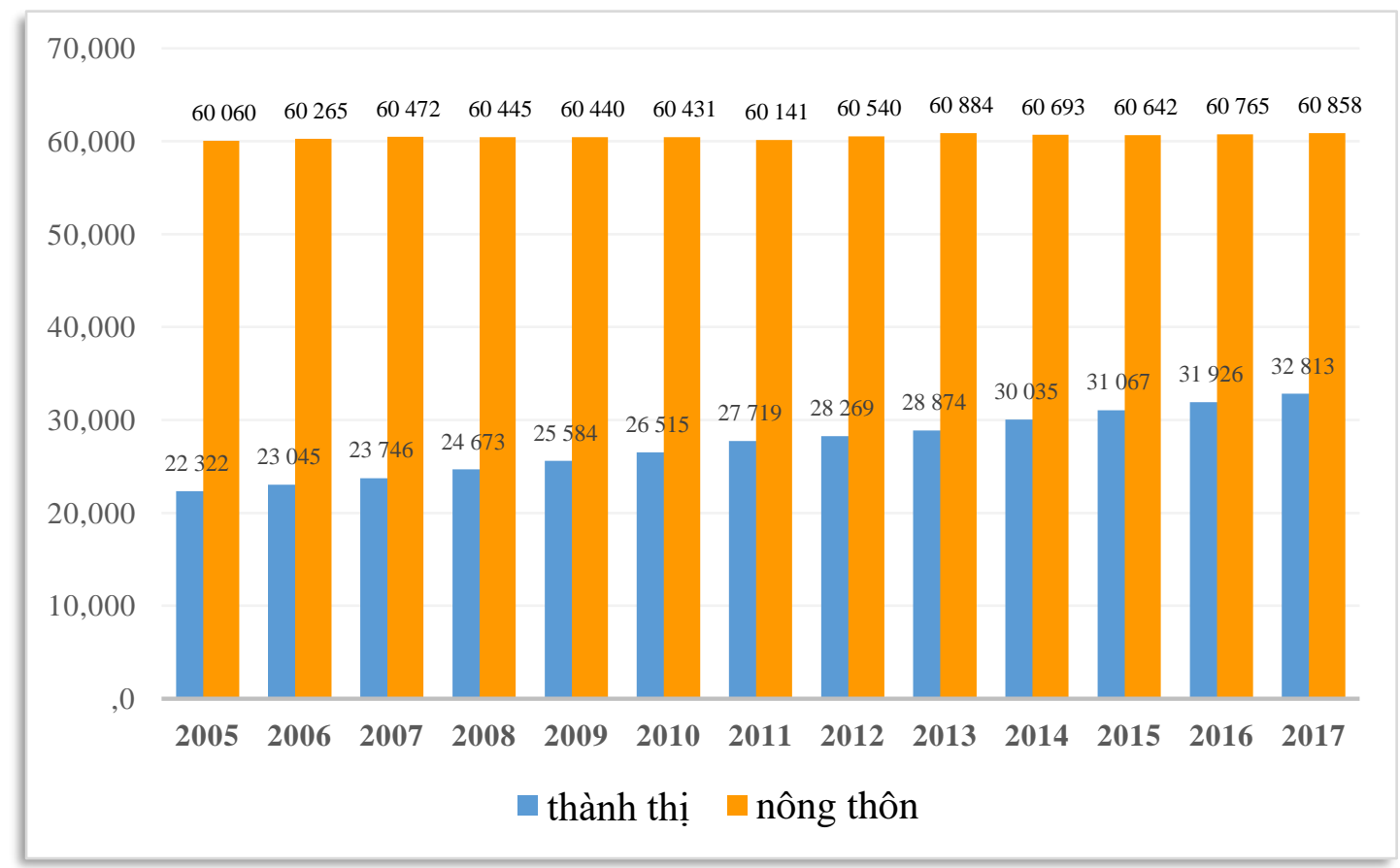

Hình 1-4 Biểu đồ dân số phân theo thành thị và nông thôn

Bảng 1-2 Tỷ lệ tăng dân số 2005 - 2017

\begin{tabular}{|c|r|r|r|r|r|r|r|r|r|r|r|r|}
\hline Năm & 2005 & 2007 & 2008 & 2009 & 2010 & 2011 & 2012 & 2013 & 2014 & 2015 & 2016 & 2017 \\
\hline Tỷ lệ tăng dân số & 1,17 & 1,09 & 1,07 & 1,06 & 1,07 & 1,05 & 1,08 & 1,07 & 1,08 & 1,08 & 1,07 & 1,06 \\
\hline
\end{tabular}

Nguồn: Tổng cục Thống kê

Đơn vị (\%)

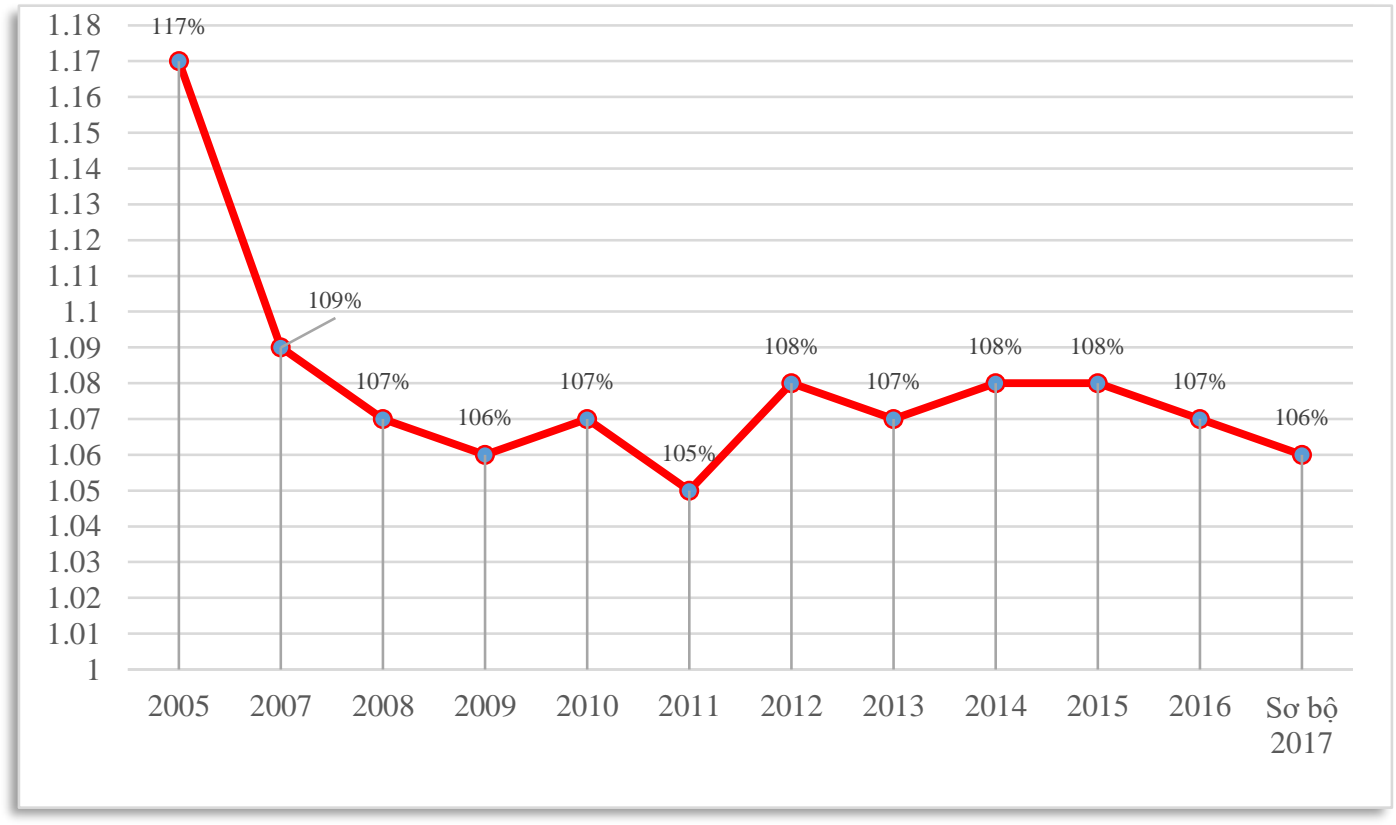

Hình 1-5 Tỷ lệ tăng dân số 2005 - 2017 


\subsubsection{Cơ cấu dân số theo tuổi}

\subsection{Tuổi thọ người Việt Nam}

Theo báo cáo của Tổng cục Thống kê, hiện nay cả nước có khoảng 11,3 triệu người cao tuổi (chiếm khoảng $11,95 \%$ dân số), trong đó, trên 1,9 triệu người từ 80 tuổi trở lên và $64,4 \%$ người cao tuổi sống ở khu vực nông thôn.

Việt Nam có trên 7.000 người trên 100 tuổi. Nếu như vào năm 1960, tuổi thọ trung bình của người Việt Nam là 40, thế giới là 48 nhưng đến năm 2015 tuổi thọ trung bình của người Việt Nam đã là 73,2 trong khi thế giới là $69 .^{2}$

Bảng 1-3 Tuổi thọ trung bình 2005 -2017

\begin{tabular}{|l|c|c|c|c|c|c|c|c|c|c|}
\hline Năm & 2005 & 2009 & 2010 & 2011 & 2012 & 2013 & 2014 & 2015 & 2016 & 2017 \\
\hline Tuổi thọ & 72,2 & 72,8 & 72,9 & 73,0 & 73,0 & 73,1 & 73,2 & 73,3 & 73,4 & 73,5 \\
\hline
\end{tabular}

Nguồn: Tổng cục Thống kê

Theo niên giám thống kê năm 2017 của Tổng cục Thống kê, tuổi thọ trung bình của nam là 70,9 tuổi, nữ là 76,2 tuổi.

\subsection{Tháp dân số}

Tháp dân số là một công cụ thông dụng được dùng để biểu thị sự kết hợp cơ cấu tuổi và cơ cấu giới tính của dân số dưới dạng hình học (hình tháp là đặc trưng). Việc phân chia dân số theo cơ cấu dân số nhóm tuổi giúp nắm bắt được tình hình sinh, tử, tuổi thọ và có phương hướng xây dựng chính sách điều chỉnh, phát triển nguồn lao động hợp lý và những vấn đề xã hội khác.

Trong cơ cấu dân số theo tuồi, có 3 nhóm tuổi:

- Nhóm dưới tuổi lao động: từ 0 đến 14 tuổi.

- Nhóm tuổi lao động: từ 14 đến 59 (hoặc 64) tuổi.

- Nhóm trên tuổi lao động: lớn hơn 60 hoặc 65 tuổi.

Theo Liên hiệp quốc:

- Một đất nước có dân số trẻ khi: có trên 35\% người từ 0-14 tuổi và số người trên 60 tuổi nhỏ hơn 10\%. Dân số trẻ đem lại nguồn lao động dồi dào cho xã hội nhưng cũng tạo nên sức ép dân số lớn.

- Một đất nước có dân số già khi: có dưới 25\% người trong độ tuổi 0-14 tuổi, trên $15 \%$ người trên 60 tuổi. Dân số già thể hiện chất lượng cuộc sống cao do những lượng dân số trên 60 tuổi đông và có nhiều kinh nghiệm sống. Tuy nhiên, đây cũng là thách thức về nguồn lao động và gánh nặng về phúc lợi xã hội nhiều hơn cho đất nước.

- Giai đoạn cơ cấu dân số vàng là một giai đoạn của quá trình chuyển đổi nhân khẩu học. Giai đoạn này còn gọi là giai đoạn "dư lợi dân số" hay còn gọi là "cửa sổ cơ hội dân số". Gia đoạn này có tỷ số phụ thuộc chung nhỏ hơn hay bằng $50 \%$, hay nói cách khác cứ có 2 người trong độ tuổi lao động (15 đến 64 tuổi) chỉ phải gánh 1 người hay dưới 1 người ngoài tuổi lao động.

\footnotetext{
${ }^{2}$ Hội thảo Định hướng chính sách chăm sóc xã hội đối với người cao tuổi thích ứng với già hóa dân số của Ủy ban Về các vấn đề xã hội của Quốc hội khóa XIV Ngày 27-8- 2018, tại Cần Thơ
} 
Năm 2007 ở Việt Nam tỷ số phụ thuộc là khoảng 50\%, có nghĩa năm 2007 dân số Việt Nam đã bước vào thời kỳ “dân số vàng”. Thời kỳ này chỉ xuất hiện duy nhất một lần đối với một quốc gia.

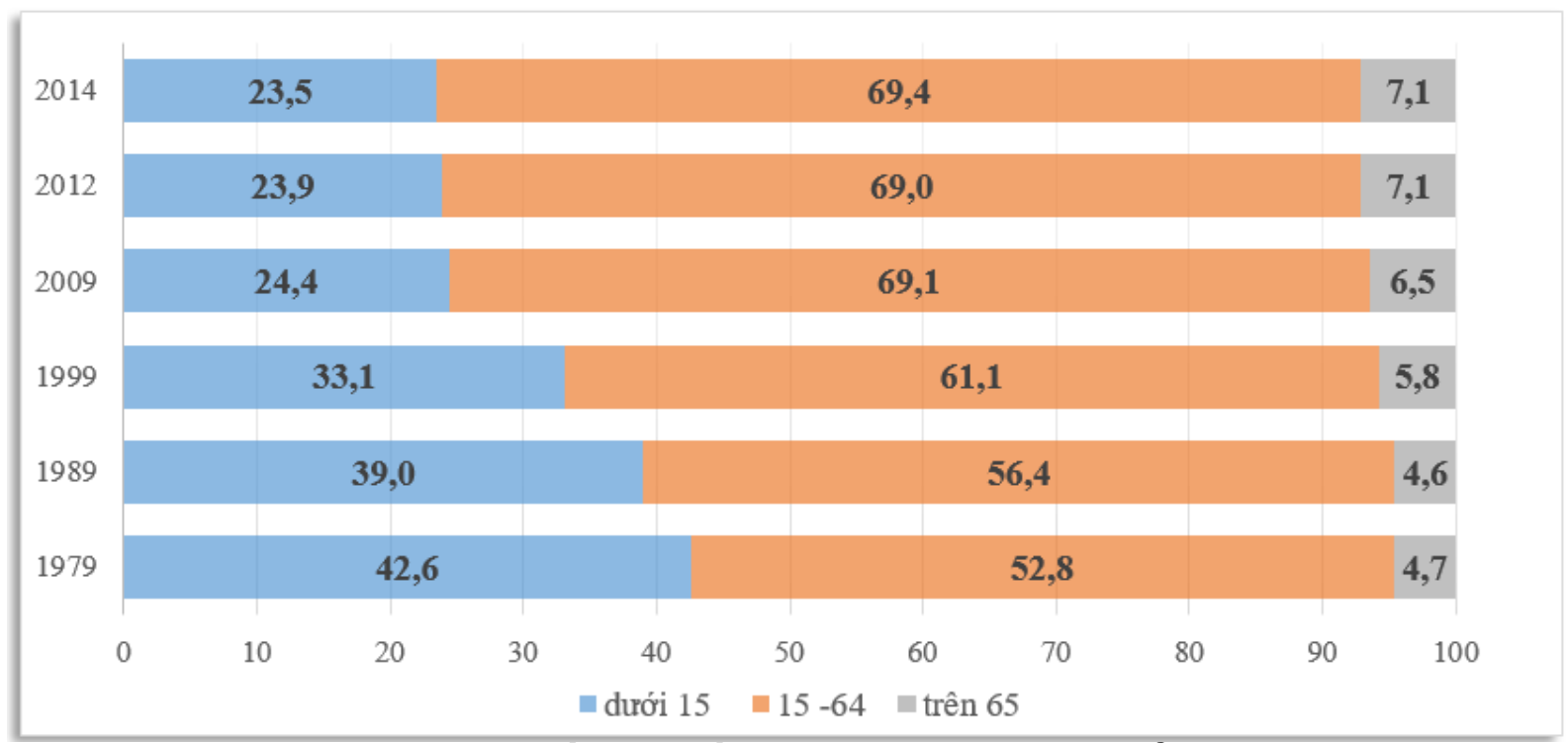

Hình 1-6 Cơ cấu dân số Việt Nam theo nhóm tuổi (\%)

Nguồn: Tổng cục Thống kê

Bảng 1-4 Cấu trúc tuổi - giới tính của dân số đã điều chỉnh, Việt Nam 2014

\begin{tabular}{|c|c|c|c|c|c|c|}
\hline \multirow{2}{*}{ Nhóm tuổi } & \multicolumn{3}{|c|}{$\begin{array}{c}\text { Tỷ trọng nhóm tuổi } \\
\text { cưa từng giới }\end{array}$} & \multicolumn{3}{c|}{$\begin{array}{c}\text { Tỷ trọng nhóm tuổi so với } \\
\text { tổng dân số }\end{array}$} \\
\cline { 2 - 7 } & Nam & Nữ & Chung & Nam & Nũ̃ & Chung \\
\hline $0-4$ & 8,89 & 7,77 & 8,53 & 4,38 & 3,94 & 8,53 \\
\hline $5-9$ & 8,18 & 7,33 & 7,75 & 4,03 & 3,72 & 7,75 \\
\hline $10-14$ & 7,71 & 7,08 & 7,39 & 3,80 & 3,59 & 7,39 \\
\hline $15-19$ & 8,17 & 7,59 & 7,87 & 4,03 & 3,85 & 7,87 \\
\hline $20-24$ & 10,03 & 9,45 & 9,73 & 4,94 & 4,79 & 9,73 \\
\hline $25-29$ & 9,33 & 9,01 & 9.17 & 4,60 & 4,57 & 9,17 \\
\hline $30-34$ & 8,53 & 8,37 & 8,45 & 4,21 & 4,25 & 8,45 \\
\hline $35-39$ & 7,52 & 7,33 & 7,42 & 3,71 & 3,71 & 7,42 \\
\hline $40-44$ & 7,11 & 6,94 & 7,02 & 3,51 & 3,52 & 7,02 \\
\hline $45-49$ & 6,35 & 6,42 & 6,39 & 3,13 & 3,26 & 6,39 \\
\hline $50-54$ & 5,51 & 5,97 & 5,74 & 2,72 & 3,03 & 5,74 \\
\hline $55-59$ & 4,23 & 4,92 & 4,58 & 2,09 & 2,49 & 4,58 \\
\hline $60-64$ & 2,74 & 3,35 & 3,05 & 1,35 & 1,70 & 3,05 \\
\hline $65-69$ & 1,89 & 2,33 & 2,11 & 0,93 & 1,18 & 2,11 \\
\hline $70-74$ & 1,34 & 1,88 & 1,61 & 0,66 & 0,95 & 1,61 \\
\hline $75-79$ & 1,07 & 1,65 & 1,36 & 0,53 & 0,84 & 1,36 \\
\hline $80^{+}$ & 1,4 & 2,61 & 2.01 & 0,69 & 1,32 & 2,01 \\
\hline Cộng & 100,00 & 100,00 & 100,00 & 49,31 & 50,69 & 100,00 \\
\hline
\end{tabular}

Nguồn: Tổng cục Thống kê, Quỹ Dân số Liên hiệp quốc (Dự báo dân số Việt Nam 2014 - 2049, Nhà xuất bản Thông tấn, Hà Nội 2016) 


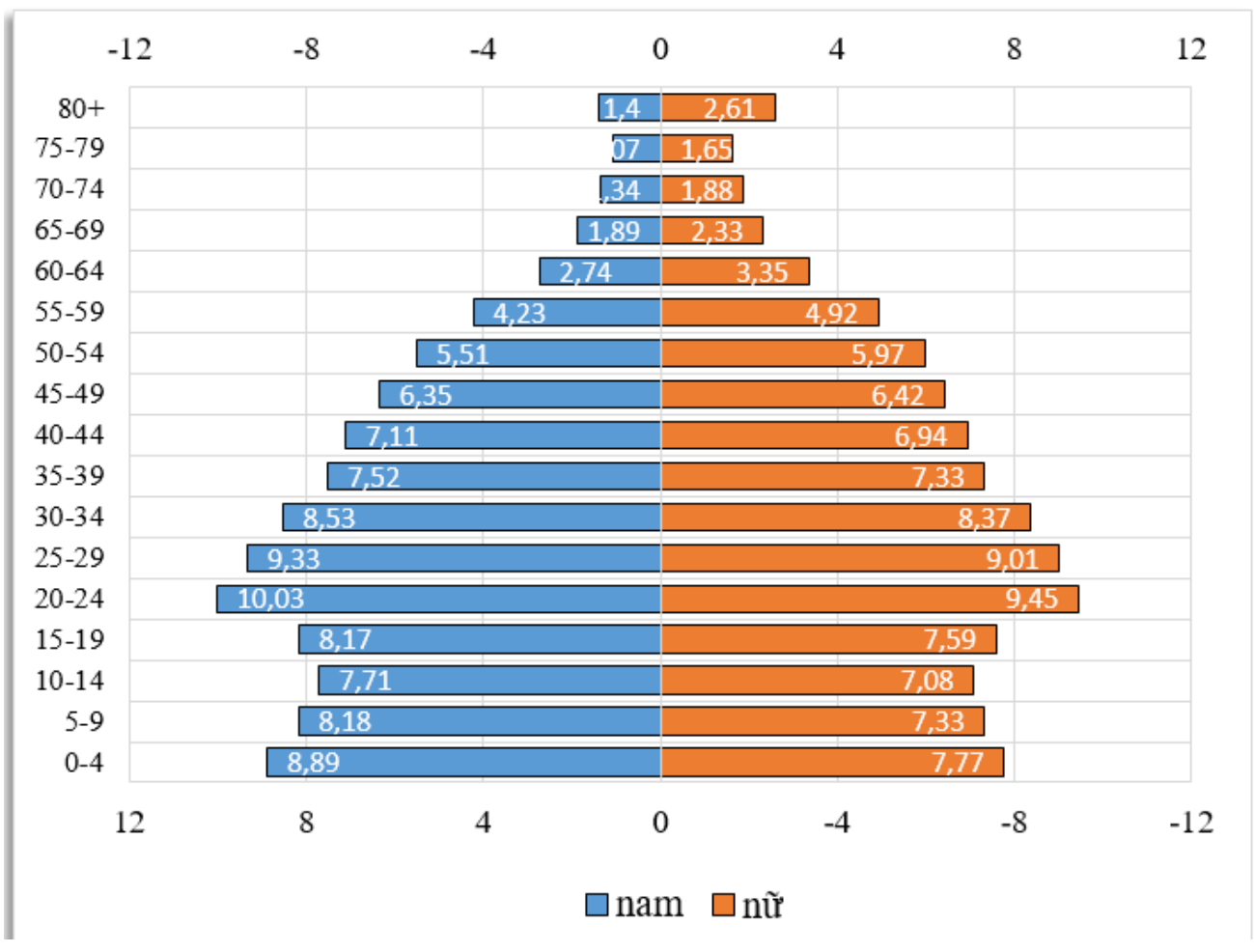

Hình 1-7 Tháp dân số Việt Nam năm 2014

Tháp dân số 2014 có dạng kiểu thu hẹp: tháp có dạng phình to ở giữa, thu hẹp về hai phía đáy và đỉnh tháp; tháp dân số thể hiện sự chuyển tiếp từ dân số trẻ sang dân số già, tỷ suất sinh giảm nhanh, nhóm trẻ em ít, gia tăng dân số có xu hướng giảm dần. Cơ cấu dân số Việt Nam biến đổi rất lớn, qua 4 cuộc Tổng điểu tra dân số từ 1979 đển 2009 cho thấy cấu trúc tuổigiới tính của dân số Việt Nam đã thay đổi đáng kể trong 3 thập kỷ qua.
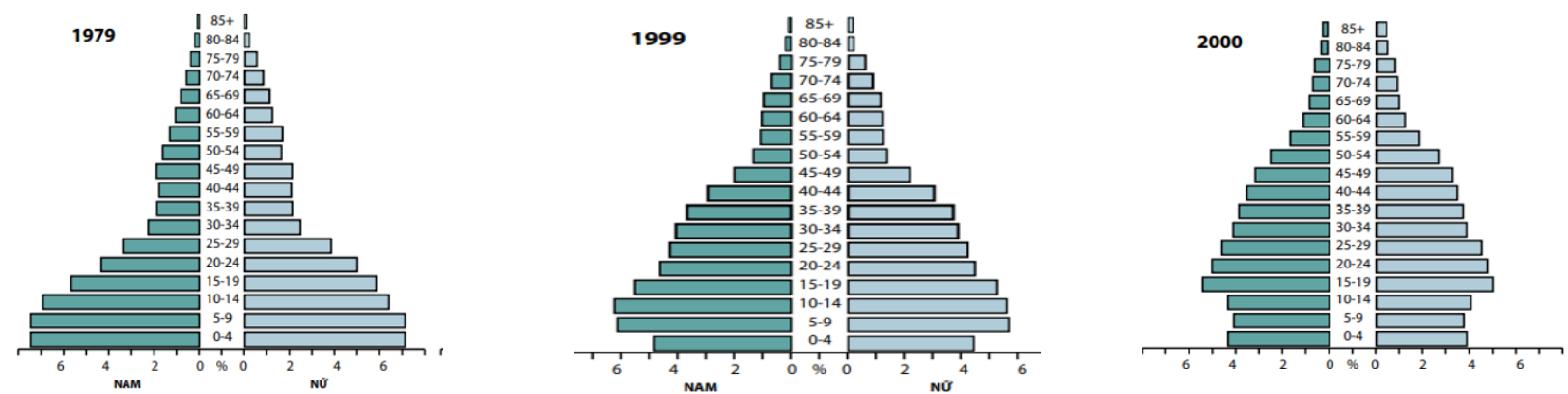

Mặc dù mức độ sinh đã bắt đầu giảm từ những năm 60 của thế kỷ 20 , nhưng đến năm 1979, nó vẫn còn ở mức khá cao. Nếu như ở giai đoạn đầu của thời kỳ quá độ, tháp dân số Việt Nam rộng nhất ở đáy và chiều rộng các tầng giảm khá nhanh theo độ tuổi (kiểu mở rộng hình tam giác) thì ở giai đoạn sau (từ năm 1999 đến nay), đáy tháp thu hẹp và không còn là chỗ rộng nhất của tháp.

Việt Nam vẫn đang trong giai đoạn dân số vàng, với số người trong độ tuổi lao động lớn hơn người phụ thuộc. Thực ra dấu hiệu già hóa dân số xuất hiện ở Việt Nam năm 2011 (dân số từ 65 tuồi trở lên chiếm từ $7 \%$ tổng dân số trở lên). Theo dự báo của Ngân hàng Thế giới (WB), 
trong 18 tới 20 năm nữa, Việt Nam sẽ già hóa dân số, là một trong những nước có tốc độ già hóa dân số nhanh.

Việt Nam là nước đông dân, với tổng dân số năm 2017 là trên 93 triệu dân, theo xếp hạng của Liên hiệp quốc Việt Nam đứng thứ 14 trên thế giới về dân số; về nhân khẩu học,Việt Nam là một trong những quốc gia có môi trường nhân khẩu trẻ nhất Châu Á, độ tuổi từ 15 đến 64 tuổi chiếm trên $60 \%$, trong đó độ tuổi 20 đến dưới 50 tuổi chiếm khoảng $40 \%$, dân số thành thị luôn luôn tăng, năm 2017 dân số thành thị trên 32 triệu người. Nhân khẩu học Việt Nam thuận lợi cho xe máy phát triển, thêm vào đó là khí hậu, thời tiêt, tốc độ đô thị hóa và phát triển kinh tế, Việt Nam là thị trường tiềm năng cho các hãng xe máy.

\subsubsection{Phát triển kinh tế}

Việt Nam đã phải trải qua 30 năm chiến tranh, chia cắt, hàng chục năm khắc phục hậu quả chiến tranh, nhiều năm xây dựng đất nước trong hoàn cảnh bị bao vây cấm vận, thiếu vốn đầu tư. Song nhờ công cuộc đổi mới hơn 30 năm qua, Việt Nam từ một nước nghèo đói và lạc hậu đã vươn lên thành quốc gia đang phát triển có thu nhập trung bình.

Năm 1975 Miền Nam hoàn toàn giải phóng, đất nước được thông nhất. Giai đoạn năm 1976 1985 Việt Nam bước vào công cuộc xây dựng đất nước, mặc dù có thuận lợi to lớn là đất nước thống nhất, hòa bình, nhưng cũng có nhiều khó khăn như: đất nước vừa trải qua cuộc chiến tranh lâu dài, xuất phát điểm của nền kinh tế quá thấp kém, duy trì quá lâu cơ chế quản lý tập trung quan liêu bao cấp. Những khó khăn khách quan, khuyết điểm chủ quan đã dẫn đến nền kinh tế-xã hội không phát triển như mong muốn mà ngược lại vào những năm giữa thập kỷ 80 nền kinh tế đã khủng hoảng trầm trọng, thể hiện là: (1) kinh tế tăng trưởng thấp và thực chất không có phát triển, nếu tính chung từ năm 1976 đến 1985 tổng sản phẩm xã hội tăng 50,5\%, bình quân hàng năm chỉ tăng ở mức 4,6\%; thu nhập quốc dân bình quân hàng năm chỉ tăng $3,7 \%$, trong khi dân số tăng trung bình hàng năm $2,3 \%$; (2) không có tích luỹ từ nội bộ nền kinh tế vì làm không đủ ăn, thu nhập quốc dân sản xuất chỉ bằng $80-90 \%$ thu nhập quốc dân sử dụng; (3) siêu lạm phát hoành hành, năm 1986 lạm phát đạt đỉnh điểm với tốc độ tăng giá 774,7\%. (4) Đời sống nhân dân hết sức khó khăn thiếu thốn ${ }^{3}$.

Giai đoạn này kinh tế không phát triển, thu nhập của người dân thấp (từ năm 1975 đến năm 1982, GDP bình quân đầu người khoảng 100 USD). Giai đoạn này phương tiện cá nhân của người dân phổ biến là xe đạp, thậm chí nhiều gia đình không thể mua nổi xe đạp. Số người có xe máy rất ít, ở Miền Nam xe máy có trước năm 1975, ở Miền Bắc một số ít người học tập, công tác ở các nước xã hội chủ nghĩa mang về.

Bảng 1-5 Thu nhập quốc dân GDP giai đoạn 1975-1982 ${ }^{4}$

\begin{tabular}{|c|c|c|c|c|}
\hline \multirow{2}{*}{ Năm } & \multicolumn{2}{|c|}{ GDP } & \multicolumn{2}{c|}{ b/q đầu ngưò̀i } \\
\cline { 2 - 5 } & $\begin{array}{c}\text { Việt Nam } \\
\text { (tr. VNĐ) }\end{array}$ & $\begin{array}{c}\text { Mỹ } \\
\text { (tr. USD) }\end{array}$ & Viêt Nam (VNĐ) & Mỹ (USD) \\
\hline 1975 & 18.300 & 4.680 & 383 & 98 \\
\hline 1976 & 19.901 & 4.975 & 405 & 101 \\
\hline 1977 & 20.305 & 5.076 & 403 & 101 \\
\hline
\end{tabular}

\footnotetext{
${ }^{3}$ Tổng cục Thống kê (TBT Nguyễn Bá Khoáng)

${ }^{4}$ Kinh tế Việt Nam thăng trầm và đột phá - Pham Minh Chính, Vương Quân Minh (NXB Chính trị Quốc gia - 15/6/2009)
} 


\begin{tabular}{|c|c|c|c|c|}
\hline \multirow{2}{*}{ Năm } & \multicolumn{2}{|c|}{ GDP } & \multicolumn{2}{c|}{ b/q dầu người } \\
\cline { 2 - 5 } & $\begin{array}{c}\text { Việt Nam } \\
\text { (tr. VNĐ) }\end{array}$ & $\begin{array}{c}\text { Mỹ } \\
\text { (tr. USD) }\end{array}$ & Viêt Nam (VNĐ) & Mỹ (USD) \\
\hline 1978 & 20.742 & 5.185 & 401 & 100 \\
\hline 1979 & 20.638 & 5.159 & 391 & 97 \\
\hline 1980 & 19.564 & 4.891 & 364 & 91 \\
\hline 1981 & 20.580 & 5.145 & 376 & 94 \\
\hline 1982 & 22.232 & 5.558 & 396 & 99 \\
\hline
\end{tabular}

Nguồn: Kimura: [58] trang 1041

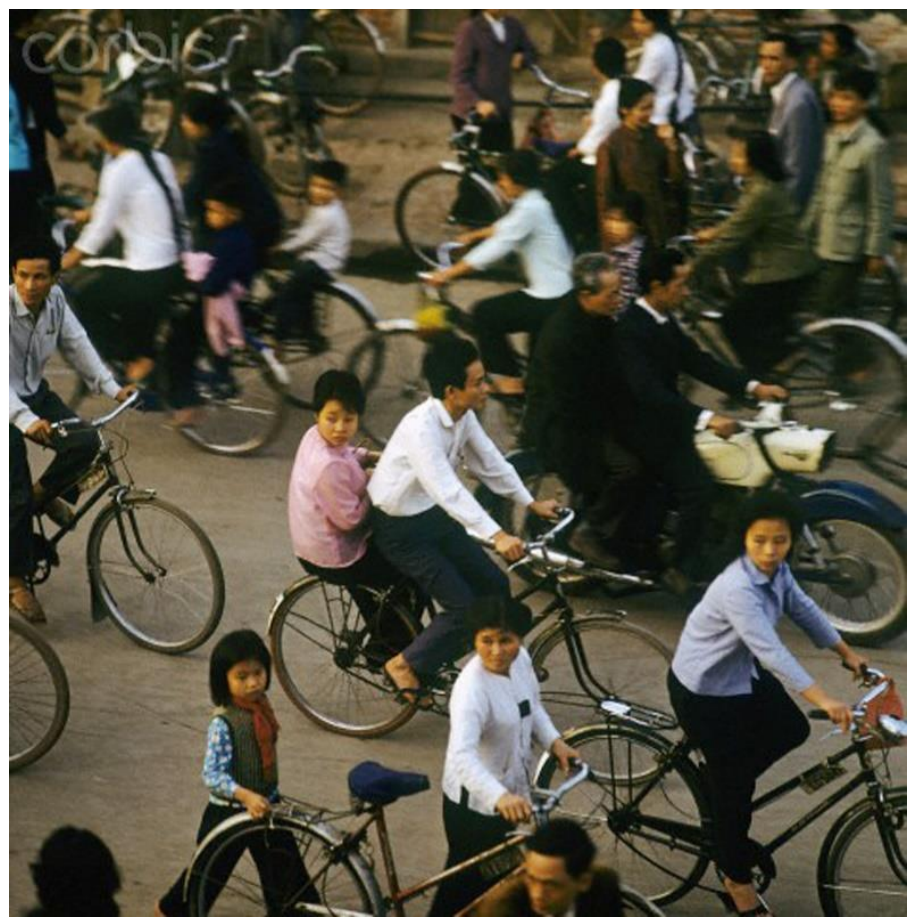

\section{Hình 1-8 Phương tiện cá nhân thời kỳ bao cấp phổ biến là xe đạp}

Phát triển kinh tế Việt Nam thời kỳ đổi mới:

Đại hội VI của Đảng tháng 12/1986 đã mở ra một giai đoạn mới trong lịch sử phát triển đất nước theo kinh tế thị trường định hướng xã hội chủ nghĩa và hội nhập quốc tế, nội dung quan trọng có tính quyết định là thực hiện dân chủ trong đời sống kinh tế; chuyển cơ chế quản lý kế hoạch hóa tập trung, bao cấp sang cơ chế thị trường, nhiều thành phần theo định hướng xã hội chủ nghĩa.

Đường lối đổi mới đúng đắn, hợp quy luật phát triển tạo nên động lực to lớn đã vực dậy nền kinh tế đang suy yếu do khủng hoảng, giải phóng các lực lượng sản xuất, phát huy các tiềm năng của đất nước và thu được nhiều thành tựu to lớn.

Tuy vậy, từ 1987 đến 1990, cuộc khủng khoảng kinh tế-xã hội vẫn diễn biến đến mức trầm trọng, "cả nước làm không đủ ăn”, lạm phát phi mã, mỗi năm phải nhập khẩu khoảng hai triệu tấn lương thực, toàn bộ xăng dầu, phần lớn sắt thép, phân bón và nguyên liệu.

Từ 1991 đến nay, mặc dù nước ta phải đổi mặt với hai cuộc khủng hoảng khu vực và thế giới nhưng đã tăng trưởng với tốc độ cao và thu được những thành tựu quan trọng. Thể hiện điều này qua một vài số liệu kinh tế tổng hợp như sau:

GDP bình quân đầu người năm 1991 là 188 USD thuộc nhóm thấp nhất, năm 2011 là 1.260 USD, gia nhập nhóm nước có thu nhập trung bình (thấp) của thế giới, năm 2016 là 2.050 USD, bằng 10,9 lần năm 1991. Tốc độ tăng trưởng kinh tế giai đoạn 1991- 2016 trung bình gần 
$7 \% /$ năm, có 3 năm trên $7 \%, 7$ năm trên $8 \%$ và 2 năm trên $9 \%$; có hai giai đoạn 6 năm liên tiếp 1992-1997 và 2002-2007 đạt được tốc độ tăng trưởng trên $7 \%{ }^{5}$

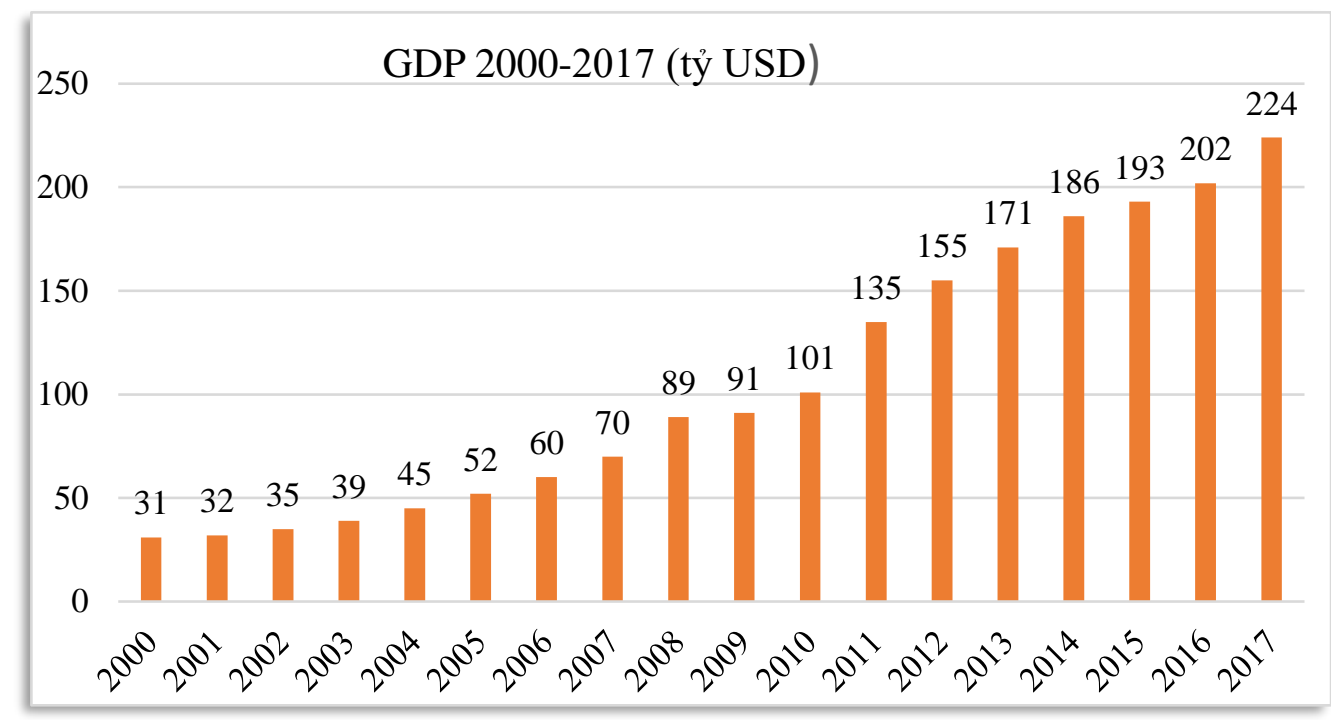

Hình 1-9 GDP Việt Nam 2000 - 2017

Nguồn: Tổng cục Thống kê

Thành tựu của công cuộc đổi mới và hội nhập quốc tế, làm cho tiềm lực kinh tế của đất nước tăng lên gấp nhiều lần, đời sống nhân dân được cải thiện rõ rệt. Đạt được thành tựu trong hơn 30 năm đổi mới phải kể đến nỗ lực hội nhập sâu với kinh tế quốc tế, đầu năm 2007, Việt Nam là thành viên thứ 105 của Tổ chức Thương mại thế giới (WTO) đánh dấu mốc quan trọng trong quan hệ đa phương của quá trình hội nhập quốc tế. Bên cạnh đó, từ 1991 đến 2016, nước ta đã tiếp nhận được nguồn vốn quốc tế khá lớn, trong đó vốn đầu tư nước ngoài thực hiện khoảng 165 tỷ USD, chiếm khoảng $22 \%$ tổng vốn đầu tư xã hội ${ }^{6}$.

Khoảng từ năm 1990-2000, số lượng xe máy đăng ký mới hàng năm không nhiều, mỗi năm tăng bình quân chừng 500.000 xe đăng ký, năm 2000 tổng số xe đăng ký là: 6.210 .823 xe. Từ sau năm 2000, số lượng xe máy bắt đầu tăng nhanh, trước hết là do đời sống người dân được cải thiện rõ rệt, thêm vào đó là các công ty vốn đầu tư nước ngoài bắt đầu xúc tiến đầu tư vào Việt Nam.

\footnotetext{
${ }^{5}$ Nhìn lại 30 năm đổi mới và hội nhập (GS.TSKH Nguyễn Mại, Báo điện tử Chính phủ nước CHXHCN Việt Nam )

${ }^{6}$ Nhìn lại 30 năm đổi mới và hội nhập (GS.TSKH Nguyễn Mại, Báo điện tử Chính phủ nước CHXHCN Việt Nam
} 


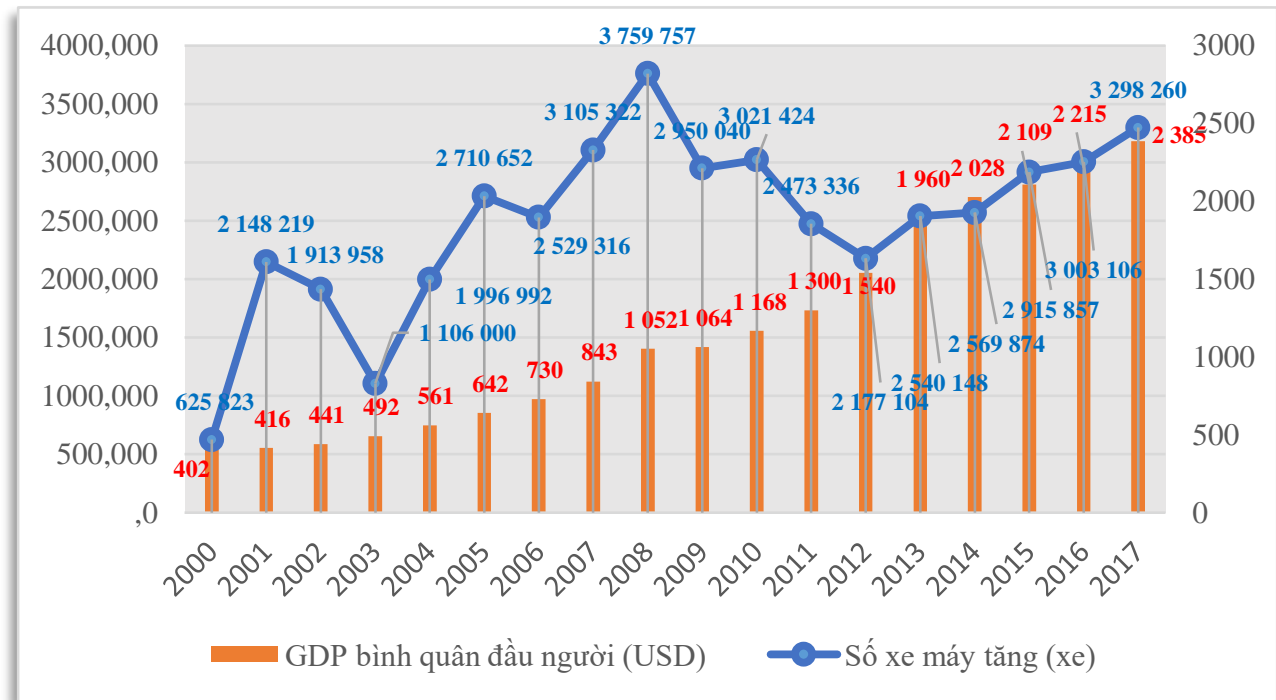

Hình 1-10 Bình quân GDP trên đầu người năm và số xe máy tăng năm 2000 đến 2017 Nguồn: GDP bình quân đầu nguời (Tổng cuc Thống kê); Số xe máy tăng hàng năm (UBATGTQG)

Do kinh tế phát triển tốt, đời sống người dân được nâng cao có điều kiện để mua xe máy, nếu trong những năm 80 xe máy là tài sản lớn của người dân thì nay xe máy chủ yếu là phương tiện đi lại. Bên cạnh đó là công nghiệp xe máy Việt Nam phát triển khá nhanh, giá thành giảm phù hợp với thu nhập bình quân của người dân; do chính sách của Chính phủ nên giá ô tô ở Việt Nam khá cao, người dân có thu nhập trung bình khó mua được.

Nghiên cứu từ nhiều năm trước cho thấy các chỉ tiêu kinh tế-xã hội có tác động nhất định tới sự tăng trưởng phương tiện cá nhân. Công trình "Duc N.H. et al., 2013" , đã chứng tỏ, $b \hat{\text { ọ }} b a$ chỉ số kinh tê-xã hội: GDP theo đầu người, dân số và tỷ lệ đô thị hóa, trong kỳ hạn dài, có tương quan chặt chẽ với sư gia tăng xe máy với hệ số tương quan gần tuyệt đối $R^{2}=0,997$. Nội dung này cũng sẽ được đề cập trong Chương sau. Tuy nhiên, nếu xét trong hạn ngắn, hoặc xét tách rời tùng chi số này, sẽ có hệ số tương quan thấp và rất thấp. Một nghiên cứu gần đây lặp lại điều sau này (hệ số tương quan $\mathrm{R}^{2}=0,622$ và $\mathrm{R}^{2}=0,2712$ ).
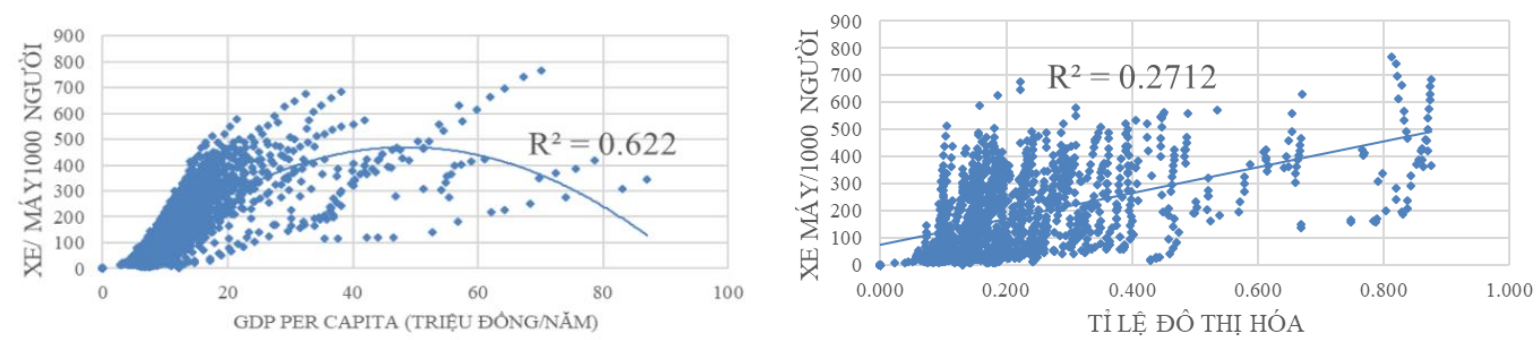

Hình 1-11 Quan hệ tỷ lệ sở hữu xe máy với GDP/đầu người và với tỷ lệ đô thị hóa

\footnotetext{
${ }^{7}$ Duc N.H., Hoa D.T.M., Huong N.T., Bao N.N. (2013) On Various Esential Data Related to Status Quo of Motorcycle in Vietnam, Journal of the Eastern Asia Socity for transportation Studies, Vol.10, 2080-2093.

8 "Báo cáo nghiên cứu vai trò xe máy trong hiện tại và tương lai tại Việt Nam"-Trung tâm nghiên cứu giao thông vận tải, trường Đại học Việt Đức (2017). Trong đó, số xe máy sở hữu là số theo đăng ký, không phải số thực tế lưu hành.
} 
Như vậy, xem xét các đặc điểm về vị trí địa lý, khí hậu, dân số, phát triển kinh tế từ năm 2000 đến nay đã hội đủ các điều kiện để số lượng xe máy ở Việt Nam phát triển rất nhanh; đến năm 2018 số xe máy đăng ký đã đạt con số 58.169 .432 xe.

\subsection{Vấn đề xe máy ở Việt Nam}

\subsubsection{Xe máy tăng nhanh}

Tuy xe máy xuất hiện trên thế giới cách đây hơn một thế kỷ, nhưng xe máy du nhập vào Việt Nam khá muộn. Trước năm 1975, xe máy ở Miền Nam khá nhiều ở các đô thị và đa phần là xe máy của Hãng Honda, ở Miền Bắc cố số lượng xe máy không đáng kể, chủ yếu do những người đi học tập, nghiên cứu ở các nước xã hội chủ nghĩa mang về.

Giai đoạn 1995 -1999 các công ty vốn đầu tư nước ngoài bắt đầu xúc tiến đầu tư vào Việt Nam. Trong lĩnh vực sản xuất, lắp ráp xe máy Công ty Honda Việt Nam là đơn vị đầu tiên, đây là liên doanh giữa Asian Honda Motor (công ty con của Honda) và Tổng công ty máy động lực nông nghiệp Việt Nam (VEAM). Tháng 3 năm1996 Honda chính thức gia nhập thị trường Việt Nam. Tiếp sau đó hàng loạt các doanh nghiệp nước ngoài xâm nhập vào thị trường sản xuất, lắp ráp xe máy Việt Nam; VEAM 1 cũng là đối tác liên doanh của các tập đoàn Toyota, Suzuki, Ford. Vào khoảng năm 1999-2000, những Tập đoàn lớn của Trung Quốc như: Lifan, Zongshen, Hongda ... theo mẫu của các động cơ đang có sẵn trên thị trường đã sản xuất hàng loạt xe máy với giá thấp kỷ lục để xuất sang các thị trường Đông Nam Á, Châu Phi, Bắc Mỹ ..., trong đó có Việt Nam.

Sự xuất hiện xe máy Trung Quốc giá rẻ đã làm thị trường xe máy ở Việt Nam sôi động, nhiều người có thu nhập thấp cũng mua được xe máy. Các doanh nghiệp lắp ráp xe máy dây chuyển dạng IKD Việt Nam gián tiếp đẩy mạnh số lượng xe máy Trung Quốc vào Việt Nam. Năm 2000-2003 xe máy Trung Quốc chiếm 60 -70\% thị phần nội địa. Tuy vậy vào những năm cuối của giai đoạn này, người tiêu dùng thiếu tin tưởng vào chất lượng xe máy Trung Quốc, sản lượng bán xe máy Trung Quốc giảm mạnh, nhập khẩu linh kiện từ Trung Quốc giảm đáng kể.

Trước sự cạnh tranh của xe máy Trung Quốc giá rẻ, Honda đã phải nghiên cứu cho ra thị trường xe máy Wave Alpha có giá chỉ cao hơn xe máy Trung Quốc khoảng 20\%, nhưng chất lượng tốt hơn hẳn.

Trước năm 1999, xe máy là tài sản lớn với đa số người Việt Nam, là phương tiện giao thông mơ ước của nhiều người. Nhưng sau năm 2000 đến nay xe máy đã là phương tiện giao thông phổ biến, giao thông chính của mọi người. Công nghiệp xe máy Việt Nam đều đặn cung cấp ra thị trường mỗi năm từ 2.000.000-3.000.000 xe máy các loại và Việt Nam nằm trong nhóm các nước sản xuất xe máy nhiều nhất thế giới. 
Bảng 1-6 Số lượng xe máy đăng ký 1990-2018

Đơn vị: xe

\begin{tabular}{|c|c|c|c|c|c|c|c|}
\hline \multirow{2}{*}{ Năm } & \multirow{2}{*}{ Xe máy } & \multicolumn{2}{|c|}{ So sánh } & \multirow{2}{*}{ Năm } & \multirow{2}{*}{ Xe máy } & \multicolumn{2}{c|}{ So sánh } \\
\cline { 8 - 9 } \cline { 7 - 8 } & & Tăng & \% & & & Tăng & \% \\
\hline 1990 & 1.209 .463 & & & 2004 & 13.375 .992 & 1.996 .992 & $17,50 \%$ \\
\hline 1991 & 1.522 .184 & 312.721 & $25,90 \%$ & 2005 & 16.086 .644 & 2.710 .652 & $20,30 \%$ \\
\hline 1992 & 2.039 .000 & 516.816 & $34,00 \%$ & 2006 & 18.615 .960 & 2.529 .316 & $15,70 \%$ \\
\hline 1993 & 2.427 .163 & 388.163 & $19,00 \%$ & 2007 & 21.721 .282 & 3.105 .322 & $16,70 \%$ \\
\hline 1994 & 3.000 .000 & 572.837 & $23,60 \%$ & 2008 & 25.481 .039 & 3.759 .757 & $17,30 \%$ \\
\hline 1995 & 3.578 .156 & 578.156 & $19,30 \%$ & 2009 & 28.431 .079 & 2.950 .040 & $11,60 \%$ \\
\hline 1996 & 4.208 .274 & 630.118 & $17,60 \%$ & 2010 & 31.452 .503 & 3.021 .424 & $10,60 \%$ \\
\hline 1997 & 4.827 .219 & 618.945 & $14,70 \%$ & 2011 & 33.925 .839 & 2.473 .336 & $7,90 \%$ \\
\hline 1998 & 5.200 .000 & 372.781 & $7,70 \%$ & 2012 & 36.102 .943 & 2.177 .104 & $6,40 \%$ \\
\hline 1999 & 5.585 .000 & 385.000 & $7,40 \%$ & 2013 & 38.643 .091 & 2.540 .148 & $7,00 \%$ \\
\hline 2000 & 6.210 .823 & 625.823 & $11,20 \%$ & 2014 & 41.212 .965 & 2.569 .874 & $6,70 \%$ \\
\hline 2001 & 8.359 .042 & 2.148 .219 & $34,60 \%$ & 2015 & 44.128 .822 & 2.915 .857 & $7,10 \%$ \\
\hline 2002 & 10.273 .000 & 1.913 .958 & $22,90 \%$ & 2016 & 47.131 .928 & 3.003 .106 & $6,80 \%$ \\
\hline 2003 & 11.379 .000 & 1.106 .000 & $10,80 \%$ & 2017 & $54.606 .388^{\mathbf{1 0}}$ & 3.298 .260 & $7,00 \%$ \\
\hline & & & & 2018 & $58.169 .432^{\mathbf{1 1}}$ & 4.002 .931 & $7,33 \%$ \\
\hline
\end{tabular}

Nguồn: Ủy ban An toàn giao thông Quốc gia

Từ Bảng 1 có thể phân tích về các giai đoạn gia tăng xe máy, bình quân số xe máy trên 100 dân như dưới đây:

\footnotetext{
${ }^{9}$ Do xe máy điện năm 2015 mới phát triển và đăng ký vì vậy để so sánh đồng nhất với các năm trước nên số liệu "xe máy” ở đây chưa bao gồm xe máy điện. Xe máy điện được thống ke theo bảng riêng

${ }^{10}$ Tổng số xe máy đăng ký 2017 được điều chỉnh do sai số các năm trước

${ }^{11}$ Sai số: 103.183 xe
} 


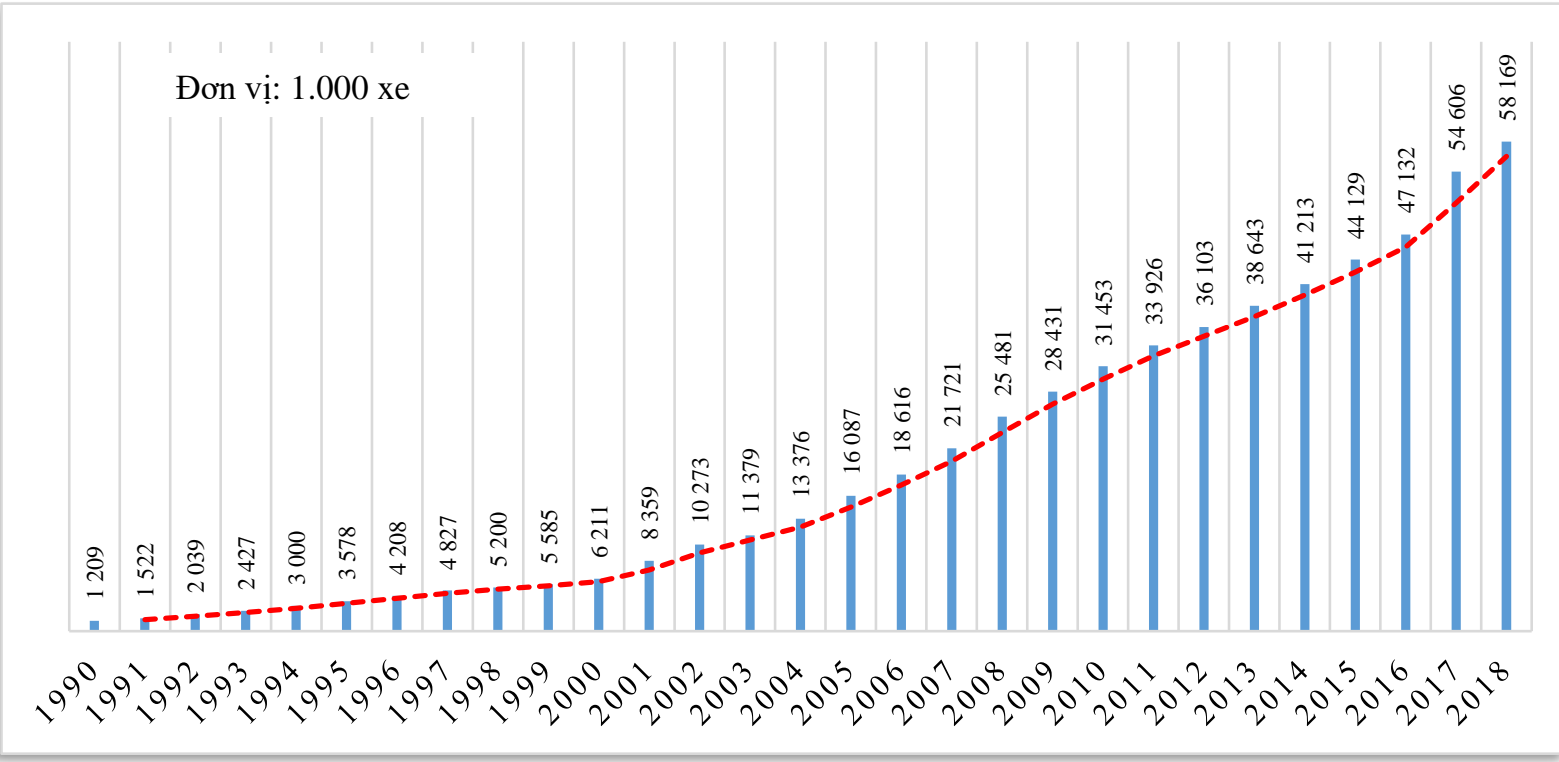

\section{Hình 1-12 Số lượng xe máy 1990 - 2018}

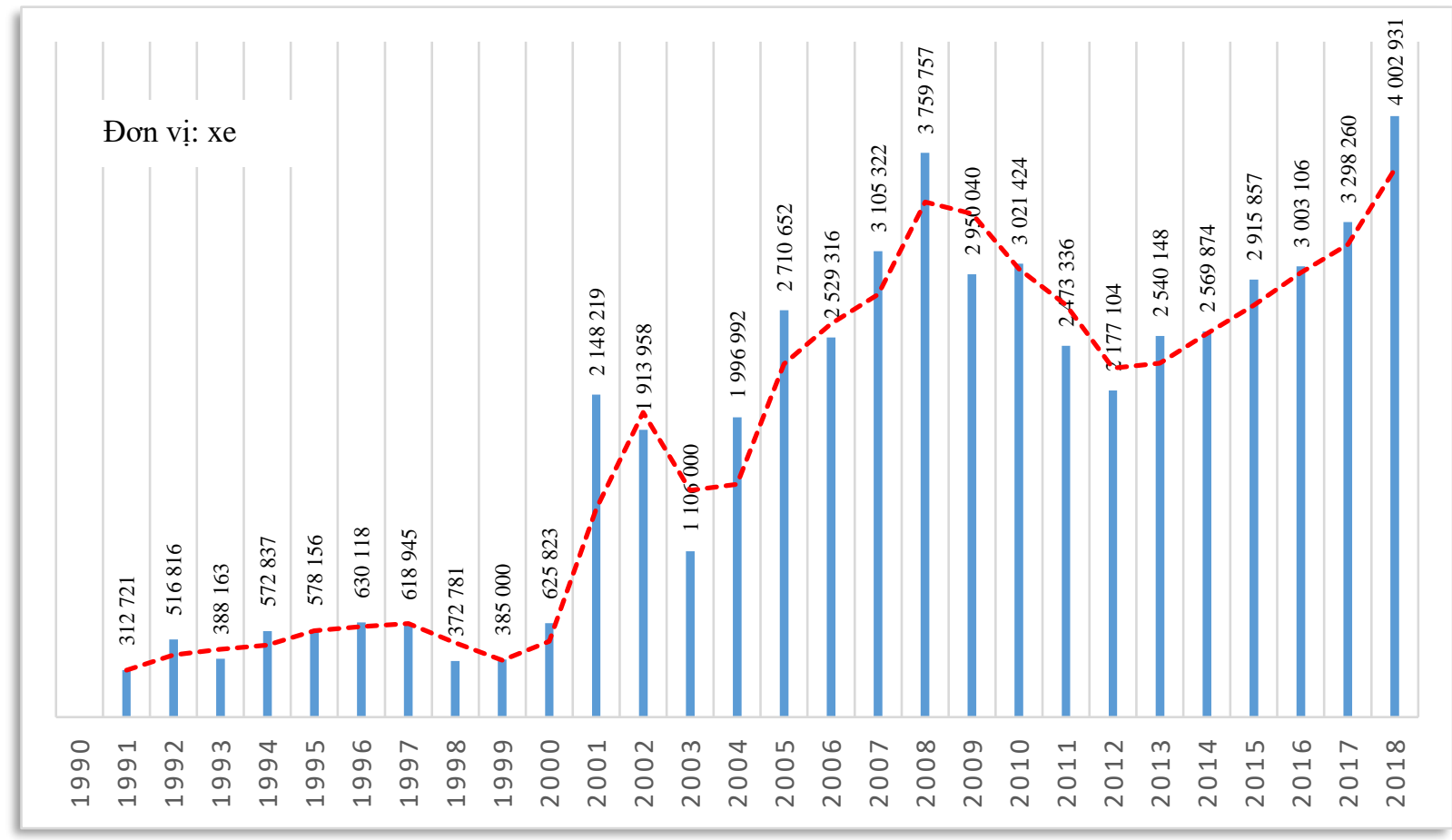

\section{Hình 1-13 Số xe máy tăng hàng năm so với năm liền trước}

Giai đoạn 1990 - 2000, bình quân mỗi năm tăng 500.000 xe máy, bình quân mỗi năm tăng $18,04 \%$.

Giai đoạn 2001- 2006, bình quân mỗi năm tăng 2.067.523 xe máy, bình quân mỗi năm tăng 20,30\%, riêng năm 2001, do xe máy Trung Quốc giá rẻ ồ ạt vào Việt nam nên năm 2001 số lượng xe máy tăng đột biến 2.148.219, tăng 34\% so với năm 2000.

Giai đoạn 2007- 2017, bình quân mỗi năm tăng 2.892.203 xe máy, bình quân mỗi năm tăng $9,55 \%$. 
Từ năm 1990 đến năm 2017, xe máy ở Việt Nam tăng 41 lần, tăng 49.220 .735 xe; từ 1995 đến 2017 số xe máy bình quân trên 100 dân tăng từ 5 xe/100 dân lên 54 xe/100 dân.

Bảng 1-7 Số xe máy trên 100 dân 1995-2018

\begin{tabular}{|c|c|c|c|}
\hline Năm & Dân số (1.000 dân) & Xe máy (1.000 xe) & bq xe máy/100 dân \\
\hline 1995 & 71.995 & 3.578 & 5 \\
\hline 1996 & 73.156 & 4.208 & 6 \\
\hline 1997 & 74.306 & 4.827 & 6 \\
\hline 1998 & 75.456 & 5.200 & 7 \\
\hline 1999 & 76.596 & 5.585 & 7 \\
\hline 2000 & 77.630 & 6.211 & 8 \\
\hline 2001 & 78.620 & 8.359 & 11 \\
\hline 2002 & 79.537 & 10.273 & 13 \\
\hline 2003 & 80.467 & 11.379 & 14 \\
\hline 2004 & 81.436 & 13.376 & 16 \\
\hline 2005 & 82.392 & 16.087 & 20 \\
\hline 2006 & 83.311 & 18.616 & 22 \\
\hline 2007 & 84.218 & 21.721 & 26 \\
\hline 2008 & 85.118 & 25.481 & 30 \\
\hline 2009 & 86.025 & 28.431 & 33 \\
\hline 2010 & 86.947 & 31.453 & 36 \\
\hline 2011 & 87.860 & 33.926 & 39 \\
\hline 2012 & 88.809 & 36.103 & 41 \\
\hline 2013 & 89.759 & 38.643 & 43 \\
\hline 2014 & 90.728 & 41.213 & 45 \\
\hline 2015 & 91.709 & 44.129 & 48 \\
\hline 2016 & 92.695 & 47.132 & 51 \\
\hline 2017 & 93.700 & 54.606 & 58 \\
\hline 2018 & $94.700^{12}$ & 58.169 & 61 \\
\hline
\end{tabular}

Nguồn: dân số -Tổng cục Thống kê

${ }^{12}$ Dự báo dân số năm 2018 của Tổng cục Dân số-Kế hoạch hóa gia đình (Bộ Y tế) năm 2017 


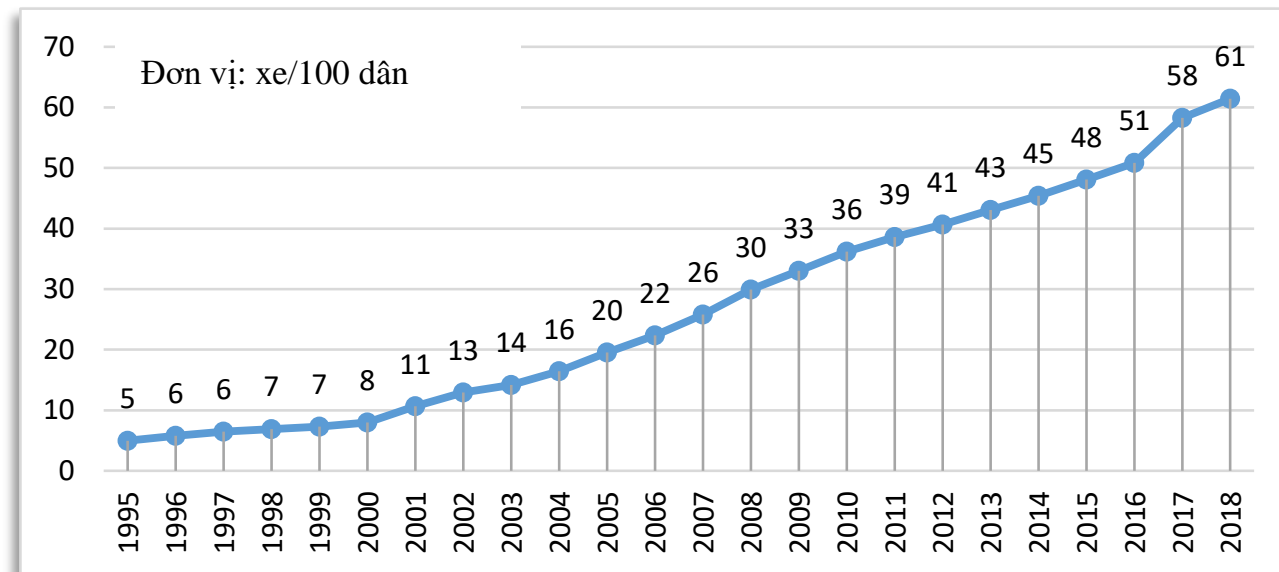

\section{Hình 1-14 Số xe máy bình quân trên 100 dân 1995 - 2018}

Bảng 1-8 Xe máy điện 2015-2018

\begin{tabular}{|l|r|r|r|}
\hline Năm & Đăng ký mới (xe) & Tăng \% & \multicolumn{1}{c|}{ Tổng số } \\
\hline 2015 & 152.806 & & 152.806 \\
\hline 2016 & 501.400 & $328 \%$ & 654.206 \\
\hline 2017 & 227.051 & $35 \%$ & 881.257 \\
\hline 2018 & 194.373 & $22 \%$ & 1.075 .630 \\
\hline
\end{tabular}

Nguồn: UBATGTQG

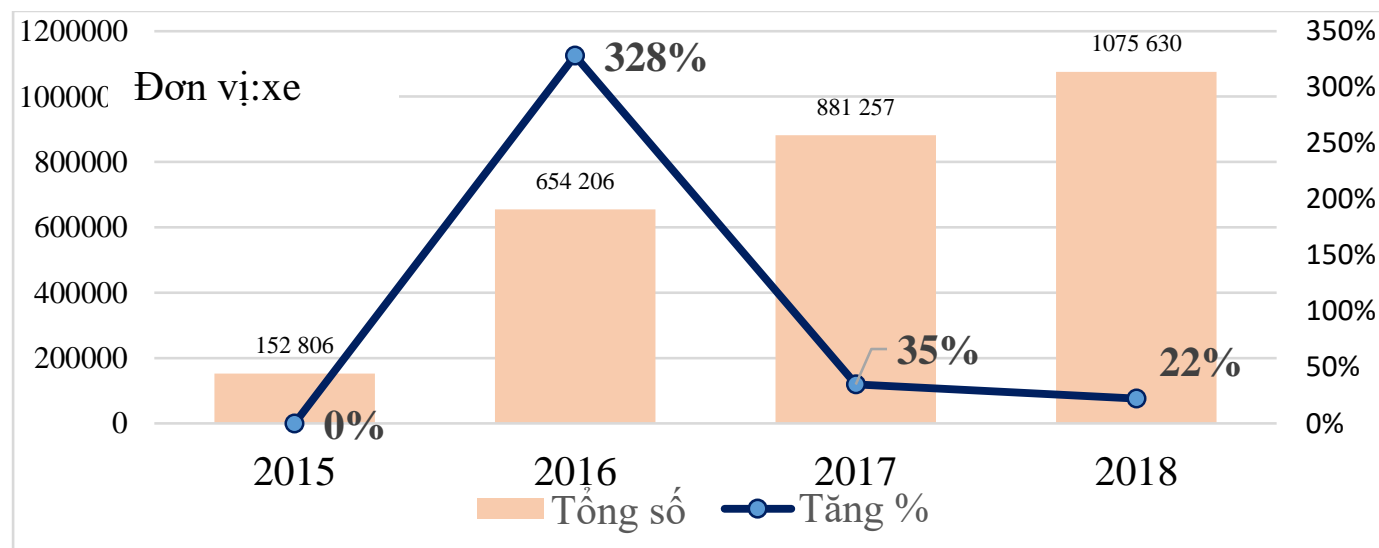

Hình 1-15 Số xe máy điện và gia tăng xe máy điện hàng năm từ 2015-2018

Số liệu phân tích ở trên cho thấy Việt Nam phát triển xe máy quá nhanh, hiện nay vẫn trong giai đoạn bùng nổ phương tiện xe máy. Xe máy tăng quá nhanh sẽ có những hệ lụy năng nề về: tai nạn giao thông, ô nhiễm môi trường và ùn tắc giao thông ở các thành phố lớn. Việt Nam đứng đầu các nước ASEAN về tỷ lệ xe máy trên tổng số phương tiện cơ giới đường bộ và về số xe máy trên 100 dân. 


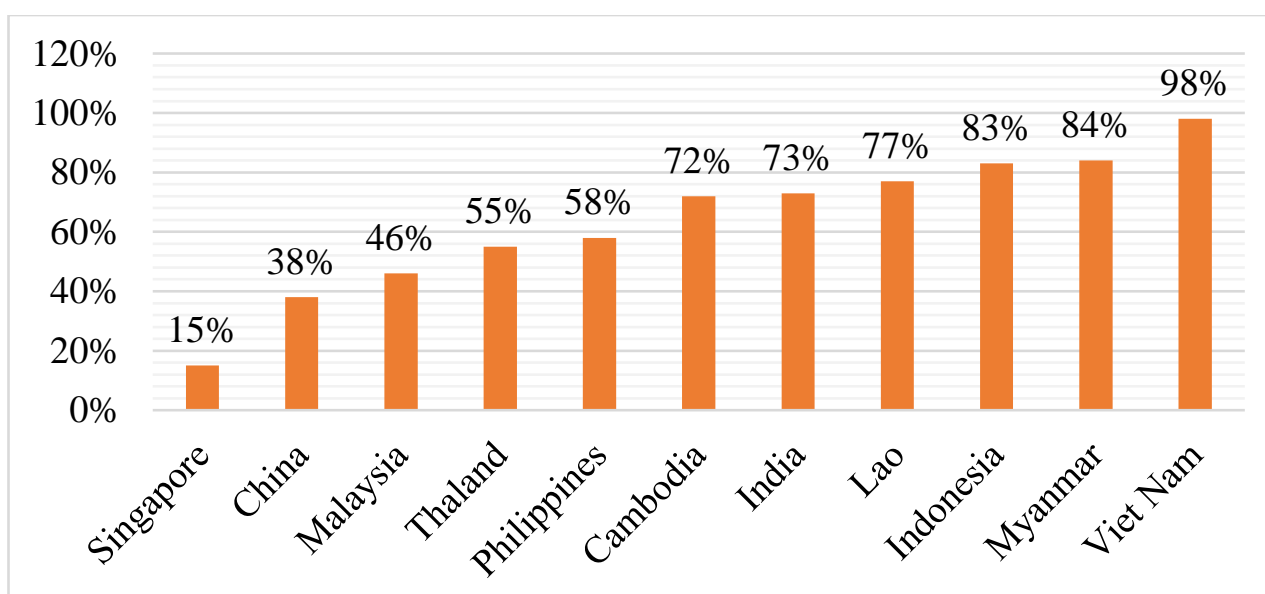

Hình 1-16 Số lượng xe máy trong tổng số phương tiện cơ giới đường bộ các nước ASEAN, Trung Quốc và Ần Độ

Nguồn: Báo cáo tình trạng toàn cầu về an toàn giao thông đường bộ 2018 của WHO ( Global Status Report on Road Safety 2018) (Trung Quốc, Indonesia Báo cáo tình trạng toàn cầu về an toàn giao thông đường bộ 2015 của WHO ( Global Status Report on Road Safety 2015)

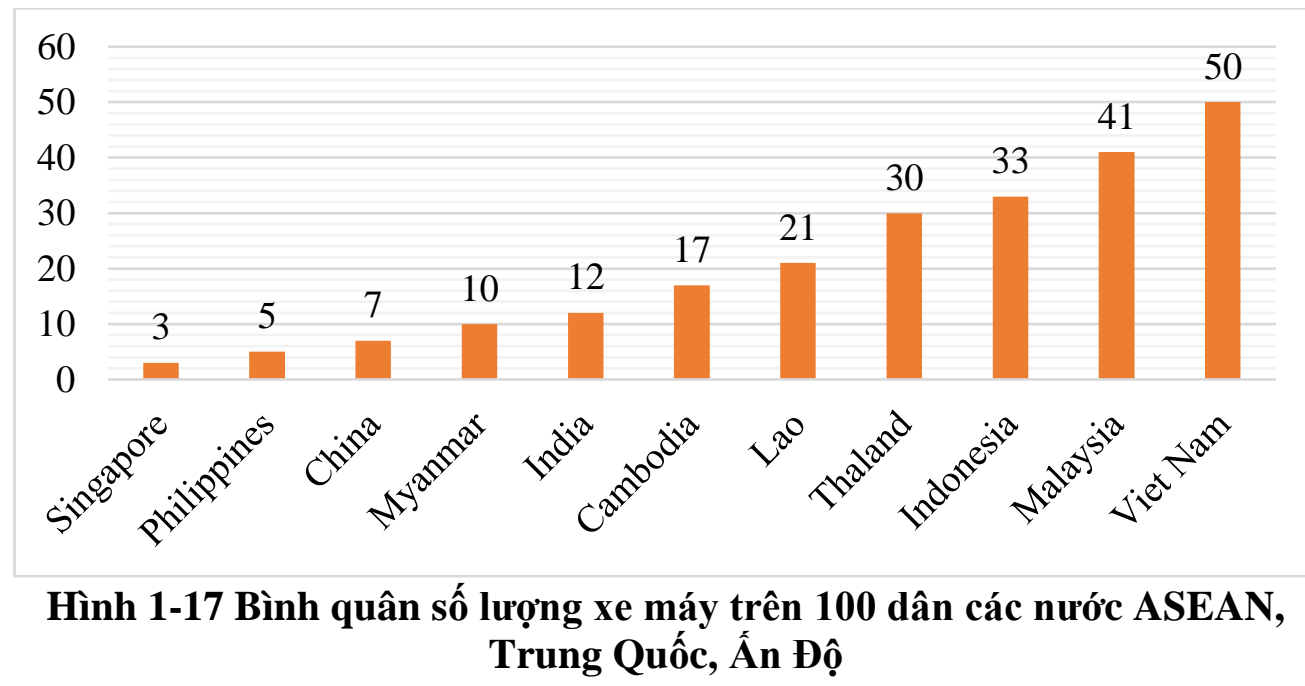

Nguồn: Báo cáo tình trạng toàn cầu về an toàn giao thông đường bộ 2018 của WHO ( Global status report on road safety 2018) (Trung Quốc, Indonesia Báo cáo tình trạng toàn cầu về an toàn giao thông đường bộ 2015 của WHO ( Global status report on road safety 2015)

\subsubsection{Những đặc điểm của xe máy ở Việt Nam}

Đặc điểm vấn đề xe máy ở Việt Nam có nhiều điểm chung như các nước Châu Á, tuy nhiên Việt Nam có một số điểm khác biệt như sau:

(1) Tỷ lệ xe máy trên tổng số phương tiện cơ giới đường bộ quá cao, chiếm $94 \%$ tổng số phương tiện cơ giới đường bộ.

(2) Là phương tiện giao thông phổ biến cho nhiều đối tượng, ngành nghề, độ tuổi, xe máy không đơn thuần là phương tiện đi lại cá nhân mà còn dùng làm phương tiện kiếm sống, kinh doanh (chở người, chở hàng). 
(3) Số lượng xe máy giữa nông thôn và thành thị chênh lệch khá cao. Xe máy ở Việt Nam phân bố không đều, tập trung nhiều ở các đô thị, đặc biệt là ở Hà Nội và Thành phố Hồ Chí Minh. Tỷ lệ xe máy bình quân trên đầu người ở vùng nông thôn thấp hơn tỷ lệ này ở đô thị.

Bảng 1-9 Xe máy tính trên 1000 dân các địa phương ${ }^{13}$

\begin{tabular}{|c|c|c|c|c|}
\hline STT & Địa phương & $\begin{array}{l}\text { Dân số trung bình } \\
\text { (Nghìn người) }\end{array}$ & Số xe máy đăng ký & $\begin{array}{c}\text { Bình quân xe máy } \\
\text { trên } 1.000 \text { dân }\end{array}$ \\
\hline 1 & Bắc Giang & 1674,4 & 1679890 & 1003 \\
\hline 2 & Tây Ninh & 1126,2 & 1045634 & 928 \\
\hline 3 & TP Hồ Chí Minh & 8444,6 & 7415051 & 878 \\
\hline 4 & Đà Nẵng & 1064,1 & 844153 & 793 \\
\hline 5 & Bà Rịa-Vũng Tàu & 1101,6 & 872585 & 792 \\
\hline 6 & Hà Nội & 7420,1 & 5483313 & 739 \\
\hline 7 & Khánh Hòa & 1222,2 & 885214 & 724 \\
\hline 8 & Bình Định & 1529 & 1086447 & 711 \\
\hline 9 & Lâm Đồng & 1298,9 & 907831 & 699 \\
\hline 10 & Long An & 1496,8 & 1017000 & 679 \\
\hline 11 & Bình Phước & 968,9 & 654496 & 676 \\
\hline 12 & Đồng Nai & 3027,3 & 2010876 & 664 \\
\hline 13 & Tiền Giang & 1751,8 & 1154898 & 659 \\
\hline 14 & Bến Tre & 1266,7 & 807034 & 637 \\
\hline 15 & Bình Thuận & 1230,4 & 775936 & 631 \\
\hline 16 & Phú Yên & 904,4 & 567042 & 627 \\
\hline 17 & Đăk Lăk & 1896,6 & 1156791 & 610 \\
\hline 18 & Hải Dương & 1797,3 & 1094041 & 609 \\
\hline 19 & Thừa Thiên-Huế & 1154,3 & 701888 & 608 \\
\hline 20 & An Giang & 2161,7 & 1306923 & 605 \\
\hline 21 & Bạc Liêu & 894,3 & 530854 & 594 \\
\hline 22 & Vĩnh Long & 1050,2 & 616774 & 587 \\
\hline 23 & Ninh Thuận & 607 & 353400 & 582 \\
\hline 24 & Quảng Trị & 627,3 & 359041 & 572 \\
\hline 25 & Thái Nguyên & 1255,1 & 714065 & 569 \\
\hline 26 & Cần Thơ & 1272,8 & 723755 & 569 \\
\hline 27 & Vĩnh Phúc & 1079,5 & 609049 & 564 \\
\hline 28 & Trà Vinh & 1045,6 & 584559 & 559 \\
\hline 29 & Quảng Nam & 1493,8 & 834044 & 558 \\
\hline 30 & Kiên Giang & 1792,6 & 991255 & 553 \\
\hline 31 & Đồng Tháp & 1690,3 & 934652 & 553 \\
\hline 32 & Hải Phòng & 1997,7 & 1099506 & 550 \\
\hline 33 & Quảng Ninh & 1243,6 & 680778 & 547 \\
\hline
\end{tabular}

${ }^{13}$ Số liệu từ 16/11/2016 đến 15/11/2017; số liệu Bắc Giang, Long An điều chỉnh theo báo cáo của Ban An toàn giao thông Bắc Giang và Long An 


\begin{tabular}{|c|c|c|c|c|}
\hline STT & Địa phương & $\begin{array}{l}\text { Dân số trung bình } \\
\text { (Nghìn người) }\end{array}$ & Số xe máy đăng ký & $\begin{array}{c}\text { Bình quân xe máy } \\
\text { trên } 1.000 \text { dân }\end{array}$ \\
\hline 34 & Tuyên Quang & 773,5 & 422169 & 546 \\
\hline 35 & Bắc Ninh & 1215,2 & 658402 & 542 \\
\hline 36 & Phú Thọ & 1392,9 & 752610 & 540 \\
\hline 37 & Đăk Nông & 625,6 & 334756 & 535 \\
\hline 38 & Bình Dương & 2071 & 1104530 & 533 \\
\hline 39 & Quảng Ngãi & 1261,6 & 651364 & 516 \\
\hline 40 & Nam Định & 1853,3 & 945881 & 510 \\
\hline 41 & Gia Lai & 1437,4 & 732636 & 510 \\
\hline 42 & Lạng Sơn & 778,4 & 392936 & 505 \\
\hline 43 & Bắc Kạn & 323,2 & 160816 & 498 \\
\hline 44 & Quảng Bình & 882,5 & 431437 & 489 \\
\hline 45 & Yên Bái & 807,3 & 392735 & 486 \\
\hline 46 & Kon Tum & 520 & 249890 & 481 \\
\hline 47 & Nghệ An & 3131,3 & 1495015 & 477 \\
\hline 48 & Hà Tĩnh & 1272,2 & 592672 & 466 \\
\hline 49 & Lào Cai & 694,4 & 322842 & 465 \\
\hline 50 & Hưng Yên & 1176,3 & 543212 & 462 \\
\hline 51 & Thanh Hóa & 3544,4 & 1619208 & 457 \\
\hline 52 & Thái Bình & 1791,5 & 799669 & 446 \\
\hline 53 & Sóc Trăng & 1314,3 & 585242 & 445 \\
\hline 54 & Cao Bằng & 535,4 & 237850 & 444 \\
\hline 55 & Điện Biên & 567 & 245177 & 432 \\
\hline 56 & Hà Nam & 805,7 & 344532 & 428 \\
\hline 57 & Hậu Giang & 774,6 & 330944 & 427 \\
\hline 58 & Hòa Bình & 838,8 & 353948 & 422 \\
\hline 59 & Cà Mau & 1226,3 & 514840 & 420 \\
\hline 60 & Sơn La & 1228,9 & 513610 & 418 \\
\hline 61 & Ninh Bình & 961,9 & 364020 & 378 \\
\hline 62 & Hà Giang & 833,5 & 292663 & 351 \\
\hline 63 & Lai Châu & 446,1 & 138244 & 310 \\
\hline
\end{tabular}

Nguồn:

- Tổng cục Thống kê: Dân số các địa phương

- UBATGTQG: Xe máy đăng ký các địa phương 


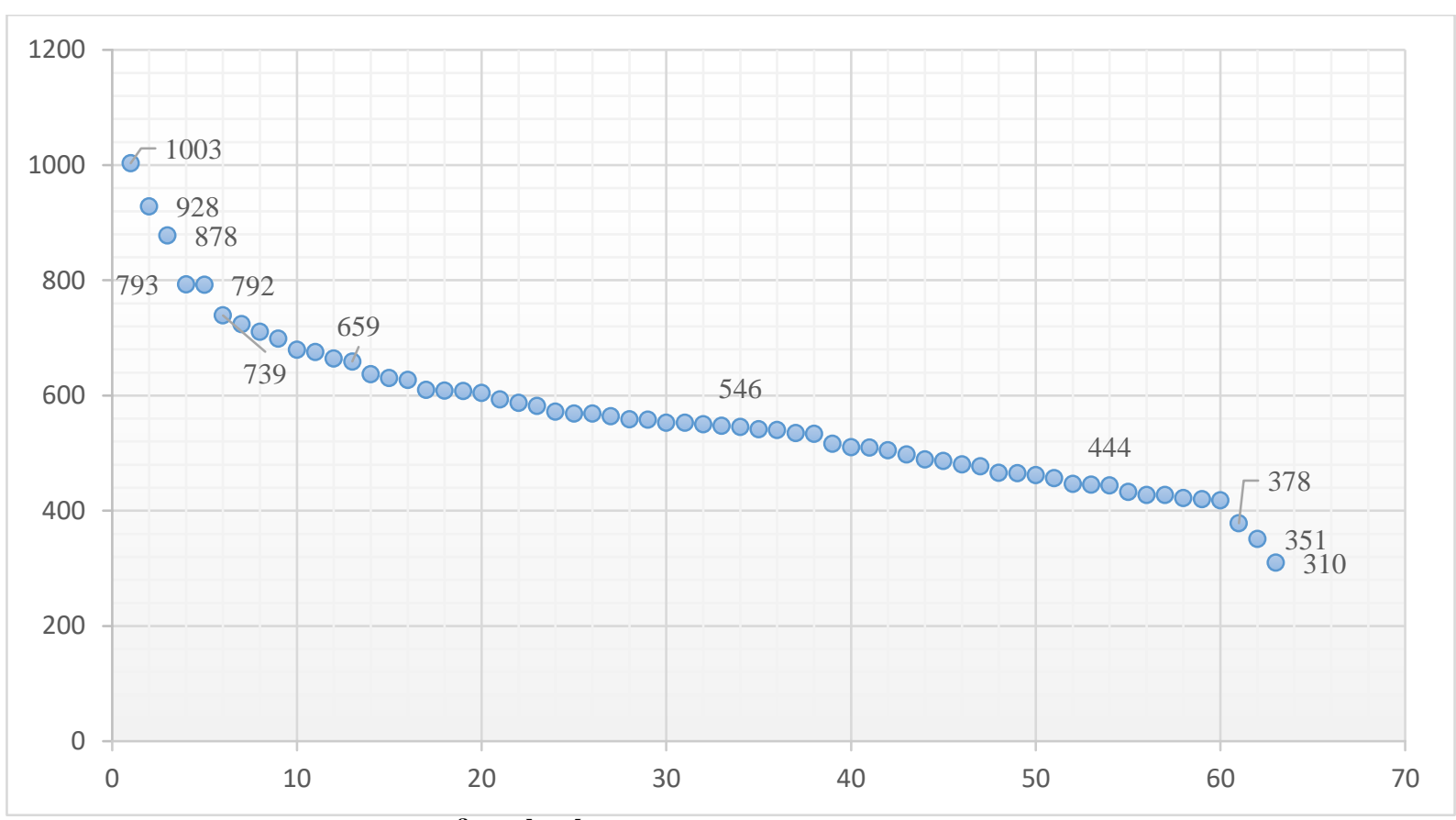

Hình 1-18 Biểu đồ số xe máy trên 1.000 dân các địa phương

Số liệu trên cho thấy: 7 địa phương có số xe máy trên 1.000 dân trên 700 xe ; 11 địa phương có số xe máy trên 1.000 dân từ trên 600 xe đến dưới 700 xe; 22 địa phương có số xe máy trên 1.000 dân từ trên 500 xe đến dưới 600 xe; 18 địa phương có số xe máy trên 1.000 dân từ trên 400 xe đến dưới 500 xe; 5 địa phương có số xe máy trên 1.000 dân từ dưới 400 xe. Như vậy có 40 địa phương có có số xe máy trên 1.000 dân từ trên 400 xe đến dưới 600 xe.

Số xe máy trên 1.000 dân chia theo các vùng như sau:

Bảng 1-10 Xe máy tính trên 1.000 dân theo khu vực năm 2017

\begin{tabular}{|c|l|r|r|c|}
\hline STT & \multicolumn{1}{|c|}{ Địa phương } & $\begin{array}{c}\text { Dân số trung bình } \\
\text { (Nghìn người) }\end{array}$ & $\begin{array}{c}\text { Số xe máy đăng } \\
\text { ký }\end{array}$ & $\begin{array}{c}\text { Bình quân xe } \\
\text { máy } \\
\text { trên } 1.000 \text { dân }\end{array}$ \\
\hline & & \multicolumn{3}{|c|}{ Đồng bằng Sông Hồng } \\
\hline 1 & Hà Nội & 7420,1 & 5483313 & 739 \\
\hline 2 & Vĩnh Phúc & 1079,5 & 609049 & 564 \\
\hline 3 & Bắc Ninh & 1215,2 & 658402 & 542 \\
\hline 4 & Quảng Ninh & 1243,6 & 680778 & 547 \\
\hline 5 & Hải Dương & 1797,3 & 1094041 & 609 \\
\hline 6 & Hải Phòng & 1997,7 & 1099506 & 550 \\
\hline 7 & Hưng Yên & 1176,3 & 543212 & 462 \\
\hline 8 & Thái Bình & 1791,5 & 799669 & 446 \\
\hline 9 & Hà Nam & 805,7 & 344532 & 428 \\
\hline 10 & Nam Định & 1853,3 & 945881 & 510 \\
\hline 11 & Ninh Bình & 961,9 & 364020 & 378 \\
\hline B/q xe máy trên 1.000 dân & $\mathbf{2 1 3 4 2 , 1}$ & $\mathbf{1 2 6 2 2 4 0 3}$ & $\mathbf{5 9 1}$ \\
\hline \multicolumn{4}{|r|}{ Trung du và miền núi Phía Bắc } \\
\hline
\end{tabular}




\begin{tabular}{|c|c|c|c|c|}
\hline STT & Địa phương & $\begin{array}{l}\text { Dân số trung bình } \\
\text { (Nghìn người) }\end{array}$ & $\begin{array}{l}\text { Sồ xe máy đăng } \\
\text { ký }\end{array}$ & $\begin{array}{c}\text { Bình quân xe } \\
\text { máy } \\
\text { trên } 1.000 \text { dân }\end{array}$ \\
\hline 12 & Hà Giang & 833,5 & 292663 & 351 \\
\hline 13 & Cao Bằng & 535,4 & 237850 & 444 \\
\hline 14 & Bằc Kạn & 323,2 & 160816 & 498 \\
\hline 15 & Tuyên Quang & 773,5 & 422169 & 546 \\
\hline 16 & Lào Cai & 694,4 & 322842 & 465 \\
\hline 17 & Yên Bái & 807,3 & 392735 & 486 \\
\hline 18 & Thái Nguyên & 1255,1 & 714065 & 569 \\
\hline 19 & Lạng Sơn & 778,4 & 392936 & 505 \\
\hline 20 & Bằc Giang & 1674,4 & 1679890 & 1003 \\
\hline 21 & Phú Thọ & 1392,9 & 752610 & 540 \\
\hline 22 & Điện Biên & 567 & 245177 & 432 \\
\hline 23 & Lai Châu & 446,1 & 138244 & 310 \\
\hline 24 & Sơn $\mathrm{La}$ & 1228,9 & 513610 & 418 \\
\hline 25 & Hòa Bình & 838,8 & 353948 & 422 \\
\hline \multicolumn{2}{|c|}{ B/q xe máy trên 1.000 dân } & 12148,9 & 6619555 & 545 \\
\hline \multicolumn{5}{|c|}{ Băc Trung Bộ và Duyên hải miên Trung } \\
\hline 26 & Thanh Hóa & 3544,4 & 1619208 & 457 \\
\hline 27 & Nghệ An & 3131,3 & 1495015 & 477 \\
\hline 28 & Hà Tỉnh & 1272,2 & 592672 & 466 \\
\hline 29 & Quảng Bình & 882,5 & 431437 & 489 \\
\hline 30 & Quảng Trị & 627,3 & 359041 & 572 \\
\hline 31 & Thừa Thiên - Huề & 1154,3 & 701888 & 608 \\
\hline 32 & Đà Nẳng & 1064,1 & 844153 & 793 \\
\hline 33 & Quảng Nam & 1493,8 & 834044 & 558 \\
\hline 34 & Quảng Ngãi & 1261,6 & 651364 & 516 \\
\hline 35 & Bình Định & 1529 & 1086447 & 711 \\
\hline 36 & Phú Yên & 904,4 & 567042 & 627 \\
\hline 37 & Khánh Hòa & 1222,2 & 885214 & 724 \\
\hline 38 & Ninh Thuận & 607 & 353400 & 582 \\
\hline 39 & Bình Thuận & 1230,4 & 775936 & 631 \\
\hline \multicolumn{2}{|c|}{ B/q xe máy trên 1.000 dân } & 19924,5 & 11196861 & 562 \\
\hline \multicolumn{5}{|c|}{ Tây Nguyên } \\
\hline 40 & Kon Tum & 520 & 249890 & 481 \\
\hline 41 & Gia Lai & 1437,4 & 732636 & 510 \\
\hline 42 & Đăk Lăk & 1896,6 & 1156791 & 610 \\
\hline 43 & Đăk Nông & 625,6 & 334756 & 535 \\
\hline 44 & Lâm Đồng & 1298,9 & 907831 & 699 \\
\hline \multicolumn{2}{|c|}{ B/q xe máy trên 1.000 dân } & 5778,5 & 3381904 & 585 \\
\hline \multicolumn{5}{|c|}{ Đông Nam Bộ } \\
\hline 45 & Bình Phước & 968,9 & 654496 & 676 \\
\hline
\end{tabular}


Dự án: Xây dựng chiến lược an toàn giao thông đối với xe máy và kế hoạch hành động: một khởi đầu của Việt Nam

Nghiên cứu hiện trạng giao thông xe máy Việt Nam

\begin{tabular}{|c|l|r|r|c|}
\hline STT & \multicolumn{1}{|c|}{ Địa phương } & $\begin{array}{c}\text { Dân số trung bình } \\
\text { (Nghìn người) }\end{array}$ & $\begin{array}{c}\text { Số xe máy đăng } \\
\text { ký }\end{array}$ & $\begin{array}{c}\text { Bình quân xe } \\
\text { máy } \\
\text { trên } 1.000 \text { dân }\end{array}$ \\
\hline 46 & Tây Ninh & 1126,2 & 1045634 & 928 \\
\hline 47 & Bình Dương & 2071 & 1104530 & 533 \\
\hline 48 & Đồng Nai & 1027,3 & 2010876 & 664 \\
\hline 49 & Bà Rịa - Vũng Tàu & 1101,6 & 872585 & 792 \\
\hline 50 & $\begin{array}{l}\text { Thành phố Hồ Chí } \\
\text { Minh }\end{array}$ & 8444,6 & 7415051 & 878 \\
\hline B/q xe máy trên 1.000 dân & $\mathbf{1 6 7 3 9 , 6}$ & $\mathbf{1 3 1 0 3 1 7 2}$ & $\mathbf{7 8 3}$ \\
\hline \multicolumn{2}{|r|}{ Đồng bằng sông Cửu Long } \\
\hline 51 & Long An & 1496,8 & 1017000 & 679 \\
\hline 52 & Tiền Giang & 1751,8 & 1154898 & 659 \\
\hline 53 & Bến Tre & 1266,7 & 807034 & 637 \\
\hline 54 & Trà Vinh & 1045,6 & 584559 & 559 \\
\hline 55 & Vình Long & 1050,2 & 616774 & 587 \\
\hline 56 & Đồng Tháp & 1690,3 & 934652 & 553 \\
\hline 57 & An Giang & 2161,7 & 1306923 & 605 \\
\hline 58 & Kiên Giang & 1792,6 & 991255 & 553 \\
\hline 59 & Cần Thơ & 1272,8 & 723755 & 569 \\
\hline 60 & Hậu Giang & 774,6 & 330944 & 427 \\
\hline 61 & Sóc Trăng & 1314,3 & 585242 & 445 \\
\hline 62 & Bạc Liêu & 894,3 & 530854 & 594 \\
\hline 63 & Cà Mau & 1226,3 & 514840 & 420 \\
\hline B/q xe máy trên 1.000 dân & $\mathbf{1 7 7 3 8}$ & $\mathbf{1 0 0 9 8 7 3 0}$ & $\mathbf{5 6 9}$ \\
\hline
\end{tabular}

Nguồn: Tồng cục Thống kê : Dân số các địa phương; UBATGTQG: Xe máy đăng ký các địa phương

Số xe máy khu vực Đông Nam bộ cao nhất: 783 xe/1.000 dân, sau đó khu vực sông Hồng gần 600 xe trên 1.000 dân; các khu vực Tây Nguyên, Bắc Trung Bộ và miền duyên hải, Đồng bằng sông Cửu Long trong khoảng 500 xe trên 1.000 dân; khu vực Trung du miền núi Phía Bắc thấp nhất trên 400 xe tính trên 1.000 dân.

\subsubsection{Những điều kiện phù hợp để xe máy phát triển nhanh}

Việt Nam hội nhiều điều kiện cho xe máy phát triển, đặc biệt trong khoảng 20 năm trở lại đây. Những điều kiện phù hợp để xe máy tăng nhanh xuất phát từ những ưu điểm của bản thân xe máy và những vấn đề xã hội, thời tiết, khí hậu ....Những điều kiện đó là:

(1) Điều kiện thời tiết, khí hậu cho phép sử dụng xe máy quanh năm. Việt Nam có khí hậu nhiệt đới, nhiệt độ trung bình tại Việt Nam dao động từ $21^{\circ} \mathrm{C}$ đến $27^{\circ} \mathrm{C}$, nóng dần về phía Nam, Việt Nam nằm trong vành đai nội chí tuyến, quanh năm có nhiệt độ cao và và độ ẩm lớn. Do thời tiết không quá khắc nghiệt nên có thể sử dụng xe máy quanh năm.

(2) Từ khi Việt Nam tiến hành công cuộc đổi mới, GDP không ngừng tăng trưởng, GDP bình quân trên đầu người cũng tăng liên tục. Việt Nam đã thoát nghèo, trở thànhnước có thu nhập trung bình, vì vậy nhiều người dân có điều kiện để mua xe máy. Tuy đời sống của người dân đã được nâng cao một bước, song người dân có thu nhập bình thường vẫn khó có thể mua nổi ô tô; một trong những lý do là giá ô tô của Việt Nam vào loại đắt trên thế giới, nằm ngoài khả năng mua sắm của người dân nói chung. Để đi lại thì phù hợp nhất vẫn là sử dụng xe máy. 
(3) Tốc độ công nghiệp hóa và đô thị hóa diễn ra rất nhanh, thúc đẩy nhu cầu đi lại cá nhân; trong khi đó giao thông công cộng, nhất là giao thông công cộng nội đô kém phát triển, phát triển chậm chạp, vì lẽ này buộc người dân phải sử dụng phương tiện giao thông cá nhân và chủ yếu là sử dụng xe máy.

(4) Quy hoạch đô thị, quy hoạch kiến trúc trong suốt thời gian qua, một phần nào đó đã tạo điều kiện cho gia tăng xe máy quá mức ở đô thị của Việt Nam. Nhiều khu vực đô thị ở Hà Nội, Thành phố Hồ Chí Minh trước là làng, xóm nay được đô thị hóa thành phố, người dân xây nhà nhiều tầng, mật độ dân tăng cao; đô thị hóa nằm dọc con đường làng nhỏ hẹp, mặc dù được trải nhựa tốt hơn; quy hoạch không dài hơi, manh mún đã tạo ra mạng lưới các ngõ ngách, chiều rộng ngõ ngách hẹp, số lượng cư dân lớn sống trong khu vực này chỉ có thể tiếp cận nơi ở bằng xe 2 bánh. Tình trạng đô thị như vậy thì tất nhiên xe máy sẽ còn tồn tại và vẫn phát triển trong nhiều năm nữa.

(5) Sống trong môi trường đô thị như nêu trên, dùng xe máy lâu ngày đã tạo thói quen ngại đi bộ, thói quen đi xe máy có thể đi từ "cửa" tới "cửa", với chợ cóc, chợ tạm mọc ở khắp nơi như hiện nay thì đi xe máy rất thuận tiện.

(6) Cuối cùng phải kể đến lợi thế linh hoạt của xe máy, có thể dừng đỗ, tìm nơi để xe dễ dàng, thuận tiện linh hoạt trong di chuyển, thực hiện được nhiều chuyến liên tục trong ngày, đặc biệt chi phí vận hành thấp.

\subsubsection{Những tác động tiêu cực do phát triển xe máy quá mức}

Không thể phủ nhận vai trò của xe máy trong nhiều năm qua ở Việt Nam, xe máy với tính cơ động cao, thuận tiện, có thể đến tận nơi cần đến không cần phải trung chuyển, nếu đi bộ đến được đâu thì xe máy cũng có thể đến được hầu hết nơi đó; diện tích chiếm chỗ của xe máy nhỏ hơn ô tô nhiều lần, thông thường xe máy chỉ chiếm khoảng 1/4 diện tích so với ô tô khi di chuyển trên đường; so với ô tô xe máy gây ô nhiễm môi trường ít hơn. Có thể nói, sau năm 1980 xe máy phát triển thay thế xe đạp là sự tiến bộ không thể không thừa nhận.

Tuy vậy, xe máy chưa bao giờ được coi là phương tiện an toàn và tiện nghi vì vậy nếu xe máy phát triển quá khả năng của kết cấu hạ tầng giao thông sẽ có nhiều hệ lụy rất đáng lo ngại. Hệ lụy đầu tiên là có nguy cơ gia tăng tai nạn giao thông; hệ lụy thứ hai là gây ùn tắc giao thông, đặc biệt là ở các đô thị lớn; hệ lụy thứ ba là gây ô nhiễm môi trường trầm trọng.

\subsubsection{Nguy co’ về tai nạn giao thông}

Người đi ô tô được bảo vệ bởi vỏ xe, chịu được va đập tốt, thiết kế bảo vệ khu vực người ngồi rất tốt; ngoài ra ô tô còn được trang bị nhiều thiết bị an toàn như : hệ thống chống bó cứng phanh ABS (Anti-Break lock System), hệ thống phân bổ lực phanh điện tử EBD (Electronic Brakeforce Distribution), các thiết bị an toàn thụ động (túi khí, dây an toàn). Đối với người đi xe máy thì duy nhất chỉ có chiếc mũ bảo hiểm để bảo vệ, vì vậy khi xẩy ra va chạm, thậm chí tự ngã cũng dẫn đến đến tử vong hay bị thương tật.

Trước khi thực hiện quy định bắt buộc đội mũ bảo hiểm khi đi xe máy (ngày 15 tháng 12 năm 2007) thì tai nạn giao thông đường bộ nói chung, tai nạn giao thông liên quan đến xe máy nói 
riêng luôn luôn đồng biến với gia tăng số lượng xe máy, đặc biệt những năm số lượng xe máy tăng đột biến thì tai nạn giao thông cũng tăng đột biến.

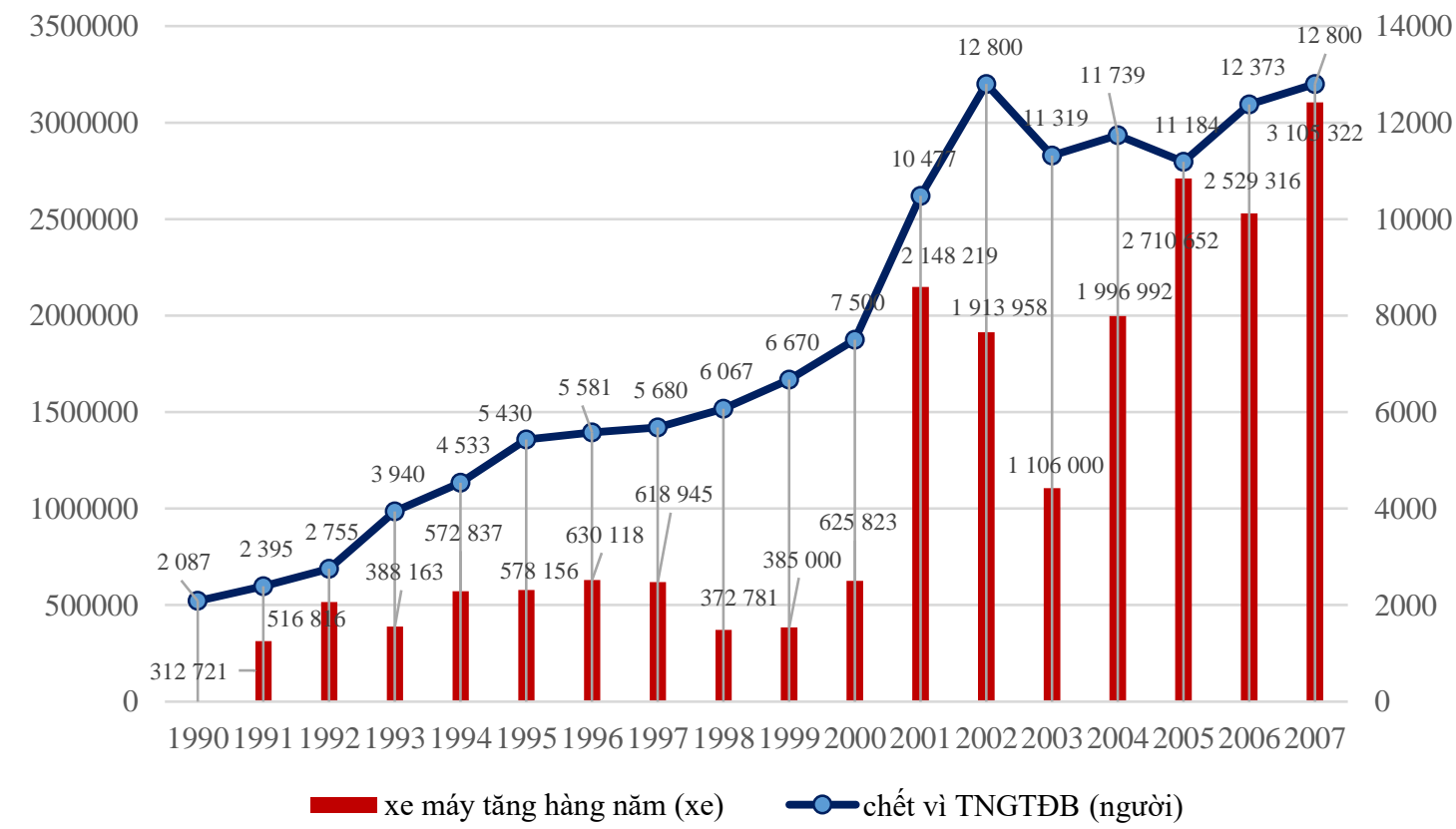

Hình 1-19 Số xe máy tăng và số người bị chết vì tai nạn giao thông 1990 - 2007

Nguồn: Cục Cảnh sát giao thông

Tai nạn giao thông xe máy luôn luôn chiếm tỷ lệ cao trong tổng số tai nạn giao thông đường bộ, trước những năm 2014 tai nạn giao thông xe máy chiếm trên $70 \%$ số vụ tai nạn giao thông đường bộ, từ năm 2015 tai nạn giao thông xe máy có giảm xuống dưới $70 \%$ số vụ tai nạn giao thông đường bộ.

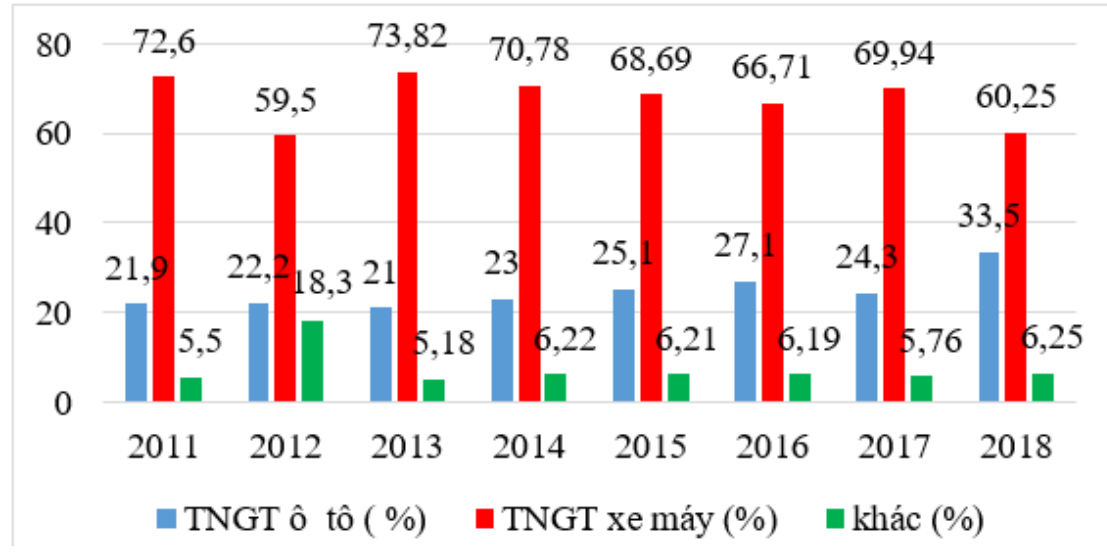

Hình 1-20 Tỷ lệ vụ tai nạn giao thông xe máy trong tổng số vụ TNGT đường bộ

Nguồn: Cục Cảnh sát giao thông

\subsubsection{Gây ùn tắc giao thông ở các đô thị, trầm trọng là ở Hà Nội và Thành phố Hồ Chí Minh}

Không kiểm soát được phương tiện giao thông cá nhân, không phát triển được vận tải hành khách công cộng nội đô sẽ dẫn đến tình trạng ùn tắc giao thông ở các đô thị. Năm 2016 Hà Nội có 42 xe ô tô con /1.000 dân, 684 xe máy/1.000 dân, xe máy chiếm 91,54 \% tổng số phương 
tiện cơ giới đường bộ, trong khi đó xe ô tô chỉ chiếm 8,46\%. Năm 2017 Thành phố Hồ Chính Minh có 26 ô tô con/1.000 dân, 860 xe máy /1.000 dân, xe máy chiếm 93,5\% tổng số phương tiện cơ giới đường bộ, trong khi đó ô tô chiếm $6,4 \%^{(5)}$. Số lượng ô tô cá nhân của Hà Nội và Thành phố Hồ Chí Minh chưa ở mức cao, nhưng số xe máy quá lớn và đang là nguyên nhân gây ùn tắc giao thông.

\subsubsection{Xe máy góp phần gây ô nhiễm trầm trọng ở các đô thị, đặc biệt là ở Hà Nội và Thành phố Hồ Chí Minh}

Các nguồn gây ô nhiễm không khí tại các đô thị được chỉ ra chủ yếu gồm hoạt động giao thông vận tải, hoạt động xây dựng, hoạt động của các xí nghiệp nội đô, sinh hoạt của dân cư, xử lý rác thải và các nguồn ô nhiễm từ ngoại thành chuyển vào được xem là những nguyên nhân chính khiến môi trường không khí tại các khu đô thị ngày càng trở nên nhức nhối.

Trong tổng lượng phát thải gây ô nhiễm môi trường không khí đô thị thì khí thải từ các phương tiện giao thông cơ giới đường bộ chiếm vị trí hàng đầu. Trong các loại phương tiện giao thông thì xe máy chiếm tỷ lệ lớn nhất đồng thời cũng là nguồn phát thải chất gây ô nhiễm lớn nhất. Có thể khẳng định, khí thải ô nhiễm môi trường ở đô thị có tới $70 \%$ bắt nguồn từ các phương tiện giao thông. Ở Việt Nam, khoảng $75 \%$ số lượng ô tô chạy bằng nhiên liệu xăng, $25 \%$ số lượng ô tô chạy bằng dầu $\mathrm{DO}, 100 \%$ xe máy chạy bằng xăng.

Xe máy ở Việt Nam bao gồm nhiều chủng loại, có nhiều xe qua nhiều năm sử dụng và không thường xuyên bảo dưỡng, hiệu quả sử dụng nhiên liệu thấp, nồng độ chất độc hại và bụi trong khí thải cao. Xe máy hiện vẫn là nguồn đóng góp chính các loại khí ô nhiễm, đặc biệt đối với các khí thải như $\mathrm{CO}$ và VOC. 


\section{CHÍNH SÁCH, VĂN BẢN PHÁP LUẬT VỀ HẠN CHẾ TAI NẠN GIAO THÔNG XE MÁY VÀ QUẢN LÝ XE MÁY}

Chính sách được hiểu chung là "sách lược và các chủ trương, biện pháp cụ thể để thực hiện đường lối và nhiệm vụ trong một thời kỳ lịch sử nhất định"14. Chính sách là cơ sở nền tảng để chế định nên pháp luật, pháp luật là kết quả của sự thể chế hóa chính sách; với quan niệm nêu trên chương II chủ yếu nghiên cứu các chính sách liên quan trực tiếp đến hạn chế tai nạn giao thông đến xe máy và quản lý xe máy đã được thể chế hóa thành pháp luật. Tuy nhiên, trong một vài trường hợp có thể đề cập đến một số chính sách chưa được luật hóa, hoặc có khả năng sẽ được luật hóa trong tương lai gần. Một số chủ đề như: thực hiện quy định bắt buộc đội mũ bảo hiểm khi đi xe máy, chính sách phát triển vận tải khách công cộng, tuyên truyền an toàn giao thông được nghiên cứu sâu hơn để có những cơ sở xây dựng chiến lược an toàn giao thông cho xe máy, quản lý xe máy trong dài hạn và kế hoạch hành động 3 năm .

\subsection{Văn bản pháp luật về an toàn giao thông xe máy và quản lý xe máy}

\subsubsection{Văn bản pháp luật trật tự an toàn giao thông đường bộ trước khi ban hành Luật giao thông đường bộ 2001}

Sau khi thống nhất đất nước năm 1975, kinh tế Việt Nam bước vào giai đoạn 1976 -1986, giai đoạn thời kỳ bao cấp, là giai đoạn áp dụng mô hình kinh tế cũ ở miền Bắc cho cả nước sau khi thống nhất và đồng thời là giai đoạn của những tìm tòi để thoát khỏi mô hình này.

Trong 5 năm, từ năm1976 đến năm 1980, trên mặt trận kinh tế, nhân dân Việt Nam đã đạt được những thành tựu quan trọng: khắc phục từng bước những hậu quả nặng nề của chiến tranh xâm lược do đế quốc Mỹ gây ra và của cuộc chiển tranh biên giới; khôi phục phần lớn những cơ sở công nghiệp, nông nghiệp, giao thông ở miền Bắc và xây dựng lại các vùng nông thôn ở miền Nam bị chiến tranh tàn phá; củng cố kinh tế quốc doanh và kinh tế tập thể ở miền Bắc, bước đầu cải tạo và sắp xếp công thương nghiệp tư doanh ở miền Nam, đưa một bộ phận nông dân Nam Bộ, nông dân Nam Trung Bộ vào con đường làm ăn tập thể; bước đầu phân bố lại lực lượng lao động xã hội; tăng cường một bước cơ sở vật chất-kỹ thuật của nền kinh tế quốc dân.

Tuy vậy, tình hình kinh tế-xã hội và đời sống nhân dân vẫn còn nhiều khó khăn, khủng hoảng kinh tế-xã hội vẫn trầm trọng mà biểu hiện là:

- Kinh tế tăng trưởng thấp và thực chất không phát triển.

- Không có tích luỹ từ nội bộ nền kinh tế vì làm không đủ ăn, thu nhập quốc dân sản xuất chỉ bằng $80-90 \%$ thu nhập quốc dân sử dụng.

- Siêu lạm phát hoành hành, năm 1986 lạm phát đạt đỉnh điểm với tốc độ tăng giá 774,7\%

- Đời sống nhân dân hết sức khó khăn, thiếu thốn. ${ }^{15}$

Có thể coi đây là giai đoạn kinh tế khó khăn lần thứ nhất sau khi đất nước thống nhất. Kinh tế không phát triển nên giao thông đường bộ cũng phát triển chậm, phương tiện cơ giới đường bộ tăng không đáng kể, đi lại khó khăn vì vậy tai nạn giao thông đường bộ chưa là vấn đề bức xúc của xã hội.

\footnotetext{
${ }^{14}$ Từ điển tiếng Việt

${ }^{15}$ Một vài nét về về kinh tế-xã hội Việt Nam - Cổng thông tin điện tử Chính phủ
} 
Năm 1986, nhờ chính sách đổi mới, sản xuất lương thực đạt kết quả thần kỳ, dầu thô được khai thác và xuất khẩu ... Việt Nam vượt qua khó khăn kinh tế, chuyển từ nước kém phát triển sang nhóm nước đang phát triển. Cùng với phát triển kinh tế, phương tiện giao thông cơ giới đường bộ bắt đầu gia tăng đáng kể.

Từ năm 1990 đến năm 1996 ô tô tăng bình quân: 23.464 xe/năm (8\%/năm), xe máy tăng bình quân: 499.802 xe/năm (23\%/năm).

Phương tiện cơ giới đường bộ bắt đầu tăng, nhu cầu đi lại, giao thương tăng nhanh, tai nạn giao thông đường bộ có xu hướng gia tăng.

Trước năm 1995, các văn bản pháp luật về trật tự an toàn giao thông đường bộ còn sơ sài, ví dụ Nghị định 143-CP của Hội đồng Chính phủ ngày 27 tháng 5 năm 1977 về ban hành Điều lệ phạt vi cảnh, phần hành vi gây trở ngại cho trật tự an toàn giao thông đường bộ chỉ quy định có 21 hành vi bị xử phạt.

Bảng 2-1 Phương tiện cơ giới đường bộ 1990-1996 ${ }^{16}$

\begin{tabular}{|c|c|c|c|c|c|c|c|}
\hline \multirow{2}{*}{ Năm } & \multicolumn{3}{|c|}{ Ô tô } & \multicolumn{3}{c|}{ Xe máy } & \multirow{2}{*}{$\begin{array}{c}\text { Tổng số } \\
\text { PTCGĐB }\end{array}$} \\
\cline { 2 - 7 } & Số đăng ký & Tăng / giảm & $\%$ & Số đăng ký & Tăng / giảm & \% & \multirow{2}{*}{ PTC } \\
\hline 1990 & 246.194 & & & 1.209 .463 & & & 1.455 .657 \\
\hline 1991 & 256.989 & 10.795 & $4 \%$ & 1.522 .184 & 312.721 & $26 \%$ & 1.779 .173 \\
\hline 1992 & 268.000 & 11.011 & $4 \%$ & 2.039 .000 & 516.816 & $34 \%$ & 2.307 .000 \\
\hline 1993 & 292.000 & 24.000 & $9 \%$ & 2.427 .163 & 388.163 & $19 \%$ & 2.719 .163 \\
\hline 1994 & 330.000 & 38.000 & $13 \%$ & 3.000 .000 & 572.837 & $24 \%$ & 3.330 .000 \\
\hline 1995 & 340.779 & 10.779 & $3 \%$ & 3.578 .156 & 578.156 & $19 \%$ & 3.918 .935 \\
\hline 1996 & 386.979 & 46.200 & $14 \%$ & 4.208 .274 & 630.118 & $18 \%$ & 4.595 .253 \\
\hline bq/năm & & 23.464 & $8 \%$ & & 499.802 & $23 \%$ & \\
\hline
\end{tabular}

Từ năm 1995 khi số người bị chết vị tai nạn giao thông đường bộ vượt trên 5.000 người, Chính phủ, đặc biệt Thủ tướng Chính phủ Võ văn Kiệt là người đầu tiên quan tâm đến công tác bảo đảm trật tự an toàn giao thông đường bộ. Yêu cầu đầu tiên để giải quyết vấn đề tai nạn giao thông là phải nhanh chóng xây dựng hệ thống pháp luật về trật tự an toàn giao thông đường bộ. Thủ tướng Chính phủ Võ văn Kiệt đã chỉ đạo xây dựng Nghị định 36-CP ngày 29 tháng 5 năm 1995 về bảo đảm trật tự an toàn giao thông đường bộ và trật tự an toàn giao thông đô thị, Nghị định có hiệu lực từ ngày 1 tháng 8 năm 1995.

\section{Bảng 2-2 Tai nạn giao thông 1990-1996 ${ }^{17}$}

\begin{tabular}{|c|c|c|c|c|c|c|c|c|c|}
\hline \multirow{2}{*}{ Năm } & \multicolumn{3}{|c|}{ Số vụ } & \multicolumn{3}{c|}{ Số người bị chết } & \multicolumn{3}{c|}{ Số người bị thương } \\
\cline { 2 - 11 } & Số vụ & $\begin{array}{c}\text { Tăng / } \\
\text { giảm }\end{array}$ & $\%$ & $\begin{array}{c}\text { Số } \\
\text { người }\end{array}$ & $\begin{array}{c}\text { Tăng / } \\
\text { giảm }\end{array}$ & $\%$ & Số người & $\begin{array}{c}\text { Tăng / } \\
\text { giảm }\end{array}$ & $\%$ \\
\hline 1990 & 6.110 & & & 2.268 & & & 4.956 & & \\
\hline 1991 & 7.382 & 1.272 & $21 \%$ & 2.602 & 334 & $15 \%$ & 7.114 & 2.158 & $44 \%$ \\
\hline 1992 & 9.470 & 2.088 & $28 \%$ & 3.077 & 475 & $18 \%$ & 10.048 & 2.934 & $41 \%$ \\
\hline 1993 & 11.582 & 2.112 & $22 \%$ & 4.140 & 1.063 & $35 \%$ & 11.854 & 1.806 & $18 \%$ \\
\hline
\end{tabular}

\footnotetext{
16 Số liệu UBATGTQG

${ }^{17}$ Số liệu UBATGTQG
} 
Dự án: Xây dựng chiến lược an toàn giao thông đối với xe máy và kế hoạch hành động: một khởi đầu của Việt Nam

\begin{tabular}{|c|c|c|c|c|c|c|c|c|c|}
\hline \multirow{2}{*}{ Năm } & \multicolumn{3}{|c|}{ Số vụ } & \multicolumn{3}{c|}{ Số người bị chết } & \multicolumn{3}{c|}{ Số người bị thương } \\
\cline { 2 - 11 } & Số vụ & $\begin{array}{c}\text { Tăng / } \\
\text { giảm }\end{array}$ & $\%$ & $\begin{array}{c}\text { Số } \\
\text { người }\end{array}$ & $\begin{array}{c}\text { Tăng / } \\
\text { giảm }\end{array}$ & $\%$ & Số người & $\begin{array}{c}\text { Tăng / } \\
\text { giảm }\end{array}$ & $\%$ \\
\hline 1994 & 13.760 & 2.178 & $19 \%$ & 4.897 & 757 & $18 \%$ & 14.174 & 2.320 & $20 \%$ \\
\hline 1995 & 15.999 & 2.239 & $16 \%$ & 5.728 & 831 & $17 \%$ & 17.167 & 2.993 & $21 \%$ \\
\hline 1996 & 19.638 & 3.639 & $23 \%$ & 5.932 & 204 & $4 \%$ & 21.718 & 4.551 & $27 \%$ \\
\hline bq/năm & & 2.255 & $22 \%$ & & 611 & $18 \%$ & & 2.794 & $28 \%$ \\
\hline
\end{tabular}

Để đảm bảo hiệu lực của Nghị định 36-CP, ngay sau khi Pháp lệnh sửa đổi Điều 6 Pháp lệnh Lực lượng Cảnh sát nhân dân Việt Nam được ban hành ngày 6 tháng 7 năm 1995, Pháp lệnh xử lý vi phạm hành chính ban hành ngày 06 tháng 7 năm 1995, Chính phủ đã ban hành kịp thời Nghị định 49/CP ngày 26 tháng 7 năm 1995 về quy định xử phạt hành chính về hành vi vi phạm trật tự an toàn giao thông đường bộ và trật tự an toàn giao thông đô thị. Nghị định 49/CP có 4 chương, 30 điều, nội dung tương đối đầy đủ, bao quát hầu hết các hành vi vi phạm có thể xẩy ra trong giao thông đường bộ và đô thị.

Nghị định 36-CP có hai nội dung cơ bản là:

(1) Quản lý nhà nước về trật tự an toàn giao thông đường bộ và trật tự an toàn giao thông đô thị, quy định rõ nhiệm vụ, trách nhiệm và quyền hạn của các Bộ, Ủy ban nhân dân các địa phương.

(2) Chính phủ cũng đã quyết định chuyển giao từ Bộ Nội vụ (nay là Bộ Công an) sang cho Bộ Giao thông vận tải nhiệm vụ sau:

- Quản lý đào tạo, cấp bằng (giấy phép lái xe) cho những người điều khiển phương tiện giao thông cơ giới đường bộ.

- Quy định tiêu chuẩn kỹ thuật, tổ chức kiểm tra, giám sát chất lượng kỹ thuật các loại phương tiện giao thông cơ giới đường bộ, cấp giấy phép lưu động theo định kỳ, quy định điều kiện, tiêu chuẩn, thủ tục để cấp phép hành nghề cho các cơ sở kiểm tra kỹ thuật định kỳ đối với các phương tiện giao thông đường.

(3) Ban hành Điều lệ trật tự an toàn giao thông đường bộ và trật tự an toàn giao thông đô thị. Phần này bao gồm 7 chương, 74 Điều bao quát đầy đủ các lĩnh vực trong hoạt động giao thông đường bộ: công trình giao thông đường bộ, phương tiện tham gia giao thông, người tham gia giao thông, quy tắc giao thông trên đường bộ, trật tự an toàn giao thông đô thị.

(4) Từ thời điểm ban hành Nghị định 36-CP (ban hành ngày 29 tháng 5 năm 1995), Chỉ thị 317/TTg (ban hành ngày 26 tháng 5 năm 1995) đến thời điểm có hiệu lực của văn bản trên (ngày 1 tháng 8 năm 1995, Thủ tướng Chính phủ đã chỉ đạo các Bộ, ngành, đặc biệt các địa phương triển khai chi tiết, cụ thể, đồng bộ về xây dựng văn bản pháp luật, hướng dẫn, phổ biến, tổ chức lực lượng ...

Do công tác chuẩn bị chu đáo nên ngay từ ngày đầu, các tỉnh, thành phố trực thuộc Trung ương cùng đồng loạt ra quân, đã tạo được một bước ngoặt về công tác trật tự an toàn giao thông đường bộ trên phạm vi toàn quốc, nâng cao được nhận thức về an toàn giao thông cho toàn xã hội, thiết lập được hành lang an toàn đường bộ, đường thông hè thoáng ở tất cả các đô thị, tai nạn giao thông đường bộ năm 1996, 1997, 1998 được kiềm chế. 


\subsubsection{Luật Giao thông đường bộ 2001}

Năm 1999, 2000, 2001 tai nạn giao thông đường bộ bắt đầu có xu hướng tăng, đặc biệt năm 2000 số người bị chết vì tai nạn giao thông đường bộ tăng đột biến (tăng 2.942 người, tăng 37\%), mặt khác quá trình thực hiện Nghị định 36-CP cũng cho thấy nhiều bất cập, vướng mắc cần phải giải quyết ở văn bản pháp luật có giá trị pháp lý cao hơn, cần thiết phải xây dựng Luật Giao thông đường bộ.

Bảng 2-3 Tai nạn giao thông đường bộ 1999-2002 ${ }^{18}$

\begin{tabular}{|c|c|c|c|c|c|c|c|c|c|}
\hline \multirow[b]{2}{*}{ Năm } & \multicolumn{3}{|c|}{ Số vụ } & \multicolumn{3}{|c|}{ Số người bị chết } & \multicolumn{3}{|c|}{ Số người bị thương } \\
\hline & Số vụ & Tăng / giảm & $\%$ & Số người & $\begin{array}{l}\text { Tăng / } \\
\text { giảm }\end{array}$ & $\%$ & Số người & $\begin{array}{l}\text { Tăng / } \\
\text { giảm }\end{array}$ & $\%$ \\
\hline 1999 & 21.528 & & & 7.095 & & & 24.179 & & \\
\hline 2000 & 23.327 & 1.799 & $8 \%$ & 7.924 & 829 & $12 \%$ & 25.693 & 1.514 & $6 \%$ \\
\hline 2001 & 25.831 & 2.504 & $11 \%$ & 10.866 & 2.942 & $37 \%$ & 29.449 & 3.756 & $15 \%$ \\
\hline 2002 & 27.993 & 2.162 & $8 \%$ & 13.186 & 2.320 & $21 \%$ & 30.999 & 1.550 & $5 \%$ \\
\hline \multicolumn{2}{|c|}{ bq/năm } & 2.155 & $9 \%$ & & 2.030 & $23 \%$ & & 2.273 & $9 \%$ \\
\hline
\end{tabular}

Ngày 29/6/2001 Quốc hội nước Cộng hòa xã hội chủ nghĩa Việt Nam khoá X kỳ họp thứ 9 đã thông qua Luật Giao thông đường bộ số: 26/2001/QH10 (sau đây gọi là Luật Giao thông đường bộ 2001), có hiệu lực thi hành kể từ ngày 01/01/2002. Đây là Luật đầu tiên về lĩnh vực giao thông đường bộ, được xây dựng trên cơ sở nội dung và thực tiễn của những văn bản pháp luật trước đó, ví dụ như: Chỉ thị số 317/TTg ngày 26 tháng 5 năm 1995 của Thủ tướng Chính phủ về tăng cường công tác quản lý trật tự an toàn giao thông đường bộ và trật tự an toàn giao thông đô thị, Nghị định số 36-CP ngày 29 tháng 5 năm 1995 của Chính phủ về bảo đảm an toàn giao thông đường bộ và trật tự an toàn giao thông đô thị; Pháp lệnh Bảo vệ kết cấu hạ tầng giao thông, Nghị định số 172/1999/NĐ-CP ngày 07 tháng 12 năm 1999 của Chính phủ quy định chi tiết thi hành Pháp lệnh Bảo vệ công trình giao thông đối với công trình giao thông đường bộ; Nghị định số 49/CP ngày 26 tháng 7 năm 1995 quy định xử phạt hành chính về hành vi vi phạm trật tự an toàn giao thông đường bộ và trật tự an toàn giao thông đô thị ...

Luật Giao thông đường bộ 2001 gồm 9 chương, 77 điều, phạm vi điều chỉnh của Luật bao quát toàn diện các lĩnh vực về quy tắc giao thông đường bộ; kết cấu hạ tầng giao thông đường bộ; phương tiện tham gia giao thông đường bộ; người tham gia giao thông đường bộ; vận tải đường bộ; quản lý nhà nước về giao thông đường bộ. Trong 6 năm (2001-2007) Chính phủ, các Bộ, UBND các tỉnh, thành phố trực thuộc Trung ương đã ban hành 190 văn bản dưới Luật, trong đó Chính phủ ban hành 14 Nghị định và 02 Nghị quyết, Thủ tướng Chính phủ ban hành 09 Quyết định và 05 Chỉ thị; Bộ Giao thông vận tải ban hành 93 Quyết định, 11 Thông tư và 09 Chỉ thị; Bộ Công an ban hành 10 Quyết định, 13 Thông tư, 02 Chỉ thị; Bộ Tài chính ban hành 02 Quyết định và 11 Thông tư; Bộ Y tế ban hành 01 Quyết định và các Bộ ban hành 08 Thông tư liên tịch; Uỷ ban nhân dân các tỉnh, thành phố trực thuộc Trung ương cũng ban hành nhiều văn bản hướng dẫn thực hiện Luật ở địa phương. Hệ thống văn bản dưới Luật đã góp phần sớm đưa Luật Giao thông đường bộ 2001 vào cuộc sống. ${ }^{19}$

Luật Giao thông đường bộ 2001 và các văn bản dưới Luật có tính xã hội sâu rộng đã tác động mạnh đến đến mọi mặt của đời sống kinh tế-xã hội, quốc phòng-an ninh và phát triển của đất

\footnotetext{
${ }^{18}$ Số liệu UBATGTQG

${ }^{19}$ Đề cương giới thiệu Luật đường bộ (Vụ Phổ biến, giáo dục pháp luật - Bộ Tư pháp; Vụ Pháp chế (Bộ GTVT)
} 
nước. Luật Giao thông đường bộ 2001 tạo được hành lang pháp lý để điều chỉnh hoạt động giao thông đường bộ; đóng góp to lớn đến phát triển kết cấu hạ tầng giao thông đường bộ, công tác quản lý, bảo trì đường bộ có những tiến bộ đáng kể; công tác đào tạo, sát hạch cấp giấy phép lái xe chuyển nhanh sang áp dụng công nghệ mới, đảm bảo đào tạo và sát hạch chặt chẽ, nâng cao chất lượng, giảm phiền hà, tiêu cực, đặc biệt với chủ trương xã hội hóa công tác đào tạo nên đã tạo được hệ thống cơ sở đào tạo, trung tâm sát hạch tập trung được trang bị hiện đại và trải đều khắp các địa phương; hệ thống trung tâm đăng kiểm, kiểm tra an toàn kỹ thuật và bảo vệ môi trường phương tiện giao thông cơ giới đường bộ được tiêu chuẩn hóa, áp dụng khoa học, công nghệ đảm bảo kết quả kiểm tra chính xác, quản lý chặt chẽ đến từng đầu phương tiện; hoạt động vận tải phát triển, từng bước đi vào nề nếp, trật tự, chất lượng phục vụ được nâng cao, đáp ứng tốt nhu cầu đi lại của nhân dân; hoạt động tuần tra, kiểm soát, xử lý vi phạm được đẩy mạnh và bắt đầu áp dụng, trang bị các thiết bị hiện đại; đặc biệt cùng với Nghị quyết số 13/2002/NQ-CP ngày 19 tháng 11 năm 2002 của Chính phủ về các giải pháp kiềm chế gia tăng và tiến tới giảm dần tai nạn giao thông và ùn tắc giao thông đã tác động trực tiếp đến kết quả kiềm chế tai nạn giao thông những năm 2003, 2004, 2005, trong đó tai nạn giao thông đường bộ năm 2003 giảm kỷ lục (giảm 1.322 người bị chết vì tai nạn giao thông).

\subsubsection{Luật Giao thông đường bộ 2008}

Bên cạnh sự phát triển của đất nước, xu thế hội nhập kinh tế quốc tế thì tình hình trật tự an toàn giao thông đường bộ diễn biến ngày càng phức tạp, năm 2006, tai nạn giao thông đường bộ lại bắt đầu gia tăng (tăng 1.223 người chết so với năm 2005), năm 2007 số người bị chết vì tai nạn giao thông đường bộ tăng đột biến, tăng xấp xỉ năm 2002 (chết 13.150 người); Chính phủ thấy cần thiết phải nghiên cứu sửa đổi, bổ sung Luật Giao thông đường bộ 2001 cho phù hợp với tình hình mới.

Ngày 13 tháng 11 năm 2008 Quốc hội nước Cộng hòa xã hội chủ nghĩa Việt Nam khóa XII, kỳ họp thứ 4 thông qua Luật Giao thông đường bộ số: 23/2008/QH12 (sau đây gọi là Luật Giao thông đường bộ 2008). Luật Giao thông đường bộ 2008 có hiệu lực từ ngày 01 tháng 7 năm 2009 và thay thế Luật giao thông đường bộ số: 26/2001/QH10 ngày 29 tháng 6 năm 2001.

Luật Giao thông đường bộ 2008 gồm 8 chương 89 điều. Luật Giao thông đường bộ 2008 giữ nguyên 03 điều của Luật năm 2001 (chiếm 3,37\%); 68 điều bổ sung, sửa đổi (chiếm 76,40\%) và 18 điều mới (chiếm 20,23\%). So với Luật Giao thông đường bộ 2001 có những thay đổi cơ bản sau:

\section{1) Chương 1. Những Quy định chung}

Quy định rõ hơn về phạm vi điều chỉnh theo hướng liệt kê tên chương để thể hiện đầy đủ các lĩnh vực điều chỉnh (không chỉ có vấn đề an toàn giao thông đường bộ mà còn quản lý vận tải, phương tiện giao thông đường bộ, người điều khiển phương tiện tham gia giao thông đường bộ, đầu tư, xây dựng, khai thác, bảo vệ kết cấu hạ tầng giao thông), đồng thời quy định rõ và bổ sung một số nguyên tắc trong hoạt động giao thông đường bộ cho phù hợp với phạm vi điều chỉnh toàn diện hoạt động giao thông vận tải đường bộ. Bổ sung một số quy định mới về giải thích từ ngữ, quy hoạch phát triển giao thông vận tải đường bộ và các hành vi bị nghiêm cấm, trong đó quy định về nồng độ cồn trong máu hoặc hơi thở của người điều khiển xe ôtô, máy kéo, xe máy chuyên dùng tham gia giao thông nghiêm khắc hơn.

2) Chương 2. Quy tắc giao thông

Luật Giao thông đường bộ 2008 bổ sung một số quy định về quy tắc giao thông đường bộ như đèn tín hiệu giao thông; chấp hành báo hiệu đường bộ; dừng xe, đỗ xe trên đường; quyền ưu 
tiên của một số xe, các loại xe được tham gia giao thông trên đường cao tốc; chở người trên xe ô tô chở hàng; quy định cụ thể về độ tuổi của trẻ em được chở thêm trên xe mô tô, xe gắn máy và xe đạp; bắt buộc đội mũ bảo hiểm và cai quai đúng quy cách đối với người điều khiển, người ngồi trên xe mô tô hai bánh, xe mô tô 3 bánh, xe gắn máy, xe đạp máy; quy tắc qua đường của người đi bộ; các hoạt động văn hóa, diễu hành trên đường bộ; trách nhiệm của chính quyền địa phương nơi xảy ra tai nạn giao thông.

\section{3) Chương 3. Kết cấu giao thông đường bộ}

Bổ sung khái niệm các loại đường và quy định về thẩm quyền phân loại và điều chỉnh các hệ thống đường bộ; bổ sung quy định về việc đặt tên, số hiệu đường bộ, quy định cụ thể tỷ lệ quỹ đất giao thông đô thị so với đất xây dựng đô thị; quy định cụ thể hơn việc sử dụng đất nằm trong phạm vi đất dành cho đường bộ; bổ sung quy định về công tác thẩm định an toàn giao thông đối với công trình đường bộ; xây dựng công trình bảo đảm giao thông cho người đi bộ, người khuyết tật; quy định cụ thể việc đấu nối, việc xây dựng đường gom để bảo đảm an toàn giao thông cho hệ thống quốc lộ; quy định chặt chẽ đối với việc sử dụng, quản lý công trình báo hiệu đường bộ.

Luật Giao thông đường bộ 2008 cũng bổ sung những quy định mang tính nguyên tắc đối với việc đầu tư xây dựng, khai thác kết cấu hạ tầng giao thông đường bộ; bổ sung quy định ràng buộc trách nhiệm của đơn vị thi công công trình trên đường bộ đang khai thác.

Đối với công tác quản lý, bảo trì đường bộ, Luật đã làm rõ khái niệm bảo trì đường bộ, quy định cụ thể hơn về nguồn tài chính cho quản lý, bảo trì đường bộ. Luật cũng bổ sung quy định trách nhiệm quản lý nhà nước đối với trạm thu phí, trạm kiểm tra tải trọng xe, quy định cụ thể việc bảo vệ kết cấu hạ tầng giao thông đường bộ và trách nhiệm của từng cơ quan quản lý nhà nước liên quan.

\section{4) Chương 4. Phương tiện tham gia giao thông đường bộ}

Chương này quy định về điều kiện tham gia giao thông đường bộ của các loại phương tiện, cấp, thu hồi đăng ký và biển số xe cơ giới, quy định về chất lượng an toàn kỹ thuật và bảo vệ môi trường của xe cơ giới tham gia giao thông đường bộ. So với Luật Giao thông đường bộ năm 2001, Luật Giao thông đường bộ 2008 bổ sung quy định về việc cho phép xe ô tô có tay lái bên phải của các nước được vào Việt Nam theo cam kết quốc tế hoặc theo quy định của Chính phủ; giao thẩm quyền thu hồi đăng ký, biển số các loại xe cơ giới cho Bộ Công an, thu hồi đăng ký, biển số xe máy chuyên dùng cho Bộ Giao thông vận tải; quy định và sửa đổi một số từ ngữ cho phù hợp với Luật Tiêu chuẩn và quy chuẩn kỹ thuật.

\section{5) Chương 5. Người điều khiển phương tiện tham gia giao thông đường bộ}

Chương này quy định về điều kiện của người điều khiển phương tiện tham gia giao thông, giấy phép lái xe, tuổi và sức khỏe của người lái xe, đào tạo, sát hạch, cấp giấy phép lái xe. So với Luật Giao thông đường bộ 2001, Luật Giao thông đường bộ 2008 đã bổ sung quy định về các loại giấy tờ mà người lái xe, người điều khiển xe máy chuyên dùng tham gia giao thông phải mang theo; bổ sung quy định về phạm vi sử dụng của giấy phép lái xe, trình độ văn hóa tối thiểu của người có nhu cầu được đào tạo nâng hạng giấy phép lái xe lên hạng $\mathrm{D}, \mathrm{E}$; quy định nâng độ tuổi của người lái xe ô tô khách, nâng hạng giấy phép lái xe đối với lái xe kéo sơ mi rơ moóc. 
6) Chương 6. Vận tải đường bộ

Luật Giao thông đường bộ 2008 đã phân biệt, làm rõ hoạt động vận tải đường bộ và dịch vụ hỗ trợ vận tải đường bộ; bổ sung quy định về quản lý hoạt động vận tải đường bộ, quy định chặt chẽ điều kiện kinh doanh vận tải bằng ô tô, đặc biệt quy định việc gắn thiết bị giám sát hành trình của phương tiện kinh doanh vận tải; bổ sung quy định về quyền và nghĩa vụ của người kinh doanh vận tải, người lái xe và nhân viên phục vụ trên ô tô vận tải hành khách, hành khách, người thuê vận tải, người nhận hàng; quy định về vận chuyển động vật sống, vận tải đa phương thức; tổ chức, hoạt động của bến xe ôtô, bãi đỗ xe, trạm dừng nghỉ.

\section{7) Chương 7. Quản lý nhà nước}

Chương này quy định nội dung quản lý nhà nước về giao thông đường bộ, trách nhiệm quản lý nhà nước về giao thông đường bộ; thanh tra đường bộ; tuần tra, kiểm soát của cảnh sát giao thông đường bộ. So với Luật Giao thông đường bộ 2001, Luật Giao thông đường bộ 2008 bổ sung một số nội dung quản lý nhà nước về vận tải đường bộ, phân định rõ trách nhiệm quản lý nhà nước về giao thông đường bộ, bổ sung quy định nhiệm vụ, quyền hạn của thanh tra đường bộ; việc tuần tra, kiểm soát của cảnh sát giao thông đường bộ, đặc biệt quy định việc huy động các lực lượng cảnh sát khác và công an xã phối hợp với cảnh sát giao thông đường bộ tham gia tuần tra, kiểm soát trật tự an toàn giao thông đường bộ trong trường hợp cần thiết để đáp ứng tình hình thực tế.

- Đến nay, đã có 164 văn bản quy phạm pháp luật được ban hành để hướng dẫn thi hành Luật Giao thông đường bộ, trong đó ${ }^{20}$ :

- Chính phủ: ban hành 22 Nghị định

- Thủ tướng Chính phủ ban hành 01 Quyết định

- Các Bộ ban hành 138 Thông tư, Thông tư liện bộ:

+ Bộ trưởng Bộ GTVT ban hành 87 Thông tư

+ Bộ trưởng Bộ Công an ban hành 25 Thông tư

+ Bộ trưởng Bộ Tài chính ban hành 11 Thông tư

+ Bộ trưởng Bộ Y tế ban hành 01 Thông tư

+ Bộ trưởng Bộ Quốc phòng ban hành 01 Thông tư

+ Liên Bộ ban hành 18 Thông tư Liên Bộ

\subsubsection{Nghị định của Chính phủ}

Căn cứ quy định tại Luật Giao thông đường bộ 2008 và nhiệm vụ, quyền hạn quy định tại luật Chính phủ, Chính phủ ban hành nhiều Nghị định về các lĩnh vực kết cấu hạ tầng giao thông đường bộ, đào tạo, sát hạch, cấp giấy phép lái xe, đăng ký xe, kiểm tra chất lượng an toàn kỹ thuật và bảo vệ môi trường, tuần tra,kiểm soát, xử lý vi phạm, quản lý vận tải ...

Riêng Nghị định về xử lý vi phạm hành chính trong lĩnh vực giao thông đường bộ, Chính phủ đặc biệt quan tâm, thường xuyên sửa đổi, bổ sung để nâng cao tính răn đe, giáo dục. Từ năm 1995, Chính phủ đã ban hành 10 Nghị định về lý vi phạm hành chính trong lĩnh vực giao thông đường bộ.

Nhìn chung, trong quá trình ban hành, sửa đổi, bổ sung các Nghị định về xử lý vi phạm hành chính trong lĩnh vực giao thông đường bộ thì những hành vi là nguyên nhân trực tiếp gây tai nạn giao thông (như vượt quá tốc độ quy định, sử dụng rượu bia khi lái xe ...) đều tăng mức phạt, đồng thời bổ sung nhiều hành vi bị xử phạt, mức độ răn đe nghiêm khắc hơn.

${ }^{20}$ Báo cáo tổng kết 6 năm thi hành Luật GTĐB 2008 (Bộ GTVT) 
Dự án: Xây dựng chiến lược an toàn giao thông đối với xe máy và kế hoạch hành động: một khởi đầu của Việt Nam

Bảng 2-4 Các Nghị định xử lý vi phạm hành chính được ban hành từ năm 1995 đến 2018

\begin{tabular}{|c|c|c|c|c|}
\hline STT & Số hiệu & Tên nghị định & $\begin{array}{l}\text { Ngày ban } \\
\text { hành }\end{array}$ & Ghi chú \\
\hline 1 & 49-CP & $\begin{array}{l}\text { Quy định xử phạt hành chính về hành vi vi phạm } \\
\text { TTATGT đường bộ và TTATGT đô thị }\end{array}$ & 26/7/1995 & 3 năm \\
\hline 2 & 78/1998/NĐ-CP & $\begin{array}{l}\text { Bổ sung sửa đổi một số điều của Nghị định số 49-CP } \\
\text { ngày 26/7/1995 }\end{array}$ & 26/9/1998 & 3 năm \\
\hline 3 & 39/2001/NĐ-CP & $\begin{array}{l}\text { Quy định xử phạt hành chính về hành vi vi phạm } \\
\text { TTATGT đường bộ và TTATGT đô thị }\end{array}$ & $13 / 7 / 2001$ & 3 năm \\
\hline 4 & 15/2003/NĐ- CP & $\begin{array}{l}\text { Quy định xử phạt vi phạm hành chính về giao thông } \\
\text { đường bộ }\end{array}$ & $19 / 2 / 2003$ & 2 năm \\
\hline 5 & 152/2005/NĐ-CP & $\begin{array}{l}\text { Quy định xử phạt vi phạt hành chính trong lĩnh vực } \\
\text { giao thông đường bộ }\end{array}$ & $15 / 12 / 2005$ & 2 năm \\
\hline 6 & 146/2007/NĐ- CP & $\begin{array}{l}\text { Quy định xử phạt vi phạt hành chính trong lĩnh vực } \\
\text { giao thông đường bộ }\end{array}$ & $14 / 9 / 2007$ & 2 năm \\
\hline 7 & 34/2010/NĐ-CP & $\begin{array}{l}\text { Quy định xử phạt vi phạt hành chính trong lĩnh vực } \\
\text { giao thông đường bộ }\end{array}$ & $2 / 4 / 2010$ & 3 năm \\
\hline 8 & 71/2012/NĐ-CP & $\begin{array}{l}\text { Sửa đổi, bổ sung một số điều của Nghị định } \\
\text { 34/2010/NĐ-CP của chính phủ quy định xử phạt vi } \\
\text { phạm hành chính trong lĩnh vực giao thông đường bộ }\end{array}$ & $19 / 9 / 2012$ & 2 năm \\
\hline 9 & 171/2013/NĐ-CP & $\begin{array}{l}\text { Quy định xử phạt vi phạm hành chính trong lĩnh vực } \\
\text { giao thông đường bộ và đường sắt }\end{array}$ & $13 / 11 / 2013$ & 1 năm \\
\hline 10 & 46/2016/NDD0-CP & $\begin{array}{l}\text { Quy định xử phạt vi phạm hành chính trong lĩnh vực } \\
\text { giao thông đường bộ vă đường sắt }\end{array}$ & $26 / 5 / 2016$ & 3 năm \\
\hline
\end{tabular}

Bảng 2-5 Một số thay đổi mức phạt đối với hành vi vi phạm trong giao thông đường bộ (người điều khiển xe máy)

Đơn vị: VNĐ

\begin{tabular}{|c|c|c|c|c|c|c|}
\hline \multirow[b]{2}{*}{ STT } & \multirow[b]{2}{*}{ Nghị định } & \multicolumn{5}{|c|}{ Mức xử phạt cao nhất đối với một số hành vi vi phạm (xe máy) } \\
\hline & & Tốc độ & Rượu, bia & $\begin{array}{c}\text { Mũ bảo } \\
\text { hiểm }\end{array}$ & $\begin{array}{l}\text { Đi vào đường } \\
\text { cấm, khu vực } \\
\text { cấm }\end{array}$ & $\begin{array}{l}\text { Không } \\
\text { có GPLX }\end{array}$ \\
\hline 1 & 49-CP & 100.000 & 500.000 & & 100.000 & 100.000 \\
\hline 2 & 78/1998/NĐ-CP & 100.000 & 500.000 & & 100.000 & 100.000 \\
\hline 3 & 39/2001/NĐ-CP & 100.000 & 500.000 & & 100.000 & 100.000 \\
\hline 4 & 15/2003/NĐ-CP & 500.000 & 500.000 & 15.000 & 60.000 & 100.000 \\
\hline 5 & 152/2005/NĐ-CP & 500.000 & 500.000 & 40.000 & 200.000 & 200.000 \\
\hline 6 & 146/2007/NĐ-CP & 800.000 & 800.000 & 200.000 & 200.000 & 200.000 \\
\hline 7 & 34/2010/NĐ-CP & 1.000 .000 & 1.000 .000 & 200.000 & 200.000 & 200.000 \\
\hline 8 & 71/2012/NĐ-CP & 3.000 .000 & 3.000 .000 & 200.000 & 400.000 & 1.200 .000 \\
\hline 9 & 171/2013/NĐ-CP & 3.000 .000 & 3.000 .000 & 200.000 & 400.000 & 1.200 .000 \\
\hline 10 & 46/2014/NĐ-CP & 4.000 .000 & 4.000 .000 & 200.000 & 400.000 & 1.200 .000 \\
\hline
\end{tabular}




\subsubsection{Nghị quyết của Chính phủ về bảo đảm trật tự an toàn giao thông đường bộ}

Giai đoạn trước khi ban hành Luật ban hành văn bản quy phạm pháp luật năm 2008 (có hiệu lực từ này 01 tháng 01 năm 2009), văn bản quy phạm pháp luật của Chính phủ gồm: nghị quyết, nghị định; văn bản quy phạm pháp luật của Thủ tướng Chính phủ gồm: quyết định, chỉ thị. Từ ngày 01 tháng 01 năm 2009 đến nay văn bản quy phạm pháp luật của Chính phủ chỉ còn nghị định; văn bản quy phạm pháp luật của Thủ tướng Chính phủ chỉ còn quyết định.

Căn cứ theo quy định của Luật văn bản quy phạm pháp luật những Nghị quyết của Chính phủ ban hành trước ngày 1 tháng 1 năm 2009 vẫn là văn bản quy phạm pháp luật, những Nghị quyết của Chính phủ ban hành sau ngày 1 tháng 1 năm 2009 sẽ không phải là văn bản quy phạm pháp luật. Tuy nhiên, để có căn cứ xây dựng chiến lược an toàn giao thông cho xe máy, quản lý xe máy trong dài hạn và kế hoạch hành động 3 năm có hiệu quả, dự án sẽ nghiên cứu những thành công và hạn chế của các giải pháp vể bảo đảm trật tự an toàn giao thông đường bộ tại các Nghị quyết về bảo đảm trật tự an toàn giao thông đường bộ của Chính phủ từ năm 2001.

Từ năm 2001 đến nay, Chính phủ đã ban hành các Nghị quyết về bảo đảm trật tự an toàn giao thông đường bộ như sau:

\subsubsection{Nghị quyết 13/2002/NQ-CP ngày 19 tháng 11 năm 2002 về các giải pháp kiềm chế gia tăng và tiến tới giảm dần tai nạn giao thông và ùn tắc giao thông}

Tóm tắt Nội dung Nghị quyết 13/2002/NQ-CP ngày 19 tháng 11 năm 2002 về các giải pháp kiềm chế gia tăng và tiến tới giảm dần tai nạn giao thông và ùn tắc giao thông.

1) Các biện pháp giải quyết ùn tắc giao thông giao thông

- Hoàn thiện phương án phát triển thích hợp các loại phương tiện vận tải đường bộ theo hướng ưu tiên phát triển vận tải công cộng, hạn chế thấp nhất phương tiện giao thông cá nhân.

- Phát triển nhanh vận tải khách công cộng ở các đô thị, trước mắt cần đẩy mạnh phát triển xe buýt; Hà Nội, thành phố Hồ Chí Minh và các thành phố, thị xã có mật độ dân cư lớn phải thành lập các doanh nghiệp nhà nước công ích đủ sức thực hiện nhiệm vụ vận tải khách công cộng; ban hành các chính sách cụ thể nhằm khuyến khích các thành phần kinh tế tham gia vận tải khách công cộng theo quy hoạch và khuyến khích, vận động người dân sử dụng phương tiện vận tải công cộng.

- Sớm xây dựng đề án phát triển các loại phương tiện vận tải khách có khả năng vận chuyển số lượng lớn ở các thành phố như : xe điện, tàu điện ngầm ...

- Song song với việc phát triển vận tải khách công cộng và đầu tư phát triển kết cấu hạ tầng giao thông đồ thị, cần khẩn trương ban hành các giải pháp đồng bộ nhằm kiềm chế sự gia tăng mô tô, xe máy, tiến tới giảm dần số lượng mô tô, xe máy lưu hành trong nội thành, nội thị các thành phố, thị xã.

- Hà Nội, thành phố Hồ Chí Minh ban hành lộ trình và các biện pháp chặt chẽ, phù hợp nhằm kiềm chế tối đa sự gia tăng số lượng mô tô, xe máy, trong đó có xem xét cụ thể việc tạm dừng đăng ký mô tô, xe máy mới và quy định các tuyến đường, khu vực, thời gian không cho mô tô, xe máy lưu hành

2) Các giải pháp kiềm chế tai nạn giao thông

- Trước hết phải tập trung kiểm tra, xử phạt nghiêm những người điều khiển mô tô không có giấy phép lái xe. 
- Kiên quyết xử phạt những người điều khiển và ngồi trên mô tô, xe máy không đội mũ bảo hiểm trên những đoạn đường bắt buộc đội mũ bảo hiểm.

- Kiểm tra các cơ sở đào tạo và công tác sát hạch cấp giấy phép lái xe, kiên quyết thu hồi giấy phép đào tạo của những cơ sở đào tạo lái xe không đủ tiêu chuẩn quy định.

- Quy định việc đánh dấu số lần vi phạm Luật Giao thông đường bộ trên giấy phép lái xe.

- Cử cán bộ cảnh sát giao thông là sát hạch viên tham gia các Hội đồng sát hạch để cấp giấy phép lái xe của ngành giao thông vận tải.

- Bộ Giáo dục và Đào tạo có trách nhiệm chỉ đạo việc quản lý, giáo dục học sinh chấp hành pháp luật về trật tự an toàn giao thông, bảo đảm chấm dứt tình trạng học sinh chưa đủ tuổi quy định đi học bằng mô tô, xe máy; tiếp tục mở rộng giáo dục pháp luật về trật tự an toàn giao thông trong trường học trên phạm vi toàn quốc.

- Tăng cường công tác kiểm định phương tiện giao thông.

- Khi đăng ký mô tô, xe máy, người đăng ký phải xuất trình giấy phép lái xe; phải mua bảo hiểm trách nhiệm dân sự của chủ xe cơ giới và đóng các loại phí và lệ phí theo quy định.

- Sửa đổi, bổ sung quy tắc, biểu phí, tăng mức bảo hiểm bắt buộc trách nhiệm dân sự của chủ xe cơ giới; tăng mức thu lệ phí trước bạ, lệ phí đăng ký và lệ phí lưu hành mô tô, xe máy ở các thành phố, thị xã.

- Huy động các cơ quan thông tin đại chúng ở Trung ương và các địa phương, trước hết là báo Nhân Dân, Đài Truyền hình Việt Nam, Đài Tiếng nói Việt Nam,... tham gia vào công tác tuyên truyền, giáo dục ý thức chấp hành pháp luật về trật tự an toàn giao thông cho mọi tầng lớp nhân dân và thực hiện các giải pháp nêu trong Nghị quyết này của Chính phủ.

\subsubsection{Nghị quyết 32/2007/NQ-CP ngày 29 tháng 6 năm 2007 của Chính phủ về một số giải pháp cấp bách nhằm kiềm chế tai nạn giao thông và ùn tắc giao thông}

Tóm tắt nội dung Nghị quyết Nghị quyết 32/2007/NQ-CP ngày 29 tháng 6 năm 2007 của Chính phủ về một số giải pháp cấp bách nhằm kiềm chế tai nạn giao thông và ùn tắc giao thông.

1) Đẩy mạnh công tác tuyên truyền, phổ biến, giáo dục pháp luật trật tự an toàn giao thông.

- Giáo dục, tuyên truyền, phổ biến pháp luật trật tự an toàn giao thông cho mọi đối tượng tham gia giao thông để mọi người tự giác chấp hành là biện pháp quan trọng hàng đầu; yêu cầu các cơ quan nhà nước, chính quyền các cấp, các tổ chức chính trị xã hội, các đoàn thể, các cơ quan thông tin, báo chí phải đặc biệt quan tâm, thực hiện thường xuyên, kiên trì và liên tục.

- Thủ trưởng các cơ quan nhà nước, các tổ chức, các đoàn thể, các doanh nghiệp có trách nhiệm giáo dục cho cán bộ, công chức, viên chức, người lao động và các thành viên trong tổ chức của mình gương mẫu chấp hành pháp luật trật tự an toàn giao thông.

- Ban hành chương trình giáo dục trật tự an toàn giao thông phù hợp trong nhà trường, tăng thời lượng giảng dạy chính khóa, các hoạt động ngoại khóa về trật tự an toàn giao thông.

- Hiệu trưởng các trường phổ thông, các trường cao đẳng, đại học, trung học chuyên nghiệp quản lý chặt chẽ học sinh, sinh viên về chấp hành pháp luật trật tự an toàn giao thông; thường xuyên nhắc nhở, đưa thông tin liên quan đến trật tự an toàn giao thông vào nội dung sinh hoạt đầu tuần, lễ chào cờ, sinh hoạt lớp, sinh hoạt Đoàn, Đội; quy định việc đánh giá đạo đức đối với học sinh, sinh viên vi phạm pháp luật trật tự an toàn giao thông. 
- Quy định việc thông báo về cơ quan, trường học, phường, xã, tổ dân phố, cự dân cư những cán bộ, công chức, viên chức, học sinh, sinh viên và người vi phạm pháp luật trật tự an toàn giao thông để kiểm điểm, giáo dục.

- Trung ương Đoàn Thanh niên Cộng sản Hồ Chí Minh, Hội Thanh niên Việt Nam, Hội đồng Đội Trung ương quy định việc phổ biến nội dung pháp luật trật tự an toàn giao thông trong các buổi sinh hoạt thường kỳ, biểu dương người tốt, việc tốt, phê phán các cá nhân vi phạm

- Tổ chức, chỉ đạo và huy động các cơ quan thông tin, báo chí, tuyên truyền nêu cao vai trò, trách nhiệm, tích cực tham gia vào công tác tuyên truyền, giáo dục ý thức chấp hành pháp luật trật tự an toàn giao thông cho mọi tầng lớp nhân dân và thực hiện Nghị quyết này

2) Cưỡng chế thi hành pháp luật trật tự an toàn giao thông và nâng cao năng lực cho lực lượng cảnh sát, thanh tra giao thông vận tải:

- Từ ngày 01 tháng 01 năm 2008, đình chỉ lưu hành ô tô đã hết niên hạn sử dụng, xe công nông, xe tự chế 3,4 bánh. Trường hợp cố tình vi phạm sẽ bị tịch thu xử lý bán phế liệu, sung vào công quỹ

- Thực hiện đình chỉ lưu hành các phương tiện cơ giới đường bộ vi phạm các quy định về bảo đảm trật tự an toàn giao thông bằng hình thức tạm giữ phương tiện.

- Đình chỉ hoạt động các cơ sở lắp ráp, tự chế các loại phương tiện giao thông cơ giới đường bộ và đường thủy nội địa trái phép.

- Tạm giữ mô tô, xe gắn máy 30 ngày trở lên nếu người điều khiển vi phạm một trong các quy định sau: chở quá số người cho phép, đi vào đường ngược chiều, đường cấm, lạng lách đánh võng, vượt đèn đỏ, không chấp hành hiệu lệnh của cảnh sát giao thông.

- Tạm giữ mô tô, xe gắn máy 90 ngày không phân biệt sở hữu đối với trường hợp học sinh, sinh viên chưa đủ tuổi hoặc không có Giấy phép lái xe điều khiển mô tô, xe gắn máy.

3) Kết cấu hạ tầng giao thông:

- Giải tỏa dứt điểm trước ngày 30 tháng 3 năm 2009 các trường hợp lấn chiếm đất hành lang an toàn giao thông đường bộ các quốc lộ trên địa bàn trong phạm vi đã được đền bù, xử lý; xử lý kỷ luật Chủ tịch Ủy ban nhân dân cấp huyện, cấp xã nếu để tái lấn chiếm hành lang an toàn giao thông; những trường hợp cố tình vi phạm phải truy cứu trách nhiệm hình sự.

- Trong năm 2008 hoàn thành việc quy hoạch hệ thống đường gom ngoài hành lang an toàn hệ thống quốc lộ.

- Tổ chức phân làn riêng cho mô tô, gắn máy trên những tuyến đường, tuyến phố đủ điều kiện để khắc phục tình trạng lưu thông hỗn hợp; quy định khi xây dựng mới quốc lộ, các tuyến phố mới phải tổ chức phân làn riêng cho xe mô tô, xe gắn máy, lắp đặt các hệ thống giám sát an toàn.

4) Tăng cường quản lý và nâng cao chất lượng an toàn kỹ thuật của phương tiện giao thông vận tải:

- Quy định việc đăng ký, cấp biển số cho phương tiện cơ giới của thương binh và người khuyết tật; thu hồi biển số đăng ký của phương tiện giao thông đã hết niên hạn sử dụng.

- Xây dựng chính sách hỗ trợ phát triển vận tải khách công cộng bằng xe buýt; nghiên cứu việc tăng lệ phí trước bạ, tăng lệ phí đăng ký mô tô và xe gắn máy ở các thành phố lớn. 
- Ủy ban nhân dân thành phố Hà Nội và thành phố Hồ Chí Minh quy định việc cấm mô tô và xe gắn máy lưu thông trên một số tuyến đường trong khoảng thời gian phù hợp nhằm giảm ùn tắc giao thông đô thị.

5) Giải pháp đối với người điều khiển phương tiện:

- Tăng cường kiểm tra chất lượng đào tạo lái xe, thu hồi vĩnh viễn Giấy phép cơ sở đào tạo lái xe không đủ tiêu chuẩn hoặc có tiêu cực; đơn giản hóa thủ tục cấp, đồi giấy phép lái xe

- Thực hiện việc bắt buộc học và kiểm tra lại Luật Giao thông đường bộ trước khi nhận lại Giấy phép lái xe đối với những lái xe vi phạm pháp luật trật tự an toàn giao thông đến mức bị tạm giữ Giấy phép lái xe từ 60 ngày trở lên; thu hồi không thời hạn Giấy phép lái xe của lái xe khách chuyên nghiệp các loại $\mathrm{D}, \mathrm{E}$ để xảy ra tai nạn giao thông đặc biệt nghiêm trọng hoặc chở khách quá $100 \%$ số khách quy định. Thu hồi không thời hạn Giấy phép lái xe của những lái xe nghiện ma túy.

6) Giải pháp giảm thiểu thiệt hại do tai nạn giao thông:

- Từ ngày 15 tháng 9 năm 2007, người đi mô tô, xe gắn máy trên các quốc lộ bắt buộc phải đội mũ bảo hiểm.

- Từ ngày 15 tháng 12 năm 2007, người đi mô tô, xe gắn máy trên tất cả các tuyến đường bắt buộc phải đội mũ bảo hiểm.

- Quy định hướng dẫn tổ chức hoạt động cứu hộ, cứu nạn giao thông đường bộ bảo đảm ứng cứu kịp thời, hạn chế đến mức thấp nhất hậu quả do tai nạn giao thông gây ra.

- Quy định việc thành lập các trạm cấp cứu tai nạn giao thông trên các quốc lộ trọng điểm với khoảng cách giữa các trạm hợp lý và theo quy định; thường xuyên tổ chức các lớp tập huấn, phổ biến kiến thức cấp cứu tai nạn giao thông cho các đối tượng liên quan đến cứu hộ, cứu nạn và giải quyết tai nạn giao thông.

- Nghiên cứu sửa đổi, bổ sung các quy định mức phí bảo hiểm bắt buộc trách nhiệm dân sự của chủ xe cơ giới, có tăng hoặc giảm tuỳ theo mức độ tai nạn của mỗi chủ xe nhằm khuyến khích việc ngăn ngừa tai nạn đối với chủ xe và lái xe; đồng thời tiếp tục đổi mới các thủ tục tham gia bảo hiểm và điều kiện bồi thường thiệt hại; nghiên cứu nâng mức phí bảo hiểm bắt buộc để mức bồi thường bảo hiểm có thể bù đắp được thiệt hại; hướng dẫn sử dụng một phần kinh phí từ nguồn bảo hiểm bắt buộc trách nhiệm dân sự của chủ xe cơ giới để đầu tư lại cho công tác phòng ngừa tai nạn giao thông.

\subsubsection{Nghị quyết 88/NQ-CP ngày 24 tháng 8 năm 2011 về tăng cường thực hiện các giải pháp trọng tâm bảo đảm trật tự an toàn giao thông}

Tóm tắt nội dung của Nghị quyết 88/NQ-CP ngày 24 tháng 08 năm 2011 của Chính phủ về tăng cương thục hiện các giải pháp trọng tâm bảo đảm trật tụ an toàn giao thông

1) Tăng cường phòng chống và kiểm soát người điều khiển phương tiện cơ giới đường bộ sử dụng rượu, bia:

- Tuyên truyền mạnh mẽ và thường xuyên tác hại của lạm dụng rượu, bia đối với sức khỏe và trật tự an toàn xã hội; nguy cơ gây tai nạn do lái xe uống rượu, bia; hậu quả tai nạn giao thông nguyên nhân từ rượu, bia; các quy định của pháp luật về xử phạt đối với người lái xe uống rượu, bia.

- Thủ trưởng các cơ quan nhà nước, các tổ chức đoàn thể, doanh nghiệp yêu cầu cán bộ, công chức, viên chức, đoàn viên, hội viên, nhân viên gương mẫu không uống rượu, bia trước khi lái xe; đồng thời, ban hành quy định của cơ quan, đơn vị về không uống rượu, 
bia trong giờ làm việc, giờ nghỉ trưa; xử lý kỷ luật nghiêm người vi phạm, không phân biệt là cán bộ hay nhân viên.

- Quy định quản lý việc quảng cáo rượu, bia trên các phương tiện quảng cáo, yêu cầu khi quảng cáo rượu, bia phải gắn kèm nội dung cảnh báo tác hại của việc lạm dụng rượu, bia đối với sức khỏe và nguy cơ xảy ra tai nạn nếu điều khiển phương tiện tham gia giao thông.

- Hoàn thiện các văn bản quy phạm pháp luật và quy định kỹ thuật về đo lường liên quan đến thiết bị đo, kiểm tra nồng độ cồn trong hơi thở.

- Tăng cường trang thiết bị kiểm tra nồng độ cồn, tổ chức các đợt hoạt động cao điểm kiểm tra, xử lý đối với người điều khiển phương tiện sử dụng rượu, bia (tập trung tại khu vực có nhiều người lái xe uống rượu, bia).

- Quy định về việc xét nghiệm nồng độ cồn trong máu của người điều khiển phương tiện cơ giới đường bộ

- Các doanh nghiệp, cơ sở sản xuất, nhập khẩu rượu, bia phải đưa các khuyến cáo trên bao bì của sản phẩm về tác hại của việc lạm dụng rượu, bia; các cơ sở kinh doanh dịch vụ ăn uống, bến xe, trạm dừng nghỉ không bán rượu, bia cho người lái xe.

2) Duy trì và tiếp tục đẩy mạnh thực hiện đội mũ bảo hiểm; ngăn chặn học sinh, sinh viên chưa đủ tuổi, không có giấy phép lái xe điều khiển xe môtô, xe gắn máy:

- Các cơ quan truyền thông, tổ chức, đoàn thể: Đẩy mạnh tuyên truyền về đội mũ bảo hiểm khi tham gia giao thông bằng xe môtô, xe gắn máy (đặc biệt là đối với khu vực nông thôn, vùng sâu, vùng xa); tuyên truyền, giáo dục, vận động người lớn tự giác đội mũ bảo hiểm cho trẻ em khi tham gia giao thông, sử dụng mũ bảo hiểm bảo đảm chất lượng, cài quai đúng quy cách; giáo dục thanh, thiếu niên chưa đủ tuổi không điều khiển xe mô tô, xe gắn máy.

- Huy động các lực lượng cảnh sát trật tự, cảnh sát cơ động, công an xã tăng cường phối hợp kiểm tra phát hiện và xử phạt nghiêm đối với người điều khiển, người ngồi trên môtô, xe gắn máy không đội mũ bảo hiểm, chở trẻ em không đội mũ bảo hiểm; học sinh, sinh viên chưa đủ tuổi, không có giấy phép lái xe điều khiển xe môtô, xe gắn máy.

- Có biện pháp cấp bách ngăn chặn việc sản xuất, lưu thông, buôn bán loại mũ có kiểu dáng giống mũ bảo hiểm và mũ bảo hiểm không bảo đảm quy chuẩn, chất lượng; phối hợp với chính quyền địa phương tăng cường kiểm tra, xử lý nghiêm các tổ chức, cá nhân vi phạm.

3) Đẩy mạnh công tác giáo dục an toàn giao thông trong trường học:

- Tiếp tục chỉ đạo nâng cao chất lượng giáo dục kiến thức an toàn giao thông trong trường học; triển khai chương trình giảng dạy về an toàn giao thông vào các trường sư phạm để đào tạo đội ngũ giáo viên có kiến thức và phương pháp giáo dục hiệu quả về an toàn giao thông, phổ biến và hướng dẫn thực hiện các tiêu chí văn hóa giao thông trong từng cấp học từ năm học 2012.

- Hiệu trưởng các trường phải kiên quyết xử lý kỷ luật đối với học sinh, sinh viên chưa đủ tuổi, không có giấy phép lái xe điều khiển xe môtô, xe gắn máy.

4) Tăng cường công tác cứu hộ, cứu nạn, cấp cứu tai nạn giao thông:

- Hoàn thiện quy định về trạm cấp cứu tai nạn giao thông dọc trên các tuyến quốc lộ; phát triển hệ thống cấp cứu 115 đạt tiêu chuẩn, củng cố trung tâm cấp cứu 115 hiện có ở các tỉnh, thành phố; đào tạo nâng cao trình độ chuyên môn về cấp cứu, nâng cao năng lực đáp ứng cấp cứu tai nạn giao thông cho cán bộ y tế; đào tạo kỹ năng cấp cứu ban đầu 
về chấn thương do tai nạn giao thông cho Cảnh sát giao thông, Thanh tra giao thông và tình nguyện viên.

- Xây dựng Đề án tổ chức cấp cứu tai nạn giao thông trên mạng đường bộ cao tốc.

5) Đẩy mạnh tuyên truyền văn hóa giao thông.

6) Tăng cường quản lý hoạt động vận tải bằng ôtô.

7) Tăng cường công tác tổ chức giao thông, nâng cao điều kiện an toàn của kết cấu hạ tầng giao thông:

- Rà soát, điều chỉnh hợp lý hệ thống báo hiệu đường bộ (đặc biệt là các biển báo liên quan đến tốc độ chạy xe trên đường); triển khai lắp đặt dải phân cách để tách dòng xe môtô 2 bánh, xe thô sơ với dòng xe ôtô trên các tuyến đường có đủ điều kiện và có mật độ phương tiện giao thông lớn; khi lập dự án nâng cấp, cải tạo, xây dựng mới các tuyến đường bộ, tuyến tránh đô thị phải thiết kế phân làn đường dành riêng cho xe môtô, xe gắn máy.

- Đẩy mạnh việc thực hiện Kế hoạch lập lại trật tự hành lang an toàn giao thông đường bộ theo Quyết định số 1856/QĐ-TTg ngày 27 tháng 12 năm 2007 của Thủ tướng Chính phủ.

- Hà Nội và thành phố Hồ Chí Minh tiếp tục đẩy mạnh thực hiện các giải pháp về từng bước khắc phục ùn tắc giao thông của Nghị quyết số 16/2008/NQ-CP. Đẩy nhanh tiến độ triển khai thực hiện dự án vận chuyển hành khách công cộng khối lượng lớn; xây dựng cầu vượt, hầm cho người đi bộ ở hai thành phố; thực hiện các biện pháp để hạn chế xe môtô, xe gắn máy và xe ôtô lưu thông trên một số tuyến phố vào một số giờ nhất định phù hợp với điều kiện cụ thể của từng khu vực trong thành phố

- Bộ Giao thông vận tải chủ trì phối hợp với các Bộ, ngành và Ủy ban nhân dân các tỉnh, thành phố liên quan xây dựng đề án hạn chế và lộ trình cấm xe môtô, xe gắn máy tham gia giao thông tại các đô thị lớn, trình Thủ tướng Chính phủ trong quý IV năm 2012.

8) Tăng cường công tác thanh tra, tuần tra, kiểm soát, xử lý vi phạm:

- Lực lượng cảnh sát tăng cường tuần tra, kiểm soát, xử lý nghiêm các hành vi vi phạm pháp luật về trật tự an toàn giao thông; đẩy mạnh việc phát hiện và xử lý vi phạm bằng các phương tiện kỹ thuật nghiệp vụ.

- Sớm triển khai thực hiện các dự án thuộc Đề án "Tăng cường và hiện đại hóa công tác tuần tra kiểm soát, xử lý vi phạm trật tự an toàn giao thông” theo Quyết định số 617/QĐTTg ngày 15 tháng 5 năm 2009 của Thủ tướng Chính phủ, trọng tâm là hệ thống giám sát, xử lý vi phạm trật tự an toàn giao thông trên các tuyến quốc lộ trọng điểm để áp dụng từ năm 2012.

- Nghiên cứu đề xuất cơ chế huy động các nguồn vốn cho các dự án đầu tư bảo đảm trật tự, an toàn giao thông, trong đó khuyến khích các thành phần kinh tế tham gia đầu tư xây dựng hệ thống giám sát trật tự an toàn giao thông đường bộ bằng hình ảnh.

9) Tăng cường quản lý về đào tạo, sát hạch lái xe:

- Đẩy mạnh thực hiện các biện pháp để nâng cao hơn nữa chất lượng đào tạo, sát hạch lái xe; tiếp tục hoàn thiện giáo trình đào tạo, quy trình sát hạch lái xe; tăng cường công tác giám sát các kỳ sát hạch lái xe.

- Thực hiện việc đổi mới giấy phép lái xe; xây dựng hệ thống cơ sở dữ liệu về giấy phép lái xe thống nhất toàn quốc 


\subsubsection{Nghị quyết số 16/2008/NQ-CP ngày 31 tháng 7 năm 2008 của Chính phủ về từng bước khắc phục ùn tắc giao thông tại Hà Nội và Thành phố Hồ Chí Minh}

\section{Tóm tắt nội dung Nghị quyết 16/2008/NQ-CP ngày 31 tháng 07 năm 2008 của Chính phủ ${ }^{21}$}

1) Quy hoạch phát triển kết cấu hạ tầng giao thông đô thị.

2) Quy hoạch và thực hiện di dời trụ sở các cơ quan hành chính nhà nước, các trường đại học, cao đẳng, dạy nghề, bệnh viện lớn ra ngoài khu vực trung tâm.

3) Tuyên truyền, phổ biến pháp luật, tổ chức cuộc vận động xây dựng nếp "văn hóa giao thông" và “văn minh đô thị”, tăng cường cưỡng chế thi hành pháp luật về trật tự an toàn giao thông và trật tự đô thị.

4) Đẩy mạnh phát triển vận tải hành khách công cộng, hạn chế phương tiện cá nhân tham gia giao thông, tổ chức giao thông hợp lý và hiệu quả

5) Tiếp tục duy trì chính sách trợ giá cho hoạt động vận tải khách công cộng bằng xe buýt:

- Nghiên cứu đầu tư tăng thêm các tuyến đường có làn đường dành riêng cho xe buýt.

- Trong quý IV năm 2008 hoàn thành việc rà soát mạng lưới các tuyến xe buýt để điều chỉnh những bất hợp lý, bổ sung thêm các tuyến mới bảo đảm mạng lưới các tuyến xe buýt bao phủ hết các khu vực; quảng bá rộng rãi mạng lưới xe buýt để mọi người dân chọn hành trình hợp lý; bố trí lại chủng loại xe buýt phù hợp với hạ tầng giao thông từng tuyến, từng khu vực.

- Chỉ đạo các cơ quan chức năng phối hợp với các trường học, các doanh nghiệp để tổ chức loại hình xe buýt chuyên trách (có trợ giá) đưa đón học sinh, cán bộ, công nhân theo Nghị quyết số 13/2002/NQ-CP ngày 19 tháng 11 năm 2002 của Chính phủ, thực hiện từ quý I năm 2009.

- Nghiên cứu đề xuất các giải pháp đẩy mạnh xã hội hóa hoạt động vận tải hành khách công cộng nhằm huy động các thành phần kinh tế tham gia; nghiên cứu và kiến nghị chính sách hỗ trợ trực tiếp và gián tiếp đối với các doanh nghiệp thuộc mọi thành phần kinh tế tham gia kinh doanh vận tải khách công cộng.

- Phối hợp với các Bộ, ngành đẩy nhanh tiến độ thực hiện các dự án phát triển vận tải hành khách công cộng có khối lượng lớn như: đường sắt đô thị, xe buýt có sức chở lớn

6) Quy định việc cấm mô tô, xe gắn máy và ô tô lưu thông trên một số tuyến phố vào một số giờ nhất định phù hợp với điều kiện cụ thể của từng khu vực trong thành phố.

7) Nghiên cứu việc điều chỉnh giờ làm việc hợp lý nhằm giảm bớt lưu lượng tham gia giao thông trong giờ cao điểm.

8) Quy định miễn tiền thuê đất để xây dựng trạm bảo dưỡng, sửa chữa, bãi đỗ xe của các doanh nghiệp kinh doanh vận tải khách công cộng nội đô.

9) Quy định về cơ chế hỗ trợ lãi suất cho doanh nghiệp vay vốn đầu tư phương tiện vận tải khách công cộng nội đô; xây dựng cơ chế xã hội hóa hoạt động vận tải khách bằng xe buýt.

10) Quy định về phí, lệ phí liên quan đến phương tiện giao thông cơ giới đường bộ của cá nhân.

${ }^{21}$ Chỉ trích những nội dung liên quan đến quy định hạn chế gia tăng xe máy 


\subsubsection{Văn bản quy định về đăng ký xe}

Từ năm 2002 đến nay, Bộ Công an đã ban hành các thông tư hướng dẫn tổ chức cấp đăng ký, biển số phương tiện cơ giới đường bộ như sau:

a) Thông tư số $01 / 2002 / \mathrm{TT}-\mathrm{BCA}(\mathrm{C} 11)$ ngày 04 tháng 01 năm 2002 hướng dẫn tổ chức cấp đăng ký, biển số phương tiện cơ giới đường bộ.

b) Thông tư 02/003/TT- BCA(C11) ngày 13 tháng 1 năm 2003 bổ sung một số quy định của Thông tư số $01 / 2002 / T T-B C A(C 11)$ ngày 04 tháng 01 năm 2002 của Bộ Công an về hướng dẫn tổ chức cấp đăng ký, biển số phương tiện cơ giới đường bộ.

c) Thông tư 17/2005/TT- BCA(C11) ngày 21 tháng 11 năm 2005 sửa đổi, bổ sung Điểm 2 Thông tư 02/003/TT- BCA(C11) ngày 13 tháng 1 năm của Bộ Công an về hướng dẫn tổ chức cấp đăng ký, biển số phương tiện cơ giới đường bộ.

d) Thông tư 36/2010/TT- BCA ngày 12 tháng 10 năm 2010 quy định về đăng ký xe.

e) Thông tư 12/2013/TT- BCA ngày 01 tháng 03 năm 2013 sửa đổi, bổ sung khoản 3 Điều 20

f) Thông tư 36/2010/TT - BCA ngày 12 tháng 10 năm 2010 quy định về đăng ký xe.

g) Thông tư 15/2014/TT- BCA ngày 04 tháng 4 năm 2014 quy định về đăng ký xe.

h) Thông tư 64/2017/TT- BCA ngày 28 tháng 12 năm 2017 sửa đổi, bổ sung một số điều của Thông tư 15/2014/TT- BCA ngày 04 tháng 4 năm 2014 quy định về đăng ký xe.

Trong các Thông tư của Bộ Công an về đăng ký xe có thể chú ý một số điểm như sau: Thông tư 02/003/TT- BCA(C11) ngày 13 tháng 1 năm 2003 quy định " mỗi người chỉ được đăng ký 01 xe mô tô hoặc xe gắn máy"; Thông tư 17/2005/TT- BCA(C11) ngày 21 tháng 11 năm 2005 bỏ quy định "mỗi người chỉ được đăng ký 01 xe mô tô hoặc xe gắn máy”; Thông tư 12/2013/TTBCA ngày 01 tháng 03 năm 2013 nhằm giải quyết đăng ký xe đối với trường hợp xe đã đăng ký, chuyển nhượng qua nhiều người với thời hạn từ 15 tháng 4 năm 2013 đến 31 tháng 12 năm 2014.

\subsubsection{Văn bản kiểm tra chất lượng an toàn kỹ thuật và bảo vệ môi trường xe máy}

Hiện nay Việt Nam chưa quy định kiểm tra an toàn kỹ thuật và bảo vệ môi trường đối với xe máy. Đối với xe máy nhập khẩu và lắp ráp trong nước trước khi đưa ra thị trường phải kiểm tra cấp giấy chứng nhận theo Thông tư 45/2012/TT -BGTVT ngày 23 tháng 10 năm 2012 Quy định về kiểm tra chất lượng an toàn kỹ thuật và bảo vệ môi trường trong sản xuất, lắp ráp mô tô, xe gắn máy; Thông tư 44/2012/TT- BGTVT ngày 23 tháng 10 năm 2012 Quy định về kiểm tra chất lượng an toàn kỹ thuật và bảo vệ môi trường xe mô tô, xe gắn máy nhập khẩu và động cơ nhập khẩu sử dụng để sản xuất, lắp ráp xe mô tô, xe gắn máy.

Một số văn bản liên quan đến kiểm tra chất lượng an toàn kỹ thuật và bảo vệ môi trường đối với xe máy như sau:

a) QCVN 14 : 2015/BGTVT Quy chuẩn kỹ thuật Quốc gia về chất lượng an toàn kỹ thuật và bảo vệ môi trường đối với xe mô tô, xe gắn máy ban hành kèm theo Thông tư số 67/2015/ TT- BGTVT ngày 06 tháng 11 năm 2015.

b) Quyết định 49/2011/QĐ-TTg ngày 01 tháng 9 năm 2011 của Thủ tướng Chính phủ về việc quy định lộ trình áp dụng tiêu chuẩn khí thải đối với xe ô tô, xe mô tô hai bánh sản xuất, lắp ráp và nhập khẩu mới. 
c) QCVN 04 : 2009/BGTVT Quy chuẩn Quốc gia về khí thải xe mô tô hai bánh sản xuất, lắp ráp và nhập khẩu mới ban hành kèm theo Thông tư số 30/2009/ TT- BGTVT ngày 19 tháng 11 năm 2009.

d) QCVN 77 : 2014/BGTVT Quy chuẩn Quốc gia về khí thải mức 3 đối với xe mô tô hai bánh sản xuất, lắp ráp và nhập khẩu mới ban hành kèm theo Thông tư 45/2014/TTBGTVT ngày 03 tháng 10 năm 2014.

e) Quyết định số 16/2015/QĐ-TTg ngày 22 tháng 5 năm 2015 của Thủ tướng Chính phủ Quy định thu hồi, xử lý sản phẩm thải bỏ.

Từ năm 1995 công tác kiểm định an toàn kỹ thuật và môi trường đối với phương tiện cơ giới đường bộ được chuyển giao từ Bộ Nội vụ (nay là Bộ Công an) sang cho Bộ GTVT. Đến nay công tác kiểm định phương tiện cơ giới đường bộ đã có những thay đổi cơ bản, trước hết là bộ tiêu chuẩn an toàn kỹ thuật và môi trường phương tiện cơ giới đường bộ. Bộ tiêu chuẩn này cũng đã được sửa đổi, bổ sung nhiêu lần. Hệ thống kiểm tra chất lượng an toàn kỹ thuật và bảo vệ môi trường đối với các loại xe cơ giới sản xuất, lắp ráp mới trong nước và nhập khẩu vào Việt Nam nhằm mục đích kiểm soát chất lượng phương tiện từ nguồn. Phương thức chứng nhận được xây dựng trên cơ sở phù hợp với thông lệ quốc tế, hệ thống tiêu chuẩn, quy chuẩn kỹ thuật sẽ từng bước hoàn thiện hài hòa với hệ thống tiêu chuẩn chung của khu vực và thế giới (UNECE). Công tác kiểm định phương tiện cơ giới đường bộ được xã hội hóa mạnh mẽ. Năm 2015 toàn quốc có 132 trung tâm và chi nhánh đăng kiểm xe cơ giới với 261 dây chuyền cơ giới hóa hoạt động tại 63 tỉnh, thành phố trực thuộc Trung ương. Hàng năm đã kiểm định trên 2,5 triệu lượt xe.

\subsubsection{Văn bản về đào tạo, sát hạch cấp giấy phép lái xe máy}

Theo quy định tại Điều 61 Luật Giao thông đường bộ 2008: “Cở sở đào tạo lái xe là loại hình cơ sở dạy nghề, phải có đủ điều kiện về lớp học, sân tập lái, xe tập lái, đội ngũ giáo viên, giáo trình, giáo án và phải được giấy cấp phép theo quy định" Chính phủ đã ban hành Nghị định số 65/2016/NĐ-CP ngày 01 tháng 07 năm 2016 Quy định về Điều kiện kinh doanh dịch vụ đào tạo lái xe ô to và dịch vụ sát hạch lái xe; Bộ Giao thông vận tải ban hành QCVN 40 : 2015/BGTVT Quy chuẩn kỹ thuật Quốc gia về trung tâm sát hạch lái xe cơ giới đường bộ ban hành kèm theo Thông tư 79/2015/TT-BGTVT ngày 10 tháng 12 năm 2015 ( bãi bỏ Thông tư 18/2012/TT-BGTVT ngày 06 tháng 6 năm 2012 ban hành Quy chuẩn kỹ thuật Quốc gia về trung tâm sát hạch lái xe cơ giới đường bộ).

Về người điều khiển xe máy, Luật Giao thông đường bộ 2008 quy định:

1) Người lái xe mô tô phải có giấy phép lái xe không thời hạn, bao gồm các loại:

- Hạng A1 cấp cho người lái xe mô tô hai bánh có dung tích xi-lanh từ $50 \mathrm{~cm}^{3}$ đến dưới $175 \mathrm{~cm}^{3}$;

- Hạng A2 cấp cho người lái xe mô tô hai bánh có dung tích xi-lanh từ $175 \mathrm{~cm} 3$ trở lên và các loại xe quy định cho giấy phép lái xe hạng $\mathrm{A} 1$;

- Hạng A3 cấp cho người lái xe mô tô ba bánh, các loại xe quy định cho giấy phép lái xe hạng $\mathrm{A} 1$ và các xe tương tự.

- Người khuyết tật điều khiển xe mô tô ba bánh dùng cho người khuyết tật được cấp giấy phép lái xe hạng A1.

2) Về tuổi quy định như sau:

- Người đủ 16 tuổi trở lên được lái xe gắn máy có dung tích xi-lanh dưới $50 \mathrm{~cm}^{3}$; 
- Người đủ 18 tuổi trở lên được lái xe mô tô hai bánh, xe mô tô ba bánh có dung tích xilanh từ $50 \mathrm{~cm}^{3}$ trở lên và các loại xe có kết cấu tương tự; xe ô tô tải, máy kéo có trọng tải dưới $3.500 \mathrm{~kg}$; xe ô tô chở người đến 9 chỗ ngồi;

Bộ Giao thông vận tải đã ban hành Thông tư số 12/2017/TT-BGTVT ngày 15 tháng 4 năm 2017 Quy định về đào tạo, sát hạch, cấp giấy phép lái xe cơ giới đường bộ, trong đó quy định: hình thức đào tạo (các hạng $\mathrm{A} 1, \mathrm{~A} 2, \mathrm{~A} 3$, A được tự học lý thuyết); chương trình đào tạo lái xe (thời gian đào tạo, các môn kiểm tra), quy trình sát hạch ...; Bộ Giao thông vận tải cũng ban hành Thông tư 29/2015/TT-BGTVT ngày 06 tháng 7 năm 2015 Quy định về cấp, sử dụng giấy phép lái xe quốc tế.

Ngày 21 tháng 8 năm 2015, Bộ Giao thông vận tải và Bộ Y tế ban hành Thông tư liên tịch số 24/2015/TTLT-BYT-BGTVT Quy định về tiêu chuẩn sức khỏe của người lái xe, việc khám sức khỏe đối với người lái xe, khám sức khỏe định kỳ đối với người lái xe ô tô và quy định về cơ sở y tế khám sức khỏe cho người lái xe.

Từ năm 1995, công tác đào tạo, sát hạch cấp giấy phép lái xe có nhiều thay đổi, cơ sở đào tạo được đầu tư, đổi mới trang thiết bị hiện đại (bài giảng điện tử, kiểm tra lý thuyết trên máy tính), nội dung chương trình đào tạo được cải tiến liên tục thống nhất, đặc biệt hệ thống trung tâm sát hạch tập trung được tự động hóa theo quy chuẩn thống nhất. Với chủ trương xã hội hóa, đến nay toàn quốc có 322 cơ sở đào tạo lái xe, 105 trung tâm sát hạch tập trung.

\subsubsection{Văn bản về tuần tra, kiểm soát xử lý vi phạm}

Công tác tuần tra, kiểm soát giao thông đường bộ của CSGT được thực hiện theo quy định tại Thông tư số 01/2016/TT-BCA ngày 04 tháng 1 năm 2016 của Bộ Công an Quy định nhiệm vụ, quyền hạn, hình thức, nội dung tuần tra, kiểm soát giao thông đường bộ của cảnh sát giao thông.

Thông tư quy định về nhiệm vụ, quyền hạn; trang bị, sử dụng phương tiện, thiết bị kỹ thuật nghiệp vụ, vũ khí, công cụ hỗ trợ; hình thức, nội dung tuần tra, kiểm soát, xử lý vi phạm hành chính; phân công trách nhiệm và quan hệ phối hợp trong công tác tuần tra, kiểm soát giao thông đường bộ của Cảnh sát giao thông.

Cán bộ tuần tra, kiểm soát giao thông đường bộ thực hiện các nhiệm vụ của lực lượng Cảnh sát nhân dân và nhiệm vụ, quyền hạn cụ thể sau đây:

1) Nhiệm vụ:

- Thực hiện chỉ đạo của Bộ Công an, Cục Cảnh sát giao thông, Giám đốc Công an tỉnh, thành phố trực thuộc Trung ương (sau đây viết gọn là Công an cấp tỉnh); Trưởng phòng Hướng dẫn tuần tra, kiểm soát giao thông đường bộ, Trưởng phòng Tuần tra, kiểm soát giao thông đường bộ cao tốc thuộc Cục Cảnh sát giao thông; Trưởng phòng Cảnh sát giao thông đường bộ-đường sắt, Trưởng phòng Cảnh sát giao thông Công an cấp tỉnh (sau đây viết gọn là Trưởng phòng Cảnh sát giao thông); Trưởng Công an huyện, quận, thị xã, thành phố thuộc tỉnh (sau đây viết gọn là Trưởng Công an cấp huyện); kế hoạch tuần tra, kiểm soát đã được cấp có thẩm quyền phê duyệt.

- Bảo đảm trật tự, an toàn giao thồng thuộc phạm vi tuyển đường, địa bàn phân công tuần tra, kiểm soát; phát hiện, xử lý kịp thời, nghiêm minh các hành vi vi phạm theo quy định của pháp luật.

- Báo cáo, đề xuất cấp có thẩm quyền kiến nghị với cơ quan liên quan có biện pháp khắc phục kịp thời những sơ hở, thiếu sót trong quản lý nhà nước về an ninh, trật tự và trật 
tự, an toàn giao thông đường bộ; phối hợp với cơ quan quản lý đường bộ phát hiện, ngăn chặn hành vi vi phạm quy định bảo vệ công trình đường bộ và hành lang an toàn đường bộ.

- Hướng dẫn, tuyên truyền người tham gia giao thông chấp hành nghiêm chỉnh pháp luật về giao thông đường bộ.

- Tổ chức cấp cứu người bị nạn, bảo vệ hiện trường, giải quyết tai nạn giao thông theo quy định của pháp luật và của Bộ Công an; phối hợp tham gia tìm kiếm cứu nạn, cứu hộ và khắc phục hậu quả do thiên tai gây ra trên đường bộ.

- Phối hợp với các đơn vị nghiệp vụ Công an nhân dân đấu tranh phòng, chống tội phạm và các hành vi vi phạm pháp luật khác trên các tuyến giao thông đường bộ, phương tiện giao thông đường bộ (sau đây viết gọn là phương tiện), địa bàn được phân công theo quy định của pháp luật.

2) Quyền hạn:

- Được dừng các phương tiện đang tham gia giao thông đường bộ; kiểm soát phương tiện, giấy tờ của phương tiện; kiểm soát người và giấy tờ của người điều khiển phương tiện, giấy tờ tùy thân của người trên phương tiện đang kiểm soát, việc thực hiện các quy định về hoạt động vận tải đường bộ theo quy định pháp luật.

- Xử lý các hành vi vi phạm hành chính trong lĩnh vực giao thông đường bộ, an ninh, trật tự, an toàn xã hội và các vi phạm hành chính trong các lĩnh vực quản lý Nhà nước khác theo quy định của pháp luật.

- Được áp dụng các biện pháp ngăn chặn và bảo đảm cho việc xử lý vi phạm hành chính theo quy định của pháp luật; tạm giữ giấy phép lái xe, giấy đăng ký xe và giấy tờ khác có liên quan đến phương tiện, người điều khiển phương tiện hoặc những người trên phương tiện khi có hành vi vi phạm pháp luật, giấy tờ liên quan đến hoạt động vận tải để bảo đảm cho việc thi hành quyết định xử phạt vi phạm hành chính theo quy định của pháp luật.

- Được yêu cầu cơ quan, đơn vị, tổ chức, cá nhân phối hợp, hỗ trợ giải quyết tai nạn giao thông; ùn tắc, cản trở giao thông hoặc trường hợp khác gây mất trật tự, an toàn giao thông.

- Được sử dụng vũ khí, công cụ hỗ trợ và phương tiện, thiết bị kỹ thuật nghiệp vụ theo quy định của pháp luật.

- Được trưng dụng các loại phương tiện giao thông; phương tiện thông tin liên lạc; các phương tiện, thiết bị kỹ thuật khác của cơ quan, tổ chức, cá nhân và người điều khiển, sử dụng các phương tiện, thiết bị đó theo quy định của pháp luật.

- Tạm thời đình chỉ người và phương tiện đi lại ở một số đoạn đường nhất định, phân lại luồng, phân lại tuyến và nơi tạm dừng phương tiện, đỗ phương tiện khi xảy ra ùn tắc giao thông hoặc có yêu cầu cần thiết khác về bảo đảm an ninh, trật tự, an toàn xã hội.

- Thực hiện các quyền hạn khác theo quy định của pháp luật.

3) Các hình thức tuần tra, kiểm soát.

- Tuần tra, kiểm soát công khai.

- Tuần tra, kiểm soát công khai kết hợp với hóa trang.

- Kiểm soát thông qua hệ thống giám sát, xử lý vi phạm trật tự, an toàn giao thông đường bộ.

4) Huy động các lực lượng Cảnh sát khác và Công an xã phối hợp tuần tra, kiểm soát.

Theo Nghị định 27/2010/NĐ-CP ngày 24 tháng 3 năm 2010 của Chính phủ quy định việc huy động các lực lượng Cảnh sát khác và Công an xã phối hợp với Cảnh sát giao thông đường bộ 
tham gia tuần tra, kiểm soát trật tự, an toàn giao thông đường bộ trong trường hợp cần thiết và Thông tư số 47/2011/TT-BCA ngày 02 tháng 7 năm 2011 của Bộ trưởng Bộ Công an quy định chi tiểt thi hành một số điều của Nghị định số 27/2010/NĐ-CP.

- Lực lượng được huy động gồm:

+ Cảnh sát trật tự, Cảnh sát phản ứng nhanh, Cảnh sát cơ động, Cảnh sát bảo vệ, Cảnh sát quản lý hành chính về trật tự, an toàn xã hội, Công an phụ trách xã, Công an phường (sau đây gọi chung là Cảnh sát khác).

+ Công an xã, Công an thị trấn nơi chưa bố trí tổ chức Công an chính quy (sau đây gọi chung là Công an xã).

- Những trường hợp cần thiết phải huy động các lực lượng Cảnh sát khác và Công an xã phối hợp với Cảnh sát giao thông đường bộ tham gia tuần tra, kiểm soát trật tự, an toàn giao thông đường bộ.

+ Trong thời gian diễn ra các ngày lễ kỷ niệm; sự kiện chính trị-xã hội; hoạt động văn hoá, thể thao lớn của Nhà nước và địa phương.

+ Các đợt cao điểm bảo đảm trật tự, an toàn giao thông theo chỉ đạo của Bộ Công an, Tổng cục Cảnh sát quản lý hành chính về trật tự, an toàn xã hội hoặc của Giám đốc Công an tỉnh, thành phố trực thuộc Trung ương.

+ Khi tình hình vi phạm trật tự, an toàn giao thông, tai nạn giao thông và ùn tắc giao thông có diễn biến phức tạp.

+ Trường hợp khác mà trật tự, an toàn giao thông đường bộ gây ảnh hưởng xấu đến an ninh chính trị, trật tự, an toàn xã hội.

Ngoài những văn bản trên, một số văn bản quy phạm pháp luật liên quan đến hoath động tuần tra, kiểm soát, xử lý vi phạm của lực lượng CSGT bao gồm:

- Nghị định 165/2013/NĐ-CP của Chính phủ ngày 12 tháng 11 năm 2013 Quy định việc quản lý sử dụng và danh mục các phương tiện, thiết bị kỹ thuật nghiệp vụ được sử dụng để phát hiện vi phạm hành chính về trật tự an toàn giao thông và bảo vệ môi trường.

- Thông tư 40/2015/TT-BCA của Bộ Công an ngày 24 tháng 8 năm 2015 Quy định việc quản lý sử dụng phương tiện, thiết bị kỹ thuật nghiệp vụ trong Công an nhân dân để phát hiện vi phạm hành chính về trật tự an toàn giao thông và bảo vệ môi trường.

- Thông tư liên tịch số 26/2014/TTLT-BYT-BCA Quy định về xét nghiệm nồng độ cồn trong máu của người điều khiển phương tiện cơ giưới đường bộ.

\subsubsection{Văn bản về thống kê phân tích tai nạn giao thông đường bộ}

Luật Giao thông đường bộ 2008 quy định Bộ công an có trách nhiệm thống kê, tổng hợp, xây dựng cơ sở dữ liệu thông tin về tai nạn giao thông đường bộ, cung cấp cho cơ quan tổ chức, cá nhân theo qui định pháp luật.

Quyết định số 43/2010/QĐ-TTg ngày 02 tháng 6 năm 2010 của Thủ tướng Chính phủ (thay thế Quyết định số 305/2005/QĐ -TTg ngày 24 tháng 11 năm 2005) về việc ban hành Hệ thống chỉ tiêu thống kê quốc gia, trong đó giao Bộ Công an chịu trách nhiệm thu thập, thống kề, tổng hợp báo cáo số liệu số vụ tai nạn giao thông, số người chết và bị thương do tai nạn giao thông.

Bộ trưởng Bộ Công an ban hành Quyết định số 7836/QĐ-BCA ngày 29 tháng 12 năm 2014 qui định chức năng, nhiệm vụ, quyền hạn của Cục CSGT đã giao Cục CSGT có trách nhiệm "Phối hợp với các đơn vị nghiệp vụ trong ngành Công an và các ngành chức năng nghiên cứu các nguyên nhân, điều kiện xảy ra TNGT để đề xuất chủ trương, biện pháp phòng ngừa TNGT; 
thống kê cung cấp dữ liệu TNGT đường bộ, đường sắt, đường thủy nội địa và các số liệu khác theo qui định của pháp luật và của Bộ trưởng”.

Ngoài ra, Bộ trưởng Bộ Công an cũng ban hành nhiều văn bản về chế độ báo cáo, công tác thống kê trong CAND như: Thông tư số 64/2015/TT- BCA qui định về chế độ báo cáo của lực lượng CAND; Thông tư số 12/2016/TT-BCA qui định về công tác thống kê trong Công an nhân dân và Thông tư số 58/2009/TT- $\mathrm{BCA}(\mathrm{C} 11)$ ngày 28 tháng 10 năm 2009 qui định và hướng dẫn, tổng hợp, xây dựng cơ sở dữ liệu, cung cấp thông tin TNGT đường bộ.

Thông tư 58/2009/TT-BCA qui định các nội dung sau:

- Khái niệm, phân loại tai nạn giao thông.

- Các chỉ tiêu thống kê tổng hợp, gồm nhóm chỉ tiêu:

+ Nhóm chỉ tiêu chung về số vụ, số người chết, số người bị thương, thiệt hại về tài sản;

+ Nhóm chỉ tiêu về tuyến đường, địa bàn xảy ra tai nạn giao thông;

+ Nhóm chỉ tiêu về phương tiện gây tai nạn giao thông;

+ Nhóm chỉ tiêu về độ tuổi;

+ Nhóm chỉ tiêu về nguyên nhân xảy ra tai nạn giao thông;

+ Nhóm chỉ tiêu về kết quả điều tra, giải quyết tai nạn;

- Chế độ báo cáo, thống kê, tổng hợp tai nạn giao thông;

- Phân công trách nhiệm báo cáo, thống kề, tổng hợp tai nạn giao thông;

- Xây dựng cơ sở dữ liệu về tai nạn giao thông;

- Thẩm quyền, hình thức cung cấp thông tin và sử dụng cơ sở dữ liệu thống kê, tổng hợp tai nạn giao thông .

Bộ Giao thông vận tải và Bộ Công an ban hành Thông tư liên tịch số 01/2010/TTLT- BCABGTVT ngày 30 tháng 3 năm 2010 quy định về phối hợp cung cấp số liệu đăng ký, đăng kiểm phương tiện giao thông có giới đường bộ, dữ liệu tai nạn giao thông và cấp, đổi, thu hồi, tước quyền sử dụng giấy phép lái xe.

\subsubsection{Văn bản về vận tải}

Trước năm 2013, Hệ thống các văn bản quản lý vận tải chưa đầy đủ, ngoài Luật Giao thông đường bộ chỉ có $02 \mathrm{Nghị} \mathrm{định} \mathrm{và} 02$ Thông tư để điều chỉnh toàn bộ các hoạt động kinh doanh vận tải bằng xe ô tô và 01 Thông tư về sử dụng xe máy vận chuyển hành khách, hàng hóa.

Từ năm 2013 đến nay, Hệ thống các văn bản quản lý vận tải đã từng bước được bổ sung, hoàn thiện, ngoài Luật Giao thông đường bộ có 02 Nghị định và 07 Thông tư quy định về quản lý hoạt đông kinh doanh vận tải bằng xe ô tô. Trong đó quy định về:

- Quản lý hoạt động kinh doanh vận tải hàng hóa.

- Quy định về cung cấp, quản lý và sử dụng dữ liệu từ thiết bị giám sát hành trình của xe ô tô.

- Ban hành quy trình quản lý an toàn giao thông và tiêu chuẩn chất lượng dịch vụ vận tải áp dụng trong đơn vị vận tải ô tô.

- Quy định hệ thống sổ sách ghi chép và các nội dung công việc cụ thể trong công tác đảm bảo an toàn giao thông tại các đơn vị vận tải.

- Quy định các hình thức xử lý vi phạm ngoài biện pháp xử phạt hành chính.

Riêng về đối với xe máy chở hành khách và hàng hóa Bộ Giao thông vận tải ban hành 02 Thông tư như sau: 
- Thông tư 08/2009/TT-BGTVT ngày 23 tháng 6 năm 2009 Hướng dẫn việc sử dụng xe thô sơ, xe gắn máy, xe mô tô hai bánh, xe mô tô ba bánh và các loại xe tương tự để vận chuyển hành khách, hàng hóa.

- Thông tư 03/2002/TT-BGTVT ngày 27 tháng 02 năm 2002 Hướng dẫn việc sử dụng xe thô sơ, xe gắn máy, xe mô tô hai bánh, xe mô tô ba bánh và các loại xe tương tự để vận chuyển khách, hàng.

- Thông tư 46/2014/TT-BGTVT ngày 06 tháng 10 năm 2014 Sửa đổi, bổ sung một số điều của Thông tư 08/2009/TT-BGTVT ngày 23 tháng 6 năm 2009 Hướng dẫn việc sử dụng xe thô sơ, xe gắn máy, xe mô tô hai bánh, xe mô tô ba bánh và các loại xe tương tự để vận chuyển hành khách, hàng hóa.

\subsubsection{Văn bản về ứng phó sau tai nạn giao thông}

Trong hệ thống tiếp cận an toàn giao thông, vấn đề ứng phó sau tai nạn giao thông được coi là một giải pháp quan trọng để giảm được số người bị thương vong do tai nạn giao thông. Các quy định về cấp cứu y tế, cứu nạn, cứu hộ như sau:

\subsubsection{Cấp cứu $\mathbf{y}$ tế}

- Hệ thống chăm sóc chấn thương trước viên bao gồm:

- Thông tin.

- Vận chuyển cấp cứu.

- Cấp cứu ban đầu tại hiện trường.

- Chăm sóc nâng cao tại cơ sở y tế.

Bằng chứng trên thế giới cho thấy nêu cung cấp chăm sóc chấn thương trước viện đúng và kịp thời có thể giảm $20 \%$ đến $25 \%$ tử vong. Chính vì điều này nên Nghị quyết $32 / 2007 / \mathrm{NQ}-\mathrm{CP}$ ngày 29 tháng 6 năm 2007 của Chính phủ về một số giải pháp cấp bách nhằm kiềm chế tai nạn giao thông và ùn tắc giao thông, Nghị quyết 88/NQ-CP ngày 24 tháng 8 năm 2011 về tăng cường thực hiện các giải pháp trọng tâm bảo đảm trật tự an toàn giao thông đã đặc biệt quan tâm đến xây dựng hệ thống cấp cứu y tế, cứu nạn, cứu hộ tai nạn giao thông.

Bộ Y tế được giao trách nhiệm chính về tổ chức cấp cứu y tế tai nạn giao thông, đến nay đã ban hành môt số văn bản về cấp cứu y tế như sau:

Trong Chính sách quốc gia phòng, chống tai nạn thương tích giai đoạn 2002-2010, Bộ Y tế chịu trách nhiệm triển khai các hoạt động phòng chống tai nạn thương tích (trong đó có tai nạn giao thông đường bộ) tập trung vào các nội dung giám sát thống kê tai nạn thương tích, tổ chức tuyên truyền nâng cao nhận thức cho người dân về phòng chống tai nạn thương tích, chăm sóc sức khoẻ, phục hồi chức năng cho người bị nạn và xây dựng cộng đồng an toàn

Ngày 29 tháng 6 năm 2007, sau khi Chính phủ đã ban hành Nghị quyết 32/2007/NQ-CP về một số giải pháp cấp bách nhằm kiềm chế tai nạn giao thông và ùn tắc giao thông, trong đó có quy định bắt buộc người dân đội mũ bảo hiểm trên tất cả các tuyến đường từ ngày 15 tháng 12 năm 2008, Bộ Y tế cũng đã xây dựng Chỉ thị số 04/2007/CT- BYT ngày 08 tháng 11 năm 2007 của Bộ trưởng Bộ Y tế về việc triển khai thực hiện Nghị quyết 32/2007/NQ-CP.

Trên cơ sở chỉ thị này và theo chức năng nhiệm vụ, Bộ Y tế cũng đã ban hành các văn bản pháp quy góp phần kiềm chế tai nạn giao thông: 
- Quyết định số 1356/QĐ-BYT ngày 18 tháng 4 năm 2008 về việc báo cáo các trường hợp tai nạn giao thông đến cấp cứu tại bệnh viện.

- Quyết định số 12/2008/QĐ-BYT ngày 27 tháng 2 năm 2008 về tiêu chuẩn kiến thức, kỹ năng của nhân viên y tế và trang thiết bị trong chăm sóc chấn thương thiết yếu.

- Quyết định số 01 /2008/QĐ-BYT ngày 21 tháng 01 năm 2008 về việc ban hành quy chế cấp cứu, hồi sức tích cực và chống độc.

- Quyết định 933/QĐ-BYT ngày 23 tháng 3 năm 2010 ban hành Quy định về đo nồng độ cồn (Ethanol) trong máu" áp dụng trong các bệnh viện.

- Quyết định 1203/QĐ -TTg ngày 19 tháng 7 năm 2013 của Thủ tướng Chính phủ Phê duyệt Đề án tổ chức cấp cứu tai nạn giao thông trên mạng đường bộ cao tốc đến măm 2020

- Thông tư 49/2016/TT- BYT của Bộ Y tế ngày 30 tháng 12 năm 2016 Quy định tổ chức cấp cứu tai nạn giao thông trên đường cao tốc.

- Các tài liệu hướng dẫn cấp cứu tai nạn giao thông đường bộ

Việt Nam có hệ thống trung tâm cấp cứu 115 và số điện thoại gọi cấp cứu y tế 115 , tuy vậy hệ thống này chỉ có ở một số tỉnh, thành phố lớn và năng lực cũng hạn chế, chỉ đáp ứng được khoảng $10 \%$ các cuộc gọi cấp cứu tai nạn. Theo nghiên cứu của Viên Quân y 103, nạn nhân được cấp cứu nhờ người đi đường chiếm $91 \%$, tự cấp cứu $3,2 \%$, được nhân viên y tế cấp cứu $4,9 \%$; trên $60 \%$ nạn nhân TNGT được chuyển đến bệnh viện trong 6 giờ đầu, trong đó có đến hơn $8 \%$ đến bệnh viện sau 72 giờ.

Thực tế hiện nay còn cho thấy tình trạng, các vụ tai nạn giao thông có nhiều nạn nhân thì các cơ sở y tế (huyện, tỉnh) hết sức lúng túng do chưa được đào tạo, trang thiết bị, nhân lực thiếu. Thực trạng này càng đáng lo ngại khi hệ thống đường cao tốc đang phát triển rất nhanh.

Hệ thống cấp cứu tai nạn giao thông chủ yếu tập trung ở các bệnh viện trong khi hệ thống cấp cứu ngoại viện (ở nhà, cơ quan, ngoài đường...) chưa được quan tâm đầy đủ, đầu tư hợp lý. Phần lớn các nạn nhân được người đi đường sơ cứu, vận chuyển bằng taxi, xe mô tô, xe đạp ...trong đó đa số người sơ cứu không được đào tạo về sơ, cấp cứu nạn nhân tai nạn giao thông, điều này thực sự là điều đáng lo ngại, nhiều trường hợp dẫn đến những hậu quả đáng tiếc cho nạn nhân tai nạn giao thông.

Một trong những rào cản, hạn chế sự giúp đỡ của người đi đường đối với nạn nhân tai nạn giao thông là sự lo ngại phiền phức cho mình từ phía gia đình nạn nhân, cộng đồng, thậm chí từ cơ quan nhà nước. Nhiều nước đã ban hành luật bảo vệ những cá nhân cung cấp, hỗ trợ cho người khác đang bị thương, đau yếu hay gặp nguy hiểm hoặc bị mất khả năng.

\subsubsection{Cứu nạn, cứu hộ tai nạn giao thông}

Theo quy định của Việt Nam công tác cứu hộ, cứu nạn được định nghĩa như sau:

1) Cứu nạn là hoạt động cứu người bị nạn khỏi nguy hiểm đe dọa đến sức khỏe, tính mạng của họ do sự cố, tai nạn, bao gồm: phát hiện, định vị, mở lối tiếp cận người bị nạn, bố trí phương tiện, dụng cụ, lực lượng cứu nạn, cứu hộ; xác định, ngăn chặn, loại bỏ các yếu tố đe dọa tính mạng, sức khỏe người bị nạn và lực lượng cứu nạn, cứu hộ; tư vấn biện pháp y tế ban đầu, sơ cứu; đưa người bị nạn khỏi vị trí nguy hiểm và các biện pháp khác đưa người bị nạn đến vị trí an toàn. 
2) Cứu hộ là hoạt động cứu phương tiện, tài sản khỏi nguy hiểm do sự cố, tai nạn, bao gồm: Phát hiện, định vị, mở lối tiếp cận phương tiện, tài sản bị nạn, bố trí phương tiện, dụng cụ, lực lượng cứu nạn, cứu hộ; xác định, ngăn chặn, loại bỏ các yếu tố nguy hiểm đe dọa an toàn phương tiện, tài sản và sức khỏe, tính mạng lực lượng cứu nạn, cứu hộ; đưa phương tiện, tài sản khỏi vị trí nguy hiểm và các biện pháp khác đưa phương tiện, tài sản đến vị trí an toàn.

3) Trách nhiệm quản lý nhà nước về cứu nạn, cứu hộ:

- Chính phủ thống nhất quản lý nhà nước về cứu nạn, cứu hộ.

- Bộ Công an chịu trách nhiệm trước Chính phủ thực hiện quản lý nhà nước về cứu nạn, cứu hộ.

4) Các văn bản về cứu nạn, cứu hộ:

- Quyết định 46/2006/QĐ -TTg của Thủ tướng Chính phủ ngày 28 tháng 02 năm 2006 Phê duyệt Đề án quy hoạch tổng thể lĩnh vực tìm kiếm cứu nạn đến năm 2015 tầm nhìn 2020.

- Nghị định 83/2017/NĐ-CP của Chính phủ ngày 18 tháng 7 năm 2007 Quy định về công tác cứu hộ, cứu nạn của lực lượng phòng cháy và chữa cháy.

- Thông tư 08/2018/TT-BCA ngày 05 tháng 3 năm 2018 Quy định chi tiết một số điều của Nghị định 83/2017/NĐ-CP của Chính phủ ngày 18 tháng 7 năm 2007 Quy định về công tác cứu hộ, cứu nạn của lực lượng phòng cháy và chữa cháy.

- Quyết định 118/2008/QĐ-TTg của Thủ tướng Chính phủ ngày 27 tháng 8 năm 2008 Ban hành Quy chế quản lý tài chính đối với hoạt động tìm kiếm cứu nạn, cứu hộ, ứng phó thiên tai, thảm họa.

Trong những năm gần đây Bộ Công an tích cực nâng cao năng lực, trình độ, mua sắm trang thiết bị cho lực lượng cảnh sát phòng cháy, chữa cháy, cứu nạn, cứu hộ trong lĩnh vực cứu nạn, cứu hộ tai nạn giao thông đường bộ. Tuy nhiên so với yêu cầu vẫn còn nhiều bất cập về: tổ chức thông tin, tính kịp thời, trang thiết bị hiện đại xử lý các vụ tai nạn giao thông phức tạp...vì vậy nhiều vụ tai nạn giao thông vẫn sử dụng các lực lượng tại chỗ không chuyên nghiệp, dẫn đến khả năng khắc phục hậu quả tai nạn giao thông không cao.

\subsection{Những thành công và chưa thành công của các chính sách về an toàn giao thông và quản lý đối với xe máy}

Tình hình tai nạn giao thông luôn luôn diễn biến phức tạp, căn cứ tình hình từng giai đoạn Chính phủ đưa ra những chính sách cụ thể để đạt được mục tiêu giảm thiểu tai nạn giao thông, ùn tắc giao thông. Những chính sách này thường được luật hóa như: luật, nghị định, quyết định của Thủ tướng Chính phủ, thông tư của các Bộ ... và những giải pháp cụ thể trong từng giai đoạn được thể hiện rõ nhất trong các Nghị quyết của Chính phủ về bảo đảm trật tự an toàn giao thồng đường bộ. Không đặt vấn đề đánh giá các văn bản pháp luật về trật tự an toàn giao thông đường bộ, phần này chỉ nghiên cứu về những thành công, chưa thành công của các giải pháp đã nêu trong các Nghị quyết của Chính phủ để xây dựng chiến lược, kế hoạch về an toàn giao thông và quản lý xe máy. 


\subsubsection{Quan điểm của Chính phủ về bảo đảm an toàn giao thông}

\subsubsection{Tai nạn giao thông, vấn đề xã hội bức xúc, tiếp cận hệ thống giải quyết tai nạn giao thông}

Trước hết cần khẳng định tai nạn giao thông là một vấn nạn, là vấn đề xã hôi. Đúng vậy, mặc dù có rất nhiều định nghĩa về "vấn đề xã hội", có nhiều ý kiến khác nhau, nhưng có lẽ dễ hiểu nhất có thể xem định nghĩa sau: "vấn đề xã hội là một tình trạng trong một giai đoạn xã hội cụ thể nó có hại cho đa số các thành viên và cần phải khắc phục" ${ }^{22}$, đồng thời có thể nhận dạng qua tiêu chí sau:

- Có liên quan và tác động tới nhiều nhóm trong xã hội (thậm chí toàn thể dân chúng)

- Có liên quan và ảnh hưởng đến nhiều thiết chế, lĩnh vực khác nhau.

- Mang tính chất quốc gia, quốc tế.

- Trở thành một chủ đề được bàn bạc nhiều trong các chương trình nghị sự.

- Nhận được sự quan tâm của dư luận xã hội, nhiều người biết và bầy tỏ quan điểm về nó.

- Khó giải quyết tận gốc và triệt để.

Trình bầy như trên để khẳng định để giải quyết vấn đề tai nạn giao thông thì cần giải quyết nó như giải quyết một vấn đề xã hội, không phải như giải quyết một vấn đề kỹ thuật.

Hiện nay, trên thế giới có nhiều cách tiếp cận giải quyết tai nạn giao thông, thông thường có mấy cách tiếp cận như sau:

1) Ma trận Haddon

\begin{tabular}{|c|c|c|c|c|}
\hline \multirow{2}{*}{\multicolumn{2}{|c|}{ Giai đoạn }} & \multicolumn{3}{|c|}{ Các yếu tố } \\
\hline & & Con người & $\begin{array}{l}\text { Phương tiện, } \\
\text { thiết bị }\end{array}$ & $\begin{array}{l}\text { Môi trường, } \\
\text { con đường }\end{array}$ \\
\hline 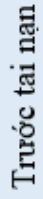 & $\begin{array}{l}\text { Phòng } \\
\text { tránh tai } \\
\text { nạn }\end{array}$ & $\begin{array}{l}\text { - Ý thức chấp hành } \\
\text { pháp luật } \\
\text { - Kỹ năng lái xe } \\
\text { - Cưỡng chế } \\
\text { - .... }\end{array}$ & $\begin{array}{l}\text { - Phanh } \mathrm{ABS} \text {, hệ } \\
\text { thống phân bố lực } \\
\text { phanh điện tử EBD, } \\
\text { hệ thống cân bằng } \\
\text { điện tử ESC... }\end{array}$ & $\begin{array}{l}\text { - Bề mặt chống trơn } \\
\text { trượt } \\
\text { - Giao thông thông } \\
\text { minh ITS } \\
\text { - ... }\end{array}$ \\
\hline 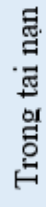 & $\begin{array}{l}\text { Giàm } \\
\text { thương } \\
\text { vong } \\
\text { trong tai } \\
\text { nạn }\end{array}$ & $\begin{array}{l}\text { - Đội mũ bào hiểm } \\
\text { - Thắt dây an toàn } \\
\text { - ... }\end{array}$ & $\begin{array}{l}\text { - Túi khí } \\
\text { - Hấp thụ xung lực } \\
\text { khi va chạm } \\
\text { - Seatbell } \\
\text { - . . }\end{array}$ & $\begin{array}{l}\text { - Loại trừ mối nguy } \\
\text { hiểm trên đường (vật } \\
\text { sắc nhọn ...) }\end{array}$ \\
\hline 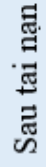 & $\begin{array}{l}\text { Hỗ trợ } \\
\text { sự sống }\end{array}$ & $\begin{array}{l}\text { - Cấp cứu y tế, cứu } \\
\text { hộ, cứu nạn } \\
-\ldots\end{array}$ & $\begin{array}{l}\text { - Dịch vụ cứu hộ } \\
\text { phương tiện } \\
\text { - . . }\end{array}$ & $\begin{array}{l}\text { - Tiếp cận vụ tai nạn } \\
\text { giao thông nhanh } \\
\text { chóng ... }\end{array}$ \\
\hline
\end{tabular}

${ }^{22}$ Linda A. Mooney, David, Knox và Caroline Schacht. Understanding social prolems. East Carolina University, 2009. 
2) Tiếp cận 4E: Kỹ thuật (Engineering); giáo dục (Education); cưỡng chế (Enforcement) và cấp cứu (Emergency)

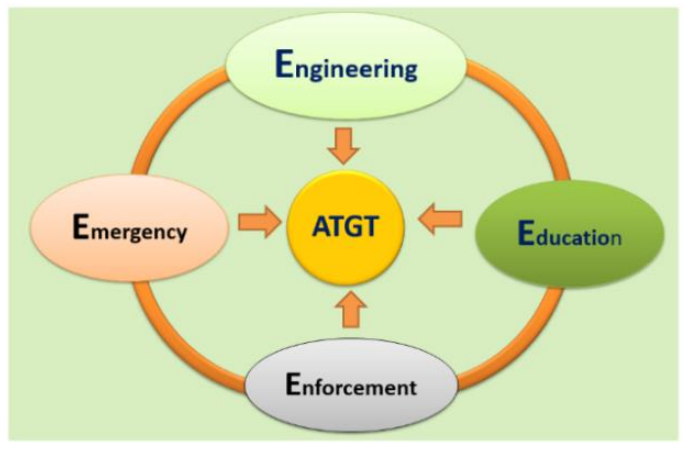

3) Tiếp cận năm trụ cột của Nghị quyết A/64/255 của Đại hội đồng Liên Hợp Quốc

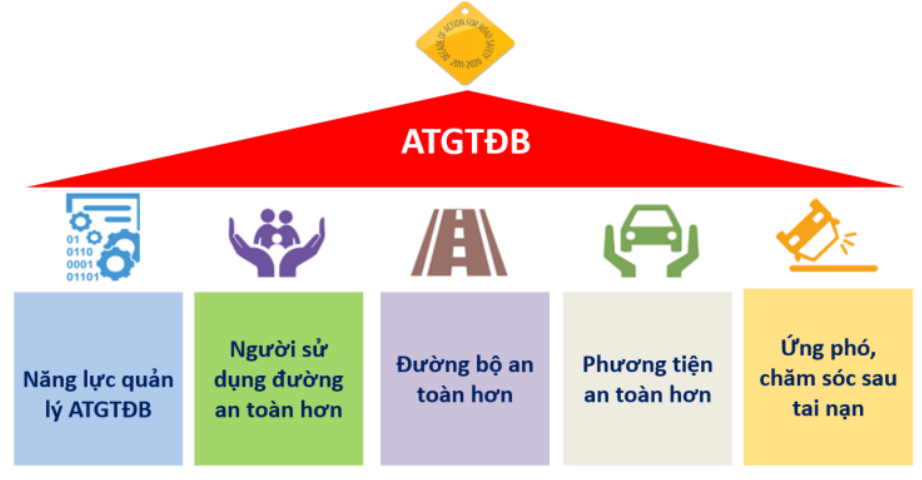

Nhìn chung các cách tiếp cận hệ thống an toàn giao thông nêu trên đều xem xét các yếu tố gây tai nạn giao thông và cách tiếp cận để giải quyết, những yếu tố này tương đối giống nhau, tuy nhiên tùy theo quan điểm có thể nhấn mạnh một điểm tiếp cận nào đấy, ví dụ cách tiếp cận trụ cột tách riêng vai trò năng lực quản lý nhà nước thành một trụ cột với quan điểm tiếp cận này có vai trò quan trọng. Trong khi đó ở Ma trân Haddon thì thể chế, pháp luật nằm trong ô con người và trước tai nạn.

\subsubsection{Quan điểm chung của Chính phủ về xây dựng chính sách bảo đảm trật tự an toàn giao thông}

Chính sách của Chính phủ về trật tự an toàn giao thông cũng theo cách tiếp cận cơ bản như hệ thống nêu trên, tuy nhiên do tổ chức xã hội, hệ thống chính trị của chúng ta có những ưu điểm nổi bật, vì vậy có thể thay đổi cho phù hợp, cụ thể có mấy điểm nhấn mạnh sau:

\section{1) Quan điểm Toàn dân.}

Trước hết, tại Điều 4 Luật Giao thông đường bộ 2008 khẳng định: "Bảo đảm trật tự, an toàn giao thông đường bộ là trách nhiệm của cơ quan, tổ chức, cá nhân”.

Quyết định 1586/QĐ-TTg ngày 24 tháng 10 năm 2012 của Thủ tướng Chính phủ Phê duyệt Chiến lược quốc gia bảo đảm trật tự an toàn giao thông đường bộ đến năm 2000 và tầm nhìn đến năm 2030, tại Điều 1 cũng nêu rõ quan điểm: "Bảo đảm trật tự an toàn giao thông và hạn chế tai nạn giao thông là trách nhiệm của cả hệ thống chính trị, của toàn dân, toàn xã hội, trước hết là của các cơ quan nhà nước có chức năng và của người tham gia giao thông" 
Như trên đã nêu tai nạn giao thông là vấn đề xã hội, giải quyết không dễ và nó cũng do các thành viên, các tổ chức trong xã hội gây ra. Vậy để giải quyết nó trước hết phải toàn xã hội, toàn dân phải cùng chung tay hành động. Mặt khác Việt Nam có một hệ thống chính trị thống nhất dưới sự lãnh đạo toàn diện của Đảng, nếu toàn hệ thống chính trị cùng tham gia, cùng vào cuộc chắc chắn tạo được sức mạnh tổng hợp và sẽ thay đổi được vấn nạn tai nạn giao thông . Hầu hết các Nghị quyết đều nêu rõ trách nhiệm của các Bộ, ngành, yêu cầu phối hợp chặt chẽ với các tổ chức chính trị-xã hội, Trung ương Mặt trận Tổ quốc Việt Nam và các cơ quan thành viên của Mặt trận.

\section{2) Quan điểm Đồng bộ.}

Chính phủ, Thủ tướng Chính phủ đều nhấn mạnh muốn giải quyết tai nạn giao thông có hiệu quả phải thực hiện đồng bộ các giải pháp, trong đó có chọn các vấn đề ưu tiên để tập trung giải quyết sớm mang lại hiệu quả. Cũng tại Quyết định 1586/QĐ-TTg ngày 24 tháng 10 năm 2012 của Thủ tướng Chính phủ Phê duyệt Chiến lược quốc gia bảo đảm trật tự an toàn giao thông đường bộ đến năm 2000 và tầm nhìn đến năm 2030, tại Điều 1 cũng nêu rõ quan điểm: "xây dựng các giải pháp mạnh, đột phá, đồng bộ, thực hiện từng bước, liên tục và kiên trì nhằm cải thiện môi trường giao thông trật tự, an toàn, văn minh, hiện đại, thân thiện và bền vững".

Các chính sách về bảo đảm trật tự an toàn giao thông do Chính phủ ban hành thể rất rõ quan điểm này, các chính sách đều đề cập về thể chế, kết cấu hj tầng giao thông, người tham gia giao thông, phương tiện giao thông và ứng phó sau tai nạn.

Trong Kế hoạch hành động, kế hoạch phối hợp thực hiện các chính sách bảo đảm trật tự an toàn giao thông của Ủy ban An toàn giao thông Quốc gia, các Bộ, ngành, các địa phương đều xác định nhiệm vụ ưu tiên.

\subsubsection{Những thành công và chưa thành công của các chính sách về an toàn giao thông và quản lý đối với xe máy}

Kể từ năm 2002 đến nay, Chính phủ đã ban hành các Nghị quyết về bảo đảm trật tự an toàn giao thông đường bộ như sau:

- Nghị quyết 13/2002/NQ-CP ngày 19 tháng 11 năm 2002 về các giải pháp kiềm chế gia tăng và tiến tới giảm dần tai nạn giao thông và ùn tắc giao thông.

- Nghị quyết 32/2007/NQ-CP ngày 29 tháng 6 năm 2007 của Chính phủ về một số giải pháp cấp bách nhằm kiềm chế tai nạn giao thông và ùn tắc giao thông.

- Nghị quyết số 16/2008/NQ-Chính phủ ngày 31 tháng 7 năm 2008 của Chính phủ về từng bước khắc phục ùn tắc giao thông tại Hà Nội và Thành phố Hồ Chí Minh.

- Nghị quyết 88/NQ-CP ngày 24 tháng 8 năm 2011 về tăng cường thực hiện các giải pháp trọng tâm bảo đảm trật tự an toàn giao thông.

Những Nghị quyết nêu trên sẽ được nghiên cứu, xem xét mức độ thành công và chưa thành công trong thực tiễn từ năm 2002 đến nay.

Nhóm nghiên cứu sử dụng tiêu chí số người bị chết vì tai nạn giao thông đường bộ để đánh giá tai nạn giao thông tăng hay giảm. 
Nhìn tổng quát trên biểu đồ diễn biến số người bị chết vì tai nạn giao thông từ 1999 đến năm 2017, tai nạn giao thông đều bị tác động mạnh của các chính sách, sau mỗi lần ban hành một Nghị quyết mới thì tai nạn giao thông đều được kiềm chế và giảm. Như vậy, có thể nói những chính sách về trật tự an toàn giao thông đã ban hành đều tương đối thành công với mục tiêu kiềm chế, giảm thiểu tai nạn giao thông.

Nghiên cứu phân chia thành 2 vấn đề : tác động của chính sách đối với tai nạn giao thông và tác động của chính sách đến quản lý xe máy để đơn giản hóa nghiên cứu. Thực tế sự tăng giảm xe máy đều ảnh hưởng nhiều đến tai nạn giao thông; nếu hạn chế được gia tăng xe máy sẽ có tác động giảm tai nạn giao thông.

Trong phần tác động của chính sách đến kiềm chế tai nạn giao thông, những biện pháp hạn chế phát triển xe máy chính là một biện pháp để giảm tai nạn giao thông.

\subsubsection{Tác động của chính sách đến kiềm chế tai nạn giao thông}

Từ năm 2000 đến năm 2017 có thể chia làm ba giai đoạn để xem xét tác động của chính sách đến tai nạn giao thông.

\subsection{Giai đoạn tù̀ 2002 đến 2005}

\section{1) Bối cảnh ban hành Nghị quyết 13/2002/NQ-CP}

Giai đoạn này gắn liền với các chính sách của Nghị quyết 13/2002/NQ-CP; bối cảnh giai đoạn này như sau: từ năm 1995 đến năm 2000 số người bị chết vì tai nạn giao thông tăng nhưng mức độ tăng không nhiều, mỗi năm bình quân tăng 333 người bị chết vì tai nạn giao thông; từ năm 2000 đến 2002 số người bị chết vì tai nạn giao thông tăng đột biến, chỉ trong năm 2001và năm 2002 bình quân số người bị chết vì tai nạn giao thông mỗi năm tăng 2.631 người, năm 2002 số người bị chết vì tai nạn giao thông cao đỉnh điểm là 13.186 người. Nguyên nhân tai nạn giao thông tăng đột biến là do số lượng xe máy tăng đột biến; trước năm 2000, bình quân mỗi năm chỉ tăng 500.000 xe, từ cuối năm 2000 xe máy giá rẻ của Trung Quốc nhập khẩu ồ ạt vào Việt Nam vì vậy số lượng xe máy tăng đột biến, riêng năm 2001 tăng 2.148.219 xe, tăng 34,9\% so với năm 2000.

Trước tình hình gia tăng tai nạn giao thông đột biến, toàn xã hội hết sức bức xúc, trên cơ sở Đề án tăng cường bảo đảm tật tự an toàn giao thông giai đoạn 2000 - 2005 ( phê duyệt tại văn bản số 356/CN-CP ngày 17 tháng 4 năm 2000), Chính phủ kịp thời ban hành Nghị quyết 13/2002/NQ-CP ngày 19 tháng 11 năm 2002; mục tiêu của Nghị quyết 13/2002/NQ-CP là phải nhanh chóng kiềm chế tai nạn giao thông và ùn tắc giao thông bằng nhiều giải pháp đồng bộ, có những biện pháp đột phá trước mắt và những giải pháp lâu dài; một số biện pháp được tập trung chỉ đạo, thực hiện quyết liệt và có tác động trực tiếp giảm thiểu tai nạn giao thông. 


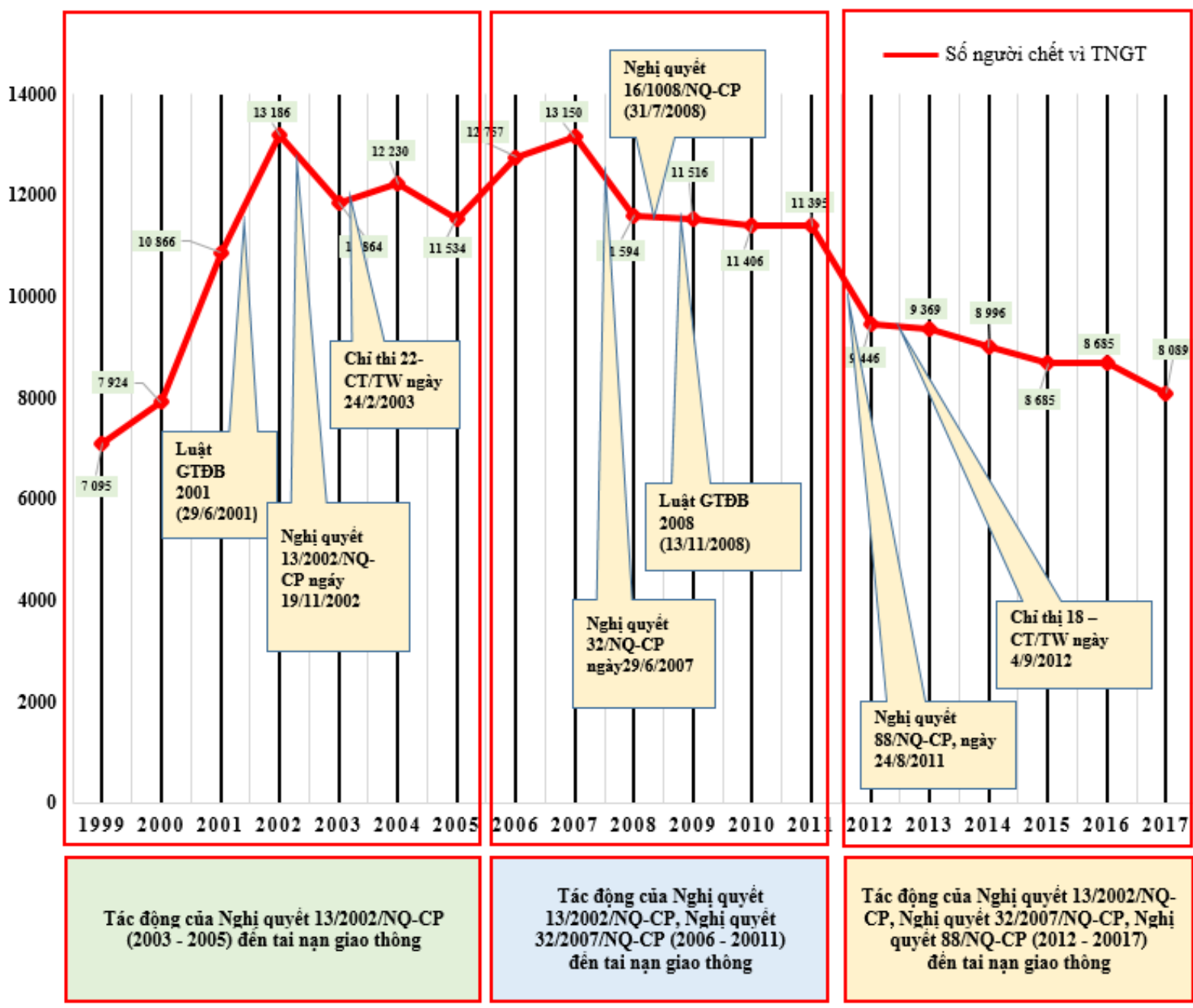

Hình 2-1 Tác động của chính sách đến tai nạn giao thông²3

2) Một số giải pháp trọng tâm đã được thực hiện trong giai đoạn này

- Giảm ngay sự gia tăng xe máy: một mặt thực hiện chủ trương “Song song với việc phát triển vận tải khách công cộng và đầu tư phát triển kết cấu hạ tầng giao thông đô thị, cần khẩn trương ban hành các giải pháp đồng bộ nhằm kiềm chế sự gia tăng mô tô, xe máy, tiến tới giảm dần số lượng mô tô, xe máy lưu hành trong nội thành, nội thị các thành phố, thị xã”, mặt khác áp dụng ngay biện pháp hành chính cứng rắn: "Ủy ban nhân dân thành phố Hà Nội, thành phố Hồ Chí Minh ban hành lộ trình và các biện pháp chặt chẽ, phù hợp nhằm kiềm chế tối đa sự gia tăng số lượng mô tô, xe máy, trong đó có xem xét cụ thể việc tạm dừng đăng ký mô tô, xe máy mới và quy định các tuyến đường, khu vực, thời gian không cho mô tô, xe máy lưu hành để hạn chế ùn tắc giao thông".

- "Trước hết phải tập trung kiểm tra, xử phạt nghiêm những người điều khiển mô tô không có giấy phép lái xe, kiên quyết chấm dứt tình trạng người điều khiển mô tô không có giấy phép lái xe".

${ }^{23}$ Nguồn: Ủy ban An toàn giao thông Quốc gia. Năm 2018 tai nạn giao thông đường bộ tiếp tục giảm cả 3 tiêu chí, năm 2018 xẩy ra 18.490 vụ, làm chết 8.079 người, bị thương 14.732 người, so với năm 2017 giảm 6,61\% về số vụ, giảm $0,12 \%$ về số người bị chết, giảm 13,19\% về số người bị thương (báo cáo kết quả công tác bảo đảm trật tự an toàn giao thông năm 2018 và nhiệm vụ trọng tâm năm 2019) 
- “Quy định việc đánh dấu số lần vi phạm Luật Giao thông đường bộ trên giấy phép lái xe hiện hành để quản lý người điều khiển phương tiện cơ giới đường bộ (kể cả người điều khiển mô tô)".

3) Ngoài biện pháp nêu trên, còn một số biện pháp khác, những biên pháp này tác động không nhiều đến tình hình tai nạn giao thông, đó là:

- Cảnh sát giao thông phải kiên quyết xử phạt những người điều khiển và ngồi trên mô tô, xe máy không đội mũ bảo hiểm trên những đoạn đường bắt buộc đội mũ bảo hiểm"

- "Thường xuyên kiểm tra các cơ sở đào tạo và công tác sát hạch cấp giấy phép lái xe, kiên quyết thu hồi giấy phép đào tạo của những cơ sở đào tạo lái xe không đủ tiêu chuẩn quy định, đình chỉ hoạt động và xử lý nghiêm khắc Hội đồng sát hạch nếu có sai phạm hoặc sát hạch viên có hành vi tiêu cực".

- "Khi đăng ký mô tô, xe máy, người đăng ký phải xuất trình giấy phép lái xe; phải mua bảo hiểm trách nhiệm dân sự của chủ xe cơ giới và đóng các loại phí và lệ phí theo quy định".

- "Sửa đổi, bổ sung quy tắc, biểu phí, tăng mức bảo hiểm bắt buộc trách nhiệm dân sự của chủ xe cơ giới; tăng mức thu lệ phí trước bạ, lệ phí đăng ký và lệ phí lưu hành mô tô, xe máy ở các thành phố, thị xã; đồng thời ban hành chính sách hỗ trợ tài chính cho phát triển vận tải khách công cộng bằng xe buýt và đầu tư xây dựng hạ tầng giao thông đô thị”.

\section{4) Những kết quả đã đạt được trong giai đoạn $2003-2005^{24}$}

a) Tai nạn giao thông được chặn đứng và đẩy lùi.

Bộ Công an ban hành Thông tư 02/2003/TT-BCA(C11) ngày 13 tháng 1 năm 2003 bổ sung một số quy định của Thông tư số $01 / 2002 / T T-B C A(C 11)$ ngày 04 tháng 01 năm 2002 về hướng dẫn tổ chức cấp đăng ký, biển số phương tiện giao thông cơ giới đường bộ. Trong đó quy định:

"Khi đăng ký mô tô, xe máy, người đứng tên đăng ký phải có hộ khẩu thường trú ở tỉnh, thành phố nơi đăng ký xe. Riêng chủ xe là cán bộ, chiến sĩ trong lực lượng vũ trang (Công an, Quân đội) vẫn thực hiện theo Thông tư 01/2002/TT-BCA(C11) ngày 04/01/2002. Mỗi người chỉ được đăng ký 01 xe mô tô hoặc xe gắn máy. Trong hồ sơ đăng ký xe phải có thêm bản phô-tô các giấy tờ sau (khi nộp bản phô-tô phải xuất trình bản chính để đối chiếu): giấy phép lái xe theo quy định (trừ chủ xe là cơ quan, tổ chức); giấy chứng nhận bảo hiểm bắt buộc trách nhiệm dân sự của chủ xe cơ giới”

Hội đồng nhân dân Thành phố Hà Nội ban hành Nghị quyết số 34/2003/NQ-HĐ ngày 13 tháng 02 năm 2003 về một số giải pháp và cơ chế, chính sách để kiềm chế gia tăng và tiến tới giảm dần tai nạn giao thông và ùn tắc giao thông trên địa bàn thành phố Hà Nội. Nghị quyết số 34/2003/NQ-HĐ có 9 giải pháp, trong đó có biện pháp hạn chế gia tăng mô tô, xe máy: " Giao UBND Thành phố chỉ đạo các cơ quan chuyên môn xây dựng lộ trình hợp lý để tiến tới dừng đăng ký xe máy trên toàn Thành phố, tổ chức thực hiện thí điểm dừng đăng ký xe máy tại 4 quận nội thành cũ trong năm 2003”, sau đó UBND Thành phố Hà Nội mở rộng thêm 3 quận: Thanh Xuân, Tây Hồ, Cầu Giấy từ 1 tháng 1 năm 2005 và sẽ mở rộng thêm quận: Hoàng Mai, Long Biên vào năm 2008.

\footnotetext{
${ }^{24}$ Báo cáo ATGT năm 2003 của UBATGTQG
} 
Với biện pháp cứng rắn nêu trên, số lượng xe máy đăng ký mới năm 2003 chỉ còn tăng 1.106.000 xe, tăng 10,8\% (năm 2000 tăng 11,2\%, năm 2001 tăng 34,6\%. năm 2002 tăng 22,9\%); xe mô tô đăng ký mới ở Hà Nội giảm $39 \%$, thành phố Hồ Chí Minh giảm 57\% so với năm 2002. Cùng với số lượng xe đăng ký mới giảm số người bị chết tai nạn giao thông cũng giảm, năm 2003 giảm 1.322 người bị chết vì tai nạn giao thông so với năm 2002 (giảm $8,1 \%$ ).

b) Số người điều khiển xe mô tô không có giấy phép giảm

Năm 2001 tổng số xe máy là 8.359 . 823 xe nhưng chỉ có 4.114 .491 người có giấy phép lái xe, chiếm $47,9 \%$, như vậy có rất nhiều người không cần học luật, không cần thi lấy giấy phép lái xe nhưng vẫn điều khiển phương tiện. Phân tích 208.840 vụ tai nạn xe mô tô (đầu năm 2001) có dến 9.313 xe không đăng ký (4,4\%), 47.303 người điều khiển bị tai nạn không có giấy phép lái xe $(22,6 \%){ }^{25}$

Cuối năm 2002 và năm 2003 Bộ Công an đã mở nhiều chiến dịch kiểm tra, xử lý người đi xe máy không có giấy phép lái xe, vì vậy tạo ra trào lưu đi học thi lấy giấy phép lái xe trên toàn quốc. Năm 2003 đã cấp được 4.962 .352 giấy phép lái xe mô tô, tổng số đã cấp được 10.734.428 giấy phép lái xe mô tô /11.379.407 xe mô tô $(94,3 \%)$.

c) Nâng cấp các cơ sở đào tạo lái xe.

Kiểm tra tất cả các cơ sở đào tạo lái xe trong phạm vi toàn quốc, chấn chỉnh, thu hồi nhiều giấy phép của cơ sở đào tạo không đạt tiêu chuẩn. Từ năm 2005 đã áp dụng công nghệ vào khâu sát hạch (thi lý thuyết trên máy tính, đưa nhiều trung tâm sát hạch tự động vào hoạt động).

d) Ý thức người tham gia giao thông có chuyển biến, đặc biệt người điều khiển xe máy.

Một mặt huy động các cơ quan thông tin, tuyên truyền, các tổ chức chính trị-xã hội, hệ thống trường học tích cực tuyên truyền pháp luật trật tự an toàn giao thông, mặt khác xử lý nghiêm các hành vi vi phạm, trong đó biện pháp đục lỗ giấy phép lái xe, tạm giữ phương tiện, tăng mức xử phạt có tác dụng răn đe cao; chọn quốc lộ làm trọng tâm tuần tra, kiểm soát, xử lý vi pham. Năm 2003 lực lượng cảnh sát giao thông đã xử lý 3 triệu 542 trường hợp vi phạm với tổng số tiền phạt là 420 tỷ đồng, so với năm 2002 số vụ xử lý tăng 3 lần, số tiền phạt tăng 230 tỷ đồng.

e) Bắt đầu hình thành hệ thống xe buýt ở Hà Nội và Thành phố Hồ Chí Minh

Hà Nội đã đưa vào hoạt động 39 tuyến với 678 xe buýt, số người đi lại bằng phương tiện công cộng ngày càng tăng (năm 2003 đã vận chuyển được trên 173 triệu lượt hành khách, tăng 3,7 lần so với năm 2002). Chương trình xe buýt của Thành phố Hồ Chí Minh đã có những bước tiến khả quan, đã thay toàn bộ xe quá niên hạn, đầu tư mới 792 xe buýt (thành phố đầu tư 350 xe trong chương trình 1318 xe, xã viên hợp tác xã tự đầu tư 348 xe) đến tháng 12 năm 2003 thành phố đã có 97 tuyến với 1.923 xe buýt hoạt động, sản lượng đạt 91.397.514 lượt hành khách. Một số tỉnh như: Bình Định, Bình Dương, Khánh Hoà, Kiên Giang.. đã bắt đầu tổ chức các tuyến xe buýt trong thành phố, thị xã...và bước đầu đã thu hút được người dân.

${ }^{25}$ Báo cáo của UBATGTQG 


\subsection{Giai đoan 2006 -2011}

\section{1) Bối cảnh ban hành Nghị quyết 32/2007/NQ -CP}

Tháng 11 năm 2005 bãi bỏ quy định mỗi người chỉ được đăng ký 01 xe máy (Thông tư 17/2005/TT- BCA (C11) ngày 21 tháng 11 năm 2005), số lượng xe máy tăng trở lại trên $20 \%$ (tăng 2.710.652 xe) và bắt đầu từ năm 2006 tai nạn giao thông diễn biến phức tạp, tăng nhanh, đỉnh điểm thời kỳ này là số người bị chết vì tai nạn giao thông năm 2007 lên đến con số 13.150 người (so với năm 2005 tăng 1.616 người chết vì tai nạn giao thông). Trước bức xúc của toàn xã hội, các cơ quan truyền thông đều lên tiếng, Chính phủ, Bộ GTVT, Bộ Công an, Ủy ban An toàn giao thông Quốc gia đã có nhiều cuộc họp tìm những giải pháp cấp bách để kiểm soát tình hình tai nạn giao thông.

Tháng 6 năm 2007, Chính phủ ban hành Nghị quyết 32/2007/NQ-CP với nhiều giải pháp cấp bách, có nhiều giải pháp đột phá để có thể chặn đứng và đẩy lùi tai nạn giao thông, một số điểm nhấn như sau:

- Công tác tuyên truyền, phổ biến, giáo dục pháp luật trật tự an toàn giao thông nhấn nạnh vai trò gương mẫu của cán bộ, công chức viên chức, vai trò của thủ trưởng các cơ quan nhà nước, các tổ chức, các đoàn thể, các doanh nghiệp; đối với hệ thống giáo dục, hiệu trưởng các trường phải có trách nhiệm quản lý, giáo dục về chấp hành pháp luật trật tự an toàn giao thông. Đặc biệt quy định tổ chức thông báo người vi phạm về nơi sinh hoạt để giáo dục.

- Yêu cầu 01 tháng 01 năm 2008 đình chỉ ô tô đã hết niên hạn sử dụng, xe công nông, xe tự chế 3 , 4 bánh; tạm giữ mô tô, xe gắn máy 30 ngày trở lên nếu người điều khiển vi phạm một trong các quy định sau: chở quá số người cho phép, đi vào đường ngược chiều, đường cấm, lạng lách đánh võng, vượt đèn đỏ, không chấp hành hiệu lệnh của cảnh sát giao thông; tạm giữ mô tô, xe gắn máy 90 ngày không phân biệt sở hữu đối với trường hợp học sinh, sinh viên chưa đủ tuổi hoặc không có Giấy phép lái xe điều khiển mô tô, xe gắn máy.

- Tổ chức phân làn riêng cho mô tô, gắn máy trên những tuyến đường, tuyến phố đủ điều kiện để khắc phục tình trạng lưu thông hỗn hợp; quy định khi xây dựng mới quốc lộ, các tuyến phố mới phải tổ chức phân làn riêng cho xe mô tô, xe gắn máy, lắp đặt các hệ thống giám sát an toàn.

- Thực hiện việc bắt buộc học và kiểm tra lại Luật Giao thông đường bộ trước khi nhận lại Giấy phép lái xe đối với những lái xe vi phạm pháp luật trật tự an toàn giao thông đến mức bị tạm giữ Giấy phép lái xe từ 60 ngày trở lên; thu hồi không thời hạn Giấy phép lái xe của lái xe khách chuyên nghiệp các loại $\mathrm{D}, \mathrm{E}$ để xảy ra tai nạn giao thông đặc biệt nghiêm trọng hoặc chở khách quá $100 \%$ số khách quy định; thu hồi không thời hạn Giấy phép lái xe của những lái xe nghiện ma túy.

- Từ ngày 15 tháng 9 năm 2007, người đi mô tô, xe gắn máy trên các quốc lộ bắt buộc phải đội mũ bảo hiểm. Từ ngày 15 tháng 12 năm 2007, người đi mô tô, xe gắn máy trên tất cả các tuyến đường bắt buộc phải đội mũ bảo hiểm.

\section{2) Những kết quả đã đạt được trong giai đoạn $2006-2011^{26}$.}

Những biện pháp nêu trên (loại trừ quy định phân làn riêng cho xe mô tô, xe máy) đều thực hiện được và góp phần vào thành công kiềm chế tai nạn giao thông trong giai đoạn này.

26 Báo cáo ATGT của UBATGTQG 
- Thực hiện thành công quy định bắt buộc đội mũ bảo hiểm khi đi mô tô, xe gắn máy; đây là giải pháp có tác động mạnh nhất đến giảm tai nạn giao thông trong giai đoạn này và còn tiếp tục phát huy ở những năm sau này (xem điểm 5: thực hiện Quy định bắt buộc đội mũ bảo hiểm khi đi xe máy ở Việt Nam).

- Tai nạn giao thông giảm sâu cả 3 tiêu chí, đặc biệt số người bị chết năm 2008 so với năm 2007 giảm 1.556 người. Thực hiện thành công quy định bắt buộc quy định đội mũ bảo hiểm khi đi mô tô, xe gắn máy, cùng các biện pháp khác quy định ở Nghị quyết 32/2007/NQ-CP đã tạo ra một bước đột phá quan trọng, tai nạn giao thông ở Việt Nam liên tục giảm liên tục trong 10 năm qua.

\subsection{Giai đoạn 2012 đến 2017}

\section{1) Bối cảnh ban hành Nghị quyết 88/NQ -CP}

Mặc dù, thực hiện thành công quy định bắt buộc đội mũ bảo hiểm, tai nạn giao thông 2009, 2010, 2011 vẫn tiếp tục giảm nhưng giảm không nhiều; số người bị chết vì tai nạn giao thông vẫn ở mức cao vì vậy vẫn phải tiếp tục đẩy mạnh hơn nữa, thực hiện những biện pháp đột phá để giảm hơn nữa tai nạn giao thông và giảm tai nạn giao thông bền vững.

Ngày 24 tháng 8 năm 2011 Chính phủ ban hành Nghị quyết 88/NQ-CP về tăng cường thực hiện các giải pháp trọng tâm bảo đảm trật tự an toàn giao thông, Nghị quyết tập trung vào một số giải pháp trong tâm sau:

- Tăng cường phòng chống và kiểm soát người điều khiển phương tiện cơ giới đường bộ sử dụng rượu, bia, đây là giải pháp được ưu tiên. Giải pháp này được thực hiện đồng bộ như: tuyên truyền rộng rãi đến cơ sở; cán bộ, công chức, viên chức gương mẫu, trách nhiệm của thủ trưởng các đơn vị, người đứng đầu; quy định hạn chế quảng cáo, in khuyến cáo tác hại của lạm dụng rượu, bia

- Duy trì và tiếp tục đẩy mạnh thực hiện đội mũ bảo hiểm; ngăn chặn học sinh, sinh viên chưa đủ tuổi, không có giấy phép lái xe điều khiển xe môtô, xe gắn máy

- Tăng cường công tác cứu hộ, cứu nạn, cấp cứu tai nạn giao thông

- Đẩy mạnh tuyên truyền văn hóa giao thông

- Tăng cường quản lý hoạt động vận tải bằng ôtô

- Triển khai lắp đặt dải phân cách để tách dòng xe môtô 2 bánh, xe thô sơ với dòng xe ôtô trên các tuyến đường có đủ điều kiện và có mật độ phương tiện giao thông lớn; khi lập dự án nâng cấp, cải tạo, xây dựng mới các tuyến đường bộ, tuyến tránh đô thị phải thiết kế phân làn đường dành riêng cho xe môtô, xe gắn máy.

\section{2) Những kết quả đã đạt được trong giai đoạn 2012-2017}

- Ngay sau năm ban hành Nghị quyết, năm 2012 số người bị chết vì tai nạn giao thông giảm cao nhất từ trước tới nay, giảm 1.591 người so với năm 2011 (giảm 14,4\% ); và cũng từ năm 2012 số người bị chết tai nạn giao thông giảm xuống con số dưới 10.000 người và liên tục giảm đến nay, năm 2017 số người bị chết vì tai nạn giao thông giảm xuống còn 8.089 người.

- Tình trạng lái xe sử dụng rượu bia có giảm, lái xe ô tô thương mại (xe khách, xe tải, xe taxi) ít vi phạm, số đông vi phạm là người điều khiển xe máy và lái xe con cá nhân; phân tích 91.026 trường hợp vi phạm thì người lái xe ô tô vi phạm 4,77\%, người điều khiển mô tô vi phạm $95,23 \%{ }^{27}$

${ }^{27}$ Sách trắng về trật tự an toàn giao thông đường bộ năm 2016-2017 (Viện Khoa học cảnh sát - Học viện Cảnh sát nhân dân) 
- Y Ý thức người tham gia giao thông, đặc biệt cán bộ, công chức, viên chức có nhiều chuyển biến.

\subsection{Những bài học thành công và hạn chế}

\subsection{Bài học thành công của chính sách về giảm tai nạn giao thông tù̀ năm 2003 đến 2017}

1) Sự tập trung lãnh đạo chỉ đạo quyết liệt của Đảng, Quốc hội và Chính phủ, đặc biệt vai trò của các đồng chí đứng đầu.

Trật tự an toàn giao thông là vấn đề xã hội, để giải quyết cần được sự quan tâm đặc biệt, toàn diện của Đảng và Nhà nước, quyết tâm chính trị của đồng chí lãnh đạo đứng đầu Nhà nước.

Cùng với Nghị quyết 13/2002/NQ-CP, Ban Bí thư ban hành Chỉ thị số 22-CT/TW ngày 24 tháng 02 năm 2003 về tăng cường sự lãnh đạo của Đảng đối với công tác bảo đảm trật tự an toàn giao thông, ngoài những chủ trương mang tính chiến lược, những giải pháp mang tính cấp bách, Chỉ thị còn yêu cầu Chủ tịch ủy ban nhân dân các cấp phải trực tiếp làm trưởng ban an toàn giao thông ở cấp mình và chịu trách nhiệm cá nhân trước lãnh đạo cấp trên về thực hiện các giải pháp bảo đảm trật tự an toàn giao thông trong phạm vi địa phương. Với sự chỉ đạo như trên, công tác bảo đảm trật tự an toàn giao thông ở địa phương có sự chuyển biến khác hẳn, đơn vị trực tiếp thực hiện các chính sách chuyển biến là đảm bảo chắc chắn cho thành công.

Sau năm 2011, Chính phủ ban hành Nghị quyết 88/NQ-CP, Ban Bí thư cũng ban hành Chỉ thị 18-CT/TW ngày 04 tháng 9 năm 2012 về tăng cường sự lãnh đạo của Đảng đối với công tác bảo đảm trật tự an toàn giao thông đường bộ, đường sắt, đường thủy nội địa và khắc phục ùn tắc giao thông, Chỉ thị này cũng tạo thêm sức mạnh để triển khai thành công Nghị quyết $88 / \mathrm{NQ}$ Chính phủ.

2) Huy động được cả hệ thống chính trị tham gia

Hệ thống chính trị là một chỉnh thể các tổ chức chính trị trong xã hội bao gồm các Đảng, Nhà nước và các tổ chức chính trị-xã hội hợp pháp được liên kết với nhau trong một hệ thống tổ chức nhằm tác động vào các quá trình của đời sống xã hội.

Nếu huy động được cả hệ thống chính trị tham gia vào các hoạt động bảo đảm trật tự an toàn giao thông thì với hệ thống chính trị được liên kết chặt chẽ dưới sự lãnh đạo của Đảng cùng tác động vào xã hội sẽ tạo chuyển biến to lớn về an toàn giao thông trong xã hội. Thực tế trong những năm qua, chúng ta đã làm được, đã tập hợp được sức mạnh tổng hợp của cả hệ thống chính trị trong thực hiện an toàn giao thông.

3) Chuẩn bị đầy đủ các quy định pháp lý

Lĩnh vực bảo đảm trật tự an toàn giao thông là lĩnh vực đa ngành, tổng hợp, vì vậy với một chủ trương của Chính phủ thì đòi hỏi các Bô, ngành với chức năng quản lý nhà nước của mình phải ban hành hàng loạt các văn bản hướng dẫn, tổ chức thực hiện kịp thời, đồng bộ. Kinh nghiệm cho thấy để thực hiện được yêu cầu này thì vai trò của cơ quan tổ chức phối hợp, điều phối rất quan trọng, nhiều năm qua Ủy ban An toàn giao thông Quốc gia đã đảm đương khá tốt nhiệm vụ này. 
4) Công tác tuyên truyền, phổ biến, giáo dục pháp luật phải coi trọng, phải được coi là giải pháp hàng đầu, yêu cầu phải làm kiên trì, thường xuyên và liên tục.

Qua hơn 20 năm thực hiện tuyên truyền, phổ biến, giáo dục pháp luật trật tự an toàn giao thông cho thấy nâng cao nhận thức, ý thức và thay đổi hành vi của người tham gia giao thông là quá trình lâu dài; thay đổi hành vi thông qua tuyên truyền, giáo dục diễn ra chậm, khó khăn nhưng bền vững, Thực hiện quy định bắt buộc đội mũ bảo hiểm đã thành thói quen của phần đông người đi xe máy, thói quen đội mũ bảo hiểm tác động nhiều đến kết quả giảm tai nạn giao thông trong hơn 10 năm qua. Ngoài ra, do nhận thức, ý thức của số đông người điều khiển xe máy được nâng cao nên những năm gần đây tuy số lượng xe máy tiếp tục tăng cao nhưng tai nạn giao thông vẫn giảm.

5) Để thực hiện một giải pháp đột phá cần chuẩn bị dư luận tốt, được sự đồng tình của các cơ quan truyền thông, cơ quan báo chí, trong đó vai trò của truyền hình rất quan trọng.

6) Cán bộ, công chức, viên chức gương mẫu thực hiện.

Để thực hiện được quy định bắt buộc đội mũ bảo hiểm khi đi mô tô, xe gắn máy, Chính phủ đã yêu cầu cán bộ, công chức, viên chức phải gương mẫu làm trước. Thực tế thực hiện được yêu cầu này đã tạo ra hiệu ứng xã hội rất tốt và góp phần không nhỏ vào thực hiện quy định bắt buộc đội mũ bảo hiểm khi đi mô tô, xe gắn máy. Trong khi đó với chủ trương không sử dụng rượu, bia khi điều khiển xe máy, Nghị quyết $88 / \mathrm{NQ}-\mathrm{CP}$ cũng yêu cầu cán bộ, công chức, viên chức, các cơ quan nhà nước gương mẫu thực hiện, song đáng tiếc đã không làm được, nên kết quả thực hiện chủ trường này rất hạn chế.

7) Mức xử phạt phải đủ sức răn đe, hợp lý; lực lượng cảnh sát kiên quyết đồng loạt sẵn sàng xử lý vi phạm trên phạm vi toàn quốc.

Bất cứ điều luật nào cũng được thực hiện bằng sức mạnh cưỡng chế nhà nước, tuy nhiên mức xử phạt phải đủ sức răn đe, hợp lý thì điều luật nhanh đi vào cuộc sống. Ví dụ quy định bắt buộc đội mũ bảo hiểm khi đi mô tô, xe gắn máy đã được quy định từ năm 1995, năm 2000 khi tai nạn giao thông xe máy tăng cao, Chính phủ quyết định thực quy định bắt buộc đội mũ bảo hiểm khi đi mô tô, xe gắn máy, song từ 2000 đến 2007 không thực hiện thành công; một trong nguyên nhân thất bại là không có chế tài hoặc chế tài không đủ sức răn đe.

Một bài học thành công khi thực hiện chính sách giảm thiểu tai nạn giao thông là công tác cưỡng chế chuyên đề cần làm đồng loạt trong cả nước, cùng một thời điểm sẽ tạo được hiệu quả rất cao.

Từ năm 1995 đến năm 2017, Chính phủ đã ban hành 10 Nghị định xử phạt vi phạm hành chính trong lĩnh vực giao thông đường bộ; Nghị định sau so với Nghị định trước thì số hành vi bị xử phạt đều tăng, những hành vi là nguyên nhân gây nhiều tai nạn giao thông xu hướng mức phạt ngày càng nặng, áp dụng nhiều hình phạt bổ sung như: tạm giữ phương tiện, giấy phép lái xe, phải thi lại luật ... Xử phạt nghiêm đã góp phần giảm tai nạn giao thông, thay đổi hành vi nhanh hơn.

8) Kết hợp tốt giữa truyền thông và cưỡng chế.

Chiến dịch kết hợp giữa truyền thông và cưỡng chế nổi bật nhất, có hiệu quả là chiến dịch truyền thông quy định bắt buộc đội mũ bảo hiểm khi đi mô tô, xe gắn máy tiến hành từ tháng 6 
năm 2007 đến tháng 12 năm 2007. Trong chiến dich này thể hiện vai trò tổ chức phối hợp của Ủy ban An toàn giao thông Quốc gia, truyền thông đã tạo dư luận đồng tình của toàn xã hội đã tạo thuận lợi cho chiến dịch xử lý vi phạm quy định bắt buộc đội mũ bảo hiểm khi đi mô tô, xe gắn máy và cao điểm là ngày 15 tháng 12 năm 2007.

9) Chuẩn bị chu đáo, toàn diện.

Để thực hiện thành công một chủ trương cần chuẩn bị chu đáo, toàn diện, thể hiện kế hoạch thực hiện phải chuẩn bị kỹ, có lộ trình hợp lý, đặc biệt kế hoạch phải được sự đồng thuận cao của các lực lượng tham gia. Kế hoạch phải bắt đầu từ xây dựng các văn bản pháp luật, đến từng công việc cụ thể và trách nhiệm thực hiện của các bên tham gia, đặc biệt phải bảo đảm cơ sở vật chất thực hiện kế hoạch.

10) Tổ chức thực hiện, phối hợp liên ngành là khâu quan trọng, quyết định thành công, trong đó Cơ quan phối hợp liên ngành đóng vai trò chủ chốt.

\subsection{Nhũng hạn chế thục hiện các chính sách kiềm chế tai nạn giao thông}

Bên cạnh nhiều thành công thực hiện chính sách kiềm chế tai nạn giao thông thì còn nhiều chủ trương, biện pháp giảm thiểu tai nạn giao thông không thực hiện được hoặc làm không đến nơi đến chốn. Nhìn chung, những biện pháp đột phá thực hiện trong thời gian ngắn, được sự quan tâm tập trung chỉ đạo của Chính phủ, Thủ tướng Chính phủ thường làm thành công; đối với những giải pháp có lộ trình dài, cần đầu tư thì nhiều chủ trương sau một thời gian bị quên lãng hoặc không làm đến cùng. Một số điển hình của hạn chế này như sau:

1) Quy định phân làn đường riêng cho xe máy: Việt Nam còn phải sử dụng xe máy nhiều năm vì vậy để giảm thiểu tai nạn giao thông xe máy thì cần tách làn xe máy thành làn đi riêng. Nghị quyết 32/2007/ NQ-CP đã giao cho Bộ GTVT: "Quy định khi xây dựng mới quốc lộ, các tuyến phố mới phải tổ chức phân làn riêng cho xe mô tô, xe gắn máy, lắp đặt các hệ thống giám sát an toàn", đến Nghị quyết 88/NQ-CP lại tiếp tục giao cho Bộ GTVT: "chỉ đạo các Sở Giao thông vận tải và các đơn vị trực thuộc triển khai lắp đặt dải phân cách để tách dòng xe môtô 2 bánh, xe thô sơ với dòng xe ôtô trên các tuyến đường có đủ điều kiện và có mật độ phương tiện giao thông lớn; khi lập dự án nâng cấp, cải tạo, xây dựng mới các tuyến đường bộ, tuyến tránh đô thị phải thiết kế phân làn đường dành riêng cho xe môtô, xe gắn máy". Đến nay vẫn chua có văn bản nào quy định cụ thể nội dung trên và thực tế cũng chỉ có Hà Nội thí điểm tách làn xe máy trên một số tuyến phố như: Bà Triệu, Đại Cồ Việt, Trần Khát Chân, đường Giải phóng, nhưng cũng thất bại.

2) Nghị quyết 88/NQ-CP đặc biệt quan tâm đến công tác ứng phó sau tai nạn giao thông bao gồm hệ thống trạm cấp cứu, cứu hộ, cứu nạn, tập huấn cấp cứu tai nạn giao thông. Sau gần 7 năm công tác này chủ yếu vẫn áp dụng phương châm "tại chỗ" là chủ yếu. Thực tế đã có nhiều nạn nhân tai nạn giao thông chết oan vì không được cấp cứu y tế, cứu hộ, cứu nạn kịp thời hoặc cấp cứu không đúng cách.

3) Tình trạng người điều khiển xe máy sử dụng rượu, bia chuyển biến chậm

Nghị quyết 88/NQ-CP coi nhiệm vụ phòng chống người điều khiển phương tiện cơ giới đường bộ sử dụng đồ uống có cồn khi điều khiển phương tiện là biện pháp trọng tâm, hàng đầu. Theo báo cáo của Cục CSGT, số vụ tai nạn giao thông do rượu bia gây ra không cao, khoảng 5\% số vụ. Song thực tế số này cao hơn nhiều, nó thường là các nguyên nhân gián tiếp. Sau gần 7 năm 
tập trung tuyên truyền, xử lý vi phạm, rất nhiều dự án tài trợ cho chuyên đề này nhưng chuyển biến rất chậm, người đi xe máy sau khi uống rượu bia là chuyện bình thường, không lo ngại bị xử lý, mặc dù xử phạt khá nặng.

4) Không lập lại được hành lang an toàn đường bộ 28

Hành lang an toàn đường bộ từ nhiều năm bị lấn chiếm nghiêm trọng, là nguy cơ tiềm ẩn tai nạn giao thông, vì vậy xuyên suốt từ Nghị quyết 13/2002/ NQ-CP, Nghị quyết 32/2007/NQ$\mathrm{CP}, \mathrm{Nghị} \mathrm{quyết} \mathrm{88/NQ-CP,} \mathrm{Chính} \mathrm{phủ} \mathrm{đều} \mathrm{đặt} \mathrm{yêu} \mathrm{cầu} \mathrm{lập} \mathrm{lại} \mathrm{hành} \mathrm{lang} \mathrm{an} \mathrm{toàn} \mathrm{đường} \mathrm{bộ.}$

Song thực tế đến nay tình hình lấn chiếm hành lang an toàn đường bộ và các điểm đấu nối trái phép vào quốc lộ rất phức tạp. Khảo sát của Tổng cục Đường bộ Việt Nam cho biết năm 2009 có 29.801 đường ngang đấu nối vào quốc lộ, trong đó có phép là 218 trường hợp, không phép 4.058 trường hợp, còn lại 25.525 trường hợp do lịch sử để lại.

Tính đến tháng 4 năm 2017 trên toàn mạng lưới đường sắt có 5.793 điểm giao cắt giữa đường sắt và đường bộ; tỷ lệ lối đi dân sinh chiếm $74 \%$; bình quân $1 \mathrm{~km}$ đường sắt có 1,85 lối giao cắt, cụ thể:

Đường ngang: 1.514 đường (hợp pháp), trong đó:

+ Đường ngang có người gác: 641;

+ Đường ngang cảnh báo tự động: 366;

+ Đường ngang biển báo: 507;

Đường dân sinh, lối đi dân sinh: 4279 điểm.

+ Số đường dân sinh có chiều rộng < $3 \mathrm{~m}$ là 4.095 lối;

+ Số đường dân sinh có chiều rộng $\geq 3 \mathrm{~m}$ là 184 đường.

Từ kết quả khảo sát của Cục Đường bộ (nay là Tổng cục Đường bộ Việt Nam) cho thấy xấp xỉ 70\% các đoạn đường không đảm bảo giới hạn hành lang an toàn đường bộ.

5) Nghị quyết 88/NQ-CP yêu cầu kiểm tra phát hiện và xử phạt nghiêm đối với người điều khiển, người ngồi trên môtô, xe gắn máy không đội mũ bảo hiểm, chở trẻ em không đội mũ bảo hiểm; có biện pháp cấp bách ngăn chặn việc sản xuất, lưu thông, buôn bán loại mũ có kiểu dáng giống mũ bảo hiểm và mũ bảo hiểm không bảo đảm quy chuẩn, chất lượng; phối hợp với chính quyền địa phương tăng cường kiểm tra, xử lý nghiêm các tổ chức, cá nhân vi phạm.

Thực hiện nhiệm vụ này, sau khi Thủ tướng Chính phủ ban hành Chỉ thị số 04/CT-TTg ngày $8 / 3 / 2013$ về việc tăng cường quản lý sản xuất, kinh doanh và sử dụng mũ bảo hiểm $(\mathrm{MBH})$ cho người đi mô tô, xe máy và xe đạp máy khi tham gia giao thông ngày, Ủy ban An toàn giao thông Quốc gia ban hành Kế hoạch số: 69/ KH-UBATGTQG ngày 18 tháng 4 năm 2014 về tổ chức chiến dịch tuyên truyền và triển khai đợt cao điểm kiểm tra, xử lý vi phạm về sản xuất, kinh doanh và sử dụng mũ không phải mũ bảo hiểm cho người đi mô tô, xe gắn máy, xe đạp máy

Sau thời gian làm tuyên truyền 3 tháng, đến 1 tháng 7 năm 2014 được quy định thời gian bắt đầu xử phạt thì bùng nổ bão dư luận và sau đó, Kế hoạch 69/KH-UBATGTQG thất bại. Có 02 lý do sau:

${ }^{28}$ Nguồn : Tổng cục Đường bộ Việt Nam 
- Không chuẩn bị chế tài, Nghị định số 171/2013/NĐ-CP ngày 13/11/2013 của Chính phủ quy định xử phạt vi phạm hành chính trong lĩnh vực giao thông đường bộ và đường sắt không có quy định xử phạt người đi xe máy đội mũ bảo hiểm giả mạo mũ bảo hiểm ( đã nhầm lẫn cho rằng đội mũ bảo hiểm giả mạo mũ bảo hiểm được coi như không đội).

- Không phối hợp được với Bộ Công an, tại cuộc họp báo của Chính phủ tối ngày 1 tháng 7 năm 2017, Bộ Công an không chỉ đạo xử phạt người đội mũ bảo hiểm sai quy chuẩn.

6) Nghị quyết 32/2007/NQ-CP yêu cầu nghiên cứu sửa đổi, bổ sung các quy định mức phí bảo hiểm bắt buộc trách nhiệm dân sự của chủ xe cơ giới, có tăng hoặc giảm tuỳ theo mức độ tai nạn của mỗi chủ xe

Yêu cầu này nhằm dùng đòn bẩy bảo hiểm bắt buộc để nhằm khuyến khích việc ngăn ngừa tai nạn đối với chủ xe và lái xe. Song đến nay không được Bộ Tài chính quan tâm và không thực hiện. Số người đi xe máy mua bảo hiểm bắt buộc trách nhiệm dân sự của chủ xe cơ giới cũng rất ít, theo Theo thống kê của Hiệp hội Bảo hiểm Việt Nam khoảng $80 \%$ không mua bảo hiểm dân sự bắt buộc

\subsubsection{Tác động của chính sách đến hạn chế gia tăng xe máy}

Yêu cầu hạn chế phát triển xe máy được đặt ra vào khoảng năm 2000, khi xe máy bắt đầu có xu hướng tăng nhanh và cũng bắt đầu tai nạn giao thông, ùn tắc giao thông có xu hướng tăng. Song nhìn biểu đồ gia tăng số lượng xe máy thì các chính sách đã ban hành và thực hiện hầu như không tác động đến nhiệm vụ hạn chế xe máy, loại trừ năm 2003 số xe máy chỉ tăng trên 1.000 .000 xe, còn từ năm 2004 đến năm 2017 mỗi năm xe máy đều tăng từ xấp xỉ từ 2.000 .000 xe đến 3.000 .000 xe, thậm chí có năm tăng gần 4.000 .000 xe máy.

\subsection{Nhũ̃ng tác động tích cụcc của chính sách đến hạn chế xe máy}

1) Kìm hãm tốc độ tăng xe máy năm 2003, 2004 tạo điều kiện phát triển xe buýt ở Hà Nội và Thành phố Hồ Chí Minh.

Trước tình hình năm 2001 tai nạn giao thông tăng đột biến, nguyên nhân được xác định là số lượng xe máy tăng đột biến; đồng thời Chính phủ cũng đã thấy nguy cơ cao về ùn tắc giao thông ở Hà Nội, Thành phố Hồ Chí Minh và một số đô thị lớn khác; để giải quyết không có cách nào khác là phát triển vận tải khách công cộng song song với hạn chế phát triển phương tiện giao thông cá nhân. Không thể cùng một lúc vừa phát triển vận tải khách công cộng vừa phát triển phương tiện giao thông cá nhân, đặc biệt là xe máy.

Nghị quyết 13/2002/NQ-CP đã quy định: Ủy ban nhân dân thành phố Hà Nội, thành phố Hồ Chí Minh ban hành lộ trình và các biện pháp chặt chẽ, phù hợp nhằm kiềm chế tối đa sự gia tăng số lượng mô tô, xe máy, trong đó có xem xét cụ thể việc tạm dừng đăng ký mô tô, xe máy mới và quy định các tuyến đường, khu vực, thời gian không cho mô tô, xe máy lưu hành để hạn chế ùn tắc giao thông.

Trên cơ sở Nghị quyết 13/200/NQ-CP, Bộ Công an ban hành Thông tư 02/2003/TT-BCA(C11) ngày 13 tháng 1 năm 2003 bổ sung một số quy định của Thông tư số 01/2002/TT-BCA(C11) ngày 04 tháng 01 năm 2002 về hướng dẫn tổ chức cấp đăng ký, biển số phương tiện giao thông cơ giới đường bộ. Thông tư 02/2003/TT-BCA(C11) quy định mỗi người chỉ đăng ký 01 mô tô hoặc xe gắn máy. Hà Nội ban hành Nghị quyết số 34/2003/NQ-HĐ ngày 13 tháng 02 năm 2003 về một số giải pháp và cơ chế, chính sách để kiềm chế gia tăng và tiến tới giảm dần tai nạn giao 
thông và ùn tắc giao thông trên địa bàn thành phố Hà Nội. Nghị quyết số 34/2003/NQ-HĐ có 9 giải pháp, trong đó có biện pháp hạn chế gia tăng mô tô, xe máy: "xây dựng lộ trình hợp lý để tiến tới dừng đăng ký xe máy trên toàn Thành phố, tổ chức thực hiện thí điểm dừng đăng ký xe máy tại 4 quận nội thành cũ trong năm 2003"

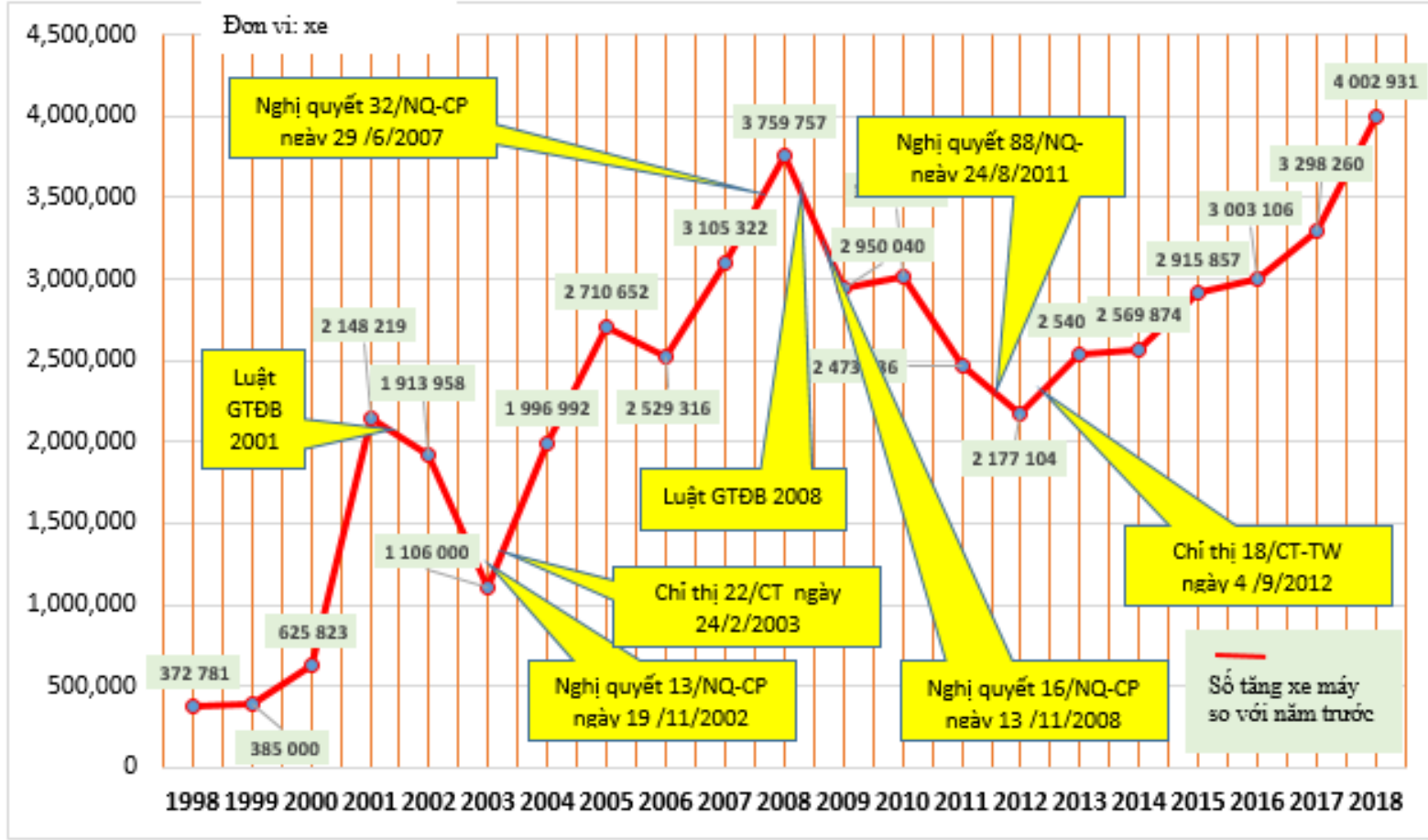

\section{Hình 2-2 Tác động của chính sách đến hạn chế gia tăng xe máy 1998-2018²9}

Bằng biện pháp hành chính này, lập tức số xe máy đăng ký toàn quốc giảm, năm 2003 chỉ tăng $9,3 \%$ so với năm 2002 (1.106.000 xe) đây là số xe máy tăng thấp nhất từ năm 2001 đến $2017^{30}$. Năm 2003 Hà Nội có 83.000 xe máy mới được đăng ký mới, giảm 48\% so với số xe đăng ký năm 2002. Năm 2004 lượng xe máy tiếp tục được kiềm chế và giữ mức tăng $17 \%$ so với năm 2003 (đăng ký mới 97.000 xe máy), theo số liệu của Phòng CSGT, CATP Hà Nội, 10 tháng đầu năm 2005, lượng xe máy đăng ký mới tại Hà Nội là 63.400 xe, giảm 22,4\% so với cùng kỳ năm $2004^{31}$.

Biện pháp kiên quyết này gặp rất nhiều phản ứng của dư luận, song cần nhấn mạnh là chỉ tạm dừng, ngoài nhiệm vụ chặn đứng và đẩy lùi tai nạn giao thông còn tạo điều kiện cho xe buýt phát triển. Chỉ đáng tiếc là các địa phương không tận dụng được thời cơ hội vàng này để phát triển nhanh xe buýt, đáng ra Hà Nội, Thành phố Hồ Chí Minh phải đầu tư hàng nghìn xe buýt trong thời gian nay, thay vì chỉ phát triển được vài trăm $\mathrm{xe}^{\mathbf{3 2}}$.

\footnotetext{
${ }^{29}$ Nguồn: Ủy ban An toàn giao thông Quốc gia. Năm 2018 tai nạn giao thông đường bộ tiếp tục giảm cả 3 tiêu chí, năm 2018 xẩy ra 18.490 vụ, làm chết 8.079 người, bị thương 14.732 người, so với năm 2017 giảm $6,61 \%$ về số vụ, giảm $0,12 \%$ về số người bị chết, giảm $13,19 \%$ về số người bị thương (báo cáo kết quả công tác bảo đảm trật tự an toàn giao thông năm 2018 và nhiệm vụ trọng tâm năm 2019)

${ }^{30}$ Nguồn: UBATGTQG

${ }^{31}$ Nguồn: Sở GTVT, CA thành phố Hà Nội (năm 2005 lấy số liệu 10 tháng vì tháng 11/2005 đã bỏ quy định mỗi người chỉ được đăng ký một xe máy

${ }^{32}$ Hà Nội đã đưa vào hoạt động 39 tuyến với 678 xe buýt, năm 2003 đã vận chuyển được trên 173 triệu lượt hành khách, tăng 3,7 lần so với năm 2002. Thành phố Hồ Chí Minh đầu tư mới 792 xe buýt, đưa vào hoạt động 97 tuyến với 1.923 xe buýt.
} 
2) Ngăn chăn được phát triển loại xe ba bánh chở hàng, chở khách, xe ba bánh tự chế, xe công nông.

Sau khi giải phóng năm 1975, xe lam được đưa ra Miền Bắc và phát triển mạnh trên toàn quốc, xe lam 3 bánh là loại xe kém an toàn, chiếm dụng đường lớn và gây ô nhiễm môi trường. Phải mất nhiều năm chúng ta mới loại được xe lam 3 bánh. Đến năm 2000 xuất hiện nguy cơ phát triển xe 3 bánh tự chế, đặc biệt nhiều doanh nghiệp đang chuẩn bị nhập khẩu xe 3 bánh chở hàng, chở khách của Trung Quốc vào Việt Nam. Trước nguy cơ trên, Nghị quyết 32/2007/NQCP đã quy định : "Từ ngày 01 tháng 01 năm 2008, đình chỉ lưu hành ô tô đã hết niên hạn sử dụng, xe công nông, xe tự chế 3,4 bánh. Trường hợp cố tình vi phạm sẽ bị tịch thu xử lý bán phế liệu, sung vào công quỹ”. Cùng với lệnh cấm, Thủ tường Chính phủ cũng ban hành trợ cấp cho chủ phương tiện xe 3 bánh chuyển đổi sang phương tiện loại được lưu thông.

Thực tế đã ngăn chặn được phát triển loại xe 3 bánh. Nếu không ngăn chặn từ sớm thì với hàng triệu xe 3 bánh trên các đường phố Hà Nội, Thành phố Hồ Chí Minh thì sẽ là thảm họa. ${ }^{33}$

\subsection{Hạn chế của chính sách về hạn chế phát triển xe máy}

1) Quy định mỗi người chỉ được đăng ký 01 xe máy trên toàn quốc, hay tạm dừng đăng ký xe máy ở 4 quận nội thành, sau đó tiến tới dừng đăng ký xe máy trên toàn thành phố Hà Nội là biện pháp hành chính, tạm thời mang tính tình thế. Quy định không được sự đồng tình, ủng hộ của dư luận; mặt khác quy định cũng phát sinh tình trạng đứng tên đăng ký hộ, dân ngoại thành Hà Nội "bán suất" đăng ký xe máy, bất bình đẳng của người dân sống ở các khu vự khác nhau. Nhiều cơ quan cho rằng Quy định hạn chế quyền sở hữu của công dân, vi Hiến.

Sau thời gian thực hiện lệnh cấm gần 3 năm, ngày 21 tháng 11 năm 2005 Bộ Công an ban hành thông tư số 17/2005/TT-BCA bãi bỏ quy định mỗi người chỉ được đăng ký 01 xe máy và cũng không bắt buộc trong hồ sơ đăng ký xe phải có thêm bản photocopy giấy chứng nhận bảo hiểm trách nhiệm dân sự của chủ xe cơ giới. Ngày 14 tháng 12 năm 2005, UBND thành phố Hà Nội cũng ban hành Quyết định 221/QĐ-UBND bãi bỏ việc thí điểm ngừng đăng ký xe máy tại 7 quận nội thành.

2) Tăng lệ phí đăng ký, trước bạ, phí trông giữ phương tiện nhưng không tác động đến hạn chế phát triển xe máy.

Tất cả các Nghị quyết về bảo đảm trật tự an toàn giao thông đều chủ trương tăng lệ phí trước bạ, lệ phí đăng ký xe máy nhằm hạn chế gia tăng xe máy, tuy vậy trong thực tế do mức tăng đối với xe máy qua nhiều lần thay đổi không nhiều nên hầu như chủ trương này không có hiệu quả hạn chế xe máy.

Lệ phí trước bạ đăng ký xe máy thay đổi qua các năm như sau:

+ Năm 1999 : 2\%, nộp lệ phí trước bạ tại Việt Nam lần thứ 2 trở đi là 1\%.

+ Năm 2003: 2\%, ở các thành phố trực thuộc Trung ương, thành phố tỉnh và thị xã nơi

UBND tỉnh đóng trụ sở nộp lệ phí trước bạ lần đầu $5 \%$, lần thứ hai trở đi $1 \%$.

+ Năm 2008: không thay đổi.

+ Năm 2011: không thay đổi.

\footnotetext{
${ }^{33}$ Xe 3 bánh của Hà Nội Năm 2017: tổng số 4.362 xe. Đối tượng sử dụng gồm thương binh (566 xe), bệnh binh (82 xe), người khuyết tật (133 xe) và các trường hợp khác (3.483 xe). (nguồn: viện chiến lược và phát triển GTVT)
} 
+ Năm 2016: không thay đổi.

Lệ phí đăng ký xe máy qua các năm cũng tăng nhưng không đáng kể, chỉ góp phần tăng ngân sách $^{34}$

Ngày 5/12/2017, kỳ họp thứ 5 HĐND thành phố Hà Nội khóa XV đã thông qua Nghị quyết về việc sửa đổi, bổ sung quy định thu phí sử dụng tạm thời lòng đường, hè phố trên địa bàn thành phố. Mức thu phí mới áp dụng từ ngày $1 / 1 / 2018$. giá trông giữ xe máy sẽ tăng từ 3.000-5.000 đồng/xe/lượt, ô tô tăng từ 30.000-50.000 đồng/xe/lượt. Có những khu vực mức giá trông xe tháng sẽ tăng từ 1,7 triệu đồng lên 2,6 triệu đồng/ô tô/tháng.

Cùng với tăng giá trông giữ xe, mức thu phí sử dụng trông giữ xe cũng tăng, cụ thể mức thu phí sử dụng diện tích trông giữ ô tô tăng thấp nhất là $50 \%$ và tăng cao nhất là $300 \%$ so với mức cũ, tương đương với việc tăng từ 20.000 đồng/m2/tháng đến 160.000 đồng/m2/tháng. Mức thu phí sử dụng diện tích trông giữ xe đạp, xe máy tăng thấp nhất là 5.000 đồng/m2/tháng và cao nhất là 90.000 đồng/m2/tháng tùy theo khu vực, tuyến phố theo nguyên tắc mức phí cao nhất thuộc 12 tuyến phố khu bảo tồn cấp 1 đô thị lõi quận Hoàn Kiếm và giảm dần xa trung tâm...Bước đầu thực hiện dư luận có nhiều ý kiến trái chiều, theo phản ảnh của báo chí khu vực trung tâm thành phố lưu lượng phương tiện có vắng hơn.

3) Sau nhiều lần đề nghị, Thủ tướng Chính phủ đã ban hành Quyết định số 16/2015/QĐ-TTg ngày 22 tháng 5 năm năm 2015 về thu hồi, xử lý sản phẩm loại bỏ, trong danh mục thu hồi, xử lý sản phẩm loại bỏ có: xe mô tô, xe máy các loại, thời hạn bắt đầu thu hồi, loại bỏ: ngày 01/01/2018. Đến nay chưa thấy tuyên truyền, phổ biến, tổ chức thực hiện như thế nào?

4) Giải pháp giảm phương tiện cá nhân, tăng phương tiện vận tải công cộng để chống ùn tắc giao thông ở các thành phố lớn đạt kết quả chưa như mong muốn.

Những giải pháp giải quyết ùn tắc giao thông ở Hà Nội và Thành phố Hồ Chí Minh trong nhiều năm qua như: tổ chức ô tô đi theo ngày chẵn lẻ, thu phí phương tiện vào trung tâm, đấu giá quyền lưu hành phương tiện... thực chất mới chỉ là đề xuất. Những đề xuất này đều bị dư luận phản ứng gay gắt, sau một thời gian ồn ào bị rơi vào quên lãng. Nguyên do là đề xuất tác động trực tiếp đến đời sống, đi lại của đa số người dân, mặt khác mọi người cũng chưa thấy, chưa tin vào khả năng phát triển vận tải công cộng đáp ứng được đi lại trong thành phố.

Ngày 24 tháng 8 năm 2017, UBND thành phố Hà Nội ban hành Quyết định số 5953/QĐ-UBND về việc phê duyệt Đề án "Tăng cường quản lý phương tiện giao thông đường bộ nhằm giảm ùn tắc giao thông và ô nhiễm môi trường trên địa bàn thành phố Hà Nội giai đoạn 2017 - 2020 tầm nhìn 2030". Điều dư luận quan tâm là lộ trình : "Giai đoạn 2017-2030: Từng bước hạn chế hoạt động trên một số khu vực và thời gian, đồng thời chuẩn bị các điều kiện cần thiết để dừng hoạt động xe máy trên địa bàn các quận vào năm 2030”. Đa số người dân đồng tình phải bỏ xe máy ở khu vực nội đô, song quan trọng đối với họ là trả lời được câu hỏi : đi bằng gì? có thuận tiện không ? thời gian 13 năm có đủ đề thực hiện các điều kiện cần thiết không?

${ }^{34}$ Lệ phí trước bạ đối với xe máy áp dụng tại Hà Nội:

- $\quad$ Lệ phí trước bạ là $5 \%$.

- Lệ phí cấp mới giấy đăng ký kèm biển số phương tiện:

+ Đối với xe có giá trị nhỏ hơn 15 triệu đồng là 500.000 đồng;

+ Đối với xe có giá trị từ 15-40 triệu đồng là 2.000.000 đồng;

+ Đối với xe có giá trị trên 40 triệu là 4.000 .000 đồng.

- Phí bảo hiểm trách nhiệm dân sự: 66.000-106.000 đồng. 
Thành phố Hồ Chí Minh cũng đang nghiên cứu một đề án tương tự như Hà Nội để thông qua trong thời gian tới.

Như trên đã bình luận, hầu như những giải pháp trong lĩnh vực an toàn giao thông có tính lâu dài đều không thực hiện được hoặc làm không đến cùng. Hy vọng với sức ép ùn tắc giao thông, quyết liệt bền vững của chính quyền lộ trình hạn chế xe máy sẽ thành công.

\subsubsection{Kết luận}

Nhiệm vụ của phần nghiên cứu này là nhìn lại bức tranh về tai nạn giao thông liên quan đến xe máy, kết quả hạn chế phát triển xe máy từ năm 2000 đến năm 2017 dưới tác động của các chính sách đã ban hành và thực hiện. Những nghiên cứu này là một trong những có sở để xây dựng chiến lược, kế hoạch theo mục tiêu của Dự án.

Nghiên cứu đề cập đến nội dung cốt lõi của các chính sách do Chính phủ ban hành và xem nội dung nào đã thực hiện, nội dung nào chưa thực hiện, đã thực hiện thì tác động đến mục tiêu: kiềm chế tai nạn giao thông xe máy, hạn chế phát triển xe máy như thế nào. Nói cách khác, nội dung nào của chính sách thành công, kết quả như thế nào, nội dung nào chưa thành công.

Chắc chắn nội dung của chiến lược và kế hoạch của dự án sẽ đề cập đến một số giải pháp của các chính sách đã được ban hành trong thời gian qua, vậy tiếp cận như thế nào để phát huy được những giải pháp đã thành công, đảm bảo thành công của Dự án.

\subsection{Chính sách phát triển vận tải hành khách công cộng đô thị}

Vấn đề ùn tắc giao thông ở Hà Nội và Thành phố Hồ Chí Minh đã có chiều hướng đáng lo ngại từ năm 2000, vì vậy tại Nghị quyết số 13/2002/NQ-CP của Chính phủ về các giải pháp kiềm chế gia tăng và tiến tới giảm dần tai nạn giao thông và ùn tắc giao thông, Chính phủ đã nhấn mạnh giải pháp "Song song với phát triển vận tải khách công cộng và đầu tư phát triển kết cấu hạ tầng giao thông đô thị, cần khẩn trương ban hành các giải pháp đồng bộ nhằm kiềm chế sự gia tăng mô tô, xe máy, tiến tới giảm dần số lượng mô tô, xe máy lưu hành trong nội thành, nội thị các thành phố, thị xã”. Năm 2008, Chính phủ ban hành Nghị quyết 16/2008/NQ-CP về Từng bước khắc phục ùn tắc giao thông tại Hà Nội và Thành phố Hồ Chí Minh, Nghị quyết nêu nhiều biện pháp toàn diện, bao gồm về: quy hoạch phát triển kết cấu hạ tầng giao thông đô thị; quy hoạch và thực hiện di dời trụ sở các cơ quan hành chính nhà nước, các trường đại học, cao đẳng, dạy nghề, bệnh viện lớn ra ngoài khu vực trung tâm; tuyên truyền, phổ biến pháp luật, tổ chức cuộc vận động xây dựng nếp "văn hóa giao thông" và "văn minh đô thị", tăng cường cưỡng chế thi hành pháp luật về trật tự an toàn giao thông và trật tự đô thị; đẩy mạnh phát triển vận tải hành khách công cộng, hạn chế phương tiện cá nhân tham gia giao thông, tồ chức giao thông hợp lý và hiệu quả.

Chính phủ đã sơ kết, đánh giá Nghị quyết 16/2008/NQ-CP ba lần (năm 2009, 2013, 2018); lần tổng kết 10 năm thục hiện Nghị quyết (năm 2018) Chính phủ đã giao Bộ Giao thông vận tải chủ trì, phối hợp với các Bộ, cơ quan có liên quan (Công an, Tư pháp, Xây dựng, Kế hoạch và Đầu tư, Tài chính, Khoa học và Công nghệ, Tài nguyên và Môi trường, Ủy ban An toàn giao thông Quốc gia...) và Ủy ban nhân dân các thành phố: Hà Nội, Thành phố Hồ Chí Minh tổng kết 10 năm thực hiện Nghị quyết số 16/2008/NQ-CP, trên cơ sở đó xây dựng dự thảo Nghị quyết về các giải pháp khắc phục ùn tắc giao thông tại Hà Nội và Thành phố Hồ Chí Minh (thay 
thế Nghị quyết số 16/2008/NQ-CP), trình Thủ tướng Chính phủ trước ngày 30 tháng 6 năm 2018.

Phát triển kết cấu hạ tầng giao thông, phát triển vận tải hành khách công cộng và hạn chế phương tiện cá nhân có quan hệ chặt chẽ với nhau. Phát triển kết cấu hạ tầng giao nội đô thường chậm hơn so với việc gia tăng phương tiện giao thông, để giảm ùn tắc giao thông không có cách nào khác là phải giảm phương tiện giao thông cá nhân để tăng nhanh vận tải khách công cộng. Không phát triển vận tải hành khách công cộng thì không hạn chế được phương tiện giao thông cá nhân, đặc biệt là mô tô, xe máy và ngược lại không hạn chế được phương tiện giao thông cá nhân, mà trước hết là mô tô, xe máy thì không phát triển được vận tải hành khách công cộng.

Thực tế hiện nay ở Hà Nội và Thành phố Hồ Chí Minh số lượng xe máy ngày càng tăng cao, đồng thời xe buýt cũng từng bước phát triển, nhưng kết cấu hạ tầng giao thông đô thị phát triển chậm chạp dẫn đến ùn tắc giao thông ngày càng trầm trọng, việc mở rộng mạng lưới xe buýt ngày càng khó khăn. Người dân vẫn đi lại chủ yếu bằng xe máy, có nghĩa xe máy vẫn tiếp tục gia tăng. Đây là vòng luẩn quẩn, càng ngày càng khó giải quyết, nếu không có biện pháp đột phá.

Nghị quyết số 16/2008/NQ-CP ngày 31 tháng 7 năm 2008 của Chính phủ về từng bước khắc phục ùn tắc giao thông tại thành phố Hà Nội và thành phố Hồ Chí Minh đưa ra 4 giải pháp sau:

1) Quy hoạch phát triển kết cấu hạ tầng giao thông đô thị;

2) Quy hoạch và thực hiện di dời trụ sở các cơ quan hành chính nhà nước, các trường đại học, cao đẳng, dạy nghề, bệnh viện lớn ra ngoài khu vực trung tâm;

3) Tuyên truyền, phổ biến pháp luật, tổ chức cuộc vận động xây dựng nếp "văn hóa giao thông" và “văn minh đô thị”, tăng cường cưỡng chế thi hành pháp luật về trật tự an toàn giao thông và trật tự đô thị;

4) Đẩy mạnh phát triển vận tải hành khách công cộng, hạn chế phương tiện cá nhân tham gia giao thông, tổ chức giao thông hợp lý và hiệu quả.

Tại giải pháp thứ 4 của Nghị quyết 16/2008/NQ-CP đã giao nhiệm vụ cụ thể cho các cơ quan:

1) Ủy ban nhân dân hai thành phố:

- Tiếp tục duy trì chính sách trợ giá cho hoạt động vận tải khách công cộng bằng xe buýt;

- Nghiên cứu đầu tư tăng thêm các tuyến đường có làn đường dành riêng cho xe buýt;

- Trong quý IV năm 2008 hoàn thành việc rà soát mạng lưới các tuyến xe buýt để điều chỉnh những bất hợp lý, bổ sung thêm các tuyến mới bảo đảm mạng lưới các tuyến xe buýt bao phủ hết các khu vực; quảng bá rộng rãi mạng lưới xe buýt để mọi người dân chọn hành trình hợp lý; bố trí lại chủng loại xe buýt phù hợp với hạ tầng giao thông từng tuyến, từng khu vực;

- Chỉ đạo các cơ quan chức năng phối hợp với các trường học, các doanh nghiệp để tổ chức loại hình xe buýt chuyên trách (có trợ giá) đưa đón học sinh, cán bộ, công nhân theo Nghị quyết số 13/2002/NQ-CP ngày 19 tháng 11 năm 2002 của Chính phủ, thực hiện từ quý I năm 2009;

- Nghiên cứu đề xuất các giải pháp đẩy mạnh xã hội hóa hoạt động vận tải hành khách công cộng nhằm huy động các thành phần kinh tế tham gia; nghiên cứu và kiến nghị 
chính sách hỗ trợ trực tiếp và gián tiếp đối với các doanh nghiệp thuộc mọi thành phần kinh tế tham gia kinh doanh vận tải khách công cộng;

- Phối hợp với các Bộ, ngành đẩy nhanh tiến độ thực hiện các dự án phát triển vận tải hành khách công cộng có khối lượng lớn như: đường sắt đô thị, xe buýt có sức chở lớn;

- Quy định việc cấm môtô, xe gắn máy và ôtô lưu thông trên một số tuyến phố vào một số giờ nhất định phù hợp với điều kiện cụ thể của từng khu vực trong thành phố;

- Nghiên cứu việc điều chỉnh giờ làm việc hợp lý nhằm giảm bớt lưu lượng tham gia giao thông trong giờ cao điểm.

2) Bộ Tài chính nghiên cứu ban hành theo thẩm quyền hoặc trình cấp có thẩm quyền ban hành trong quý I năm 2009 các văn bản về:

- Quy định miễn tiền thuê đất để xây dựng trạm bảo dưỡng, sửa chữa, bãi đỗ xe của các doanh nghiệp kinh doanh vận tải khách công cộng nội đô;

- Quy định về cơ chế hỗ trợ lãi suất cho doanh nghiệp vay vốn đầu tư phương tiện vận tải khách công cộng nội đô; xây dựng cơ chế xã hội hóa hoạt động vận tải khách bằng xe buýt;

- Quy định về phí, lệ phí liên quan đến phương tiện giao thông cơ giới đường bộ của cá nhân

Trên cơ sở nhiệm vụ của Dự án, phần này sẽ nghiên cứu những thành công và tồn tại việc thực hiện giải pháp thứ 4 của Nghị quyết 16/2008/NQ-CP.

\subsubsection{Các cơ chế, chính sách khuyến khích phát triển VTHKCC bằng xe buýt}

\subsubsection{Cơ chế chính sách chung cho toàn quốc}

Thực hiện Nghị quyết 16/2008/NQ-CP, Chính phủ và các Bộ đã ban hành nhiều cơ chế chính sách để ưu tiên, khuyến khích VTHKCC bằng xe buýt, trong đó quan trọng là các văn bản sau:

- Quyết định số 62/2009/QĐ-TTg ngày 20 tháng 4 năm 2009 của Thủ tướng Chính phủ về miễn tiền thuế đất để xây dựng trạm bảo dưỡng, sửa chữa, bãi đỗ xe của doanh nghiệp kinh doanh vận tải hành khách công cộng.

- Quyết định số 55/2012/ QĐ-TTg ngày 19 tháng 12 năm 2012 của Thủ tướng Chính phủ về sửa đổi, bổ sung Quyết định số 62/2009/QĐ-TTg của Thủ tướng Chính phủ ngày 20 tháng 4 năm 2009 về miễn tiền thuế đất để xây dựng trạm bảo dưỡng, sửa chữa, bãi đỗ xe của doanh nghiệp kinh doanh vận tải hành khách công cộng.

- Quyết định số 13/2015 ngày 05 tháng 05 năm 2015 của Thủ tướng Chính phủ về cơ chế, chính sách khuyến khích phát triển VTHKCC bằng xe buýt.

- Thông tư 06/2012/TT- BTC ngày 11 tháng 1 năm 2012 của Bộ Tài chính Hướng dẫn thi hành một số Điều của Luật thuế giá trị gia tăng, hướng dẫn thi hành Nghị định số 123/2008/NĐ-CP ngày 08 tháng 12 năm 2008 và Nghị định số 121/2011/ NĐ-CP ngày 27 tháng 12 năm 2011 của Chính phủ (được sửa đổi bổ sung tại Thông tư 65/2013/TTBTC ngày 17 tháng 5 năm 2013).

- Thông tư 185/2012/TT- BTC ngày 30 tháng 10 năm 2012 hướng dẫn miễn thuế nhập khẩu đối với phụ tùng, linh kiện để sản xuất lắp ráp xe buýt của dự án đầu tư phát triển VTHKCC bằng xe buýt tại thành phố Hà Nội và Thành phố Hồ Chí Minh. 


\subsubsection{Cơ chế chính sách do địa phương ban hành}

Trên toàn quốc chủ yếu áp dụng 05 loại hình khuyến khích hỗ trợ VTHKCC như: trợ giá; miễn, giảm giá vé cho người sử dụng; hỗ trợ lãi suất vay đầu tư phương tiện; hỗ trợ đầu tư kết cấu hạ tầng; hỗ trợ các loại phí (bến bãi, cầu phà, sử dụng đường bộ).

Cơ chế áp dụng ở một số địa phương:

- Nghị quyết số 03/2013/NQ-HĐND ngày 12/07/2013 của HĐND Hà Nội quy định trợ giá cho hoạt động VTHKCC bằng xe buýt, hỗ trợ lãi vay đầu tư hạ tầng VTHKCC và mua sắm xe buýt, hỗ trợ tiền phí sử dụng đường bộ, trợ giá vé cho người sử dụng dịch vụ VTHKCC bằng xe buýt...,

- Quyết định số 15/2010/QĐ-UBND ngày 18/03/2010 của UBND Thành phố Hồ Chí Minh quy định các chính sách: quy định tổ chức, quản lý và hỗ trợ tài chính cho hoạt động VTHKCC bằng xe buýt tại Quyết định số 20/2014/QĐ-UBND ngày 30/05/2014 và khuyến khích đầu tư bến bãi vận tải đường bỗ trên địa bàn Thành phố.

- Thành phố Đà Nẵng ban hành Quyết định số 37/2013/QĐ-UBND ngày 26/11/2013 áp dụng các chính sách: hỗ trợ của Nhà nước về kết cấu hạ tầng xe buýt, hỗ trợ tài chính của Nhà nước trong đầu tư phương tiện.

- Tuyên Quang ban hành Quyết định số 02/2012/QĐ-UBND ngày 17 tháng 02 năm 2012 áp dụng các chính sách: ưu đãi về giá dịch vụ lưu đậu xe, hỗ trợ đầu tư xây dựng hạ tầng, thông tin tuyên truyền.

- Khánh Hòa ban hành Quyết định số 09/2012/QĐ-UBND ngày 05 tháng 03 năm 2012 áp dụng các chính sách: ưu đãi về phí cầu đường và giá dịch vụ lưu đậu xe, ưu đãi về hỗ trợ tín dụng, hỗ trợ đầu tư xây dựng hạ tầng, thông tin tuyên truyền, chính sách trợ giá.

- Một số tỉnh, thành phố đã xây dựng và ban hành định mức kinh tế kỹ thuật: Đồng Nai (Quyết định số 51/2013); TP. Hồ Chí Minh (Quyết định số 76/2009); Đăk Lăk (Quyết định số 09/2007); Hà Nội (Quyết định số 1494/QĐ-UBND ngày 01/03/2017 về ban hành định mức kinh tế kỹ thuật và đơn giá vận hành VTHKCC bằng xe buýt trên địa bàn thành phố Hà Nội); Thừa Thiên Huế (Quyết định số 845/2012); Hải Phòng (Quyết định số 2803/2014).

Nhìn chung đến nay các chính sách hỗ trợ, ưu tiên phát triển VTHKCC bằng xe buýt được ban hành tương đối đầy đủ, tuy nhiên một số cơ chế chính sách ban hành chậm so với yêu cầu.

\subsubsection{Xã hội hóa VTHKCC bằng xe buýt}

Các địa phương đều quan tâm thực hiện đẩy mạnh xã hội hóa hoạt động vận tải hành khách công cộng, huy động được các thành phần kinh tế tham gia VTHKCC bằng xe buýt, trong đó nổi bật là Hà Nội và Thành phố Hồ Chí Minh.

- Các đơn vị xe buýt Hà Nội:

+ Tổng Công ty vận tải Hà Nội - Transerco (doanh nghiệp nhà nước)

+ Công ty TNHH Bắc Hà

+ Công ty Cổ phần Vận tải, Thương mại và Du lịch Đông Anh

+ Công ty TNHH Du lịch, Dịch vụ, Xây dựng Bảo Yến

+ Công ty Liên doanh Vận chuyển Quốc tế Hải Vân

+ Công ty Cổ phần Xe Khách Hà Tây

+ Công ty Cổ phần Dịch vụ và Vận tải Bảo Châu 
- Các đơn vị xe buýt Thành phố Hồ Chí Minh :

+ Công ty TNHH một thành viên xe khách Sài Gòn (doanh nghiệp nhà nước)

+ Công ty liên doanh: Công ty TNHH Ngôi sao Sài gòn

+ Công ty TNHH Vận tải Sài gòn

+ 27 Hợp tác xã

Hà Nội có nhiều đơn vị VTHKCC bằng xe buýt nhưng chủ lực vẫn là Transerco với $82 \%$ số tuyến và $90 \%$ sản lượng vận chuyển hành khách bằng xe buýt toàn thành phố.

Thành phố Hồ Chí Minh tỷ lệ xã hội hóa VTHKCC bằng xe buýt khá cao, Thành phố Hồ Chí Minh tận dụng được nguồn lực và tài chính của khối hợp tác xã nên lúc đầu phát triển xe buýt khá nhanh, tạo sự cạnh tranh trong thị trường vận tải; hiện nay tình trạng hạn chế về năng lực quản lý, quy mô sản xuất manh mún, chất lượng dịch vụ không đồng đều của các hợp tác xã đang là khó khăn cho phát triển VTHKCC bằng xe buýt ở Thành phố Hồ Chí Minh.

\subsubsection{Hiện trạng VTHKCC bằng xe buýt trên toàn quốc}

1) Số địa phương có hệ thống VTHKCC bằng xe buýt: 55/63 (04 địa phương không có VTHKCC bằng xe buýt: Bắc Kạn, Điện Biên, Hà Giang, Lai Châu).

2) 42 tỉnh, thành phố có quy hoạch VTHKCC bằng xe buýt, 11 tỉnh có quy hoạch liên quan đến VTHKCC bằng xe buýt (quy hoạch VTHKCC bằng xe buýt trong quy hoạch GTVT), 03 tỉnh đang chờ phê duyệt, 7 tỉnh chưa có quy hoạch.

3) Mạng lưới tuyến: 684 tuyến xe buýt với tổng chiều dài $26.599 \mathrm{~km}$, trong đó có 541 tuyến nội đô, nội tỉnh với tổng chiều dài $20.603 \mathrm{~km}, 143$ tuyến liền kề dài $6.382 \mathrm{~km}$. Chiều dài bình quân tuyến nội đô, nội tỉnh 37,6 km, tuyến liền kề 45,8 km. Mật độ tuyến bình quân: 0,09 (km/km2).

4) Sản lượng: 1,06 tỷ lượt HK (Hà Nội: 450.triệu lượt HK, Thành phố Hồ Chí Minh: 334,540 triệu lượt $\mathrm{HK}$, Hà Nội và Thành phố Hồ Chí Minh chiếm 78\% sản lượng VTHKCC bằng xe buýt toàn quốc).

5) Đoàn phương tiện: 9.264 xe (Hà Nội: 1.546 xe, Thành phố Hồ Chí Minh: 2.786 xe. Hà Nội và Thành phố Hồ Chí Minh : 4.332 xe, chiếm 46,8\% đoàn phương tiện toàn quốc).

Sau 16 năm thực hiện Nghị quyết 13/2002/NQ-CP của Chính phủ và 10 năm thực hiện Nghị quyết 16/2008/NQ-CP của Chính phủ ở hầu hết các tỉnh, thành phố trực thuộc TW đều hình thành mạng lưới VTHKCC bằng xe buýt, tuy nhiên mức độ phát triển chênh lệch nhiều, phát triển VTHKCC bằng xe buýt chủ yếu vẫn là Hà Nội, Thành phố Hồ Chí Minh, sau đó là Cần Thơ, Đà Nẵng, Hải Phòng ...nhưng sản lượng đạt dưới 15 triệu lượt HK, nhiều tỉnh đạt chưa đến 1 triệu lượt hành khách, thâm chí có địa phương hoạt động cầm chừng như Điện Biên. 


\subsubsection{Hiện trạng xe buýt Hà Nội}

\subsubsection{Phương tiện giao thông ở Hà Nội}

Bảng 2-6 Số lượng ô tô và xe máy của Hà Nội 2005 - $2018^{35}$

\begin{tabular}{|c|c|c|c|c|c|}
\hline Năm & $\begin{array}{c}\text { Số ô tô } \\
\text { đăng ký (xe) }\end{array}$ & $\begin{array}{c}\text { Ô tô } \\
\text { tăng (\%) }\end{array}$ & $\begin{array}{c}\text { Số xe máy } \\
\text { đăng ký (xe) }\end{array}$ & $\begin{array}{c}\text { Xe máy } \\
\text { Tăng ( \%) }\end{array}$ & $\begin{array}{c}\text { Tổng số } \\
\text { PTCGGĐB }\end{array}$ \\
\hline 2005 & 105.640 & & 1.970 .959 & & 2.076 .599 \\
\hline 2006 & 119.039 & $13 \%$ & 2.152 .270 & $9 \%$ & 2.271 .309 \\
\hline 2007 & 147.171 & $24 \%$ & 2.409 .317 & $12 \%$ & 2.556 .488 \\
\hline 2008 & 185.640 & $26 \%$ & 2.837 .810 & $18 \%$ & 3.023 .450 \\
\hline 2009 & 234.499 & $26 \%$ & 3.249 .315 & $15 \%$ & 3.483 .814 \\
\hline 2010 & 273.541 & $17 \%$ & 3.577 .041 & $10 \%$ & 3.850 .582 \\
\hline 2011 & 321.177 & $17 \%$ & 3.980 .070 & $11 \%$ & 4.301 .247 \\
\hline 2012 & 334.399 & $4 \%$ & 4.444 .127 & $12 \%$ & 4.778 .526 \\
\hline 2013 & 342.122 & $2 \%$ & 4.660 .761 & $5 \%$ & 5.002 .883 \\
\hline 2014 & 376.417 & $10 \%$ & 4.852 .380 & $4 \%$ & 5.228 .797 \\
\hline 2015 & 408.713 & $9 \%$ & 5.045 .672 & $4 \%$ & 5.454 .385 \\
\hline 2016 & 485.955 & $19 \%$ & 5.255 .245 & $4 \%$ & 5.741 .200 \\
\hline 2017 & 669.216 & $38 \%$ & $5.483 .313^{36}$ & $4 \%$ & 6.152 .529 \\
\hline 2018 & 717.172 & $7 \%$ & 5.686 .501 & $4 \%$ & 6.403 .673 \\
\hline \multicolumn{2}{|c|}{ B/q tăng hàng năm } & $16 \%$ & & $9 \%$ & \\
\hline
\end{tabular}

Theo số liệu đăng ký phương tiện giao thông năm 2016, Hà Nội đang quản lý: trên 5,6 triệu xe máy, 717.172 xe ô tô các loại, trên 1,2 triệu xe đạp, trên 11 nghìn xe đạp điện và xe máy điện (chưa kể số lượng khoảng 10-15\% các phương tiện ngoại tỉnh hoạt động); tốc độ tăng trưởng bình quân giai đoạn 2011-2018 là $16 \%$ /năm đối với ô tô và $9 \%$ /năm đối với xe máy, trong khi đó tốc độ tăng trưởng bình quân chiều dài đường bộ chỉ đạt 3,85\%/năm. ${ }^{37}$

Năm 2015, Hà Nội có 1.208 ô tô buýt được trợ giá, diện tích đất dành cho giao thông trên diện tích đất xây dựng đô thị đạt $8,65 \%$ (năm 2010 đạt $7 \%$ ), tốc độ tăng trưởng tuyến giao thông đường bộ từ 2010 đến 2015 là: $3,9 \%$ /năm về chiều dài và $0,25 \% /$ năm về diện tích mặt đường ${ }^{38}$

Năm 2016 xe máy chiếm 91,54 \% tổng số phương tiện cơ giới đường bộ, trong khi đó xe ô tô chỉ chiếm $8,46 \%$.

\footnotetext{
35 Đề án Tăng cường quản lý phương tiện giao thông nhằm giảm ùn tắc giao thông và ô nhiễm môi trường trên địạ bàn thành phố Hà Nội giai đoạn 2017 - 2020 tầm nhìn 2030 (viết tắt: ĐAQLPTHN)

36 Số liệu năm 2017, 2018: Phòng CSGT Hà Nội

37 ĐAQLPTHN (trang 19)

38 Đề án nâng cao chất lượng dịch vụ và phát triển hệ thống vận tải hành khách công cộng bằng xe buýt thủ đô Hà Nội giai đoạn 2016 - 2020 định hướng 2025 (viết tắt : ĐAXBHN)
} 


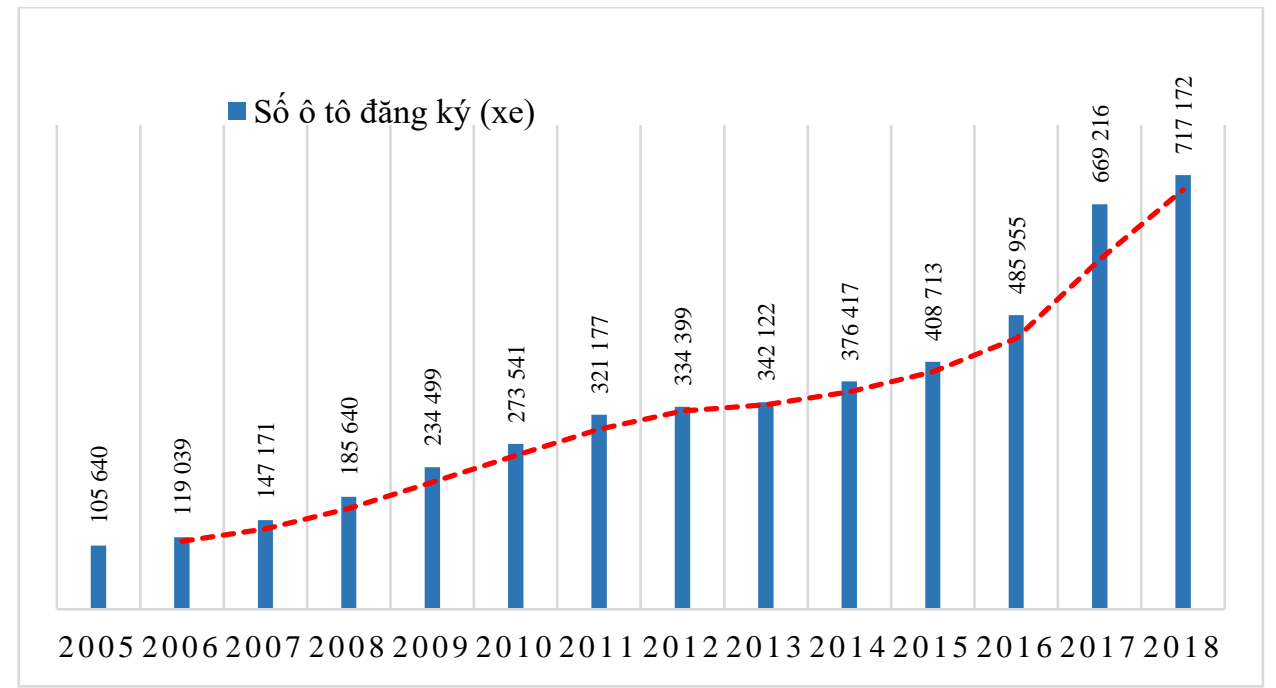

Hình 2-3 Biểu đồ gia tăng ô tô của Hà Nội 2005 - 2018

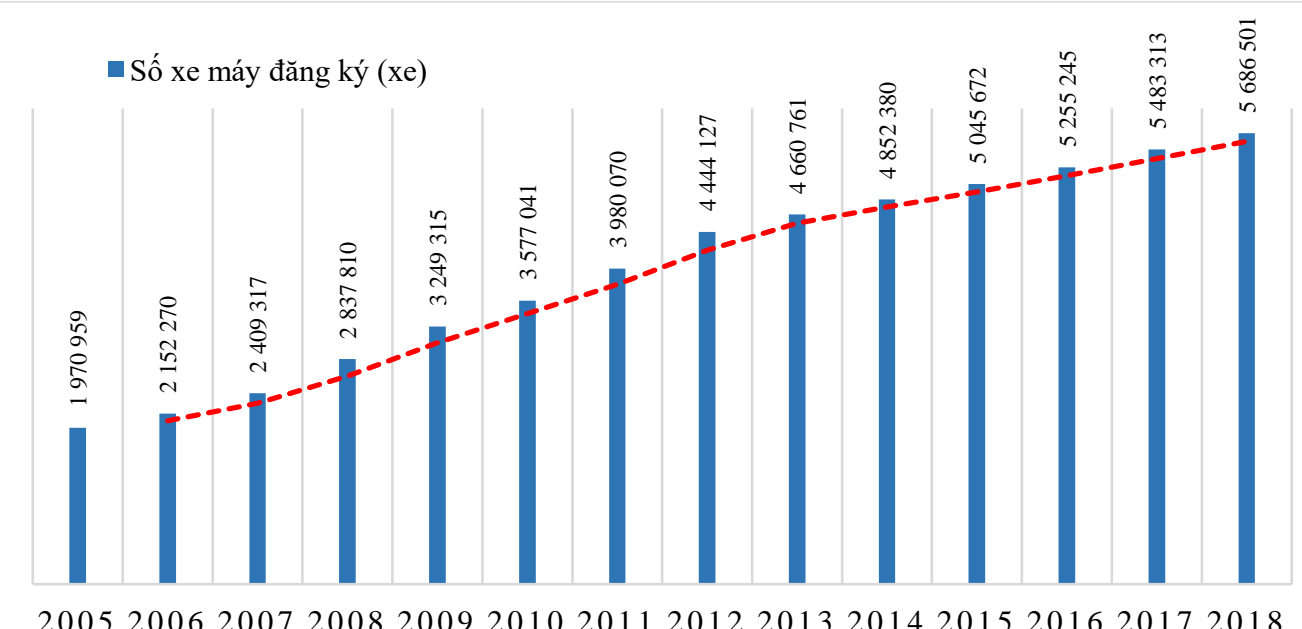

Hình 2-4 Biểu đồ gia tăng xe máy của Hà Nội 2005 - 2018

\subsubsection{Phát triển xe buýt của Hà Nội}

Thực hiện Nghị quyết 13/2002/NQ-CP của Chính phủ, VTHKCC bằng xe buýt đã được chính quyền thành phố quan tâm. Từ 2000 đến 2017 VTHKCC bằng xe buýt của Hà Nội phát triển về mạng lưới, đoàn phương tiện và sản lượng như sau:

Bảng 2-7 Tổng họ̣p chỉ tiêu VTHKCC bằng xe buýt 2000-2017

\begin{tabular}{|c|l|l|c|c|c|c|c|c|c|c|c|c|}
\hline STT & Chỉ tiêu & \multicolumn{1}{|c|}{ Đơn vị } & $\mathbf{2 0 0 0}$ & $\mathbf{2 0 0 9}$ & $\mathbf{2 0 1 0}$ & $\mathbf{2 0 1 1}$ & $\mathbf{2 0 1 2}$ & $\mathbf{2 0 1 3}$ & $\mathbf{2 0 1 4}$ & $\mathbf{2 0 1 5}$ & $\mathbf{2 0 1 6}$ & $\mathbf{2 0 1 7}$ \\
\hline 1 & Mạng lưới & tuyến & 31 & 66 & 80 & 86 & 86 & 89 & 91 & 91 & 96 & 109 \\
\hline 2 & $\begin{array}{l}\text { Đoàn } \\
\text { phương tiện }\end{array}$ & xe & 334 & 983 & $1.046^{\mathbf{3 9}}$ & 1.360 & 1.399 & 1.465 & 1.480 & 1.482 & 1.546 & 1.546 \\
\hline 3 & Sản lượng & $10^{6}$ lượt khách & 10,696 & 413,296 & 462 & 483 & 496,6 & 499,8 & 506 & 468,9 & 436 & 450 \\
\hline
\end{tabular}

39 Đoàn phương tiện từ năm 2010 là số xe buýt có trợ giá (ĐAXBHN), số liệu đoàn phương tiện 2000, 2009, 2010: ĐAXBHN; số liệu đoàn phương tiện 2011, 2012, 2013, 2014, 2015: ĐAQLPTHN; số liệu đoàn phương tiện 2016, 2017: Transerco 
Năm 2000, Hà Nội chỉ có 3 doanh nghiệp nhà nước tham gia VTHKCC bằng xe buýt với quy mô nhỏ, tốc độ phát triển châm chạp, năm 1993 sản lượng vận chuyển hành khách chỉ đạt 4,8 triệu lượt hành khách, đến năm 2000 đạt 10,6 triệu lượt hành khách, năm 2001 cũng chỉ đạt được 15, 2 triệu lượt khách.

Năm 2002, Nghị quyết 13/2002/NQ-CP của Chính phủ đã tác động mạnh đến phát triển VTHKCC bằng xe buýt ở Hà Nội. Năm 2004, Hà Nội thành lập Tổng Công ty Transerco, Tổng Công ty đầu tiên được thí điểm theo mô hình công ty mẹ-công ty con. Ngay trong năm đầu tiên thành lập, Transerco đã triển khai 41 tuyến với 700 đầu xe, đạt sản lượng 285,3 triệu lượt hành khách, tăng 64\% so với năm 2003.

Giai đoạn từ năm 2000 đến năm 2009 là giai đoạn phát triển vượt bậc về VTHKCC bằng xe buýt của Hà Nội, sản lượng vận chuyển hành khách tăng 38,6 lần, tỷ lệ tăng trưởng bình quân hàng năm đạt $51 \% /$ năm$^{40}$.

Giai đoạn 2010 đến 2014, sản lượng vận chuyển khách bằng xe buýt tăng liên tục, nhưng chỉ tăng bình quân 4,18\%/năm, năm 2014 sản lượng cao nhất là 506 triệu lượt hành khách. Năm 2015, 2016 sản lượng vận chuyển hành khách có xu hướng giảm, đến năm 2017 tăng trở lại, nhưng cũng chỉ đạt 450 triệu hành khách.

Ngoài chỉ tiêu sản lượng vận chuyển khách, Hà Nội cũng đạt được một số tiêu chí sau: đang khai thác 109 tuyến (74 tuyến được trợ giá, 15 tuyến thí điểm, 11 tuyến không trợ giá, 9 tuyến liền kề), chỉ tính 89 tuyến (74 tuyến trợ giá, 15 tuyến thí điểm) thì tổng số xe hoạt động là 14.289 lượt xe/ngày với bình quân 1,1 triệu lượt hành khách/ngày; số km xe buýt trên số km đường có thể chạy được xe buýt đạt 48,9\% (1.947km xe buýt $/ 3.974 \mathrm{~km}$ đường có thể chạy được xe buýt); số đường phố đã có xe buýt tính trên tổng số đường phố có thể chạy được xe buýt đạt 34\% (319 phố đã có xe buýt/ 928 đường phố có thể chạy được xe buýt); số khu vực trung tâm hành chính đã có xe buýt tính trên tổng số trung tâm hành chính của các quận, huyện toàn thành phố đật $73 \%(38 / 52)$. Toàn mạng lưới hiện có 1.546 xe buýt các loại đang vận hành khai thác, xe buýt loại vừa và lớn chiếm $96 \%$, loại nhỏ (24 chỗ) chiếm $4 \%$; mạng lưới xe buýt đã phủ được 12 quận nội thành, phát triển mở rộng đến 26/40 khu vực huyện lỵ, trung tâm hành chính huyện ngoại thành.

Bảng 2-8 Tổng hợp trợ giá cho xe buýt của Hà Nội ${ }^{41}$

\begin{tabular}{|c|l|c|c|c|c|c|c|c|}
\hline TT & \multicolumn{1}{|c|}{ Chỉ tiêu } & Đơn vị tính & $\mathbf{2 0 1 0}$ & $\mathbf{2 0 1 1}$ & $\mathbf{2 0 1 2}$ & $\mathbf{2 0 1 3}$ & $\mathbf{2 0 1 4}$ & $\mathbf{2 0 1 5}$ \\
\hline 1 & Doanh thu & $10^{6}$ đồng & 395.843 & 409.299 & 515.196 & 727.316 & 868.678 & 825.978 \\
\hline 2 & Chi phí & $10^{6}$ đồng & 983.356 & 1.225 .881 & 1.642 .708 & 1.796 .112 & 1.969 .248 & 1.798 .244 \\
\hline 3 & Trợ giá & 10 đồng & 587.513 & 816.581 & 1.127 .511 & 1.068 .796 & 1.100 .570 & 972.266 \\
\hline & Trợ giá/Chi phí & $\%$ & $59,7 \%$ & $66,6 \%$ & $68,6 \%$ & $59,5 \%$ & $55,9 \%$ & $54,1 \%$ \\
\hline 4 & Chi phí TB theo cự ly & đồng/km & $11.857,4$ & $14.622,9$ & $19.009,5$ & $19.955,8$ & $21.574,5$ & $19.188,6$ \\
\hline 5 & $\begin{array}{l}\text { Chi phí TB theo hành } \\
\text { khách }\end{array}$ & đồng/người & $2.331,1$ & $2.782,8$ & $3.620,5$ & $3.914,4$ & $4.248,5$ & $4.163,6$ \\
\hline
\end{tabular}

$\left.{ }^{40}\left((413,296 / 10,696)^{\wedge}(1 / 9)-1\right) * 100\right)$

${ }^{41}$ Đề án Nâng cao chất lượng dịch vụ và phát triển hệ thống vân tải hành khách công cộng bằng xe buýt thủ đô Hà Nội giai đoạn 2016 - 2020, định hướng 2025 (Công ty cổ phần phát triển đô thị bền vững - Đại học Giao thông vận tải) 
Dự án: Xây dựng chiến lược an toàn giao thông đối với xe máy và kế hoạch hành động: một khởi đầu của Việt Nam

\begin{tabular}{|c|c|c|c|c|c|c|c|c|}
\hline TT & Chỉ tiêu & Đơn vị tính & $\mathbf{2 0 1 0}$ & $\mathbf{2 0 1 1}$ & $\mathbf{2 0 1 2}$ & $\mathbf{2 0 1 3}$ & $\mathbf{2 0 1 4}$ & $\mathbf{2 0 1 5}$ \\
\hline 6 & Trợ giá TB theo cự ly & Đ/km & $7.084,3$ & $9.740,6$ & $13.047,6$ & $11.874,9$ & $12.057,5$ & $10.374,8$ \\
\hline 7 & $\begin{array}{l}\text { Trợ giá TB theo hành } \\
\text { khách }\end{array}$ & Đ/HK & $1.392,7$ & $1.853,7$ & $2.485,0$ & $2.329,3$ & $2.374,4$ & $2.251,1$ \\
\hline
\end{tabular}

Về mức độ tiếp cận của hành khách đối với tuyến xe buýt ở mức dưới $500 \mathrm{~m}$ đạt $11 \%$, khó tiếp cận (trên 500m) khoảng 53\%.

Hà Nội thực hiện tốt chính sách trợ giá cho xe buýt. Tổng hợp từ 2010 đến năm 2015, trợ giá trên tổng chi phí từ $50 \%$ đến $60 \%$.

\subsubsection{Thành công và hạn chế xe buýt của Hà Nội}

Để đánh giá mạng xe buýt ở một đô thị tốt hay không tốt, hiệu quả hay không thì cần phải đánh giá toàn diện về nhiều mặt theo những tiêu chuẩn nhất định, ví dụ như: tiêu chuẩn về kết cấu hạ tầng tuyến và mạng lưới, tiêu chuẩn về đoàn phương tiện và người phục vụ, tiêu chuẩn về tổ chức quản lý khai thác và điều hành, tiêu chuẩn về hiệu quả đầu tư và phát triển, tiêu chuẩn về sự hài lòng, thuận tiện...

Tuy nhiên, trong khuôn khổ của dự án, nghiên cứu chỉ dừng lại ở phạm vi xem xét việc thực hiện nhiệm vụ phát triển VTHKCC bằng xe buýt để hạn chế phương tiện cá nhân nhằm giải quyết tình trạng ùn tắc giao thông theo chủ trương của Nghị quyết 16/2008/NQ-CP của Chính phủ.

\subsection{Thành công của Hà Nội về đẩy mạnh phát triển vận tải hành khách công cộng bằng xe buýt}

Chính quyền thành phố Hà Nội rất quan tâm đến tổ chức vận tải khách công cộng để giải quyết ùn tắc của Thủ đô, trong nhiều năm qua đã từng bước thực hiện các cơ chế chính sách ưu tiên phát triển, đầu tư hệ thống xe buýt theo tinh thần Nghị quyết 16/2008/NQ-CP của Chính phủ. Cho đến nay có thể khẳng định hệ thống xe buýt của Hà Nội phát triển tốt nhất so với nhiều địa phương, thể hiện trên các mặt: sản lượng, tuyến, đoàn phương tiện, chất lượng phục vụ, hạ tầng phục vụ xe buýt.

Một số điểm nổi bật của thành công là:

1) Sau 17 năm (2000 -2017) mạng xe buýt được mở rộng và bước đầu thu hút được hành khách, số tuyến tăng trên 3,5 lần, đoàn xe tăng 4,6 lần (70\% xe buýt có tuổi dưới 10 năm), hạ tầng xe buýt từng bước được cải thiện, sản lượng tăng 42 lần, đặc biệt đã đáp ứng được $10 \%-12 \%$ nhu cầu đi lại. VTHKCC bằng xe buýt đã góp phần vào giảm ùn tắc giao thông ở nhiều điểm (ở một số tuyến khảo sát như: trục Cầu Giấy, Kim Mã, Nguyễn Văn Cừ ... tỷ lệ chiếm dụng đường của xe buýt dưới $10 \%$ nhưng vận chuyển được trên $15 \%$ nhu cầu đi lại). Về chất lượng, theo thang điểm 5 dựa vào 6 nhóm yếu tố bao gồm chi phí, khả năng tiếp cận, mức độ an toàn, độ tin cậy, phương tiện và nhân viên cho kết quả là 3,52 điểm/5 điểm, đạt mức khá. Kết quả điều 
tra xã hội học cũng cho kết quả: $26 \%$ số người được hỏi đánh giá chất lượng dịch vụ xe buýt đạt mức tốt, $65 \%$ đánh giá trung bình, $8 \%$ đánh giá kém và $1 \%$ đánh giá rất kém ${ }^{42}$.

2) Ban hành kịp thời chính sách ưu đãi cho đầu tư phát triển VTHKCC bằng xe buýt ; có cơ chế, chính sách phát triển xe buýt phù hợp với từng giai đoạn.

3) Bên cạnh chủ trương xã hội hóa đầu tư phát triển xe buýt vẫn duy trì, phát triển đơn vị nhà nước làm chủ công phát triển xe buýt (Transerco), năm 2004 thành lập Transerco được xem là cú "hích" quan trọng để VTHKCC bằng xe buýt ở Hà Nội phát triển ngoạn mục.

4) Xây dựng được trung tâm quản lý và điều hành giao thông đô thị Hà Nội (Tramoc), Trung tâm điều hành xe buýt hiện đại của Transerco (điều hành 92 tuyến, 1.100 xe buýt). Không chỉ chăm lo phát triển tuyến, đoàn phương tiện mà còn quan tâm đến kết cấu hạ tầng xe buýt.

5) Năm 2016, 2017, 2018 tiến hành đầu tư, đổi mới đoàn phương tiện, Transerco đã đầu tư thay thế trên 300 xe buýt mới.

6) Áp dụng hệ thống quản lý mạng xe buýt bằng công nhệ hiên đại.

7) Từng bước nâng cao được chất lượng phục vụ của lái xe, phụ xe.

\subsection{Nhũng hạn chế về VTHKCC bằng xe buýt của Hà Nội}

Một trong mục tiêu trong tâm của Nghị quyết 16/2006/NQ-CP của Chính phủ là phát triển VTHKCC mà trước tiên là VTHKCC bằng xe buýt để nhanh chóng giảm đi lại bằng phương tiện giao thông cá nhân. Kiểm điểm lại, mặc dù VTHKCC bằng xe buýt của Hà Nội đã có những phát triển tốt nhưng thực sự chưa đủ tầm để người dân từ bỏ xe máy, đến nay tỷ lệ đi lại bằng xe máy vẫn là giao thông chủ yếu ở Hà Nội (năm 2012 chiếm 67,42\% chuyến đi trên toàn thành phố, năm 2015 chiếm 59,6\%) (33 $^{\mathbf{4 3}}$; một trong những nguyên nhân năm 2015, 2016, 2017 sản lượng vận chuyển hành khách bằng xe buýt giảm so với năm 2014 là do xe máy tăng nhanh, ùn tắc giao thông (trên $80 \%$ điểm ùn tắc tập trung trong khu vực trung tâm thành phố), thi công các công trình trọng điểm, các điểm dừng đỗ, nhà chờ liên tục bị điều chỉnh, lấn chiếm làm hạn chế tốc độ của xe buýt, kéo dài thời gian đi lại, một số tuyến không hợp lý kéo dài thới gian chờ đợi nên nhiều người quay lại đi xe máy.

VTHKCC bằng xe buýt Hà Nội phát triển chậm so với tốc độ đô thị hóa, dân số tăng nhanh (tăng bình quân 2,4\%/năm), đòi hỏi dịch vụ cao hơn, đối tượng khách đi xe buýt đa dạng hơn, thu nhập bình quân trên đầu người tăng, cư ly đi lại dài hơn, đòi hỏi tiếp cận cao hơn, tính kết nối tốt hơn ..., đặc biệt là không thực hiện được di dời trụ sở các cơ quan hành chính nhà nước, các trường đại học, cao đẳng, dạy nghề, bệnh viên lớn ra ngoài khu vực trung tâm (giải pháp 2 của Nghị quyết 13/2002/NQ-CP của Chính phủ) mà ngược lại nhiều khu đô thị lớn, nhà cao tầng, trung tâm thương mại .. vẫn được phát triển ở vùng lõi đô thị trên nền kết cấu hạ tầng giao

${ }^{42}$ Số liệu Ths. Hoàng Thị Hồng Lê - Trường Đại học Công nghệ GTVT (Tạp chí Giao thông vận tải)

${ }^{43}$ Đề án Nâng cao chất lượng dịch vụ và phát triển hệ thống vân tải hành khách công cộng bằng xe buýt thủ đô Hà Nội giai đoạn 2016 - 2020, định hướng 2025 (Công ty cổ phần phát triển đô thị bền vững - Đại học Giao thông vận tải) 
thông không thể phát triển được. Nếu không giải "nén" lõi đô thị thì không thể phát triển được xe buýt, xe máy tiếp tục tăng và ùn tắc giao thông không có lời giải.

Xem xét thêm về tỷ lệ tăng trưởng dân số, tỷ lệ tăng trưởng sản lượng vận chuyển hành khách của Hà Nội trong những năm qua thấy như sau:

Bảng 2-9 Dân số, sản lượng vận chuyển hành khách đường bộ và sản lượng vận chuyển hành khách bằng xe buýt của Hà Nội

\begin{tabular}{|c|c|c|c|c|c|c|}
\hline \multirow{2}{*}{ Năm } & \multicolumn{2}{|c|}{ Dân số } & \multicolumn{2}{|c|}{ Sản lưọng VCHK bằng xe buýt } & \multicolumn{2}{|c|}{ Số lượt VCHK bằng đường bộ } \\
\hline & $\begin{array}{l}\text { Dân số } \\
\text { (người) }\end{array}$ & $\begin{array}{c}\text { Tỷ lệ } \\
\text { tăng (\%) }\end{array}$ & $\begin{array}{l}\text { SLVCHK } \\
(10)^{6} \text { ngưò̀i }\end{array}$ & $\begin{array}{c}\text { Tỷ lệ } \\
\text { tăng (\%) }\end{array}$ & $\begin{array}{l}\text { Số lượt khách } \\
\left(\mathbf{1 0}^{6}\right) \text { người) }\end{array}$ & $\begin{array}{c}\text { Tỷ lệ } \\
\text { tăng (\%) }\end{array}$ \\
\hline 2005 & 5.910 .200 & & & & & \\
\hline 2006 & 6.030 .000 & $2,03 \%$ & & & & \\
\hline 2007 & 6.159 .300 & $2,14 \%$ & & & & \\
\hline 2008 & 6.350 .000 & $3,10 \%$ & & & 495 & \\
\hline 2009 & 6.476 .900 & $2,00 \%$ & 413 & & 547 & $11 \%$ \\
\hline 2010 & 6.617 .900 & $2,18 \%$ & 462 & $11,78 \%$ & 646 & $18 \%$ \\
\hline 2011 & 6.779 .300 & $2,44 \%$ & 483 & $4,55 \%$ & 651 & $1 \%$ \\
\hline 2012 & 6.957 .300 & $2,63 \%$ & 496 & $2,82 \%$ & 719 & $10 \%$ \\
\hline 2013 & 7.128 .300 & $2,46 \%$ & 499 & $0,64 \%$ & 776 & $8 \%$ \\
\hline 2014 & 7.306 .508 & $2,50 \%$ & 506 & $1,24 \%$ & 855 & $10 \%$ \\
\hline 2015 & 7.489 .170 & $2,50 \%$ & 468 & $-7,33 \%$ & 917 & $7 \%$ \\
\hline 2016 & 7.676 .399 & $2,50 \%$ & 436 & $-7,02 \%$ & & \\
\hline 2017 & & & 450 & $3,21 \%$ & & \\
\hline \multicolumn{2}{|c|}{ Tỷ lệ tăng b/q } & $2,4 \%$ & & $1,24 \%$ & & $9,2 \%$ \\
\hline
\end{tabular}

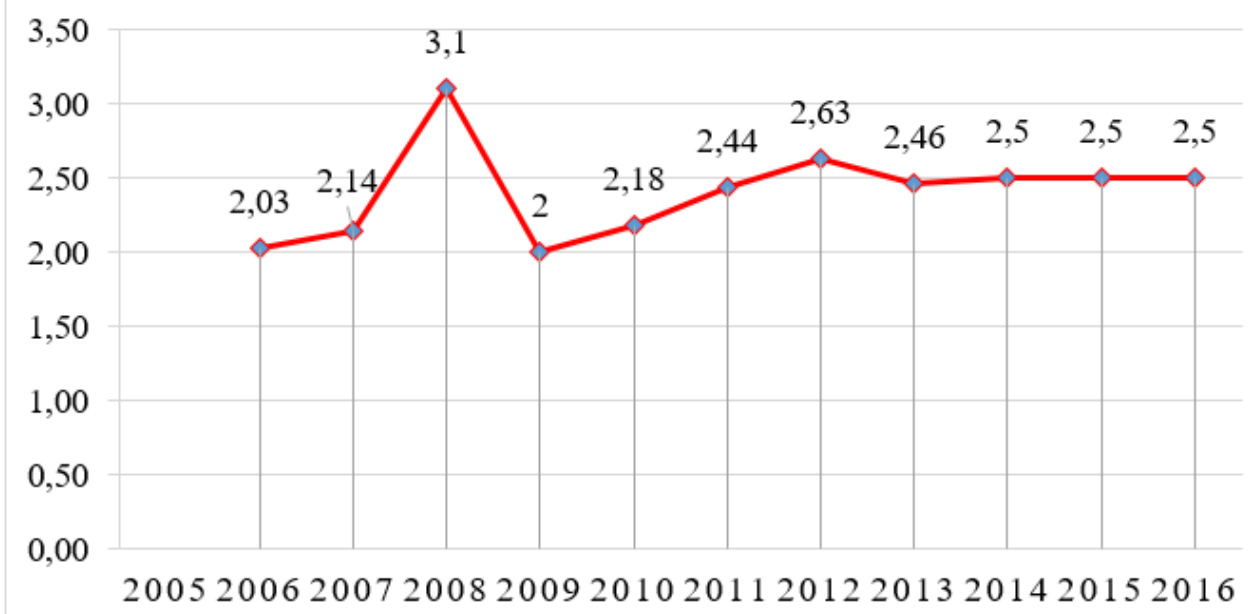

Hình 2-5 Tỷ lệ tăng trưởng dân số Hà Nội 2005 - 2016 (\%) 


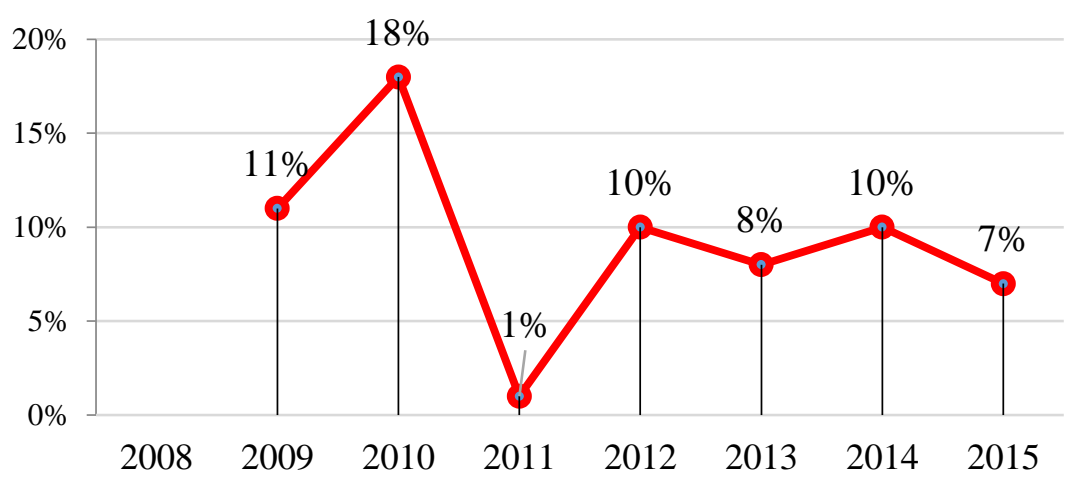

Hình 2-6 Tỷ lệ tăng trưởng vận chuyển hành khách bằng đường bộ 2008 - 2015 (\%)

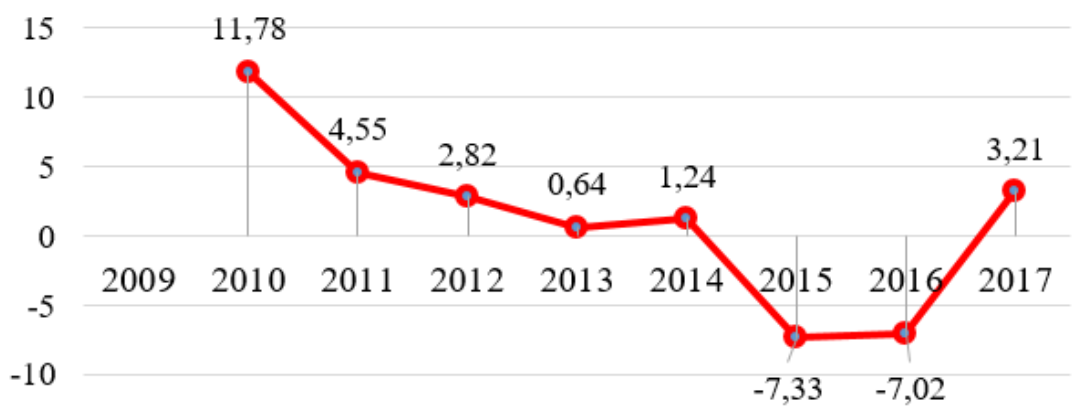

Hình 2-7 Tỷ lệ tăng trưởng sản lượng xe buýt Hà Nội 2009-2017 (\%)

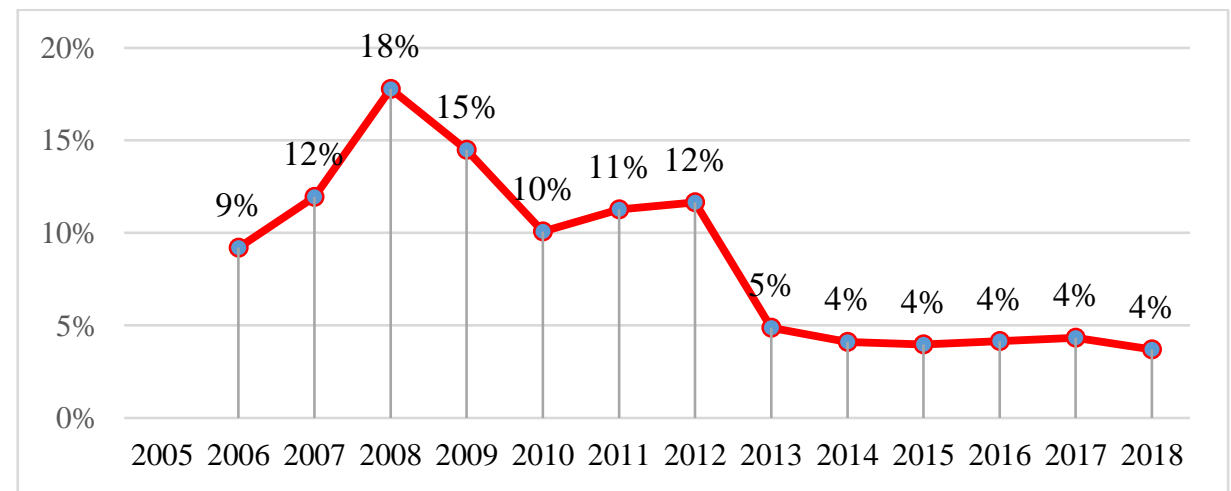

Hình 2-8 Tỷ lệ tăng trưởng xe máy Hà Nội 2005 - 2018

Tỷ lệ tăng dân số cơ học bình quân Hà Nội hàng năm khoảng 2,4\%/ năm, tỷ lệ tăng trưởng vận chuyền lượt khách bằng đường bộ là $9,2 \% /$ năm, trong khi đó tỷ lệ tăng trưởng sản lượng vận chuyển hành khách bằng xe buýt bình quân chỉ đạt 1,24\%/năm, chưa kể năm 2015, 2016 tăng trưởng âm, theo báo cáo Tổng kết năm 2018 của Trung tâm Quản lý và Điều hành giao thông đô thị Hà Nội thì năm 2018 sản lượng hành khách toàn mạng xe buýt đạt 453 triệu lượt hành khách, 3,1\% so với năm 2017. 


\subsubsection{Hiện trạng xe buýt Thành phố Hồ Chí Minh}

\subsubsection{Phương tiện giao thông Thành phố Hồ Chí Minh}

Năm 2016, Thành phố Hồ Chí Minh đang quản lý 455.198 ô tô các loại và 7.287.066 xe máy, tổng số phương tiện cơ giới đường bộ năm 2016 là 7.742.264 xe; giai đoạn 2011 - 2017 tốc độ tăng trưởng của xe máy: $6,77 \% /$ năm, ô tô : $10,02 \% /$ năm (ô tô con là $11,7 \% /$ năm).

Tính đến 12 năm 2017, Thành phố Hồ Chí Minh chiều dài đường bộ: 4.202,65 km, trong đó có $1.827 \mathrm{~km}$ đường có bề rộng trên $7 \mathrm{~m}$, tăng trưởng bình quân giai đoạn 2011-2017 đạt $1,47 \% /$ năm (khu vực trung tâm kết cấu hạ tầng giao thông đường bộ gần như không tăng, giai đoạn 2011 - 2017 chỉ tăng $0,3 \%$ /năm); tăng trưởng diện tích mặt đường 4,82\%, đất dành cho giao thông so với đất xây dựng đô thị chỉ có $8,8 \%$, mật độ đường đạt: $2,01 \mathrm{~km} / \mathrm{km}^{2}$.

Giai đoạn 2011-2017, tốc độ tăng trưởng phương tiện giao thông cơ giới cá nhân tăng gấp nhiều lần tăng trưởng kết cấu hạ tầng giao thông đường bộ: xe máy tăng gấp 5 lần chiều dài đường bộ, 1,44 lần diện tích mặt đường, ô tô con tăng gấp 7 lần chiều dài đường bộ, 2 lần diện tích mặt đường. ${ }^{44}$

\section{Bảng 2-10 Số lượng phương tiện giao thông trên địa bàn TP. Hồ Chí Minh giai đoạn $2011-2017^{45}$}

\begin{tabular}{|c|c|c|c|c|c|c|c|c|}
\hline Năm & Ô tô con & $\begin{array}{c}\text { Xe } \\
\text { khách }\end{array}$ & Xe tải & $\begin{array}{c}\text { Xe } \\
\text { chuyên } \\
\text { dùng }\end{array}$ & $\begin{array}{c}\text { Xe } \\
\text { khác }\end{array}$ & $\begin{array}{c}\text { Tổng ô } \\
\text { tô }\end{array}$ & $\begin{array}{c}\text { Tổng xe } \\
\text { mô tô, xe } \\
\text { gắn máy }\end{array}$ & $\begin{array}{c}\text { Tổng số } \\
\text { phương } \\
\text { tiện }\end{array}$ \\
\hline 2011 & 148.158 & 24.530 & 102.861 & 4.020 & 14.119 & 293.688 & 5.029 .342 & 5.323 .030 \\
\hline 2012 & 157.233 & 25.091 & 106.366 & 4.062 & 14.972 & 307.724 & 5.465 .356 & 5.773 .080 \\
\hline 2013 & 161.303 & 25.255 & 109.518 & 4.027 & 16.083 & 316.186 & 5.899 .193 & 6.215 .379 \\
\hline 2014 & 183.327 & 26.027 & 119.762 & 4.055 & 19.194 & 352.365 & 6.352 .926 & 6.705 .291 \\
\hline 2015 & 198.951 & 25.638 & 129.929 & 4.444 & 23.562 & 382.524 & 6.889 .351 & 7.271 .875 \\
\hline 2016 & 245.121 & 29.591 & 149.787 & 5.077 & 25.622 & 455.198 & 7.287 .066 & 7.742 .264 \\
\hline $\mathbf{2 0 1 7}$ & $\mathbf{2 8 5 . 6 1 2}$ & $\mathbf{3 2 . 2 4 2}$ & $\mathbf{1 6 5 . 3 8 2}$ & $\mathbf{5 . 5 0 0}$ & $\mathbf{2 8 . 2 2 0}$ & $\mathbf{5 1 6 . 9 5 6}$ & $\begin{array}{c}7,4 \text { triệu } \\
\text { (ước tính) }\end{array}$ & $\begin{array}{c}8,0 \text { triệu } \\
\text { (ước tính) }\end{array}$ \\
\hline
\end{tabular}

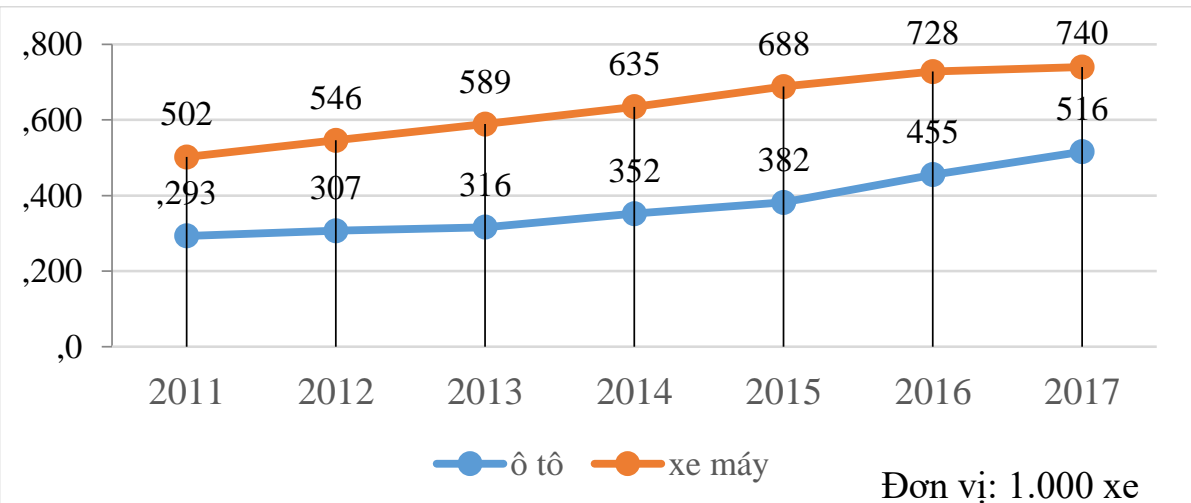

Hình 2-9 Tăng trưởng phương tiện giao thông cơ giới đường bộ Thành phố Hồ Chí Minh 2011-2017

\footnotetext{
${ }^{44}$ Đề án tăng cường vận tải hành khách công cộng kết hợp kiểm soát sử dụng phương tiện có giới cá nhân tham gia giao thông trên địa bàn Thành phố Hồ Chí Minh

45 Số phương tiện đăng ký. Nguồn Cục đăng kiểm Việt Nam, Công an Thành phố HCM
} 
Năm 2017, xe máy chiếm 93,5\% tổng số phương tiện cơ giới đường bộ, ô tô chiếm 6,4\% tổng số phương tiện cơ giới đường bộ

\subsubsection{Phát triển xe buýt Thành phố Hồ Chí Minh}

Thành phố Hồ Chí Minh đã bắt đầu xuất hiện tình trạng ùn tắc giao thông từ những năm 1990, vì vậy UBND Thành phố Hồ Chí Minh đã quan tâm đến xe buýt khá sớm. UBND Thành phố Hồ Chí Minh đã ban hành Quyết định 4196/QĐ-UB-CN ngày 12 tháng 9 năm 1996 và Quyết định 355/1998/QĐ-UB-CN ngày 19 tháng 1 năm 1998 về thành lập và quy định Quy chế hoạt động của Trung tâm Quản lý và Điều hành vân tải khách công cộng; đồng thời nhiều xí nghiệp, doanh nghiệp xe khách quốc doanh được đầu tư, đổi mới hoạt động để tham gia VCHKCC bằng xe buýt (SaigonBus chuyển thành doanh nghiệp công ích). Giai đoạn này số lượng hành khách đi xe buýt thấp, chất lượng dịch vụ kém, cơ sở hạ tầng cho xe buýt không đảm bảo.

Năm 2002, thực hiện Nghị quyết 13/2002/NQ-CP của Chính phủ, Thành phố Hồ Chí Minh công bố Kế hoạch nâng cao chất lượng VTHKCC bằng xe buýt, bao gồm xây dựng 20 tuyến xe buýt, tạo điều kiện về lãi suất để doanh nghiệp vay vốn đầu tư xe buýt, trợ giá cho xe buýt. Ngày 21 tháng 1 năm 2002, tuyến xe buýt mẫu hoạt động với 141 xe; sau 2 tuần hoạt động đã vận chuyển được 368.758 lượt khách, tăng $59 \%$ trước khi tổ chức tuyến mẫu; đến 31 tháng 5 khai trương thêm17 tuyến xe mẫu, đồng thời do trợ giá nên vé xe đồng hạng chỉ 1.000 đ/lượt nên lượng hành khách tăng cao trên các tuyến. Tổng số xe buýt đầu tư, thay mới trong năm là 1.381 xe buýt cỡ lớn, một số doanh nghiệp tư nhân đầu tư hơn 500 xe buýt loại nhỏ 12 chỗ (do Daihatsu và Suzuki sản xuất).

Tính đến tháng 7 năm 2017, Thành phố Hồ Chí Minh có 145 tuyến xe buýt (105 tuyến có trợ giá, 40 tuyến không trợ giá-các tuyến không trợ giá chủ yếu là các tuyến liền kề; 57 tuyến vận chuyển công nhân, 158 trường học tham gia chương trình đưa đón học sinh bằng xe buýt), với số phương tiện 2.603 xe (xe được trợ giá: 2.359 xe, xe không được trợ giá: 244 xe). Tổng chiều dài mạng lưới trên $3.500 \mathrm{~km}$, chiều dài bình quân các tuyến trợ giá đạt $20,5 \mathrm{~km}$ (tuyến cự ly dài tên $18 \mathrm{~km}$ là các tuyến xuyên tâm, các tuyến cự ly ngắn là các tuyến gom).

Mạng tuyến buýt đã kết nối được giữa khu vực trung tâm với khu vực ngoại thành, giữa nội thành với ngoại thành, giữa thành phố và một số tỉnh liền kề. Mật độ mạng lưới tuyến là: 1,67 $\mathrm{km} / \mathrm{km}^{2}$ (trị số chuẩn $2-2,5 \mathrm{~km} / \mathrm{km}^{2}$ ), mật độ này không đồng đều, khu vực trung tâm khá cao: $2,46 \mathrm{~km} / \mathrm{km}^{2}$, khu vực ngoại ô là $0,22 \mathrm{~km} / \mathrm{km}^{2}$; vận tải hành khách công cộng bằng xe buýt bao phủ $27,33 \%$ diện tích và $67,10 \%$ dân số, tuy nhiên bao phủ không đồng đếu khu vực trung tâm là: $88,10 \%$ và $84,93 \%$, ngoại ô là: $30,2 \%$ và $18,07 \%$

Phát triển VTHKCC bằng xe buýt Thành phố Hồ Chí Minh có thể chia ra các giai đoạn:

- Giai đoạn 2002-2008: Sản lượng VTHKCC bằng xe buýt tăng trưởng nhanh, bình quân 49\%/năm.

- Giai đoạn 2009-2012: Sản lượng VTHKCC bằng xe buýt tăng trưởng không ổn định, bình quân 5\%/năm.

- Giai đoạn 2013-2016: Sản lượng VTHKCC bằng xe buýt suy giảm, giảm bình quân $5,64 \% \% /$ năm.

46 Số liệu : Đề án hành khách công cộng Thành phố Hồ Chí Minh 


\section{Bảng 2-11 Tổng hợp chỉ tiêu VTHKCC bằng xe buýt của thành phố Hồ Chí Minh giai đoạn 2011-2017}

\begin{tabular}{|c|c|c|c|c|c|c|c|c|c|}
\hline STT & Chỉ tiêu & Đơn vị & $\mathbf{2 0 1 1}$ & $\mathbf{2 0 1 2}$ & $\mathbf{2 0 1 3}$ & $\mathbf{2 0 1 4}$ & $\mathbf{2 0 1 5}$ & $\mathbf{2 0 1 6}$ & $\mathbf{2 0 1 7}$ \\
\hline 1 & Mạng lưới & tuyến & 146 & 1150 & 145 & 1137 & 1136 & 142 & 145 \\
\hline 2 & $\begin{array}{c}\text { Đoàn phương } \\
\text { tiện }\end{array}$ & xe & 2.951 & 2.953 & 2.871 & 2.797 & 2.786 & 2.985 & 2.603 \\
\hline 3 & Sản lượng & $\begin{array}{c}49 \\
\text { người }\end{array}$ & 358 & 413,1 & 411,2 & 367 & 334,5 & 326,2 & \\
\hline
\end{tabular}

Tỷ lệ các loại hình VTHKCC bằng xe buýt trong cơ cấu tổng sản lượng vận chuyển:

- Trợ giá phổ thông chiếm: 73,5\%

- Trợ giá học sinh, sinh viên, công nhân chiếm: 5,89\%

- Không trợ giá phổ thông chiếm: $8,83 \%$

- Không trợ giá khác (học sinh, công nhân, hợp đông) chiếm 11,71\%

Hiện nay,Thành phố Hồ Chí Minh đang phải đối mặt với tình trạng xe buýt xuống cấp với hơn 1.300 xe buýt không đảm bảo chất lượng kỹ thuật và dịch vụ (chiếm gần $50 \%$ số xe buýt hiện có); Thành phố Hồ Chí Minh đã lập dự án đổi mới 1.680 xe buýt (300 xe chạy nhiên liệu sạch CNG) trong năm 2016, 2017.

Thành phố Hồ Chí Minh vẫn bảo đảm thường xuyên trợ giá cho VTHKCC bằng xe buýt, số liệu như sau:

Bảng 2-12 Kinh phí trọ̣ giá VTHKCC bằng xe buýt Thành phố Hồ Chí Minh năm $2011-2015^{50}$

\begin{tabular}{|c|c|c|c|c|c|c|c|}
\hline STT & Chỉ tiêu & Đơn vị & $\mathbf{2 0 1 1}$ & $\mathbf{2 0 1 2}$ & $\mathbf{2 0 1 3}$ & $\mathbf{2 0 1 4}$ & $\mathbf{2 0 1 5}$ \\
\hline 1 & Số tuyến trợ giá & tuyến & 108 & 110 & 110 & 107 & 105 \\
\hline 2 & Kinh phí & tỷ đồng & $1.263,6$ & $1.290,2$ & $1.156,9$ & $1.131,2$ & 818,87 \\
\hline
\end{tabular}

\subsubsection{Thành công và hạn chế phát triển vận tải hành khách công cộng (VTHKCC) bằng xe buýt tại Thành phố Hồ Chí Minh}

Theo Niên giám thống kê năm 2016, dân số Thành phố Hồ Chí Minh là 8.441 .902 người (nếu tính những người cư trú không đăng ký thì dân số thực tế của thành phố này năm 2017 là 13 triệu người), tốc độ tăng dân số giai đoạn 2005 - 2007 là 3,16\% /năm.

Thành phố Hồ Chí Minh giữ vai trò quan trọng trong nền kinh tế Việt Nam, là địa phương có đóng góp ngân sách lớn nhất. Tuy vậy, Thành phố Hồ Chí Minh đang phải đối diện với những vấn đề của một đô thị lớn có dân số tăng quá nhanh, trong nội đô thành phố, đường sá trở nên quá tải, thường xuyên ùn tắc. Hệ thống giao thông công cộng kém hiệu quả. Môi trường thành phố cũng đang bị ô nhiễm do phương tiện giao thông, các công trường xây dựng và công nghiệp sản xuất.

${ }^{47}$ Số liệu : Đề án hành khách công cộng Thành phố Hồ Chí Minh

${ }^{48}$ Số liệu 2011 -2014: Đề án nâng cao chất lượng vận tải hành khách công cộng bằng xe buýt, số liệu 2015 - 2017: Đề án hành khách công cộng Thành phố Hồ Chí Minh

${ }^{49}$ Đề án hành khách công cộng Thành phố Hồ Chí Minh

${ }^{50}$ Đề án Nâng cao chất lượng vận tải hành khách công cộng bằng xe buýt (Viện Chiến lược Bộ GTVT) 
Trước những thách thức về ùn tắc giao thông, Thành phố Hồ Chí Minh ngay từ rất sớm, từ năm 1990 đã quan tâm đến nhiệm vụ tổ chức VTHKCC bằng xe buýt. Đến nay, qua hơn 20 năm VTHKCC bằng xe buýt của Thành phố Hồ Chí Minh đã đạt nhiều thành công quan trọng, tuy vậy cũng còn nhiều hạn chế, chưa đáp ứng được yêu cầu.

\subsection{Nhũng thành công về phát triển VTHKCC bằng xe buýt của Thành phố Hồ Chí Minh}

1) Ngay từ khi Chính phủ ban hành Nghị quyết số 13/2002/NQ-CP ngày 19 tháng 11 năm 2002, Thành phố Hồ Chí Minh đã xây dựng "Đầu tư phương tiện vận tải hành khách công cộng bằng xe buýt TPHCM giai đoạn 2002-2003" và đã đầu tư 1.318 xe buýt trong năm 2002 -2003 (gồm 489 xe loại 80 khách, 561 xe loại 60 khách và 268 xe loại 40 khách do Công ty Xe khách Sài Gòn làm chủ đầu tư; tổng mức đầu tư lên đến hơn 1.364 tỉ đồng, trong đó, vốn vay từ Quỹ Đầu tư phát triển đô thị Thành phố hơn 864 tỉ đồng, lãi vay do ngân sách Trung ương bù chênh lệch hơn 334 tỉ đồng). Nhờ cú "hích" quan trọng này nên ngay từ đầu VTHKCC bằng xe buýt đã phát triển rất khởi sắc, sản lượng VTHKCC bằng xe buýt năm 2002 cao gấp 3 lần Hà Nội, trong giai đoạn 2002-2008 sản lượng VTHKCC bằng xe buýt tăng trưởng nhanh, bình quân 49\%/năm.

2) Sản lượng VTHKCC bằng xe buýt hiện nay so với năm 2002 tăng gần 12 lần, số tuyến tăng 7 lần, số lượng đoàn xe tăng gần 2 lần, chất lượng dịch vụ cũng từng bước được cải thiện, mạng xe buýt phủ khắp thành phố và khu vực lân cận.

3) Về kết cấu hạ tầng cho VTHKCC bằng xe buýt đã tăng nhiều so với năm 2002. Hiện nay có 4.059 điểm dừng đô̂, trong số đó có 497 nhà chờ được thiết kế có mai che, ghế chờ, có 1 điểm trung chuyển được đưa vào khai thác năm 2015; toàn hệ thống có 75 điểm đầu cuối.

4) UBND Thành phố Hồ Chí Minh ban hành kịp thời các chính sách vay vốn, hỗ trợ lãi suất mua sắm, đổi mới xe buýt, cơ chế trợ giá cho các loại: phổ thông, học sinh, sinh viên, công nhân, khuyến khích đầu tư xe buýt sử dụng nhiên liệu sạch.

5) Thành lập Trung tâm quản lý giao thông công cộng trực thuộc sở GTVT có chức năng quản lý, điều hành, xây dựng các để án, đề tài, kế hoạch phát triển VTHKCC bằng xe buýt; tham mưu chính sách về vốn, giá vé, mức trợ giá...

6) Tích cực đổi mới, hiện đại đoàn phương tiện (dự án 1.680 xe buýt).

\subsection{Nhũng hạn chế về VTHKCC bằng xe buýt của Thành phố Hồ Chí Minh}

1) Khởi sắc VTHKCC bằng xe buýt của Thành phố Hồ Chí Minh xuất phát từ xã hội hóa dựa chủ yếu vào lực lượng HTX vận tải, hiện nay lực lượng vận tải hợp tác xã chiếm thị phần lớn trong VTHKCC bằng xe buýt, số xe chiểm $73,1 \%$ tổng số đoàn phương tiện, sản lượng chiếm $73,2 \%$ lượt khách, số tuyến chiêm $66,9 \%$ số tuyến toàn thành phố.

2) Việc xã hội hóa VTHKCC bằng xe buýt nhìn chung là chủ trương đúng, tuy nhiên thực tế tại Thành phố Hồ Chí Minh cho thấy còn có vấn đề sau: quy mô HTX vận tải hành khách còn nhỏ. Ngoài một số ít HTX có số đầu xe từ 500-1000 như HTX vận tải số 2, số 4, số 5, số 9, 19/5, Hiệp Phát, Việt Thắng, Thống Nhất, Miền Đông,...còn lại có quy mô nhỏ, chất lượng xe còn thấp, phương tiện quản lý lạc hậu, manh mún, trình độ quản lý chưa theo kịp đà phát triển, chậm áp dụng khoa học công nghệ quản lý, chưa có chiến lược phát triển phù hợp với chiến lược chung của thành phố và khu vực, mối liên kết giữa các HTX còn lỏng lẻo, đặc biệt là 
nguồn nhân lực đang làm việc trong khu vực kinh tế tập thể chưa đáp ứng yêu cầu về trình độ học vấn, về độ tuổi nên ảnh hưởng rất lớn đến khả năng phát triển của HTX, v.v. ... Đây là những rào cản, khó khăn cho Thành phố Hồ Chí Minh có thể tạo đột phá trong VTHKCC bằng xe buýt.

3) Đoàn phương tiện xe buýt của Thành phố Hồ Chí Minh phát triển chậm, lạc hậu, cũ nát, tuổi đời trên 10 năm không đáp ứng được yêu cầu ngày càng cao của người đi xe buýt. Liên hiệp HTX vận tải Thành phố Hồ Chí Minh có khoảng 600 xe buýt thì trong đó có đến 550 xe cũ, nhiều xe tuổi xe đến 15 năm, tối thiểu cũng đến 10 năm. Ngay công ty cổ phần xe khách Saigonbus có 700 xe buýt thì trong đó $95 \%$ số xe có tuổi trên 10 năm.

4) Tình trạng đội ngũ lái xe, tiếp viên thiếu trách nhiệm, thái độ phục vụ chưa tốt, một khảo sát của dự án về văn hóa xe buýt ở Thành phố Hồ Chí Minh cho thấy tỷ lệ lý do không sử dụng xe buýt như sau:

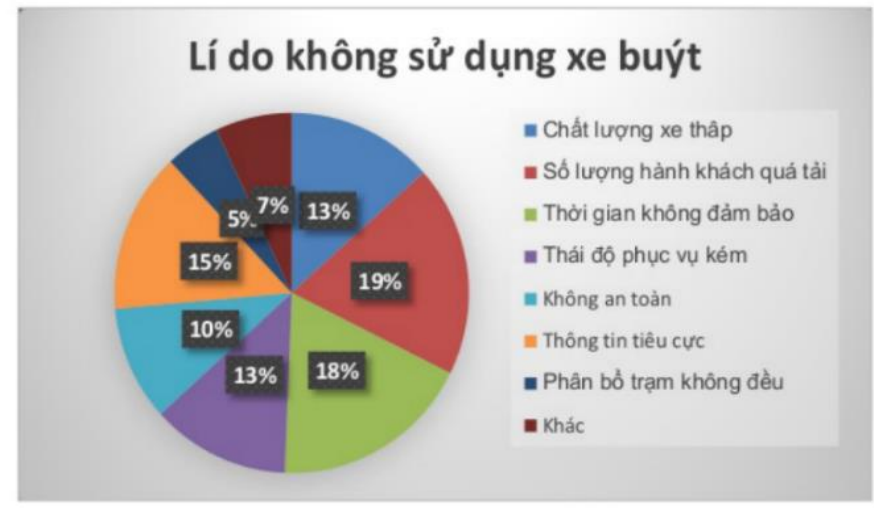

\section{Hình 2-10 Lý do không sử dụng xe buýt ở Thành phố Hồ Chí Minh}

Ngày 13/8/2014, Ủy ban nhân dân thành phố ban hành Thông báo số 93/TB-UBND về công bố kết quả khảo sát chỉ số hài lòng của tổ chức và công dân về dịch vụ công năm 2013, cụ thể như sau: Đa số các hộ dân đều hài lòng trên mức trung bình (biến động ở các mức độ hài lòng khác nhau) đối với 08 loại hình dịch vụ công, với chỉ số hài lòng dao động từ mức thấp nhất đạt + 0,21 đến mức cao nhất là $+0,77$, ở mức lớn hơn 0 (trên mức trung bình)

\section{Bảng 2-13 Khảo sát chỉ số hài lòng Thành phố Hồ Chí Minh}

\begin{tabular}{|c|l|c|c|c|c|}
\hline STT & \multicolumn{1}{|c|}{ Ngành } & Chỉ số & STT & \multicolumn{1}{|c|}{ Ngành } & Chỉ số \\
\hline $\mathbf{1}$ & Giáo dục mầm non & $+0,77$ & 5 & Vận tải hành khách xe buýt & $+0,26$ \\
\hline $\mathbf{2}$ & Cấp nước & $+0,68$ & 6 & Thuế thu nhập cá nhân & $+0,21$ \\
\hline $\mathbf{3}$ & Dịch vụ thu gom rác & $+0,61$ & 7 & Cấp phép xây dựng & $+0,59$ \\
\hline $\mathbf{4}$ & Dịch vụ y tế & $+0,46$ & 8 & Cấp giấy chù quyền nhà đất & $+0,33$ \\
\hline
\end{tabular}

Chỉ số hài lòng của dịch vụ vận tải hành khách công cộng bằng xe buýt đã bị giảm khá nhiều so với năm 2008 như sau: giảm đi từ $+0,43$ năm 2008 còn $+0,26$ năm 2013. Chỉ số hài lòng của dịch vụ vận tài hành khách công cộng bằng xe buýt vẫn còn trên mức trung bình, nhưng sự giảm sút chỉ số hài lòng 05 năm qua là phù hợp với thực trạng hiện nay, khi cơ sở hạ tầng giao thông thành phố đã quá tải, xe cá nhân ngày càng tăng, một số tai nạn do xe buýt gây ra là những nguyên nhân tác động làm giảm sút chỉ số hài lòng của người dân đối với dịch vụ xe buýt. 
5) Ngoài ra còn do xe máy, ô tô cá nhân phát triển nhanh, ùn tắc giao thông, chậm chuyến, mất chuyến (năm 2013 có 5.761 mất chuyến, năm 2014 có 5.724 mất chuyến, năm 2015 có 7.925 trường hợp mất chuyến do ùn tắc giao thông)

6) VTHKCC bằng xe buýt chưa đáp ứng được nhu cầu.

So sánh tỷ lệ tăng trưởng sản lượng vận chuyển hành khách bằng xe buýt với tăng tăng trưởng dân số, tăng trưởng xe máy, tăng trưởng vận chuyển hành khách bằng đường bộ thì tỷ lệ tăng bình quân VTHKCC bằng xe buýt của Thành phố Hồ Chí Minh (5\%) thấp hơn tỷ lệ tăng trưởng bình quân vận chuển hành khách bằng đường bộ $(9 \%)$, tỷ lệ tăng trưởng xe máy $(9 \%)$. Qua đó cho thấy VTHKCC bằng xe buýt của Thành phố Hồ Chí Minh chưa đáp ứng được yêu cầu.

\section{Bảng 2-14 Tỷ lệ tăng dân số, VTHK bằng đường bộ, xe máy và sản lượng VTHKCC} bằng xe buýt 51

\begin{tabular}{|c|c|c|c|c|c|c|c|c|}
\hline \multirow{2}{*}{ Năm } & \multicolumn{2}{|c|}{ Dân số (người) } & \multicolumn{2}{|c|}{$\begin{array}{c}\text { VT HK bằng đường } \\
\text { bộ }\end{array}$} & \multicolumn{2}{|c|}{ VTHK bằng xe buýt } & \multicolumn{2}{|c|}{ Xe máy } \\
\hline & Dân số & $\begin{array}{c}\% \\
\text { Tăng } \\
\end{array}$ & $\begin{array}{c}\text { Triệu lươt } \\
\text { HK }\end{array}$ & \% tăng & $\begin{array}{c}\text { triệu lượt } \\
\text { HK }\end{array}$ & \% tăng & $\mathbf{X e}$ & \% tăng \\
\hline 2005 & $6,239,936$ & & 298 & & 208 & & $2,566,962$ & \\
\hline 2006 & $6,541,508$ & $5 \%$ & 362 & $21 \%$ & 253 & $22 \%$ & $2,854,440$ & $11 \%$ \\
\hline 2007 & $6,778,867$ & $4 \%$ & 423 & $17 \%$ & 296 & $17 \%$ & $3,133,186$ & $10 \%$ \\
\hline 2008 & $7,000,746$ & $3 \%$ & 489 & $16 \%$ & 342 & $16 \%$ & $3,427,372$ & $9 \%$ \\
\hline 2009 & $7,201,550$ & $3 \%$ & 488 & $0 \%$ & 342 & $0 \%$ & $3,780,572$ & $10 \%$ \\
\hline 2010 & $7,396,446$ & $3 \%$ & 496 & $2 \%$ & 364 & $6 \%$ & $4,169,451$ & $10 \%$ \\
\hline 2011 & $7,590,138$ & $3 \%$ & 523 & $5 \%$ & 358 & $-2 \%$ & $4,696,646$ & $13 \%$ \\
\hline 2012 & $7,791,789$ & $3 \%$ & 586 & $12 \%$ & 413 & $15 \%$ & $5,097,620$ & $9 \%$ \\
\hline 2013 & $7,939,752$ & $2 \%$ & 548 & $-6 \%$ & 411 & $0 \%$ & $5,532,120$ & $9 \%$ \\
\hline 2014 & $8,097,748$ & $2 \%$ & 626 & $14 \%$ & 367 & $-11 \%$ & $6,911,061$ & $7 \%$ \\
\hline 2015 & $8,347,829$ & $3 \%$ & 708 & $13 \%$ & 334 & $-9 \%$ & $6,410,176$ & $8 \%$ \\
\hline 2016 & $8,611,000$ & & & & & & $6,778,909$ & $6 \%$ \\
\hline 2017 & & & & & & & $7,256,074$ & $7 \%$ \\
\hline \multicolumn{2}{|c|}{ Tỷ lệ tăng bình quân } & $3 \%$ & & $9 \%$ & & $5 \%$ & & $9 \%$ \\
\hline
\end{tabular}

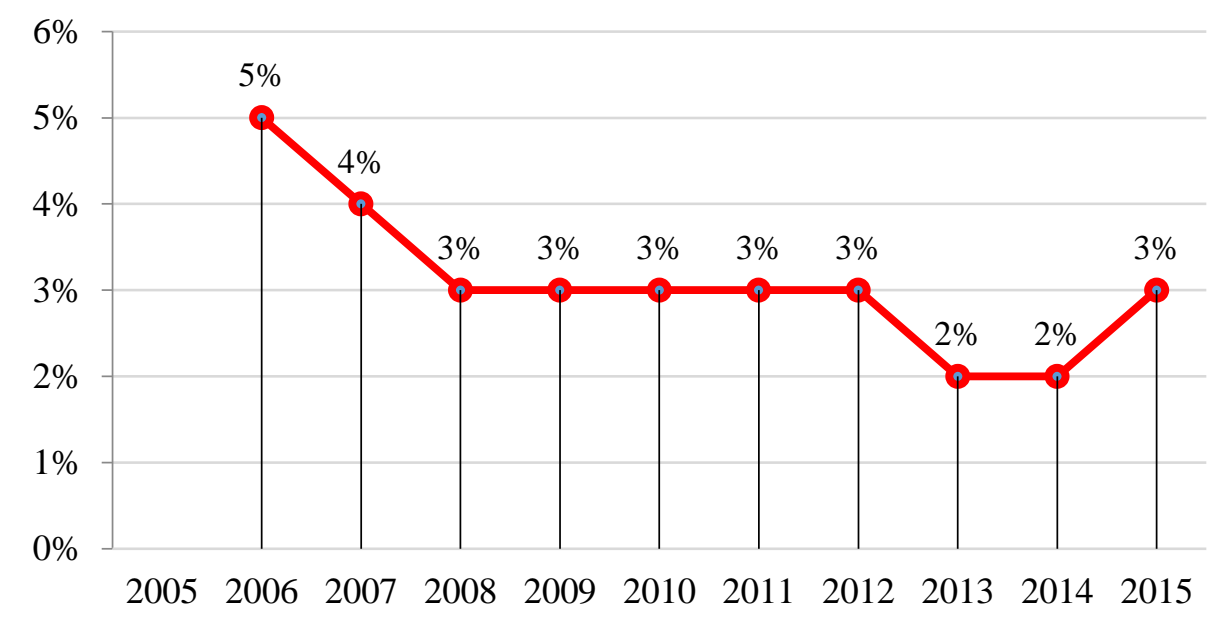

Hình 2-11 Tỷ lệ tăng dân số Thành phố Hồ Chí Minh 2005 - 2015

\footnotetext{
${ }^{51}$ Nguồn: DAHKCCTPHCM (dân số gồm dân số tạm trú, phương tiện có giới bao gồm phương tiện vãng lai)
} 


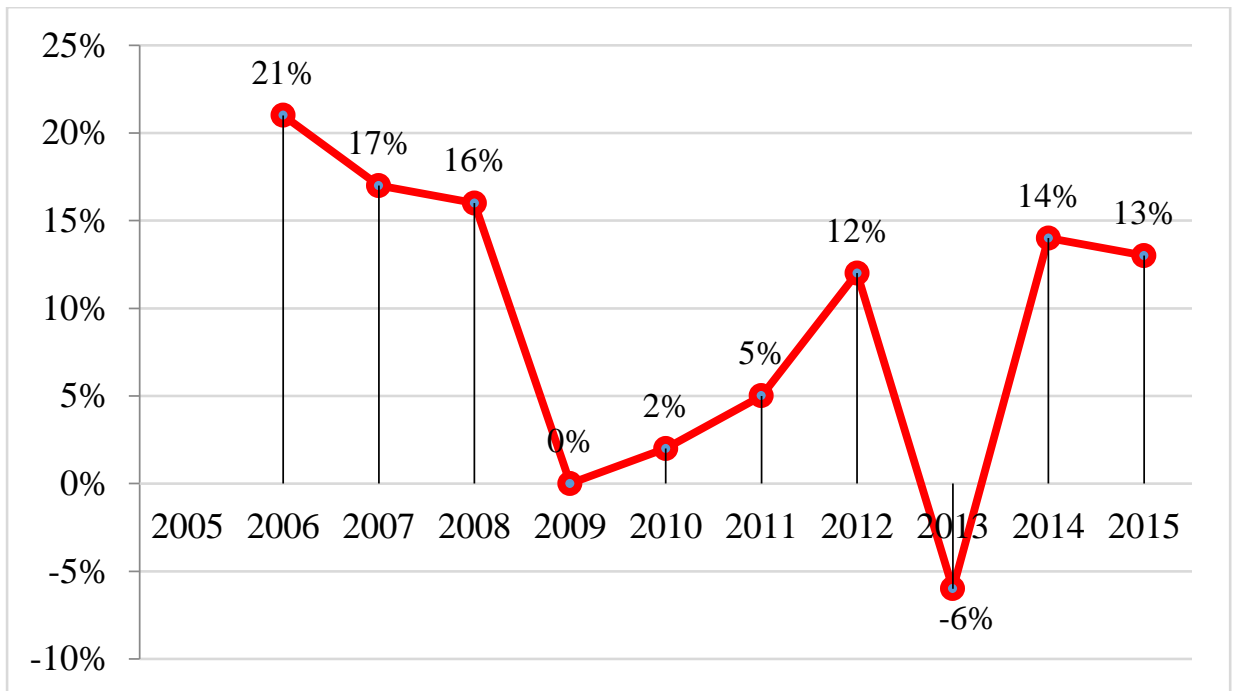

Hình 2-12 Tỷ lệ tăng vận tải hành khách đường bộ Thành phố Hồ Chí Minh 2005 - 2015

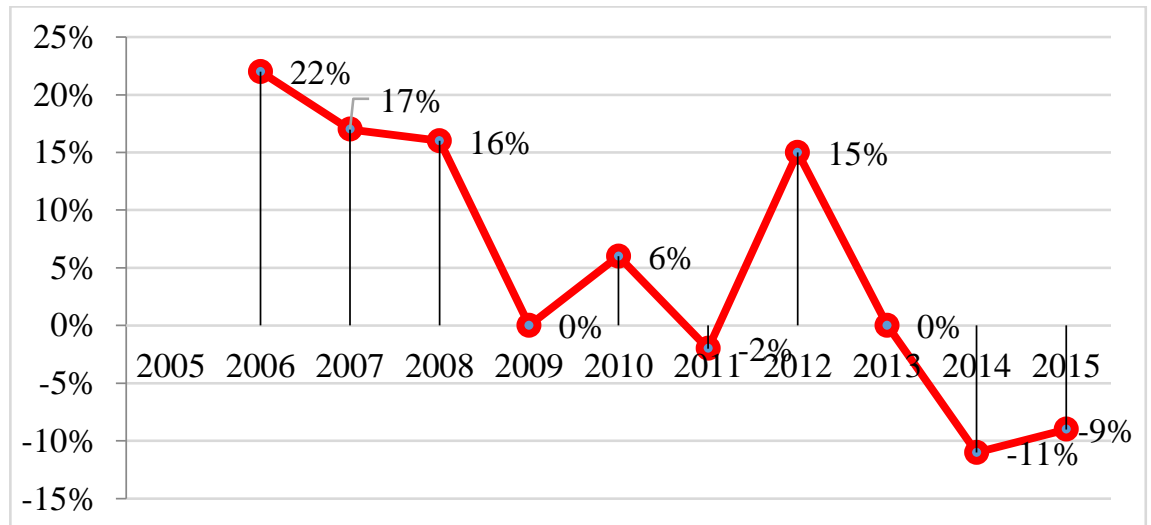

Hình 2-13 Tỷ lệ tăng trưởng sản lượng xe buýt Thành phố Hồ Chí Minh 2005 - 2015

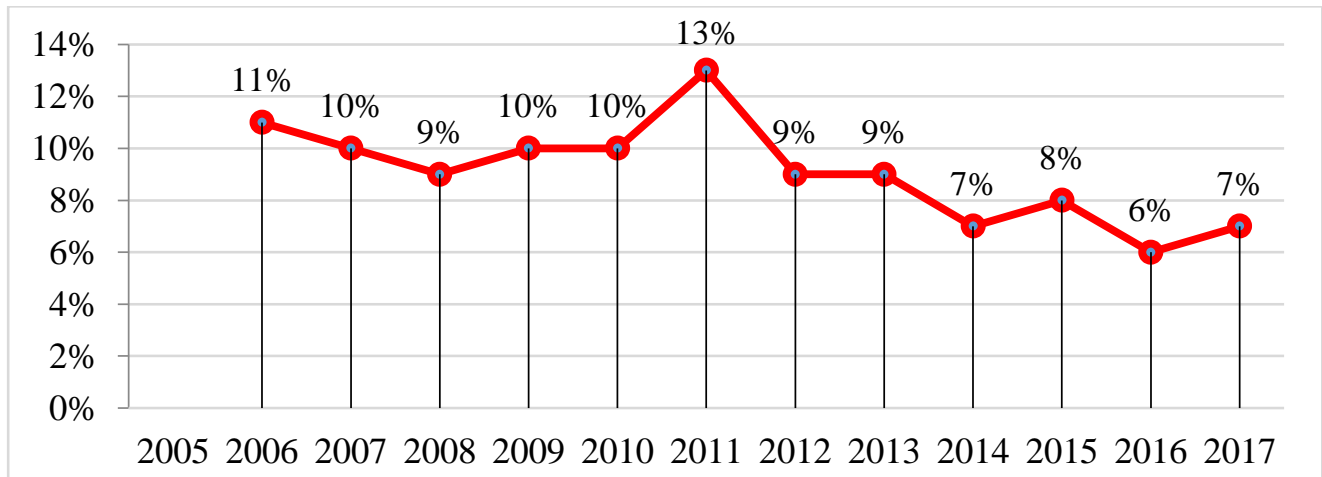

Hình 2-14 Tỷ lệ tăng trưởng xe máy Thành phố Hồ Chí Minh 2005 - 2017

Đặc biệt tỷ lệ tăng trưởng xe máy khá cao, điều này có nghĩa VTHKCC bằng xe buýt của Thành phố Hồ Chí Minh chưa đủ sức đề hạn chế phát triển xe máy, ngược lại mấy năm gần đây phát triển xe máy cao đã làm sản lượng VTHKCC bằng xe buýt có xu hướng giảm, tuy nhiên còn những lý do khác như đã nêu ở trên.

Theo nhiều báo cáo VTHKCC bằng xe buýt chỉ đáp ứng khoảng 7\% nhu cầu đi lại của Thành phố Hồ Chí Minh. Theo kết quả khảo sát thì tỷ lệ người dân chủ yếu đi lại bằng phương tiện cá 
nhân chiếm 95,3\% (xe máy và xe máy điện chiếm $86,93 \%$, ô tô con chiếm $2,75 \%$ ), đây thật sự là thách thức lớn của Thành phố Hồ Chí Minh khi giải quyết ùn tắc giao thông nói chung và phát triển VTHKCC nói riêng.

\subsection{5. Đường sắt đô thị, xe buýt nhanh}

Ngay từ Nghị quyết 13/2002/NQ-CP Chính phủ đã đặt vấn đề xây dựng giao thông đô thị vận chuyển khối lượng lớn tại Hà Nội và Thành phố Hồ Chí Minh.

Quyết định 519/QĐ-TTg của Thủ tướng Chính phủ ngày 31 tháng 3 năm 2016 Về việc phê duyệt Quy hoạch phát triển giao thông vận tải Thủ đô Hà Nội đến năm 2030 và Quyết định 568/QĐ-TTg của Thủ tướng Chính phủ ngày 08 tháng 4 năm 2013 Về việc phê duyệt Điều chỉnh Quy hoạch phát triển giao thông vận tải Thành phố Hồ Chí Minh đến năm 2020 và tầm nhìn sau năm 2020 đã xác định đường sắt đô thị và hệ thống xe buýt nhanh như sau:

\subsubsection{Quy hoạch đường sắt đô thị và xe buýt nhanh Hà Nội}

Bảng 2-15 Quy hoạch đường sắt đô thị Hà Nội

\begin{tabular}{|c|c|c|c|}
\hline STT & Tên dụ̣ án & Giai đoạn thụcc hiện & Chiều dài \\
\hline \multicolumn{4}{|c|}{ I. Đường sắt đô thị } \\
\hline \multirow[t]{3}{*}{1} & Tuyến số 1 (Ngọc Hồi-Yên Viên-Như Quỳnh) & & \\
\hline & Đoạn Ngọc Hồi-Yên Viên & $2016-2020$ & $26 \mathrm{~km}$ \\
\hline & - Đoạn Gia Lâm-Dương Xá & $2020-2030$ & $10 \mathrm{~km}$ \\
\hline \multirow[t]{6}{*}{2} & Tuyến số 2 (Nội Bài-Thượng Đình-Bưởi) & & \\
\hline & - Đoạn Nam Thăng Long-Trần Hưng Đạo & $2016-2020$ & $12 \mathrm{~km}$ \\
\hline & - Đoạn Trần Hưng Đạo-Thượng Đình & 2016-2020 & $6 \mathrm{~km}$ \\
\hline & - Đoạn Thượng Đình-Vành đai 2,5-Bưởi & $2020-2030$ & $7 \mathrm{~km}$ \\
\hline & - Đoạn Nội Bài-Nam Thăng Long & $2020-2030$ & $18 \mathrm{~km}$ \\
\hline & Kéo dài tuyến số 2 đến Sóc Sơn & Sau năm 2030 & $9 \mathrm{~km}$ \\
\hline \multirow[t]{3}{*}{3} & Tuyến số $2 \mathrm{~A}$ & & \\
\hline & - Tuyến số 2A (Cát Linh-Hà Đông) & $2016-2020$ & $14 \mathrm{~km}$ \\
\hline & Kéo dài tuyến số $2 \mathrm{~A}$ đến Xuân Mai & Sau năm 2030 & $20 \mathrm{~km}$ \\
\hline \multirow[t]{5}{*}{4} & Tuyến số 3 (Trôi-Nhổn-Yên Sở) & & \\
\hline & - Đoạn Nhổn-Ga Hà Nội & $2016-2020$ & $13 \mathrm{~km}$ \\
\hline & Đoạn Trôi-Nhổn & $2020-2030$ & $6 \mathrm{~km}$ \\
\hline & Đoạn Ga Hà Nội-Yên Sở & $2020-2030$ & $8 \mathrm{~km}$ \\
\hline & Kéo dài tuyến số 3 đến Sơn Xây & Sau năm 2030 & $30 \mathrm{~km}$ \\
\hline 5 & Tuyến số 4 (Mê Linh-Sài Đồng-Liên Hà) & Sau năm 2030 & $54 \mathrm{~km}$ \\
\hline \multirow[t]{3}{*}{6} & Tuyến số 5 (Văn Cao-Hòa Lạc) & & \\
\hline & - Đoạn từ Văn Cao-Vành đai 4 & $2016-2020$ & $14 \mathrm{~km}$ \\
\hline & - Tuyến số 5 (Vành đai 4-Hòa Lạc) & $2020-2030$ & $26 \mathrm{~km}$ \\
\hline 7 & Tuyến số 6 (Nội Bài-Ngọc Hồi) & $2020-2030$ & $43 \mathrm{~km}$ \\
\hline 8 & Tuyến số 7 (Mê Linh-Hà Đông) & $2020-2030$ & $28 \mathrm{~km}$ \\
\hline \multirow[t]{3}{*}{9} & Tuyến số 8 (Sơn Động-Mai Dịch-Dương Xá) & & \\
\hline & - Đoạn Sơn Động-Mai Dịch & $2020-2030$ & $12 \mathrm{~km}$ \\
\hline & - Đoạn Mai Dịch-Vành đai 3-Dương Xá & Sau năm 2030 & $25 \mathrm{~km}$ \\
\hline 10 & Xây dựng tuyến đường sắt đô thị kết nối các đô thị vệ tinh & Sau năm 2030 & $32 \mathrm{~km}$ \\
\hline
\end{tabular}


Dự án: Xây dựng chiến lược an toàn giao thông đối với xe máy và kế hoạch hành động: một khởi đầu của Việt Nam

\begin{tabular}{|c|l|c|c|}
\hline STT & \multicolumn{1}{|c|}{ Tên dự án } & Giai đoạn thực hiện & Chiều dài \\
\hline \multicolumn{2}{|c|}{ II. Tàu một ray (monorail) } \\
\hline 1 & Tuyến M1 (Liên Hà-Tân Lập-An Khánh) & $2020-2030$ & $11 \mathrm{~km}$ \\
\hline 2 & $\begin{array}{l}\text { Tuyến M2 (Mai Dịch-Mỹ Đình-Văn Mỗ-Phúc La và Giáp Bát-Thanh } \\
\text { Liệt-Phú Lương) }\end{array}$ & $2020-2030$ & $22 \mathrm{~km}$ \\
\hline 3 & Tuyến M3 (Nam Hồng-Mê Linh-Đại Thịnh) & $2020-2030$ & $11 \mathrm{~km}$ \\
\hline
\end{tabular}

\section{Bảng 2-16 Quy hoạch xe buýt nhanh (BRT) Hà Nội}

\begin{tabular}{|c|l|c|c|}
\hline STT & \multicolumn{1}{|c|}{ Tên dự án } & Giai đoạn thực hiện & Chiều dài \\
\hline 1 & Tuyến xe buýt nhanh Kim Mã-Lê Văn Lương-Yên Nghĩa & $2016-2020$ & $14 \mathrm{~km}$ \\
\hline 2 & $\begin{array}{l}\text { Tuyến đi theo Vành đai 3 từ Mai Dịch-Dương Xá (giai đoạn 2 tuyến } \\
\text { đường sắt đô thị số 8) }\end{array}$ & $2016-2020$ & $25 \mathrm{~km}$ \\
\hline 3 & $\begin{array}{l}\text { Tuyến xe buýt nhanh đi theo Vành đai 2,5 và Quốc lộ 5 kéo dài (tuyến } \\
\text { đường sắt đô thị số 4) }\end{array}$ & $2016-2020$ & $54 \mathrm{~km}$ \\
\hline 4 & Tuyến Ngọc Hồi-Phú Xuyên (đi theo Quốc lộ 1 cũ) & $2020-2030$ & $27 \mathrm{~km}$ \\
\hline 5 & Tuyến Sơn Đồng-Ba Vì (đi theo trục Hồ Tây-Ba Vì) & Sau năm 2030 & $20 \mathrm{~km}$ \\
\hline 6 & $\begin{array}{l}\text { Tuyến Phù Đồng-Bát Tràng-Hưng Yên (đi theo đường Vành đai 3 và } \\
\text { hhập vào đường Hà Nội-Hưng Yên) }\end{array}$ & $2020-2030$ & $15 \mathrm{~km}$ \\
\hline 7 & Tuyến Gia Lâm-Mê Linh (đi theo Vành đai 3) & $2020-2030$ & $30 \mathrm{~km}$ \\
\hline 8 & $\begin{array}{l}\text { Tuyến Mê Linh-Sơn Đồng-Yên Nghĩa-Ngọc Hồi-Quốc lộ 5-Lạc Đạo } \\
\text { (ii theo Vành đai 4) }\end{array}$ & $2020-2030$ & $53 \mathrm{~km}$ \\
\hline 9 & Tuyến Ba La-Ứng Hòa (đi theo trục Quốc lộ 21B) & $2020-2030$ & $29 \mathrm{~km}$ \\
\hline 10 & $\begin{array}{l}\text { Ưng Hòa-Phú Xuyên (đi theo đường Đô̂ Xá-Quan Sơn đến khu vực } \\
\text { giao Quốc lộ 21B) }\end{array}$ & $2020-2030$ & $17 \mathrm{~km}$ \\
\hline 11 & $\begin{array}{l}\text { Tuyến Sơn Tây-Hòa Lạc-Xuân Mai (tuyến đường sắt đô thị kết nối các } \\
\text { khu đô thị vệ tinh) }\end{array}$ & $2020-2030$ & $32 \mathrm{~km}$ \\
\hline
\end{tabular}

\subsubsection{Quy hoạch đường sắt đô thị và xe buýt nhanh Thành phố Hồ Chí Minh}

\section{Bảng 2-17 Quy hoạch đường sắt đô thị Thành phố Hồ Chí Minh}

\begin{tabular}{|c|c|c|c|c|c|c|}
\hline $\begin{array}{l}\text { Màu } \\
\text { đại } \\
\text { diện }\end{array}$ & $\begin{array}{l}\text { Biểu } \\
\text { trưng }\end{array}$ & $\begin{array}{c}\text { Tuyến } \\
\text { số }\end{array}$ & Tên tuyến & Đường đi & $\begin{array}{c}\text { Chiều } \\
\text { dài (km) }\end{array}$ & $\begin{array}{l}\text { Hoàn } \\
\text { thành }\end{array}$ \\
\hline đỏ & & Tuyến 1 & Tuyến Sài Gòn (S) & $\begin{array}{l}\text { Bến Thành-Xa lộ Hà } \\
\text { Nội }\end{array}$ & 19,7 & 2020 \\
\hline vàng & $\underline{\text { B }}$ & Tuyến 2 & Tuyến Bà Quẹo (B) & $\begin{array}{l}\text { Khu đô thị Tây } \\
\text { Bắc (Củ Chi) -Thủ } \\
\text { Thiêm }\end{array}$ & 48 & 2026 \\
\hline tím & $\mathbf{K}$ & Tuyến 3A & Tuyến Tân Kiên (K) & $\begin{array}{l}\text { Bến Thành-Ga Tân } \\
\text { Kiên }\end{array}$ & 19,8 & 2026 \\
\hline $\begin{array}{l}\text { nước } \\
\text { biển }\end{array}$ & $\underline{\mathbf{N}}$ & Tuyến 3B & Tuyến Thị Nghè (N) & $\begin{array}{l}\text { Ngã } 6 \text { Cộng Hòa-Hiệp } \\
\text { Bình Phước }\end{array}$ & 12,2 & -- \\
\hline lá cây & $\underline{G}$ & Tuyến 4A & Tuyến Gò Vấp (G) & $\begin{array}{l}\text { Thạnh Xuân-Khu đô } \\
\text { thị Hiệp Phước }\end{array}$ & 35,8 & -- \\
\hline lá cây & $T$ & Tuyến 4B & Tuyến Tân Sơn Nhất (T) & $\begin{array}{l}\text { Công viên Gia Định - } \\
\text { Lăng Cha Cả }\end{array}$ & 3,2 & 2024 \\
\hline da trời & $\mathbf{T}$ & $\begin{array}{l}\text { Tuyến } \\
\text { 4B1 }\end{array}$ & $\begin{array}{l}\text { Tuyến Tân Sơn Nhất } \\
\text { (T) }\end{array}$ & $\begin{array}{l}\text { Công viên Hoàng Văn } \\
\text { Thụ-Sân bay Tân Sơn } \\
\text { Nhất }\end{array}$ & 1,5 & -- \\
\hline
\end{tabular}


Dự án: Xây dựng chiến lược an toàn giao thông đối với xe máy và kế hoạch hành động: một khởi đầu của Việt Nam

Nghiên cứu hiện trạng giao thông xe máy Việt Nam

\begin{tabular}{|c|c|c|c|c|c|c|}
\hline $\begin{array}{c}\text { Màu } \\
\text { đại } \\
\text { diện }\end{array}$ & $\begin{array}{c}\text { Biểu } \\
\text { trưng }\end{array}$ & $\begin{array}{c}\text { Tuyến } \\
\text { số }\end{array}$ & Tên tuyến & Đường đi & $\begin{array}{c}\text { Chiều } \\
\text { dài }(\mathbf{k m})\end{array}$ & $\begin{array}{c}\text { Hoàn } \\
\text { thành }\end{array}$ \\
\hline da trời & $\underline{\mathbf{C}}$ & Tuyến 5 & Tuyến Cần Giuộc (C) & $\begin{array}{l}\text { Bến xe Cần Giuộc } \\
\text { mới-Quốc lộ 50-Cầu } \\
\text { Sài Gòn }\end{array}$ & 23,4 & 2025 \\
\hline da cam & $\underline{\text { Đ }}$ & Tuyến 6 & Tuyến Đầm Sen (Đ) & $\begin{array}{l}\text { Bà Quẹo-Âu cơ-Vòng } \\
\text { xoay Phú Lâm }\end{array}$ & 6,8 & -- \\
\hline
\end{tabular}

Bảng 2-18 Quy hoạch tuyến Tramway, Monorail Thành phố Hồ Chí Minh

\begin{tabular}{|c|l|l|l|l|c|c|}
\hline $\begin{array}{c}\text { Màu } \\
\text { đại } \\
\text { diện }\end{array}$ & $\begin{array}{c}\text { Biểu } \\
\text { trưng }\end{array}$ & Tuyến số & \multicolumn{1}{|c|}{ Tên tuyến } & \multicolumn{1}{|c|}{ Đường đi } & $\begin{array}{c}\text { Chiều } \\
\text { dài } \\
\text { (km) }\end{array}$ & $\begin{array}{c}\text { Hoàn } \\
\text { thành }\end{array}$ \\
\hline nâu đất & $\underline{\mathbf{T 1}}$ & Tramway 1 & Ba Son-Miền Tây & $\begin{array}{l}\text { Ba Son-Tôn Đức } \\
\text { Thắng-Bến xe Miền Tây }\end{array}$ & 12,8 & 2022 \\
\hline hồng & $\underline{\text { MR2 }}$ & Monorail 2 & Thanh Đa-Bình Hưng & $\begin{array}{l}\text { Quốc lộ 50-Khu đô } \\
\text { thị Bình Quới }\end{array}$ & 27,2 & 2020 \\
\hline nâu & $\underline{\text { MR3 }}$ & Monorail 3 & $\begin{array}{l}\text { Gò Vấp-Tân Chánh } \\
\text { Hiệp }\end{array}$ & $\begin{array}{l}\text { Ngã tư (Nguyễn Oanh- } \\
\text { Phan Văn Trị) -Ga Tân } \\
\text { Chánh Hiệp }\end{array}$ & 16,5 & - \\
\hline
\end{tabular}

Bảng 2-19 Quy hoạch xe buýt nhanh (BRT) Thành phố Hồ Chí Minh

\begin{tabular}{|c|c|l|c|}
\hline STT & Tuyến số & \multicolumn{1}{c|}{ Tuyến } & $\begin{array}{c}\text { Chiều dài } \\
\text { (km) }\end{array}$ \\
\hline 1 & BRT 1 & Theo đại lộ Võ Văn Kiệt-Mai Chí Thọ & 20,5 \\
\hline 2 & BRT 2 & Theo đường Nguyễn Văn Linh từ Bền xe Miền Tây mới iới cầu Phú Mỹ & 24 \\
\hline 3 & BRT 3 & Dọc theo đường Vành đai 2 từ ngã tư An Sương đền Bến xe Miền Tây mới & 19 \\
\hline 4 & BRT 4 & Theo trục đường Tân Sơn Nhất-Bình Lợi & 14,5 \\
\hline 5 & BRT 5 & $\begin{array}{l}\text { Theo trục đường Thoại Ngọc Hầu-Vành đai trong-nối dài ra đường Nguyễn } \\
\text { Văn Linh }\end{array}$ & 6,7 \\
\hline 6 & BRT 6 & Dọc theo đường Quang Trung & 8,5 \\
\hline
\end{tabular}

\subsubsection{Tình hình thực hiện}

Hiện nay có 4 dự án đường sắt đô thị đang được triển khai trên thực địa tại Hà Nội và Thành phố Hồ Chí Minh, cụ thể như sau:

\subsection{Thụ̣c hiện tại Thành phố Hà Nội}

1) Tuyến đường sắt Cát Linh-Hà Đông dài $13 \mathrm{~km}$, gồm 12 ga đi trên cao. Dự án do chủ thầu Trung Quốc thực hiện. Ban đầu dự kiến triển khai dự án từ tháng 11/2008 đến tháng 11/2013 hoàn thành, tổng mức đầu tư hơn 552 triệu USD (trong đó gồm nguồn vốn chính phủ kết hợp với vốn vay ODA của Trung Quốc). Tuy vậy đến tháng 10/2011 dự án mới chính thức triền khai và điều chỉnh tổng vốn đầu tư lên hơn 868 triệu USD (hơn 18.000 tỷ đồng). Dự án đã được đóng điện toàn hệ thống vào cuối tháng 7 năm 2018, ngày 20 tháng 8 năm 2018 Tổng thầu bắt đầu vận hành thử đoàn tàu.

2) Tuyến đường sắt đô thị số 3 Nhổn-Ga Hà Nội đã đạt được $70 \%$ khối lượng đoạn trên cao, đoạn ngầm đạt $45 \%$ khối lượng. Dự kiến đoạn đường sắt đô thị trên cao sẽ đưa vào hoạt động vào cuối năm 2020, toàn tuyến sẽ đưa vào hoạt động vào cuối năm 2022.

3) Tuyến buýt nhanh BRT Kim Mã -Yên Nghĩa được đưa vào khi thác từ tháng 12 năm 2016. 


\subsection{Thực hiện tại Thành phố Hồ Chí Minh}

1) Dự án Bến Thành - Suối Tiên bắt đầu triển khai từ tháng 3/2007, dự kiến hoàn thành đưa vào khai thác năm 2018. Tuy nhiên, do việc chậm trễ trong công tác giải toả và phải lập lại thiết kế kỹ thuật cho nhà ga ngầm Bến Thành nhằm tích hợp giữa các tuyến đường sắt đô thị số 1 , số 2 , số $3 \mathrm{a}$ và số 4 nên thời gian hoàn thành xây dựng, đưa vào vận hành toàn tuyến được dự kiến vào năm 2020. Đến nay Dự án đã đạt khoảng $50 \%$ khối lượng thực hiện $(5 / 6$ gói thầu đã được chủ đầu tư phê duyệt dự toán và ký hợp đồng với nhà thầu trúng thầu để triển khai từ năm 2012). Tỷ lệ giải ngân vốn đối ứng đạt $26 \%$, vốn vay ODA đạt $38 \%$. Dự án đường sắt đô thị TPHCM, tuyến số 1 Bến Thành-Suối Tiên bị "đội vốn" khi tăng tổng mức đầu tư từ 17.388 tỷ đồng khi phê duyệt lần đầu vào năm 2007 lên hơn 47.000 tỷ đồng.

2) Tuyến metro số 2 Bến Thành-Tham Lương với tổng mức đầu tư là 26.116 tỷ đồng. Tuy nhiên, sau khi cập nhật, tính toán lại, tại thời điểm tháng 8/2017, tổng mức đầu tư dự kiến điều chỉnh là 48.771 tỷ đồng. Hiện nay, dự án đã thực hiện công tác giải phóng mặt bằng; cơ bản hoàn thành nhà văn phòng, các công trình phụ trợ tại depot Tham Lương. Dự án đang trong giai đoạn đấu thầu tuyển chọn nhà thầu xây dựng song song với quá trình điều chỉnh dự án.

\subsubsection{Kết luận}

Đô thị hóa nhanh tất yếu làm tăng phương tiện giao thông cá nhân, hệ thống kết cấu hạ tầng giao thông bị quá tải, gây ùn tắc giao thông và ô nhiễm môi trường. Chính quyền đô thị phải can thiệp bằng các cơ chế chính sách, biện pháp để hạn chế gia tăng phương tiện giao thông cá nhân, giải quyết đi lại cho người dân bằng các phương tiện HK công cộng.

Bắt đầu từ năm 2000, Việt Nam đã quan tâm nhiều đến phát triển VTHKCC bằng xe buýt và từng bước đầu tư phương tiện VTHKCC bằng các phương tiện khối lượng lớn. Đặc biệt năm 2008. Chính phủ ban hành Nghị quyết số 16/2008/NQ-CP ngày 13 tháng 7 năm 2008 để đẩy mạnh hơn nữa việc giải quyết ùn tắc giao thông ở các thành phố, trong đó tập trung giải quyết ở Hà Nội và Thành phố Hồ Chí Minh.

Sau 10 năm thực hiện Nghị quyết số 16/2008/NQ-CP, nhìn chung đã đạt được một số thành công nhất định. Trước hết, tất cả các địa phương đều nhận thức và thấy cần thiết phải nhanh chóng đầu tư, phát triển hệ thống VTHKCC bằng xe buýt, mặc dù ở một số địa phương chưa xẩy ra ùn tắc giao thông những vẫn có quy hoạch và thực hiện xây dựng hệ thống VTHKCC bằng xe buýt. Chính phủ, các Bộ, ngành, địa phương đều ban hành các cơ chế, chính sách tạo điều kiện đầu tư, phát triển VTHKCC bằng xe buýt, trong đó quan trọng là cơ chế, chính sách huy động được các thành phần kinh tế tham gia, đã xã hội hóa được đầu tư, xây dựng, phát triển VTHKCC bằng xe buýt. Trong thập kỷ vừa qua xe buýt cũng góp phần giải quyết ùn tắc giao thông ở Hà Nội và Thành phố Hồ Chí Minh, tạo được thói quen đi lại bằng phương tiện xe buýt cho một bộ phận dân cư.

Bên cạnh những thành công nêu trên, so với yêu cầu, vẫn còn nhiều vấn đề cần được tiếp tục quan tâm giải quyết mạnh mẽ hơn nữa, đặc biệt ở Hà Nội và Thành phố Hồ Chí Minh. Trong những khoảng từ năm 2002 đến 2014, VTHKCC bằng xe buýt ở Hà Nội và Thành phố Hồ Chí Minh đều phát triển tốt, nhiều năm được cho là "ngoạn mục". Song từ năm 2016 đến nay VTHKCC bằng xe buýt có chiều hướng kém đi, sản lượng sụt giảm, một số người dân quay lại đi xe máy. Điều cần được nhấn mạnh là dù đã được quan tâm, tạo điều kiện, một số năm có phát triển tốt nhưng VTHKCC bằng xe buýt chưa khi nào đáp ứng được nhu cầu đi lai như kỳ vọng; tốc độ phát triển luôn chậm hơn tốc độ gia tăng nhu cầu đi lại, tốc độ tăng trưởng của xe máy, ô tô. Tình trạng này ngày càng khó để phát triển VTHKCC bằng xe buýt. Trong nhiều dự báo, tính toán của các đề án phát triển VTHKCC bằng xe buýt ở Hà Nội và Thành phố Hồ Chí 
Minh vẫn giữ kịch bản xe máy tiếp tục gia tăng song hành cùng việc gia tăng thị phần cho xe buýt đến 15\%-20\% nhu cầu đi lại, trong khi đó kết cấu hạ tầng giao thông chưa tương xứng. Rất khó thực hiện được đồng thời các điều này.

Để giải quyết ùn tắc giao thông, Nghị quyết số 16/2008/NQ-CP của Chính phủ xác định bên cạnh việc phát triển VTHKCC bằng xe buýt để hạn chế phương tiện giao thông cá nhân thì đồng thời phải giải quyết đồng bộ: về quy hoạch phát triển kết cấu hạ tầng giao thông; thực hiện di dời trụ sở các cơ quan hành chính nhà nước, các trường đại học, cao đẳng, dạy nghề, bệnh viện lớn ra ngoài khu vực trung tâm; tuyên truyền, phổ biến pháp luật, tổ chức cuộc vận động xây dựng nếp "văn hóa giao thông" và "văn minh đô thị", tăng cường cưỡng chế thi hành pháp luật về trật tự an toàn giao thông và trật tự đô thị. Thực hiện đồng bộ những giải pháp nêu trên sẽ tạo điều kiện để phát triển VTHKCC bằng xe buýt, hạn chế phương tiện giao thông cá nhân, giải quyết ùn tắc giao thông. Nhìn lại, thực tế thực hiện các giải pháp đồng bộ nêu trên còn hạn chế. Thực hiện di dời, "giải nén" cho khu vực trung tâm làm chưa tốt, thậm chí ở nhiều khu vực còn tăng "nén" do xây dựng quá nhiều nhà cao tầng, các khu đô thị đông dân cư ...Tăng dân số khu vực trung tâm, trong khi không thể mở rộng được kết cấu hạ tầng giao thông thì chắc chắn không còn đường cho xe buýt, sẽ phải giảm tuyến, giảm tần suất, kéo dài thời gian chờ đợi, thời gian đi lại, đồng nghĩa với việc người dân tiếp tục sử dụng xe máy làm phương tiện đi lại, giải pháp tăng VTHKCC bằng xe buýt thất bại.

Một mình xe buýt không thể giải quyết nhanh việc hạn chế xe máy, cần có các biện pháp hành chính, kinh tế tác động đến người sử dụng xe máy. Những biện pháp này cùng với phát triển tốt VTHKCC bằng xe buýt sẽ giúp người dân bỏ đi lại bằng xe máy. Các biện pháp hành chính, kinh tế tác động đển thói quen của người đi xe máy vừa qua cũng chỉ dừng ở khâu đề xuất, hoặc có một vài biện pháp như tăng giá gửi xe ở trung tâm ... thì cũng chưa đủ mạnh nên hầu như không có hiệu quả.

Một vấn đề cơ bản để giải quyết cơ bản ùn tắc giao thông ở Hà Nội và Thành phố Hồ Chí Minh là cần tập trung đẩy nhanh xây dựng các tuyến đường sắt đô thị đã được phê duyệt, đặc biệt là 4 tuyến đang thi công.

Sau 10 năm thực hiện Nghị quyết số 16/2008/NQ-CP, Chính phủ đã 03 lần tổng kết, đánh giá và gần đây nhất Chính phủ đã giao cho các Bộ, ngành chuẩn bị một văn bản khác để thay thế Nghị quyết số 16/2008/NQ-CP. Hy vọng trong thời gian tới sẽ có những quyết sách quyết liệt hơn để giải quyết thành công hơn nữa mục tiêu của Nghị quyết số 16/2008/NQ-CP. Chắc chắn càng chậm thì càng khó.

\subsection{Thực hiện Quy định bắt buộc đội mũ bảo hiểm khi đi xe máy ở Việt Nam}

Số lượng xe máy ở Việt Nam khá lớn, chiếm tỷ lệ $94 \%$ tổng số phương tiện cơ giới đường bộ; tai nạn giao thông xe máy chiếm khoảng $70 \%$ số vụ tai nạn giao thông đường bộ. Trong nhiều năm qua, Chính phủ đặc biệt quan tâm đến thực hiện các giải pháp giải pháp đồng bộ để giảm thiểu tai nạn giao thông liên quan đến xe máy. Một trong những giải pháp có hiệu quả cao là thực hiện bắt buộc người đi xe máy phải đội mũ bảo hiểm.

Trước năm 2008, những năm số lượng xe máy tăng đột biến thì tai nạn giao thông cũng tăng đột biến, làm chết và bị thương nhiều người. Tại những giai đoạn đó, Chính phủ đều chủ trương thực hiện quy định bắt buộc đội mũ bảo hiểm đối với người đi xe máy, song phải qua nhiều lần thất bại, đến năm 2007 mới thực hiện thành công. Đây cũng là bài học kinh nghiệm rất bổ ích để thực hiện các giải pháp khác về trật tự an toàn giao thông đường bộ. 
Thực hiện thành công quy định bắt buộc đội mũ bảo hiểm đối với người đi xe máy cuối năm 2007, thì ngay năm 2008 số người bị chết, số người bị thường vì tai nạn giao thông đường bộ giảm đáng kể. Tác động của thực hiện quy định bắt buộc đội mũ bảo hiểm đối với người đi xe máy đã góp phần giảm số người bị chết vì tai nạn giao thông ở Việt Nam từ năm 2008 đến nay, năm 2017 số người bị chết vì tai nạn giao thông đã xuống còn dưới 9.000 người. Trong quá trình thực hiện xuất hiện một số vấn đề như: chất lượng mũ bảo hiểm, đội mũ bảo hiểm cho trẻ em, tỷ lệ người chấp hành quy định bắt buộc đội mũ bảo hiểm đối với người đi xe máy ở vùng núi, vùng nông thôn ... Để khắc phục những tồn tại nêu trên, ngày 19 tháng 01 năm 2018 Thủ tướng Chính phủ đã ban hành Chỉ thị 04/CT-TTg về việc đẩy mạnh triển khai các giải pháp nhằm nâng cao hiệu quả thực hiện quy định bắt buộc đội mũ bảo hiểm đối với người đi xe máy, xe đạp điện.

\subsubsection{Quá trình thực hiện quy định bắt buộc đội mũ bảo hiểm khi đi xe máy ở Việt Nam}

Từ năm 1995, Chính phủ đã quy định bắt buộc đội mũ bảo hiểm khi đi xe máy, tuy vậy phải 12 năm sau Việt Nam mới thực thành công thực hiện quy định bắt buộc đội mũ bảo hiểm khi đi xe máy. Quá trình thực hiện quy định bắt buộc đội mũ bảo hiểm khi đi xe máy có thể phân làm các giai đoạn sau:

\subsubsection{Giai đoạn trước cuối năm 2000}

Năm 1986, nhờ chính sách đổi mới, sản xuất lương thực đạt kết quả thần kỳ, dầu thô được khai thác và xuất khẩu ... Việt Nam vượt qua khó khăn kinh tế, chuyển từ nước kém phát triển sang nhóm nước đang phát triển. Tăng trưởng kinh tế của thời kỳ 1992-1997 đã cao gấp hơn hai lần của thời kỳ 1977-1991 (8,77\%/năm so với 4,07\%/năm). Cùng với phát triển kinh tế, phương tiện giao thông cơ giới đường bộ bắt đầu gia tăng đáng kể. Từ năm 1990 đến năm 1996 ô tô tăng bình quân: 23.464 xe/năm (8\%/năm), xe máy tăng bình quân: 499.802 xe/năm (23\%/năm).

Phương tiện cơ giới đường bộ bắt đầu tăng, nhu cầu đi lại, giao thương tăng nhanh, tai nạn giao thông đường bộ có xu hướng gia tăng. Từ năm 1995 khi số người bị chết vị tai nạn giao thông đường bộ vượt trên 5.000 ngươi, Chính phủ, đặc biệt Thủ tướng Chính phủ Võ Văn Kiệt là người đầu tiên quan tâm đặc biệt đến công tác bảo đảm trật tự an toàn giao thông đường bộ. Ngày 29 tháng 5 năm 1995 Chính phủ ban hành Nghị định 36-CP về bảo đảm trật tự an toàn giao thông đường bộ và trật tự an toàn giao thông đô thị, Nghị định có hiệu lực từ ngày 1 tháng 8 năm 1995. Đây là văn bản đầu tiên có giá trị pháp lý cao về bảo đảm trật tự an toàn giao thông đường bộ.

Ngay từ khi bắt đầu quan tâm đến trật tự an toàn giao thông đường bộ, Chính phủ đã nhìn nhận về khả năng phát triển xe máy ở Việt Nam nên tại Điều 34 của Nghị định 36-CP đã quy định "Người ngồi trên xe mô tô phải đội mũ bảo hiểm".

Từ năm 1990 đến năm 2000, bình quân mỗi năm chỉ tăng 500.000 xe máy, bình quân mỗi năm tăng 18,04\%. Về tai nạn giao thông, bình quân mỗi năm số người bị chết vì tai nạn giao thông đường bộ là: 5.111 người, mỗi năm bình quân tăng trên 500 người. Đến năm 2000 số phương tiện cơ giới đường bộ là: 6.694 .740 xe, số ô tô là: 483.917 xe, mô tô là: 6.210 .823 xe, số người bị chết vì tai nạn giao thông đường bộ là: 7.500 người, số người bị thương vì tai nạn giao thông đường bộ là: 25.400 người, số vụ tai nạn giao thông đường bộ là: 22.486 vụ. Trong giai đoạn này tai nạn giao thông vẫn là nguyên nhân hàng đầu gây thương vong ở Việt Nam, song không xẩy ra những đột biến vì vậy mức độ quan tâm của các Bộ, ngành, các địa phương không thật 
quyết liệt. Do đó việc thực hiện quy định bắt buộc đội mũ bảo hiểm khi đi xe máy cũng không thật cấp bách.

Bảng 2-20 Tai nạn giao thông đường bộ $1990-2000^{52}$

\begin{tabular}{|c|c|c|c|c|c|c|c|c|c|}
\hline \multirow{3}{*}{ Năm } & \multicolumn{3}{|c|}{ Số vụ } & \multicolumn{3}{|c|}{ Số người chết } & \multicolumn{3}{|c|}{ Số bị thương } \\
\hline & \multirow[b]{2}{*}{ Số vụ } & \multicolumn{2}{|c|}{$\begin{array}{c}\text { So sánh với năm } \\
\text { trước }\end{array}$} & \multirow{2}{*}{$\begin{array}{l}\text { Số bị } \\
\text { chết }\end{array}$} & \multicolumn{2}{|c|}{$\begin{array}{c}\text { So sánh với năm } \\
\text { trước }\end{array}$} & \multirow{2}{*}{$\begin{array}{l}\text { Số bị } \\
\text { thương }\end{array}$} & \multicolumn{2}{|c|}{$\begin{array}{c}\text { So sánh với năm } \\
\text { trước }\end{array}$} \\
\hline & & $\begin{array}{l}\text { Tăng, } \\
\text { giảm } \\
(+/-)\end{array}$ & $\%$ & & $\begin{array}{l}\text { Tăng, } \\
\text { giảm } \\
(+/-)\end{array}$ & $\%$ & & $\begin{array}{l}\text { Tăng, } \\
\text { giảm } \\
(+/-)\end{array}$ & $\%$ \\
\hline 1990 & 5.565 & & & 2.087 & & & 4.468 & & \\
\hline 1991 & 6.864 & 1.299 & $23,3 \%$ & 2.395 & 308 & $14,8 \%$ & 6.846 & 2.378 & $53,2 \%$ \\
\hline 1992 & 8.165 & 1.301 & $19,0 \%$ & 2.755 & 360 & $15,0 \%$ & 9.040 & 2.194 & $32,0 \%$ \\
\hline 1993 & 11.678 & 3.513 & $43,0 \%$ & 3.940 & 1.185 & $43,0 \%$ & 12.590 & 3.550 & $39,3 \%$ \\
\hline 1994 & 13.118 & 1.440 & $12,3 \%$ & 4.533 & 593 & $15,1 \%$ & 13.056 & 466 & $3,7 \%$ \\
\hline 1995 & 15.376 & 2.258 & $17,2 \%$ & 5.430 & 897 & $19,8 \%$ & 16.920 & 3.864 & $29,6 \%$ \\
\hline 1996 & 19.075 & 3.699 & $24,1 \%$ & 5.581 & 151 & $2,8 \%$ & 21.556 & 4.636 & $27,4 \%$ \\
\hline 1997 & 19.159 & 84 & $0,4 \%$ & 5.680 & 99 & $1,8 \%$ & 21.905 & 349 & $1,6 \%$ \\
\hline 1998 & 19.975 & 816 & $4,3 \%$ & 6.067 & 387 & $6,8 \%$ & 22.723 & 818 & $3,7 \%$ \\
\hline 1999 & 20.733 & 758 & $3,8 \%$ & 6.670 & 603 & $9,9 \%$ & 23.911 & 1.188 & $5,2 \%$ \\
\hline 2000 & 22.486 & 1.753 & $8,5 \%$ & 7.500 & 830 & $12,4 \%$ & 25.400 & 1.489 & $6,2 \%$ \\
\hline
\end{tabular}

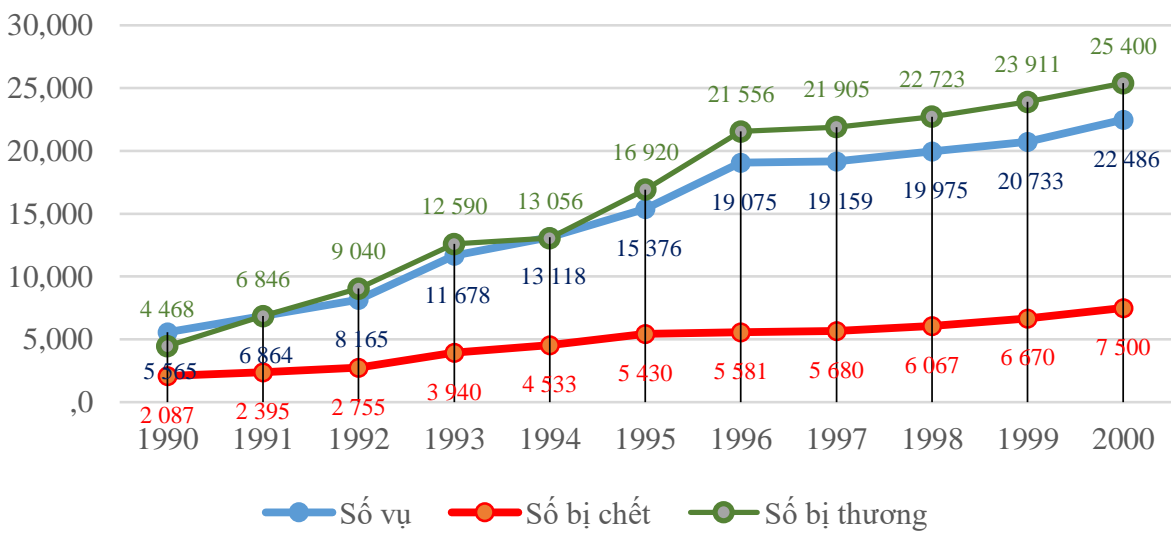

Hình 2-15 Tai nạn giao thông đường bộ năm 1990 - 2000

Mặc dù giai đoạn trước năm 2000 luật pháp có quy định bắt buộc đội mũ bảo hiểm khi đi xe máy song trong thực tế không bắt buộc số người đội mũ bảo hiểm khi đi xe máy rất ít, chỉ có một số ít người nước ngoài, người Việt Nam ở nước ngoài về tự nguyện đội mũ bảo hiểm. Giai đoạn này có thể không gọi là thất bại vì thực tế chưa thực hiện quy định bắt buộc đội mũ bảo hiểm khi đi xe máy. Một số điểm để thấy quy định bắt buộc đội mũ bảo hiểm khi đi xe máy chưa thực hiện như sau:

- Các cơ quan quản lý Nhà nước không thực sự quan tâm đến tổ chức thực hiện;

- Không quy định chế tài;

- Không tuyên truyền, phổ biến giáo dục;

- Không có đơn vị sản xuất, nhập khẩu mũ bảo hiểm;

- Mặc dù có ban hành tiêu chuẩn về mũ bảo hiểm (TCVN 5756 -1993) nhưng cơ quản lý hầu như không quan tâm kiểm tra;

- Dư luận xã hội không ủng hộ.

${ }^{52}$ Số liệu UBATGTQG 


\subsubsection{Giai đoạn cuối năm 2000 đến 2006}

Như phần về vấn đề xe máy ở Việt Nam đã phân tích: giai đoạn 2001- 2006, bình quân mỗi năm tăng 2.067.523 xe máy, bình quân mỗi năm tăng 20,30\%. Đặc biệt riêng năm 2001, do xe máy Trung Quốc giá rẻ ồ ạt vào Việt Nam nên năm 2001 số lượng xe máy tăng đột biến 2.148.219, tăng 34\% so với năm 2000. Hệ lụy này dẫn đến tai nạn giao thông đường bộ tăng đột biến.

Cuối năm 2000, tai nạn giao thông bắt đầu có chiều hướng tăng nhanh. Năm 2000 số người chết vì tai nạn giao thông đường bộ là: 7.500 người thì năm 2001 tăng đột biến lên 10.477 người (tăng 2.977 người) và tiếp theo năm 2002 là 12.800 người (tăng 2.323 người), trong đó đáng lo ngại là số tai nạn giao thông xe máy chiếm tỷ lệ rất cao. Thật sự đây là cú sốc đối với toàn xã hội. Dư luận xã hội lên tiếng hàng ngày, tai nạn giao thông là vấn đề nóng trong nghị trường Quốc hội, các phiên họp của Chính phủ.

Bảng 2-21 Tai nạn giao thông đường bộ 1999-200753

\begin{tabular}{|c|c|c|c|c|c|c|c|c|c|}
\hline \multirow{3}{*}{ Năm } & \multicolumn{3}{|c|}{ Số vụ TNGT ĐB } & \multicolumn{3}{|c|}{ Số người chết TNGT ĐB } & \multicolumn{3}{|c|}{ Số bị thương TNGT ĐB } \\
\hline & \multirow[b]{2}{*}{ Số vụ } & \multicolumn{2}{|c|}{$\begin{array}{c}\begin{array}{c}\text { So sánh với năm } \\
\text { trước }\end{array} \\
\end{array}$} & \multirow{2}{*}{$\begin{array}{c}\text { Số } \\
\text { ngưò̀i } \\
\text { chết }\end{array}$} & \multicolumn{2}{|c|}{$\begin{array}{c}\text { So sánh với năm } \\
\text { trước }\end{array}$} & \multirow{2}{*}{$\begin{array}{l}\text { Số bị } \\
\text { thưong }\end{array}$} & \multicolumn{2}{|c|}{$\begin{array}{c}\text { So sánh với năm } \\
\text { trước }\end{array}$} \\
\hline & & $\begin{array}{l}\text { Tăng, } \\
\text { giảm } \\
(+/-)\end{array}$ & $\%$ & & $\begin{array}{l}\text { Tăng, } \\
\text { giảm } \\
(+/-)\end{array}$ & $\%$ & & $\begin{array}{l}\text { Tăng, } \\
\text { giảm } \\
(+/-)\end{array}$ & $\%$ \\
\hline 1999 & 20.733 & & & 6.670 & & & 23.911 & & \\
\hline 2000 & 22.486 & 1.753 & $8,5 \%$ & 7.500 & 830 & $12,4 \%$ & 25.400 & 1.489 & $6,2 \%$ \\
\hline 2001 & 25.040 & 2.554 & $11,4 \%$ & 10.477 & 2.977 & $39,7 \%$ & 29.188 & 3.788 & $14,9 \%$ \\
\hline 2002 & 27.134 & 2.094 & $8,4 \%$ & 12.800 & 2.323 & $22,2 \%$ & 30.733 & 1.545 & $5,3 \%$ \\
\hline 2003 & 19.852 & -7.282 & $-26,8 \%$ & 11.319 & -1.481 & $-11,6 \%$ & 20.400 & -10.333 & $-33,6 \%$ \\
\hline 2004 & 16.911 & -2.941 & $-14,8 \%$ & 11.739 & 420 & $3,7 \%$ & 15.142 & -5.258 & $-25,8 \%$ \\
\hline 2005 & 14.141 & -2.770 & $-16,4 \%$ & 11.184 & -555 & $-4,7 \%$ & 11.760 & -3.382 & $-22,3 \%$ \\
\hline 2006 & 9.030 & -5.112 & $-36,1 \%$ & 10.654 & -531 & $-4,7 \%$ & 3.965 & -7.796 & $-66,3 \%$ \\
\hline 2007 & 13.985 & 4.956 & $54,9 \%$ & 12.800 & 2.147 & $20,1 \%$ & 10.266 & 6.302 & $158,9 \%$ \\
\hline
\end{tabular}

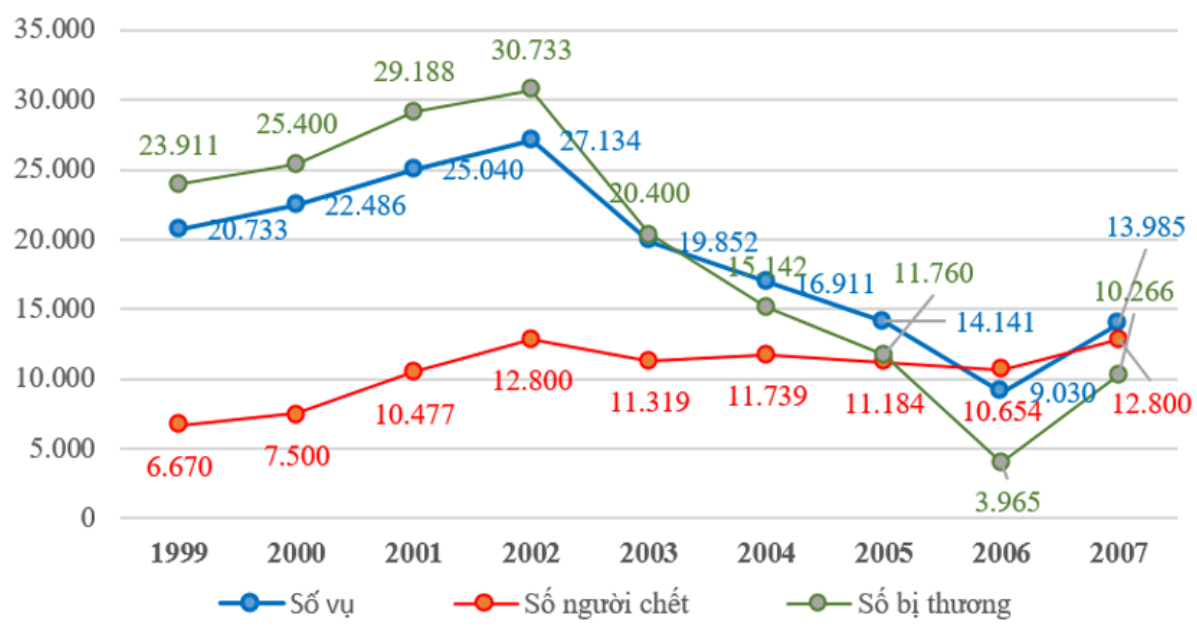

Hình 2-16 Tai nạn giao thông đường bộ năm 1999 -2007

\footnotetext{
${ }^{53}$ Số liêu: UBATGTQG
} 
Trước tình hình tai nạn giao thông xẩy ra hết sức bức xúc như nêu trên, Bộ Giao thông vận tải đã thấy cấp bách phải thực hiện bắt buộc đội mũ bảo hiểm khi đi xe máy. Ngày 10 tháng 8 năm 2000, Bộ Giao thông vận tải Căn cứ Nghị định 36/CPThông tư 312/2000/TTBGTVT với nội dung chủ yếu như sau:

- Từ ngày 1 tháng 9 năm 2000 bắt buộc đội mũ bảo hiểm đối với người ngồi trên mô tô, xe máy đi đường trường trên các quốc lộ mới được nâng cấp, cải tạo và các đường đi vào Thủ đô Hà Nội, thành phố Hồ Chí Minh, thành phố Hải phòng và thành phố Đà Nẵng.

- Từ ngày 01 tháng 01 năm 2001 bắt buộc đội mũ bảo hiểm đối với người ngồi trên mô tô, xe máy đi trên các quốc lộ, tỉnh lộ nằm ngoài phạm vi thị trấn, thị xã, thành phố thuộc tỉnh và ngoài phạm vi nội thành của thành phố trực thuộc Trung ương.

- Trước ngày 30 tháng 8 năm 2000, Cục Đường bộ Việt Nam được uỷ quyền của Bộ Giao thông vận tải sẽ thông báo công khai những đường quốc lộ, Sở Giao thông vận tải (Sở Giao thông công chính) được uỷ quyền của Uỷ ban nhân dân tỉnh, thành phố trực thuộc Trung ương sẽ thông báo công khai những đoạn đường do địa phương quản lý phải đội mũ bảo hiểm khi ngồi trên mô tô, xe máy.

- Khuyến khích và động viên bằng mọi hình thức người ngồi trên môtô, xe máy đội mũ bảo hiểm khi đi trên các đường nội đô, nội thị và các đường khác không được qui định

- Người ngồi trên mô tô, xe máy đi trên những đường quy định phải đội mũ bảo hiểm mà không đội mũ bảo hiểm là vi phạm và sẽ bị xử phạt hành chính theo quy định của pháp luật.

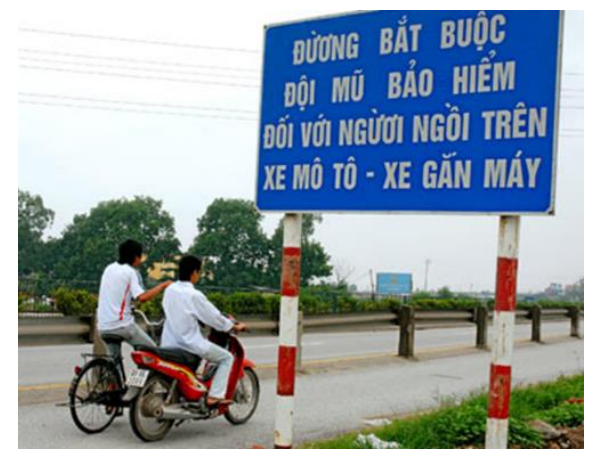

\section{Hình 2-17 Biển thông báo đoạn đường bắt buộc đội mũ bảo hiểmđối với người ngồi trên xe máy}

Thông tư 312/2000/TT- BGTVT đã không thành công, Thông tư bị dư luận xã hội, truyền thông phản ứng, nguyên nhân như sau:

Thời gian từ khi ban hành văn bản đến khi văn bản có hiệu lực quá ngắn (ban hành ngày 10 tháng 8 năm 2000, có hiệu lực 01 tháng 9 năm 2000);

- Không quy định chế tài;

- Không tổ chức tuyên truyền, phổ biến;

- Không xây dựng kế hoạch triển khai chi tiết;

- Không huy động được toàn hệ thống chính trị tham gia;

- Không quan tâm đến tình hình mũ bảo hiểm trên thị trường.

\subsubsection{Tổ chức thực hiện quy định bắt buộc đội mũ bảo hiểm khi đi xe máy năm 2001}

Trước tình hình tai nạn giao thông đường bộ diễn biến phức tạp, tại ngày 26 và 27 tháng 02 năm 2001, Chính phủ đã họp và thông qua Nghị quyết 02/2001/NQ-CP trong phiên họp Chính phủ thường kỳ tháng 02 năm 2001. Tại điểm 7 của Nghị quyết đã kết luận: 
“ 7. .. Tại phiên họp này, Bộ trưởng Bộ Giao thông vận tải báo cáo Chính phủ về những biện pháp cấp bách bảo đảm an toàn giao thông.

Chính phủ nhất trí với nội dung báo cáo. Trước mắt, yêu cầu các Bộ, ngành chức năng và Uỷ ban nhân dân các tỉnh, thành phố tiếp tục đẩy mạnh hơn nữa các biện pháp nhằm khắc phục tình trạng tai nạn và ùn tắc giao thông, tập trung triển khai ngay một số biện pháp cấp bách như tăng cường công tác kiểm tra, kiểm soát, xử lý thật nghiêm các vi phạm, kiên quyết ngăn chặn bằng được nạn đua $x e, x u ̛ ̉$ lý nghiêm các trường hợp lái xe nghiện ngập và say rượu, các trường học kiểm tra và nghiêm cấm ngay học sinh không đủ tuổi đi xe máy; thực hiện bắt buộc đội mũ bảo hiểm đối với mọi người khi đi mô tô, xe máy từ tháng 6 năm 2001 (cán bộ, công chức của các cơ quan nhà nước phải gương mẫu thực hiện sớm hơn) ...

Giao Bộ Giao thông vận tải chủ trì, phối hợp với Bộ Công an và các cơ quan liên quan dự thảo và sớm trình Thủ tướng Chính phủ ban hành các quyết định cụ thể để tổ chức thực hiện.”

Tiếp theo, Thủ tướng Chính phủ ban hành Chỉ thị 08/2001/CT-TTg ngày 27 tháng 4 năm 2001 về việc tập trung thực hiện một số biện pháp nhằm hạn chế tai nạn giao thông và khắc phục tình trạng ùn tắc giao thông, Chỉ thị giao nhiệm vụ cho Bộ Giao thông vận tải như sau:

\section{“2. Bộ Giao thông vận tải:}

a) Phối hợp với các cơ quan liên quan vận động tuyên truyền liên tục, rộng rãi mọi người đội mũ bảo hiểm khi đi xe mô tô, xe máy. Đồng thời tiếp tục thực hiện tốt công tác kiểm định chất lượng mũ bảo hiểm, hướng dẫn sản xuất các loại mũ bảo hiểm phù hợp với điều kiện Việt Nam, bảo đảm tháng 6 năm 2001 có đủ mũ cung cấp cho thị trường với giá cả ổn định. Trình Chính phủ các quy định pháp luật cần thiết để bắt buộc đội mũ bảo hiểm khi đi xe mô tô, xe máy.

Đôn đốc và tạo điều kiện cho các Bộ, ngành tổ chức cho cán bộ, công chức gương mẫu thực hiện trước việc bắt buộc đội mũ bảo hiểm khi đi mô tô, xe máy."

Ngày 15 tháng 5 năm 2001, Chính phủ ban hành công văn số 407/CP-CN yêu cầu Các Bộ, cơ quan ngang Bộ, cơ quan thuộc Chính phủ, ủy ban nhân dân các tỉnh, thành phố trực thuộc Trung ương chỉ đạo thực hiện nghiêm chỉnh Nghị quyết của Chính phủ về việc bắt buộc đội mũ bảo hiểm khi đi mô tô, xe máy từ tháng 6 năm 2001 và Bộ Giao thông vận tải chủ trì, phối hợp với các cơ quan liên quan hoàn thiện dự thảo Nghị định của Chính phủ quy định xử phạt vi phạm hành chính trong lĩnh vực bảo đảm trật tự an toàn giao thông, trong đó quy định cụ thể về xử phạt đối với hành vi không đội mũ bảo hiểm khi đi mô tô, xe máy, trình Chính phủ ban hành trong tháng 6 năm 2001.

Căn cứ Nghị quyết 02/2001/NQ-CP, Chỉ thị 08/2001/CT-TTg, công văn số 407/CP-CN, Bộ Giao thông vận tải ban hành Thông tư 08/2001/TT- BGTVT ngày 16 tháng 5 năm 2001, trong đó quy định như sau:

“1. Từ ngày 01 tháng 6 năm 2001 bắt buộc đội mũ bảo hiểm đối với người ngồi trên mô tô, xe máy (kể cả trẻ em) đi trên hệ thống đường bộ Việt Nam theo đúng Nghị quyết số 02/2001/NQCP ngày 2 tháng 3 năm 2001 của Chính phủ.

Tuy nhiên căn cứ tình hình thực tế, trước mắt chỉ nhắc nhở, chưa xử phạt những người không đội mũ bảo hiểm khi đi mô tô xe máy trong nội thành, nội thị. Những người ngồi trên mô tô, xe 
máy (kể cả trẻ em) đi trên các quốc lộ, tỉnh lộ nằm ngoài nội thành, nội thị mà không đội mũ bảo hiểm sẽ bị xử phạt theo quy định của pháp luật.

2. Tiếp tục tuyên truyền, vận động mọi người ngồi trên mô tô, xe máy đội mũ bảo hiểm khi đi trên các đường nội thành, nội thị.

Cán bộ, công chức của các cơ quan nhà nước và sinh viên, học sinh các trường Đại học, Cao đẳng, Trung học chuyên nghiệp và dạy nghề khi đi trên các đường nội thành, nội thị cần gương mẫu thực hiện đội mũ bảo hiểm theo Nghị quyết 02/2001/NQ-CP của Chính phủ.

3. Trước ngày 31 tháng 5 năm 2001, Cục đường bộ Việt Nam, Sở giao thông vận tải hoặc Sở giao thông công chính phải hoàn thành việc cắm các biển báo hiệu để chỉ rõ ranh giới phạm vi nội thành, nội thị trên tất cả các tuyến đường để mọi người đi mô tô, xe máy biết và thực hiện việc đội mũ bảo hiểm.

4. Trước ngày 31 tháng 5 năm 2001, Cục đăng kiểm Việt Nam thông báo công khai trên các phương tiện thông tin đại chúng về các địa điểm kiểm định, quy trình kiểm định, tiêu chuẩn kiểm định mũ bảo hiểm để các doanh nghiệp sản xuất, kinh doanh mũ bảo hiểm đến kiểm định. Đồng thời có trách nhiệm thông báo đầy đủ, chi tiết về tem kiểm định dán trên mũ bảo hiểm, các kiểu, loại mũ bảo hiểm đã được kiểm định để nhân dân biết khi mua"

Ngày 29/6/2001 Quốc hội nước Cộng hòa xã hội chủ nghĩa Việt Nam khoá X kỳ họp thứ 9 đã thông qua Luật Giao thông đường bộ (sau đây gọi là Luật Giao thông đường bộ 2001), có hiệu lực thi hành kể từ ngày 01/01/2002. Luật Giao thông đường bộ 2001 giao cho Chính phủ quy định về việc bắt buộc đội mũ bảo hiểm khi đi mô tô, xe máy

Ngày 08 tháng 1 năm 2003 Bộ Giao thông vận tải ban hành Thông tư 01/2003/TT- BGTVT hướng dẫn đội mũ bảo hiểm khi đi xe mô tô, xe gắn máy thay thế Thông tư 08/2001/TT-BGTVT ngày $16 / 5 / 2001$, trong đó quy định cụ thể đoạn tuyến, tuyến quốc lộ bắt buộc đội mũ bảo hiểm khi đi xe mô tô, xe gắn máy

Ngày 19 tháng 2 năm 2005 Chính phủ ban hành Nghị định 14/2003/NĐ-CP Quy định chi tiết một số điều của Luật Giao thông đường bộ. Tại Điều 8 Nghị định quy định: "Người điều khiển, người ngồi trên xe mô tô hai bánh, xe mô tô ba bánh, xe gắn máy phải đội mũ bảo hiểm khi đi trên các tuyến đường bộ quy định phải đội mũ bảo hiểm"

Văn bản quy định bắt buộc đội mũ bảo hiểm đối với người đi xe máy được ban hành liên tiếp thể hiện đây là giải pháp cấp bách, sự quan tâm đặc biệt của Chính phủ đến giảm số thương vong do tai nạn giao thông xe máy. Tuy vậy, thực tế sau ngày 01 tháng 6 năm 2001 số người đi xe máy đội mũ bảo hiểm tăng không đáng kể, có thể thấy lần này tổ chức quy định bắt buộc đội mũ bảo hiểm đối với người đi xe máy không thành công. Năm 2003 giảm được tai nạn giao thông là do thực hiện Nghị quyết 13/2002/NQ-CP ngày 19 tháng 11 năm 2002 về các giải pháp kiềm chế gia tăng và tiến tới giảm dần tai nạn giao thông và ùn tắc giao thông.

Báo cáo Tình hình trật tự an toàn giao thông số: 230/UBATGTQG ngày 24 tháng 10 năm 2003 của Ủy ban An toàn giao thông Quốc gia gửi Thủ tướng Chính phủ đã đánh giá "Quy định bắt buộc đội mũ bảo hiểm trên các đoạn đường bắt buộc đội mũ bảo hiểm thực hiện yếu”.

Những lý do thực hiện quy định bắt buộc đội mũ bảo hiểm đối với người đi xe máy chưa thành công trong giai đoạn này như sau: 
1) Công tác chuẩn bị không tốt, thể hiện sự nóng vội.

2) Về văn bản pháp luật: không ban hành chế tài; mặc dù công văn số 407/CP-CN đã giao nhiệm vụ cho Bộ Giao thông vận tải chủ trì, phối hợp với các cơ quan liên quan hoàn thiện dự thảo Nghị định của Chính phủ quy định xử phạt vi phạm hành chính trong lĩnh vực bảo đảm trật tự an toàn giao thông, trong đó quy định cụ thể về xử phạt đối với hành vi không đội mũ bảo hiểm khi đi mô tô, xe máy, trình Chính phủ ban hành trong tháng 6 năm 2001.

3) Đến 19 tháng 02 năm 2003 Nghị định 15/2003/NĐ-CP Quy định xử phạt hành chính về giao thông đường bộ mới được ban hành. Nghị định 15/2002/NĐ-CP quy định "cảnh cáo hoặc phạt tiền từ 10.000 đ đến 20.000 đ đối với người điều khiển, người ngồi trên xe mô tô, xe gẳn máy không đội mũ bảo hiểm trên đường quy định phải đội mũ bảo hiểm", mức xử phạt tại Nghị định này quá thấp không đủ sức răn đe. Sau đó Nghị định 152/2005/NĐ-CP ban hành ngày 15 tháng 12 năm 2005 Quy định xử phạt hành chính về giao thông đường bộ sửa đổi tăng mức phạt lên 20.000 đ đến 40.000 đ, mức phạt này vấn rất thấp.

4) Không xây dựng kế hoạch chi tiết phối hợp tổ chức thực hiện.

5) Không tổ chức chiến dịch truyền thông.

6) Không có chiến dịch phối hợp cưỡng chế và truyền thông.

7) Tuy Thông tư 08/2001/TT- BGTVT ngày 16 tháng 5 năm 2001 của Bộ Giao thông vận tải có đề cập đến việc kiểm định chất lượng mũ bảo hiểm, nhưng các doanh nghiệp sản xuất mũ bảo hiểm chưa thật quan tâm, cơ quan quản lý thị trường không đủ sức để kiểm tra, kiểm soát.

8) Nghị quyết 02/2001/NQ-CP của Chính phủ có đề cấp đến cán bộ, công chức, viên chức gương mẫu thực hiện trước, nhưng hầu như không có cơ quan nào phát động cán bộ, công chức, viên chức gương mẫu thực hiện.

9) Chỉ bắt buộc người đi xe máy đội mũ bảo hiểm đối trên những đoạn đường có quy định bắt buộc đội mũ bảo hiểm khó thực hiện.

10) Trong những năm 2003, 2004, 2005, 2006, tai nạn giao thông được kiềm chế do hạn chế xe máy đăng ký mới, vì vậy chủ trương quy định bắt buộc đội mũ bảo hiểm đối với người đi xe máy gần như bị sao lãng.

\subsubsection{Thực hiện quy định bắt buộc đội mũ bảo hiểm đối với người đi xe máy năm 2007}

\subsection{Quá trình tổ chức thực hiện quy định bắt buộc đội mũ bảo hiểm khi đi xe máy theo Nghị quyết 32/200/NQ-CP}

Từ 2002 đến 2005 tình hình tai nạn giao thông có dịu xuống, nhưng đến năm 2006 số người bị chết vì tai nạn giao thông bắt đầu tăng trở lại xấp xỉ năm 2002 và năm 2007 số người bị chết vì tai nạn giao thông tăng trở lại như năm 2002 (12.800 người bị chết vì tai nạn giao thông đường bộ-xem Bảng 7, Hình 10 ). Vấn đề tai nạn giao thông một lần nữa trở thành vấn đề xã hội được Đảng, Quốc hội và Chính phủ và dư luận xã hội đặc biệt quan tâm.

Trên tinh thần chỉ đạo tại Chỉ thị 22- CT/TW ngày 24 tháng 02 năm 2003 của Ban Bí thư Trung ương Đảng về Tăng cường bảo đảm trật tự an toàn giao thông, tiếp tục thực hiện các giải pháp 
của Nghị quyết số 13/2002/NQ-CP ngày 19 tháng 11 năm 2002 của Chính phủ về các giải pháp kiềm chế gia tăng và tiến tới giảm dần tai nạn giao thông và ùn tắc giao thông, trên cơ sở Đề án bảo đảm trật tự an toàn giao thông đường bộ đến năm 2010 đã được Thủ tướng Chính phủ phê duyệt, ngày 29 tháng 6 năm 2007 Chính phủ ban hành Nghị quyết 32/2007/NQ-CP về một số giải pháp cấp bách nhằm kiềm chế tai nạn giao thông và ùn tắc giao thông. Tại phiên họp Chính phủ thông qua Nghị quyết 32/2007/NQ-CP dưới sự chủ trì của Thủ tướng Chính phủ Nguyễn Tấn Dũng các Thành viên Chính phủ đã tỏ thái độ quyết liệt thực hiện các giải pháp của Nghị quyết, đặc biệt là thực hiện cho được quy định bắt buộc đội mũ bảo hiểm đối với người đi xe máy.

Nghị quyết 32/2007/NQ-CP bao gồm nhiều giải pháp đồng bộ, riêng giải pháp giảm thiểu thiệt hại do tai nạn giao thông quy định:

- Từ ngày 15 tháng 9 năm 2007, người đi mô tô, xe gắn máy trên các quốc lộ bắt buộc phải đội mũ bảo hiểm.

- Từ ngày 15 tháng 12 năm 2007, người đi mô tô, xe gắn máy trên tất cả các tuyến đường bắt buộc phải đội mũ bảo hiểm.

Rút kinh nghiệm thực hiện quy định bắt buộc đội mũ bảo hiểm đối với người đi xe máy những giai đoạn trước, Nghị quyết 32/2007/NQ-CP ban hành 29 tháng 6 năm 2017 nhưng toàn quốc bắt đầu thực hiện từ 15 tháng 12 năm 2007, như vậy Chính phủ đã để 6 tháng làm công tác chuẩn bị.

Các cơ quan được giao nhiệm vụ xây dựng kế hoạch chi tiết, Ủy ban An toàn giao thông Quốc gia với tư cách là cơ quan phối hợp xây dựng kế hoạch phối hợp giữa các cơ quan liên quan, đặc biệt kế hoạch phối hợp giữa truyền thông và cưỡng chế (kế hoạch 272/UBATGTQG, kế hoạch 4359/BGTVT ngày 13 tháng 7 năm 2007, kế hoạch 76/KH/BVA(C11) ngày 07 tháng 7 năm 2007, kế hoạch 273/UBATGTQG ngày 18 tháng 7 năm 2007 về tuyên truyền), sau đó ngày 22 tháng 7 năm 2007 tổ chức Hội nghị toàn quốc phổ biến triển khai Nghị quyết 32/2007/NQ-CP đến tất cả các Bộ, ngành, các địa phương, các cơ quan thông tấn báo chí, truyền thông.

Ngày 14 tháng 9 năm 2007, Chính phủ ban hành Nghị định 146/2007/NQ-CP Quy định xử phạt vi phạm hành chính trong lĩnh vực giao thông đường bộ thay thế Nghị định số 152/2005/NĐCP ngày 15 tháng 12 năm 2005 của Chính phủ quy định về xử lý vi phạm hành chính trong lĩnh vực giao thông đường bộ. Tại điểm g, khoản 3 Điều 9 Nghị định 146/2007/NQ-CP quy định phạt tiền từ 100.000 đồng đến 200.000 đồng đối với Người điều khiển, người ngồi trên xe mô tô, xe gắn máy không đội mũ bảo hiểm khi đi trên đường theo quy định.

Vấn đề khả năng cung ứng mũ bảo hiểm của thị trường, giá cả và chất lượng của mũ bảo hiểm được kiểm tra kỹ lưỡng đề đảm bảo đến 15 tháng 12 năm 2007 phải cung ứng đủ mũ bảo hiểm với chất lượng đảm bảo. Gần sát thời điểm bắt buộc phải đội mũ bảo hiểm, người dân dân bắt đầu tăng cường mua mũ bảo hiểm, thậm chí một số tuyến đường bán MBH ở Thành phố Hồ Chí Minh tối ngày 14 tháng 12 năm 2007 còn xảy ra hiện tượng kẹt xe do người dân đổ ra đường mua $\mathrm{MBH}$. Tuy vậy không gây ra cơn sốt mũ bảo hiểm, giá cả ổn định.

Ngày 10 tháng 12 năm 2007, trước thời điểm 15 tháng 12 năm 2007 thực hiện quy định bắt buộc đội mũ bảo hiểm khi đi xe máy, Thủ tướng phủ Chính Nguyễn Tấn Dũng ban hành Công điện số 1928/CĐ-TTg nhắc nhở các bộ, ngành, các địa phương những điểm phải đặc biệt quan tâm để thực hiện thành công quy định bắt buộc đội mũ bảo hiểm khi đi xe máy. 
Ngày 15 tháng 12 năm 2007 toàn quốc đồng loạt ra quân, các lực lượng truyền thông, cưỡng chế, các tổ chức chính trị-xã hội các đoàn thể đề̀u xuống đường. Ngày 15 tháng 12 năm 2007 thực sự là cuộc cách mạng trên toàn quốc về đội mũ bảo hiểm khi đi xe máy. Ngày 15 tháng 12 năm 2007 thực hiện thành công quy định bắt buộc đội mũ bảo hiểm đối với người đi xe máy. Chỉ qua một đêm 14 tháng 12 năm 2007 sang sáng 15 tháng 12 năm 2007 người đi xe máy trong cả nước gần như $100 \%$ đều đội mũ bảo hiểm. Chiều tối 14 tháng 12 năm 2017 khảo sát ở Hà Nội thì chỉ có khoảng 30\% người đi xe máy đội mũ bảo hiểm nhưng sang sáng 15 tháng 12 năm 2017 thì khác hẳn: $99 \%$ người đi xe máy đội mũ bảo hiểm. Theo một thống kê của Tố chức Y Tế Thế giới (WHO), sau khi quy định bắt buộc đội $\mathrm{MBH}$ có hiệu lực thì $96 \%$ người lớn khi tham gia giao thông có đội mũ bảo hiểm ${ }^{54}$

\subsection{Bài học thành công thụ̣c hiện quy định bắt buộc đội MBH khi đi xe máy}

Ngay năm 2008, sau ngày bắt đầu thực hiện quy định bắt buộc đội mũ bảo hiểm khi đi xe máy, tai nạn giao thông năm 2008 đã giảm đáng kể. So với năm 2007 số người bị chết vì tai nạn giao thông đường bộ giảm 1.557 người $(12,2 \%)$, số người bị thương vì tai nạn giao thông đường bộ giảm 2.495 người (24,3\%). Cũng từ năm 2008, thực hiện thành công quy định bắt buộc đội mũ bảo hiểm khi đi xe máy đã góp phần giảm tai nạn giao thông đường bộ liên tục từ năm 2008 đến nay.

Có thể tóm tắt bài học thành công thực hiện quy định bắt buộc đội mũ bảo hiểm khi đi xe máy năm 2007 như sau:

1) Thể hiện quyết tâm cao của lãnh đạo cấp cao của Nhà nước.

2) Huy động được toàn thể hệ thống chính trị, các tổ chức chính trị - xã hội.

3) Chuẩn bị đầy đủ các quy định pháp lý để thực hiện, đặc biệt quy định chế tài đủ sức răn đe.

4) Cơ quan phối hợp phát huy được vai trò tổ chức phối hợp.

5) Chuẩn bị dư luận tốt, được sự đồng lòng ủng hộ của các cơ quan truyền thông, báo chí, đặc biệt vai trò của truyền hình.

6) Cán bộ, công chức nhà nước gương mẫu thực hiện.

7) Lực lượng cảnh sát kiên quyết, đồng loạt sẵn sàng xử lý vi phạm trên phạm toàn quốc, lực lượng cảnh sát được truyền thông ủng hộ.

8) Tổ chức tốt giữa truyền thông và cưỡng chế.

9) Chuẩn bị chu đáo về mọi mặt (loại mũ nửa đầu, số lượng cung ứng, chất lượng, giá cả, kiểm định ...).

10) Chọn thời điểm thích hợp.

${ }^{54}$ http://www.wpro.who.int/NR/rdonlyres/98CCB43F-C168-4AA8-9367-

FE4D6A6C8138/0/fs_helmet_motorcycle_safety_vn.pdf ngày truy cập 28/12/2011. (Mũ bảo hiểm xe máy ở Việt Nam - Chương trình giảng dậy kinh tế FULBRIGHT - Vũ Thành Tự Anh, Đỗ Hoàng Phương 02/01/2013) 


\subsubsection{Tình hình thực hiện quy định bắt buộc đội mũ bảo hiểm khi đi xe máy từ 2008 đến nay}

Sau hơn 10 năm thực hiện quy định bắt buộc đội mũ bảo hiểm khi đi xe máy về cơ bản đội mũ bảo hiểm khi đi xe máy đã trở thành thói quen của người Việt Nam.

Theo thống kê của Ủy ban An toàn giao thông quốc gia, sau 10 năm thực hiện triển khai quy định bắt buộc đội mũ bảo hiểm đối với người đi mô tô, xe gắn máy, tỷ lẹ̣ người dân chấp hành đội mũ bảo hiểm khi tham gia giao thông đã đạt hơn $90 \%$. Việc đội mũ bảo hiểm góp phần quan trọng trong kết quả giảm số người chết vì tai nạn giao thông xuống dưới 9.000 người mỗi năm cũng như hạn chế nhiều thương tích nặng ${ }^{55}$.

Tuy nhiên đến nay, thực hiện quy định bắt buộc đội mũ bảo hiểm khi đi xe máy có những vấn đề nổi cộm, cần tiếp tục giải quyết như sau:

1) Tỷ lệ người đi xe máy đội mũ bảo hiểm.

Tuy chưa có điều tra đầy đủ về số liệu tỷ lệ người đi xe máy đội mũ bảo hiểm, nhưng theo nhiều chuyên gia nhận định: tỷ lệ người đi xe máy đội mũ bảo hiểm ở các đô thị, thành phố lớn tỷ lệ người đi xe máy đội mũ bảo hiểm khoảng từ $80 \%$ đến $90 \%$, các tỉnh Phía Nam có tỷ lệ cao hơn các tỉnh Phía Bắc. Tỷ lệ người đi xe máy đội mũ bảo hiểm ở vùng nông thôn, đặc biệt vùng núi, vùng hẻo lánh, xa xôi thì tỷ lệ người đi xe máy đội mũ bảo hiểm khá thấp.

Lý giải nguyên nhân này như sau:

- OỎ vùng nông thôn, vùng núi, vùng hẻo lánh, xa xôi nhận thức của người tham gia giao thông hạn chế hơn ở đô thị, thành phố lớn; công tác tuyên truyền, vận động ở những vùng này chưa được quan tâm đúng mức.

- Lực lượng cưỡng chế thi hành pháp luật ở vùng nông thôn, vùng núi, vùng hẻo lánh, xa xồi thường rất mỏng, chủ yếu chỉ có công an xã.

2) Đội mũ không đúng cách.

Tình trạng này không phổ biến, số người vi phạm không đáng kể.

3) Không đội mũ cho trẻ em khi đi xe máy.

Tình trạng này số đông vi phạm ở các đô thị, thành phố lớn, cha mẹ, người lớn chở con, cháu đi học, đi chơi không đội mũ bảo hiểm cho trẻ em. Mặc dù Luật quy định sẽ xử phạt, trong nhiều năm qua các tổ chức quốc tế, tổ chức phi chính phủ, Bộ Giáo dục và Đào tạo đã mở nhiều chiến dịch truyền thông nâng cao nhận thức, thay đồi hành vi cho phụ huynh học sinh nhưng thường chỉ có hiệu quả trong chiến dịch, kết quả không bền vững.

4) Đội mũ bảo hiểm không đảm bảo chất lượng, thậm chí đội mũ giả mạo mũ bảo hiểm (mũ rởm).

${ }^{55}$ Chỉ thị 04/CT-TTg ngày 19 tháng 01 năm 2018 về việc đẩy mạnh triển khai các giải pháp nhằm nâng cao hiệu quả thực hiện quy định bắt buộc đội mũ bảo hiểm đối với người đi mô tô, xe gắn máy, xe đạp điện 
Ngay từ ngày đầu thực hiện quy định bắt buộc đội mũ bảo hiểm, Chính phủ đã quan tâm nhiều đến chất lượng mũ bảo hiểm. Một loạt các văn bản dưới đây cho thấy Chính phủ chỉ đạo quyết liệt về vấn đề chất lượng mũ bảo hiểm.

Nghị quyết số 10/2001/NQ-CP ngày 31 tháng 8 năm 2001 về Phiên họp Chính phủ thường kỳ tháng 8 năm 2001, khẳng định: Chính phủ quyết định: mũ bảo hiểm người đi xe máy là loại hàng hóa bắt buộc phải áp dụng Tiêu chuẩn Việt Nam; Bộ Khoa học, Công nghệ và Môi trường thực hiện quản lý nhà nước về chất lượng mũ bảo hiểm người đi xe máy; việc giám định tiêu chuẩn chất lượng mũ bảo hiểm là hoạt động dịch vụ...Chính phủ giao Bộ Khoa học, Công nghệ và Môi trường phối hợp với Bộ Giao thông vận tải và các cơ quan liên quan, tổ chức triển khai thực hiện.

Chỉ thị 04/CT-TTg ngày 08 tháng 3 năm 2013 về việc tăng cường quản lý sản xuất, kinh doanh và sử dụng mũ bảo hiểm khi tham gia giao thông.

Nghị định 87/2016/NĐ-CP ngày 01 tháng 7 năm 2016 Quy định về điều kiện kinh doanh mũ bảo hiểm cho người đi mô tô xe máy ${ }^{56}$.

Các Nghị định về xử lý vi phạm hành chính trong lĩnh vực giao thông đường bộ từ 2007 đến 2016, điều khoản xử phạt về hành vi không đội mũ bảo hiểm liên tục được thay đổi như sau:

- Nghị định 146/2007/NQ-CP quy định phạt tiền từ 100.000 đồng đến 200.000 đồng đối với Người điều khiển, người ngồi trên xe mô tô, xe gắn máy không đội mũ bảo hiểm khi đi trên đường theo quy định.

- Nghị định 34/2010/NĐ-CP Quy định xử phạt hành chính trong lĩnh vực giao thông đường bộ phạt tiền từ 100.000 đ đến 200.000 đ người điều khiển, người ngồi trên xe không đội mũ bảo hiểm hoặc đội mũ bảo hiểm không cài quai đúng quy cách khi tham gia giao thông.

- Nghị định 71/2012/NĐ-CP ngày 19/9/2012 Quy định xử phạt hành chính trong lĩnh vực giao thông đường bộ quy định phạt tiền từ 100.000 đ đến 200.000 đ người điều khiển, người ngồi trên xe không đội mũ bảo hiểm hoặc đội mũ bảo hiểm không cài quai đúng quy cách khi tham gia giao thông trên đường bộ; chở người ngồi trên xe không đội mũ bảo hiểm hoặc đội mũ bảo hiểm không cài quai đúng quy cách, trừ trường hợp chở người bệnh đi cấp cứu, trẻ em dưới 06 tuổi, áp giải người có hành vi vi phạm pháp luật.

- Nghị định 171/2013/NĐ-CP ngày 13/11/2013 Quy định xử phạt hành chính trong lĩnh vực giao thông đường bộ và đường sắt phạt tiền từ 100.000 đ đến 200.000 đ đối với các hành vi: Người điều khiển, người ngồi trên xe không đội "mũ bảo hiểm cho người đi mô tô, xe máy" hoặc đội "mũ bảo hiểm cho người đi mô tô, xe máy" không cài quai đúng quy cách khi tham gia giao thông trên đường bộ; chở người ngồi trên xe không đội "mũ bảo hiểm cho người đi mô tô, xe máy" hoặc đội“mũ bảo hiểm cho người đi mô tô, xe máy" không cài quai đúng quy cách, trừ trường hợp chở người bệnh đi cấp cứu, trẻ em dưới 06 tuổi, áp giải người có hành vi vi phạm pháp luật.

\footnotetext{
${ }^{56}$ Nghị định 154/2018/NĐ-CP ngày 09/11/2018 sửa đổi, bổ sung, bãi bỏ một số quy định về điều kiện đầu tư, kinh doanh trong lĩnh vực quản lý nhà nước của Bộ Khoa học và Công nghệ và một số quy định về kiểm tra chuyên ngành.. Trong đó, bãi bỏ Nghị định số 87/2016/NĐ-CP ngày 1/7/2016 của Chính phủ về điều kiện kinh doanh mũ bảo hiểm cho người đi mô tô, xe máy.
} 
- Nghị định 146/2016/NĐ-CP Quy định xử phạt hành chính trong lĩnh vực giao thông đường bộ và đường sắt hành vi không đội mũ bảo hiểm khi đi xe mô tô, xe máy được giữ như Nghị định 171/2013/NĐ-CP.

Bộ Khoa học, Công nghệ và Môi trường đã ban hành các tiêu chuẩn về chất lượng mũ bảo hiểm như sau:

- Năm 1993 ban hành Tiêu chuẩn TCVN 5756:1993 ngày 17 tháng 12 năm 1993.

- Năm 2001 ban hành tiêu chuẩn TCVN 5756:2001 Mũ bảo vệ cho người đi xe máy ngày 24 tháng 01 năm 2001 thay thế TCVN 5756:1993.

- Năm 2004 ban hành Tiêu chuẩn TCVN 6769:2001 Mũ bảo hiểm cho trẻ em khi tham gia giao thông trên mô tô và xe máy ngày 27 tháng 10 năm 2004.

- Năm 2017 ban hành TCVN 5756:2017 Mũ bảo hiểm cho người đi mô tô, xe máy ngày 24 tháng 10 năm 2017 thay thế TCVN 5756:2001 Mũ bảo vệ cho người đi mô tô và xe máy, TCVN 6070:2001 Mũ bảo hiểm cho trẻ em khi tham gia giao thông trên mô tô và xe máy.

- Năm 2008 ban hành QCVN 2:2008/BKHCN, Quy chuẩn kỹ thuật quốc gia về mũ bảo hiểm cho người đi mô tô xe máy ngày 28 tháng 4 năm 2008.

- Thông tư liên Bộ Khoa học và Công nghệ, Công thương, Bộ Công an, Bộ Giao thông vận tải số 06/2013/TTLT - BKHCN-BCT-BCA-BGTVT ban hành ngày 28 tháng 02 năm 2013 Quy định về sản xuất, nhập khẩu, kinh doanh và sử dụng mũ bảo hiểm cho người đi mô tô, xe gắn máy, xe đạp máy.

Để quyết tâm thực hiện Ủy ban An toàn giao thông Quốc gia ban hành Kế hoạch 69/KHUBATGTQG ngày 18 tháng 4 năm 2014 Tổ chức chiến dịch tuyên truyền và triển khai đợt cao điểm kiểm tra, xử lý vi phạm về sản xuất, kinh doanh và sử dụng mũ không phải mũ bảo hiểm cho người đi mô tô, xe gắn máy, xe đạp máy với nội dung:

- Chiến dịch truyền thông từ 20 tháng 5 năm 2014 đến 19 tháng 6 năm 2014 .

- Chiến dịch cưỡng chế:

Xử lý các vi phạm trong sản xuất, kinh doanh buôn bán MBH giả, mũ không phải mũ bảo hiểm dành cho người đi mô tô, xe máy. Tháng cao điểm từ 20/5/2014 đến 19/6/2014 xử lý hành vi đội mũ không phải $\mathrm{MBH}$ cho người đi mô tô, xe gắn máy khi tham gia giao thông. Thời gian xử lý từ ngày 01 tháng 7 năm 2014, trong đó quy định: xử lý vi phạm đối với đối tượng đội mũ không phải mũ bảo hiểm cho người đi mô tô, xe gắn máy: Yêu cầu dừng xe, tuyên truyền nhắc nhở, từ 15-30/6/2014; yêu cầu dừng xe, xử phạt theo Nghị định số 171/2013/NĐ-CP, giao nộp để tiêu hủy mũ không phải mũ bảo hiểm

Trong giai đoạn tuyên truyền bắt đầu từ năm 2013 và đợt thí điểm kiểm tra, xử lý vi phạm về sản xuất, kinh doanh và sử dụng mũ không phải mũ bảo hiểm cho người đi mô tô, xe gắn máy, xe đạp máy trên địa bàn thành phố Hà Nội tình hình có những dấu hiệu tốt, các hàng vỉa hè bán mũ bảo hiểm "rởm" đã phải dè chừng, số người đội mũ bảo hiểm "rởm" ở Hà Nội có giảm.

Tuy vậy, đến giai đoạn cưỡng chế ngày 1 tháng 7 năm 2014 Kế hoạch 69/KH-UBATGTQG không thành công, nguyên nhân là:

- Không có chế tài xử phạt người đi xe máy đội mũ không phải mũ bảo hiểm cho người đi mô tô, xe gắn máy (Kế hoạch 69/KH-UBATGTQG quy định đối tượng đội mũ không phải mũ bảo hiểm cho người đi mô tô, xe gắn máy bị xử phạt theo Nghị định 
171/2013/NĐ-CP và phải giao nộp để tiêu hủy là không đúng quy định của Nghị định 171/2013/NĐ-CP).

- Lực lượng Cảnh sát không tham gia xử phạt người đi xe máy đội máy không phải mũ bảo hiểm. Như vậy, việc phối hợp không chặt chẽ.

Tựu trung lại, đến thời điểm này, vấn đề người đi xe máy đội mũ không phải mũ bảo hiểm chưa giải quyết được. Nếu càng để kéo dài, số mũ bảo hiểm "rởm" càng nhiều thì giải quyết càng khó khăn.

\subsubsection{Kết luận}

Với số lượng lớn xe máy như hiện nay, việc duy trì nâng cao hiệu quả của quy định bắt buộc đội mũ bảo hiểm khi đi xe máy vẫn là giải pháp quan trọng để có thể giảm số người bị chết, bị chấn thương sọ não vì tai nạn giao thông.

Từ đầu năm 2018, sau khi tổng kết 10 năm thực hiện quy định bắt buộc đội mũ bảo hiểm khi đi xe máy, Thủ tướng Chính phủ đã ban hành Chỉ thị 04/CT-TTg ngày 19 tháng 01 năm 2018 về việc đẩy mạnh triển khai các giải pháp nhằm nâng cao hiệu quả thực hiện quy định bắt buộc đội mũ bảo hiểm đối với người đi mô tô, xe gắn máy, xe đạp điện là thuận lợi để giải quyết những tồn tại như nêu trên.

Ngoài việc kiên trì làm tốt công tác tuyên truyền, phổ biến, giáo dục về trật tự an toàn giao thông, cần quan tâm nhiều hơn cho vùng nông thôn, vùng núi, nơi xa xôi, hẻo lánh; những năm gần đây tai nạn giao thông ở những vùng này đang có xu hướng tăng. Trong thời gian tới với chủ trương tăng cường lực lượng công an xã chính quy của Chính phủ cũng tạo điều kiện để làm tốt thực hiện quy định bắt buộc đội mũ bảo hiểm khi đi xe máy.

Đến thời điểm này, thực hiện quy định bắt buộc đội mũ bảo hiểm khi đi xe máy đã được 10 năm, đội mũ bảo hiểm đã thành thói quen của đại đa số người dân Việt Nam, số vi phạm là số nhỏ vì vậy cần phải tăng mức xử phạt về hành vi không đội mũ bảo hiểm khi đi xe máy lên mức cao hơn để tăng sức răn đe.

Đối với việc đội mũ bảo hiểm cho trẻ em, nhất là đối với học sinh trên 6 tuổi trở lên, Ủy ban An toàn giao thông Quốc gia phối hợp với Bộ Giáo dục và Đào tạo tiếp tục tuyên truyền, giáo dục, vận động, năm 2018 Công ty Honda tài trợ một số lượng lớn mũ bảo hiểm cho học sinh lớp một là một thuận lợi cho công tác tuyên truyền. Tuy nhiên, cần công bố thời điểm toàn quốc xử lý người lớn không đội mũ bảo hiểm cho trẻ em khi đi xe máy.

Để tiếp tục xử lý hiệu quả với người sản xuất mũ bảo hiểm không đảm bảo chất lượng, mũ bảo hiểm "rởm" theo quy định của pháp luật về sản xuất, lưu thông hàng hóa; đối với người đi xe máy đội mũ không phải mũ bảo hiểm cho người đi xe máy nên nghiên cứu kỹ phương án xử lý, bổ sung sửa đổi Nghị định 46/2016/NĐ-CP để xử lý, trước hết tập trung giải quyết ở Hà Nội, Hà Nội là địa phương có số người sử dụng mũ bảo hiểm "rởm" nhiều nhất.

\subsection{Công tác tuyên truyền, phổ biến, giáo dục pháp luật trật tự an toàn giao thông}

Mặc dù không có văn bản quy phạm pháp luật riêng về tuyên truyền, phổ biến, giáo dục pháp luật về trật tự an toàn giao thông, song tất cả câc Nghị quyết của Chính phủ về bảo đảm trật tự an toàn giao thông đều coi công tác tuyên truyền, phổ biến, giáo dục pháp luật về trật tự an toàn giao thông là biện pháp quan trọng, hàng đầu nhằm từng bước nâng cao nhận thức, ý thức cho 
mọi tầng lớp nhân dân về trật tự an toàn giao thông, coi đây là giải pháp giảm thiểu tai nạn giao thông bền vững.

Những văn bản về tuyên truyền, phổ biến, giáo dục pháp luật về trật tự an toàn giao thông:

- Quyết định số 1928/QĐ-TTg ngày 20 tháng 11 năm 2009 của Thủ tướng Chính phủ về việc phê duyệt Đề án Nâng cao chất lượng công tác phổ biến, giáo dục pháp luật trong nhà trường.

- Chỉ thị số 52/2007/CT-BGDĐT ngày 31 tháng 8 năm 2007 của Bộ trưởng Bộ Giáo dục và Đào tạo về việc tăng cường công tác giáo dục $\mathrm{ATGT}$ trong các cơ sở giáo dục.

- Quyết định số 28/2008/QĐ-BGTVT ngày 11 tháng 12 năm 2008 của Bộ trưởng Bộ Giao thông vận tải ban hành chương trình phổ biến giáo dục pháp luật của Bộ Giao thông vận tải từ năm 2008 đến năm 2012.

- Quyết định số 983/QĐ - BGTVT ngày 04 tháng 5 năm 2012 của Bộ trưởng Bộ Giao thông vận tải Phê duyệt Đề án "Đổi mới, tiếp tục nâng cao chất lượng và hiệu quả công tác tuyên truyền,phổ biến, giáo dục pháp luật về an toàn giao thông giai đoạn 2012 2016 của Bộ Giao thông vận tải”

\subsubsection{Tuyên truyền, phổ biến, giáo dục pháp luật về trật tự an toàn giao thông trong nhà trường}

Số học sinh, sinh viên toàn quốc năm 2015 khoảng 22,21 triệu em, trong đó có: 4,42 triệu trẻ em mầm non, 15,08 triệu học sinh phổ thông, 0,35 triệu học sinh trung cấp chuyên nghiệp và 2,36 triệu sinh viên đại học, cao đẳng. Tổng số giáo viên, giảng viên toàn quốc là 1,24 triệu người, trong đó có: 277.684 giáo viên mầm non, 856.730 giáo viên phổ thông, 10.911 giáo viền trung cấp chuyên nghiệp, 91.183 giảng viên đại học, cao đẳng và khoảng 300 nghìn cán bộ quản lý giáo dục các cấp ${ }^{57}$.

Với số lượng học sinh, sinh viên chiếm gần $24 \%$ dân số, đối tượng học sinh, sinh viên cần được quan tâm đặc biệt và phải được coi là đối tượng quan trọng trong hoạt động giao thông vận tải, đồng thời cũng là đối tượng dễ bị tổn thương khi tham gia giao thông. Về lâu dài, công tác tuyên truyền, phổ biến, giáo dục pháp luật TTATGT trong nhà trường là cơ sở để hình thành một thế hệ công dân mà việc chấp hành pháp luật TTATGT trở thành thói quen và đó là cốt lõi của giảm tai nạn giao thông một cách bền vững.

Tuyên truyền, phổ biến, giáo dục pháp luật trật tự an toàn giao thông trong nhà trường được quan tâm thực hiện ngay từ những năm 1995, đồng thời tổ chức ở các cập học từ mầm non đến đâi học, thông qua hai hình thức:

- Chương trình giảng dạy chính khóa.

- Chương trình hoạt động ngoài giờ học trên lớp.

Nội dung hoạt động tuyên truyền, phổ biến, giáo dục pháp luật trật tự an toàn giao thông các cấp học được xây dựng như sau:

1) Cấp học mầm non:

${ }^{57}$ Nguồn Bộ Giáo dục và Đào tạo năm 2015 
Từ năm 1995, nội dung giáo dục an toàn giao thông được đưa vào giảng dậy chính khóa với nội dung:

- Giúp cho trẻ biết về các các phương tiện giao thông.

- Giúp cho trẻ hiểu về những người điều khiển và phục vụ trên các phương tiện giao thông.

- Giúp cho trẻ biết một số điều cần thiết khi đi trên các các phương tiện giao thông.

- Giúp cho trẻ nắm được một số điều trong luật Giao thông đường bộ, cách đi bộ qua đường, nơi chơi an toàn v.v.

Các tài liệu hiện có: Bé học luật lệ giao thông, Bé đi đường, Bé làm quen với giao thông, Cha mẹ cần biết, Bộ tranh ngã tư đường phố, đi bộ trên vỉa hè, bộ lô-gô về phương tiện giao thông.

2) Cấp tiểu học:

Từ năm 1998- 1999, UBATGTQG phối hợp với Bộ GD\&ĐT tổ chức dạy thí điểm về ATGT trong trường tiểu học. Đến nay Bộ sách giáo khoa, sách giáo viên về ATGT từ lớp 1 đến lớp 5 khá tốt và ổn định. Đến nay dạy ATGT ở cấp tiểu học được triển khai ở tất cả 63 tỉnh, thành phố.

3) Cấp trung cơ sở, trung học phổ thông.

Năm 1998 hoàn thành biên soạn tài liệu “Giáo dục pháp luật về trật tự an toàn giao thông” dùng cho giáo viên giảng dậy tích hợp vào môn Giáo dục công dân. Năm 2001, bổ sung, chỉnh lý tài liệu, đồng thời biên soạn bộ tranh : "Biển báo giao thông". Các tiết học về an toàn giao thông được đưa vào chính khóa, $100 \%$ các trường thực hiện tốt.

4) Trường đại học, cao đẳng và trung học chuyên nghiệp.

Năm 2003, đã biên soạn xong cuốn: “Tài liệu giáo dục ATGT cho sinh viên, học sinh các trường đại học, cao đẳng và trung học chuyên nghiệp" và được đưa vào phổ biến cho học sinh, sinh viên, tổ chức tập huấn cho cán bộ làm công tác này của tất cả các trường đại học, cao đẳng và trung học chuyên nghiệp trong phạm vi toàn quốc.

Hàng năm, vào "Tuần sinh hoạt công dân-học sinh, sinh viên” đầu năm học, đầu khoá học, nội dung giáo dục pháp luật về ATGT được đưa vào nội dung bắt buộc đối với học sinh, sinh viên đầu khoá, được đánh giá thông qua chấm bài thu hoạch.

Bên cạnh việc giảng dạy chính khoá, công tác giáo dục an toàn giao thông ở các nhà trường cũng được thực hiện thông qua hoạt động giáo dục ngoài giờ lên lớp ở tất cả các cấp, bậc :

- Tổ chức thi tìm hiểu, giao lưu, sáng tác, biểu diễn văn nghệ với chủ đề an toàn giao thông. Tổ chức hoạt động truyền thông, các câu lạc bộ an toàn giao thông. Tham gia hoạt động tuyên truyền và giữ gìn trật tự an toàn giao thông trong cộng đồng.

- Tổ chức đăng ký cam kết thực hiện nghiêm túc luật lệ giao thông giữa học sinh trong cùng lớp, cùng trường, giữa nhà trường-gia đình-địa phương vV... Nghiêm cấm tình trạng học sinh không đủ tuổi quy định đi xe môtô, xe gắn máy đến trường. Khuyến khích học sinh, sinh viên sử dụng các phương tiện giao thông công cộng khi tham gia giao thông. 
- Tổ chức các Đội sinh viên tình nguyện, Đội Cờ đỏ, Đội thanh niên xung kích tham gia giữ gìn trật tự ATGT khu vực cổng trường và các tuyến phố trong giờ cao điểm.

- Các trường đại học, cao đẳng, trung học chuyên nghiệp đưa nội dung đánh giá ý thức chấp hành pháp luật về an toàn giao thông vào thang điểm đánh giá kết quả rèn luyện của học sinh, sinh viên. Đối với các trường phổ thông, nhà trường có hình thức kỷ luật nghiêm khắc những học sinh, sinh viên vi phạm quy định về trật tự an toàn giao thông.

\subsubsection{Tuyên truyền, phổ biến, giáo dục pháp luật TTATGT ở cộng đồng}

Chính phủ hết sức coi trọng việc tuyên truyền, phổ biến, giáo dục pháp luật trật tự an toàn giao thông ở cộng đồng, hàng năm đều bố trí kinh phí cho hoạt động này. Hoạt động này được làm rộng khắp, liên tục, thường xuyên với nhiều hình thưc đa dạng, phong phú với chủ trương là tuyên truyền, phổ biến, giáo dục phải pháp luật trật tự an toàn giao thông phải đến được với từng người dân, từng gia đình, làng xóm, tổ dân phố. Một trong những điểm đặc biệt nổi bật là hệ thống các đoàn thể chính trị-xã hội tham gia tuyên truyền, giáo dục pháp luật trật tự an toàn giao thông rất tích cực và mạnh mẽ. Các cơ quan truyền thông đã xác định được vai trò quan trọng trong hoạt động xã hội nên thường xuyên theo dõi, bám sát các chủ trương, chính sách về trật tự an toàn giao thông để tuyên truyền giáo dục, rất nhiều cơ quan báo chí mở chuyên mục về trật tự an toàn giao thông.

\subsubsection{Kết luận}

Hơn 20 năm qua, chúng ta đã quan tâm nhiều đến tuyên truyền, giáo dục, phổ biến pháp luật về trật tự an toàn giao thông và thật sự đến nay đã có những chuyển biến tích cực về nhận thức, ý thức, thay đổi hành vi của toàn dân khi tham gia giao thông, đồng thời cũng nâng cao được trách nhiệm, năng lực của các cơ quan nhà nước có trách nhiệm trong lĩnh vực bảo đảm trật tự an toàn giao thông. Tai nạn giao thông 10 năm qua liên tục giảm là kết quả, hiệu quả của công tác tuyên truyền trật tự an toàn giao thông.

Tuy vậy, so với yêu cầu của xã hội ngày càng phát triển, đòi hỏi chất lượng cuộc sống của người dân ngày càng cao thì an toàn giao thông hiện nay vẫn chưa đáp ứng được nguyện vọng của toàn dân. Vấn đề nâng cao nhận thức, ý thức, hành vi của người tham gia giao thông cần phải tiếp tục được quan tâm nhiều hơn nữa.

Thời gian qua hoạt động tuyên truyền, phổ biến, giáo dục pháp luật vẫn còn nhiều hạn chế, hiệu quả chưa cao. Trong thời gian tới để nâng cao hiệu quả của công tác tuyên truyền, phổ biến, giáo dục trật tự an toàn giao thông cần quan tâm các vấn đề sau:

1) Nâng cao tính chuyên nghiệp về truyền thông cho đội ngũ cán bộ chuyên môn về an toàn giao thông, tập trung đào tạo đội ngũ tuyên truyền viên an toàn giao thông.

2) Xây dựng kế hoạch truyền thông theo mục tiêu thống nhất trong toàn quốc, đặc biệt phối hợp được giữa truyền thông và cưỡng chế.

3) Đảm bảo kinh phí cho truyền thông trật tự an toàn giao thông. 
PHỤ LỤC

\section{VĂN BẢN QUY PHẠM PHÁP LUẠT \\ HƯỚNG DẪN THI HÀNH LUẬT GTĐB 2008}

\begin{tabular}{|c|c|c|}
\hline $\mathbf{T T}$ & Văn bản & $\begin{array}{l}\text { Số, ký hiệu, } \\
\text { ngày ban hành }\end{array}$ \\
\hline \multicolumn{3}{|c|}{ I. KẾT CẤU HẠ TẦ GIAO THÔNG ĐỪ̀̀NG BỘ } \\
\hline 1 & $\begin{array}{l}\text { Nghị định của Chính phủ về quản lý và bảo vệ kết cấu hạ tầng giao thông đường } \\
\text { bộ }\end{array}$ & $\begin{array}{l}11 / 2010 / \mathrm{NĐ}-\mathrm{CP} \\
\text { ngày } 24 / 02 / 2010\end{array}$ \\
\hline 2 & Nghị định của Chính phủ về Qũy Bảo trì đường bộ & $\begin{array}{l}\text { 18/2012/NĐ-CP } \\
\text { ngày } 13 / 3 / 2012\end{array}$ \\
\hline 3 & $\begin{array}{l}\text { Nghị định của Chính phủ quy định việc quản lý, sử dụng và khai thác tài sản kết } \\
\text { cấu hạ tầng giao thông đường bộ }\end{array}$ & $\begin{array}{l}\text { 10/2013/NĐ-CP } \\
\text { ngày } 11 / 01 / 2013\end{array}$ \\
\hline 4 & $\begin{array}{l}\text { Nghị định của Chính phủ sửa đổi, bổ sung một số điều của Nghị định số } \\
11 / 2010 / \mathrm{NĐ}-C P \text { ngày } 24 / 2 / 2010 \text { Quy định về quản lý và bảo vệ kêt cầu hạ tâng } \\
\text { giao thông đường bộ }\end{array}$ & $\begin{array}{l}\text { 100/2013/NĐ-CP } \\
\text { ngày 03/9/2013 }\end{array}$ \\
\hline 5 & $\begin{array}{l}\text { Nghị định về quản lý, khai thác và bảo trì công trình đường cao tốc 32/2014/NĐ- } \\
\text { CP ngày 22/4/2014 }\end{array}$ & $\begin{array}{l}\text { 32/2014/NĐ-CP } \\
\text { ngày 22/4/2014 }\end{array}$ \\
\hline 6 & $\begin{array}{l}\text { Nghị định sửa đổi, bổ sung một số điều của Nghị định số 18/2012/NĐ-CP ngày } \\
13 \text { tháng } 3 \text { năm } 2012\end{array}$ & $\begin{array}{l}\text { 56/2014/NĐ-CP } \\
\text { ngày 30/5/2014 }\end{array}$ \\
\hline 7 & $\begin{array}{l}\text { Nghị định sửa đổi một số Điều của Nghị định số 56/2014/NĐ-CP ngày } 30 \text { tháng } \\
5 \text { năm } 2014 \text { và Nghị định số } 18 / 2012 / \text { NĐ-CP ngày } 13 \text { tháng } 3 \text { năm } 2012 \text { của } \\
\text { Chính phủ về Quỹ bảo trì đường bộ. }\end{array}$ & $\begin{array}{l}\text { 28/2016/NĐ-CP } \\
\text { ngày } 20 / 04 / 2016\end{array}$ \\
\hline 8 & $\begin{array}{l}\text { Nghị định sửa đổi, bổ sung một số điều của Nghị định số } 11 / 2010 / \mathrm{NĐ}-\mathrm{CP} \text { ngày } \\
24 \text { tháng } 02 \text { năm } 2010 \text { của Chính phủ quy định về quản lý và bảo vệ kết cấu hạ } \\
\text { tầng giao thông đường bộ }\end{array}$ & $\begin{array}{l}\text { 64/2016/NĐ-CP } \\
\text { ngày } 01 / 7 / 2016\end{array}$ \\
\hline 9 & $\begin{array}{l}\text { Thông tư của Bộ GTVT quy định về chi phí thẩm tra ATGT đối với công trình } \\
\text { đường bộ xây dựng mới; công trình nâng cấp, cải tạo }\end{array}$ & $\begin{array}{l}\text { 45/2011/TT- } \\
\text { BGTVT ngày } \\
10 / 6 / 2011\end{array}$ \\
\hline 10 & $\begin{array}{l}\text { Thông tư của Bộ GTVT quy định về tổ chức và hoạt động của trạm kiểm tra tải } \\
\text { trọng xe trên đường bộ. }\end{array}$ & $\begin{array}{l}\text { 10/2012/TT- } \\
\text { BGTVT ngày } \\
12 / 4 / 2012\end{array}$ \\
\hline 11 & $\begin{array}{l}\text { Thông tư của Bộ GTVT quy định về việc xác định và xử lý vị trí nguy hiểm } \\
\text { thường xảy ra tai nạn giao thông trên đường bộ đang khai thác }\end{array}$ & $\begin{array}{l}\text { 26/2012/TT- } \\
\text { BGTVT ngày } \\
\text { 20/7/2012 }\end{array}$ \\
\hline 12 & $\begin{array}{l}\text { Thông tư quy định trách nhiệm và xử lý vi phạm trong quản lý, bảo trì kết cấu hạ } \\
\text { tầng GTĐB }\end{array}$ & $\begin{array}{l}\text { 31/2012/TT- } \\
\text { BGTVT ngày } \\
02 / 8 / 2012\end{array}$ \\
\hline 13 & $\begin{array}{l}\text { Thông tư quy định về tuần tra, kiểm tra bảo vệ kết cấu hạ tầng giao thông đường } \\
\text { bộ }\end{array}$ & $\begin{array}{l}\text { 47/2012/TT- } \\
\text { BGTVT ngày } \\
12 / 11 / 2012\end{array}$ \\
\hline 14 & $\begin{array}{l}\text { Thông tư ban hành Quy chuẩn quốc gia về trạm kiểm tra tải trọng xe } \\
(66: 2013 / \text { BGTVT) }\end{array}$ & $\begin{array}{l}\text { 09/2013/TT- } \\
\text { BGTVT ngày } \\
06 / 5 / 2013\end{array}$ \\
\hline
\end{tabular}


Dự án: Xây dựng chiến lược an toàn giao thông đối với xe máy và kế hoạch hành động: một khởi đầu của Việt Nam

\begin{tabular}{|c|c|c|}
\hline TT & Văn bản & $\begin{array}{l}\text { Số, ký hiệu, } \\
\text { ngày ban hành }\end{array}$ \\
\hline 15 & $\begin{array}{l}\text { Thông tư quy định về việc sử dụng kết cấu mặt đường bê tông xi măng trong xây } \\
\text { dựng giao thông đường bộ }\end{array}$ & $\begin{array}{l}\text { 12/2013/TT- } \\
\text { BGTVT ngày } \\
30 / 5 / 2013\end{array}$ \\
\hline 16 & $\begin{array}{l}\text { Thông tư quy định về quản lý, khai thác và bảo trì công trình đường bộ (thay thế } \\
\text { Thông tư } 10 / 2010 / T T-B G T V T \text { ngày 19/4/2010 quy định về công tác quản lý bảo } \\
\text { trì đường bộ) }\end{array}$ & $\begin{array}{l}\text { 52/2013/TT- } \\
\text { BGTVT ngày } \\
12 / 12 / 2013\end{array}$ \\
\hline 17 & $\begin{array}{l}\text { Thông tư hướng dẫn công tác thiết kế, thi công, nghiệm thu cầu treo và cầu trên } \\
\text { đường dân sinh, đường giao thông nông thôn }\end{array}$ & $\begin{array}{l}\text { 11/2014/TT- } \\
\text { BGTVT ngày } \\
29 / 4 / 2014\end{array}$ \\
\hline 18 & $\begin{array}{l}\text { Thông tư hướng dẫn về quy trình khai thác, vận hành, quản lý cầu treo, cầu trên } \\
\text { đường dân sinh, đường giao thông nông thôn }\end{array}$ & $\begin{array}{l}\text { 12/2014/TT- } \\
\text { BGTVT ngày } \\
29 / 4 / 2014\end{array}$ \\
\hline 19 & $\begin{array}{l}\text { Thông tư sửa đổi, bổ sung một số điều của Thông tư số 52/2013/TT-BGTVT } \\
\text { ngày } 12 / 12 / 2013 \text { về quản lý, khai thác và bảo trì công trình đường bộ }\end{array}$ & $\begin{array}{l}\text { 20/2014/TT- } \\
\text { BGTVT ngày } \\
30 / 5 / 2014\end{array}$ \\
\hline 20 & $\begin{array}{l}\text { Thông tư hướng dẫn xây dựng quy trình vận hành, khai thác bến phà, bến khách } \\
\text { ngang sông sử dụng phà một lưỡi chở hành khách và xe ô tô }\end{array}$ & $\begin{array}{l}\text { 22/2014/TT- } \\
\text { BGTVT ngày } \\
06 / 6 / 2014\end{array}$ \\
\hline 21 & $\begin{array}{l}\text { Thông tư hướng dẫn đấu thầu, đă̆t hàng sản xuất và cung ứng sản phẩm, dịch vụ } \\
\text { công ích quản lý, bảo trì công trình đường bộ sử dụng Quỹ bảo trì đường bộ trung } \\
\text { ương }\end{array}$ & $\begin{array}{l}\text { 31/2014/TT- } \\
\text { BGTVT ngày } \\
05 / 8 / 2014\end{array}$ \\
\hline 22 & Thông tư hướng dẫn về quản lý, vận hành khai thác đường giao thông nông thôn. & $\begin{array}{l}\text { 32/2014/TT- } \\
\text { BGTVT ngày } \\
08 / 8 / 2014\end{array}$ \\
\hline 23 & $\begin{array}{l}\text { Thông tư quy định về tổ chức, quản lý hoạt động kinh doanh vận tải bằng xe ô tô } \\
\text { và dịch vụ hỗ trợ vận tải đường bộ (thay thể Thông tư 18/2013, Thông tư } \\
\text { 23/2014) }\end{array}$ & $\begin{array}{l}\text { 84/2014/TT- } \\
\text { BGTVT ngày } \\
31 / 12 / 2014\end{array}$ \\
\hline 24 & $\begin{array}{l}\text { Thông tư hướng dẫn một số nội dung về quản lý, khai thác và bảo trì công trình } \\
\text { đường cao tốc }\end{array}$ & $\begin{array}{l}\text { 90/2014/TT- } \\
\text { BGTVT ngày } \\
31 / 12 / 2014\end{array}$ \\
\hline 25 & Thông tư quy định về định mức chi phí cứu hộ trên đường cao tốc & $\begin{array}{l}08 / 2015 / \text { TT- } \\
\text { BGTVT ngày } \\
14 / 4 / 2015\end{array}$ \\
\hline 26 & $\begin{array}{l}\text { Thông tư sửa đổi, bổ sung một số điều của Thông tư số 11/2014/TT-BGTVT } \\
\text { ngày } 29 \text { tháng } 4 \text { năm } 2014 \text { của Bộ trưởng Bộ Giao thông vận tải hướng dẫn công } \\
\text { tác thiết kế, thi công và nghiệm thu cầu treo dân sinh }\end{array}$ & $\begin{array}{l}\text { 38/2015/TT- } \\
\text { BGTVT ngày } \\
30 / 7 / 2015\end{array}$ \\
\hline 27 & $\begin{array}{l}\text { Thông tư quy định về tải trọng, khổ giới hạn của đường bộ; lưu hành xe quá tải } \\
\text { trọng, khồ giới hạn, xe bánh xích trên đường bộ; vận chuyê̂n hàng siêu trường, } \\
\text { siêu trọng; giới hạn xếp hàng hóa trên phương tiện giao thông đường bộ khi tham } \\
\text { gia giao thông trên đường bộ }\end{array}$ & $\begin{array}{l}\text { 46/2015/TT- } \\
\text { BGTVT ngày } \\
07 / 9 / 2015\end{array}$ \\
\hline
\end{tabular}




\begin{tabular}{|c|c|c|}
\hline TT & Văn bản & $\begin{array}{l}\text { Số, ký hiệu, } \\
\text { ngày ban hành }\end{array}$ \\
\hline 28 & $\begin{array}{l}\text { Thông tư hướng dẫn thực hiện một số điều của Nghị định số 11/2010/NĐ-CP } \\
\text { ngày } 24 \text { tháng } 02 \text { năm } 2010 \text { của Chính phủ quy định về quản lý và bảo vệ kêt cấu } \\
\text { hạ tầng giao thông đường bộ }\end{array}$ & $\begin{array}{l}\text { 50/2015/TT- } \\
\text { BGTVT ngày } \\
\text { 23/9/2015 }\end{array}$ \\
\hline 29 & $\begin{array}{l}\text { Thông tư quy định về tốc độ và khoảng cách của xe cơ giới, xe máy chuyên dùng } \\
\text { tham gia giao thông đường bộ }\end{array}$ & $\begin{array}{l}91 / 2015 / \text { TT- } \\
\text { BGTVT ngày } \\
31 / 12 / 2015\end{array}$ \\
\hline 30 & Thông tư ban hành quy chuẩn kỹ thuật quốc gia về báo hiệu đường bộ & $\begin{array}{l}\text { 06/2016/TT- } \\
\text { BGTVT ngày } \\
08 / 4 / 2016\end{array}$ \\
\hline 31 & $\begin{array}{l}\text { Thông tư quy định khung giá dịch vụ sử dụng phà thuộc tuyến quốc lộ được đầu } \\
\text { tư bằng nguồn vốn ngân sách nhà nước do Trung ương quản lý; }\end{array}$ & $\begin{array}{l}34 / 2016 / \text { TT- } \\
\text { BGTVT ngày } \\
15 / 11 / 2016\end{array}$ \\
\hline 32 & $\begin{array}{l}\text { Thông tư quy định mức giá tối đa dịch vụ sử dụng đường bộ các dự án đầu tư } \\
\text { xây dựng đường bộ để kinh doanh do Bộ Giao thông vận tải quản lý }\end{array}$ & $\begin{array}{l}35 / 2016 / \text { TT- } \\
\text { BGTVT ngày } \\
15 / 11 / 2016\end{array}$ \\
\hline 33 & $\begin{array}{l}\text { Thông tư quy định về xây dựng, tổ chức và hoạt động của trạm thu giá dịch vụ } \\
\text { sử dụng đường bộ }\end{array}$ & $\begin{array}{l}\text { 49/2016/TT- } \\
\text { BGTVT ngày } \\
\text { 30/12/2016 }\end{array}$ \\
\hline 34 & $\begin{array}{l}\text { Thông tư quy định về đào tạo thẩm tra viên và quản lý chứng chỉ thẩm tra viên } \\
\text { an toàn giao thông đường bộ. }\end{array}$ & $\begin{array}{l}\text { 29/2017/TT- } \\
\text { BGTVT } \\
\text { ngày 01/9/2017 }\end{array}$ \\
\hline 35 & $\begin{array}{l}\text { Thông tư sửa đổi, bổ sung một số điều của Thông tư số 50/2015/TT-BGTVT } \\
\text { ngày } 23 \text { tháng } 9 \text { năm } 2015 \text { của Bộ trương Bộ Giao thông vận tải hướng dẫn một } \\
\text { số điều của Nghị định số } 11 / 2010 / \text { NĐ-CP ngày } 24 \text { tháng } 02 \text { năm } 2010 \text { của Chính } \\
\text { phủ quy định về quản lý và bảo vệ kêt cấu hạ tầng giao thông đường bộ. }\end{array}$ & $\begin{array}{l}35 / 2017 / \text { TT- } \\
\text { BGTVT } \\
\text { ngày 09/10/2017 }\end{array}$ \\
\hline 36 & $\begin{array}{l}\text { Thông tư sửa đổi, bổ sung một số điều của Thông tư 31/2014/TT-BGTVT ngày } \\
\text { 05/8/2014 hướng dẫn đâu thâu, đặt hàng sản xuất và cung ứng sản phẩm, dịch vụ } \\
\text { công ích quản lý, bảo trì công trình đường bộ sử dụng Quỹ bảo trì đường bộ trung } \\
\text { ương }\end{array}$ & $\begin{array}{l}\text { 38/2017/TT- } \\
\text { BGTVT ngày } \\
01 / 11 / 2017\end{array}$ \\
\hline \multicolumn{3}{|c|}{ II. ĐÀO TẠO, SÁT HẠCH CẤP GIÁY PHÉP LÁI XE } \\
\hline 37 & $\begin{array}{l}\text { Nghị định quy định về điều kiện kinh doanh dịch vụ đào tạo lái xe ô tô và dịch vụ } \\
\text { sát hạch lái xe } \\
\text { Nghị định số } 138 / 2018 / \mathrm{NĐ}-\mathrm{CP} \text { sửa đổi, bổ sung một số điều Nghị định số } \\
\text { 65/2016/NĐ-CP ngày 01/7/2016 của Chính phủ quy định về điều kiện kinh doanh } \\
\text { dịch vụ đào tạo lái xe ô tô và dịch vụ sát hạch lái xe. }\end{array}$ & $\begin{array}{l}\text { 65/2016/NĐ-CP } \\
\text { ngày } 01 / 7 / 2016 \\
138 / 2018 / \mathrm{NĐ}- \\
\mathrm{CP} \text { ngày } 8 \\
/ 10 / 2018 \\
\end{array}$ \\
\hline 38 & $\begin{array}{l}\text { Thông tư của Bộ GTVT quy định về bồi dưỡng kiến thức pháp luật về giao thông } \\
\text { đường bộ cho người điều khiền xe máy chuyên dùng tham gia giao thông đường } \\
\text { bộ }\end{array}$ & $\begin{array}{l}\text { 09/2009/TT- } \\
\text { BGTVT ngày } \\
\text { 24/6/2009 }\end{array}$ \\
\hline 39 & Thông tư của Bộ GTVT phê duyệt mẫu GPLX mới & $\begin{array}{l}\text { 35/2010/TT- } \\
\text { BGTVT ngày } \\
15 / 11 / 2010\end{array}$ \\
\hline 40 & $\begin{array}{l}\text { Thông tư của Bộ GTVT quy định về bồi dưỡng kiến thức pháp luật về giao thông } \\
\text { đường bộ cho người điều khiển xe máy chuyên dùng tham gia giao thông đường } \\
\text { bộ (thay thế Thông tư 09/2009/TT-BGTVT) }\end{array}$ & $\begin{array}{l}\text { 06/2011/TT- } \\
\text { BGTVT ngày } \\
\text { 07/3/2011 }\end{array}$ \\
\hline
\end{tabular}


Dự án: Xây dựng chiến lược an toàn giao thông đối với xe máy và kế hoạch hành động: một khởi đầu của Việt Nam

Nghiên cứu hiện trạng giao thông xe máy Việt Nam

\begin{tabular}{|c|c|c|}
\hline TT & Văn bản & $\begin{array}{l}\text { Số, ký hiệu, } \\
\text { ngày ban hành }\end{array}$ \\
\hline 41 & $\begin{array}{l}\text { Thông tư của Bộ GTVT ban hành "Quy chuẩn quốc gia về trung tâm sát hạch lái } \\
\text { xe" (40:2012/BGTVT) }\end{array}$ & $\begin{array}{l}18 / 2012 / \text { TT- } \\
\text { BGTVT ngày } \\
\text { 06/6/2012 }\end{array}$ \\
\hline 42 & $\begin{array}{l}\text { Thông tư quy định về quản lý, vận hành và khai thác hệ thống thông tin giấy phép } \\
\text { lái xe }\end{array}$ & $\begin{array}{l}\text { 07/2013/TT- } \\
\text { BGTVT ngày } \\
\text { 3/5/2013 }\end{array}$ \\
\hline 43 & Thông tư quy định về cấp, sử dụng giấy phép lái xe quốc tế & $\begin{array}{ll}\text { 29/2015/TT- } \\
\text { BGTVT ngày } \\
\text { 6/7/2015 }\end{array}$ \\
\hline 44 & $\begin{array}{l}\text { Thông tư ban hành Quy chuẩn kỹ thuật quốc gia về trung tâm sát hạch lái xe } \\
\text { (QCVN 40:2015/BGTVT) }\end{array}$ & $\begin{array}{l}\text { 79/2015/TT- } \\
\text { BGTVT ngày } \\
\text { 10/12/2015 } \\
\end{array}$ \\
\hline 45 & $\begin{array}{l}\text { Thông tư sửa đổi, bổ sung một số điều của Thông tư số 06/2012/TT-BGTVT ngày } \\
08 \text { tháng } 3 \text { năm } 2012 \text { của Bộ trưởng Bộ Giao thông vận tải quy định trách nhiệm } \\
\text { và xử lý vi phạm trong công tác đào tạo, sát hạch, cấp giấy phép lái xe cơ giới } \\
\text { đường bộ }\end{array}$ & $\begin{array}{l}\text { 85/2015/TT- } \\
\text { BGTVT ngày } \\
\text { 30/12/2015 }\end{array}$ \\
\hline 46 & Thông tư quy định về đào tạo, sát hạch, cấp giấy phép lái xe cơ giới đường bộ. & \begin{tabular}{|l|} 
12/2017/TT- \\
BGTVT ngày \\
$15 / 4 / 2017$ \\
\end{tabular} \\
\hline 47 & $\begin{array}{l}\text { Quy định về tiêu chuẩn sức khỏe của người lái xe, việc Thông tư liên tịch Bộ } \\
\text { GTVT, Bô Y tếkhám sức khỏe đối với người lái xe, khám sức khỏe định kỳ đối với } \\
\text { người lái xe ô tô và quy định về cơ sở y tế khám sức khỏe cho người lái xe }\end{array}$ & $\begin{array}{l}\text { 24/2015/TTLT } \\
\text { BYT -BGTVT } \\
\text { ngày } 21 / 8 / 2015\end{array}$ \\
\hline \multicolumn{3}{|c|}{ III. VĂN BẢN ĐĂNG KÝ XE } \\
\hline 48 & Thông tư quy định về đăng ký xe. & $\begin{array}{l}\text { 15/2014/TT- } \\
\text { BCA ngày } 04 / 4 \\
\text { /2014 } \\
\end{array}$ \\
\hline 49 & $\begin{array}{l}\text { Thông tư sửa đổi một số điều của Thông tư số 20/2010/TT-BGTVT ngày } 30 \text { tháng } \\
7 \text { năm } 2010 \text { của Bộ trưởng Bộ Giao thông vận tải quy định về cấp, đồi, thu hồi } \\
\text { đăng ký, biển số xe máy chuyên dùng có tham gia giao thông đường bộ }\end{array}$ & $\begin{array}{l}\text { 59/2011/TT- } \\
\text { BGTVT ngày } \\
\text { 05/12/2011 }\end{array}$ \\
\hline 50 & $\begin{array}{l}\text { Thông tư của Bộ GTVT quy định về cấp, đổi, thu hồi đăng ký, biển số xe máy } \\
\text { chuyên dùng có tham gia giao thông đường bộ (Thay thế Thông tư 24/2009/TT- } \\
\text { BGTVT). }\end{array}$ & $\begin{array}{l}\text { 20/2010/TT- } \\
\text { BGTVT ngày } \\
30 / 7 / 2010\end{array}$ \\
\hline 51 & $\begin{array}{l}\text { Thông tư của Bộ GTVT quy định về cấp, đổi, thu hồi đăng ký, biển số xe máy } \\
\text { chuyên dùng có tham gia giao thông đường bộ. }\end{array}$ & $\begin{array}{l}\text { 24/2009/TT- } \\
\text { BGTVT ngày } \\
15 / 10 / 2009\end{array}$ \\
\hline 52 & $\begin{array}{l}\text { Thông tư sửa đổi, bổ sung một số điều của Thông tư 15/2014/TT- BCA ngày } 04 \\
\text { tháng } 4 \text { năm } 2014 \text { quy định về đăng ký xe. }\end{array}$ & $\begin{array}{l}\text { 64/2017/TT- } \\
\text { BCA ngày } 28 \\
/ 12 / 2017\end{array}$ \\
\hline \multicolumn{3}{|c|}{ IV. VĂN BẢN KIỂM TRA CHẤT LƯợNG ATKT VÀ BẢO VỆ MÔI TRƯờNG } \\
\hline 53 & $\begin{array}{l}\text { Thông tư Quy định về kiểm tra chất lượng an toàn kỹ thuật và bảo vệ môi trường } \\
\text { trong sản xuất, lắp ráp mô tô, xe gắn máy; }\end{array}$ & $\begin{array}{l}\text { 45/2012/TT - } \\
\text { BGTVT ngày } \\
23 / 10 / 2012\end{array}$ \\
\hline
\end{tabular}




\begin{tabular}{|c|c|c|}
\hline TT & Văn bản & $\begin{array}{l}\text { Số, ký hiệu, } \\
\text { ngày ban hành }\end{array}$ \\
\hline 54 & $\begin{array}{l}\text { Thông tư Quy định về kiểm tra chất lượng an toàn kỹ thuật và bảo vệ môi trường } \\
\text { xe mô tô, xe gắn máy nhập khẩu và động cơ nhập khẩu sử dụng đề sản xuất, lắp } \\
\text { ráp xe mô tô, xe gắn máy. }\end{array}$ & $\begin{array}{l}\text { 44/2012/TT- } \\
\text { BGTVT ngày } \\
23 / 10 / 2012\end{array}$ \\
\hline 55 & $\begin{array}{l}\text { QCVN 14:2015/BGTVT Quy chuẩn kỹ thuật Quốc gia về chất lượng an toàn kỹ } \\
\text { thuật và bảo vệ môi trường đối với xe mô tô, xe gắn máy }\end{array}$ & $\begin{array}{l}\text { Thông tư số } \\
67 / 2015 / \text { TT- } \\
\text { BGTVT ngày } \\
06 / 11 / 2015 \text {. }\end{array}$ \\
\hline 56 & $\begin{array}{l}\text { QCVN 04:2009/BGTVT Quy chuẩn Quốc gia về khí thải xe mô tô hai bánh sản } \\
\text { xuất, lắp ráp và nhập khẩu mới }\end{array}$ & $\begin{array}{l}\text { số } 30 / 2009 / \text { TT- } \\
\text { BGTVT ngày } \\
19 / 11 / 2009 \text {. }\end{array}$ \\
\hline 57 & $\begin{array}{l}\text { QCVN 77:2014/BGTVT Quy chuẩn Quốc gia về khí thải mức } 3 \text { đối với xe mô tô } \\
\text { hai bánh sản xuất, lắp ráp và nhập khẩu mới }\end{array}$ & $\begin{array}{l}\text { Thông tư } \\
45 / 2014 / T T- \\
\text { BGTVT ngày } \\
03 / 10 / 2014 \text {. }\end{array}$ \\
\hline 58 & $\begin{array}{l}\text { Quyết định của Thủ tướng Chính phủ về việc quy định lộ trình áp dụng tiêu chuẩn } \\
\text { khí thải đối với xe ô tô, xe mô tô hai bánh sản xuất, lắp ráp và nhập khẩu mới }\end{array}$ & $\begin{array}{l}\text { 49/2011/QĐ- } \\
\text { TTg ngày } 01 / 9 \\
\text { / } 2011\end{array}$ \\
\hline 59 & $\begin{array}{l}\text { Thông tư Quy định về kiểm định an toàn kỹ thuật và bảo vệ môi trường phương } \\
\text { tiện giao thông đường bộ }\end{array}$ & $\begin{array}{l}\text { 70/2015/TT- } \\
\text { BGTVT ngày } \\
09 / 11 / 2015\end{array}$ \\
\hline 60 & $\begin{array}{l}\text { Thông tư ban hành QCVN 09:2011/BGTVT, QCVN 10:2011/BGTVT, QCVN } \\
\text { 11:2011/BGTVT, QCVN 12: 2011/ BGTVT, QCVN 13:2011/BGTVT, QCVN } \\
\text { 14:2011/BGTVT }\end{array}$ & $\begin{array}{l}\text { số } 56 / \text { TT- } \\
\text { BGTVT ngày } \\
17 / 11 / 2011\end{array}$ \\
\hline 61 & Quyết định scủa Thủ tướng Chính phủ Quy định thu hồi, xử lý sản phẩm thải bỏ. & $\begin{array}{l}16 / 2015 / \mathrm{Q} \text { - } \\
\text { TTg ngày } 22 / 5 \\
\text { / } 2015\end{array}$ \\
\hline \multicolumn{3}{|c|}{ V. VĂN BẢN TUẦ TRA, KIỂM SOÁT XỦ̉ LÝ VI PHẠM } \\
\hline 62 & $\begin{array}{l}\text { Thông tư của Bộ Công an Quy định nhiệm vụ, quyền hạn, hình thức, nội dung tuần } \\
\text { tra, kiềm soát giao thông đường bộ của cảnh sát giao thông. }\end{array}$ & $\begin{array}{l}\text { 01/2016/TT- } \\
\text { BCAngày } 04 / 1 \\
\text { /2016 }\end{array}$ \\
\hline 63 & $\begin{array}{l}\text { Nghị định của Chính phủ quy định việc huy động các lực lượng Cảnh sát khác và } \\
\text { Công an xã phối hợp với Cảnh sát giao thông đường bộ tham gia tuần tra, kiểm } \\
\text { soát trật tự, an toàn giao thông đường bộ trong trường hợp cần thiết }\end{array}$ & $\begin{array}{l}27 / 2010 / \mathrm{NĐ}-\mathrm{CP} \\
\text { ngày } 24 / 3 \\
/ 2010\end{array}$ \\
\hline 64 & $\begin{array}{l}\text { Thông tư scủa Bộ trưởng Bộ Công an quy định chi tiết thi hành một số điều của } \\
\text { Nghị định số } 27 / 2010 / \mathrm{NĐ}-\mathrm{CP} \text {. }\end{array}$ & $\begin{array}{l}\text { 47/2011/TT- } \\
\text { BCA } \\
\text { ngày } 02 / 7 / 7 \\
2011\end{array}$ \\
\hline
\end{tabular}




\begin{tabular}{|c|c|c|}
\hline TT & Văn bản & $\begin{array}{l}\text { Số, ký hiệu, } \\
\text { ngày ban hành }\end{array}$ \\
\hline 65 & $\begin{array}{l}\text { Nghị định của Chính phủ Quy định việc quản lý sử dụng và danh mục các phương } \\
\text { tiện, thiết bị kỹ thuật nghiệp vụ được sử dụng để phát hiện vi phạm hành chính về } \\
\text { trật tự an toàn giao thông và bảo vệ môi trường. }\end{array}$ & $\begin{array}{l}\text { 165/2013/NĐ- } \\
\text { CP ngày } 12 \\
/ 11 / 2013\end{array}$ \\
\hline 66 & $\begin{array}{l}\text { Thông tư của Bộ Công an Quy định việc quản lý sử dụng phương tiện, thiết bị kỹ } \\
\text { thuật nghiệp vụ trong Công an nhân dân đề phát hiện vi phạm hành chính về trật tự } \\
\text { an toàn giao thông và bảo vệ môi trường. }\end{array}$ & $\begin{array}{l}\text { số } 40 / 2015 / \text { TT- } \\
\text { BCA ngày } 24 / 8 \\
\text { /2015 }\end{array}$ \\
\hline 67 & $\begin{array}{l}\text { Thông tư liên tịchQuy định về xét nghiệm nồng độ cồn trong máu của người điều } \\
\text { khiền phương tiện cơ giưới đường bộ. }\end{array}$ & $\begin{array}{l}\text { 26/2014/TTLT } \\
\text { - BYT - BCA } \\
\text { ngày } \\
23 / 11 / 2014\end{array}$ \\
\hline \multicolumn{3}{|c|}{ VI. VĂN BẢN THỐNG KÊ PHÂN TÍCH TAI NẠN GIAO THÔNG } \\
\hline 68 & $\begin{array}{l}\text { Thông tư qui định và hướng dẫn, tổng hợp, xây dựng cơ sở dữ liệu, cung cấp thông } \\
\text { tin TNGT đường bộ. }\end{array}$ & $\begin{array}{l}\text { 58/2009/TTBC } \\
\text { A(C11) ngày } \\
28 / 10 / 2009\end{array}$ \\
\hline 69 & $\begin{array}{l}\text { Thông tư liên tịch Bộ Công an-Bộ Giao thông vận tải quy định về phối hợp cung } \\
\text { cấp số liệu đăng ký, đăng kiểm phương tiện giao thông có giới đường bộ , dữ liệu } \\
\text { tai nạn giao thông và cấp, đổi, thu hồi, tước quyển sử dụng giấy phép lái xe. }\end{array}$ & $\begin{array}{l}01 / 2010 / \text { TTLT } \\
-\quad \text { BCA - } \\
\text { BGTVT ngày } \\
30 / 3 \text { n2010 }\end{array}$ \\
\hline \multicolumn{3}{|c|}{ VII. VĂN BẢN QUẢN LÝ VÂN TẢI } \\
\hline 70 & $\begin{array}{l}\text { Nghị định của Chính phủ quy định xe ô tô của người nước ngoài đăng ký tại nước } \\
\text { ngoài có tay lái bên phải tham gia giao thông tại Việt Nam }\end{array}$ & $\begin{array}{l}\text { 80/2009/NĐ-CP } \\
\text { ngày } \\
01 / 10 / 2009\end{array}$ \\
\hline 71 & $\begin{array}{l}\text { Nghị định của Chính phủ quy định danh mục hàng nguy hiểm và vận chuyển hàng } \\
\text { nguy hiểm bằng phương tiện giao thông cơ giới đường bộ }\end{array}$ & $\begin{array}{l}\text { 104/2009/NĐ- } \\
\text { CP ngày } \\
09 / 11 / 2009\end{array}$ \\
\hline 72 & $\begin{array}{l}\text { Nghị định của Chính phủ quy định về quản lý phương tiện cơ giới do người nước } \\
\text { ngoài đưa vào Việt Nam du lịch. }\end{array}$ & $\begin{array}{l}\text { 152/2013/NĐ- } \\
\text { CP ngày } \\
04 / 11 / 2013\end{array}$ \\
\hline 73 & Nghị định về kinh doanh và điều kiện kinh doanh vận tải bằng xe ô tô & $\begin{array}{l}\text { 86/2014/NĐ-CP } \\
\text { ngày } 10 / 9 / 2014\end{array}$ \\
\hline 74 & $\begin{array}{l}\text { Thông tư của Bộ GTVT hướng dẫn việc sử dụng xe thô sơ, xe gắn máy, xe mô tô } \\
\text { hai bánh, xe mô tô ba bánh và các loại xe tương tự để vận chuyển hành khách, hàng } \\
\text { hoá }\end{array}$ & $\begin{array}{l}\text { 08/2009/TT- } \\
\text { BGTVT ngày } \\
\text { 23/6/2009 }\end{array}$ \\
\hline 75 & $\begin{array}{l}\text { Thông tư của Bộ GTVT hướng dẫn thực hiện Hiệp định vận tải đường bộ VN-CPC } \\
\text { đối với xe phi thương mại }\end{array}$ & $\begin{array}{l}\text { 18/2010/TT- } \\
\text { BGTVT ngày } \\
07 / 07 / 2010\end{array}$ \\
\hline 76 & $\begin{array}{l}\text { Thông tư của Bộ GTVT hướng dẫn Hiệp định và Nghị định thư vận tải đường bộ } \\
\text { Việt Nam-Trung Quốc }\end{array}$ & $\begin{array}{l}\text { 23/2012/TT- } \\
\text { BGTVT ngày } \\
\text { 29/6/2012 }\end{array}$ \\
\hline 77 & $\begin{array}{l}\text { Thông tư ban hành Quy chuẩn kỹ thuật quốc gia về trạm dừng nghỉ đường bộ } \\
(43: 2012 / B G T V T)\end{array}$ & $\begin{array}{l}\text { 48/2012/TT- } \\
\text { BGTVT ngày } \\
15 / 11 / 2012\end{array}$ \\
\hline
\end{tabular}




\begin{tabular}{|c|c|c|}
\hline TT & Văn bản & $\begin{array}{l}\text { Số, ký hiệu, } \\
\text { ngày ban hành }\end{array}$ \\
\hline 78 & $\begin{array}{l}\text { Thông tư ban hành Quy chuẩn kỹ thuật quốc gia về bến xe ô tô khách } \\
(45: 2012 / \text { BGTVT) }\end{array}$ & $\begin{array}{l}\text { 49/2012/TT- } \\
\text { BGTVT ngày } \\
12 / 12 / 2012\end{array}$ \\
\hline 79 & Thông tư quy định về xếp hàng trên xe ô tô & $\begin{array}{l}\text { 35/2013/TT- } \\
\text { BGTVT ngày } \\
21 / 10 / 2013\end{array}$ \\
\hline 80 & $\begin{array}{l}\text { Thông tư hướng dẫn thực hiện một số Điều của Bản ghi nhớ giữa Chính phủ các } \\
\text { nước Vương quốc Campuchia, Cộng hòa dân chủ nhân dân Lào và Cộng hòa xã hội } \\
\text { chủ nghĩa Việt Nam về vận tải đường bộ, }\end{array}$ & $\begin{array}{l}\text { 63/2013/TT- } \\
\text { BGTVT ngày } \\
31 / 12 / 2013\end{array}$ \\
\hline 81 & $\begin{array}{l}\text { Thông tư sửa đổi, bổ sung một số điều của Thông tư số 08/2009/TT-BGTVT ngày } \\
23 / 6 / 2009 \text { hướng dẫn việc sử dụng xe thô sơ, xe gắn máy, xe mô tô ba bánh và các } \\
\text { loại xe tương tự để vận chuyển hành khách, hàng hóa }\end{array}$ & $\begin{array}{l}\text { 46/2014/TT- } \\
\text { BGTVT ngày } \\
\text { 06/10/2014 }\end{array}$ \\
\hline 82 & $\begin{array}{l}\text { Thông tư quy định về tổ chức, quản lý hoạt động kinh doanh vận tải bằng xe ô tô và } \\
\text { dịch vụ hồ trợ vận tải đường bộ (thay thế Thông tư 18/2013, Thông tư 23/2014) }\end{array}$ & $\begin{array}{l}\text { 63/2014/TT- } \\
\text { BGTVT ngày } \\
07 / 11 / 2014\end{array}$ \\
\hline 83 & $\begin{array}{l}\text { Thông tư ban hành bổ sung quy chuẩn kỹ thuật quốc gia về thiết bị giám sát hành } \\
\text { trình xe ô tô QCVN 31:2014/BGTVT }\end{array}$ & $\begin{array}{l}\text { 73/2014/TT- } \\
\text { BGTVT ngày } \\
15 / 12 / 2014\end{array}$ \\
\hline 84 & $\begin{array}{l}\text { Thông tư hướng dẫn thực hiện một số điều của Hiệp định và Nghị định thư thực hiện } \\
\text { Hiệp định tạo điểu kiện thuận lợi cho phương tiện cơ giới đường bộ qua lại biên gới } \\
\text { giữa Chính phủ nước Cộng hòa xã hội chủ nghĩa Việt Nam và Chính phủ nước Cộng } \\
\text { hòa dân chủ nhân dân Lào. }\end{array}$ & $\begin{array}{l}\text { 88/2014/TT- } \\
\text { BGTVT ngày } \\
\text { 31/12/2014 }\end{array}$ \\
\hline 85 & $\begin{array}{l}\text { Thông tư sửa đổi, bổ sung một số điều của Thông tư số 29/2009/TT-BGTVT ngày } \\
17 \text { tháng } 11 \text { năm } 2009 \text { của Bộ Giao thông vận tải hướng dẫn thực hiện một số điều } \\
\text { của Hiệp định tạo thuận lợi vận tải người và hàng hóa qua lại biên giới giữa các nước } \\
\text { tiểu vưng Mê Công mở rộng }\end{array}$ & $\begin{array}{l}\text { 89/2014/TT- } \\
\text { BGTVT ngày31 } \\
\text { /12/2014 }\end{array}$ \\
\hline 86 & $\begin{array}{l}\text { Thông tư quy định về cung cấp, quản lý và sử dụng dữ liệu từ thiết bị giám sát hành } \\
\text { trình của xe ô tô (thay thế Thông tư số 23/2013/TT-BGTVT) }\end{array}$ & $\begin{array}{l}\text { 09/2015/TT- } \\
\text { BGTVT ngày } \\
15 / 4 / 2015\end{array}$ \\
\hline 87 & $\begin{array}{l}\text { Thông tư quy định trách nhiệm và xử lý vi phạm trong tổ chức, quản lý hoạt động } \\
\text { kinh doanh vận tải bằng xe ô tô và dịch vụ hồ trợ vận tải đường bộ (thay thế Thông } \\
\text { tư 55/2013/TT-BGTVT ngày 26/12/2013) }\end{array}$ & $\begin{array}{l}\text { 10/2015/TT- } \\
\text { BGTVT ngày } \\
15 / 4 / 2015\end{array}$ \\
\hline 88 & $\begin{array}{l}\text { Thông tư sửa đổi, bổ sung một số điều của Thông tư số 15/2014/TT-BGTVT hướng } \\
\text { dẫn về tuyến đường vận chuyê̂n quá cảnh hàng hóa qua lãnh thổ Việt Nam }\end{array}$ & $\begin{array}{l}\text { 17/2015/TT- } \\
\text { BGTVT ngày } \\
15 / 5 / 2015\end{array}$ \\
\hline
\end{tabular}




\begin{tabular}{|c|c|c|}
\hline 89 & $\begin{array}{l}\text { Thông tư hướng dẫn thi hành một số điều của Hiệp định thư và Nghị định thư thực } \\
\text { hiện Hiệp định vận tải đường bộ giữa Chính phủ nước Cộng hòa xã hội Chủ nghĩa } \\
\text { Việt Nam và Chính phủ Hoàng gia Campuchia }\end{array}$ & $\begin{array}{l}\text { 39/2015/TT- } \\
\text { BGTVT ngày } \\
31 / 7 / 2015\end{array}$ \\
\hline TT & Văn bản & $\begin{array}{l}\text { Số, ký hiệu, } \\
\text { ngày ban hành }\end{array}$ \\
\hline 90 & $\begin{array}{l}\text { Thông tư sửa đổi, bổ sung một số điều của Thông tư 63/2014/TT-BGTVT quy định } \\
\text { vể tổ chức và hoạt động vận tải bằng xe ô tô và dịch vụ hỗ trợ vận tải }\end{array}$ & $\begin{array}{l}\text { 60/2015/TT- } \\
\text { BGTVT ngày } \\
02 / 11 / 2015\end{array}$ \\
\hline 91 & $\begin{array}{l}\text { Thông tư sửa đổi, bổ sung một số điều của Thông tư số 49/2013/TT-BGTVT ban } \\
\text { hành quy chuẩn kỹ thuật quốc gia về bên xe ô tô khách }\end{array}$ & $\begin{array}{l}\text { 73/2015/TT- } \\
\text { BGTVT ngày } \\
11 / 11 / 2015\end{array}$ \\
\hline 92 & $\begin{array}{l}\text { Thông tư quy định về quy trình lựa chọn đơn vị khai thác tuyến vận tải hành khách } \\
\text { cố định bằng xe ô tô }\end{array}$ & $\begin{array}{l}\text { 92/2015/TT- } \\
\text { BGTVT ngày } \\
31 / 12 / 2015\end{array}$ \\
\hline 93 & $\begin{array}{l}\text { Thông tư quy định quy trình sử dụng phương tiện, thiết bị kỹ thuật nghiệp vư và sử } \\
\text { dụng kêt quả thu được từ phương tiện, thiết bị kỹ thuật nghiệp vụ làm căn cư để xác } \\
\text { định vi phạm hành chính và xử phạt vi phạm hành chính trong lĩnh vực giao thông } \\
\text { đường bộ }\end{array}$ & $\begin{array}{l}\text { 06/2017/TT- } \\
\text { BGTVT ngày } \\
\text { 28/02/2017 }\end{array}$ \\
\hline \multicolumn{3}{|c|}{ VIII. VĂN BẢN XỦ̉ LÝ VI PHẠM HÀNH CHÍNH } \\
\hline 94 & Quy định xử phạt vi phạt hành chính trong lĩnh vực giao thông đường bộ & $\begin{array}{l}34 / 2010 / \mathrm{NĐ-CP} \\
\text { ngày } 2 / 4 / 2010\end{array}$ \\
\hline 95 & $\begin{array}{l}\text { Sửa đổi, bổ sung một số điều của Nghị định 34/2010/NĐ-CP của chính phủ quy } \\
\text { định xử phạt vi phạm hành chính trong lịnh vực giao thông đường bộ }\end{array}$ & $\begin{array}{l}\text { 71/2012/NĐ-CP } \\
\text { ngày 19/9/2012 }\end{array}$ \\
\hline 96 & $\begin{array}{l}\text { Quy định xử phạt vi phạm hành chính trong lĩnh vực giao thông đường bộ và đường } \\
\text { sắt }\end{array}$ & $\begin{array}{l}171 / 2013 / \mathrm{NĐ}- \\
\mathrm{CP} \text { ngày } \\
13 / 11 / 2013\end{array}$ \\
\hline 97 & $\begin{array}{l}\text { Quy định xử phạt vi phạm hành chính trong lĩnh vực giao thông đường bộ và } \\
\text { đường sắt }\end{array}$ & $\begin{array}{l}\text { 46/2016/NDD0- } \\
\text { CP ngày } \\
26 / 5 / 2016\end{array}$ \\
\hline \multicolumn{3}{|c|}{ IX. VĂN BẢN ÚNG PHÓ SAU TNGT } \\
\hline 98 & $\begin{array}{l}\text { Quyết định về việc báo cáo các trường hợp tai nạn giao thông đến cấp cứu tại bệnh } \\
\text { viện. }\end{array}$ & $\begin{array}{l}\text { 1356/QĐ-BYT } \\
\text { ngày } 18 / 4 / 2008 \\
\end{array}$ \\
\hline 99 & $\begin{array}{l}\text { Quyết định về tiêu chuẩn kiến thức, kỹ năng của nhân viên y tế và trang thiết bị } \\
\text { trong chăm sóc chấn thương thiết yếu }\end{array}$ & $\begin{array}{l}\text { 12/2008/QĐ- } \\
\text { BYT ngày } \\
27 / 2.2008\end{array}$ \\
\hline 100 & Quyết định về việc ban hành quy chế cấp cứu, hồi sức tích cực và chống độc & $\begin{array}{l}01 \quad / 2008 / \text { QĐ- } \\
\text { BYT ngày } 21 \\
/ 01 / 2008\end{array}$ \\
\hline 101 & $\begin{array}{l}\text { Quyết định ban hành Quy định về đo nồng độ cồn (Ethanol) trong máu” áp dụng } \\
\text { trong các bệnh viện }\end{array}$ & $\begin{array}{l}\text { 933/QĐ-BYT } \\
\text { ngày 23/3/2010 }\end{array}$ \\
\hline 102 & $\begin{array}{l}\text { Quyết định của Thủ tướng Chính phủ Phê duyệt Đề án tổ chức cấp cứu tai nạn giao } \\
\text { thông trên mạng đường bộ cao tốc đến măm } 2020\end{array}$ & $\begin{array}{l}1203 / \mathrm{Q} \bigoplus-\mathrm{TTg} \\
\text { ngày } 19 \text { tháng } 7 \\
\text { năm } 2013\end{array}$ \\
\hline 103 & $\begin{array}{l}\text { Thông tư của Bộ Y tế Quy định tổ chức cấp cứu tai nạn giao thông trên đường cao } \\
\text { tốc. }\end{array}$ & $\begin{array}{l}\text { 49/2016/TT- } \\
\text { BYT ngày } 30 / \\
12 / 2016\end{array}$ \\
\hline
\end{tabular}




\begin{tabular}{|c|c|c|}
\hline $\begin{array}{c}\mathrm{X} \\
104\end{array}$ & $\begin{array}{l}\text { Quyết định của Thủ tướng Chính phủ ngàyPhê duyệt Đề án quy hoạch tổng thể } \\
\text { lĩnh vực tìm kiếm cứu nạn đến năm } 2015 \text { tầm nhìn } 2020 \text {. }\end{array}$ & $\begin{array}{l}46 / 2006 / \mathrm{Q} Đ- \\
\text { TTg ngày } 28 / \\
02 / 2006\end{array}$ \\
\hline 105 & $\begin{array}{l}\text { Nghị định của Chính phủ Quy định về công tác cứu hộ, cứu nạn của lực lượng } \\
\text { phòng cháy và chữa cháy }\end{array}$ & $\begin{array}{l}83 / 2017 / \mathrm{NĐ}- \\
\text { CP, } 18 \text { tháng } 7 \\
\text { năm } 2007\end{array}$ \\
\hline TT & Văn bản & $\begin{array}{l}\text { Số, ký hiệu, } \\
\text { ngày ban hành }\end{array}$ \\
\hline 106 & $\begin{array}{l}\text { Thông tư Quy định chi tiết một số điều của Nghị định 83/2017/NĐ- CP của Chính } \\
\text { phủ ngày } 18 \text { tháng } 7 \text { năm } 2007 \text { Quy định về công tác cứu hộ, cứu nạn của lực lượng } \\
\text { phòng cháy và chữa cháy. }\end{array}$ & \begin{tabular}{l}
\multicolumn{3}{l}{$08 / 2018 /$ TT- } \\
BCA ngày 05 \\
tháng 3 năm \\
2018
\end{tabular} \\
\hline 107 & $\begin{array}{l}\text { Quyết định của Thủ tướng Chính phủ Ban hành Quy chế quản lý tài chính đối với } \\
\text { hoạt động tìm kiếm cứu nạn, cứu hộ, ứng phó thiên tai, thảm họa. }\end{array}$ & $\begin{array}{l}118 / 2008 / \mathrm{Q} Đ- \\
\text { TTg ngày } 27 \text { / } 8 \\
\text { / } 2008\end{array}$ \\
\hline
\end{tabular}




\section{GIAO THÔNG XE MÁY: PHÂN TÍCH DŨ' LIỆ VÀ TỔNG HợP KẾT QUẢ NGHIÊN CÚU KHOA HỌC}

Trong các chương trước, giao thông xe máy Việt Nam đã được xem xét về các điều kiện kinh tế-xã hội, thể chế, các bài học về việc thực hiện chủ trương chính sách. Chương này dành riêng cho việc nghiên cứu hiện trạng giao thông xe máy theo hai cách: đánh giá trên cơ sở phân tích dữ liệu và dùng các dữ liệu này để khẳng định một số kết luận từ các công trình khoa học đã công bố.

Trật tự, an toàn là một yêu cầu thiết yếu đối với giao thông. Vì vậy, trật tự, an toàn giao thông xe máy cần được xem xét từ khuôn khổ tổng thể của giao thông xe máy. Một nhân tố quan trọng là sự tăng trưởng phương tiện. Việc bảo đảm an toàn giao thông đối với xe máy không thể tách rời với việc quản lý sự tăng trưởng của phương tiện giao thông này. Cơ sở khoa học chắc chắn cho khẳng định đó sẽ được đề cập đến sau, ngay trong chương này. Do đây là những nội dung gắn liền với nhau nên dự án này sẽ xem xét cả hai.

Trước hết là về tăng trưởng xe máy, những kết luận đánh giá phân tích dưới đây được chứng minh bằng cách nghiên cứu dữ liệu về số lượng xe máy từ nhiều năm trước cho đến hết 2017 , một số trường hợp, đến hết năm 2018.

Có hai nhóm dữ liệu quan trọng để xem xét đánh giá sự tăng trưởng của giao thông xe máy. Nhóm đầu tiên là các dữ liệu theo đăng ký tại cơ quan nhà nước, ký hiệu là $\mathrm{M}_{\mathrm{reg}}$. Đây là số liệu tích lũy từ nhiều năm và là số liệu chính thức vẫn được đưa ra trong các báo cáo hàng năm. Chương 2 đã đề cập đến những số liệu này và sẽ được sử dụng tiếp trong chương 3 khi so sánh với dữ liệu khác. Nhóm thứ hai là các dữ liệu về xe máy trong sở hữu và lưu thông, ký hiệu là

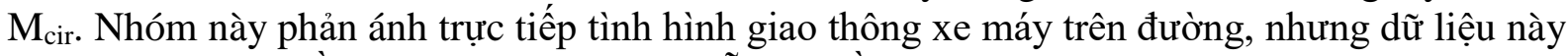
ở Việt Nam và nhiều nước khác không có sẵn mà cần có phương pháp tính toán ra.

Việc tìm và phân tích dữ liệu không chỉ đưa ra một bức tranh rõ ràng về hiện trạng, đặc biệt hơn, còn làm sáng tỏ một số quy luật trong giao thông xe máy. Cho đển nay, rất ít thông tin về những quy luật này vì chúng gần đây mới được phát hiện. Những quy luật khách quan này được tìm trên cơ sở phân tích các dữ liệu và có giá trị không nhỏ đối với việc hoạch định chủ trương, chính sách liên quan, tuy nhiên, đáng tiếc là hiện nay thông tin về chúng còn rất ít ỏi, và do vậy, các quy luật này còn ít được sử dụng trong thực tế.

Phần tiếp theo của chương 3 sẽ dành cho nhiều nội dung nghiên cứu về an toàn trong giao thông xe máy Việt Nam, cụ thể là về vấn đề TNGT, vấn đề vi phạm hành chính của người đi xe máy, về người lái xe máy và giấy phép lái xe (GPLX), về hành vi văn hóa giao thông. Chương này cũng đề cập vấn đề công cụ quản lý xe máy, vấn đề này đã được đề cập trong Chương 2 , nhưng ở đây phân tích thêm dưới góc độ khoa học theo quan điểm của Lý thuyết Hệ thống và Lý thuyết Quản lý.

Những kết luận trong chương này không chỉ có tác dụng rộng rãi trong việc quản lý xe máy toàn diện, mà còn trực tiếp phục vụ cho việc xây dựng các đầu ra: Xây dựng Chiến lược phát triển an toàn giao thông xe máy trong hạn dài (đến năm 2025 và tầm nhìn 2030) và Kế hoạch hành động 3 năm quản lý xe máy một cách hiệu quả cho Việt Nam. 
Tất cả các số liệu trong chương này, tất nhiên trừ các dữ liệu do nhóm nghiên cứu tính toán ra, đều có nguồn gốc từ các cơ quan chính thức ${ }^{58}$ : Ủy ban ATGTQG (NTSC), Cục Cảnh sát giao thông (C08), Tổng cục Đường bộ (DRVN), Tổng cục thống kê (GSO), tuy nhiên, trong trình bày sau đây, vì lý do dễ hiểu, có một vài chỗ sẽ không ghi rõ nguồn.

Chương này có nhiều dữ liệu. Để cho tiện, các bảng dữ liệu sẽ được đưa vào Phụ lục chương, còn trong phần nội dung chương, chỉ nêu những gì có liên quan.

\subsection{Dữ liệu xe máy trong sở hữu và lưu thông (Mcir)}

Các vấn đề sau sẽ được đề cập:

- Số luợng xe máy đang luu thông $\left(M_{\text {cir }}\right)$ là bao nhiêu và nếu dùng Số lương xe máy đã đăng $k y ́\left(M_{r e g}\right)$ thay cho $\mathrm{M}_{\text {cir }}$ thì sai số sẽ ở mức độ nào;

- Tính toán Số năm sủ dụng của xe gắn máy (Tuổi thọ- $T_{m c}$ ) và có giá trị thấp của nó như là một dấu hiẹu đáng ngại về chất lượng kỹ thuật nói chung của xe máy;

- Tổng số người lái xe gắn máy $\left(M_{u s e r}\right)$ và số người (trung bình) dùng chung môt xe máy $\left(R_{\text {user }}\right)$.

Như đã nêu, chương 2 đã đề cập đến nhóm dữ liệu xe máy theo đăng ký $\left(\mathrm{M}_{\mathrm{reg}}\right)$ nên để tránh trùng lặp, ta chỉ nhắc lại những gì cần thiết để tập trung vào nhóm dữ liệu khác rất quan trọng nhưng đang thiếu. Dữ liệu $\mathrm{M}_{\mathrm{reg}}$ cũng là con số xe máy mà cơ quan nhà nước đang quản lý. Nó chứa đựng số lượng xe tích lũy hàng năm mà không loại trừ đi số xe đã thải loại do nhiều nguyên nhân khác nhau (cũ, không dùng nữa, hư hỏng, mất...). Vì vậy, ở mức độ nào đó dữ liệu $\mathrm{M}_{\mathrm{reg}}$ không phản ảnh đúng tình hình giao thông xe máy. Như sẽ thấy sau, sai số trong nhiều trường hợp ở mức cao đáng kề.

Để chính xác hơn, ta cần dữ liệu về số lượng xe máy đang sở hữu và lưu thông $\left(\mathrm{M}_{\mathrm{cir}}\right)$. Dữ liệu $\mathrm{M}_{\text {cir }}$ này đóng vai trò chủ chốt trong việc thể hiện trực tiếp tình trạng giao thông xe máy. Tuy nhiên, cho đến nay, có rất ít thông tin về dữ liệu này. Trong tất cả các công việc liên quan như lập kế hoạch, báo cáo chính thức, trong phương tiện truyền thông công cộng ..., người ta đều dùng số lượng xe máy đã đăng ký $\left(M_{r e g}\right)$ thay cho $\mathrm{M}_{\text {cirr }}$. Việc sử dụng này là rất phổ biến đến mức hình như mọi người ở Việt Nam, thậm chí các chuyên gia giao thông vận tải, cứ yên tâm mặc nhiên sử dụng $\mathrm{M}_{\mathrm{reg}}$ mà không để ý rằng $\mathrm{M}_{\text {cir }}$ có thể được tìm thấy và rằng, chính $\mathrm{M}_{\text {cir }}$ nên được sử dụng trong nhiều trường hợp, chứ không phải $\mathrm{M}_{\text {reg. }}$. Ngay cả trong các công trình rất quan trọng như "Chiến lược phát triển giao thông vận tải Việt Nam đến năm 2020, tầm nhìn đến năm 2030"; "Quy hoạch phát triển giao thông vận tải đường bộ Việt Nam đến năm 2020, tầm nhìn đến năm 2030" hay "Chiến lược bảo đảm trật tự, an toàn giao thông đường bộ quốc gia đến năm 2020, tầm nhìn đến năm 2030” (GOV, 2012) và trong hầu như tất cả các công trình khác, số lượng xe máy đăng ký $\mathrm{M}_{\mathrm{reg}}$ được sử dụng như căn cứ để dự báo, bỏ qua một thực tế là rất nhiều xe gắn máy, sau một số năm, sẽ không còn được sử dụng nữa.

Việc sử dụng các $\mathrm{M}_{\text {reg }}$ thay vì $\mathrm{M}_{\text {cir }}$ trên thực tế là dùng giá trị quá cao của dữ liệu và không thể loại trừ việc này sẽ dẫn đến những sai số, thường là làm tăng lên quá mức, trong tính toán nhu cầu giao thông và do đó, dẫn đến lãng phí trong hoạch định chính sách, kế hoạch. Nguyên nhân của tình hình như vậy là cho đến bây giờ không có thông tin gì về $\mathrm{M}_{\mathrm{cir}}$, cả về giá trị cũng như

\footnotetext{
58 Xin chân thành cám ơn các cơ quan này về các thông tin, dữ liệu đã cung cấp.
} 
phương pháp để ước tính. Chỉ từ 2013, vấn đề này mới được đề cập lần đầu tiên trong "Duc N.H. et al., 2014".

Dữ liệu sở hữu xe và dữ liệu xe sử dụng trong lưu thông dĩ nhiên là khác nhau vì không phải mọi xe đều mang ra lưu thông nhưng ngược lại, không phải mọi xe đang lưu thông đều được đăng ký sở hữu. Tuy nhiên rõ ràng là sai số giữa hai loại dữ liệu này là nhỏ, vì vậy chúng ta coi $\mathrm{M}_{\text {cir }}$ chính là số xe máy sở hữu và là số xe máy trong lưu thông.

\subsubsection{Số lượng xe máy theo đăng ký (Mreg)}

Số lượng xe máy quản lý theo đăng ký được thu thập theo các công bố chính thức của Ủy ban An toàn giao thông quốc gia, và đã được đề cập đến ở chương trước. Ở đây, các số liệu này sẽ được dùng để so sánh vởi dữ liệu xe trong lưu thông $\left(\mathrm{M}_{\mathrm{cir}}\right)$, vì vậy, có một số vấn đề cần làm rõ như dưới đây.

\subsubsection{Hiệu chỉnh số liệu năm 2017}

Để thấy sự tăng trưởng xe máy, ta cần biết số lượng xe $\left(\mathrm{M}_{\mathrm{reg}}\right)$. Có tới bốn số liệu chính thức không khớp nhau về số lượng xe tới cuối 2017. Theo công bố đầu năm 2018 của cơ quan chính thức, trong năm 2017 số xe máy quản lý theo đăng ký đã tăng 3.298.260 xe, nâng tổng số xe lên 54.063.318; đến cuối năm, thống kê từ 63 tỉnh thành lại cho con số 54.606.260. Tuy nhiên, hai con số này mâu thuẫn với các dữ liệu chính thức khác của năm 2016:

a) Nếu số xe tăng trong năm (3.298.260) là đúng thì tổng số xe cuối 2017 chỉ là tổng số xe cuối 2016 (47.131.928) cộng với số tăng này và cho con số là $\mathbf{5 0 . 4 3 0 . 1 8 8 . ~}$

b) Nếu tổng số xe là 54.063 .318 hoặc 54.606 .318 là đúng thì số xe tăng trong năm là gần 7 triệu (6.931.390 và 7.474.390). Đây là một con số quá lớn. Năm gia tăng số lượng xe máy lớn nhất là 2008 cũng chỉ có 3.759 .757 xe mà rõ ràng năm 2017 không có biến động gì lớn trên thị trường xe máy.

c) Báo cáo chính thức năm 2018 nếu con số xe máy quản lý theo đăng ký là 58.169 .432 và số tăng trong năm là 4.002.931. Như vậy số lượng xe máy cuối 2017 là hiệu của chúng và bằng $54.166 .501 \mathrm{xe}$.

Như vậy, có tới 4 con số khác nhau về $\mathrm{M}_{\mathrm{reg}}$ năm 2017:

- PA1: 50.430.188,

- PA2: 54.063.318,

- PA3: 54.606.318,

- PA4: 54.166.501 xe.

Dĩ nhiên chỉ có thể chọn một trong chúng là chính xác mà thôi ${ }^{59}$. Trong khi chờ ý kiến của cơ quan chức năng, để làm căn cứ, ta thử dùng một dữ liệu khác để so sánh. May thay, có dữ liệu như vậy. Đó là dữ liệu chính thức của VAMM-Hiệp hội Các nhà sản xuất xe máy Việt Nam (Vietnam Association of Motorcycle Manufacturers). Hiệp hội này có hệ thống dữ liệu bán hàng rất đầy đủ và có công bố định kỳ. Theo đó, số xe bán ra của riêng 5 thành viên là Honda, Piaggio, Suzuki, SYM và Yamaha như trong bảng sau, chỉ ở mức hơn 3 triệu xe.

Bảng 3-1 So sánh hai số liệu tăng hàng năm khác nhau của xe máy

\begin{tabular}{|c|c|c|r|l|}
\hline Năm & Số liệu chính thức & Số liệu VAMM & Chênh lệch & \multicolumn{1}{|c|}{ Ghi chú } \\
\hline 2016 & 3.003 .106 & 3.121 .023 & -117.917 & Chênh lệch nhỏ này là do nguyên nhân \\
về mốc thời gian khác nhau.
\end{tabular}

Nguồn: Nhóm nghiên cứu sưu tầm

59 Không chỉ cho xe máy, số liệu cho xe ô tô năm 2017 cũng có hiện tượng này. 
Có ba nguyên nhân giải thích số liệu chênh lệch không lớn giữa con số của VAMM và số liệu đăng ký chính thức:
a) Nguyên nhân về mốc thời gian khác nhau. Số liệu chính thức lấy đến hết ngày 15/12 còn số liệu của VAMM, lấy đến hết $31 / 12$ hàng năm.
b) Hơn nữa, cùng với một chiếc xe máy, người dân mua xong thi VAMM đã có thể cập nhật, nhưng phải mất một thời gian mới có thể làm đăng ký, do vậy số liệu theo đăng ký cập nhật muộn hơn.
c) Ngoài 5 thành viên trên, còn một vài nhà cung cấp nhỏ lẻ khác.

Vì vậy, có thể kết luận một cách hợp lý rằng, nếu các số liệu từ những năm trước là đúng thì tổng số xe tích lũy đến hết 2017 là 50.430 .188 và số tăng trong năm đó là 3.298.260. Dù sao, đây cũng là một con số lớn. Lẽ ra, các kết luận sau đây dùng con số này. Đây là con số thấp nhất nên nếu dùng con số cao hơn thì các kết quả định tính sẽ vẫn giữ nguyên giá trị không thay đổi mà chỉ thay đổi về định lượng. Bảng dưới đây cho thấy phương án 1 phù hợp nhất với dẫy số liệu nhiều năm, trong khi phương án 3 có cơ sở khá chắc chắn là tổng số từ các tỉnh thành báo cáo trực tiếp lên.

Tuy nhiên, dễ thấy là số liệu hàng năm thường có sai số do nhiều nguyên nhân nên cơ quan chức năng đã hiệu chỉnh. Do vậy, chúng ta:

1. Tôn trọng số liệu công bố chính thức (năm 2017 số xe máy quản lý theo đăng ký đã tăng 3.298.260 xe, nâng tổng số xe lên 54.063.318)

2. Chênh lệch giữa con số tăng hàng năm sẽ giải quyết bằng cách đưa vào con số hiệu chỉnh 3.633.130 xe, từ 2017 trở đi.

3. Số liệu xe ô tô cũng theo phương án này với số hiệu chỉnh từ 2017 về sau là 296.269 xe

Bảng 3-2 So sánh độ tương quan của 3 giá trị $M_{\text {reg (2017) với các năm trước }}$

\begin{tabular}{|c|c|c|c|}
\hline Hạng mục /Item & PA1 & PA2 & PA3 \\
\hline Mreg năm 2017 & 50.430 .188 & 54.063 .318 & 54.606 .318 \\
\hline \multicolumn{4}{|l|}{ Thống kê hồi quy / Regression Statistics } \\
\hline Hệ số tương quan R / Multiple R & 0,999122748 & 0,996909376 & 0,996275066 \\
\hline Hệ số R² / R Square & 0,998246266 & 0,993828304 & 0,992564008 \\
\hline Hệ số $\mathrm{R}^{2}$ hiệu chỉnh / Adjusted R Square & 0,997767975 & 0,992145114 & 0,99053601 \\
\hline Sai số chuẩn / Standard Error & 592107,2528 & 1149689,836 & 1268793,264 \\
\hline Số quan sát / Observations & 15 & 15 & 15 \\
\hline
\end{tabular}

Nguồn: Nhóm nghiên cứu

\subsubsection{Xe máy điện}

Từ 2015, cơ quan nhà nước chính thức công bố cả số lượng xe máy điện, như đã nêu trong chương trước. Xe máy xăng và xe máy điện khác nhau về dạng năng lượng, như trong lưu thông trên đường và quy định về quản lý nhà nước là một. Vì vậy, chúng ta sẽ gộp cả hai loại này trong cụm từ "xe máy" từ nay trở đi, khi không cần xem xét từng loại riêng biệt.

Bảng dưới đây tóm tắt lại các phân tích trên và chốt lại số liệu dùng trong nghiên cứu này. 
Bảng 3-3 Số liệu phương tiện giao thông đường bộ 2015-2018

\begin{tabular}{|l|c|c|c|c|c|c|c|c|}
\hline \multicolumn{2}{|c|}{ a. Theo Báo cáo chính thức hàng năm (không khớp về phép tính giữa số tăng hàng năm và tổng số tích lũy) } \\
\hline \multirow{2}{*}{ Năm } & \multicolumn{2}{|c|}{ ô tô } & \multicolumn{2}{|c|}{ Xe máy } & \multicolumn{2}{c|}{ Xe máy điện } & \multicolumn{2}{|c|}{$\begin{array}{c}\text { Tổng số xe máy các } \\
\text { loại }\end{array}$} \\
\hline & Mói & Tổng số & Mói & Tổng số & Mói & Tổng số & Mói & Tổng số \\
\hline 2015 & 313.602 & 2.663 .269 & 2.915 .857 & 44.128 .822 & 152.806 & 152.806 & 3.068 .663 & 44.281 .628 \\
\hline 2016 & 370.258 & 3.033 .527 & 3.003 .106 & 47.131 .928 & 501.400 & 654.206 & 3.504 .506 & 47.786 .134 \\
\hline 2017 & 328.564 & 3.658 .360 & 3.298 .260 & 54.063 .318 & 227.051 & 881.257 & 3.525 .311 & 54.944 .575 \\
\hline 2018 & 339.215 & 3.884 .627 & 4.002 .931 & 58.169 .432 & 194.373 & 1.075 .630 & 4.197 .304 & 59.245 .062 \\
\hline
\end{tabular}

b. Theo Báo cáo chính thức hàng năm (chỉ giữ tổng số để tính ra số tăng hàng năm)

Phần tô vàng và in nghiêng là số liệu đã tính ra và khác với số liệu gốc

\begin{tabular}{|l|l|l|l|l|l|l|l|l|}
\hline \multirow{2}{*}{ Năm } & \multicolumn{2}{|c|}{ Ô tô } & \multicolumn{2}{c|}{ Xe máy } & \multicolumn{2}{c|}{ Xe máy điện } & \multicolumn{2}{c|}{$\begin{array}{c}\text { Tổng số xe máy các } \\
\text { loại }\end{array}$} \\
\hline & Mới & Tổng số & Mới & Tổng số & Mới & Tổng số & Mó́i & Tổng số \\
\hline 2015 & 313.602 & 2.663 .269 & 2.915 .857 & 44.128 .822 & 152.806 & 152.806 & 3.068 .663 & 44.281 .628 \\
\hline 2016 & 370.258 & 3.033 .527 & 3.003 .106 & 47.131 .928 & 501.400 & 654.206 & 3.504 .506 & 47.786 .134 \\
\hline 2017 & 624.833 & 3.658 .360 & 6.931 .390 & 54.063 .318 & 227.051 & 881.257 & 7.158 .441 & 54.944 .575 \\
\hline 2018 & 226.267 & 3.884 .627 & 4.106 .114 & 58.169 .432 & 194.373 & 1.075 .630 & 4.300 .487 & 59.245 .062 \\
\hline
\end{tabular}

c. Số liệu chốt hàng năm

\begin{tabular}{|l|c|c|c|c|c|c|c|c|}
\hline \multicolumn{1}{|c|}{ Năm } & \multicolumn{2}{|c|}{ ô tô } & \multicolumn{2}{c|}{ Xe máy } & \multicolumn{2}{c|}{ Xe máy điện } & \multicolumn{2}{c|}{ Tổng số xe máy các } \\
\hline & Mới & Tổng số & Mói & Tổng số & Mới & Tổng số & Mói & Tổng số \\
\hline 2015 & 313.602 & 2.663 .269 & 2.915 .857 & 44.128 .822 & 152.806 & 152.806 & 3.068 .663 & 44.281 .628 \\
\hline 2016 & 370.258 & 3.033 .527 & 3.003 .106 & 47.131 .928 & 501.400 & 654.206 & 3.504 .506 & 47.786 .134 \\
\hline 2017 & 328.564 & 3.658 .360 & 3.298 .260 & 54.063 .318 & 227.051 & 881.257 & 3.525 .311 & 54.944 .575 \\
\hline $\begin{array}{l}\text { Số hiệu } \\
\text { chînh } \\
\text { thêm từ } \\
2017\end{array}$ & 296.269 & & 3.633 .130 & & & & & \\
\hline 2018 & 226.267 & 3.884 .627 & 4.106 .114 & 58.169 .432 & 194.373 & 1.075 .630 & 4.300 .487 & 59.245 .062 \\
\hline
\end{tabular}

Nguồn: Nhóm nghiên cứu

Trên cơ sở xem xét trên, bảng dưới đây trích giới thiệu số lượng xe cơ giới theo đăng ký, tích lũy từ nhiều năm (bảng đầy đủ cho các năm 1990-2018 xem ở Phụ lục). 
Bảng 3-4 Dữ liệu TNGT đường bộ và số lượng xe cơ giới theo đăng ký

\begin{tabular}{|c|c|c|c|c|c|c|c|c|}
\hline \multirow[b]{2}{*}{ Năm } & \multicolumn{3}{|c|}{ TNGT đường bộ } & \multicolumn{3}{|c|}{ Số lượng tích lũy theo đăng ký } & \multirow[b]{2}{*}{ Tỷ lệ hỗn họ̣p } & \multirow[b]{2}{*}{ Dân số } \\
\hline & Số vụ & $\begin{array}{c}\text { Số } \\
\text { người } \\
\text { chết }\end{array}$ & $\begin{array}{l}\text { Số bị } \\
\text { thương }\end{array}$ & Ô tô & Xe máy & $\begin{array}{l}\text { Số xe máy } \\
\text { tăng trong } \\
\text { năm }\end{array}$ & & \\
\hline $\mathbf{Y}$ & TA & Fat & Inj & Car & Mreg & dM & $\begin{array}{c}\mathbf{r}= \\
\text { (Mreg/MC+Car) }\end{array}$ & pop \\
\hline 1990 & 5.565 & 2.087 & 4.468 & 246.194 & 1.209 .463 & & $83.09 \%$ & 66.020 .000 \\
\hline 1991 & 6.864 & 2.395 & 6.846 & 256.898 & 1.522 .184 & 312.721 & $85.56 \%$ & 67.242 .000 \\
\hline$\cdots$ & & & & & & & & \\
\hline 2006 & 14.161 & 12.373 & 11.097 & 972.912 & 18.615 .960 & 2.529 .316 & $95.03 \%$ & 83.311 .200 \\
\hline 2007 & 13.985 & 12.800 & 10.266 & 1.106 .617 & 21.721 .282 & 3.105 .322 & $95.15 \%$ & 84.218 .500 \\
\hline$\cdots$ & & & & & & & & \\
\hline 2015 & 22.326 & 8.435 & 20.815 & 2.663 .269 & 44.281 .628 & 3.068 .663 & $94.33 \%$ & 91.709 .800 \\
\hline 2016 & 21.094 & 8.417 & 19.035 & 3.033 .527 & 47.786 .134 & 3.504 .506 & $94.03 \%$ & 92.692 .200 \\
\hline 2017 & 19.798 & 8.089 & 16.970 & 3.658 .360 & 54.944 .575 & 7.158 .441 & $93.76 \%$ & 93.671 .569 \\
\hline 2018 & 18.490 & 8.079 & 14.732 & 3.884 .627 & 59.245 .062 & 4.300 .487 & $93.85 \%$ & 94.670 .000 \\
\hline
\end{tabular}

Ghi chú: Số liệu tù năm 2017 đã cộng thêm số hiệu chỉnh (296.269 ô tô và 3.633.130 xe máy) và tù̀ năm 2015 tính cả xe máy điện

Nguồn: Nhóm nghiên cứu

Bảng dữ liệu này chứa đựng rất nhiều nội dung, ở đây chúng ta chỉ xem xét một số ý như nêu dưới đây.

\section{Tốc độ tăng trưởng xe máy}

So với năm 1990 (1.209.463 xe máy), đến hết 2018 tổng số xe máy tích lũy theo đăng ký $\mathrm{M}_{\mathrm{reg}}$ đã tăng 49 lần (còn ô tô tăng 16 lần) trong vòng có 28 năm. Nếu coi như tăng đều hàng năm, thì tốc độ tăng là 14,91 \%/ năm. Cả hai con số này đều rất lớn mà ít quốc gia trên thế giới có.

\section{Tỷ lệ xe máy trong dòng giao thông hỗn hợp}

Hình dưới cho thấy xe máy chiếm tỷ lệ rất cao: thấp nhất là 83,09 \% (1990) và đạt tới cực đại với $95,15 \%$ năm 2007. Sau đó, tuy vẫn ở mức rất cao, nhưng bắt đầu giảm dần báo hiệu xu hướng tăng trưởng ô tô.

Điều quan trọng hơn, với tỷ lệ xe máy cao như vậy, thì trong dòng giao thông hỗn hợp, xét về phương tiện lại tương đối thuẩn (tỷ lệ xe máy chiểm tuyệt đại đa số); nhưng xét về các phương diện khác như tốc độ, đường xe chạy... thì tỷ lệ hỗn hợp mới cao.

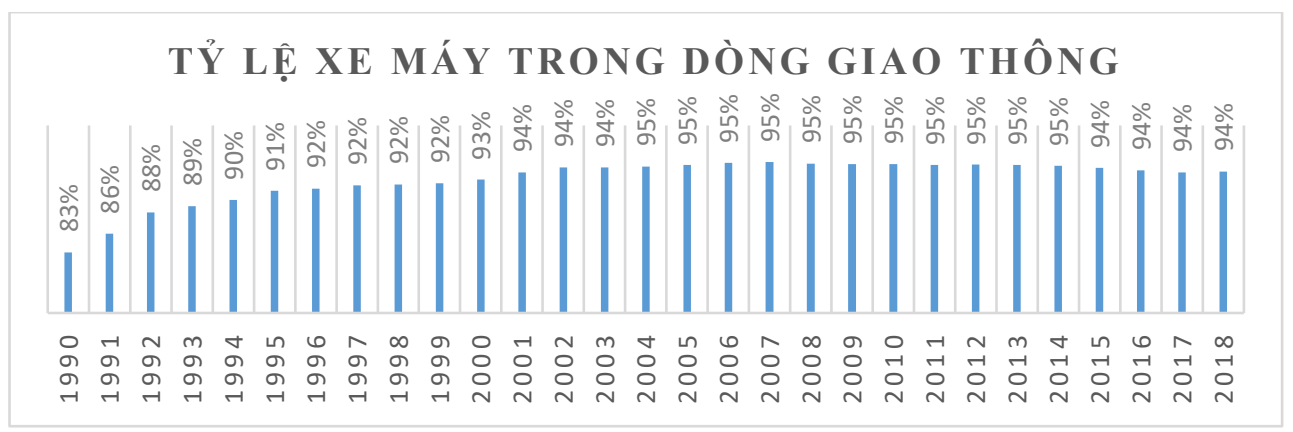

Nguồn: Nhóm nghiên cứu

\section{Hình 3-1 Tỷ lệ xe máy trong dòng giao thông hỗn hợp}




\subsubsection{Giao thông xe máy qua dữ liệu về số lượng xe trong lưu thông $\mathbf{M}_{\text {cir }}$}

\section{1) Số lượng xe trong lưu thông $M_{c i r}$}

Dựa theo phương pháp luận trong “Duc N.H. et al, 2013”, với số liệu gốc chính thức với 02 số thập phân từ Tổng cục thống kê, dữ liệu về số lượng xe máy lưu thông $\left(\mathrm{M}_{\mathrm{cir}}\right)$ trong toàn quốc 2003-2018 thể hiện trong Bảng 3.1. Trong bảng này cũng có số lượng xe máy theo đăng ký $\left(\mathrm{M}_{\mathrm{reg}}\right)$ để so sánh.

\section{Bảng 3-5 Số lượng xe máy toàn quốc theo đăng ký (Mreg) và trong lưu thông (Mcir)}

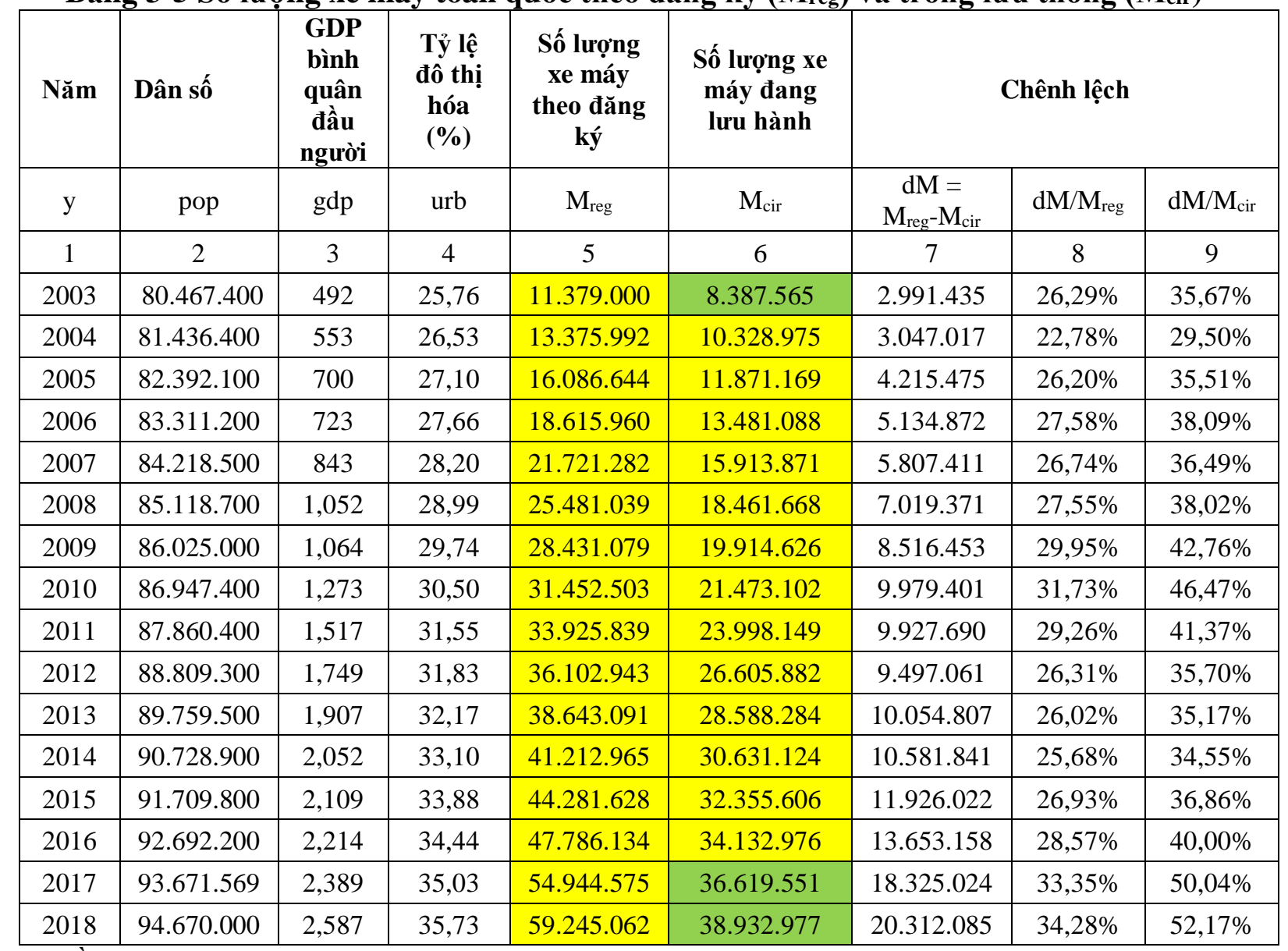

Nguồn: Nhóm nghiên cứu

Trong bảng này, cột 2-4 chứa dữ liệu thu thập từ các công bố của Tổng cục Thống kê, bao gồm cả các hiệu chỉnh chính thức. Dư liệu trong bảng cho thấy Số lượng xe máy đang lưu hành $\left(\mathrm{M}_{\mathrm{cir}}\right)$ thấp hơn nhiều so với Số lượng xe máy đã đăng ký $\left(\mathrm{M}_{\mathrm{reg}}\right)$ (xem cột 6 và 5). Như vậy, dùng $\mathrm{M}_{\mathrm{reg}}$ thay cho $\mathrm{M}_{\text {cir }}$ trong các tính toán, giá trị thục chi khoảng 66-77\% giá trị tính toán và tất nhiên, điều này có thể dẫn đến sự lãng phí lớn trong quy hoạch giao thông.

\section{2) Tính toán tuổi thọ của xe máy: dấu hiệu đáng ngại về chất lượng kỹ thuật}

Dựa vào các số liệu $\mathrm{M}_{\mathrm{reg}}$ và $\mathrm{M}_{\text {cir }}$, chúng ta có thể thấy ra nhiều điều. bảng dưới đây là số liệu về xe máy không còn lưu thông và tuổi thọ trung bình của xe máy 
Dự án: Xây dựng chiến lược an toàn giao thông đối với xe máy và kế hoạch hành động: một khởi đầu của Việt Nam

Bảng 3-6 Số xe máy không còn lưu thông và tuổi thọ

\begin{tabular}{|c|c|c|c|c|c|c|}
\hline \multirow{2}{*}{ Năm } & \multirow{2}{*}{$\begin{array}{l}\text { Số lug̣ng xe } \\
\text { máy xăng đãa } \\
\text { đăng ký }\end{array}$} & \multirow{2}{*}{$\begin{array}{l}\text { Số lương xe } \\
\text { máy đang } \\
\text { lưu hành }\end{array}$} & \multirow{2}{*}{ Tỷ lệ } & \multicolumn{3}{|c|}{ Số xe máy không còn lưu hành } \\
\hline & & & & Số lượng & \multirow{3}{*}{$\begin{array}{c}\mathbf{Y}_{\text {exc }} \\
\text { Năm mà } \\
\text { Mreg }_{\text {rexc }} \approx \\
M_{\text {exc }}\end{array}$} & Tuổi thọ \\
\hline \multirow[t]{2}{*}{$\mathrm{Y}$} & \multirow[t]{2}{*}{$\mathrm{M}_{\mathrm{reg}}$} & \multirow[t]{2}{*}{$\mathrm{M}_{\mathrm{cir}}$} & \multirow{2}{*}{$\mathrm{r}=\mathrm{M}_{\mathrm{cir}} / \mathrm{M}_{\mathrm{reg}}$} & $\mathrm{M}_{\mathrm{exc}}=$ & & $\begin{array}{c}\mathrm{T}_{\mathrm{mc}} \\
\text { (năm) }\end{array}$ \\
\hline & & & & $\mathrm{M}_{\mathrm{reg}}-\mathrm{M}_{\mathrm{cir}}$ & & $=\mathrm{Y}-\mathrm{Y}_{\mathrm{exc}}$ \\
\hline (1) & (2) & (3) & (4) & (5) & (6) & (7) \\
\hline 2003 & 11.379 .000 & 8.387 .565 & $73,71 \%$ & 2.991 .435 & 1993- & $>10$ \\
\hline 2004 & 13.375.992 & 10.328 .975 & $77,22 \%$ & 3.047 .017 & 1994 & $\approx 10$ \\
\hline 2005 & 16.086 .644 & 11.871 .169 & $73,80 \%$ & 4.215 .475 & $1995+$ & $<10$ \\
\hline 2006 & 18.615 .960 & 13.481 .088 & $72,42 \%$ & 5.134 .872 & 1998 & $\approx 8$ \\
\hline 2007 & 21.721 .282 & 15.913 .871 & $73,26 \%$ & 5.807 .411 & $1999+$ & $\approx 8$ \\
\hline 2008 & 25.481 .039 & 18.461 .668 & $72,45 \%$ & 7.019.371 & 2000 & $\approx 8$ \\
\hline 2009 & 28.431 .079 & 19.914 .626 & $70,05 \%$ & 8.516 .453 & $2001+$ & $<8$ \\
\hline 2010 & 31.452 .503 & 21.473 .102 & $68,27 \%$ & 9.979 .401 & $2002-$ & $>8$ \\
\hline 2011 & 33.925 .839 & 23.998 .149 & $70,74 \%$ & 9.927 .690 & 2002 & $\approx 9$ \\
\hline 2012 & 36.102 .943 & 26.605 .882 & $73,69 \%$ & 9.497 .061 & $2001+$ & $>10$ \\
\hline 2013 & 38.643 .091 & 28.588 .284 & $73,98 \%$ & 10.054 .807 & 2002 & $\approx 11$ \\
\hline 2014 & 41.212 .965 & 30.631 .124 & $74,32 \%$ & 10.581 .841 & 2002 & $\approx 12$ \\
\hline 2015 & 44.281 .628 & 32.355 .606 & $73,07 \%$ & 11.926 .022 & 2003 & $\approx 12$ \\
\hline 2016 & 47.786 .134 & 34.132 .976 & $71,43 \%$ & 13.653 .158 & $2003+$ & $\approx 12$ \\
\hline 2017 & 54.944 .575 & 36.619 .551 & $66,65 \%$ & 18.325 .024 & $2005+$ & $\approx 12$ \\
\hline 2018 & 59.245 .062 & 38.936 .115 & $65,72 \%$ & 20.308 .947 & $2006+$ & $\approx 12$ \\
\hline
\end{tabular}

Ghi chú: $\left(^{*}\right)$ 1995+ nghĩa là khoảng 1995-1996. Tương tự cho trường hợp khác Nguồn: Nhóm nghiên cứu

Trong bảng trên, các giá trị trong cột thứ 5 là Số lượng xe máy đã bị loại trừ khỏi lưu hành thực tế $\left(\mathrm{M}_{\mathrm{exc}}\right)$. Điều đáng để ý là số lượng này khá lớn. Bằng cách so sánh với số lượng xe máy đăng ký trong những năm trước đó, có thể ước tính Số năm sử dụng xe máy trung bình (Tuổi thọ trung bình của xe máy- $\mathrm{T}_{\mathrm{mc}}$ ). Khoảng 2006-2010, giá trị $\mathrm{T}_{\mathrm{mc}}$ chỉ khoảng 8-10 năm, thấp một cách đáng ngạc nhiên. Như đã biết, xe máy với chất lượng cao có thể được sử dụng cho vài chục năm. Vì vậy, giá trị thấp của tuổi thọ xe máy $\mathrm{T}_{\mathrm{mc}}$ cho thấy rằng giai đoạn trước đó, Việt Nam có một tỷ lệ lớn các xe gắn máy với chất lượng kỹ thuật thấp (hoặc rất thấp). Trong thực tế, khoảng năm gần chục năm trước, rất nhiều xe máy do Trung Quốc chế tạo với giá rất thấp được cung cấp trên thị trường. Sau một số năm lưu hành, những thiếu sót của loại xe này đã thể hiện rõ ràng (độ bền thấp, an toàn kỹ thuật kém... ) nên người dân dần dần loại trừ chúng. Những năm gần đây, rõ ràng chất lượng xe máy có tốt hơn, thể hiện ở giá trị $\mathrm{T}_{\mathrm{mc}}$ cao hơn (cỡ 12 năm).

\section{3) Tốc độ tăng trưởng đều của xe máy và tốc độ gia tăng đều GDP đầu người hàng năm}

Bảng dưới đây tổng hợp tốc độ tăng trưởng đều hàng năm (coi tốc độ tăng trưởng hàng năm trong cả giai đoạn dài là như nhau) của một số đại lượng liên quan. Có một điều đáng quan tâm, trong thời hạn dài như vậy, nếu có hiện tượng tốc độ gia tăng hàng năm của xe máy lớn hơn tốc độ tăng GDP theo đầu người thì đó là điều không mong muốn, vì đó là dấu hiệu người dân đã chi tiêu cho loại hàng hóa đó ở mức độ nhiều hơn số họ làm ra được. Việc người dân đã chi tiêu 
quá tay một thời gian dài sẽ dễ dẫn đến sự phát triển bong bóng, dễ có thể gây ảnh hưởng bất lợi, lên xã hội.

Xét về dài hạn, thì có nguy cơ này vì số theo đăng ký $\left(\mathrm{W}_{\text {reg }}=14,91 \%\right)$ và số xe trong lưu thông $\left(\mathrm{W}_{\mathrm{cir}}=13.20 \%\right)$ đều lớn hơn tốc độ tăng GDP đầu người ( $\left.\mathrm{W}_{\mathrm{gdp}}=12,12 \%\right)$. Các con số này xác nhận một lần nữa sự tăng trưởng quá nhanh của xe máy.

Tuy nhiên, điều may mắn là những năm gần đây, số lượng xe máy vẫn tăng, nhưng tốc độ tăng đều bắt đầu nhỏ hơn tốc độ tăng GDP đầu người $\left(11,63 \%\right.$ và $10,78 \%$ so với $\left.\mathrm{V}_{\mathrm{gdp}}=11,70 \%\right)$. Ta biết dữ liệu xe theo đăng ký luôn quá lớn so với thực tế vì nó tích lũy qua nhiều năm mà không trừ đi số xe không còn sử dụng. Trong trường hợp này, số lượng xe trong lưu thông thể hiện thực tế tốt hơn.

Như vậy, bảng này cho thấy sư tăng trưởng quá nhanh của xe máy so với các chỉ tiêu kinh tếxã hội, tuy nhiên, tuy tốc độ tăng trưởng xe máy là lớn, nhưng ở trong vùng kiểm soát được. Bảng này cũng cho thấy tốc độ gia tăng bình quân xe máy 1990-2018 tuy thấp hơn, nhưng khá gần với tốc độ gia tăng GDP theo đầu người. Điều đó xác nhận lại sự tăng trưởng nhanh một lần nữa.

Bảng 3-7 Tốc độ tăng đều của xe máy và một số chỉ tiêu kinh tế-xã hội trong hạn dài

\begin{tabular}{|c|c|c|c|c|c|c|}
\hline \multirow[t]{2}{*}{ Tốc độ tăng đều hàng năm } & \multirow[t]{2}{*}{$\begin{array}{l}\text { Ký } \\
\text { hiệu }\end{array}$} & $\begin{array}{l}\text { Tỷ lệ } \\
\text { tăng đều }\end{array}$ & $\begin{array}{l}\text { Giá trị } \\
\text { cuối kỳ } \\
\text { so với } \\
\text { đầu kỳ }\end{array}$ & $\begin{array}{l}\text { Giá trị } \\
\text { đầu kỳ }\end{array}$ & $\begin{array}{l}\text { Giá trị } \\
\text { cuối kỳ }\end{array}$ & Số năm \\
\hline & & $\mathbf{r}$ & $V_{n} / V_{0}$ & $\mathbf{V}_{0}$ & $\mathbf{V}_{\mathbf{n}}$ & $\mathbf{Y}$ \\
\hline \multicolumn{7}{|l|}{ Giai đoạn 1990-2018 } \\
\hline $\begin{array}{l}\text { Tốc độ tăng trưởng đều hàng } \\
\text { năm của xe máy theo đăng ký }\end{array}$ & $\mathrm{W}_{\text {reg }}$ & $14,91 \%$ & 48,98 & 1.209 .463 & 59.245 .062 & 28 \\
\hline $\begin{array}{l}\text { Tốc độ tăng trưởng đều hàng } \\
\text { năm của xe máy trong lưu } \\
\text { thông }(*)\end{array}$ & $\mathrm{W}_{\text {cir }}$ & $13,20 \%$ & 32,20 & 1.209 .463 & 38.943 .834 & 28 \\
\hline $\begin{array}{l}\text { Tốc độ tăng đều hàng năm của } \\
\text { GDP theo đầu người }\end{array}$ & $\mathrm{W}_{\mathrm{gdp}}$ & $12,12 \%$ & 24,64 & 105 & 2.587 & 28 \\
\hline \multicolumn{7}{|l|}{ Giai đoạn 2003-2018 } \\
\hline $\begin{array}{l}\text { Tốc độ tăng trưởng đều hàng } \\
\text { năm của xe máy theo đăng ký }\end{array}$ & $\mathrm{V}_{\text {reg }}$ & $11,63 \%$ & 5,21 & 11.379 .000 & 59.245 .062 & 15 \\
\hline $\begin{array}{l}\text { Tốc độ tăng trưởng đều hàng } \\
\text { năm của xe máy trong lưu } \\
\text { thông }\end{array}$ & $\mathrm{V}_{\text {cir }}$ & $10,78 \%$ & 4,64 & 8.387 .565 & 38.943 .834 & 15 \\
\hline $\begin{array}{l}\text { Tốc độ tăng đều hàng năm của } \\
\text { GDP theo đầu người }\end{array}$ & $\mathrm{V}_{\text {gdp }}$ & $11,70 \%$ & 5,26 & 492 & 2.587 & 15 \\
\hline \multicolumn{7}{|l|}{ Phụ lục } \\
\hline $\begin{array}{l}\text { Tốc độ tăng đều hàng năm về } \\
\text { dân số (1990-2018) }\end{array}$ & $\mathrm{W}_{\text {pop }}$ & $1,30 \%$ & 1,43 & 66.020 .000 & 94.670 .000 & 28 \\
\hline $\begin{array}{l}\text { Tốc độ đô thị hóa tăng đều } \\
\text { hàng năm (2003-2018) }\end{array}$ & $\mathrm{V}_{\text {urb }}$ & $2,21 \%$ & 1,39 & 25,76 & 35,73 & 15 \\
\hline
\end{tabular}

(*) Ghi chú:

Năm 1990 số xe máy còn ít, nên coi số lượng xe theo đăng ký bằng số lượng xe trong lưu thông.

GDP đầu người theo Tổng cục thống kê, có khác so với số liệu của WB

Nguồn: Nhóm nghiên cứu 
Ngoài ra, cũng lưu ý rằng, bằng cách so sánh giữa tổng số xe máy theo đăng ký và số xe đang lưu hành giao thông, một nghiên cứu khác còn cho thấy rằng (xem "Duc N.H.et al. 2016") trong số những chiếc xe đã được loại trừ khỏi lưu hành, có một số lượng xe đã được sửa chữa và tham gia trở lại trong giao thông.

\section{4) Phân bố xe máy trong lưu thông theo thời gian đối với các nhóm kinh tế-xã hội giai đoạn 2006-2017}

Nội dung phần này là nghiên cứu sự phân bố xe máy theo thời gian đối với ba loại nhóm kinh tế-xã hội cả giai đoạn dài 2006-2017 trên toàn quốc. Tiểu mục tiếp theo sẽ dành riêng cho phân bố xe máy theo không gian đối với năm 2017.

\section{a. Phân bố giữa thành thị và nông thôn}

Bảng dưới đây đưa ra dữ liệu về số xe lưu thông ở khu vực thành thị và nông thôn. Xét về con số tuyệt đối, số lượng xe máy đều tăng ở cả hai khu vực. Tuy nhiên vấn đề không đơn giản như vậy. So sánh về tỷ trọng, phần của nông thôn tằng từ $55 \%$ lên $60 \%$, dĩ nhiên, phần của thành thị giảm tương ứng. So về tỷ lệ tăng đều (bảng dưới nữa), tỷ lệ tăng đều hàng năm của khu vực nông thôn lên tới $10,36 \%$ cao hơn hẳn thành thị $(9,51 \%)$. Kết hợp với việc dô thị hóa ở mức trung bình $2,17 \%$ (tức là số dân nông thôn giảm đều $2,17 \%$, diện tích nông thôn cũng giảm) thì tỷ lệ tăng xe máy ở nông thôn theo đầu người và theo diện tích còn cao hơn nữa. Điều này chúng tỏ, bên cạnh dấu hiệu tích cực về mức sống dân cư đang tăng, cũng cần quan tâm hạn chế các vấn đề tiêu cực cũng rất dễ gia tăng. Do vậy, cần tăng cường quản lý giao thông xe máy ở khu vực nông thôn hơn nữa.

Bảng 3-8 Dữ liệu xe máy trong lưu thông ở khu vục thành thị và nông thôn toàn quốc (2006-2017)

\begin{tabular}{|c|c|c|c|c|c|}
\hline Năm & $\begin{array}{c}\text { Số xe } \\
\text { lưu hành }\end{array}$ & Thành thị & Nông thôn & $\begin{array}{c}\text { Thành } \\
\text { thị }\end{array}$ & $\begin{array}{c}\text { Nông } \\
\text { thôn }\end{array}$ \\
\hline $\mathbf{y}$ & $\mathbf{M}_{\text {cir }}$ & $\mathbf{M}_{\text {urb }}$ & $\mathbf{M}_{\text {rur }}$ & urb\% & rur\% \\
\hline 2006 & $\mathbf{1 3 . 4 8 1 . 0 8 8}$ & 6.043 .122 & 7.437 .966 & $44,83 \%$ & $55,17 \%$ \\
\hline 2007 & $\mathbf{1 5 . 9 1 3 . 8 7 1}$ & 6.847 .738 & 9.066 .133 & $43,03 \%$ & $56,97 \%$ \\
\hline 2008 & $\mathbf{1 8 . 4 6 1 . 6 6 8}$ & 7.758 .454 & 10.703 .213 & $42,02 \%$ & $57,98 \%$ \\
\hline 2009 & $\mathbf{1 9 . 9 1 4 . 6 2 6}$ & 8.135 .889 & 11.778 .738 & $40,85 \%$ & $59,15 \%$ \\
\hline 2010 & $\mathbf{2 1 . 4 7 3 . 1 0 2}$ & 8.541 .053 & 12.932 .049 & $39,78 \%$ & $60,22 \%$ \\
\hline 2011 & $\mathbf{2 3 . 9 9 8 . 1 4 9}$ & 9.691 .893 & 14.306 .256 & $40,39 \%$ & $59,61 \%$ \\
\hline 2012 & $\mathbf{2 6 . 6 0 5 . 8 8 2}$ & 10.691 .589 & 15.914 .293 & $40,19 \%$ & $59,81 \%$ \\
\hline 2013 & $\mathbf{2 8 . 5 8 8 . 2 8 4}$ & 11.395 .593 & 17.192 .690 & $39,86 \%$ & $60,14 \%$ \\
\hline 2014 & $\mathbf{3 0 . 6 3 1 . 1 2 4}$ & 12.326 .606 & 18.304 .519 & $40,24 \%$ & $59,76 \%$ \\
\hline 2015 & $\mathbf{3 2 . 3 5 5 . 6 0 6}$ & 13.132 .208 & 19.223 .397 & $40,59 \%$ & $59,41 \%$ \\
\hline 2016 & $\mathbf{3 4 . 1 3 2 . 9 7 6}$ & 13.909 .476 & 20.223 .500 & $40,75 \%$ & $59,25 \%$ \\
\hline 2017 & $\mathbf{3 6 . 6 1 9 . 5 5 1}$ & 14.614 .847 & 22.004 .703 & $39,91 \%$ & $60,09 \%$ \\
\hline & Chiều & & & Giảm & Tăng \\
\hline & hướng & & & & \\
\hline
\end{tabular}

Nguồn: Nhóm nghiên cứu 


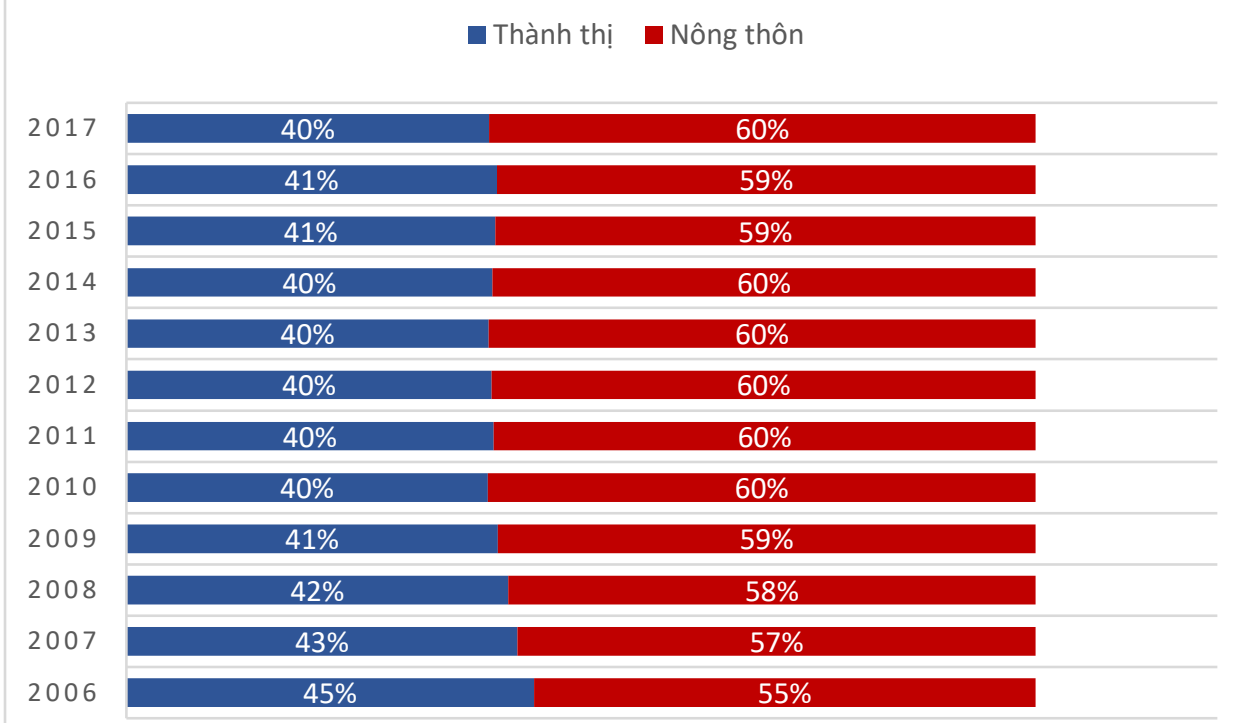

Hình 3-2 Thay đổi về tỷ lệ xe máy lưu thông ở nông thôn và thành thị hàng năm (20062017)

Nguồn: Nhóm nghiên cứu

Bảng 3-9 So sánh tốc độ tăng đều xe máy ở khu vực nông thôn và thành thị

\begin{tabular}{|c|c|c|c|c|c|c|}
\hline \multirow[t]{2}{*}{ Tốc độ tăng đều hàng năm } & \multirow[t]{2}{*}{$\begin{array}{l}\text { Ký } \\
\text { hiệu }\end{array}$} & $\begin{array}{l}\text { Tỷ lệ } \\
\text { tăng } \\
\text { đều }\end{array}$ & $\begin{array}{c}\text { Giá trị } \\
\text { cuối } \\
\text { kỳ so } \\
\text { với } \\
\text { dầu } \\
\text { kỳ } \\
\end{array}$ & $\begin{array}{l}\text { Giá trị } \\
\text { đầu kỳ }\end{array}$ & $\begin{array}{l}\text { Giá trị } \\
\text { cuối kỳ }\end{array}$ & Số năm \\
\hline & & $\mathbf{r}$ & $\mathbf{V}_{\mathbf{n}} / \mathbf{V}_{\mathbf{0}}$ & $\mathbf{V}_{\mathbf{0}}$ & $\mathbf{V}_{\mathbf{n}}$ & $\mathbf{y}$ \\
\hline \multicolumn{7}{|l|}{ Giai đoạn 2006-2017 } \\
\hline $\begin{array}{l}\text { Tốc độ tăng trưởng đều hàng năm của xe } \\
\text { máy trong lưu thông ở thành thị }\end{array}$ & $\mathrm{V}_{\text {urban }}$ & $8,36 \%$ & 2,42 & 6.043 .122 & 14.614 .847 & 11 \\
\hline $\begin{array}{l}\text { Tốc độ tăng trưởng đều hàng năm của xe } \\
\text { máy trong lưu thông ở nông thôn }\end{array}$ & $\mathrm{V}_{\text {rural }}$ & $10,36 \%$ & 2,96 & 7.437 .966 & 22.004 .703 & 11 \\
\hline $\begin{array}{l}\text { Tốc độ tăng trưởng đều hàng năm của xe } \\
\text { máy trong lưu thông toàn quốc }\end{array}$ & $\mathrm{V}_{\text {country }}$ & $9,51 \%$ & 2,72 & 13.481 .088 & 36.619 .551 & 11 \\
\hline Tốc độ đô thị hóa đều hàng năm & $\mathrm{V}_{\text {urb }}$ & $2,17 \%$ & 1,27 & $27,66 \%$ & $35,03 \%$ & 11 \\
\hline
\end{tabular}

Nguồn: Nhóm nghiên cứu

\section{b. Phân bố xe máy trong lưu thông theo năm nhóm thu nhập}

Như đã biết, theo thông lệ chung, Tổng cục Thống kê chia toàn bộ các hộ gia đình thành năm nhóm đều nhau, mỗi nhóm chiếm $20 \%$ và gọi là nhóm thu nhập, trong đó nhóm 1 có thu nhập thấp nhất và nhóm 5 , cao nhất. Nghiên cứu sự phân bố xe máy theo nhóm thu nhập cho ta các thông tin về khuynh hướng phát triển xe máy theo thu nhập.

Bảng dưới đây cho thấy, xét về số lượng, nhóm nào thì số xe máy cũng tăng suốt nhiều năm. Tuy nhiên, hình dưới cho thấy tỷ lệ xe máy giữa các nhóm có điềm đặc biệt khác nhau. Với nhóm 5 (nhóm giàu nhất) tỷ lệ xe máy giảm, đấy là vì họ có điều kiện nên mua xe ô tô nhiều hơn. Nhóm 4 có tỷ lệ gần như không đổi, trong khi với 3 nhóm còn lại, tỷ lệ xe máy đều tăng. Như vậy có thể nói, tới gần $80 \%$ các hộ gia đình vẫn tiếp tục tăng thêm xe máy và nhóm hộ càng thu nhập thấp, thì tỷ lệ xe máy càng tăng cao, nhưng không chênh lệch nhiều. 
Bảng 3-10 Phân bố xe máy trong lưu thông giai đoạn 2006-2017 theo năm nhóm thu nhập

\begin{tabular}{|c|c|c|c|c|c|c|}
\hline \multirow{2}{*}{$\begin{array}{c}\text { Năm } \\
\mathbf{y}\end{array}$} & \multirow{2}{*}{$\begin{array}{c}\text { Số xe lưu hành } \\
M_{\text {cir }} \\
\end{array}$} & \multicolumn{5}{|c|}{ Số xe máy theo 5 nhóm thu nhập (Quintiles) } \\
\hline & & Q1 & Q2 & Q3 & Q4 & Q5 \\
\hline 2006 & 13.481 .088 & 900.215 & 1.565 .704 & 2.238 .313 & 3.332 .487 & 5.444 .368 \\
\hline 2007 & 15.913 .871 & 1.210 .255 & 1.976 .568 & 2.728 .012 & 3.891 .680 & 6.107 .356 \\
\hline 2008 & 18.461 .668 & 1.540 .974 & 2.406 .806 & 3.238 .945 & 4.471 .399 & 6.803 .545 \\
\hline 2009 & 19.914 .626 & 1.828 .360 & 2.754 .109 & 3.629 .087 & 4.827 .301 & 6.875 .769 \\
\hline 2010 & 21.473 .102 & 2.137 .821 & 3.125 .978 & 4.046 .494 & 5.210 .156 & 6.952 .653 \\
\hline 2011 & 23.998.149 & 2.385 .572 & 3.587 .687 & 4.592 .239 & 5.829 .248 & 7.603 .404 \\
\hline 2012 & 26.605 .882 & 2.644 .115 & 4.072 .844 & 5.151 .719 & 6.464 .161 & 8.273 .044 \\
\hline 2013 & 28.588 .284 & 2.949 .267 & 4.425 .952 & 5.607 .336 & 6.931 .196 & 8.674 .532 \\
\hline 2014 & 30.631 .124 & 3.262 .206 & 4.791 .191 & 6.079 .735 & 7.411 .076 & 9.086 .917 \\
\hline 2015 & 32.355 .606 & 3.473 .494 & 5.057 .964 & 6.464 .523 & 7.822 .774 & 9.536 .852 \\
\hline 2016 & 34.132 .976 & 3.694 .634 & 5.334 .723 & 6.860 .306 & 8.244 .987 & 9.998 .326 \\
\hline 2017 & 36.619.551 & 4.058 .940 & 5.887 .091 & 7.429 .005 & 8.844 .165 & 10.400 .349 \\
\hline $\mathbf{y}$ & Mcir\% & $\mathrm{Mq} 1 \%$ & $\mathrm{Mq} 2 \%$ & $\mathrm{Mq} 3 \%$ & $\mathrm{Mq} 4 \%$ & Mq5\% \\
\hline 2006 & $100 \%$ & $6,68 \%$ & $11,61 \%$ & $16,60 \%$ & $24,72 \%$ & $40,39 \%$ \\
\hline 2007 & $100 \%$ & $7,61 \%$ & $12,42 \%$ & $17,14 \%$ & $24,45 \%$ & $38,38 \%$ \\
\hline 2008 & $100 \%$ & $8,35 \%$ & $13,04 \%$ & $17,54 \%$ & $24,22 \%$ & $36,85 \%$ \\
\hline 2009 & $100 \%$ & $9,18 \%$ & $13,83 \%$ & $18,22 \%$ & $24,24 \%$ & $34,53 \%$ \\
\hline 2010 & $100 \%$ & $9,96 \%$ & $14,56 \%$ & $18,84 \%$ & $24,26 \%$ & $32,38 \%$ \\
\hline 2011 & $100 \%$ & $9,94 \%$ & $14,95 \%$ & $19,14 \%$ & $24,29 \%$ & $31,68 \%$ \\
\hline 2012 & $100 \%$ & $9,94 \%$ & $15,31 \%$ & $19,36 \%$ & $24,30 \%$ & $31,09 \%$ \\
\hline 2013 & $100 \%$ & $10,32 \%$ & $15,48 \%$ & $19,61 \%$ & $24,24 \%$ & $30,34 \%$ \\
\hline 2014 & $100 \%$ & $10,65 \%$ & $15,64 \%$ & $19,85 \%$ & $24,19 \%$ & $29,67 \%$ \\
\hline 2015 & $100 \%$ & $10,74 \%$ & $15,63 \%$ & $19,98 \%$ & $24,18 \%$ & $29,48 \%$ \\
\hline 2016 & $100 \%$ & $10,82 \%$ & $15,63 \%$ & $20,10 \%$ & $24,16 \%$ & $29,29 \%$ \\
\hline 2017 & $100 \%$ & $11,08 \%$ & $16,08 \%$ & $20,29 \%$ & $24,15 \%$ & $28,40 \%$ \\
\hline & ều hướng & Tăng & Tăng & Tăng & Đều & Giảm \\
\hline
\end{tabular}

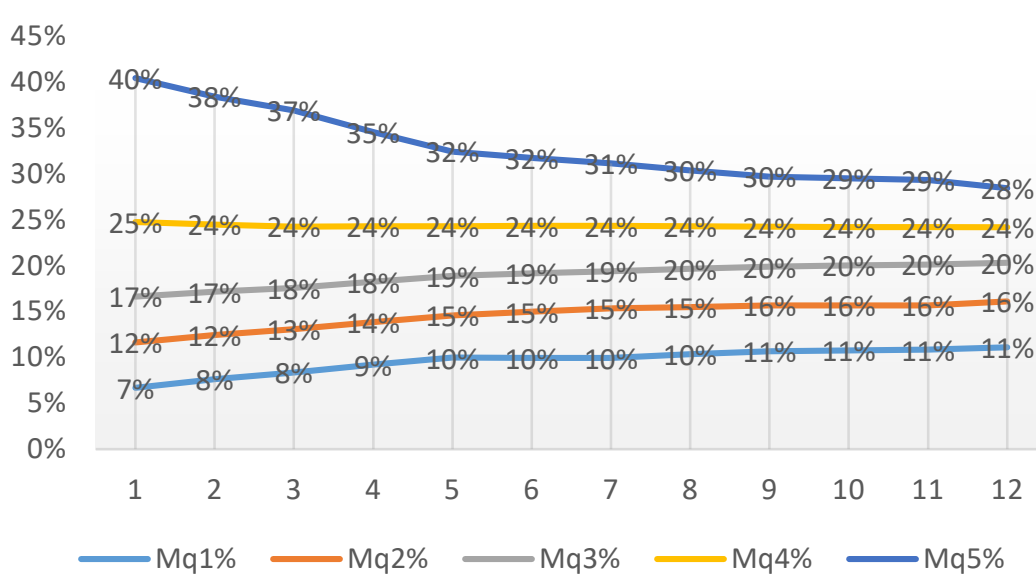

Hình 3-3 Phân bố xe máy trong lưu thông giai đoạn 2006-2017 theo năm nhóm thu nhập 
Nguồn: Nhóm nghiên cứu

\section{c. Phân bố giữa 6 vùng kinh tế xã hội}

Như đã biết, toàn quốc được chia ra thành các vùng kinh tế-xã hội khác nhau. Các vùng này không phải là một khái niệm hành chính, mà chỉ là một nhóm tỉnh-thành phố liền kề có chung một số đặc điểm kinh tế-xã hội.

Trước đây, toàn bộ các tỉnh, thành phố được chia thành 8 vùng. Nay 63 tỉnh và thành phố trực thuộc Trung ương được chia thành 6 vùng kinh tế xã hội như sau:

Vùng 1 . Đồng bằng sông Hồng gồm 11 tỉnh;

Vùng 2. Trung du và miền núi phía Bắc gốm 14 tỉnh;

Vùng 3. Bắc Trung Bộ và Duyên Hải miền Trung: gồm 14 tỉnh;

Vùng 4. Tây Nguyên gồm 5 tỉnh;

Vùng 5. Đông Nam Bộ gồm 6 tỉnh và

Vùng 6. Đồng bằng sông Cửu Long gồm 13 tỉnh.

Danh sách chi tiểt các tỉnh, thành phố xem Phụ lục (Bộ Kế hoạch Đâu tư đang lấy ý kiến về việc chia lại thành 7 vùng).

Bảng 3-11 Phân bố xe máy trong lưu thông theo 06 vùng kinh tế-xã hội

\begin{tabular}{|c|c|c|c|c|c|c|c|}
\hline \multirow{2}{*}{$\begin{array}{c}\text { Năm } \\
\mathbf{y} \\
\end{array}$} & \multirow{2}{*}{$\begin{array}{c}\begin{array}{c}\text { Số xe lưu } \\
\text { hành }\end{array} \\
\text { Mcir } \\
\end{array}$} & \multicolumn{6}{|c|}{ Phân bố theo 06 vùng kinh tế-xã hội } \\
\hline & & V1 & $\mathbf{V} 2$ & V3 & V4 & V5 & V6 \\
\hline 2008 & $18,461,668$ & 4.097 .440 & 1.917 .960 & 3.670 .271 & 1.024 .156 & 4.932 .795 & 2.819 .046 \\
\hline 2009 & $19,914,626$ & 4.512 .480 & 2.119 .456 & 3.891 .551 & 1.117 .855 & 5.102 .402 & 3.170 .883 \\
\hline 2010 & $21,473,102$ & 4.984 .372 & 2.343 .240 & 4.143 .065 & 1.221 .028 & 5.231 .949 & 3.549 .448 \\
\hline 2011 & $23,998,149$ & 5.551 .290 & 2.557 .801 & 4.715 .562 & 1.401 .195 & 5.740 .077 & 4.032 .224 \\
\hline 2012 & $26,605,882$ & 6.132 .771 & 2.778 .475 & 5.315 .762 & 1.592 .439 & 6.263 .179 & 4.523 .256 \\
\hline 2013 & $28,588,284$ & 6.507 .299 & 3.031 .472 & 5.718 .063 & 1.710 .605 & 6.680 .979 & 4.939 .866 \\
\hline 2014 & $30,631,124$ & 6.890 .713 & 3.295 .053 & 6.128 .330 & 1.830 .700 & 7.113 .448 & 5.372 .881 \\
\hline 2015 & $32,355,606$ & 7.237.599 & 3.468 .036 & 6.440 .084 & 1.906 .551 & 7.561 .837 & 5.741 .498 \\
\hline 2016 & $34,132,976$ & 7.540 .516 & 3.663 .723 & 6.838 .629 & 1.975 .195 & 8.045 .922 & 6.068 .992 \\
\hline 2017 & $36,619,551$ & 8.219 .097 & 3.919 .810 & 7.303 .783 & 2.185 .451 & 8.370 .079 & 6.621 .330 \\
\hline $\mathbf{y}$ & Mcir\% & Mv1\% & Mv2\% & Mv3\% & Mv4\% & Mv5\% & Mv6\% \\
\hline 2008 & $100 \%$ & $22,19 \%$ & $10,39 \%$ & $19,88 \%$ & $5,55 \%$ & $26,72 \%$ & $15,27 \%$ \\
\hline 2009 & $100 \%$ & $22,66 \%$ & $10,64 \%$ & $19,54 \%$ & $5,61 \%$ & $25,62 \%$ & $15,92 \%$ \\
\hline 2010 & $100 \%$ & $23,21 \%$ & $10,91 \%$ & $19,29 \%$ & $5,69 \%$ & $24,37 \%$ & $16,53 \%$ \\
\hline 2011 & $100 \%$ & $23,13 \%$ & $10,66 \%$ & $19,65 \%$ & $5,84 \%$ & $23,92 \%$ & $16,80 \%$ \\
\hline 2012 & $100 \%$ & $23,05 \%$ & $10,44 \%$ & $19,98 \%$ & $5,99 \%$ & $23,54 \%$ & $17,00 \%$ \\
\hline 2013 & $100 \%$ & $22,76 \%$ & $10,60 \%$ & $20,00 \%$ & $5,98 \%$ & $23,37 \%$ & $17,28 \%$ \\
\hline 2014 & $100 \%$ & $22,50 \%$ & $10,76 \%$ & $20,01 \%$ & $5,98 \%$ & $23,22 \%$ & $17,54 \%$ \\
\hline 2015 & $100 \%$ & $22,37 \%$ & $10,72 \%$ & $19,90 \%$ & $5,89 \%$ & $23,37 \%$ & $17,74 \%$ \\
\hline 2016 & $100 \%$ & $22,09 \%$ & $10,73 \%$ & $20,04 \%$ & $5,79 \%$ & $23,57 \%$ & $17,78 \%$ \\
\hline 2017 & $100 \%$ & $22,44 \%$ & $10,70 \%$ & $19,95 \%$ & $5,97 \%$ & $22,86 \%$ & $18,08 \%$ \\
\hline & ớng & $\begin{array}{l}\text { Tăng } \\
\text { giảm ít }\end{array}$ & Đều & Đều & Đều & Giảm & Tăng \\
\hline
\end{tabular}

Nguồn: Nhóm nghiên cứu 


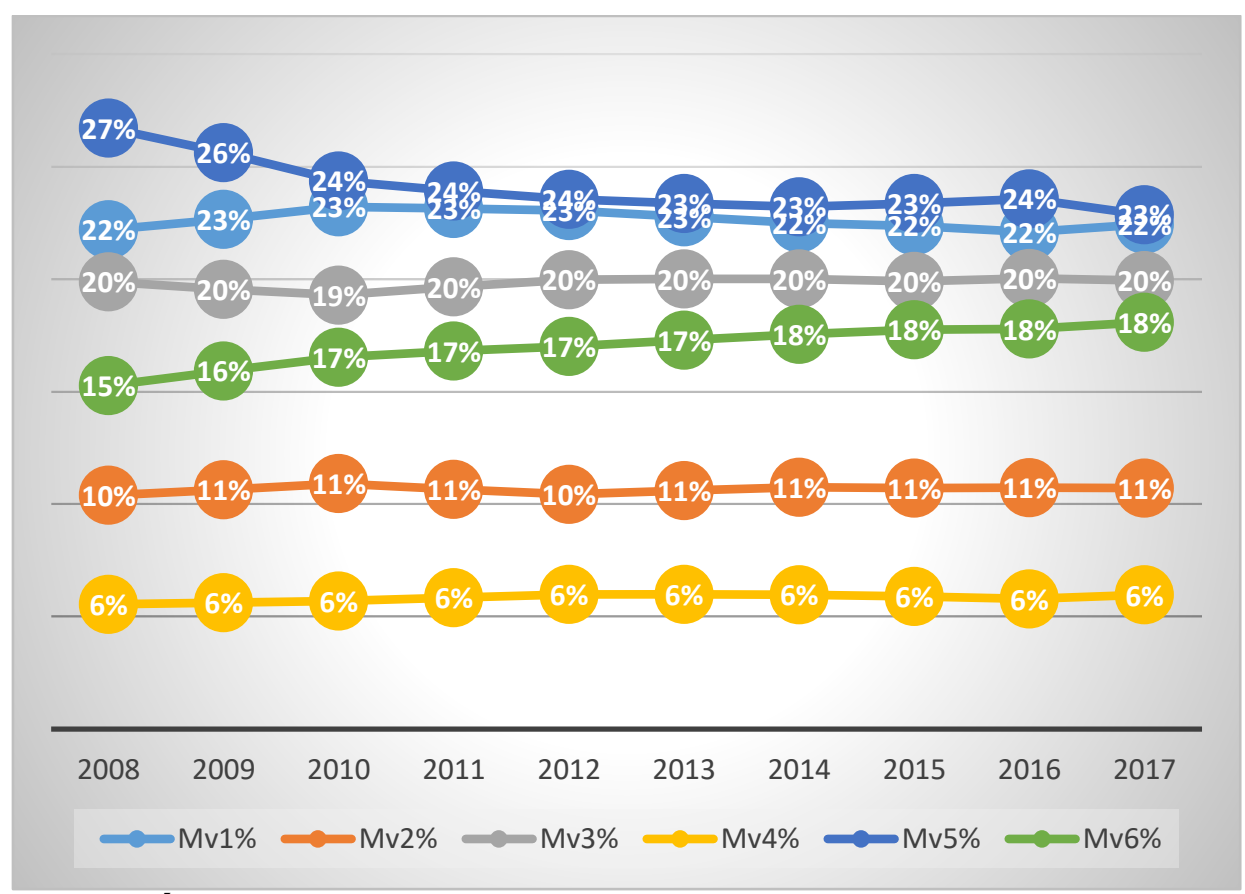

\section{Hình 3-4 Phân bố xe máy trong lưu thông giai đoạn 2006-2017 theo sáu (06) vùng kinh \\ tế-xã hội}

Nguồn: Nhóm nghiên cứu

Trong Duc N.H. (2016) ${ }^{60}$, đã có một số kết luận khi nghiên cứu 8 vùng. Bằng cách tính toán số liệu tương tự, có những kết luận sau đây: Số liệu trong Phản ảnh rất rõ trình độ phát triển kinh tế xã hội từng vùng. Tổng số xe máy, vốn là một dữ liệu từ nhiều năm, nghĩa là một dữ liệu dài hạn, có quan hệ rất chặt với các điều kiện kinh tế xã hội (xem Quy luật này ở cuối chương). Như vậy, có thể nói, số liệu xe máy trong lưu thông nhu một đại lượng phản ảnh ở mức độ nào đó sụ phát triển kinh tế-xã hội giữa các vùng, các địa phương khác nhau.

Biều đồ kèm theo cho thấy tỷ lệ tương đối về số xe máy giữa các vùng, trong đó phần của vùng 2, 3 và 4 gần như không đổi từ 2008 đến 2017.

\section{5) Phân bố xe máy trong lưu thông theo không gian năm 2017}

Trong phần trước, ta chủ yếu xem xét sự phân bố xe máy trong lưu thông theo thời gian (20062017). Phần nghiên cứu sau dành cho sự phân bố xe máy theo không gian với mốc năm 2017 .

Bảng dưới đây là số liệu xe máy trong lưu thông phân bố theo 63 tỉnh thành phố.

\footnotetext{
${ }^{60}$ Nguyễn Hữu Đức (2016) Thực trạng xe máy lưu hành ở 8 vùng kinh tế-xã hội Việt Nam: Một nghiên cứu so sánh. Hội nghị An toàn giao thông năm 2016. Hà Nội
} 
Dự án: Xây dựng chiến lược an toàn giao thông đối với xe máy và kế hoạch hành động: một khởi đầu của Việt Nam

Bảng 3-12 Phân bố xe máy ở 63 tình, thành phố năm 2017 xếp theo 6 vùng kinh tế-xã hội

\begin{tabular}{|c|c|c|c|c|c|}
\hline \\
\hline \multirow[t]{2}{*}{ Tỉnh thành } & Dân số & $\begin{array}{c}\text { Thu nhập bình } \\
\text { quân nhân khẩu } \\
1 \text { tháng }\end{array}$ & $\begin{array}{l}\text { Mức đô } \\
\text { thị hóa }\end{array}$ & $\begin{array}{c}\text { Tổng số xe } \\
\text { máy lưu } \\
\text { thông }\end{array}$ & $\begin{array}{c}\text { Số xe máy lưu } \\
\text { thông trên } 100 \\
\text { người dân }\end{array}$ \\
\hline & pop & Inc & urb & $\mathrm{M}_{\mathrm{cir}}$ & $\mathrm{M}_{\text {cir100 }}$ \\
\hline Toàn quốc & 93.671 .600 & $3.387,12$ & $35,03 \%$ & 36.619 .551 & 39,09 \\
\hline Đồng bằng sông Hồng & 21.342.100 & $4.259,19$ & $38,18 \%$ & 8.089 .840 & 37,91 \\
\hline Hà Nội & 7.420 .100 & $5.362,18$ & $58,86 \%$ & 2.985.571 & 40,24 \\
\hline Vĩnh Phúc & 1.079 .500 & $3.060,82$ & $23,30 \%$ & 431.555 & 39,98 \\
\hline Bắc Ninh & 1.215 .200 & $4.545,63$ & $28,30 \%$ & 487.354 & 40,10 \\
\hline Quảng Ninh & 1.243 .600 & $3.966,75$ & $63,61 \%$ & 406.178 & 32,66 \\
\hline Hải Dương & 1.797 .300 & $3.432,94$ & $25,20 \%$ & 631.175 & 35,12 \\
\hline Hải Phòng & 1.997 .700 & $4.744,57$ & $46,76 \%$ & 778.540 & 38,97 \\
\hline Hưng Yên & 1.176 .300 & $2.984,01$ & $12,93 \%$ & 437.326 & 37,18 \\
\hline Thái Bình & 1.791 .500 & $3.042,62$ & $10,51 \%$ & 669.263 & 37,36 \\
\hline Hà Nam & 805.700 & $2.951,32$ & $15,76 \%$ & 263.985 & 32,76 \\
\hline Nam Định & 1.853 .300 & $3.324,05$ & $18,30 \%$ & 656.294 & 35,41 \\
\hline Ninh Bình & 961.900 & $2.996,39$ & $20,91 \%$ & 342.599 & 35,62 \\
\hline $\begin{array}{l}\text { Trung du và miền núi } \\
\text { phía Bắc }\end{array}$ & 12.148.900 & $2.109,29$ & $18,47 \%$ & 3.930 .624 & 32,35 \\
\hline Hà Giang & 833.500 & $1.398,31$ & $15,00 \%$ & 171.430 & 20,57 \\
\hline Cao Bằng & 535.400 & $1.678,34$ & $23,18 \%$ & 176.103 & 32,89 \\
\hline Bắc Kạn & 323.200 & $1.548,58$ & $18,78 \%$ & 105.097 & 32,52 \\
\hline Tuyên Quang & 773.500 & $1.899,47$ & $13,74 \%$ & 280.146 & 36,22 \\
\hline Lào Cai & 694.400 & $1.907,20$ & $22,87 \%$ & 201.496 & 29,02 \\
\hline Yên Bái & 807.300 & $1.842,83$ & $20,56 \%$ & 257.172 & 31,86 \\
\hline Thái Nguyên & 1.255 .100 & $3.049,11$ & $35,10 \%$ & 522.289 & 41,61 \\
\hline Lạng Sơn & 778.400 & $1.811,15$ & $19,81 \%$ & 244.944 & 31,47 \\
\hline Bắc Giang & 1.674 .400 & $2.867,36$ & $11,43 \%$ & 635.467 & 37,95 \\
\hline Phú Thọ & 1.392 .900 & $2.523,37$ & $18,85 \%$ & 517.001 & 37,12 \\
\hline Điện Biên & 567.000 & $1.367,98$ & $15,10 \%$ & 130.865 & 23,08 \\
\hline Lai Châu & 446.100 & $1.327,42$ & $17,35 \%$ & 94.828 & 21,26 \\
\hline Sơn La & 1.228 .900 & $1.433,53$ & $13,63 \%$ & 323.117 & 26,29 \\
\hline Hoà Bình & 838.800 & $2.033,54$ & $14,77 \%$ & 270.669 & 32,27 \\
\hline $\begin{array}{l}\text { Bắc Trung Bộ và Duyên } \\
\text { hải miền Trung }\end{array}$ & 19.924.500 & $2.574,06$ & $28,69 \%$ & 7.336.820 & 36,82 \\
\hline Thanh Hoá & 3.544 .400 & $2.224,03$ & $17,19 \%$ & 1.032.751 & 29,14 \\
\hline Nghệ An & 3.131 .300 & $2.007,40$ & $15,08 \%$ & 898.531 & 28,70 \\
\hline Hà Tĩnh & 1.272 .200 & $2.241,21$ & $18,27 \%$ & 432.537 & 34,00 \\
\hline Quảng Bình & 882.500 & $2.385,63$ & $19,69 \%$ & 291.471 & 33,03 \\
\hline Quảng Trị & 627.300 & $2.157,17$ & $29,97 \%$ & 219.250 & 34,95 \\
\hline Thừa Thiên-Huế & 1.154 .300 & $2.790,02$ & $48,81 \%$ & 505.724 & 43,81 \\
\hline Đà Nẵng & 1.064 .100 & $4.703,75$ & $87,62 \%$ & 556.140 & 52,26 \\
\hline
\end{tabular}




\begin{tabular}{|c|c|c|c|c|c|}
\hline Tỉnh thành & Dân số & $\begin{array}{c}\text { Thu nhập bình } \\
\text { quân nhân khẩu } \\
1 \text { tháng }\end{array}$ & $\begin{array}{l}\text { Mức đô } \\
\text { thị hóa }\end{array}$ & $\begin{array}{l}\text { Tổng số xe } \\
\text { máy lưu } \\
\text { thông }\end{array}$ & $\begin{array}{c}\text { Số xe máy lưu } \\
\text { thông trên } 100 \\
\text { người dân }\end{array}$ \\
\hline & pop & Inc & urb & $\mathrm{M}_{\mathrm{cir}}$ & $\mathbf{M}_{\text {cir100 }}$ \\
\hline Quảng Nam & 1.493 .800 & $2.298,03$ & $24,22 \%$ & 560.297 & 37,51 \\
\hline Quảng Ngãi & 1.261 .600 & $2.190,52$ & $15,16 \%$ & 491.624 & 38,97 \\
\hline Bình Định & 1.529 .000 & $2.852,22$ & $31,03 \%$ & 637.394 & 41,69 \\
\hline Phú Yên & 904.400 & $2.481,16$ & $29,08 \%$ & 375.182 & 41,48 \\
\hline Khánh Hoà & 1.222 .200 & $3.188,73$ & $45,03 \%$ & 562.540 & 46,03 \\
\hline Ninh Thuận & 607.000 & $2.678,82$ & $36,21 \%$ & 227.200 & 37,43 \\
\hline Bình Thuận & 1.230 .400 & $2.938,39$ & $39,31 \%$ & 546.179 & 44,39 \\
\hline Tây Nguyên & $\mathbf{5 . 7 7 8 . 5 0 0}$ & $2.595,81$ & $29,22 \%$ & 2.119.087 & 36,67 \\
\hline Kon Tum & 520.000 & $2.060,55$ & $35,54 \%$ & 173.795 & 33,42 \\
\hline Gia Lai & 1.437 .400 & $2.185,60$ & $30,10 \%$ & 449.992 & 31,31 \\
\hline Đắk Lắk & 1.896 .600 & $2.524,93$ & $24,56 \%$ & 755.926 & 39,86 \\
\hline Đắk Nông & 625.600 & $2.453,42$ & $15,20 \%$ & 207.902 & 33,23 \\
\hline Lâm Đồng & 1.298 .900 & $3.162,41$ & $39,29 \%$ & 531.472 & 40,92 \\
\hline Đông Nam Bộ & 16.739 .600 & $5.106,77$ & $62,66 \%$ & 8.632.065 & 51,57 \\
\hline Bình Phước & 968.900 & $3.417,26$ & $19,93 \%$ & 444.664 & 45,89 \\
\hline Tây Ninh & 1.126 .200 & $3.568,09$ & $22,45 \%$ & 544.984 & 48,39 \\
\hline Bình Dương & 2.071 .000 & $5.202,85$ & $76,19 \%$ & 1.081 .902 & 52,24 \\
\hline Đồng Nai & 3.027 .300 & $4.507,72$ & $35,31 \%$ & 1.574.689 & 52,02 \\
\hline Bà Rịa-Vũng Tàu & 1.101 .600 & $4.773,07$ & $51,90 \%$ & 527.293 & 47,87 \\
\hline TP.Hồ Chí Minh & 8.444 .600 & $5.649,79$ & $80,82 \%$ & 4.458.534 & 52,80 \\
\hline $\begin{array}{l}\text { Đồng bằng sông Cửu } \\
\text { Long }\end{array}$ & 17.738 .000 & $\mathbf{3 . 0 0 6 , 3 7}$ & $25,52 \%$ & 6.511.116 & 36,71 \\
\hline Long An & 1.496 .800 & $3.308,51$ & $18,03 \%$ & 622.713 & 41,60 \\
\hline Tiền Giang & 1.751 .800 & $3.313,19$ & $15,49 \%$ & 753.658 & 43,02 \\
\hline Bến Tre & 1.266 .700 & $2.630,52$ & $10,67 \%$ & 499.976 & 39,47 \\
\hline Trà Vinh & 1.045 .600 & $2.448,26$ & $18,09 \%$ & 405.109 & 38,74 \\
\hline Vĩnh Long & 1.050 .200 & $2.657,09$ & $16,97 \%$ & 394.784 & 37,59 \\
\hline Đồng Tháp & 1.690 .300 & $2.778,76$ & $17,77 \%$ & 688.888 & 40,76 \\
\hline An Giang & 2.161 .700 & $3.070,58$ & $30,75 \%$ & 785.796 & 36,35 \\
\hline Kiên Giang & 1.792 .600 & $3.248,18$ & $29,48 \%$ & 535.761 & 29,89 \\
\hline Cần Thơ & 1.272 .800 & $3.540,80$ & $67,06 \%$ & 532.030 & 41,80 \\
\hline Hậu Giang & 774.600 & $2.673,95$ & $25,07 \%$ & 282.545 & 36,48 \\
\hline Sóc Trăng & 1.314 .300 & $2.549,08$ & $30,60 \%$ & 416.113 & 31,66 \\
\hline Bạc Liêu & 894.300 & $2.691,79$ & $29,29 \%$ & 260.341 & 29,11 \\
\hline Cà Mau & 1.226 .300 & $2.612,99$ & $22,69 \%$ & 333.401 & 27,19 \\
\hline
\end{tabular}

Ghi chú: Mỗi vùng sử dụng một màu khác nhau

Nguồn: Nhóm nghiên cứu 
Bảng tiếp theo cho thấy các tỉnh/thành phố xếp theo thứ tự số xe máy trong lưu thông (bảng đầy đủ xem Phụ lục) trong đó TP. Hồ Chí Minh có số lượng cao nhất, tiếp theo là Hà Nội. Điều này trùng với số lượng theo đăng ký nêu ở Chương 2 . Điều này có vẻ bình thường. Nhưng nếu ta xét số xe máy trong lưu thông tính theo 100 dân $\left(\mathrm{M}_{\text {cir100 }}\right)$ thì lại khác (xem bảng dưới nữa).

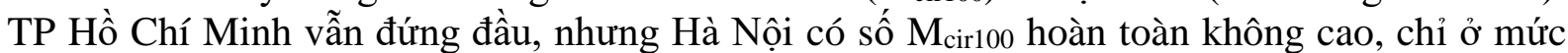
trung bình toàn quốc. Các tỉnh có tổng số xe máy trong lưu thông thấp nhất là ở miền núi phía Bắc. Điều này cho thấy. việc hạn chế xe máy ở TP Hồ Chí Minh ở mức độ cấp thiết cao hơn Hà Nội nhiều.

Bảng 3-13 Các tỉnh/thành phố xếp theo số lượng xe máy trong lưu thông Mcir

\begin{tabular}{|c|c|c|c|c|c|}
\hline \multirow[t]{2}{*}{ Thứ tự tỉnh thành xếp theo $\mathbf{M}_{\text {cir }}$} & Dân số & $\begin{array}{c}\text { Thu nhập } \\
\text { bình quân } \\
\text { nhân } \\
\text { khẩu } 1 \\
\text { tháng }\end{array}$ & $\begin{array}{l}\text { Mức đô } \\
\text { thị hóa }\end{array}$ & $\begin{array}{c}\text { Tổng số } \\
\text { xe máy } \\
\text { lưu thông }\end{array}$ & $\begin{array}{c}\text { Số xe máy } \\
\text { lưu thông } \\
\text { trên } 100 \\
\text { người dân }\end{array}$ \\
\hline & Pop & inc & Urb & $\mathrm{M}_{\mathrm{cir}}$ & $\mathrm{M}_{\mathrm{cir} 100}$ \\
\hline Toàn quốc & 93.671 .600 & 3387,12 & $35,03 \%$ & 36.619 .551 & 39,09 \\
\hline TP. Hồ Chí Minh & 8.444 .600 & $5.649,79$ & $80,82 \%$ & 4.458.534 & 52,80 \\
\hline Hà Nội & 7.420 .100 & $5.362,18$ & $58,86 \%$ & 2.985 .571 & 40,24 \\
\hline Đồng Nai & 3.027 .300 & $4.507,72$ & $35,31 \%$ & 1.574.689 & 52,02 \\
\hline Bình Dương & 2.071 .000 & $5.202,85$ & $76,19 \%$ & 1.081.902 & 52,24 \\
\hline Thanh Hoá & 3.544 .400 & $2.224,03$ & $17,19 \%$ & 1.032.751 & 29,14 \\
\hline \multicolumn{6}{|l|}{........., } \\
\hline Lang Sơn & 778.400 & $1.811,15$ & $19,81 \%$ & 244.944 & 31,47 \\
\hline Hà Giang & 833.500 & $1.398,31$ & $15,00 \%$ & 171.430 & 20,57 \\
\hline Điện Biên & 567.000 & $1.367,98$ & $15,10 \%$ & 130.865 & 23,08 \\
\hline Bắc Kạn & 323.200 & $1.548,58$ & $18,78 \%$ & 105.097 & 32,52 \\
\hline Lai Châu & 446.100 & $1.327,42$ & $17,35 \%$ & 94.828 & 21,26 \\
\hline Toàn quốc & 93.671 .600 & 3387,12 & $35,03 \%$ & 36.619 .551 & 39,09 \\
\hline Đông Nam Bộ & 16.739 .600 & $5.106,77$ & $62,66 \%$ & 8.632.065 & 51,57 \\
\hline Đồng bằng sông Hồng & 21.342 .100 & $4.259,19$ & $38,18 \%$ & 8.089 .840 & 37,91 \\
\hline $\begin{array}{l}\text { Bắc Trung Bộ và Duyên hải miền } \\
\text { Trung }\end{array}$ & 19.924.500 & $2.574,06$ & $28,69 \%$ & 7.336 .820 & 36,82 \\
\hline Đồng bằng sông Cửu Long & 17.738.000 & 3.006,37 & $25,52 \%$ & 6.511 .116 & 36,71 \\
\hline Trung du và miền núi phía Bắc & 12.148 .900 & $2.109,29$ & $18,47 \%$ & 3.930 .624 & 32,35 \\
\hline Tây Nguyên & 5.778 .500 & $2.595,81$ & $29,22 \%$ & 2.119 .087 & 36,67 \\
\hline
\end{tabular}

Ghi chú: Mỗi vùng sử dụng một màu khác nhau

Nguồn: Nhóm nghiên cứu

Bảng 3-14 Các tỉnh/thành phố xếp theo số lượng xe máy trong lưu thông tính theo 100 dân Mcir100

\begin{tabular}{|l|c|c|c|c|c|}
\hline \multicolumn{1}{|c|}{ Tỉnh thành xếp theo Mcir100 } & Dân số & $\begin{array}{c}\text { Thu nhập } \\
\text { bình quân } \\
\text { nhân } \\
\text { khẩu 1 } \\
\text { tháng }\end{array}$ & $\begin{array}{c}\text { Mức đô } \\
\text { thị hóa }\end{array}$ & $\begin{array}{c}\text { Tổng số } \\
\text { xe máy } \\
\text { lưu thông }\end{array}$ & $\begin{array}{c}\text { Số xe máy } \\
\text { lưu thông } \\
\text { trên 100 } \\
\text { người dân }\end{array}$ \\
\cline { 2 - 6 } & Pop & inc & urb & Mcir & Mcir100 \\
\hline TP. Hồ Chí Minh & 8.444 .600 & $5.649,79$ & $80,82 \%$ & $\mathbf{4 . 4 5 8 . 5 3 4}$ & 52,80 \\
\hline Đà Nẵng & 1.064 .100 & $4.703,75$ & $87,62 \%$ & $\mathbf{5 5 6 . 1 4 0}$ & 52,26 \\
\hline Bình Dương & 2.071 .000 & $5.202,85$ & $76,19 \%$ & $\mathbf{1 . 0 8 1 . 9 0 2}$ & 52,24 \\
\hline
\end{tabular}




\begin{tabular}{|l|r|r|r|r|c|}
\hline \multirow{2}{*}{ Tỉnh thành xếp theo Mcir100 } & Dân số & $\begin{array}{r}\text { Thu nhập } \\
\text { bình quân } \\
\text { nhân } \\
\text { khẩu 1 } \\
\text { tháng }\end{array}$ & $\begin{array}{c}\text { Mức đô } \\
\text { thị hóa }\end{array}$ & $\begin{array}{c}\text { Tổng số } \\
\text { xe máy } \\
\text { lưu thông }\end{array}$ & $\begin{array}{c}\text { Số xe máy } \\
\text { lưu thông } \\
\text { trên 100 } \\
\text { người dân }\end{array}$ \\
\hline Đông Nai & 3.027 .300 & $4.507,72$ & $35,31 \%$ & $\mathbf{1 . 5 7 4 . 6 8 9}$ & 52,02 \\
\hline & 1.126 .200 & $3.568,09$ & $22,45 \%$ & $\mathbf{5 4 4 . 9 8 4}$ & 48,39 \\
\hline Hà Nội & & & & & \\
\hline & 7.420 .100 & $5.362,18$ & $58,86 \%$ & $\mathbf{2 . 9 8 5 . 5 7 1}$ & 40,24 \\
\hline Toàn quốc & & & & & \\
\hline & $\mathbf{9 3 . 6 7 1 . 6 0 0}$ & $\mathbf{3 3 8 7 , 1 2}$ & $\mathbf{3 5 , 0 3 \%}$ & $\mathbf{3 6 . 6 1 9 . 5 5 1}$ & $\mathbf{3 9 , 0 9}$ \\
\hline Sơn La & & & & & \\
\hline Điện Biên & 1.228 .900 & $1.433,53$ & $13,63 \%$ & $\mathbf{3 2 3 . 1 1 7}$ & 26,29 \\
\hline Lai Châu & 567.000 & $1.367,98$ & $15,10 \%$ & $\mathbf{1 3 0 . 8 6 5}$ & 23,08 \\
\hline Hà Giang & 446.100 & $1.327,42$ & $17,35 \%$ & $\mathbf{9 4 . 8 2 8}$ & 21,26 \\
\hline
\end{tabular}

\begin{tabular}{|l|r|r|r|r|c|}
\hline Đông Nam Bộ & 16.739 .600 & $5.106,77$ & $62,66 \%$ & $\mathbf{8 . 6 3 2 . 0 6 5}$ & 51,57 \\
\hline Toàn quốc & 93.671 .600 & 3387,12 & $35,03 \%$ & 36.619 .551 & 39,09 \\
\hline Đồng bằng sông Hồng & 21.342 .100 & $4.259,19$ & $38,18 \%$ & 8.089 .840 & 37,91 \\
\hline $\begin{array}{l}\text { Bắc Trung Bộ và Duyên hải miền } \\
\text { Trung }\end{array}$ & 19.924 .500 & $2.574,06$ & $28,69 \%$ & 7.336 .820 & 36,82 \\
\hline Đồng bằng sông Cửu Long & 17.738 .000 & $3.006,37$ & $25,52 \%$ & 6.511 .116 & 36,71 \\
\hline Tây Nguyên & 5.778 .500 & $2.595,81$ & $29,22 \%$ & $\mathbf{2 . 1 1 9 . 0 8 7}$ & 36,67 \\
\hline Trung du và miền núi phía Bắc & 12.148 .900 & $2.109,29$ & $18,47 \%$ & 3.930 .624 & 32,35 \\
\hline
\end{tabular}

Ghi chú: Mỗi vùng sử dụng một màu khác nhau

Nguồn: Nhóm nghiên cứu

\subsection{Nghiên cứu về tai nạn giao thông do xe máy}

Có hai khái niệm đôi khi lẫn lộn. Đó là phương tiện gây TNGT và phương tiện liên quan đến TNGT, trong đó khái niệm sau rộng hơn, vì nó bao gồm cả phương tiện bị thiệt hại do TNGT, còn khái niệm đầu không bao gồm loại này. Trong mục này, ta sẽ xem xét xe máy về mặt là phương tiện gây TNGT và cũng xem xét xe máy là phương tiện liên quan đến TNGT.

\subsubsection{Xe máy như một loại phương tiện gây TNGT: nhiều nhất, nhưng không phải nguy hiểm nhất}

Có ý kiến cho rằng xe máy là phương tiện gây TNGT nhiều nhất. Tuy nhiên xem xét vấn đề này dựa theo dữ liệu tính toán sẽ thấy rằng kết luận này có phần chưa chính xác.

Bảng dưới đây trình bày kết quả tính toán với số liệu gốc từ UBATGTQG. Kết quả cho thấy điều đó đúng theo nghĩa tổng số TNGT do xe máy gây ra nhiều nhất, nhưng khả năng gây rủi ro TNGT của một chiếc xe máy thấp hơn nhiều so với một chiếc ô tô: Số liệu lần đầu tiên được công bố ở bảng này cho thấy, thực ra, tuy gây nhiều TNGT, nhưng mức độ gây TNGT của ô tô gấp nhiều lần xe máy (khoảng 4,4 lần xét theo số xe lưu hành hay 6,7 lần theo số đăng ký). Do số xe máy gấp 15 lần xe ô tô nên tổng số TNGT do xe máy gây ra nhiều hơn. Điều này có hai kết luận mang ý nghĩa thực tế và lý luận quan trọng sau: 
1. Để giảm TNGT do xe máy, cần giảm sự gia tăng nhanh chóng số lượng xe. Như thế, kết luận này xác thực tính cần thiết việc gắn liền giữa nghiên cứu về ATGT với sự tăng trưởng xe máy như Dự án này làm. Như vậy, việc giảm mức gia tăng phương tiện đi lại cá nhân, không chỉ góp phần làm giảm ùn tắc, mà làm giảm cả TNGT.

2. Do tốc độ gia tăng xe ô tô cao hơn so với xe máy nên rủi ro tăng TNGT là rõ, vì vậy, việc các lực lượng chức năng kiểm soát chặt chẽ giao thông ô tô hơn xe máy là cần thiết.

Bảng 3-15 So sánh khả năng gây TNGT giữa xe máy và ô tô

\begin{tabular}{|c|c|c|c|c|c|}
\hline STT & Phương tiện gây TNGT 2016-2018 & $\begin{array}{c}\text { Trung } \\
\text { bình } 01 \\
\text { năm }\end{array}$ & 2018 & 2017 & 2016 \\
\hline 1 & Xe máy & $65,63 \%$ & $60,25 \%$ & $69,94 \%$ & $66,70 \%$ \\
\hline 2 & Ô tô & $28,28 \%$ & $33,50 \%$ & $24,28 \%$ & $27,07 \%$ \\
\hline 3 & Khác & $6,09 \%$ & $6,25 \%$ & $5,78 \%$ & $6,23 \%$ \\
\hline 4 & Tỷ lê TNGT do xe máy so với ô tô & 2,32 & 1,80 & 2,88 & 2,46 \\
\hline 5 & $\begin{array}{l}\text { Số lượng xe máy (cả xe xăng và xe điện) so } \\
\text { với số ô tô đang quản lý }\end{array}$ & 15,31 & 15,25 & 14,98 & 15,70 \\
\hline & Số lượng ô tô đang quản lý & & 3.884 .627 & 3.658 .360 & 3.033 .527 \\
\hline & Số lương xe máy xăng đang quản lý & & 58.169 .432 & 54.063 .318 & 47.131 .928 \\
\hline & Số luợng xe máy điện đang quản lý & & 1.075 .630 & 728.451 & 501.400 \\
\hline 6 & $\begin{array}{l}\text { Số lượng xe máy so với số ô tô đang lưu } \\
\text { hành }\end{array}$ & & & 12,78 & \\
\hline & Số luợng ô tô đang luu hành & & $N A$ & 2.865 .202 & $N A$ \\
\hline & Số luợng xe máy đang lưu hành $\left(M_{\text {cir }}\right)$ & & 38.530 .436 & 36.619 .551 & 34.132 .976 \\
\hline \multicolumn{6}{|c|}{ Nếu 100 ô tô có khả năng gây 01 TNGT thì số xe máy có khả năng gây 01 TNGT là: } \\
\hline 7 & Theo số luọng đăng ký (Mreg) & 668 & 848 & 520 & 637 \\
\hline 8 & Theo số luọng lưu hành (Mcir) & 444 & & 444 & \\
\hline
\end{tabular}

Nguồn: Số liệu gốc tập hợp từ các Báo cáo hàng năm của UBATGTQG. Số liệu còn lại do Nhóm nghiên cứu tính toán.

\subsubsection{Xe máy-phương tiện liên quan với TNGT}

\section{1) Xe máy-phương tiện liên quan với TNGT nhiều nhất}

Như đã nêu ở trên, người đi xe máy dễ bị thương tổn do TNGT hơn đi xe ô tô vì thiết bị bảo vệ ít hơn. Vì vậy, xe máy là phương tiện liên quan đến TNGT nhiều nhất nếu xét đến cả việc xe máy gây ra và xe máy chịu hậu quả của TNGT.

Phân tích 61.628 vụ TNGT liên quan tới xe máy trong tổng số 74.296 vụ đã xảy ra năm 20132017, bảng dưới đây cho thấy rõ điều đó. 
Bảng 3-16 Phân tích TNGT liên quan xe máy về loại phương tiện

\begin{tabular}{|c|c|r|r|}
\hline STT & $\begin{array}{l}\text { Phương tiện liên } \\
\text { quan tới TNGT }\end{array}$ & \multicolumn{1}{c|}{ Số lượng } & \multicolumn{1}{|c|}{$\%$} \\
\hline 1 & Xe máy & 80.417 & $77,76 \%$ \\
\hline 2 & Ô tô các loại & 18.055 & $17,46 \%$ \\
\hline & Ô tô con & 8.234 & $7,96 \%$ \\
\hline & Ô tô tải & 7.890 & $7,63 \%$ \\
\hline 3 & Ô tô khách & 1.931 & $1,87 \%$ \\
\hline 4 & $\begin{array}{l}\text { Xe đạp, phương } \\
\text { tiện thô sơ khác }\end{array}$ & 4.939 & $4,78 \%$ \\
\hline \multicolumn{2}{|c|}{ Cộng } & 103.411 & $100,00 \%$ \\
\hline
\end{tabular}

\section{2) Nguyên nhân TNGT liên quan đến xe máy}

Bảng và hình dưới đây cho thấy các nguyên nhân chính, trong đó 03 nguyên nhân đứng đầu là do "Đi không đúng làn đường, phần đường quy định", "Chuyển hướng không đúng quy định" và "Không chấp hành quy định về tốc độ".

Các nguyên nhân sau ở mức trung bình, trong đó có nồng độ cồn:

- Không giữ khoảng cách an toàn với xe chạy liền trước

- Không chấp hành quy định nhường đường tại nơi giao nhau

- Sử dụng rượu, bia có nồng độ cồn vượt mức quy định

- Do người đi bộ

- Tránh xe không đúng quy định

- Không chấp hành báo hiệu đường bộ.

Ba nguyên nhân sau chiếm tỷ lệ thấp:

- Vượt xe không đúng quy định

- Dừng, đỗ không đúng quy định

- Không tuân thủ quy trình thao tác lái xe.

Bảng 3-17 Phân tích nguyên nhân TNGT liên quan đến xe máy

\begin{tabular}{|l|c|r|}
\hline \multicolumn{1}{|c|}{ Nguyên nhân } & Số vụ TNGT & Tỷ lệ \\
\hline Đi không đúng làn đường, phần đường quy định & 15.693 & $41,96 \%$ \\
\hline Chuyền hướng không đúng quy định & 5.054 & $13,51 \%$ \\
\hline Không chấp hành quy định về tốc độ & 3.804 & $10,17 \%$ \\
\hline Không giữ khoảng cách an toàn với xe chạy liền trước & 3.513 & $9,39 \%$ \\
\hline Không chấp hành quy định nhường đường tại nơi giao nhau & 2.658 & $7,11 \%$ \\
\hline Sử dụng rượu, bia có nồng độ cồn vượt mức quy định & 2.509 & $6,71 \%$ \\
\hline Do người đi bộ & 1.595 & $4,26 \%$ \\
\hline Tránh xe không đúng quy định & 1.168 & $3,12 \%$ \\
\hline Không chấp hành báo hiệu đường bộ & 817 & $2,18 \%$ \\
\hline Vượt xe không đúng quy định & 323 & $0,86 \%$ \\
\hline Dừng, đỗ không đúng quy định & 186 & $0,50 \%$ \\
\hline Không tuân thủ quy trình thao tác lái xe & 83 & $0,22 \%$ \\
\hline
\end{tabular}


- Đi không đúng làn đường, phần đường

- Chuyễn hướng không đúng quy định

- Không chấp hành quy định về tốc độ

- Không giữ khoảng cách an toàn

- Không nhường đường tại nơi giao nhau

- Nồng độ cồn vượt mức quy định

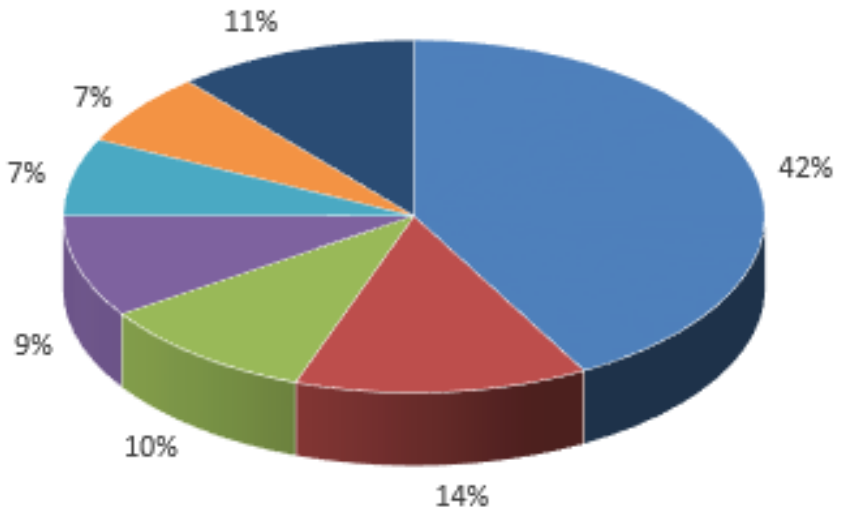

$14 \%$

- Khác

Hình 3-5 Phân tích nguyên nhân TNGT liên quan đến xe máy

Nguồn dữ liệu: Cục CSGT và Học viện CSND

\section{3) Phân tích các yếu tố liên quan tới TNGT xe máy}

Bảng dưới đây trình bầy kết quả phân tích tổng hợp các yếu tố liên quan tới TNGT xe máy. Với ba yếu tố đầu, kết quả đã khá quen biết: TNGT xảy ra nhiều ở quốc lộ, đường tỉnh và nội thị hơn nơi khác; ở khoảng thời gian $12 \mathrm{~h} 00-18 \mathrm{~h} 00$ và $18 \mathrm{~h} 00-24 \mathrm{~h} 00$ và ở nới ánh sáng kém. Điều đáng lưu ý là ở các yếu tố khách quan khác: trong điều kiện thuận lợi hơn thì TNGT lại nhiều hơn (đường thẳng, mặt đường khô, kết cấu bê tông nhựa...). Như vậy, có thể nói, chủ quan của người lái xe máy là yếu tố chính dẫn đến TNGT.

Bảng 3-18 Phân tích tổng họ̣p các yếu tố liên quan tới TNGT xe máy

\begin{tabular}{|c|c|c|c|c|c|c|c|}
\hline \multirow[b]{2}{*}{ STT } & \multirow[b]{2}{*}{ Yếu tố phân tích (2013-2017) } & \multicolumn{2}{|c|}{ Số vụ xem xét (*) } & \multicolumn{2}{|c|}{ Người chết } & \multicolumn{2}{|c|}{ Số bị thương } \\
\hline & & Số lượng & $\%$ & Số lượng & $\%$ & $\begin{array}{c}\text { Số } \\
\text { lượng }\end{array}$ & $\%$ \\
\hline 1 & Tuyến đường xảy ra TNGT & 61.628 & $100 \%$ & 27.107 & $100 \%$ & 40.430 & $100 \%$ \\
\hline & Cao tốc & 169 & $0,27 \%$ & 93 & $0,34 \%$ & 77 & $0,19 \%$ \\
\hline & Quốc lộ & 18.979 & $30,80 \%$ & 11.030 & $40,69 \%$ & 10.841 & $26,81 \%$ \\
\hline & Đuờng tỉnh & 10.955 & $17,78 \%$ & 5.791 & $21,36 \%$ & 7.372 & $18,23 \%$ \\
\hline & Nội thị & 21.092 & $34,22 \%$ & 5.007 & $18,47 \%$ & 15.317 & $37,89 \%$ \\
\hline & Nông thôn & 6.962 & $11,30 \%$ & 3.380 & $12,47 \%$ & 4.748 & $11,74 \%$ \\
\hline & Tuyến đường khác & 3.471 & $5,63 \%$ & 1.806 & $6,66 \%$ & 2.075 & $5,13 \%$ \\
\hline 2 & Thời gian xảy ra TNGT & 61.628 & $100 \%$ & 27.107 & $100 \%$ & 40.430 & $100 \%$ \\
\hline & 00h00-06h00 & 5.496 & $8,92 \%$ & 2.675 & $9,87 \%$ & 3.241 & $8,02 \%$ \\
\hline & $06 \mathrm{~h} 00-12 \mathrm{~h} 00$ & 9.694 & $15,73 \%$ & 4.193 & $15,47 \%$ & 5.700 & $14,10 \%$ \\
\hline & $12 \mathrm{~h} 00-18 \mathrm{~h} 00$ & 19.407 & $31,49 \%$ & 8.631 & $31,84 \%$ & 12.375 & $30,61 \%$ \\
\hline & $18 h 00-24 h 00$ & 27.031 & $43,86 \%$ & 11.608 & $42,82 \%$ & 19.114 & $47,28 \%$ \\
\hline 3 & Điều kiện ánh sáng nơi TNGT & 47.865 & $100 \%$ & 20.608 & $100 \%$ & 27.768 & $100 \%$ \\
\hline & Có ánh sáng công cộng & 11.430 & $23,88 \%$ & 6.242 & $30,29 \%$ & 7.112 & $25,61 \%$ \\
\hline & Không ánh sáng công công & 14.314 & $29,90 \%$ & 5.149 & $24,99 \%$ & 9.442 & $34,00 \%$ \\
\hline
\end{tabular}


Dự án: Xây dựng chiến lược an toàn giao thông đối với xe máy và kế hoạch hành động: một khởi đầu của Việt Nam

Nghiên cứu hiện trạng giao thông xe máy Việt Nam

\begin{tabular}{|c|c|c|c|c|c|c|c|}
\hline \multirow[b]{2}{*}{ STT } & \multirow[b]{2}{*}{ Yếu tố phân tích (2013-2017) } & \multicolumn{2}{|c|}{ Số vụ xem xét (*) } & \multicolumn{2}{|c|}{ Người chết } & \multicolumn{2}{|c|}{ Số bị thương } \\
\hline & & Số lượng & $\%$ & Số lượng & $\%$ & $\begin{array}{c}\text { Số } \\
\text { lượng }\end{array}$ & $\%$ \\
\hline & Không rõ & 22.121 & $46,22 \%$ & 9.217 & $44,73 \%$ & 11.214 & $40,38 \%$ \\
\hline \multirow[t]{8}{*}{4} & Hạ tầng đường bộ & 56.275 & $100 \%$ & 24.661 & $100 \%$ & 35.023 & $100 \%$ \\
\hline & Đuòng thẳng & 45.027 & $80,01 \%$ & 18.693 & $75,80 \%$ & 27.945 & $79,79 \%$ \\
\hline & Đường cong & 4.231 & $7,52 \%$ & 2.459 & $9,97 \%$ & 2.488 & $7,10 \%$ \\
\hline & Cầu & 1.331 & $2,37 \%$ & 212 & $0,86 \%$ & 193 & $0,55 \%$ \\
\hline & Đèo dốc & 395 & $0,70 \%$ & 267 & $1,08 \%$ & 234 & $0,67 \%$ \\
\hline & Hầm & 12 & $0,02 \%$ & 1 & $0,00 \%$ & 14 & $0,04 \%$ \\
\hline & Phà & 3 & $0,01 \%$ & 2 & $0,01 \%$ & 1 & $0,00 \%$ \\
\hline & Không rõ & 5.276 & $9,38 \%$ & 3.027 & $12,27 \%$ & 4.148 & $11,84 \%$ \\
\hline \multirow[t]{6}{*}{5} & Kết cầu mặt đường & 56.275 & $100 \%$ & 24.661 & $100 \%$ & 35.023 & $100 \%$ \\
\hline & Bê tông nhựa & 45.460 & $80,78 \%$ & 19.088 & $77,40 \%$ & 28.763 & $82,13 \%$ \\
\hline & Bê tông xi măng & 2.323 & $4,13 \%$ & 1.178 & $4,78 \%$ & 1.263 & $3,61 \%$ \\
\hline & Đường đá & 440 & $0,78 \%$ & 204 & $0,83 \%$ & 242 & $0,69 \%$ \\
\hline & Đường đất & 344 & $0,61 \%$ & 190 & $0,77 \%$ & 172 & $0,49 \%$ \\
\hline & Không rõ & 7.708 & $13,70 \%$ & 4.001 & $16,22 \%$ & 4.583 & $13,09 \%$ \\
\hline \multirow[t]{7}{*}{6} & Điều kiện mặt đường & 47.542 & $100 \%$ & 20.596 & $100 \%$ & 27.730 & $100 \%$ \\
\hline & Khô & 36.586 & $76,96 \%$ & 16.318 & $79,23 \%$ & 22.046 & $79,50 \%$ \\
\hline & U’ớt. trươn & 2.135 & $4,49 \%$ & 940 & $4,56 \%$ & 1.225 & $4,42 \%$ \\
\hline & Sa lầy & 4 & $0,01 \%$ & 2 & $0,01 \%$ & 1 & $0,00 \%$ \\
\hline & Ngập nước & 33 & $0,07 \%$ & 14 & $0,07 \%$ & 19 & $0,07 \%$ \\
\hline & Đang thi công. sửa chữa & 195 & $0,41 \%$ & 101 & $0,49 \%$ & 121 & $0,44 \%$ \\
\hline & Không rõ & 8.589 & $18,07 \%$ & 3.221 & $15,64 \%$ & 4.318 & $15,57 \%$ \\
\hline \multirow[t]{5}{*}{7} & Tác nhân va chạm & 37.031 & $100 \%$ & 15.942 & $100 \%$ & 21.979 & $100 \%$ \\
\hline & Xe vói xe & 17.298 & $46,71 \%$ & 7.370 & $46,23 \%$ & 10.880 & $49,50 \%$ \\
\hline & Ngườ vói xe & 15.623 & $42,19 \%$ & 6.253 & $39,22 \%$ & 9.159 & $41,67 \%$ \\
\hline & Tự gây TNGT & 2.168 & $5,85 \%$ & 1.207 & $7,57 \%$ & 1.021 & $4,65 \%$ \\
\hline & Khác & 1.942 & $5,24 \%$ & 1.112 & $6,98 \%$ & 919 & $4,18 \%$ \\
\hline \multirow[t]{5}{*}{8} & Chiều đi trên đường & 39.693 & $100 \%$ & 16.995 & $100 \%$ & 23.741 & $100 \%$ \\
\hline & Một chiều & 2.397 & $6,04 \%$ & 794 & $4,67 \%$ & 1.286 & $5,42 \%$ \\
\hline & Hai chiều không phân cách & 29.385 & $74,03 \%$ & 13.095 & $77,05 \%$ & 18.250 & $76,87 \%$ \\
\hline & Hai chiều có dải phân cách giữa & 5.018 & $12,64 \%$ & 2.267 & $13,34 \%$ & 3.043 & $12,82 \%$ \\
\hline & Hai chiều có vạch dọc liền ở giữa & 2.893 & $7,29 \%$ & 839 & $4,94 \%$ & 1.162 & $4,89 \%$ \\
\hline \multirow[t]{7}{*}{9} & Điều kiện thời tiết & 49.936 & $100 \%$ & 21.157 & $100 \%$ & 30.063 & $100 \%$ \\
\hline & Đêm (không mura) & 18.699 & $37,45 \%$ & 7.554 & $35,70 \%$ & 12.617 & $41,97 \%$ \\
\hline & Đêm mưa & 1.319 & $2,64 \%$ & 464 & $2,19 \%$ & 997 & $3,32 \%$ \\
\hline & Nắng & 15.295 & $30,63 \%$ & 7.111 & $33,61 \%$ & 8.909 & $29,63 \%$ \\
\hline & Râm & 11.912 & $23,85 \%$ & 5.277 & $24,94 \%$ & 6.463 & $21,50 \%$ \\
\hline & Mưa. lũ lụt & 2.544 & $5,09 \%$ & 644 & $3,04 \%$ & 997 & $3,32 \%$ \\
\hline & Sương mù & 134 & $0,27 \%$ & 92 & $0,43 \%$ & 61 & $0,20 \%$ \\
\hline
\end{tabular}


Dự án: Xây dựng chiến lược an toàn giao thông đối với xe máy và kế hoạch hành động: một khởi đầu của Việt Nam

\begin{tabular}{|l|l|r|r|r|r|r|r|}
\hline \multirow{2}{*}{ STT } & \multirow{2}{*}{ Yếu tố phân tích (2013-2017) } & \multicolumn{2}{|c|}{ Số vụ xem xét (*) } & \multicolumn{2}{|c|}{ Người chết } & \multicolumn{2}{c|}{ Số bị thương } \\
\cline { 3 - 8 } & & Số lượng & $\%$ & Số lượng & $\%$ & $\begin{array}{c}\text { Số } \\
\text { lượng }\end{array}$ & $\%$ \\
\hline & Bão. gió & 33 & $0,07 \%$ & 15 & $0,07 \%$ & 19 & $0,06 \%$ \\
\hline
\end{tabular}

(*) Đây là số vụ được xem xét để phân tích. không phải số vụ TNGT xảy ra

Nguồn: Nhóm nghiên cứu và Học viện CSND

\subsection{Hành vi vi phạm hành chính trên đường của người sử dụng xe máy}

\subsubsection{Dũ liệu xử lý vi phạm giao thông xe máy}

\section{1) Dữ liệu và cơ sở dữ liệu (CSDL) vi phạm}

Dữ liệu về hành vi vi phạm hành chính (trong mục này, ta gọi tắt là 'vi phạm') của người sử dụng xe máy có thể có từ ba nguồn:

- Dũ liệu của Cảnh sát giao thông (CSGT),

- Dũ liệu của Thanh tra giao thông,

- Dữ liệu của Cảnh sát trật tự (CSTT).

Tuy nhiên, theo phân cấp, chỉ có dữ liệu của CSGT là liên quan đến hành vi vi phạm khi đang sử dụng đường bộ, các dữ liệu của Thanh tra và CSTT không nhiều như của CSGT và liên quan chủ yếu đến "trạng thái tĩnh" như lỗi để xe, làm hỏng thiết bị trên đường....

Dữ liệu vi phạm rất quan trọng. Nếu thu thập đầy đủ và có một CSDL vi phạm, chúng ta có thể biết chính xác mức độ vi phạm của từng người, do vậy có thể thực hiện các biện pháp rất hiệu quả và cải thiện một cách đáng kể công tác quản lý người lái. Nhiều nước đã áp dụng các biện pháp rất mạnh như quy định người dùng phải đóng phí bảo hiểm càng cao hơn, thời hạn của GPLX càng ngắn và điều kiện cấp lại GPLX càng khó nếu họ vi phạm càng nhiều...

Tuy nhiên xây dựng CSDL như vậy không dễ vì:

- Dữ liệu trải rộng cả về không gian (trên toàn quốc) và thời gian (nhiều năm);

- Khối lượng dữ liệu rất lớn: cỡ 4-7 triệu bản ghi dữ liệu mỗi năm; nhưng không chỉ cần xử lý theo kiểu Dữ liệu lớn (Big Data, chỉ lấy ra các đặc trưng chung) được mà cần chính xác tới chi tiết.

Vì vậy, tuy đã có thí điểm trên phạm vi 10 tỉnh phía Bắc trong một dự án vốn vay Nhật Bản ${ }^{61}$, nhưng không tiếp tục duy trì và triển khai được.

Do vậy, chủ yếu dữ liệu vi phạm vẫn là tập hợp từ địa phương báo cáo lên và mức độ đầy đủ, chính xác chưa được bảo đảm.

\section{2) Số liệu tuần tra, kiểm soát của CSGT}

Bảng dưới đây thể hiện chung số liệu tuần tra kiểm soát của CSGT. Như vậy số trường hợp xử lý vi phạm trong giai đoạn 2011-2015 cỡ 5 triệu vụ/năm, trừ năm 2012 lên tới 7 triệu, giảm xuống cỡ 4 triệu vụ/năm từ 2016 đến nay.

\footnotetext{
${ }^{61}$ Dự án Tăng cường ATGT trên các QL ở phía Bắc Việt Nam, vốn vay JICA nhằm giảm thiểu tai nạn giao thông ở 10 tỉnh
} dọc các Quốc lộ 3, 5, 10, 18 (tháng 12/2009 - tháng 09/2014). 
Trong các phương thức, thì vi phạm đường bộ luôn chiếm một tỷ lệ cao tuyệt đối. Trong vi phạm đường bộ thì số vi phạm do xe máy cao hơn ô tô, nhưng do số lượng xe máy tới hàng chục triệu, gấp mấy chục lần xe ô tô, nên thực ra, lỗi vi phạm tính trên 100 xe của ô tô được xử lý cao hơn xe máy.

Đáng chú ý là số xe máy tạm giữ mỗi năm khá cao, khoảng 600.000 xe, một con số không nhỏ. Số GPLX (chung cả ô tô và xe máy) bị tước cũng khá cao, khoảng 400.000 giấy mỗi năm.

\section{Bảng 3-19 Số liệu tuần tra, kiểm soát của CSGT}

\begin{tabular}{|c|c|c|c|c|}
\hline Hạng mục & Phạm vi & 2018 & 2017 & 2016 \\
\hline Số trường hợp xử lý vi phạm & \multirow{3}{*}{$\begin{array}{l}\text { Cả đường bộ, } \\
\text { đường sắt và } \\
\text { đường thủy nội } \\
\text { địa }\end{array}$} & 4.176 .791 & 4.490 .104 & 4.178 .438 \\
\hline $\begin{array}{l}\text { Phạt tiền do vi phạm (triệu } \\
\text { đồng) }\end{array}$ & & 2.613 .587 & 2.795 .618 & 2.694 .632 \\
\hline $\begin{array}{l}\text { Tước GPLX, bằng chứng chỉ } \\
\text { chuyên môn }\end{array}$ & & NA & 365.999 & NA \\
\hline Số trường hợp xử lý vi phạm & Riêng đường bộ & NA & $\mathrm{NA}$ & 3.972 .192 \\
\hline $\begin{array}{l}\text { Phạt tiền do vi phạm (triệu } \\
\text { dồng) }\end{array}$ & Cả ô tô và xe máy & NA & NA & 2.582 .730 \\
\hline Tước GPLX & Cả ô tô và xe máy & 346.486 & NA & 382.112 \\
\hline Tạm giữ phương tiện & Cả ô tô và xe máy & 601.704 & 697.528 & 595.077 \\
\hline Tạm giữ phương tiện & Riêng xe máy & NA & NA & 560.418 \\
\hline Tạm giữ phương tiện & Riêng ô tô & NA & $\mathrm{NA}$ & 34.659 \\
\hline
\end{tabular}

\begin{tabular}{|c|c|c|c|c|c|c|}
\hline Hạng mục & Phạm vi & 2015 & 2014 & 2013 & 2012 & 2011-2015 \\
\hline Số trường hợp xử lý vi phạm & \multirow{3}{*}{$\begin{array}{l}\text { Cả đường bộ, } \\
\text { đường sắt và } \\
\text { đường thủy nội } \\
\text { địa }\end{array}$} & NA & 5.091 .699 & 5.744 .633 & 7.307 .950 & NA \\
\hline $\begin{array}{l}\text { Phạt tiền do vi phạm (triệu } \\
\text { đồng) }\end{array}$ & & NA & 5.002 .411 & 5.648 .515 & 2.446 .030 & NA \\
\hline $\begin{array}{l}\text { Tước GPLX, bằng chứng chỉ } \\
\text { chuyên môn }\end{array}$ & & NA & NA & NA & 378.583 & NA \\
\hline Số trường hợp xử lý vi phạm & \multirow{6}{*}{$\begin{array}{l}\text { Riêng đường bộ } \\
\text { Cả ô tô và xe máy } \\
\text { Cả ô tô và xe máy } \\
\text { Cả ô tô và xe máy } \\
\text { Riêng xe máy } \\
\text { Riêng ô tô }\end{array}$} & NA & 4.883 .692 & 5.536 .203 & 7.102 .156 & 27.570 .844 \\
\hline $\begin{array}{l}\text { Phạt tiền do vi phạm (triệu } \\
\text { đồng) }\end{array}$ & & NA & 2.838 .597 & 2.901 .880 & 2.331 .000 & 12.214 .400 \\
\hline Tước GPLX & & NA & 403.055 & 449.223 & 378.439 & 945.395 \\
\hline Tạm giữ phương tiện & & $\mathrm{NA}$ & 633.131 & 641.352 & 704.895 & 1.296 .542 \\
\hline Tạm giữ phương tiện & & NA & 601.332 & 609.945 & 679.527 & 1.241 .174 \\
\hline Tạm giữ phương tiện & & NA & 31.799 & 31.407 & 25.368 & 55.368 \\
\hline
\end{tabular}

Nguồn: UBATGTQG, nhóm nghiên cứu tập hợp từ các Báo cáo hàng năm

\section{3) Phân tích số liệu vi phạm 2017 và 2018}

Bảng dưới đây cho thấy kết quả phân tích dữ liệu vi phạm của năm 2017 và 2018 dựa theo Báo cáo hàng năm của UBATGTQG.

Bảng này cho thấy, lỗi về mũ bảo hiểm được xử lý nhiều nhất. Điều này dễ hiểu, vì vi phạm này dễ phát hiện nhất. Tỷ lệ không có GPLX tới gần $6 \%$ là một con số đáng ngại. Vi phạm về nồng độ cồn ở mức dưới $3 \%$, không có nghĩa là ít, mà có lẽ là do chưa thấy và xử lý vì khó phát hiện hơn so với vi phạm mũ bảo hiểm. 
Dự án: Xây dựng chiến lược an toàn giao thông đối với xe máy và kế hoạch hành động: một khởi đầu của Việt Nam

Nghiên cứu hiện trạng giao thông xe máy Việt Nam

\begin{tabular}{|c|c|c|c|c|}
\hline \multicolumn{5}{|c|}{ Bảng 3-20 Phân tích số liệu vi phạm 2017 và 2018} \\
\hline \multirow{2}{*}{ Phân tích số liệu vi phạm của xe máy } & \multicolumn{2}{|c|}{2017} & \multicolumn{2}{|c|}{2018} \\
\hline & Số lượng & $\%$ & Số lượng & $\%$ \\
\hline Tổng số trường hợp phân tích & 1.096 .843 & $100,00 \%$ & 822.090 & $100,00 \%$ \\
\hline Chạy quá tốc độ quy định & 52.558 & $4,79 \%$ & 33.782 & $4,11 \%$ \\
\hline Không đội mũ bảo hiểm, không cài quai & 631.613 & $57,58 \%$ & 432.163 & $52,57 \%$ \\
\hline Đi không đúng phần đường, làn đường & 25.218 & $2,30 \%$ & 16.880 & $2,05 \%$ \\
\hline Không có GPLX & 64.319 & $5,86 \%$ & 48.702 & $5,92 \%$ \\
\hline Chở quá số người quy định & 10.169 & $0,93 \%$ & 6.209 & $0,76 \%$ \\
\hline Vi phạm quy định về nồng độ cồn & 30.608 & $2,79 \%$ & 21.402 & $2,60 \%$ \\
\hline $\begin{array}{l}\text { Không có giấy bảo hiểm trách nhiệm dân } \\
\text { sự }\end{array}$ & 43.735 & $3,99 \%$ & 33.883 & $4,12 \%$ \\
\hline Không chấp hành hiệu lệnh đèn & 13.083 & $1,19 \%$ & 4.068 & $0,49 \%$ \\
\hline Không có, không mang giấy đăng ký xe & 22.949 & $2,09 \%$ & 24.533 & $2,98 \%$ \\
\hline Các lỗi khác, như: & 202.591 & $18,47 \%$ & 200.468 & $24,39 \%$ \\
\hline Chở hàng vuoơt quá kích thước xe & $N A$ & & $N A$ & \\
\hline Không chấp hành hiệu lệnh dùng xe & $N A$ & & 2.413 & \\
\hline Đi vào đường cấm, đi ngược chiều đuờng & $N A$ & & 11.829 & \\
\hline Lối tránh vuoọt & $N A$ & & 5.053 & \\
\hline Lạg lách, đánh võng & $N A$ & & 523 & \\
\hline Chua đủ tuối điều khiển phuoong tiện & $N A$ & & 5.803 & \\
\hline
\end{tabular}

Nguồn: CSGT qua UBATGTQG, nhóm nghiên cứu tập hợp từ các Báo cáo hàng năm

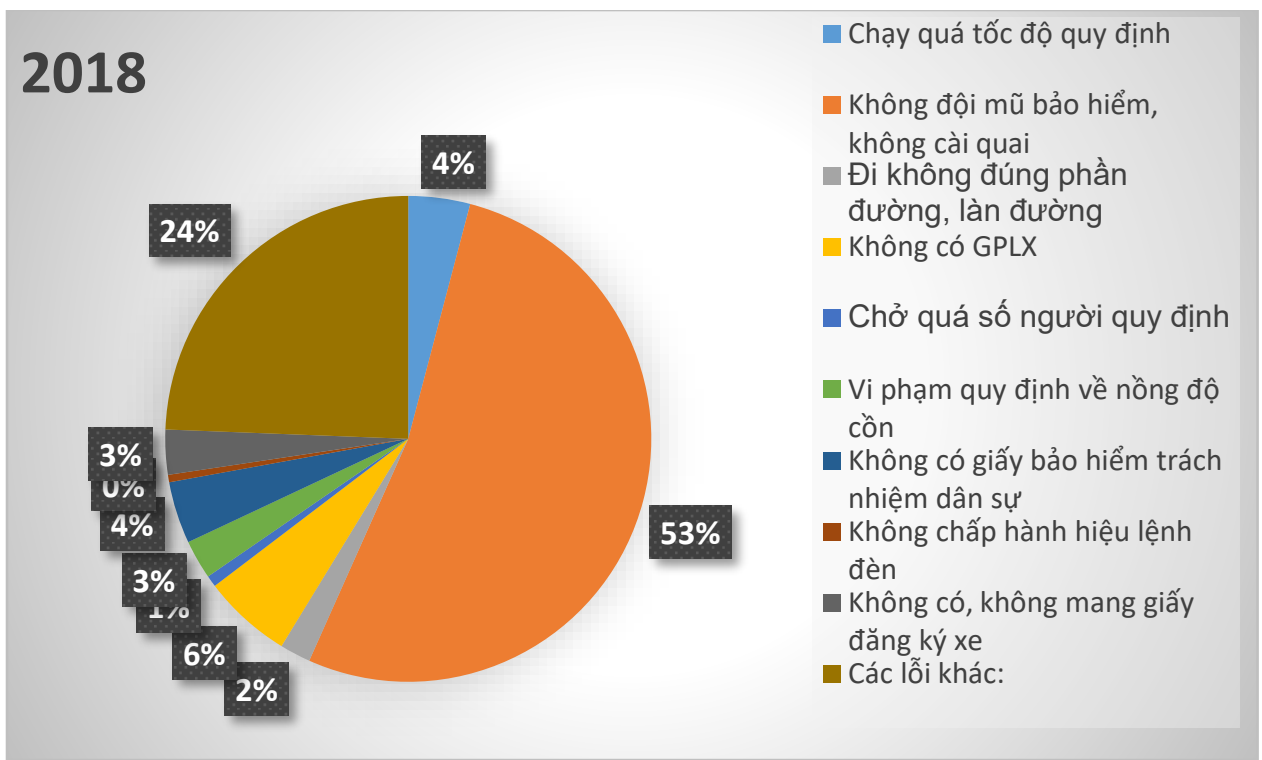

Hình 3-6 Các lỗi vi phạm chính

Nguồn dữ liệu: UBATGTQG, tập hợp từ các Báo cáo hàng năm 


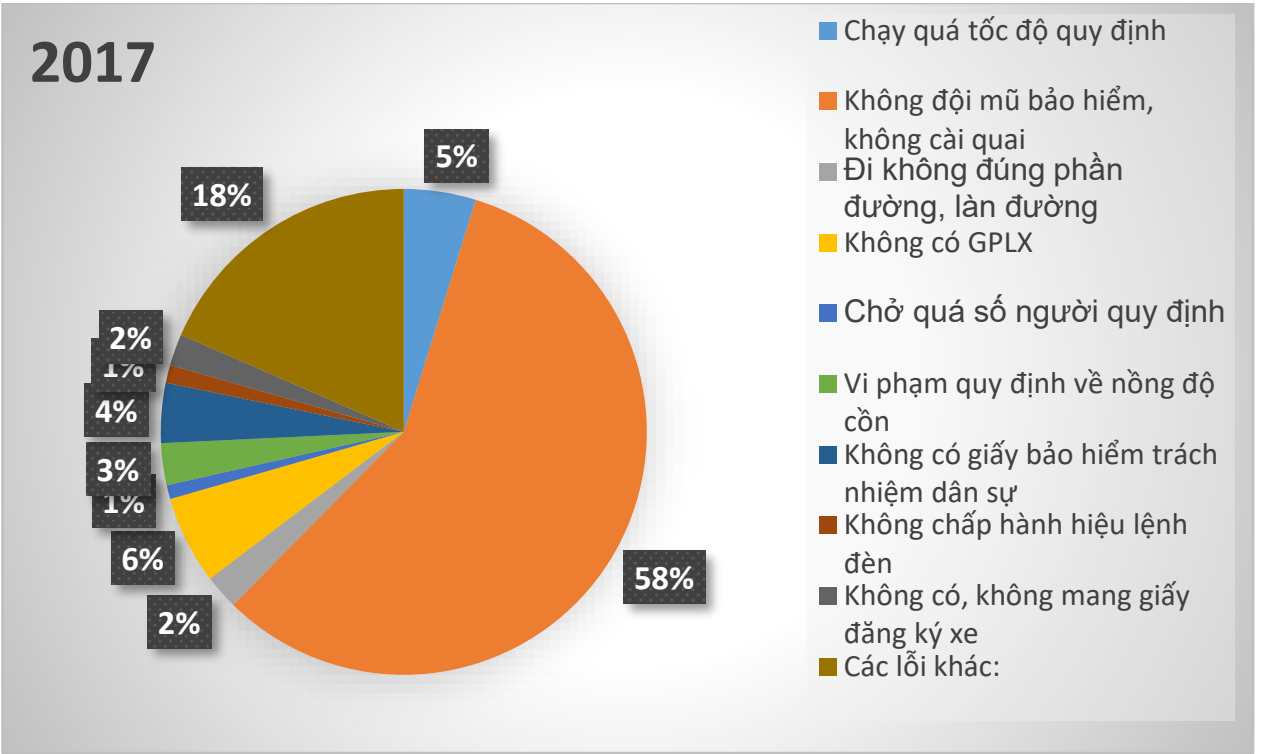

Hình 3-7 Tỷ lệ giữa các lỗi vi phạm năm 2017 và 2018

Nguồn dữ liệu: UBATGTQG, tập hợp từ các Báo cán hàng năm

Bảng dưới đây so sánh vi phạm giữa ô tô và xe máy. Hai lỗi (chạy quá tốc độ quy định và chở quá số người quy định) do ô tô nhiều hơn do xe máy. Có thể thấy là vi phạm tốc độ của xe máy không phải ít, nhưng khó phát hiện hơn ô tô, chưa kể, tuy không thống kê cụ thể, nhưng nhiều xe máy đã hỏng bộ đo tốc độ. Hai lỗi khác (Đi không đúng phần đường, làn đường và Vi phạm quy định về nồng độ cồn) do xe máy nhiều hơn do ô tô, có lẽ phản ảnh đúng thực chất giao thông trên đường.

Bảng tiếp theo cho thấy một số lỗi vi phạm khác của xe máy ít được xử lý so với ô tô.

Bảng 3-21 So sánh tỷ lệ một số lối vi phạm giữa ô tô và xe máy

\begin{tabular}{|l|r|r|r|r|}
\hline \multirow{2}{*}{\multicolumn{1}{|c|}{ Lỗi vi phạm }} & \multicolumn{2}{|c|}{$\mathbf{2 0 1 7}$} & \multicolumn{2}{c|}{$\mathbf{2 0 1 8}$} \\
\cline { 2 - 5 } & \multicolumn{1}{|c|}{ Ô tô } & \multicolumn{1}{c|}{ Xe máy } & \multicolumn{1}{c|}{ Ô tô } & \multicolumn{1}{c|}{ Xe máy } \\
\hline Chạy quá tốc độ quy định & $12,70 \%$ & $4,79 \%$ & $13,75 \%$ & $4,11 \%$ \\
\hline Đi không đúng phần đường, làn đường & $0,92 \%$ & $2,30 \%$ & $0,67 \%$ & $2,05 \%$ \\
\hline Chở quá số người quy định & $2,98 \%$ & $0,93 \%$ & $2,66 \%$ & $0,76 \%$ \\
\hline Vi phạm quy định về nồng độ cồn & $1,45 \%$ & $2,79 \%$ & $1,75 \%$ & $2,60 \%$ \\
\hline
\end{tabular}

Vi phạm ít xử lý của xe máy so với ô tô

\begin{tabular}{|c|l|}
\hline STT & \multicolumn{1}{|c|}{ Vi phạm } \\
\hline 1 & Tránh vượt sai quy định \\
\hline 2 & Dừng đồ không đúng quy định \\
\hline 3 & Chuyển hướng không đúng quy định \\
\hline 4 & Đang chịu ảnh hưởng do sử dụng ma túy \\
\hline
\end{tabular}

Nguồn: Nhóm nghiên cứu tập hợp từ số liệu gốc của CSGT

Bảng dưới đây khá đặc biệt, nêu lên một số lỗi do ô tô thì có xử lý, nhưng với xe máy thì không, trong khi những lỗi này có khả năng gây rủi ro TNGT không nhỏ. Lý do chủ yếu là vì chưa có công cụ thể chế (chưa có quy định pháp luật) để có thể xử lý. 
Bảng 3-24 Tốp 10 địa phương xử lý số lượng vi phạm giao thông cao nhất

\begin{tabular}{|c|l|c|}
\hline STT & \multicolumn{1}{|c|}{ Địa phương (2012-2017) } & \multicolumn{1}{|c|}{ Tổng toàn bộ vi phạm } \\
\hline $\mathrm{a}$ & \multicolumn{1}{|c|}{ b } & \multicolumn{1}{|c|}{ c } \\
\hline 1 & Thành phố Hà Nội & 3.191 .742 \\
\hline 2 & Thành phố Hồ Chí Minh & 2.944 .669 \\
\hline 3 & Tỉnh Đồng Nai & 1.124 .256 \\
\hline 4 & Tỉnh Quảng Ninh & 1.033 .564 \\
\hline 5 & Tỉnh Nghệ An & 655.353 \\
\hline 6 & Tỉnh Phú Thọ & 538.052 \\
\hline 7 & Thành phố Hải Phòng & 485.657 \\
\hline 8 & Tỉnh Đắk Lắk & 448.446 \\
\hline 9 & Tỉnh Thanh Hóa & 442.835 \\
\hline 10 & Tỉnh Bình Phước & 395.255 \\
\hline 11 & Toàn quốc & 23.051 .889 \\
\hline
\end{tabular}

Nguồn: Nhóm nghiên cứu tập hợp từ số liệu gốc của CSGT

Bảng 3-25 Tốp 10 địa phương có tỷ lệ xử lý vi phạm giao thông /1000 dân cao nhất

\begin{tabular}{|l|l|c|c|}
\hline STT & \multicolumn{1}{|c|}{$\begin{array}{c}\text { Địa phương } \\
\mathbf{2 0 1 2 - 2 0 1 7}\end{array}$} & Tổng toàn bộ vi phạm & $\begin{array}{c}\text { Tổng số vi phạm } \\
\text { /1000 dân }\end{array}$ \\
\hline a & \multicolumn{1}{|c|}{ b } & c & d \\
\hline 1 & Tỉnh Quảng Ninh & 1.033 .564 & 856,07 \\
\hline 2 & Tỉnh Đắk Nông & 298.166 & 513,80 \\
\hline 3 & Tỉnh Lạng Sơn & 351.254 & 462,81 \\
\hline 4 & Thành phố Hà Nội & 3.191 .742 & 446,47 \\
\hline 5 & Tỉnh Bình Phước & 395.255 & 421,10 \\
\hline 6 & Tỉnh Quảng Trị & 243.824 & 394,52 \\
\hline 7 & Tỉnh Phú Thọ & 538.052 & 393,86 \\
\hline 8 & Tỉnh Đồng Nai & 1.124 .256 & 391,82 \\
\hline 9 & Tỉnh Bà Rịa-Vũng Tàu & 392.818 & 367,97 \\
\hline 10 & Thành phố Hồ Chí Minh & 2.944 .669 & 365,42 \\
\hline 11 & Toàn quốc & 23.051 .889 & 252,63 \\
\hline
\end{tabular}

Nguồn: Nhóm nghiên cứu tập hợp từ số liệu gốc của CSGT 
Bảng 3-26 Tốp 10 địa phương có tỷ lệ xử lý vi phạm không đội mũ bảo hiểm (MBH) cao nhất

\begin{tabular}{|l|l|c|c|c|}
\hline STT & \multicolumn{1}{|c|}{$\begin{array}{c}\text { Địa phương } \\
\mathbf{2 0 1 2 - 2 0 1 7}\end{array}$} & $\begin{array}{c}\text { Tổng toàn số } \\
\text { hành vi vi phạm }\end{array}$ & $\begin{array}{c}\text { Số hành vi } \\
\text { không đội } \\
\text { MBH }\end{array}$ & $\begin{array}{c}\text { Hành vi không MBH / tổng } \\
\text { số vi phạm }\end{array}$ \\
\hline $\mathrm{a}$ & \multicolumn{1}{|c|}{$\mathrm{b}$} & $\mathrm{c}$ & $\mathrm{d}$ & $\mathrm{e}$ \\
\hline 1 & Tỉnh Vĩnh Phúc & 165.751 & 66.998 & $40,42 \%$ \\
\hline 2 & Tỉnh Quảng Ninh & 1.033 .564 & 367.360 & $35,54 \%$ \\
\hline 3 & Tỉnh Hà Giang & 101.700 & 32.392 & $31,85 \%$ \\
\hline 4 & Tỉnh Lào Cai & 90.720 & 28.044 & $30,91 \%$ \\
\hline 5 & Tỉnh Nam Định & 294.881 & 81.641 & $27,69 \%$ \\
\hline 6 & Tỉnh Ninh Bình & 194.662 & 50.100 & $25,74 \%$ \\
\hline 7 & Tỉnh Nghệ An & 655.353 & 164.976 & $25,17 \%$ \\
\hline 8 & Tỉnh Điện Biên & 117.279 & 27.275 & $23,26 \%$ \\
\hline 9 & Tỉnh Bà Rịa-Vũng Tàu & 392.818 & 75.858 & $19,31 \%$ \\
\hline 10 & Tỉnh Hoà Bình & 115.136 & 21.575 & $18,74 \%$ \\
\hline 11 & Toàn quốc & 23.051 .889 & 2.875 .020 & $12,47 \%$ \\
\hline
\end{tabular}

Nguồn: Nhóm nghiên cứu tập hợp từ số liệu gốc của CSGT

\subsection{Nghiên cứu dữ liệu Giấy phép lái xe (GPLX)}

Theo quy định của Luật Giao thông đường bộ hiện hành của Việt Nam (2008), tất cả người lái xe cơ giới cần phải có một GPLX phù hợp. Tùy thuộc vào kiểu loại, công suất động cơ, tải trọng và công dụng của xe cơ giới, giấy phép lái xe được phân loại thành các hạng khác nhau. Nhưng với phạm vi của nghiên cứu này, GPLX sẽ được gộp lại thành hai loại: đó là GPLX với xe máy (ứng với hạng $\mathrm{A} 1, \mathrm{~A} 2$ và $\mathrm{A} 3$ ) và của xe ô tô (tất cả các loại cho xe khách và xe tải). Các loại còn lại (như xe máy kéo, rơ moóc hoặc sơ mi rơ moóc) chỉ chiếm một tỷ lệ nhỏ và sẽ không được xem xét.

Như khẳng định trong nhiều tài liệu ${ }^{63}$, người lái xe máy chiếm một tỷ lệ rất lớn trong vi phạm và tai nạn. Nhưng tỷ lệ này thay đổi theo thời gian. Vì vậy, việc tìm hiểu xu hướng của tai nạn giao thông và vi phạm giao thông do xe máy nói riêng và việc so sánh $\mathrm{xu}$ hướng này với xe ô tô có thể dẫn đến những kết luận hữu ích cho việc đảm bảo trật tự an toàn giao thông. Đây dĩ nhiên là một trong các thông tin cần thiết và sẽ được thực hiện dưới đây

Tiếp theo, cần thiết phải ước tính Tỷ lẹ người lái xe máy không có GPLX phù hợp (ký hiệu là $R_{\text {without }}$ ). Tỷ lệ này ở một mức độ nhất định sẽ phản ánh tình hình của một thành phần quan trọng của hệ thống giao thông: người lái xe. Trong việc này, dữ liệu của cảnh sát giao thông về vi phạm giao thông liên quan đến GPLX tích lũy từ nhiều năm sẽ được sử dụng.

\subsubsection{Vi phạm liên quan đến GPLX của xe máy}

Trong công tác của mình, cảnh sát giao thông phân ra hai loại vi phạm có liên quan đến giấy phép lái xe là "Lái xe không có giấy phép" và "Giấy phép giả”. Sự khác biệt giữa hai loại là

\footnotetext{
${ }^{63}$ Cơ quan Hợp tác quốc tế Nhật Bản (JICA) (2009) Nghiên cưu Quy hoạch tổng thể về an toàn giao thông, Final Report, Hanoi.
} 
không đáng kể trong nghiên cứu này, vì chúng có cùng ý nghĩa là người lái xe máy không có giấy phép.

Bảng dưới ghi nhận tỷ lệ phần trăm hàng năm các vi phạm liên quan đến GPLX trong tổng số vi phạm được xử lý với kết quả tính từ dữ liệu gốc của CSGT. Dữ liệu từ bảng này cho phép thấy:

- Tỷ lệ người dùng xe máy không có giấy phép lái xe tuy thay đổi hàng năm nhưng dường như tương đối cao. Như đã nói ở trên, do tính vào ngẫu nhiên của vi phạm được xử lý, con số này có thể được coi là tỷ lệ người lái xe máy không có GPLX phù hợp $\left(\mathrm{R}_{\text {without }}\right)$. Giá trị cao của $\mathrm{R}_{\text {without }}$ nên được xem như một dấu hiệu báo động cho các nhà chức trách về giao thông vận tải.

- Một điều nữa là nói chung, xu hướng của hành vi thiếu GPLX có năm giảm nhưng sau đó lại tăng. Điều này phản ánh nhận thức của người dân trong vấn đề có liên quan đang chưa vững chắc và rất cần sự nỗ lực của các cơ quan liên quan.

\section{Bảng 3-27 Tỷ lệ phần trăm hàng năm các vi phạm liên quan đến GPLX}

\begin{tabular}{|c|c|}
\hline Năm & $\begin{array}{c}\text { Tỷ lệ } \\
\text { không } \\
\text { GPLX }\end{array}$ \\
\hline Y & R without \\
\hline 1 & 2 \\
\hline 2005 & $17,58 \%$ \\
\hline 2006 & $11,21 \%$ \\
\hline 2007 & $13,46 \%$ \\
\hline 2008 & $17,87 \%$ \\
\hline 2009 & $12,56 \%$ \\
\hline 2010 & $10,56 \%$ \\
\hline 2011 & $9,87 \%$ \\
\hline
\end{tabular}

\begin{tabular}{|c|c|}
\hline Năm & $\begin{array}{c}\text { Tỷ lệ } \\
\text { không } \\
\text { GPLX }\end{array}$ \\
\hline Y & R $_{\text {without }}$ \\
\hline 1 & 2 \\
\hline 2012 & $4,94 \%$ \\
\hline 2013 & $11,44 \%$ \\
\hline 2014 & $8,46 \%$ \\
\hline 2015 & $2,68 \%$ \\
\hline 2016 & $9,45 \%$ \\
\hline 2017 & $9,86 \%$ \\
\hline 2018 & $9,26 \%$ \\
\hline
\end{tabular}

Nguồn: Nhóm nghiên cứu tập hợp từ số liệu gốc của CSGT

Giá trị của $\mathrm{R}_{\text {without }}$ còn có một ý nghĩa quan trọng khác. Nó biểu thị tỷ lệ trung bình của người lái xe máy người không có đầy đủ giấy phép. Điều nhận xét này sẽ được sử dụng ở dưới đây. Tỷ lệ cao vi phạm về GPLX thu hút sự chú ý lớn của các chuyên gia giao thông và các cơ quan: nó báo hiệu có vấn đề tồn tại trong quản lý người lái xe. Đó là lý do tại sao, $\mathrm{R}_{\text {without }}$ có giá trị thực tiễn rất lớn.

\subsubsection{Số lượng GPLX của người lái xe máy còn sống và tình hình thực hiện quy định về GPLX}

Điều 58 Luật Giao thông đường bộ 2008 quy định rõ điều kiện: "Người lái xe tham gia giao thông phải ... có GPLX phù hợp với loại xe được phép điều khiển do cơ quan nhà nước có thẩm quyền cấp" (sau đây gọi tắt là Quy địinh về GPLX). Các cơ quan liên quan đã có rất nhiều nỗ lực nhằm thực hiện quy định này. Vì vậy, rât nên đánh giá xem mức độ đạt được là đến đâu.

Để làm điều đó, ta xét đến một đại lượng là Số lương GPLX của người lái xe máy còn sống (Number of Licenses of Living Vehicle Operators- $\boldsymbol{M}_{\text {liv }}$ ).

Các cơ quan giao thông vận tải có công bố Số lượng giấy phép lái xe máy mới ban hành trong năm $\left(M_{n e w}\right)$. Trong nhiều văn bản, ví dụ, trong tài liệu đã dẫn của JICA (2009), Tổng số giầy 
phép của người lái xe gắn máy $\left(M_{a c c}\right)$ chỉ đơn giản là sự tích tụ từ năm này sang năm khác mà không kể đến việc chủ sở hữu giấy phép này có còn sống hay không. Đó là lý do tại sao, giá trị của $\mathrm{M}_{\mathrm{acc}}$ là cao hơn thực tế. Để khắc phục điều đó, ta cần hiệu chỉnh tỷ lệ chủ nhân GPLX đã từ trần. Muốn vậy, có thể giả định hợp lý rằng tỷ lệ chết của chủ sở hữu giấy phép là giống như tỷ lệ chết cua toàn bộ dân số. Vì vậy, giá trị tích lũy hàng năm của giấy phép nên chiết giảm theo $T y$ suất chết thô $(C D R)$. Giá trị cua $\mathrm{CDR}$ có sẵn trong các Niên giám thống kê của Tổng cục Thống kê.

Trong bảng dưới, số lượng GPLX tích lũy hàng năm của những người lái xe máy còn sống $\left(\mathrm{M}_{\text {liv }}\right)$ được tính bằng cách điều chỉnh với Tỷ suất chết thô theo công thức đề xuất như sau:

$$
\mathrm{M}_{\mathrm{liv}, \mathrm{i}}=\mathrm{M}_{\mathrm{liv}, \mathrm{i}-1} \cdot(1-\mathrm{CDR} / 1000)+\mathrm{M}_{\text {new }, \mathrm{i}}
$$

Trong đó,

- $\quad \mathrm{M}_{\mathrm{liv}, \mathrm{i}}$ và $\mathrm{M}_{\mathrm{liv}, \mathrm{i}-1}$ : Số lượng GPLX của những người lái xe máy còn sống năm thứ $\mathrm{i}$ và i-1;

- CDR: Tỷ suất chết thô;

- $\quad \mathrm{M}_{\text {new,i }}$ : Số lượng giấy phép lái xe máy mới ban hành trong năm

Kết luận: Tỷ lệ số GPLX so với tổng số dân trong cột cuối bảng trên và theo đồ thị ở hình kèm theo cho thấy tình hình thực hiện quy định về GPLX là tiến triển khả quan. Mặt khác, cột cuối bảng dưới và hình kèm theo cho thấy, tuy dân số tăng, nhưng tỷ lệ người đi xe máy có GPLX tăng liên tục, đây là dấu hiệu cũng cho thấy ý thức người dân về GPLX có nâng cao rõ.

Bảng 3-28 Số lượng GPLX của người dùng xe máy còn sống ( $\left.\mathrm{M}_{\text {liv }}\right)$

\begin{tabular}{|c|c|c|c|c|c|c|}
\hline Năm & Dân số & $\begin{array}{c}\text { GPLX cấp } \\
\text { mới }\end{array}$ & $\begin{array}{c}\text { Số lượng } \\
\text { GPLX tích } \\
\text { lũy (trừ số } \\
\text { cấp đổi) }\end{array}$ & $\begin{array}{c}\text { Tỷ suất chết } \\
\text { thố }\end{array}$ & $\begin{array}{c}\text { Số lượng } \\
\text { GPLX của } \\
\text { ngườ còn } \\
\text { sống }\end{array}$ & $\begin{array}{c}\text { Tỷ lệ số GPLX } \\
\text { so với số dân }\end{array}$ \\
\hline $\mathrm{Y}$ & pop & $\mathrm{M}_{\text {new }}$ & $\mathrm{M}_{\text {acc }}$ & CDR $(\%)$ & $\mathrm{M}_{\text {liv }}(*)$ & $\mathrm{R}_{\text {license }}\left({ }^{*}\right)$ \\
\hline 1 & 2 & 3 & 4 & 5 & 6 & 7 \\
\hline 1990 & 66.020 .000 & $\mathrm{NA}$ & 570.222 & 6,36 & 570.222 & $0,86 \%$ \\
\hline 1991 & 67.242 .000 & 13.419 & 583.641 & 6,26 & 580.071 & $0,86 \%$ \\
\hline 1992 & 68.450 .000 & 9.467 & 593.108 & 6,16 & 585.965 & $0,86 \%$ \\
\hline 1993 & 69.644 .000 & 9.995 & 603.103 & 6,06 & 592.409 & $0,85 \%$ \\
\hline 1994 & 70.824 .000 & 604.413 & 1.207 .516 & 5,96 & 1.193 .291 & $1,68 \%$ \\
\hline 1995 & 71.995 .500 & 728.995 & 1.936 .511 & 6,19 & 1.914 .900 & $2,66 \%$ \\
\hline 1996 & 73.156 .700 & 1.007 .558 & 2.944 .069 & 5,99 & 2.910 .988 & $3,98 \%$ \\
\hline 1997 & 74.306 .900 & 291.071 & 3.235 .140 & 5,81 & 3.185 .146 & $4,29 \%$ \\
\hline 1998 & 75.456 .300 & 281.234 & 3.516 .374 & 5,67 & 3.448 .320 & $4,57 \%$ \\
\hline 1999 & 76.596 .700 & 356.188 & 3.872 .562 & 5,54 & 3.785 .404 & $4,94 \%$ \\
\hline 2000 & 77.630 .900 & 4770.504 & 4.343 .066 & 5,43 & 4.235 .354 & $5,46 \%$ \\
\hline 2001 & 78.620 .500 & 891.172 & 5.234 .238 & 5,10 & 5.104 .925 & $6,49 \%$ \\
\hline 2002 & 79.537 .700 & 1.140 .941 & 6.375 .179 & 5,80 & 6.216 .258 & $7,82 \%$ \\
\hline 2003 & 80.467 .400 & 4.962 .352 & 11.337 .531 & 5,80 & 11.142 .556 & $13,85 \%$ \\
\hline 2004 & 81.436 .400 & 3.362 .285 & 14.699 .816 & 5,40 & 14.444 .671 & $17,74 \%$ \\
\hline 2005 & 82.392 .100 & 3.025 .692 & 17.725 .508 & 5,30 & 17.393 .806 & $21,11 \%$ \\
\hline 2006 & 83.311 .200 & 1.961 .576 & 19.687 .084 & 5,30 & 19.263 .195 & $23,12 \%$ \\
\hline 2007 & 84.218 .500 & 2.012 .618 & 21.699 .702 & 5,30 & 21.173 .718 & $25,14 \%$ \\
\hline 2008 & 85.118 .700 & 1.991 .986 & 23.691 .688 & 5,30 & 23.053 .483 & $27,08 \%$ \\
\hline & & & & & & \\
\hline
\end{tabular}




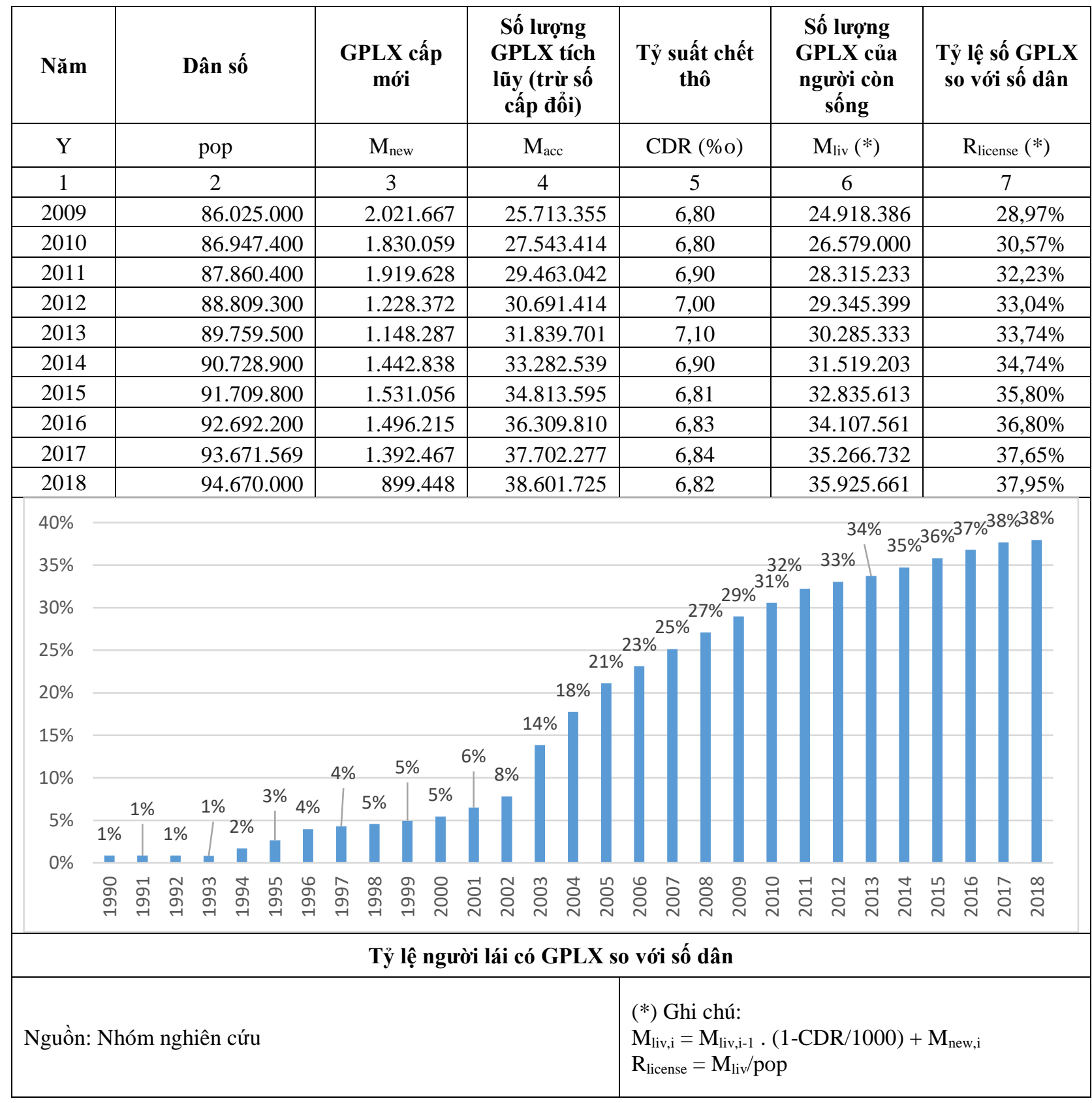

\subsubsection{Tổng số người lái xe gắn máy (Muser) và số người (trung bình) dùng chung một xe máy ( $\left.\mathbf{R}_{\text {user }}\right)$}

Các kết quả trên có thể được sử dung để tìm thêm thông tin hữu iích. Bảng dưới đây với các công thức tính toán kèm theo cho: Tổng số nguoòi lái xe gắn máy $\left(M_{\text {user }}\right)$ và đặc biệt là, $T y ̉$ lệ nguơi lái xe máy so với số dân $\left(R_{m c}\right)$. Tỷ lệ này tăng đáng kể, xác nhận lại sự tăng trưởng lớn trong nhu cầu đi lại bằng xe máy của người dân. Cùng với đó, Số nguoòi (trung bình) dùng chung một xe máy $\left(R_{\text {user }}\right)$ trong cột cuối cùng giảm liên tục. Điều đó có thể được giải thích bởi mức sống vẫn tăng và ngày càng nhiều người dân có xe máy riêng. Tỷ lệ 1,03 của năm 2018 cho thấy dấu hiệu đáng lưu ý là sắp đến ngưỡng, mỗi xe máy trong lưu hành chỉ ứng với một người sử dụng. Nếu dùng theo số đăng ký thì hết năm 2018 có 59.245 .062 xe trên tổng số người lái 39.592.247 cho con số ngược hẳn lại: một người dân dùng tới 1,50 xe. 


\section{Bảng 3-29 Tổng số người lái xe gắn máy ( $\mathrm{M}_{\text {user }}$ ) và số người (trung bình) dùng chung một xe máy ( $\left.\mathbf{R}_{\text {user }}\right)$}

\begin{tabular}{|c|c|c|c|c|c|c|c|}
\hline Năm & Dân số & $\begin{array}{l}\text { Số xe lưu } \\
\text { hành }\end{array}$ & $\begin{array}{l}\text { Tỷ lệ } \\
\text { không } \\
\text { GPLX }\end{array}$ & $\begin{array}{c}\text { Số lượng } \\
\text { GPLX của } \\
\text { người đi } \\
\text { xe máy } \\
\text { còn sống }\end{array}$ & $\begin{array}{l}\text { Tổng số } \\
\text { người lái } \\
\text { xe máy }\end{array}$ & $\begin{array}{l}\text { Tỷ lệ người } \\
\text { lái xe máy } \\
\text { so với số } \\
\text { dân }\end{array}$ & $\begin{array}{c}\text { Số người } \\
\text { (trung } \\
\text { bình) } \\
\text { dùng } 01 \\
\text { xe máy }\end{array}$ \\
\hline $\mathbf{Y}$ & pop & $M_{\text {cir }}$ & $\mathbf{R}_{\text {without }}$ & $M_{\text {liv }}$ & Muser & $\mathbf{R}_{\mathbf{m c}}$ & $\mathbf{R}_{\text {user }}$ \\
\hline 1 & 2 & 3 & 4 & 5 & 6 & 7 & 8 \\
\hline 2005 & 82.392 .100 & 11.871 .169 & $17,58 \%$ & 17.393 .806 & 21.103 .866 & $25,61 \%$ & 1,78 \\
\hline 2006 & 83.311 .200 & 13.481 .088 & $11,21 \%$ & 19.263 .195 & 21.695 .230 & $26,04 \%$ & 1,61 \\
\hline 2007 & 84.218 .500 & 15.913 .871 & $13,46 \%$ & 21.173 .718 & 24.466 .972 & $29,05 \%$ & 1,54 \\
\hline 2008 & 85.118 .700 & 18.461 .668 & $17,87 \%$ & 23.053 .483 & 28.069 .503 & $32,98 \%$ & 1,52 \\
\hline 2009 & 86.025 .000 & 19.914 .626 & $12,56 \%$ & 24.918 .386 & 28.497 .697 & $33,13 \%$ & 1,43 \\
\hline 2010 & 86.947 .400 & 21.473 .102 & $10,56 \%$ & 26.579 .000 & 29.717 .129 & $34,18 \%$ & 1,38 \\
\hline 2011 & 87.860 .400 & 23.998 .149 & $9,87 \%$ & 28.315 .233 & 31.415 .992 & $35,76 \%$ & 1,31 \\
\hline 2012 & 88.809 .300 & 26.605 .882 & $4,94 \%$ & 29.345.399 & 30.870 .778 & $34,76 \%$ & 1,16 \\
\hline 2013 & 89.759 .500 & 28.588 .284 & $11,44 \%$ & 30.285 .333 & 34.199 .162 & $38,10 \%$ & 1,20 \\
\hline 2014 & 90.728 .900 & 30.631 .124 & $8,46 \%$ & 31.519 .203 & 34.432 .565 & $37,95 \%$ & 1,12 \\
\hline 2015 & 91.709 .800 & 32.355 .606 & $2,68 \%$ & 32.835 .613 & 33.740 .089 & $36,79 \%$ & 1,04 \\
\hline 2016 & 92.692 .200 & 34.132 .976 & $9,45 \%$ & 34.107 .561 & 37.667 .747 & $40,64 \%$ & 1,10 \\
\hline 2017 & 93.671 .569 & 36.619 .551 & $9,86 \%$ & 35.266 .732 & 39.124 .775 & $41,77 \%$ & 1,07 \\
\hline 2018 & 94.670 .000 & 38.530 .436 & $9,26 \%$ & 35.925 .661 & 39.592 .247 & $41,82 \%$ & 1,03 \\
\hline \multicolumn{8}{|c|}{$\begin{array}{l}\text { Số xe máy theo một đầu người lái: } \\
\text { Theo số đăng ký: } 1.50 \\
\text { Theo số lưu hành: } 0.97\end{array}$} \\
\hline
\end{tabular}

Nguồn: Nhóm nghiên cứu tập hợp từ số liệu gốc của CSGT

Bảng dưới cho thấy tỷ lệ số GPLX của người còn sống với số xe máy lưu hành cho thấy sau năm 2003 thì năm 2004 có đột biến trong việc cấp GPLX (xem chương 2).

Bảng 3-30 Tổng số GPLX của người còn sống và số lượng xe máy đang lưu hành

\begin{tabular}{|c|c|c|c|}
\hline Năm & $\begin{array}{c}\text { Số lượng GPLX của } \\
\text { người còn sống }\end{array}$ & $\begin{array}{l}\text { Số lượng xe máy } \\
\text { đang lưu hành }\end{array}$ & $\begin{array}{l}\text { Số GPLX so với sô } \\
\text { xe máy trên thực tế }\end{array}$ \\
\hline Y & $\mathbf{M}_{\text {liv }}$ & $\mathrm{M}_{\mathrm{cir}}$ & $\begin{array}{l}\mathrm{GPLX}_{\text {real }}= \\
\mathrm{M}_{\text {liv }} / \mathrm{M}_{\mathrm{cir}}\end{array}$ \\
\hline 1 & 2 & 3 & 4 \\
\hline 2003 & 11.142 .556 & 8.387 .565 & 1,33 \\
\hline 2004 & 14.444 .671 & 10.328 .975 & 1,40 \\
\hline 2005 & 17.393 .806 & 11.871 .169 & 1,47 \\
\hline 2006 & 19.263 .195 & 13.481 .088 & 1,43 \\
\hline 2007 & 21.173 .718 & 15.913 .871 & 1,33 \\
\hline 2008 & 23.053 .483 & 18.461 .668 & 1,25 \\
\hline 2009 & 24.918 .386 & 19.914 .626 & 1,25 \\
\hline 2010 & 26.579 .000 & 21.473 .102 & 1,24 \\
\hline 2011 & 28.315 .233 & 23.998 .149 & 1,18 \\
\hline 2012 & 29.345 .399 & 26.605 .882 & 1,10 \\
\hline 2013 & 30.285 .333 & 28.588 .284 & 1,06 \\
\hline 2014 & 31.519 .203 & 30.631 .124 & 1,03 \\
\hline
\end{tabular}




\begin{tabular}{|l|l|l|l|}
2015 & 32.835 .613 & 32.355 .606 & 1,01 \\
\hline 2016 & 34.107 .561 & 34.132 .976 & 1,00 \\
\hline 2017 & 35.266 .732 & 36.619 .551 & 0,96 \\
\hline 2018 & 35.925 .661 & 38.530 .436 & 0,93 \\
\hline
\end{tabular}

Nguồn: Nhóm nghiên cứu tập hợp từ số liệu gốc của CSGT

\subsection{Nghiên cứu hành vi Văn hóa giao thông của người điều khiển xe máy}

Nói đến văn hóa giao thông, thực chất là nói đến cách ứng xử của con người với các quy định của pháp luật về trật tự an toàn giao thông và quan hệ giữa con người với nhau. Có thể nói, văn hóa giao thông là bao gồm văn hóa của người tham gia giao thông, văn hóa của những người quản lý, hoạch định giao thông. Trong những yếu tố trên đây thì người trực tiếp tham gia giao thông đóng một vai trò quan trọng tạo nên văn hóa giao thông.

Để tìm hiểu văn hóa giao thông của người điều khiển xe máy, cần tiến hành điều tra xã hội học. Sau đây là tổng hợp kết quả điều tra về văn hóa giao thông của người đi xe máy trên cơ sở hai cuộc điều tra thực tế là bằng phương pháp bảng hỏi và bằng cách ghi nhận trực tiếp trên đường qua phương pháp dùng camera ghi lại hình ảnh tại các nút giao thông.

\subsection{1 Điều tra bằng phương pháp bảng hỏi}

Chúng tôi dùng phương pháp bảng hỏi về các nội dung: số lượng phương tiện thuộc sở hữu của các hộ gia đình, ý kiến của người dân về hành vi vi phạm giao thông, về thói quen của người điều khiển xe máy, về hiểu biểt tiêu chí văn hóa giao thông do Bộ Văn hóa, Thể thao và Du lịch ban hành. Phần đầu sẽ giới thiệu về các bước trong quá trình tiến hành điều tra. Kết quả chính trình bày ở phần sau.

\section{1) Quá trình điều tra}

\section{a) Thông tin chung}

\section{Mục đích và nội dung điều tra}

- Đánh giá về số lượng phương tiện thuộc sở hữu của các hộ gia đình

- Khảo sát ý kiến của người dân về hành vi vi phạm giao thông của người điều khiển xe máy.

- Khảo sát ý kiến của người dân về thói quen của người điều khiển xe máy.

- Khảo sát ý kiến của người dân về hiểu biết tiêu chí văn hóa giao thông do Bộ Văn hóa, Thể thao và Du lịch ban hành.

\section{Đối tượng điều tra:}

Cán bộ công chức viên chức, nhân viên văn phòng, công nhân, nông dân, công an, bộ đội, học sinh sinh viên và một số cán bộ về hưu, người dân buôn bán nhỏ ở các vùng thành thị và nông thôn thuộc một số tỉnh trong cả nước.

Phương pháp điều tra: sử dụng Phương pháp điều tra bằng bảng hỏi

\section{b) Phạm vi điều tra}


Nội dung: Giới hạn một số vấn đề liên quan đến hành vi thường vi phạm nhất của người điều khiển xe máy, thói quen ngại đi bộ của người dân và hiểu biết về tiêu chí văn hóa giao thông do Bộ Văn hóa, Thể thao và Du lịch ban hành.

Dung lượng mẫu: 4.112 mẫu

Mẫu chọn: theo phương pháp chọn mẫu tự nhiên

Địa điểm điều tra: trong một số tỉnh thành trên cả nước

Cụ thể:

Bảng 3-31 Số phiếu điều tra phân theo địa phương

\begin{tabular}{|c|c|c|}
\hline STT & Tỉnh, thành phố & Số phiếu \\
\hline 1 & Thành phố Hà Nội & 802 \\
\hline 2 & Tỉnh Cao Bằng & 27 \\
\hline 3 & Tỉnh Tuyên Quang & 15 \\
\hline 4 & Tỉnh Lào Cai & 35 \\
\hline 5 & Tỉnh Sơn La & 18 \\
\hline 6 & Tỉnh Hoà Bình & 18 \\
\hline 7 & Tỉnh Thái Nguyên & 59 \\
\hline 8 & Tỉnh Lạng Sơn & 19 \\
\hline 9 & Tỉnh Quảng Ninh & 105 \\
\hline 10 & Tỉnh Bắc Giang & 35 \\
\hline 11 & Tỉnh Phú Thọ & 23 \\
\hline 12 & Tỉnh Vĩnh Phúc & 53 \\
\hline 13 & Tỉnh Bắc Ninh & 33 \\
\hline 14 & Tỉnh Hải Dương & 40 \\
\hline 15 & Thành phố Hải Phòng & 72 \\
\hline 16 & Tỉnh Hưng Yên & 26 \\
\hline 17 & Tỉnh Thái Bình & 64 \\
\hline 18 & Tỉnh Hà Nam & 119 \\
\hline 19 & Tỉnh Nam Định & 123 \\
\hline 20 & Tỉnh Ninh Bình & 28 \\
\hline 21 & Tỉnh Thanh Hóa & 349 \\
\hline 22 & Tỉnh Nghệ An & 273 \\
\hline 23 & Tỉnh Hà Tĩnh & 21 \\
\hline 24 & Tỉnh Quảng Bình & 32 \\
\hline 25 & Tỉnh Quảng Trị & 57 \\
\hline 26 & Tỉnh Thừa Thiên Huế & 28 \\
\hline 27 & Thành phố Đà Nẵng & 89 \\
\hline 28 & Tỉnh Quảng Nam & 26 \\
\hline 29 & Tỉnh Quảng Ngãi & 44 \\
\hline 30 & Tỉnh Bình Định & 203 \\
\hline 31 & Tỉnh Phú Yên & 15 \\
\hline 32 & Tỉnh Khánh Hòa & 19 \\
\hline
\end{tabular}




\begin{tabular}{|c|l|c|}
\hline STT & \multicolumn{1}{|c|}{ Tỉnh, thành phố } & Số phiếu \\
\hline 33 & Tỉnh Bình Thuận & 150 \\
\hline 34 & Tỉnh Kon Tum & 19 \\
\hline 35 & Tỉnh Gia Lai & 16 \\
\hline 36 & Tỉnh Đắk Lắk & 22 \\
\hline 37 & Tỉnh Lâm Đồng & 15 \\
\hline 38 & Tỉnh Bình Dương & 60 \\
\hline 39 & Tỉnh Đồng Nai & 31 \\
\hline 40 & Tỉnh Bà Rịa-Vũng Tàu & 25 \\
\hline 41 & Thành phố Hồ Chí Minh & 501 \\
\hline 42 & Tỉnh Long An & 29 \\
\hline 43 & Tỉnh Bến Tre & 52 \\
\hline 44 & Tỉnh Trà Vinh & 53 \\
\hline 45 & Tỉnh Vĩnh Long & 64 \\
\hline 46 & Tỉnh Đồng Tháp & 15 \\
\hline 47 & Tỉnh An Giang & 15 \\
\hline 48 & Tỉnh Kiên Giang & 52 \\
\hline 49 & Thành phố Cần Thơ & 82 \\
\hline 50 & Tỉnh Sóc Trăng & $\mathbf{2 2}$ \\
\hline 51 & Tỉnh Bạc Liêu & \\
\hline & Tổng cộng & $\mathbf{1 1 2}$ \\
\hline & & \\
\hline
\end{tabular}

\section{2) Quy trình và kỹ thuật điều tra}

\section{Thiết kế phiếu phỏng vấn}

Quy trình thiết kế gồm các bước: xác định mục tiêu, nội dung cụ thể cần nghiên cứu, thiết kế câu hỏi theo từng nội dung cụ thể đó. Phiếu phỏng vấn (dự thảo) được xin ý kiến các chuyên gia và cộng tác viên của dự án trước khi tổ chức điều tra thử nghiệm.

Phiếu phỏng vấn được lập và đưa ra mẫu phiếu cuối cùng sau khi thảo luận trong nội bộ tổ tư vấn và các chuyên gia, cộng tác viên của dự án.

Nội dung của phiếu phỏng vấn về văn hóa giao thông gồm 02 phần:

+ Phần 1: thông tin chung về người trả lời: nội dung khảo sát về giới tính, nơi ở, tuổi, nghề nghiệp, số thành viên trong gia đình, số lượng các loại phương tiện giao thông thuộc sở hữu hộ gia đình

+ Phần 2: ý kiến cá nhân

Quan điểm và ý kiến: nội dung khảo sát về ý kiến của người được hỏi về các hành vi vi phạm quy định giao thông của người điều khiển xem máy, thói quen của người đi xe máy, thói quen ngại đi bộ của người dân và hiểu biết về tiêu chí văn hóa giao thông do Bộ Văn hóa, Thể thao và Du lịch ban hành.

\section{Điều tra thử nghiệm}

Phiếu phỏng vân được được hỏi 50 người tại Hà Nội, đại diện cho các đối tượng sẽ điều tra chính thức. Mục đích của điều tra thử là để phát hiện những sai sót của phiếu phỏng vấn. Dựa trên những ý kiến góp ý của người được hỏi, phiếu phỏng vấn được chỉnh sửa, sau đó một lần nữa xin ý kiến chuyên gia hoàn thiện trước khi triển khai chính thức. 


\section{Điều tra chính thức}

Sau khi phiếu phỏng vấn được chỉnh sửa, đã tiến hành điều tra chính thức, tổ chức lấy thông tin vào phiếu phỏng vấn người dân sống tại 51 tỉnh và thành phố, kết quả thu thập được 4.112 phiếu.

\section{Làm sạch, kiểm tra, mã hóa, nhập số liệu}

Các phiếu phỏng vấn được kiểm tra, phát hiện các sai sót như: bỏ trống, trả lời có mâu thuẫn, trả lời không đúng quy định để hiệu chỉnh, những phiếu phỏng vấn không đáp ứng được yêu cầu của cuộc điều tra sẽ bị loại bỏ trước khi nhập số liệu.

\section{Xử lý và phân tích số liệu}

Số liệu được xử lý sau khi đã kiểm tra đầy đủ và thống nhất trong khâu nhập liệu. Số liệu được phân tích theo bảng tần xuất (tính \%) và bảng chéo để so sánh mức độ khác biệt giữa các nhóm đối tượng nghiên cứu. Một bảng tần xuất được thiết lập cho mỗi câu hỏi bao gồm những thông tin về số tuyệt đối những người trả lời và tỷ lệ phần trăm tương ứng, số người trả lời và tỷ lệ phần trăm tương ứng thể hiện ở từng thang đo trong phiếu phỏng vấn.

\section{Báo cáo kết quả điều tra}

Báo cáo được xây dựng dựa trên số liệu của bảng tần xuất, bảng chéo kết hợp với việc phân tích, tổng hợp tư liệu có liên quan đến ý kiến về hành vi vi phạm giao thông của người sử dụng xe máy. Mồi nội dung trong phiếu phỏng vấn được báo cáo mô tả và dẫn chiếu bằng số liệu về tỷ lệ \% tuyệt đối, đồng thời có so sánh sự khác biệt giữa các nhóm đối tượng nhằm tìm kiếm sự khác biệt về ý kiến giữa các nhóm đối tượng của cuộc điều tra, từ đó đưa ra những nhận định làm cơ sở cho các kiến nghị sau này.

\section{3) Kết quả điều tra}

\section{1) Thông tin chung}

Bảng 3-32 Thông tin về người trả lời phỏng vấn văn hóa giao thông xe máy

\begin{tabular}{|l|c|}
\hline 1. Nhóm tuổi & Tỷ lệ \\
\hline Dưới 25 tuổi & $38,64 \%$ \\
\hline Từ 26 đến 35 tuổi & $25,75 \%$ \\
\hline Từ 36 đến 45 tuổi & $19,29 \%$ \\
\hline Từ 46 đến 55 tuổi & $11,41 \%$ \\
\hline Trên 55 tuổi & $4,91 \%$ \\
\hline \multicolumn{1}{|c|}{ Tổng cộng } & $100,00 \%$ \\
\hline 2. Nơi ở & \\
\hline Thành thị & $57,86 \%$ \\
\hline Nông Thôn & $42,14 \%$ \\
\hline \multicolumn{1}{|c|}{ Tổng cộng } & $100,00 \%$ \\
\hline 3. Nghề nghiệp/công việc & \\
\hline Công chức, viên chức, nhân viên văn phòng & $25,41 \%$ \\
\hline Công nhân, nông dân & $10,65 \%$ \\
\hline Công an, bộ đội & $11,07 \%$ \\
\hline Học sinh, sinh viên & $34,44 \%$ \\
\hline
\end{tabular}




\begin{tabular}{|c|c|}
\hline Khác & $18,43 \%$ \\
\hline Tổng công & $100,00 \%$ \\
\hline
\end{tabular}

\section{b) Kết quả điều tra}

- Số phương tiện tính trên 100 hộ gia đình

Bảng 3-33 Số phương tiện trên 100 hộ gia đình

\begin{tabular}{|c|l|r|r|r|}
\hline STT & Loại phương tiện & \multicolumn{1}{c|}{ Thành thị } & \multicolumn{1}{c|}{ Nông thôn } & \multicolumn{1}{c|}{ Chung } \\
\hline 1 & Xe đạp & 57,26 & 64,92 & 60,46 \\
\hline 2 & Xe đạp điện & 22,33 & 28,66 & 24,98 \\
\hline 3 & Xe máy & 225,06 & 223,84 & 224,55 \\
\hline 4 & Xe Máy điện & 13,19 & 14,39 & 13,69 \\
\hline 5 & Xe ô tô & 40,56 & 18,25 & 31,24 \\
\hline
\end{tabular}

\section{- Về các hành vi vi phạm quy định giao thông của người điều khiển xe máy}

\section{Về hành vi vưột đèn đỏ}

Vượt đèn đỏ là một trong những nguyên nhân dẫn đến tai nạn giao thông. Điều đáng nói là nét văn hóa dừng xe khi gặp đèn đỏ của người điều khiển xe máy lại bị xem nhẹ. Hiện tượng vi phạm vượt đèn đỏ còn phổ biến, chỉ có 5,7\% người được hỏi trả lời là không thấy hiện tượng vượt đèn đỏ của người điều khiển xe máy.

Các biểu đồ sau là ý kiến của người được hỏi về hành vi vượt đèn đỏ của người điều khiển xe máy. Trong đó có phân theo các nhóm tuổi, nghề nghiệp, nơi ở của người được hỏi.
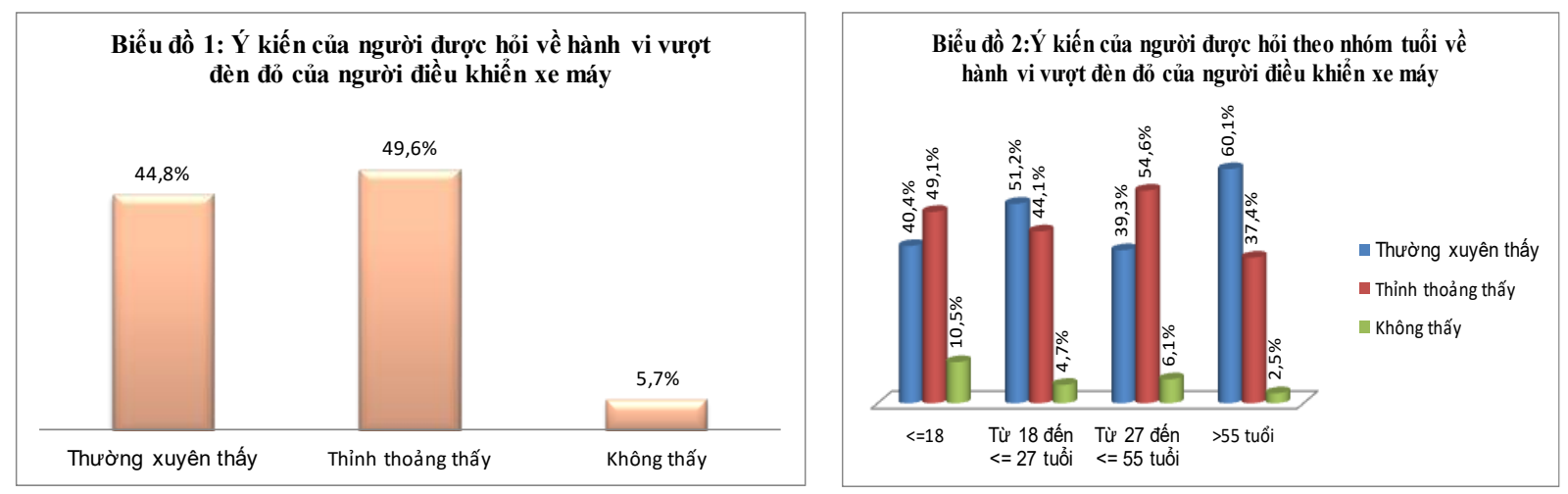

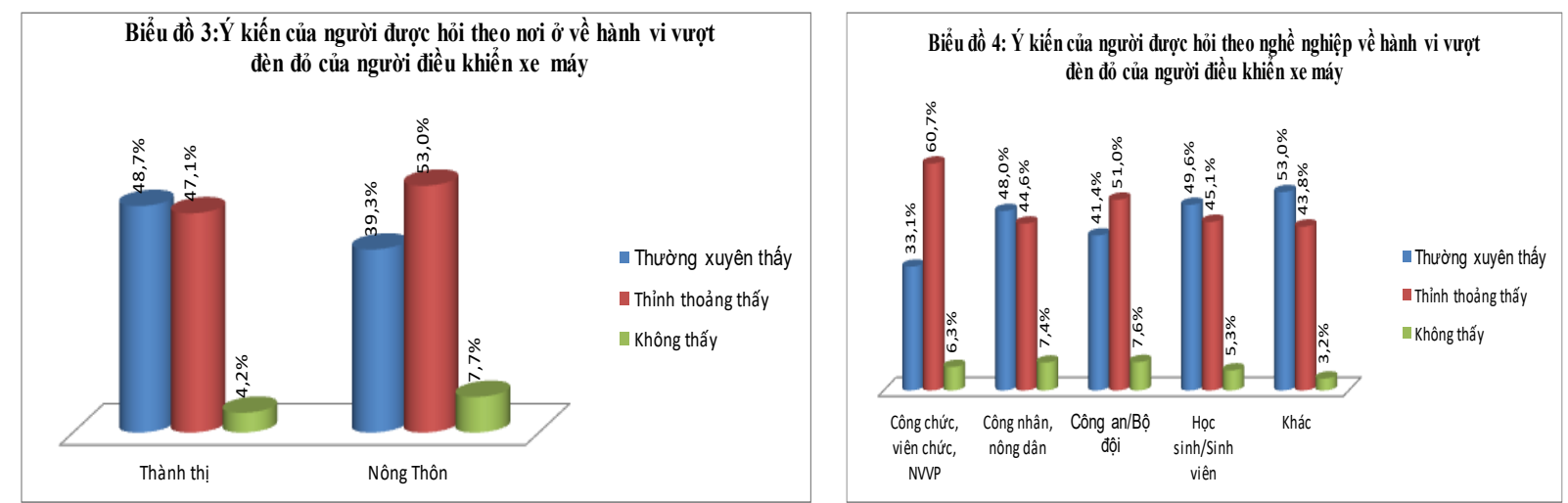

Suy nghĩ của người được hỏi đối với hành vi vượt đèn đỏ nhu sau:

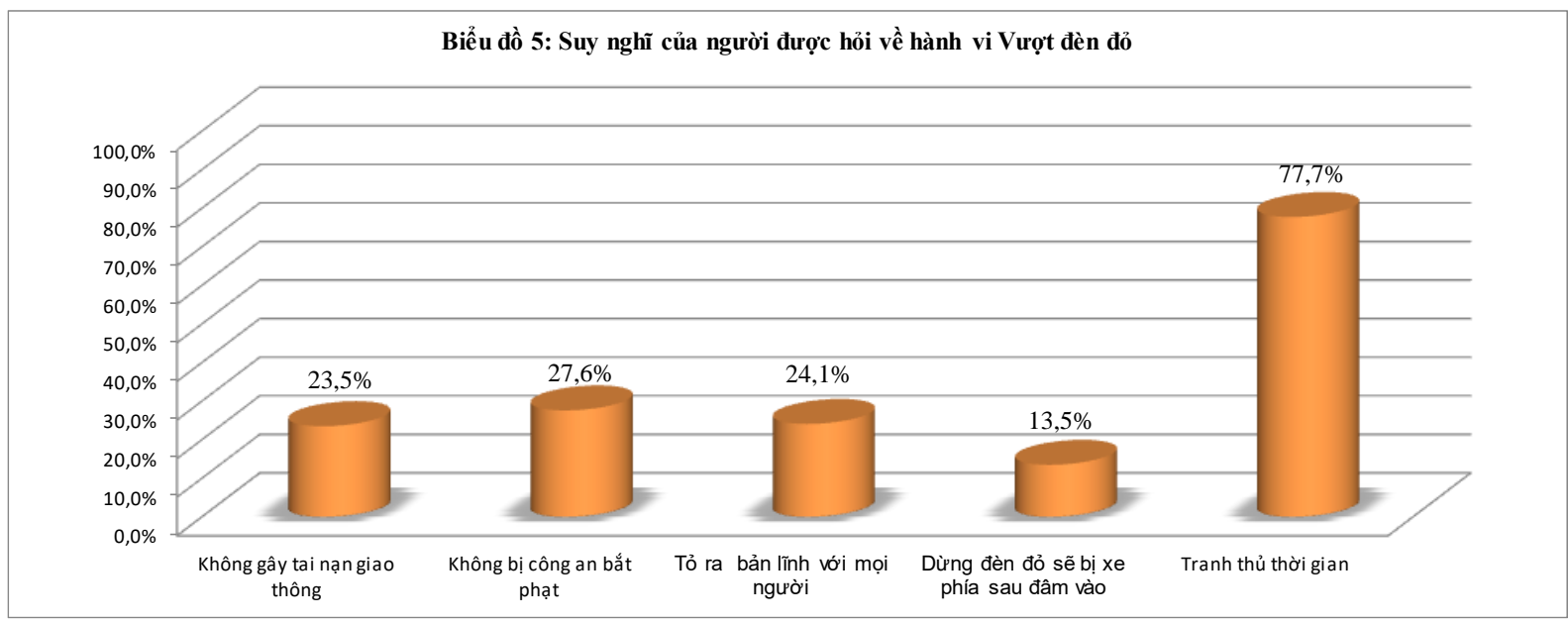

Đa số người được hỏi (chiếm 77,7\%) suy nghĩ rằng người điều khiển xe máy vượt đèn đỏ là do tranh thủ thời gian.

\section{Về hành vi không đội mũ bảo hiểm khi đi xe máy}

Tình trạng người dân ngồi trên xe máy khi tham gia giao thông không đội mũ bảo hiểm diễn ra khá phổ biến. Hành vi này không chỉ vi phạm quy định của pháp luật mà còn đe dọa trực tiếp đến sức khỏe, sinh mạng của người ngồi trên xe máy khi không may xảy ra tai nạn giao thông. Hiện tượng này vẫn còn xảy ra phổ biến, chỉ có $4,5 \%$ người được hỏi trả lời là không thấy hiện tượng không đội mũ bảo hiểm khi đi xe máy.

Các biểu đồ sau là ý kiến của người được hỏi về hành vi không đội mũ bảo hiểm khi đi mô tô, xe gắn máy. Trong đó có phân theo các nhóm tuổi, nghề nghiệp, nơi ở của người được hỏi. 

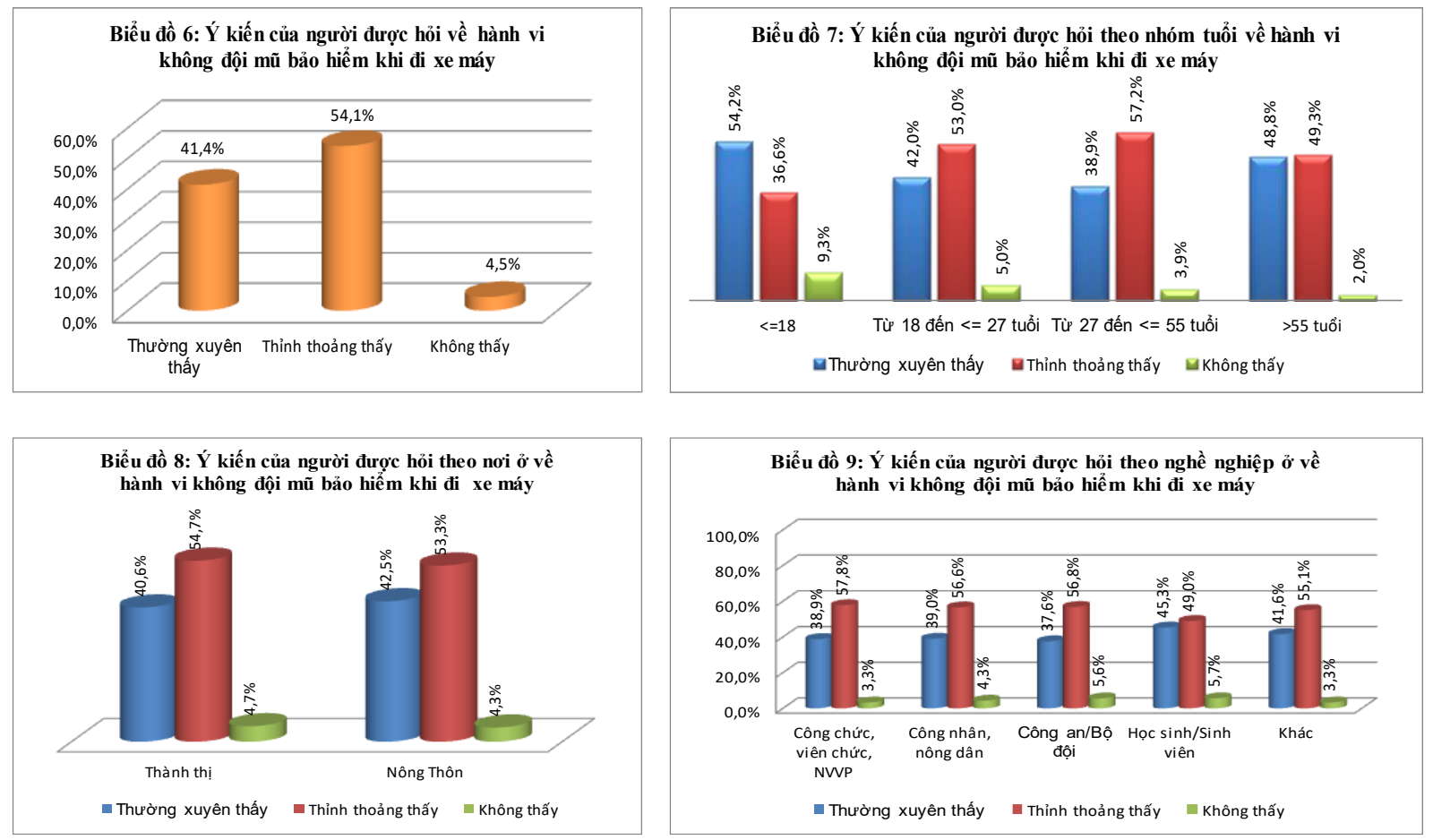

Suy nghĩ của người được hỏi đối với hành vi không đội mũ bảo hiểm khi đi xe máy như sau:

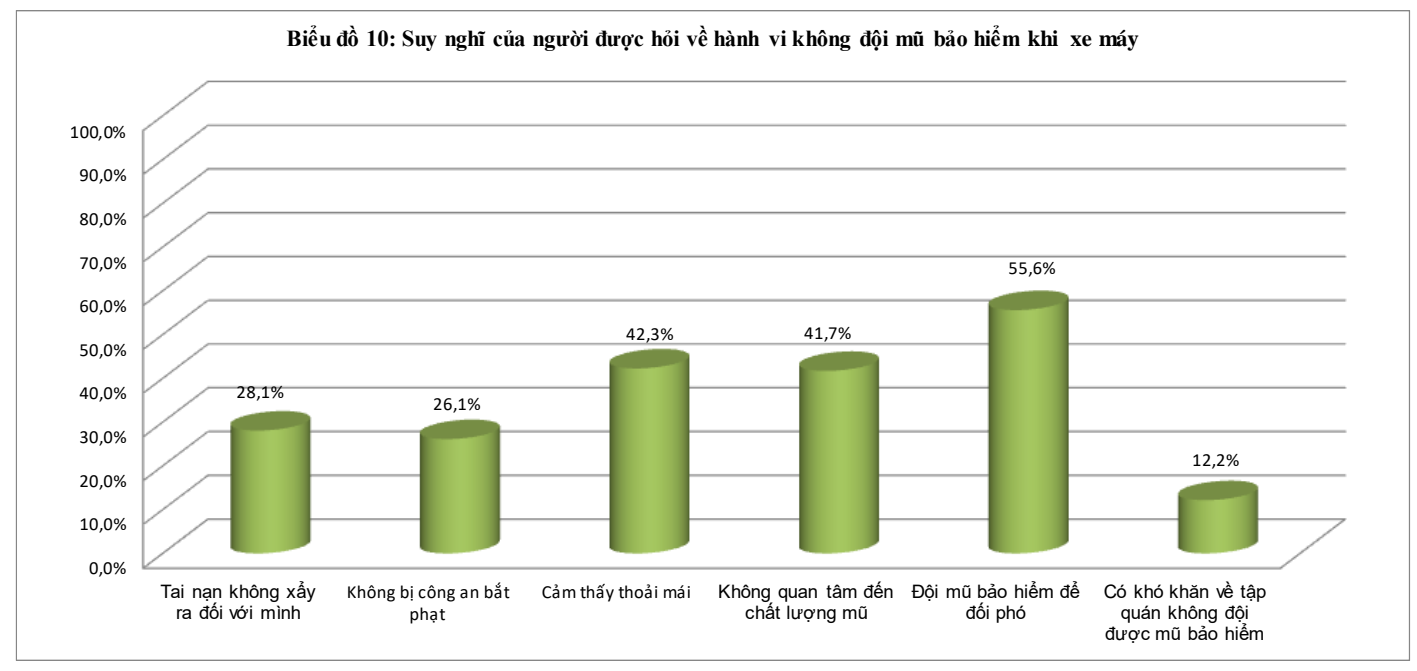

Có đến 55,6\% người được hỏi suy nghĩ rằng đội mũ bảo hiểm để đối phó và 42,3\% người được hỏi suy nghĩ rằng cảm thấy thoải mái nếu không đội mũ bảo hiểm khi đi xe máy.

\section{Về hành vi chạy quá tốc độ quy định}

Luật giao thông đường bộ quy định người lái xe, người điều khiển xe máy phải tuân thủ về tốc độ xe chạy trên đường, đồng thời nghiêm cấm hành vi điều khiển xe cơ giới chạy quá tốc độ quy định. Song trong tất cả những lỗi vi phạm giao thông thì chạy quá tốc độ là lỗi thường gặp nhất đối với những người điều khiển ô tô và xe máy. Chỉ có $8,2 \%$ người được hỏi trả lời là không thấy hành vi chạy quá tốc độ quy định của người điều khiển xe máy

Các biểu đồ sau là ý kiến của người được hỏi về hành vi chạy quá tốc độ quy định của người điều khiển xe máy. Trong đó có phân theo các nhóm tuổi, nghề nghiệp, nơi ở của người được hỏi. 

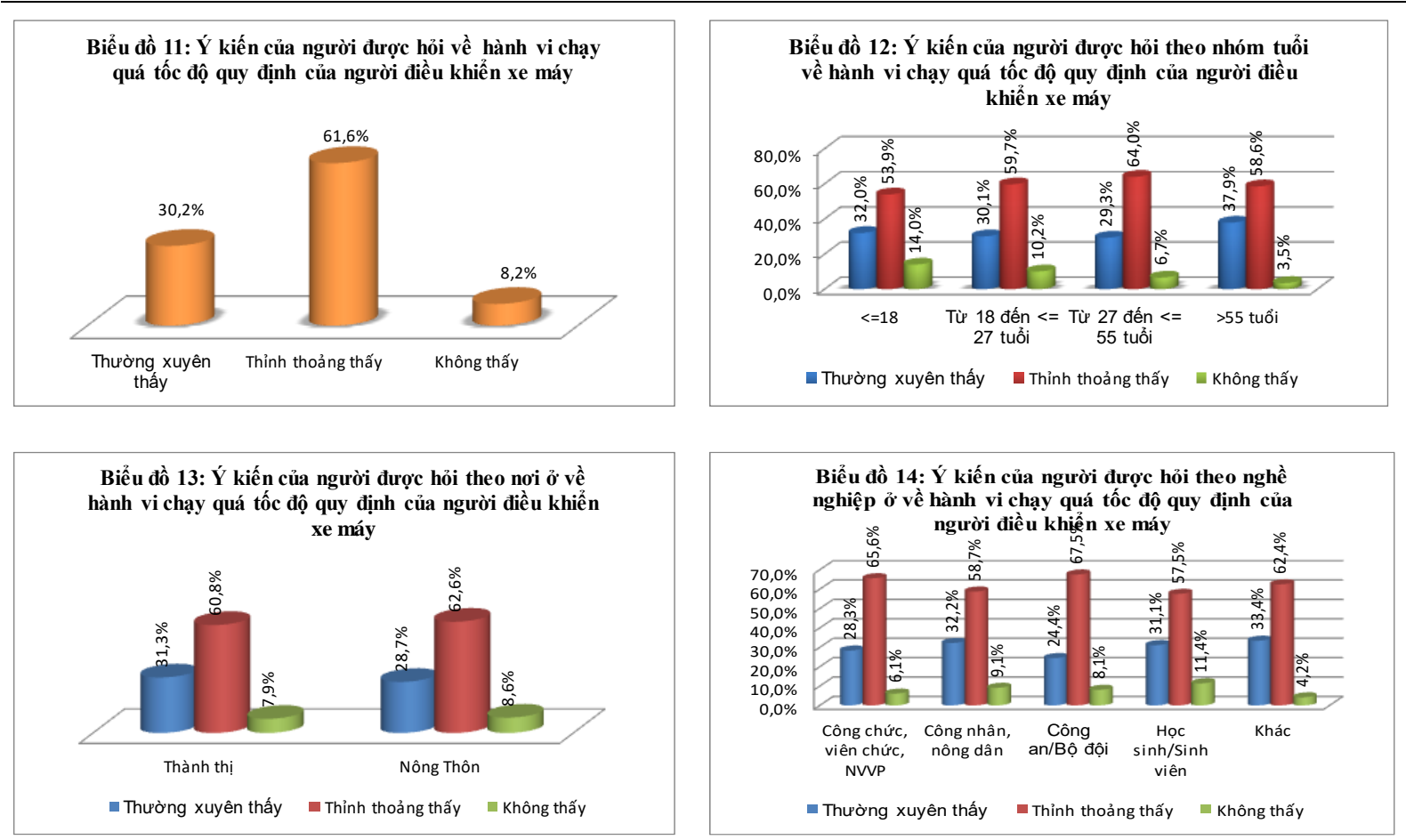

Suy nghĩ của nguời được hỏi đối với hành vi chạy quá tốc độ quy định của người điều khiển xe máy nhu sau:

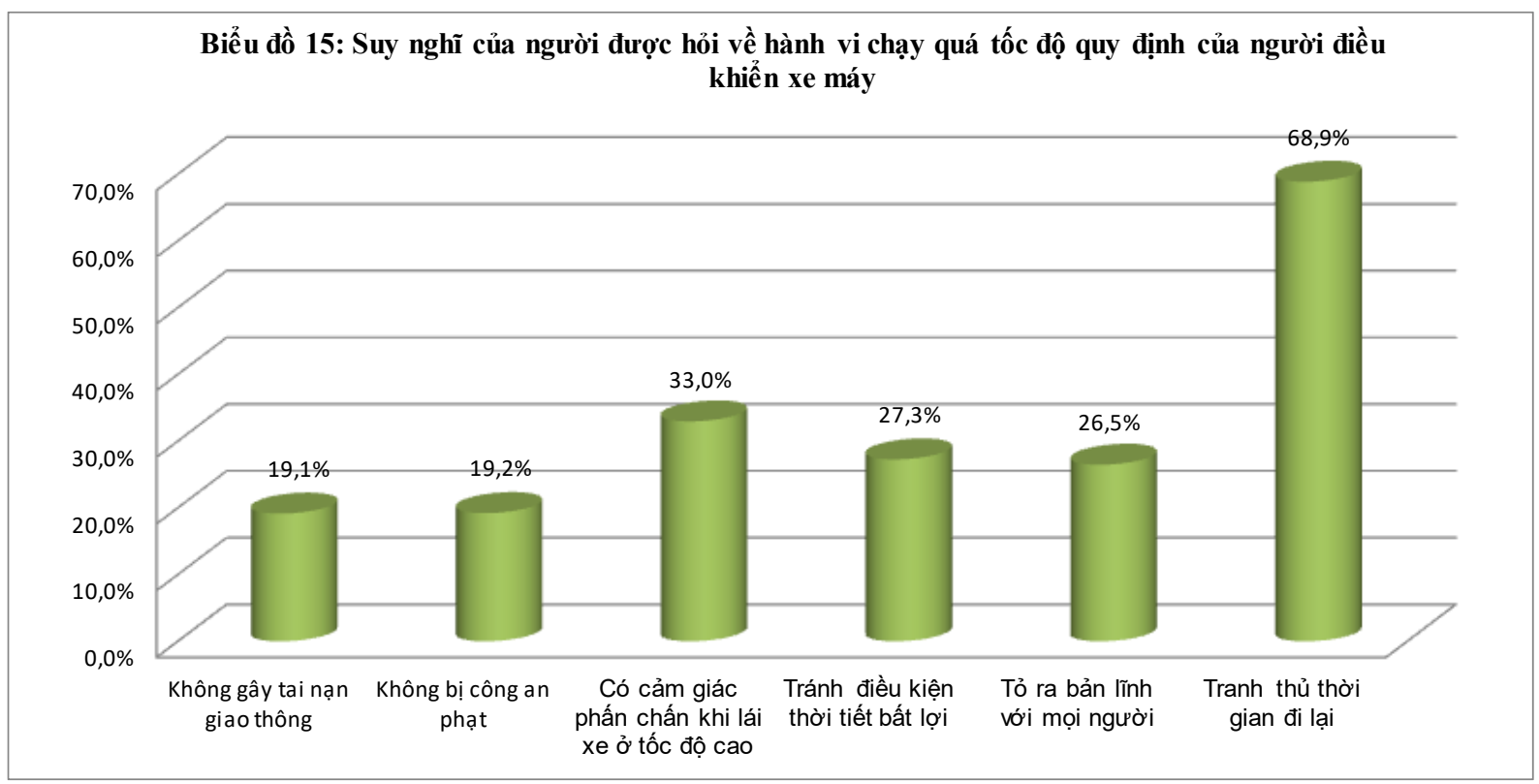

Đa số người được hỏi (chiếm 68,9\%) suy nghĩ rằng chạy quá tốc độ quy định để tranh thủ thời gian đi lại.

\section{Về hành vi lái xe trong tình trạng còn ảnh hưởng của rượu bia}

Đặc điểm của người điểu khiển phương tiện sau khi uống rượu, bia thường là chạy tốc độ cao, lạng lách, không làm chủ được tay lái, phán đoán và xử lý tình huống kém. Do đó, say rượu bia thường có liên quan mật thiết với việc vi phạm tốc độ, tránh, vượt sai quy định, đi sai phần đường... Hiện tượng người sử dụng xe máy vần lái xe trong tình trạng còn ảnh hưởng của rượu bia còn phổ biến, chỉ có $10,1 \%$ người đươc hỏi trả lời là không thấy hiện tượng người điều khiển xe máy lái xe trong tình trạng còn ảnh hưởng của rượu bia. 
Các biểu đồ sau là ý kiến của người được hỏi về hành vi lái xe khi còn ảnh hưởng của rượu bia của người điều khiển xe máy. Trong đó có phân theo các nhóm tuổi, nghề nghiệp, nơi ở của người được hỏi.
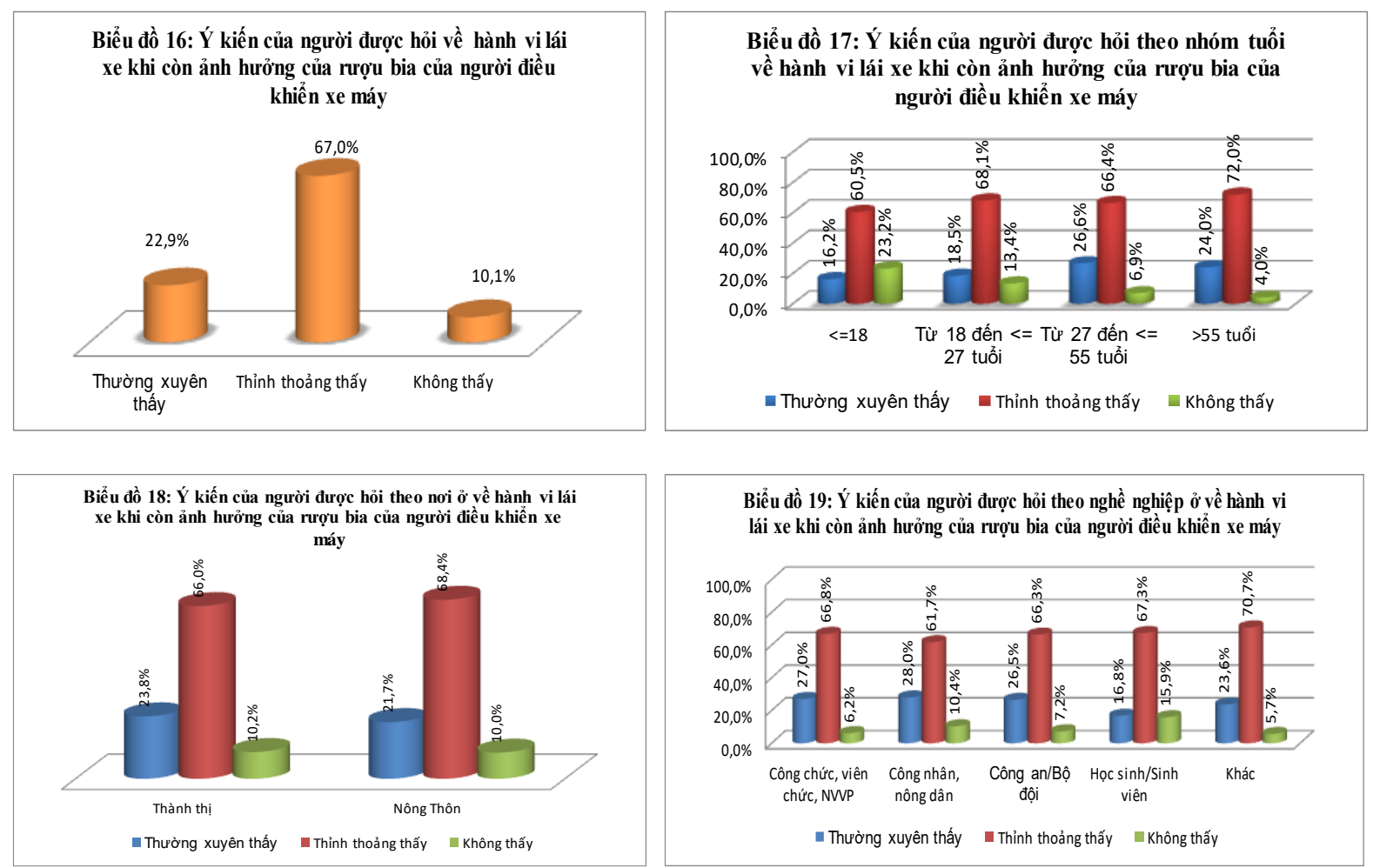

Suy nghĩ của người được hỏi đối với hành vi lái xe trong tình trạng còn ảnh hưởng của ruợu bia của người điều khiển xe máy nhu sau:

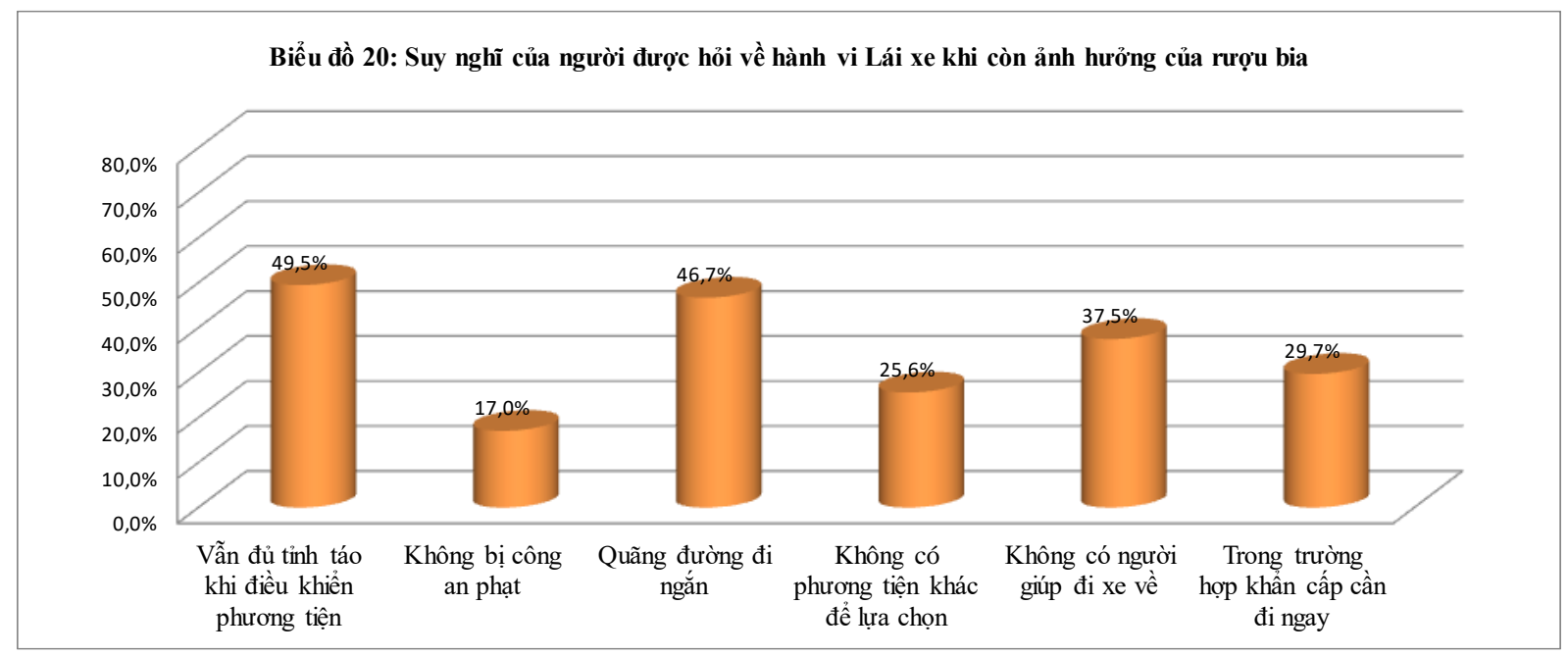

Có đến 49,5\% người được hỏi suy nghĩ rằng vẫn đủ tỉnh táo để lái xe khi còn ảnh hưởng của rượu bia, 46,7\% người được hỏi suy nghĩ rằng vẫn lái xe khi còn ảnh hưởng của rượu bia do quãng đường đi ngắn. 


\section{Về hành vi sử dụng điện thoại khi lái xe}

Vừa lái xe, vừa nhắn tin hay lướt web, vào mạng xã hội đã trở thành thói quen của không ít lái xe và đây chính là một trong những thói quen "chết người". Dưới góc độ khoa học, não của người chỉ có thể xử lý tốt một việc vào một thời điểm nhất định. Việc vừa lái xe, vừa sử dụng điện thoại di động khiến người lái bị phân tán sự tập trung, dẫn đến không thể làm tốt nhiệm vụ lái xe. Sự nguy hiểm càng tăng nếu vừa lái xe, vừa nhắn tin, do người lái chỉ điều khiển xe bằng một tay, tay còn lại sử dụng điện thoại di động, với sự tập trung dành phần lớn vào thiết bị cầm tay này. Hiện tượng sử dụng điện thoại khi lái xe của người điều khiển xe máy còn phổ biến, chỉ có 5,3\% người được hỏi trả lời là không thấy hiện tượng sử dụng điện thoại khi lái xe của người điều khiển xe máy.

Các biểu đồ sau là ý kiến của người được hỏi về hành vi sử dụng điện thoại khi lái xe của người điều khiển xe máy. Trong đó có phân theo các nhóm tuổi, nghề nghiệp, nơi ở của người được hỏi.
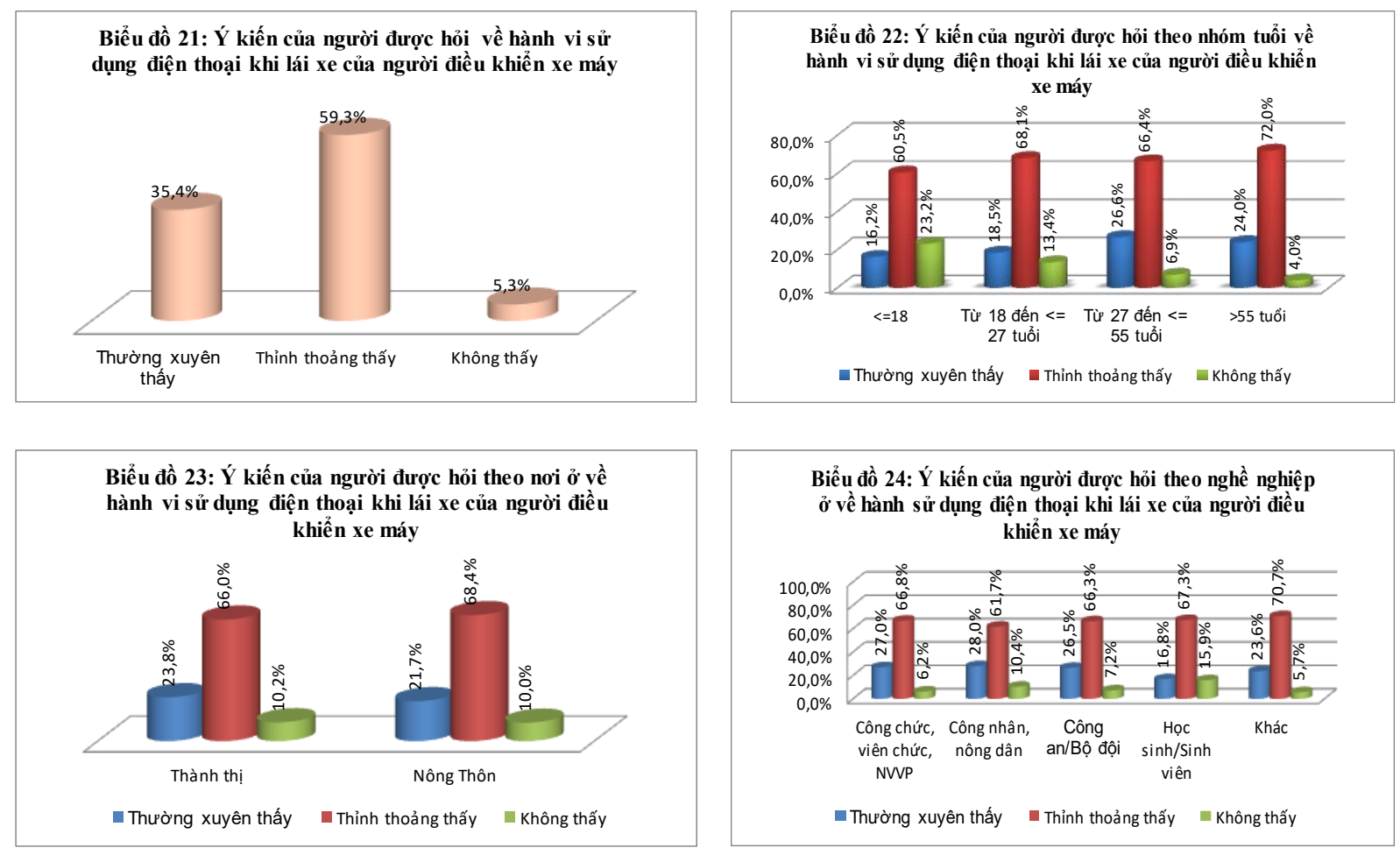

Suy nghĩ của nguời được hỏi đối với hành vi sủ dụng điện thoại khi lái xe nhu sau:

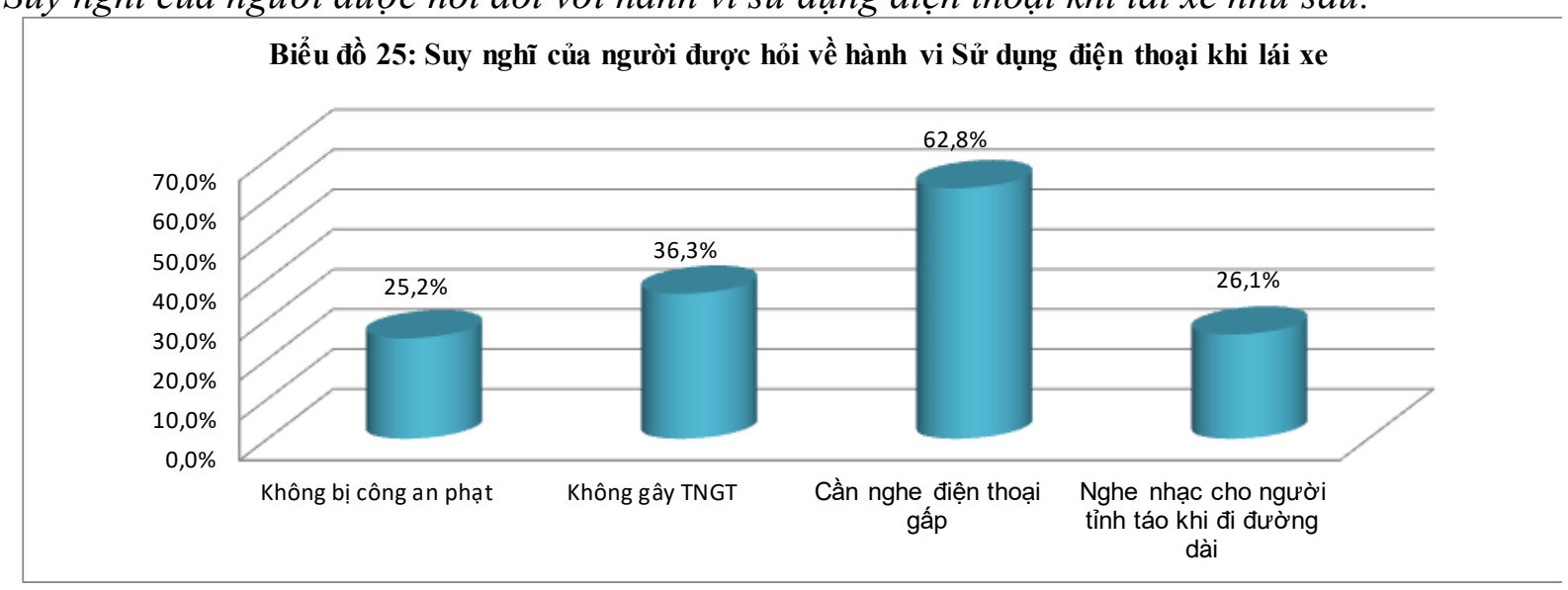


Đa số người được hỏi (chiếm 62,8\%) suy nghĩ rằng cần nghe điện thoại gấp nên sử dụng điện thoại khi lái xe.

\section{Về thói quen chen lấn, không nhường đường}

Một trong những nguyên nhân gây ra tai nạn giao thông đường bộ và ách tắc giao thông đường bộ hiện nay ở nước ta là tình trạng không ai chịu nhường đường cho ai khi tham gia giao thông. $\mathrm{Ai}$ cũng muốn cố hơn người khác dù là nửa bánh xe, đi lấn phần đường của hướng giao thông ngược chiều, đi lên vỉa hè... Kết quả khảo sát cho thấy chỉ có $12,4 \%$ người được hỏi trả lời là không thấy hiện tượng người điều khiển xe máy không có hành vi chen lấn, nhường đường khi lái xe.

Bảng sau trình bày kết quả câu trả lời về một số thói quen không tốt (người được hỏi có nghĩ rằng người điều khiển xe máy có thói quen sau không?)

Bảng 3-34 Về một số thói quen không tốt

\begin{tabular}{|c|l|r|r|}
\hline Mã & \multicolumn{1}{|c|}{ Thói quen } & Có & \multicolumn{1}{|c|}{ Không } \\
\hline 1 & $\begin{array}{l}\text { Không nhường đường cho người đi bộ qua đường tại nơi có vạch kẻ đường } \\
\text { dành cho người đi bộ }\end{array}$ & $100,00 \%$ & $0,00 \%$ \\
\hline 2 & $\begin{array}{l}\text { Không nhường đường cho người đi bộ qua đường tại nơi không có vạch kẻ } \\
\text { đường dành cho người đi bộ }\end{array}$ & $99,91 \%$ & $0,09 \%$ \\
\hline 3 & Không nhanh chóng nhường đường cho xe ưu tiên & $100,00 \%$ & $0,00 \%$ \\
\hline 4 & Không nhường đường cho xe chạy ở chiều ngược lại tại nơi đường hẹp & $100,00 \%$ & $0,00 \%$ \\
\hline 5 & Chen lấn, tạt đầu xe & $100,00 \%$ & $0,00 \%$ \\
\hline
\end{tabular}

\section{Về thói quen bấm còi tùy tiện}

Theo quy định, còi xe là thiết bị bắt buộc phải lắp đặt trên các phương tiện cơ giới khi tham gia giao thông nhằm mục đích nhắc nhở và cảnh báo khi cần thiết. Tuy nhiên, không ít chủ phương tiện đang sử dụng tiếng còi một cách tùy tiện, gây ảnh hưởng không nhỏ tới sức khỏe, tâm lý, thậm chí là cả tính mạng của người đi đường.

Vào giờ tan tầm, tình trạng bấm còi xe bừa bãi xảy ra phổ biến ở hầu khắp các tuyến phố có lưu lượng người tham gia giao thông lớn, đường ùn tắc, các phương tiện tràn lên vỉa hè, nối đuôi nhau nhích từng bước nhưng người đi sau vẫn rú ga, bóp còi inh ỏi thúc giục người đi trước để di chuyển. Cá biệt, không chỉ trên đường phố đông đúc, tại các đoạn đường vắng, thoáng xe... nhiều người vẫn giữ thói quen bấm còi. Bấm còi và nghe tiếng còi dần trở thành thói quen của không ít người. Kết quả khảo sát cho thấy chỉ có $14,1 \%$ người được hỏi trả lời là không thấy hiện tượng bấm còi tùy tiện của người điều khiển xe máy.

Kết quả câu trả lời về người được hỏi có nghĩ rằng người điều khiển xe máy có thói quen sau không: 
Bảng 3-35 Thói quen bấm còi xe

\begin{tabular}{|c|l|r|r|}
\hline Mã & \multicolumn{1}{|c|}{ Trường hợp } & \multicolumn{1}{|c|}{ Có } & \multicolumn{1}{c|}{ Không } \\
\hline 1 & Vẫn bấm còi khi đang đèn đỏ, tắc đường & $77,09 \%$ & $22,91 \%$ \\
\hline 2 & Bấm còi inh ỏi & $64,30 \%$ & $35,70 \%$ \\
\hline 3 & $\begin{array}{l}\text { Bấm còi xe trong khoảng từ 22giờ hôm trước đến 05 giờ sáng hôm } \\
\text { sau. }\end{array}$ & $47,04 \%$ & $52,96 \%$ \\
\hline 4 & Không dùng biện pháp khác (như nháy đèn) thay vì bấm còi & $57,81 \%$ & $42,19 \%$ \\
\hline
\end{tabular}

\section{c) Thói quen ngại đi bộ}

\section{Thói quen ngại đi bộ nên thường xuyên đi xe máy mặc dù cự ly ngắn}

Việc dùng xe máy lâu ngày đã tạo thói quen ngại đi bộ, có đến 79,26\% người được hỏi trả lời thường xuyên sử dụng xe máy mặc dù cự ly ngắn.

Biểu đồ 26: Thói quen ngại đi bộ nên thường xuyên đi xe máy mặc dù cự ly ngắn

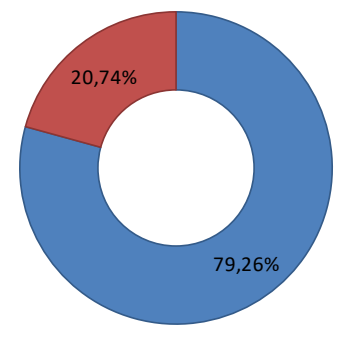

\section{Lựa chọn phương tiện thường dùng với các cự ly}

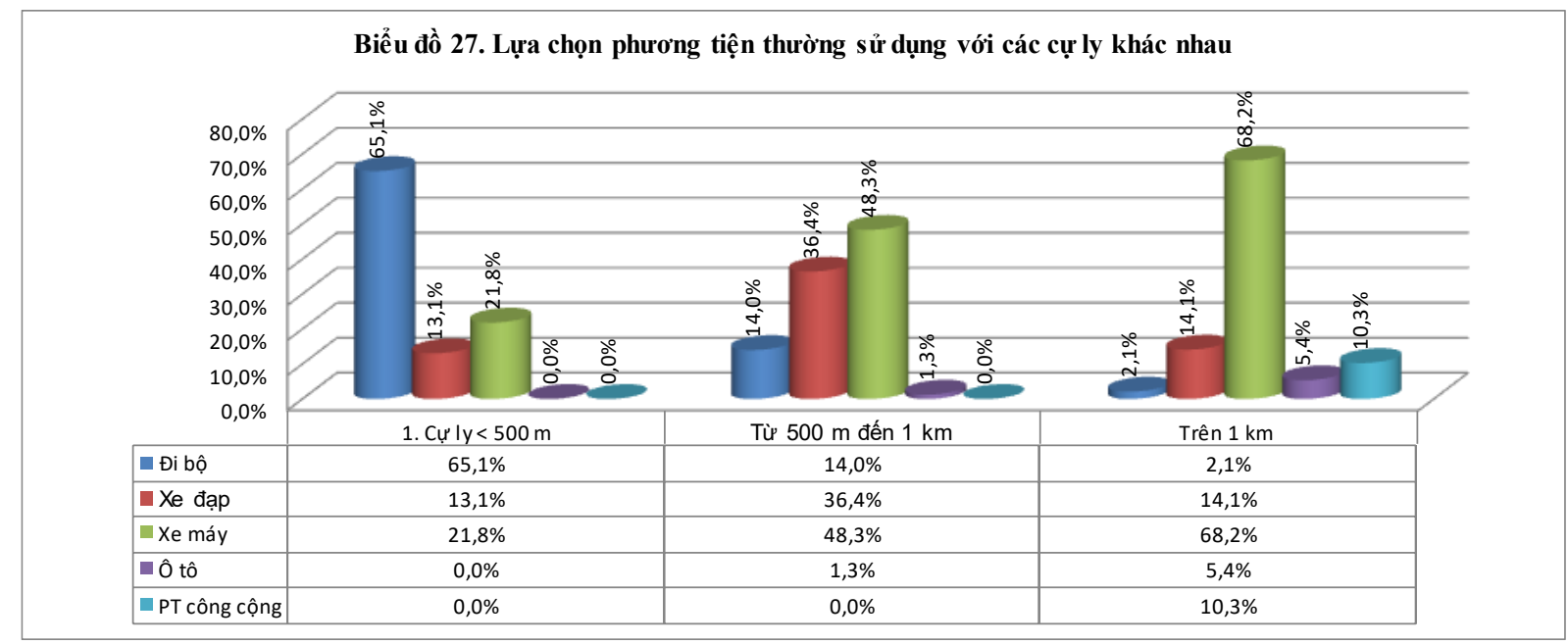

Dựa trên kết quả trả lời chúng ta thấy xe máy vẫn là phương tiện thường sử dụng của người dân. Mặc dù với cự ly rất ngắn $(<500 \mathrm{~m})$ nhưng có đến $21,8 \%$ người được hỏi trả lời sử dụng phương tiện xe máy.

\section{d) Tiêu chí văn hóa giao thông do Bộ Văn hóa, Thể thao và Du lịch ban hành}

Bộ Văn hóa Thể thao và Du lịch có ban hành quyết định số 3500/QĐ-BVHTTDL ngày 09 tháng 10 năm 2013 về việc ban hành tiêu chí văn hóa giao thông đường bộ. Chúng tôi có đề ra câu 
hỏi: "Quý vị có biết và nhớ các tiêu chí này?" thì có đến $63,1 \%$ người được hỏi trả lời là có biết và nhớ các tiêu chí này.

Biểu đồ sau đây là ý kiến của người được hỏi về tiêu chí văn hóa giao thông do Bộ Văn hóa, Thể thao và Du lịch ban hành.

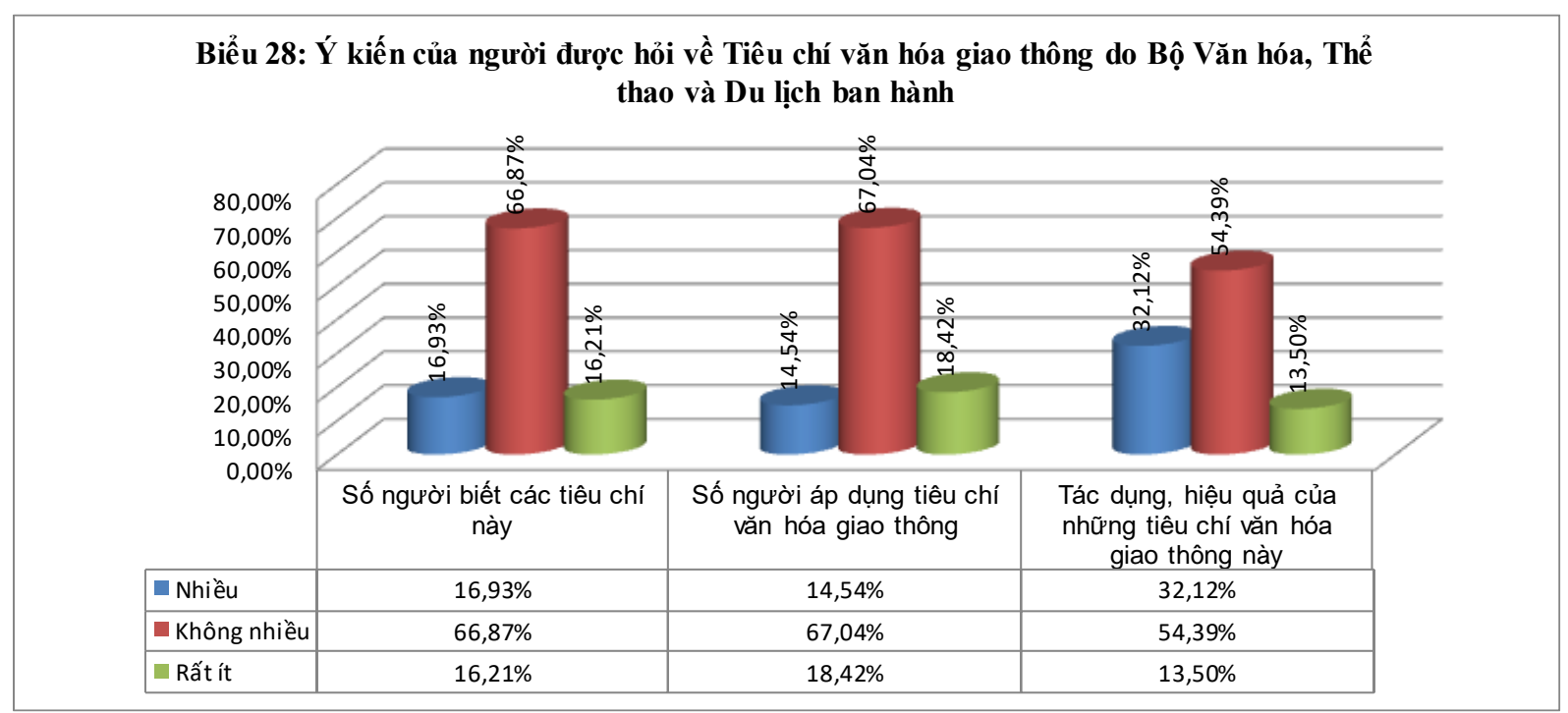

\subsubsection{Các ghi nhận trực tiếp trên đường qua phương pháp dùng camera ghi lại hình ảnh tại các nút giao thông}

1) Phương pháp điều tra: Ghi nhận trực tiếp trên đường qua phương pháp dùng camera ghi lại hình ảnh tại các nút giao thông.

\section{2) Phạm vi điều tra}

- Tư vấn chọn các nút giao thông để thực hiện khảo sát với số lượng: thành phố Hà Nội: 5 nút, thành phố Hồ Chí Minh: 5 nút, thành phố Đà Nẵng: 3 nút, thành phố Cần Thơ: 3 nút, thành phố Hải Phòng: 3 nút.

- Thời gian quay: buổi sáng từ 6 đến 9 giờ sáng; buổi chiều từ 16 giờ đến 19 giờ, mỗi nút trong 1 ngày.

- Thống kê lưu lượng xe qua các nút, hành vi vi phạm theo vào mẫu Thống kê lưu lượng giao thông và các lỗi vi phạm giao thông thường vi phạm nhất của người điều khiển xe máy.

\section{3) Kết quả điều tra}

\section{Tổng hợp chung}


Bảng tổng hợp kết quả ghi nhận tình hình vi phạm giao thông qua quay Camera của tất các nút đã quay

Đơn vị tính: \%o

\begin{tabular}{|c|c|c|c|c|c|c|c|}
\hline \multirow[b]{2}{*}{ Giờ } & \multicolumn{2}{|c|}{ Ô tô } & \multicolumn{5}{|c|}{ Xe máy } \\
\hline & $\begin{array}{c}\text { Ô tô Vượt } \\
\text { đèn đỏ }\end{array}$ & $\begin{array}{l}\text { Sử dụng } \\
\text { còi xe } \\
\text { không } \\
\text { đúng lúc }\end{array}$ & $\begin{array}{l}\text { Xe máy } \\
\text { vượt } \\
\text { đèn đỏ }\end{array}$ & $\begin{array}{c}\text { Người } \\
\text { điều } \\
\text { khiển xe } \\
\text { máy } \\
\text { không } \\
\text { đội mũ } \\
\text { bảo hiểm } \\
\end{array}$ & $\begin{array}{c}\text { Sử dụng } \\
\text { điện } \\
\text { thoại khi } \\
\text { lái xe } \\
\text { máy }\end{array}$ & $\begin{array}{c}\text { Đi xe } \\
\text { máy lên } \\
\text { vỉa hè }\end{array}$ & $\begin{array}{c}\text { Chở quá số } \\
\text { người quy } \\
\text { định, chờ hàng } \\
\text { cồng kềnh trên } \\
\text { xe máy }\end{array}$ \\
\hline $6.00-6.30$ & 13,12 & - & 37,77 & 23,02 & 1,03 & 0,18 & 3,22 \\
\hline $6.30-7.00$ & 5,90 & - & 19,99 & 13,40 & 0,55 & 0,31 & 2,19 \\
\hline 7.00-7.30 & 1,32 & - & 18,16 & 10,42 & 0,18 & 0,84 & 1,17 \\
\hline $7.30-8.00$ & 3,83 & - & 20,35 & 11,90 & 0,11 & 2,03 & 0,78 \\
\hline $8.00-8.30$ & 2,63 & - & 23,53 & 14,66 & 0,49 & 0,45 & 0,75 \\
\hline $8.30-9.00$ & 2,88 & - & 23,82 & 14,48 & 0,96 & 0,48 & 1,33 \\
\hline $16.00-16.30$ & 3,49 & - & 21,67 & 12,14 & 0,45 & 0,38 & 1,27 \\
\hline $16.30-17.00$ & 3,06 & - & 19,58 & 11,25 & 0,33 & 0,39 & 1,29 \\
\hline $17.00-17.30$ & 3,85 & - & 17,73 & 10,82 & 0,40 & 0,48 & 0,92 \\
\hline $17.30-18.00$ & 1,84 & - & 16,32 & 13,07 & 0,54 & 0,33 & 1,09 \\
\hline $18.00-18.30$ & 2,28 & - & 16,91 & 14,87 & 0,43 & 0,31 & 1,90 \\
\hline $18.30-19.00$ & 3,19 & - & 20,97 & 19,14 & 0,92 & 0,24 & 2,10 \\
\hline
\end{tabular}

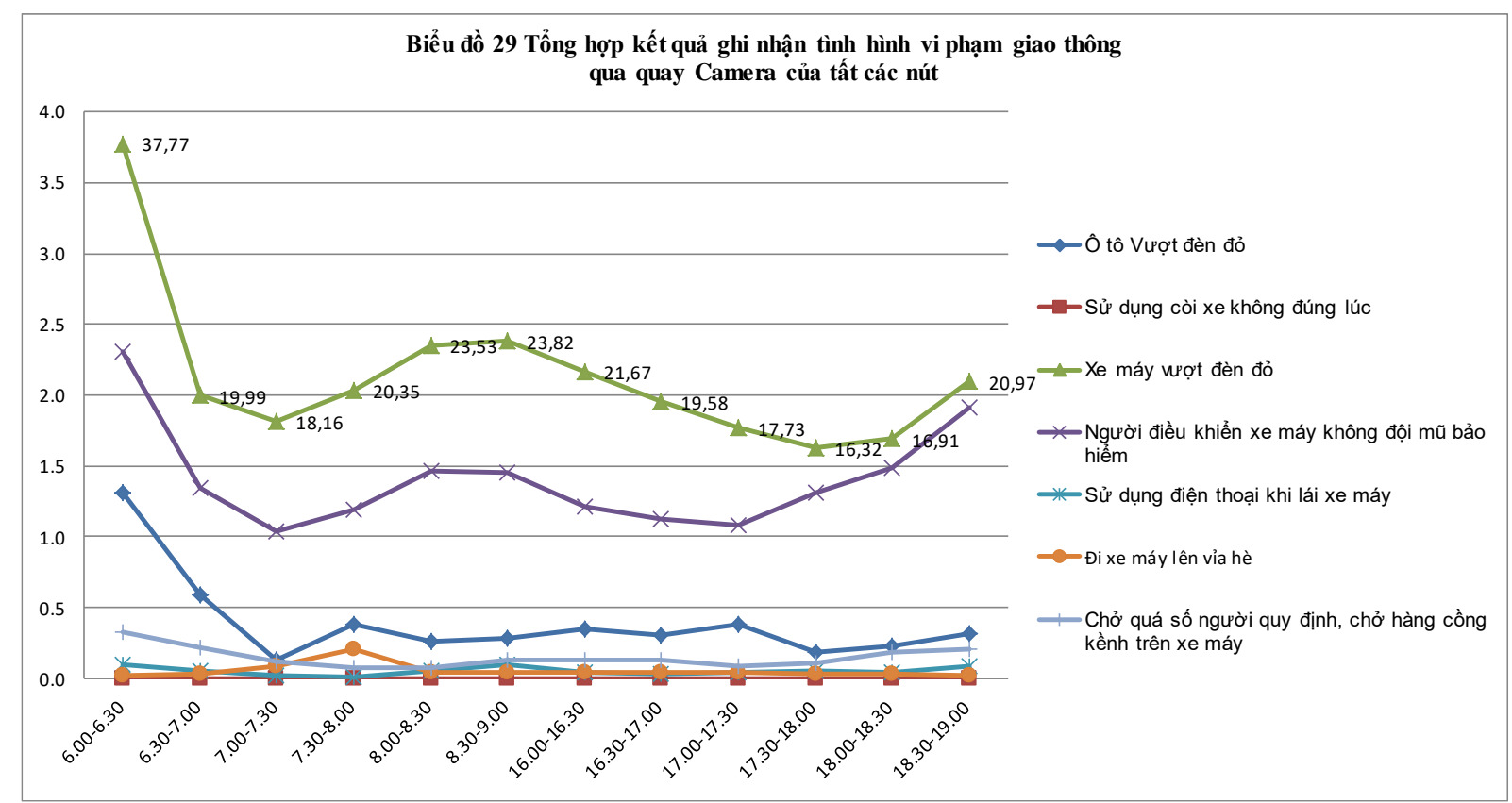

Số liệu tại Bảng tổng hợp bên trên và biểu đồ 29 cho thấy tình hình vi phạm giao thông của các phương tiện giao thông, đặc biệt là xe máy vẫn ở mức cao, khung giờ từ 6.00-6.30 tỷ lệ vi phạm nhiều nhất. Có thể nói, thời điểm tham gia giao thông vào sáng sớm là lúc mà người điều khiển phương tiện giao thông có ý thức chấp hành luật giao thông chưa cao. Họ thường chủ quan cho 
rằng chưa có lực lượng Cảnh sát giao thông xử lý, mà trên đường lại ít phương tiện giao thông nên việc vi phạm giao thông diễn ra khá phổ biến.

\section{Về hành vi vượt đèn đỏ}

Vượt đèn đỏ là một trong những nguyên nhân dẫn đến tai nạn giao thông. Qua biểu đồ 30 và biểu đồ 31 cho thấy vẫn tỷ lệ phương tiện giao thông vượt đèn đỏ khá cao, đặc biệt là Hà Nội có đến 60,64 \% người điều khiển xe máy vượt đèn đỏ khi đi qua ngã tư.
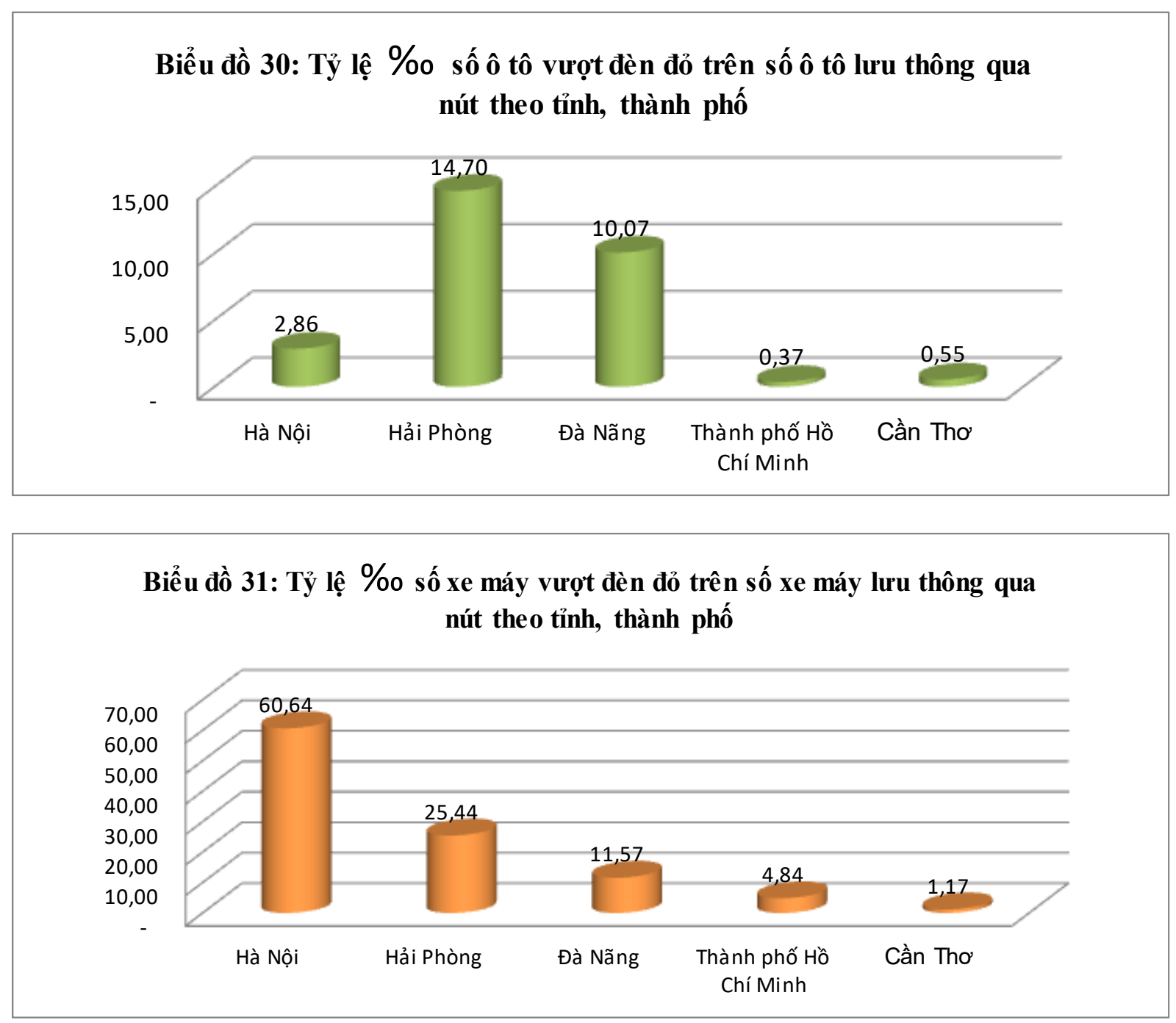

Hình dưới đây ghi lại hình ảnh xe máy vượt đèn đỏ, điều đáng lo ngại là khi một xe vi phạm vượt đèn đỏ thì các xe khác cũng vi phạm theo 


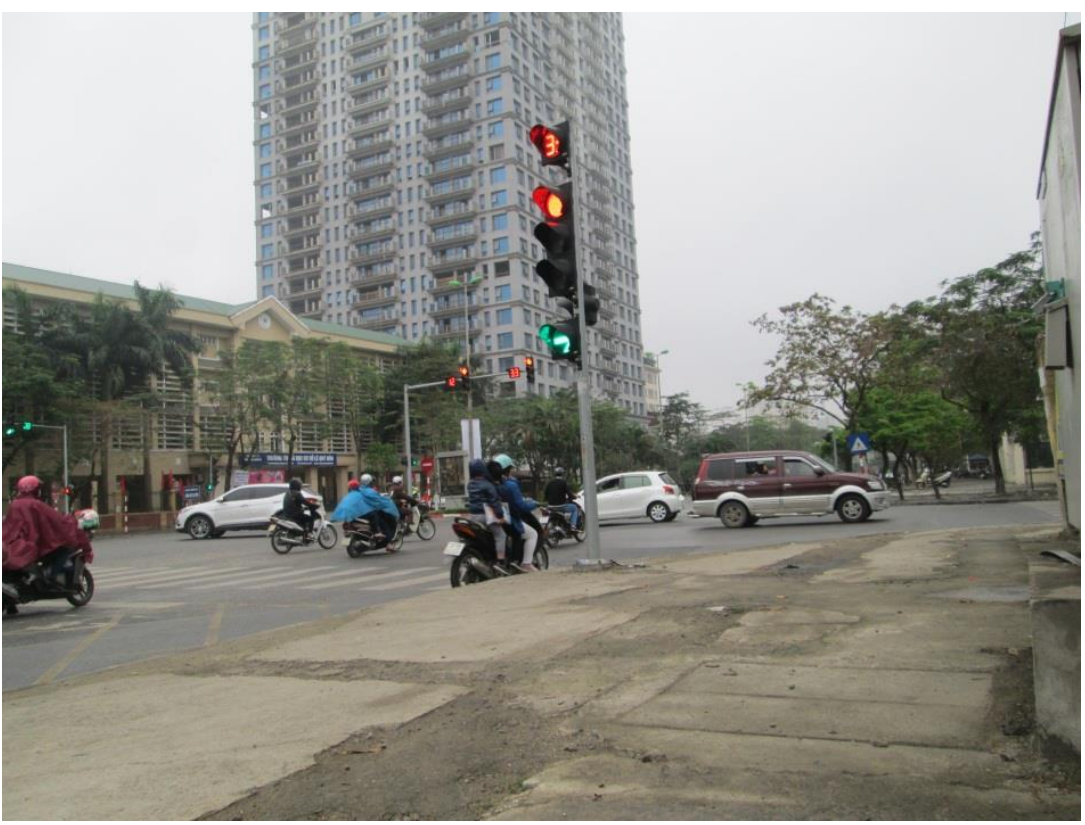

Hình ảnh xe máy vượt đèn đỏ

\section{Về hành vi không đội mũ bảo hiểm khi đi xe máy}

Thời gian vừa qua thực hiện Chỉ thị số số 04/2018 của Thủ tướng Chính phủ về việc đẩy mạnh triển khai các giải pháp nâng cao hiệu quả thực hiện quy định bắt buộc đội mũ bảo hiểm đối với người đi mô tô, xe máy, xe đạp điện. Lực lượng CSGT, cảnh sát trật tự và các lực lượng cảnh sát khác tăng cường công tác tuần tra, kiểm soát các tuyến đường, phát hiện xử lý nghiêm vi phạm trật tự an toàn giao thông liên quan đến người đi mô tô, xe máy vi phạm quy định về đội mũ bảo hiểm khi tham gia giao thông. Mặc dù vậy vẫn còn hiện tượng người điều khiển xe máy không đội mũ bảo hiểm khi tham giao giao thông đặc biệt là thành phố Hà Nội có đến 41,48 \% trường hợp người điều khiển xe máy không đội mũ bảo hiểm khi tham gia giao thông.

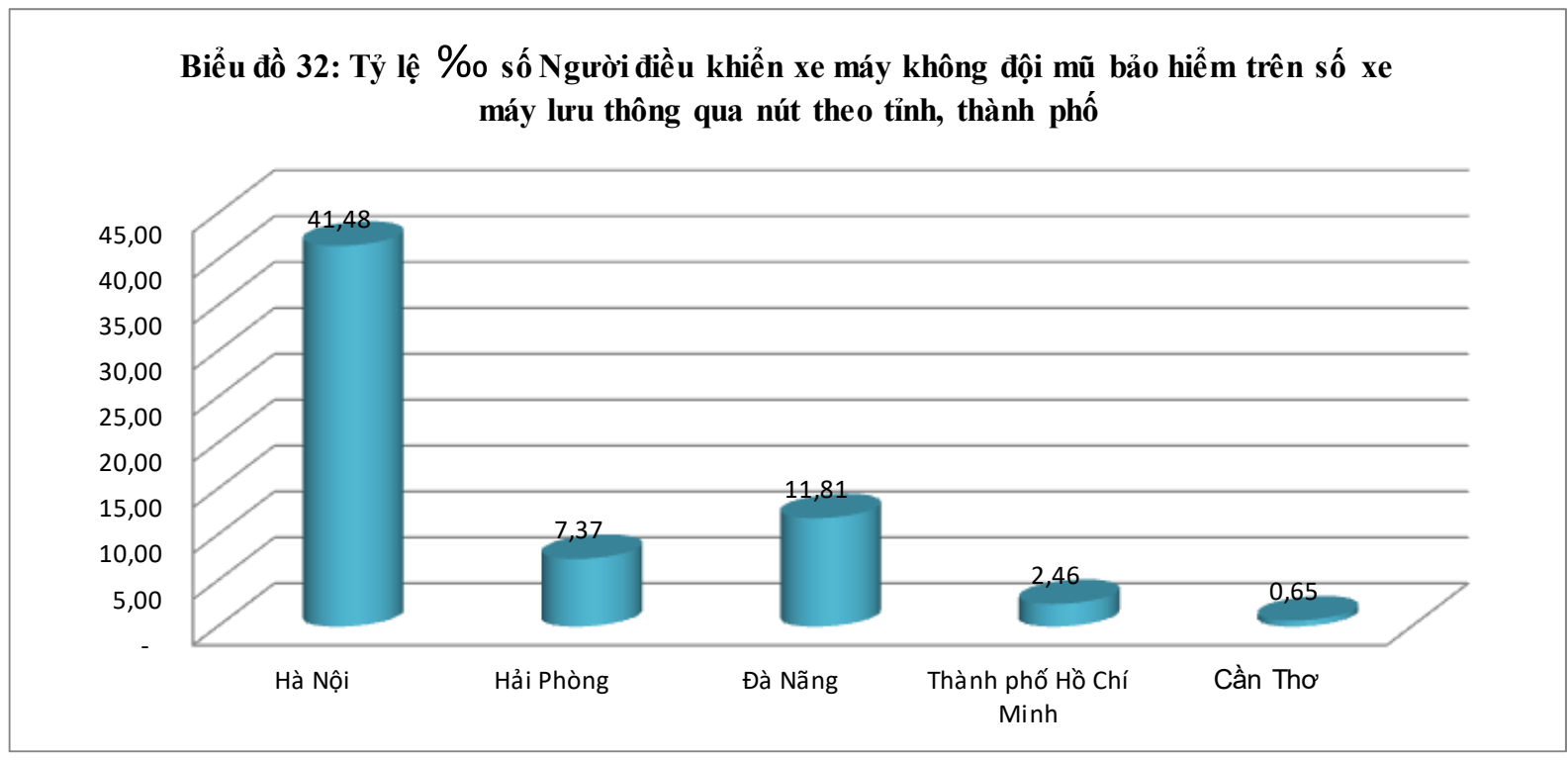

\section{Về hành vi xe máy đi trên vỉa hè}

Dù Nghị định 46/2016 về xử phạt vi phạm giao thông có quy định cấm đi ô tô, xe máy trên vỉa hè, song người điều khiển xe mô tô, xe gắn máy vẫn đi xe lên vỉa hè nhiều nhất là khi lưu lượng giao thông lớn, đặc biệt ở hai thành phố Hà Nội và Hồ Chí Minh. Việc đi xe máy, ô tô trên vỉa hè đang khiến hạ tầng vỉa hè nhanh chóng xuống cấp. 
Biểu đồ 33 cho thấy tỷ lệ \%o số xe máy đi lên vỉa hè trên số xe máy lưu thông gần nút giao thông theo các tỉnh, thành phố

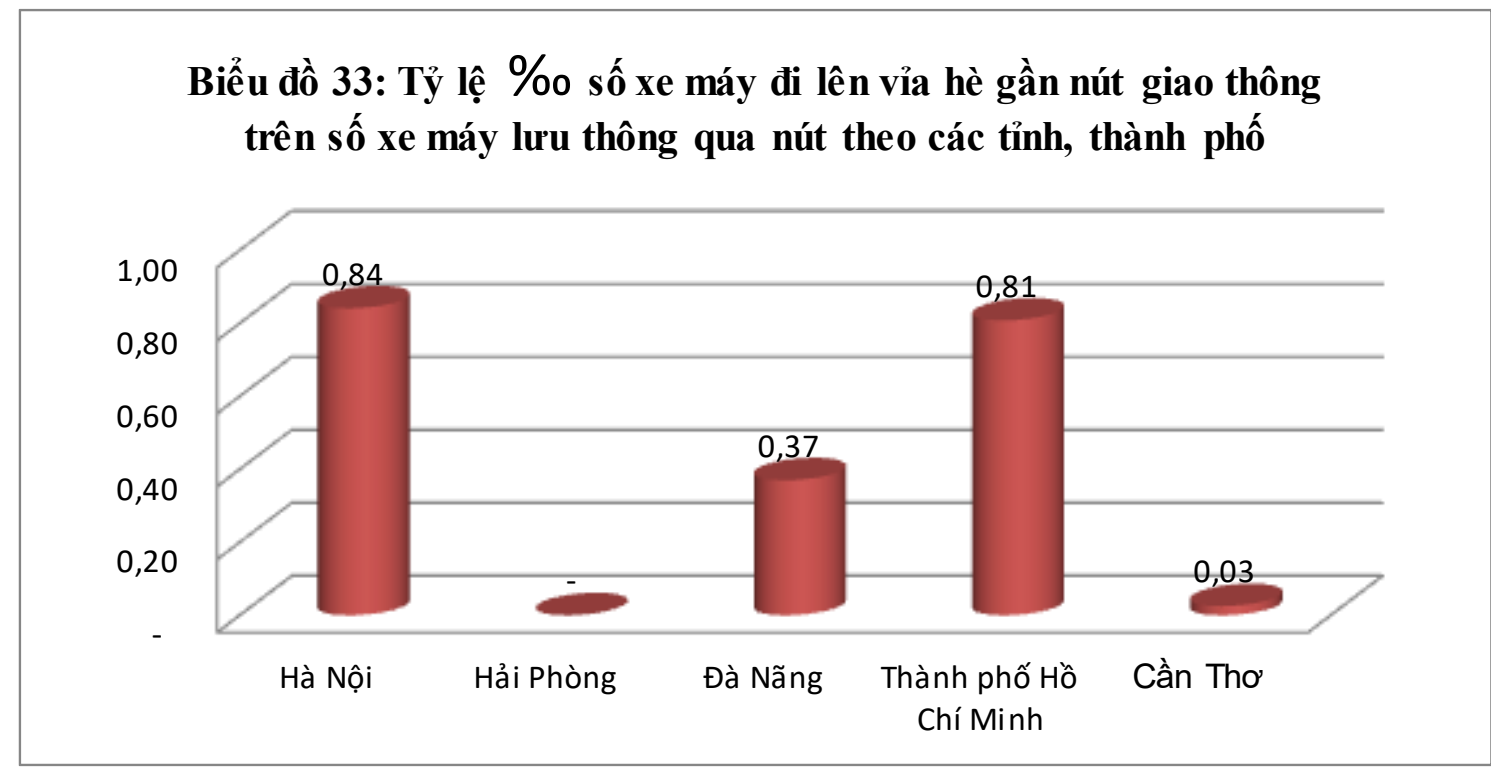

Hình dưới đây ghi lại hình ảnh xe máy đi trên vỉa hè, nguy hiểm hơn là người lớn điều khiển xe máy đi trên vỉa hè làm gương xấu cho trẻ em bắt chước đi xe đạp lên vỉa hè.
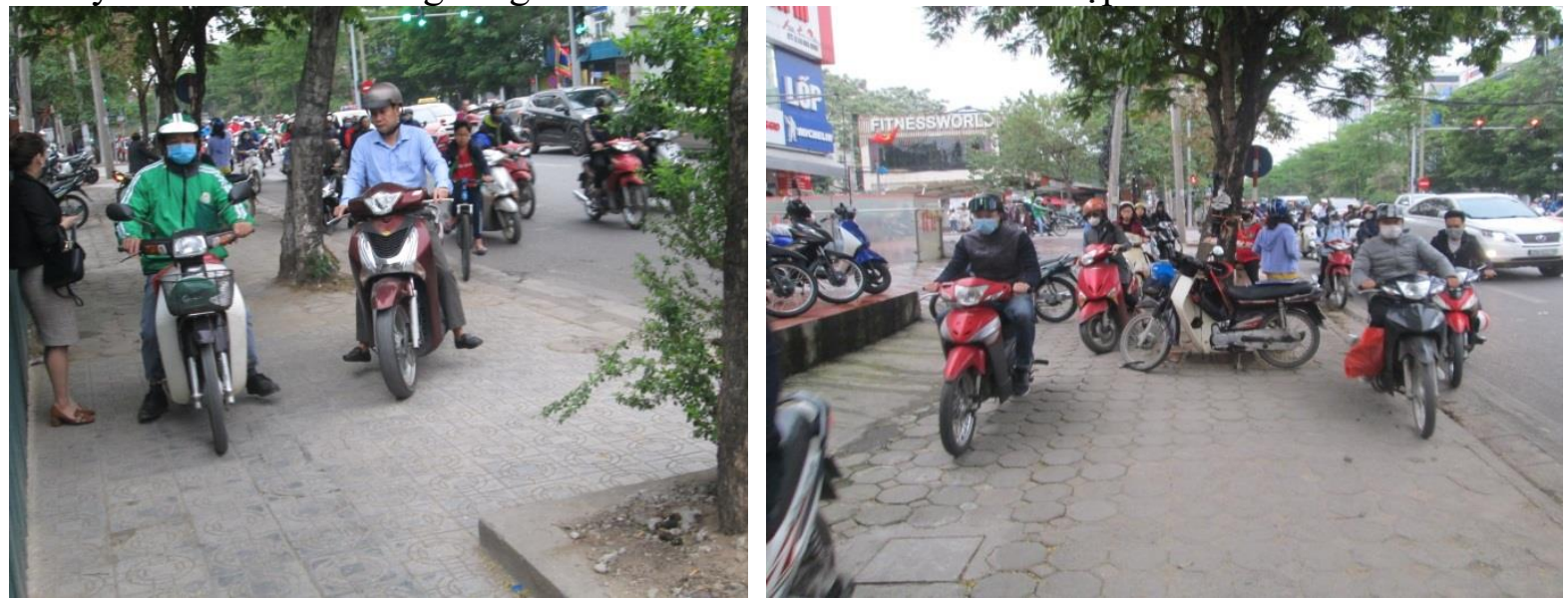

Hình ảnh xe máy đi trên vỉa hè khi giao thông ở Hà Nội

Về hành vi chở quá số người quy định, chở hàng cồng kềnh trên xe máy

Chở quá số người quy định, chở hàng cồng kềnh trên xe máy cũng tiềm ẩn tai nạn giao thông, thế nhưng hiện tượng này vẫn còn phổ biến. Biểu đồ 33 cho thấy tỷ lệ \%o trường hợp chở quá số người quy định, chở hàng cồng kềnh trên xe máy qua nút theo các tỉnh, thành phố 


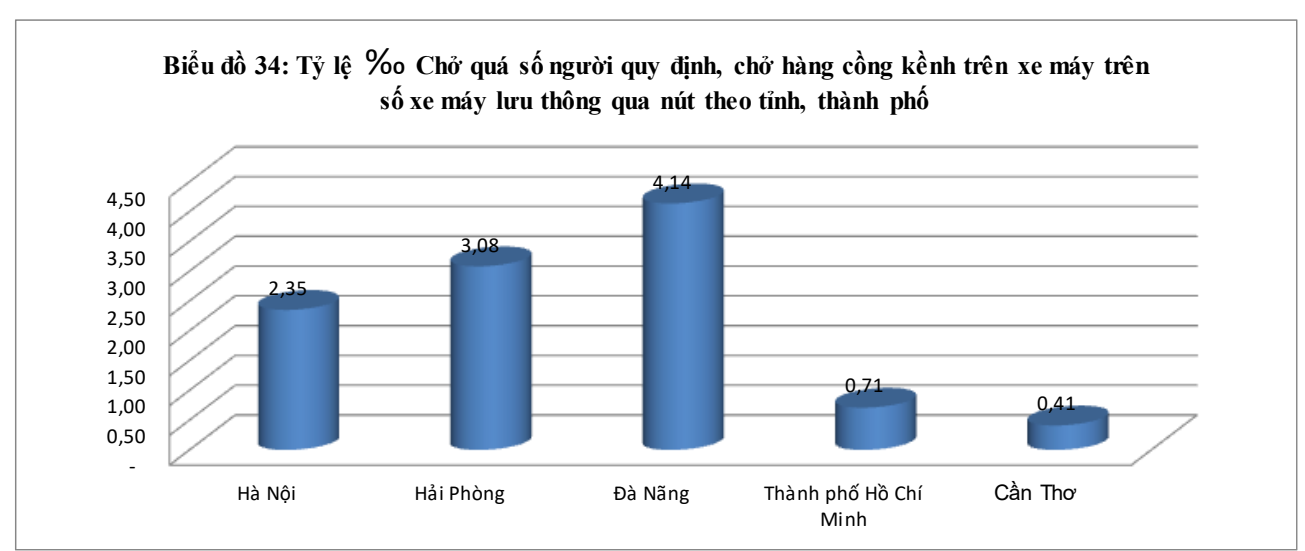

\section{So sánh mức độ vi phạm giao thông giữa các thành phố}

\section{Bảng tổng họ̣p kết quả ghi nhận tình hình vi phạm giao thông qua quay Camera theo} thành phố

\begin{tabular}{|c|c|c|c|c|c|c|c|c|c|c|}
\hline \multirow[b]{3}{*}{ Thành phố } & \multicolumn{2}{|c|}{$\hat{\text { Ô tô }}$} & \multicolumn{8}{|c|}{ Xe máy } \\
\hline & \multicolumn{2}{|c|}{$\begin{array}{c}\text { Ô tô Vượt đèn } \\
\text { đỏ }\end{array}$} & \multicolumn{2}{|c|}{$\begin{array}{l}\text { Xe máy vượt đèn } \\
\text { đỏ }\end{array}$} & \multicolumn{2}{|c|}{$\begin{array}{c}\text { Người điều } \\
\text { khiển xe máy } \\
\text { không đội mũ } \\
\text { bảo hiểm }\end{array}$} & \multicolumn{2}{|c|}{$\begin{array}{c}\text { Đi xe máy lên } \\
\text { vỉa hè }\end{array}$} & \multicolumn{2}{|c|}{$\begin{array}{c}\text { Chở quá số } \\
\text { người quy địinh, } \\
\text { chở hàng cồng } \\
\text { kềnh trên xe máy }\end{array}$} \\
\hline & $\begin{array}{c}\text { Tỷ lệ } \\
\text { \%o số } \\
\text { vi } \\
\text { phạm } \\
\text { trền } \\
\text { số ô } \\
\text { tô } \\
\text { lưu } \\
\text { thông }\end{array}$ & $\begin{array}{c}\text { Co cấu } \\
\text { \% giữa } \\
\text { các } \\
\text { thành } \\
\text { phố }\end{array}$ & $\begin{array}{c}\text { Tỷ lệ \%o } \\
\text { số vi } \\
\text { phạm } \\
\text { trên số } \\
\text { xe máy } \\
\text { lưu } \\
\text { thông }\end{array}$ & $\begin{array}{l}\text { Co cấu } \\
\text { \% giữa } \\
\text { các } \\
\text { tỉnh }\end{array}$ & $\begin{array}{c}\text { Tỷ lệ } \\
\text { \%o số } \\
\text { vi } \\
\text { phạm } \\
\text { trền } \\
\text { số xe } \\
\text { máy } \\
\text { lưu } \\
\text { thông }\end{array}$ & $\begin{array}{c}\text { Co } \\
\text { cấu } \\
\% \\
\text { giữa } \\
\text { các } \\
\text { tỉnh }\end{array}$ & $\begin{array}{c}\text { Tỷ lệ } \\
\text { \%o số } \\
\text { vi } \\
\text { phạm } \\
\text { trến } \\
\text { số xe } \\
\text { máy } \\
\text { lưu } \\
\text { thông }\end{array}$ & $\begin{array}{c}\text { Co cấu } \\
\text { \% } \\
\text { giứa } \\
\text { các } \\
\text { tỉnh }\end{array}$ & $\begin{array}{c}\text { Tỷ lệ } \\
\text { \%o số vi } \\
\text { phạm } \\
\text { trên số } \\
\text { xe máy } \\
\text { lưu } \\
\text { thông }\end{array}$ & $\begin{array}{l}\text { Cơ cấu } \\
\text { \% giữa } \\
\text { các } \\
\text { tỉnh }\end{array}$ \\
\hline Hà Nội & 2,86 & $10,0 \%$ & 60,64 & $58,5 \%$ & 41,48 & $65,0 \%$ & 0,84 & $41,1 \%$ & 2,35 & $22,0 \%$ \\
\hline Hải Phòng & 14,70 & $51,5 \%$ & 25,44 & $24,5 \%$ & 7,37 & $11,6 \%$ & - & $0,0 \%$ & 3,08 & $28,8 \%$ \\
\hline Đà Nãng & 10,07 & $35,3 \%$ & 11,57 & $11,2 \%$ & 11,81 & $18,5 \%$ & 0,37 & $18,1 \%$ & 4,14 & $38,7 \%$ \\
\hline $\begin{array}{l}\text { Thành phố } \\
\text { Hồ Chí Minh }\end{array}$ & 0,37 & $1,3 \%$ & 4,84 & $4,7 \%$ & 2,46 & $3,9 \%$ & 0,81 & $39,5 \%$ & 0,71 & $6,6 \%$ \\
\hline Cần Thơ & 0,55 & $1,9 \%$ & 1,17 & $1,1 \%$ & 0,65 & $1,0 \%$ & 0,03 & $1,2 \%$ & 0,41 & $3,8 \%$ \\
\hline
\end{tabular}

Bảng trên cho thấy Hà Nội có tỷ lệ vi phạm cao hơn rất nhiều so với các thành phố còn lại, đặc biệt là các lỗi Người điều khiển xe máy không đội mũ bảo hiểm (chiếm 41,48\%), Xe máy vượt đèn đỏ (chiếm 60,64 \%) quá cao so với các thành phố còn lại.

\subsubsection{Kết luận và kiến nghị}

Qua kết quả điều tra về văn hóa giao thông của người đi xe máy trên cơ sở hai cuộc điều tra thực tế là bằng phương pháp bảng hỏi và bằng cách ghi nhận trực tiếp trên đường qua phương pháp dùng camera ghi lại hình ảnh tại các nút giao thông, chúng ta thấy trong khi đa số có ý thức văn hóa trong giao thông thì vẫn còn một tỷ lệ nhất định người sử dụng xe máy chưa được như vậy. Vẫn còn không ít người coi nhẹ việc dừng xe khi đèn đỏ, không muốn đội mũ bảo hiểm. Người dân cho rằng những hiện tượng chưa có văn hóa như ảnh hưởng của rượu bia, không nhường đường khi có thể... còn phổ biến. Điều tra cho thấy, rất cần những nỗ lực tiếp theo để xây dựng được văn hóa giao thông cho người đi xe máy. 


\subsection{Quản lý xe máy: nhìn theo quan điểm Lý thuyết Hệ thống}

Báo cáo năm 2017 của Ủy ban ATGTQG (xem "UBATGTQG, 2018”) ghi rõ tính đến $30 / 11 / 2017$, số ô tô đang lưu hành là 2.865.202 xe (trong đó tổng số xe con 1.474.210, xe khách 149.626, xe tải 1.124.930, xe chuyên dụng 29.014 và các loại khác 87.422 xe). Tuy nhiên với xe máy, chúng ta hoàn toàn không biết tô̂ng số xe đang lưu hành, chứ chưa nói gì đến số xe máy theo từng loại như thế. Đó chỉ là một trong những bất cập liên quan đến loại hình phương tiện giao thông này.

Xe máy, từ lâu đã trở thành rất phổ biến ở nhiều quốc gia, trong đó, có nước ta. Với những ưu điểm của nó: nhỏ gọn, đi vào nhiều ngõ hẹp được, đáp ứng thói quen đi từ cửa đến cửa..., xe máy đã gắn liền với cuộc sống người dân. Bên cạnh đó, xe máy cũng gây ra rất nhiều vấn đề kinh tế, xã hội. Đã có nhiều tiếng nói khác nhau, "bênh" cũng có và "chê" cũng có, thậm chí tới mức cực đoan, đòi cấm toàn bộ xe máy! Cũng rất nhiều giải pháp đưa ra, nhưng số giải pháp thực hiện không được, thực hiện kém hiệu quả cũng nhiều. Vậy vấn đề là ở đâu? Đâu có thể là nút thắt để gỡ?

Lời giải không phải là ở chỗ cấm toàn bộ xe máy, mà là ở chỗ, cần các công cụ đủ mạnh để quản lý, để thực hiện thành công các giải pháp.

Công cụ quản lý xe máy có rất nhiều, có công cụ tác động chính về kinh tế, công cụ khác, về kỹ thuật... nhưng thông thường, công cụ thể chế, cụ thể là nhũng quy định bởi văn bản quy phạm pháp luật, thường có tác động mạnh nhất, rộng nhất, cũng ít tốn kém nhất và là bàn đạp cần thiết cho việc thực hiện các công cụ khác. Công cụ thể chế bản thân nó đã rất mạnh, nhưng chúng còn mạnh hơn khi kết hợp với nhau, với các công cụ khác.

Do những nguyên nhân lịch sử khác nhau, đến nay, đang có nhiều vấn đề tồn tại trong công tác quản lý xe máy của nước ta. Xem xét với quan điểm Lý thuyết Hệ thống và Lý thuyết Quản lý, chính là một bước tiếp cận khoa học nhằm đặt vấn đề khắc phục điều này.

\subsubsection{Việc quản lý xe máy: nhiều chính sách, giải pháp không thành công}

Điều rất rõ là các cơ quan hữu quan đã rất nỗ lực trong việc tìm các biện pháp khắc phục những hậu quả không mong muốn do xe máy gây ra. Có rất nhiều chủ trương, chính sách và giải pháp được đề ra, nhưng, như nêu trên, cũng có không ít chủ trương chính sách không đi vào cuộc sống được.

Có thể kể ra, ngày 17/06/2010, với Quyết định số 909/QĐ-TTg, Thủ tướng đã phê duyệt Đề án kiểm soát khí thải xe mô tô, xe gắn máy tham gia giao thông tại các tỉnh, thành phố, trong đó có mục tiêu: "Giai đoạn từ năm 2013 đến năm 2015... thực hiện kiểm định đạt tiêu chuẩn khí thải từ $80 \%$ đến $90 \%$ số lượng xe mô tô, xe gắn máy tham gia giao thông tại thành phố Hà Nội và thành phố Hồ Chí Minh". Đề án đã nêu rõ nhiệm vụ: " Rà soát, bổ sung hệ thống văn bản quy phạm pháp luật nhằm tạo hành lang pháp lý để triển khai kiểm soát khí thải xe mô tô, xe gắn máy". Tiếc thay, sau 8 năm (2018) hành lang pháp lý này vẫn chưa hình thành. Đây có thể là một trong các nguyên nhân khiến Đề án này chưa đi vào thực tiễn.

Tiếp theo, tình hình cũng tương tự đối với Quyết định số 16/2015/QĐ-TTg ngày 22/05/2015 của Thủ tướng Chính phủ về "thu hồi, xử lý sản phẩm thải bỏ" và Chỉ thị 29/CT-TTg ngày 05/10/2016 về việc xử lý phương tiện giao thông đường bộ hết niên hạn sử dụng, quá hạn kiểm định. Các văn bản này đặt ra nhiệm vụ sẽ thu hồi xe máy thải loại từ 01/01/2018 trên toàn quốc. 
Riêng Hà Nội, tháng 3 năm 2017, thông tin chính thức cho biết có khoảng 2,5 triệu xe máy cũ nát, quá “đát". UBND TP đã trình HĐND TP chương trình liên quan đến hạn chế xe máy trong đó nêu rõ cần phải có biện pháp thu hồi số xe máy này. Việc lưu thông của những chiếc xe máy cũ nát rõ ràng không phù hợp với một đô thị văn minh, hiện đại về mặt an toàn và bảo vệ môi trường. Thu hồi hay cấm lưu thông những chiếc xe này góp phần xây dựng thành phố văn minh, hiện đại. Nhưng việc thực hiện lại gặp ngay vướng mắc không giải quyết được do chưa có quy định về niên hạn xe máy, cũng như không có những quy định cụ thể đối với các xe máy cũ.

Vấn đề hạn chế phương tiện cá nhân, trong đó một phần lớn là xe máy, đã được bàn đến rất nhiều. Hà Nội đang với một quyết tâm mới, đã đưa ra lộ trình cấm xe máy vào các quận nội đô. Thông điệp về việc này đã được phát đi một cách mạnh mẽ. Sở Giao thông Vận tải Hà Nội khẳng định việc dừng hoạt động của xe máy và thu phí hạn chế ô tô vào nội đô là cần thiết. Hà Nội không phải bây giờ mới nóng lên việc cấm xe máy có lộ trình đến 2030 (trước đó có tin là đến 2025). Đã từ rất lâu các cơ quan công quyền, các chuyên gia, báo chí, mạng truyền thông và người dân đã lên tiếng về đề tài này. Nhưng liệu đề án cấm xe máy với lộ trình đã định có thành hiện thực, trong khi câu chuyện cấm xe máy ở Hà Nội thực sự có quá nhiều phức tạp và nan giải.

Mọi người còn nhỡ rõ, khoảng năm 2003, trước tình trạng lượng phương tiện giao thông cá nhân tăng mạnh, gây ùn tắc giao thông nghiêm trọng ở khu vực nội đô, Sở Giao thông vận tải (GTVT) Hà Nội đã nêu phương án hạn chế phương tiện cá nhân bằng quy định xe máy đi vào ngày chẵn/lẻ theo số cuối của biển số, riêng thứ bảy, chủ nhật lưu thông bình thường. Dĩ nhiên, phương án này nhanh chóng bị loại vì dư luận phản ứng dữ dội. Sau đó ít lâu (năm 2004), Hà Nội lại thực hiện quy định tạm ngừng đăng ký xe máy ở một số quận nội thành. Lập tức, quy định này trở thành "miếng bánh" để dân ngoại tỉnh, ngoại thành "bán suất" đăng ký cho người ở nội thành. Hiệu quả thấp, bị dư luận phản ứng mạnh, Bộ Tư pháp "tuýt còi”, cuối năm 2005, HĐND thành phố Hà Nội chính thức bãi bỏ quy định nêu trên. Rồi cuối năm 2011, Hà Nội tiến hành phân làn một số tuyến phố như Bà Triệu, Huế, Đại Cồ Việt, Trần Khát Chân,... nhiều tuyến được phân làn lần thứ ba với hy vọng giải pháp phân làn tách phương tiện, cho xe máy đi làn riêng, sẽ giúp giảm ùn tắc. Tuy nhiên, không khác với hầu hết các lần trước đó, do lòng đường quá hẹp, các nút giao quá gần nhau, lượng phương tiện tham gia giao thông quá đông, phương án này cũng thất bại. Giống như Hà Nội, hơn 10 năm qua, TP Hồ Chí Minh cũng nỗ lực tìm cách hạn chế xe cá nhân bằng hàng loạt đề xuất như: cho xe đi theo ngày chẵn/lẻ; thu phí phương tiện vào trung tâm thành phố; khống chế hạn ngạch đăng ký xe mới; đấu giá quyền lưu hành phương tiện,... nhưng rồi các quy định này cũng đều bị loại ngay từ khi đề xuất.

Một điều không thể không nhắc tới là vấn đề tai nạn giao thông (TNGT). Đã có nhiều nghiên cứu chỉ rõ, xe máy thường gắn một cách thường trực và tiềm tàng với tai nạn giao thông. Theo Ủy ban ATGT quốc gia, năm 2017, riêng về đường bộ, đã xảy ra 19.798 vụ TNGT, làm chết 8.089 người, bị thương 16.970 người, trong đó nguyên nhân gây ra tai nạn từ xe máy là $69,94 \%$. Từ nhiều năm nay, con số này luôn ở trong khoảng $65 \%-70 \%$. Như vậy, rõ ràng nếu chúng ta giảm được số vụ TNGT do xe máy gây ra, thì sẽ góp phần làm giảm tổng số TNGT một cách bền vững và đáng kể.

Chính quyền các cấp từ Trung ương đến địa phương đề ra không ít các chủ trương, chính sách, biện pháp liên quan đến xe máy. Đã có không ít nỗ lực thực hiện. Rất dễ thấy sự cấp thiết, tầm quan trọng của các chủ trương, chính sách, biện pháp này, nhưng điều nổi bật là nhiều trường hợp đã không thành công: nhiều chủ trương không đi được vào cuộc sống, nhiều chính sách không được thực hiện, nhiều biện pháp phải bỏ dở. Như vậy, câu hỏi lớn đặt ra là: 
Vì sao chỉ có một số ít chủ trương, chính sách, biện pháp thành công, trong khi số không thành công lại chiếm tỷ lệ khá cao? Lời giải của câu hỏi này đóng vai trò quan trong việc bảo đảm khả năng thực tế thực hiện các giải pháp.

Một trong các nguyên nhân khiến các đề án, biện pháp đưa ra bị phản đối hay không thực hiện được chính là công cụ thể chế quản lý xe máy hiện hành chưa đủ mạnh. Đó là điều sẽ xem xét ở phần tiếp theo.

\subsubsection{Nghiên cứu so sánh khuôn khổ thể chế quản lý xe máy và khuôn khổ thể chế quản lý quản lý ô tô hiện nay}

Hiên nay, có năm công cụ thể chế giúp cho việc quản lý phương tiện cơ giới đường bộ, cả cho ô tô và cho xe máy và các loại khác. Đó là các quy định về:

1. Đăng ký xe;

2. Giấy phép lái xe;

3. Bảo hiểm bắt buộc (đầy đủ: "Bảo hiểm bắt buộc trách nhiệm dân sự của chủ xe cơ giới");

4. Kiểm định (đầy đủ: "Quy định về kiểm định an toàn kỹ thuật và bảo vệ môi trường phương tiện giao thông cơ giới đường bộ ");

5. Niên hạn sử dụng.

Bảng so sánh dưới đây cho thấy rõ việc quản lý xe ô tô chặt chẽ hơn quản lý xe máy rất nhiều vì các quy định thể chế quản lý xe ô tô chặt chẽ hơn nhiều. Cũng có thể nhận xét thêm rằng, công tác tuần tra kiểm soát của lực lượng chức năng đối với ô tô thường cũng chặt chẽ hơn đối với xe máy. Vì vậy, về cơ bản, công tác quản lý ô tô tốt hơn quản lý xe máy. Bảng tiếp theo, tổng hợp kết quả quản lý hai loại phương tiện giao thông đường bộ này.

\section{Bảng 3-36 So sánh quy định thể chế về quản lý xe ô tô và quản lý xe máy}

\begin{tabular}{|c|c|c|}
\hline Quy định thể chế & Xe ô tô & Xe máy \\
\hline \multirow[t]{3}{*}{ - Đăng ký xe } & \multicolumn{2}{|c|}{ Cấp một lần, trừ khi thay đổi chủ sở hữu hay thất lạc. } \\
\hline & $\begin{array}{l}\text { Hầu hết đăng ký lại khi thay đổi chủ } \\
\text { sở hữu }\end{array}$ & $\begin{array}{l}\text { Rât nhiều trường hợp không đăng } \\
\text { ký lại khi thay đổi chủ sở hữu. }\end{array}$ \\
\hline & \multicolumn{2}{|c|}{$\begin{array}{l}\text { Cơ sở dữ liệu do Cục CSGT quản lý chặt chẽ, nhưng thường không cập } \\
\text { nhật được thay đổi về chủ xe máy }\end{array}$} \\
\hline \multirow[t]{2}{*}{ - $\quad$ Giấy phép lái xe } & Có thời hạn & Không thời hạn (nói chung) \\
\hline & \multicolumn{2}{|c|}{ Cơ sở dữ liệu do Tổng cục Đường bộ và Sở GTVT } \\
\hline \multirow{2}{*}{$\begin{array}{l}\text { - Bảo hiểm bắt buộc (đầy đủ: } \\
\text { "Bảo hiểm bắt buộc trách } \\
\text { nhiệm dân sự của chủ xe cơ } \\
\text { giới }{ }^{64} \text { ") }\end{array}$} & $\begin{array}{l}\text { Có quy định, } \\
\text { Có thời hạn, } \\
\text { CSGT kiểm tra rất chặt chẽ. }\end{array}$ & $\begin{array}{l}\text { Có quy định, } \\
\text { Có thời hạn, } \\
\text { Thường kiềm tra không chặt chẽ }\end{array}$ \\
\hline & \multicolumn{2}{|c|}{ Cơ sở dữ liệu do bên Bảo hiểm quản lý: phân tán, không đầy đủ. } \\
\hline \multirow[t]{2}{*}{$\begin{array}{l}\text { - Kiểm định định kỳ (đầy đủ: } \\
\text { "Quy định về kiểm định an } \\
\text { toàn kỹ thuật và bảo vệ môi } \\
\text { trường phương tiện giao } \\
\text { thông cơ giới đường bộ } \\
65 " \text { "); }\end{array}$} & $\begin{array}{l}\text { Quy chuẩn, tiêu chuẩn kỹ thuật khá } \\
\text { đủ, có quy định kiểm định đối với xe } \\
\text { sản xuât, lắp ráp và nhập khẩu mới } \\
\text { và cả quy định kiểm định định kỳ đối } \\
\text { với xe đang lưu hành. } \\
\text { Giá trị kiểm định có thời hạn }\end{array}$ & $\begin{array}{l}\text { Quy chuẩn, tiêu chuẩn kỹ thuật khá } \\
\text { đủ, nhưng chỉ có quy định kiểm } \\
\text { định đối với xe sản xuất, lắp ráp và } \\
\text { nhập khẩu mới. } \\
\text { Không có quy định kiểm định định } \\
\text { kỳ đối với xe đang lưu hành. }\end{array}$ \\
\hline & $\begin{array}{l}\text { Cơ sở dữ liệu do Cục Đăng kiểm } \\
\text { quản lý chặt chẽ }\end{array}$ & Không có cơ sở dữ liệu \\
\hline
\end{tabular}

\footnotetext{
${ }^{64}$ Nghị định số 103/2008/NĐ-CP ngày 16 tháng 9 năm 2008 của Chính phủ về bảo hiểm bắt buộc trách nhiệm dân sự của chủ xe cơ giới.

${ }^{65}$ Thông tư số 70/2015/TT-BGTVT ngày 09 tháng 11 năm 2015 của Bộ trưởng Bộ Giao thông vận tải quy định về kiểm định an toàn kỹ thuật và bảo vệ môi trường phương tiện giao thông cơ giới đường bộ.
} 
Dự án: Xây dựng chiến lược an toàn giao thông đối với xe máy và kế hoạch hành động: một khởi đầu của Việt Nam Code: TRN/FAC/12/006/REG

Nghiên cứu hiện trạng giao thông xe máy Việt Nam

\begin{tabular}{|c|c|c|}
\hline Quy định thể chế & Xe ô tô & Xe máy \\
\hline \multirow[t]{2}{*}{ - Niên hạn sử dụng } & $\begin{array}{l}\text { Có quy định, trừ xe ô tô chở người } \\
\text { đến } 09 \text { chô̂ ngồi (kể cả chỗ người } \\
\text { lái }{ }^{66}\end{array}$ & Không quy định \\
\hline & $\begin{array}{l}\text { Cơ sở dữ liệu do Cục Đăng kiểm } \\
\text { quản lý chặt chẽ }\end{array}$ & Không có cơ sở dữ liệu \\
\hline \multirow[t]{2}{*}{ - Kinh doanh vận tải } & $\begin{array}{l}\text { Có quy định riêng khá chi tiết với } \\
\text { từng loại hình (hàng hóa, hành } \\
\text { khách, tuyến cố định, bus...). } \\
\text { Tỷ lệ xe tham gia kinh doanh vận tải } \\
\text { trên tống số xe: không nhỏ. }\end{array}$ & $\begin{array}{l}\text { Có trên thực tế, nhưng không có } \\
\text { quy định đây là một hình thức kinh } \\
\text { doanh vận tải. } \\
\text { Tỷ lệ xe tham gia kinh doanh vận } \\
\text { tải trên tống số xe: nhỏ. Thường là } \\
\text { xe cũ, chất lượng kém. }\end{array}$ \\
\hline & \multicolumn{2}{|l|}{ Không có cơ sở dữ liệu riêng. } \\
\hline
\end{tabular}

Nguồn: Nhóm nghiên cứu

Bảng dưới đây cho thấy, với các quy định thể chế hiện hành, chúng ta có một cơ sở dữ liệu về xe ô tô đầy đủ và có chất lượng hơn, dần đến hiệu quả công tác quản lý xe ô tô tốt hơn quản lý xe máy.

\section{Bảng 3-37 So sánh hiệu quả công tác quản lý xe ô tô và quản lý xe máy}

\begin{tabular}{|c|c|c|}
\hline Hạng mục quản lý & Xe ô tô & Xe máy \\
\hline $\begin{array}{l}\text { Số lượng theo đăng ký (đến } \\
15 / 11 / 2017 \text { ) }\end{array}$ & 3.658 .360 & $\begin{array}{c}54.063 .318 \\
+760.235 \text { xe máy điện }\end{array}$ \\
\hline Số lượng phương tiện đang lưu hành & Có (Cục Đăng kiểm) & $\begin{array}{l}\text { Không. Ước khoảng } 73 \% \text { số đăng } \\
\text { ký là còn lưu hành }{ }^{67} \text {. }\end{array}$ \\
\hline Xe đã hoặc sắp hết hạn lưu hành & Có (Cục Đăng kiểm) & Không \\
\hline Tình trạng kỹ thuật tới từng chiếc xe & Có (Cục Đăng kiểm) & Không \\
\hline $\begin{array}{l}\text { Cơ quan chức năng tìm thông tin chủ } \\
\text { xe }\end{array}$ & Được và chính xác & $\begin{array}{l}\text { Tìm được nhưng khó chính xác do } \\
\text { nhiều thay đồi trong quá trình mua } \\
\text { đi, bán lại }\end{array}$ \\
\hline $\begin{array}{l}\text { Xử phạt vi phạm hành chính trong } \\
\text { lĩnh vực an toàn giao thông đường bộ } \\
\text { qua hình ảnh }\end{array}$ & $\begin{array}{l}\text { Dễ có đủ thông tin cho kết luận } \\
\text { xử lý. } \\
\text { Kết quả xử lý (nôp phat) tốt hơn. }\end{array}$ & $\begin{array}{l}\text { Không dễ có đủ thông tin cho kết } \\
\text { luận xử lý. } \\
\text { Kết quả xử lý (nôp phat) kém hơn. }\end{array}$ \\
\hline Phương tiện chính gây ra TNGT & 27-33\% số vu & $65 \%-70 \%$ số vu \\
\hline $\begin{array}{l}\text { Phí sử dụng đường bộ theo đầu } \\
\text { phương tiện }\end{array}$ & $\begin{array}{l}\text { Có quy định và thu được nhờ hệ } \\
\text { thống đăng kiểm }\end{array}$ & $\begin{array}{l}\text { Năm } 2013-2015 \text { có quy định và tổ } \\
\text { chức thu qua Uỷ ban nhân dân xã, } \\
\text { phường, thị trân. } \\
\text { Từ ngày } 05 / 06 / 2016 \text { bãi bỏ các quy } \\
\text { định liên quan vì không hiệu quả } 8 \text {. }\end{array}$ \\
\hline
\end{tabular}

Nguồn: Nhóm nghiên cứu

Kết luận phần này, ta thấy còn quá nhiều công cụ thể chế có thể dùng để quản lý xe máy mà chưa được dùng. Dễ tin rằng, nếu các quy định thể chế quản lý xe máy cũng chặt chẽ ít nhiều như quản lý ô tô, nhiều chủ trương, biện pháp của nhà nước sẽ dễ dàng được thực hiện hơn. Có thể kể ra, khi đó, hành lang pháp lý để triển khai Đề án kiểm soát khí thải xe mồ tô, xe gắn máy tham gia giao thông tại các tỉnh, thành phố, sẽ là sẵn sàng. Cũng vậy, ý định của Hà Nội thu hồi khoảng 2,5 triệu xe máy cũ nát, quá “đát” sẽ có cơ sở kỹ thuật đề thực hiện...

\footnotetext{
${ }^{66}$ Nghị định số 95/2009/NĐ-CP ngày 30/10/2009 quy định về niên hạn sử dụng đối với các loại xe ô tô chở hàng và xe ô tô chở người.

${ }^{67}$ Xem Duc N.H. (2016), Duc N.H. et al. (2013) và (2015).

${ }^{68}$ Thống kê việc thu phí xe máy sau hai năm thực hiện cho thấy công tác này rất khó khăn, hiệu quả rất thấp. Năm 2013 và 2014 số thu chỉ đạt khoảng $21 \%$ kế hoạch. Sang năm 2015, số thu sáu tháng đầu năm 2015 giảm rõ rệt và mới chỉ đạt 6,71\% kế hoạch năm. (Nguồn: Quỹ Bảo trì đường bộ trung ương)
} 


\subsubsection{Kinh nghiệm từ các quốc gia khác: Các công cụ thể chế hình thành một hệ thống chặt chẽ, hiệu lực}

Nhìn ra thế giới, có thể tổng kết rằng:

- Các nước càng phát triển, thì việc quản lý phương tiện cơ giới nói chung, quản lý xe máy càng chặt chẽ hơn.

- Còn rất nhiều công cụ thể chế để quản lý xe máy.

- Trong chương sau, năm công cụ thể chế có lẽ thích hợp nhất để nghiên cứu đưa vào nước ta trong tương lai sẽ được trình bày.

\subsubsection{Tăng cường, bổ sung các công cụ thể chế quản lý xe máy ở Việt Nam}

\section{1) Sự cần thiết}

Câu hỏi đầu tiên là liệu Việt Nam có cần các sửa đổi, bổ sung các văn bản quy phạm pháp luật để có thêm các công cụ thể chế quản lý xe máy hay không?

Để trả lời câu hỏi này, có hai ý. Trước hết ta cần nhắc tới một quy luật tổng quát về quản lý trong lịch sử thế giới. Đó là: số lượng đối tượng cần quản lý càng tăng thì các công cụ quản lý càng phải mạnh thêm cả về số lượng và chất lượng . Đây là một thể hiện của nguyên lý triết học mà ai cũng đã học ở nhà trường về "Lượng đổi - chất đổi”. Quản lý hàng chục triệu xe máy mà ta vẫn chỉ có các công cụ thể chế như mấy mươi năm trước, thì bất cập là khó tránh khỏi. So với năm 1990, đến hết 2018, số xe máy theo đăng ký tăng 45 lần, nhưng công cụ quản lý gần như không thay đổi. Như trên đã nêu, đây cũng là nguyên nhân gốc rễ dẫn đến việc nhiều giải pháp đưa ra gặp vướng mắc và không thành công được.

Ý thứ hai, một số người đã nêu rằng Việt Nam nên cấm hoàn toàn xe máy, nhưng đã bỏ lỡ thời cơ vì không cấm ngay từ đầu để bây giờ có muốn cũng không làm được. Một ví dụ là thành phố Yangon của Myanmar đã cấm hoàn toàn xe máy. Nhưng thưc ra có thể nói rằng, Việt Nam không cần cấm xe máy, mà cần các công cụ, trước hết là các công cụ thể chế để quản lý xe máy tốt hơn. Ngay thành phố Yangon, việc cấm xe máy đã làm số xe ô tô đạt mức cao, gây ra không ít nhiều vấn đề về ùn tắc giao thông, về an toàn và ô nhiễm.

\section{2) Công cụ thể chế nào?}

Câu hỏi thứ hai là các công cụ thể chế nào cần được nghiên cứu bổ sung, áp dụng?

Do mỗi công cụ thể chế đều có tác động rất rộng và mạnh, nên muốn trả lời câu hỏi này, cần gắn với một lịch trình: trước mắt, tương lai gần và tương lai xa. Và đương nhiên, cần một sự nghiên cứu, đánh giá toàn diện hơn. Tuy nhiên, có thể thẩy:

- Trước mắt các văn bản quy phạm pháp luật nhằm thực hiện Kiểm định định kỳ xe máy (về an toàn kỹ thuật và bảo vệ môi trường) có lẽ là cần được xem xét ngay. Một mặt, thì Đề án kiểm soát khí thải xe mô tô, xe gắn máy tham gia giao thông tại các tỉnh, thành phố đã duyệt và tính chất thời sự khá rõ. Mặt khác. đây cũng là cơ sở đầu tiên để tiếp tục xem xét tới công cụ thể chế tiếp theo.

- Tiếp theo sẽ là các công cụ thể chế cho việc thải bỏ xe máy. Việc thải bỏ xe máy dựa trên kết quả kiểm định (chất lượng xe máy dưới một mức nào đó, sẽ không được lưu hành, chẳng hạn), sẽ hợp lý hơn việc quy định thải bỏ xe theo niên hạn sử dụng hoặc theo số km đã chạy (xem Duc N.H. 2016). Như đã nêu, công cụ này sẽ là cơ sở để đảm bảo thực hiện Quyết định số 16/2015/QĐ-TTg ngày 22/05/2015 của Thủ tướng Chính phủ về “thu hồi, xử lý 
sản phẩm thải bỏ" và Chỉ thị 29/CT-TTg ngày 05/10/2016 về việc xử lý phương tiện giao thông đường bộ hết niên hạn sử dụng, quá hạn kiểm định.

- Trong tương lai không xa, tiếp theo, hầu hết các công cụ thể chế hiện đang quản lý ô tô, nên được xem xét áp dụng cho xe máy (trừ vấn đề niên hạn).

- Trong tương lai xa nữa, các công cụ thể chế rất mạnh như nêu trong phần 4 nên được xem xét. Chẳng hạn, "hệ thống gia hạn GPLX dựa trên vi phạm giao thông" nếu được thực hiện, sẽ tác động mạnh như một bước đột phá để làm giảm số vi phạm giao thông.

\section{3) Tổ chức thực thi các công cụ thể chế mới}

Do các công cụ thể chế này có phạm vi tác động xã hội tới đông đảo người dân nên phương án tổ chức thực thi không thể không cân nhắc kỹ. Khó khăn là dễ thấy. Với mấy chục triệu xe máy, con số quá lớn nên cũng không thể làm đồng loạt được. Chỉ riêng việc đổi GPLX cũng mất vài năm! Chưa kể dễ xuất hiện những ảnh hưởng tới đời sống người dân, nhất là đối với những người có thu nhập thấp.

Một trong các phương án khả dĩ là tập trung thực thi ở các thành phố lớn trước. Và ngay cả ở đây, cũng không làm đồng loạt. Kinh nghiệm là khi xe có vi phạm, thì áp dụng ngay các công cụ thể chế mới. Ví dụ, để thực hiện quy định về kiểm định nêu trên, nếu xe vi phạm tới mức nào đó (chẳng hạn, tới mức tạm giữ phương tiện theo quy định hiện nay) thì buộc đưa xe đi kiểm định.... tất nhiên sẽ có một số vấn đề như chủ xe và người sử dụng xe có thể khác nhau. Nhưng những vấn đề này cũng đã có cách giải quyết như hiện hành.

\subsection{Quy luật về tác động của các điều kiện kinh tế-xã hội đối với sự phát triển của xe máy}

Các dữ liệu trên cho phép rút ra rất nhiều kết luận hữu ích, trong đó nổi bật là sự tăng trưởng xe máy ở nước ta có tuân theo một quy luật. Đó là Quy luật về tác động của các điều kiện kinh tế-xã hội lên sự phát triển của xe máy. Theo đó, có một sự khác biệt lớn trong dài hạn và trong ngắn hạn. Các chỉ tiêu kinh tế-xã hội tác động rất mạnh đển sự phát triển của xe máy trong kỳ dài hạn, nhưng rất yếu trong ngắn hạn.

Quy luật này rất hữu ích và quan trọng, trong đó có việc hoạch định chính sách hay giải pháp để giảm bớt sư gia tăng loại hình xe này. Kết luận dẫn đến một số khuyến nghị thực tiễn quan trọng như sau:

1) Nếu mức tăng trưởng phương tiện cá nhân giảm được nhờ một số yếu tố ngắn hạn như biến động của thị trường, thay đổi giá cả, điều kiện lưu thông trên đường... thì khi các yếu tố này mất đi, phương tiện cá nhân sẽ gia tăng ở mức độ lớn hơn, như để bù lại.

2) Các điều kiện kinh tế-xã hội tác động mạnh mẽ vào sự phát triển của xe máy trong dài hạn, do đó, để giảm sự phát triển xe này về cơ bản, chính sách biện pháp cần có tầm nhìn dài hạn. Tất nhiên, các biện pháp ngắn hạn vẫn quan trọng, nhưng chúng phải được tích hợp vào trong một chương trình dài hạn. Sự phát triển của giao thông công cộng chính là một trong những cách tiếp cận dài hạn như vậy.

\section{Hai chiến lược tiếp cận trong kỳ hạn dài}

Phát triển giao thông công cộng và xây dựng văn hóa giao thông chính là hai chiến lược tiếp cận như vậy. Kỳ hạn dài có nghĩa là chúng ta cần một sự kiên trì nhất định để thực hiện bằng được. Một chiến lược dài hạn mà thực hiện không đủ, bỏ dở giữa chừng thì công sức từ đầu sẽ dễ dàng trôi ra sông, ra biển. Chúng ta mất 12 năm mới xây dựng được thói quen đội mũ bảo 
hiểm khi đi xe máy, nhưng khi lực lượng chức năng không kiểm soát nghiêm ngặt là vi phạm lại xảy ra.

\section{Tổ chức giao thông theo hướng ưu tiên phát triển giao thông công cộng trong tổ chức giao thông}

Dễ dàng đồng ý với chủ trương chiến lược là phát triển giao thông công cộng. Tuy nhiên, ưu tiên phát triển giao thông công cộng không thể chỉ ở việc gia tăng số lượng xe, giảm giá vé.... Những điều này là cần thiết, nhưng sẽ không đủ nếu trong tổ chức giao thông trên đường, phương tiện giao thông công cộng chưa được ưu tiên để đảm bảo hiệu quả. Tổ chức giao thông là biện pháp ngắn hạn, luôn luôn thay đổi theo tình hình lưu thông. Việc cấm/hạn chế xe ở khu vực này, đoạn đường kia cũng là biện pháp ngắn hạn. Nhưng tổ chức giao thông theo nguyên tắc "ưu tiên đủ cho giao thông công cộng" mới cần là chủ trương lâu dài. Như thế cũng có nghĩa phương tiện cá nhân sẽ lưu thông khó khăn hơn. Người dân sẽ thông cảm điều này nếu công tác tuyên truyền, xây dựng văn hóa giao thông được làm tốt 


\section{TÀI LIỆU THAM KHẢO}

Đức N. H.(2016) Thưc trạng việc thải bỏ xe máy khỏi luu hành ở Việt Nam: Một nghiên cứu đánh giá. Kỷ yếu Hội nghị An toàn giao thông Việt Nam năm 2016, tập 1, tr. 67-77.

Duc N.H., Hoa D.T.M., Huong N.T., Bao N.N. (2015) Motorcycles in Vietnam: Essential Data Estimated until 2014 and Different Impacts of Socio-economic Conditions on Their Growth for Long- and for Short-term. Journal of the Eastern Asia Society for Transportation Studies. Vol 11.

Duc N.H., Hoa D.T.M., Huong N.T., Bao N.N. (2013) On Various Essential Data Related to Status Quo of Motorcycles in Vietnam. Journal of the Eastern Asia Society for Transportation Studies, Vol.10, 2080-2093.

JICA (2009) Nghiên cưu Quy hoạch tổng thể An toàn giao thông đường bộ tại nước CHXHCN Việt Nam. Báo cáo cuối kỳ. Hà Nội.

UBATGTQG (2018) Báo cáo kết quả công tác bảo đảm trật tự, an toàn giao thông năm 2017 và nhiệm vụ trọng tâm năm 2018, Hà Nội. 


\section{PHỤ LỤC CHƯỚNG 3}

\section{CÁC BẢNG DŨ̃ LIỆU}

Bảng 3-38 P1-Dũ̃ liệu TNGTĐB và số lượng xe cơ giới theo đăng ký (1990-2018)

\begin{tabular}{|c|c|c|c|c|c|c|c|c|}
\hline \multirow[b]{2}{*}{ Năm } & \multicolumn{3}{|c|}{ TNGT đường bộ } & \multicolumn{3}{|c|}{ Số lượng tích lũy theo đăng ký } & \multirow[b]{2}{*}{ Tỷ lệ hỗn hợp } & \multirow[b]{2}{*}{ Dân số } \\
\hline & Số vụ & $\begin{array}{c}\text { Số } \\
\text { người } \\
\text { chết }\end{array}$ & $\begin{array}{c}\text { Số bị } \\
\text { thương }\end{array}$ & Ô tô & Xe máy & $\begin{array}{c}\text { Số xe máy } \\
\text { tăng trong } \\
\text { năm }\end{array}$ & & \\
\hline $\mathrm{Y}$ & TA & Fat & Inj & Car & Mreg & $\mathrm{dM}$ & $\mathrm{r}=(\mathrm{Mreg} / \mathrm{MC}+\mathrm{Car})$ & pop \\
\hline 1990 & 5.565 & 2.087 & 4.468 & 246.194 & 1.209 .463 & & $83,09 \%$ & 66.020 .000 \\
\hline 1991 & 6.864 & 2.395 & 6.846 & 256.898 & 1.522 .184 & 312.721 & $85,56 \%$ & 67.242 .000 \\
\hline 1992 & 8.165 & 2.755 & 9.040 & 268.000 & 2.039 .000 & 516.816 & $88,38 \%$ & 68.450 .000 \\
\hline 1993 & 11.678 & 3.940 & 12.590 & 292.899 & 2.427 .163 & 388.163 & $89,23 \%$ & 69.644 .000 \\
\hline 1994 & 13.118 & 4.533 & 13.056 & 330.000 & 3.000 .000 & 572.837 & $90,09 \%$ & 70.824 .000 \\
\hline 1995 & 15.376 & 5.430 & 16.920 & 340.779 & 3.578 .156 & 578.156 & $91,30 \%$ & 71.995 .500 \\
\hline 1996 & 19.075 & 5.581 & 21.556 & 386.979 & 4.208 .274 & 630.118 & $91,58 \%$ & 73.156 .700 \\
\hline 1997 & 19.159 & 5.680 & 21.905 & 418.768 & 4.827 .219 & 618.945 & $92,02 \%$ & 74.306 .900 \\
\hline 1998 & 19.975 & 6.067 & 22.723 & 443.000 & 5.200 .000 & 372.781 & $92,15 \%$ & 75.456 .300 \\
\hline 1999 & 20.733 & 6.670 & 23.911 & 465.000 & 5.585 .000 & 385.000 & $92,31 \%$ & 76.596 .700 \\
\hline 2000 & 22.486 & 7.500 & 25.400 & 483.917 & 6.210 .823 & 625.823 & $92,77 \%$ & 77.630 .900 \\
\hline 2001 & 25.040 & 10.477 & 29.188 & 557.092 & 8.359 .042 & 2.148 .219 & $93,75 \%$ & 78.620 .500 \\
\hline 2002 & 27.134 & 12.800 & 30.733 & 607.401 & 10.273 .000 & 1.913 .958 & $94,42 \%$ & 79.537 .700 \\
\hline 2003 & 19.852 & 11.319 & 20.400 & 675.000 & 11.379 .000 & 1.106 .000 & $94,40 \%$ & 80.467 .400 \\
\hline 2004 & 16.911 & 11.739 & 15.142 & 774.824 & 13.375 .992 & 1.996 .992 & $94,52 \%$ & 81.436 .400 \\
\hline 2005 & 14.141 & 11.184 & 11.760 & 891.104 & 16.086 .644 & 2.710 .652 & $94,75 \%$ & 82.392 .100 \\
\hline 2006 & 14.161 & 12.373 & 11.097 & 972.912 & 18.615 .960 & 2.529 .316 & $95,03 \%$ & 83.311 .200 \\
\hline 2007 & 13.985 & 12.800 & 10.266 & 1.106 .617 & 21.721 .282 & 3.105 .322 & $95,15 \%$ & 84.218 .500 \\
\hline 2008 & 12.065 & 11.243 & 7.771 & 1.361 .645 & 25.481 .039 & 3.759 .757 & $94,93 \%$ & 85.118 .700 \\
\hline 2009 & 11.838 & 11.729 & 7.695 & 1.535 .987 & 28.431 .079 & 2.950 .040 & $94,87 \%$ & 86.025 .000 \\
\hline 2010 & 47.397 & 11.029 & 46.194 & 1.713 .908 & 31.452 .503 & 3.021 .424 & $94,83 \%$ & 86.947 .400 \\
\hline 2011 & 43.786 & 10.950 & 48.356 & 1.882 .972 & 33.925 .839 & 2.473 .336 & $94,74 \%$ & 87.860 .400 \\
\hline 2012 & 35.820 & 9.540 & 38.170 & 1.992 .589 & 36.102 .943 & 2.177 .104 & $94,77 \%$ & 88.809 .300 \\
\hline 2013 & 30.874 & 9.627 & 31.982 & 2.147 .750 & 38.643 .091 & 2.540 .148 & $94,73 \%$ & 89.759 .500 \\
\hline 2014 & 25.238 & 8.845 & 24.637 & 2.349 .667 & 41.212 .965 & 2.569 .874 & $94,61 \%$ & 90.728 .900 \\
\hline 2015 & 22.326 & 8.435 & 20.815 & 2.663 .269 & 44.281 .628 & 3.068 .663 & $94,33 \%$ & 91.709 .800 \\
\hline 2016 & 21.094 & 8.417 & 19.035 & 3.033 .527 & 47.786 .134 & 3.504 .506 & $94,03 \%$ & 92.692 .200 \\
\hline 2017 & 19.798 & 8.089 & 16.970 & 3.658 .360 & 54.944 .575 & 7.158 .441 & $93,76 \%$ & 93.671 .569 \\
\hline 2018 & 18.490 & 8.079 & 14.732 & 3.884 .627 & 59.245 .062 & 4.300 .487 & $93,85 \%$ & 94.670 .000 \\
\hline
\end{tabular}

Ghi chú: Số liệu tù năm 2017 đã cộng thêm số hiệu chinh (296,269 ô tô và 3,633,130 xe máy) và tù̀ năm 2016 tính cả xe máy điện

File: ZZ So lieu TNGT (1990-2017-ub),xls 
Bảng 3-39 P2-Tổng họ̣p số liệu xe máy và các chỉ số kinh tê-xã hội các năm 2003-2018 và dự báo 2019-2030

\begin{tabular}{|c|c|c|c|c|c|c|c|c|}
\hline Năm & Dân số & $\begin{array}{c}\text { GDP } \\
\text { bình } \\
\text { quân } \\
\text { đầu } \\
\text { người }\end{array}$ & $\begin{array}{c}\text { Tỷ lệ } \\
\text { đô thị } \\
\text { hóa } \\
(\%)\end{array}$ & $\begin{array}{c}\text { Số lượng } \\
\text { xe máy } \\
\text { theo đăng } \\
\text { ký }\end{array}$ & $\begin{array}{c}\text { Số lượng } \\
\text { xe máy } \\
\text { đang lưu } \\
\text { hành }\end{array}$ & \multicolumn{3}{|c|}{ Chênh lệch } \\
\hline $\mathrm{Y}$ & Pop & gdp & urb & $\mathbf{M}_{\text {reg }}$ & $\mathrm{M}_{\mathrm{cir}}$ & $\mathrm{dM}$ & $\mathrm{dM} / \mathrm{M}_{\mathrm{reg}}$ & $\mathrm{dM} / \mathrm{M}_{\mathrm{cir}}$ \\
\hline 1 & 2 & 3 & 4 & 5 & 6 & 7 & 8 & 9 \\
\hline 2003 & 80.467 .400 & 492 & 25,76 & 11.379 .000 & 8.387 .565 & 2.991 .435 & $26,29 \%$ & $35,67 \%$ \\
\hline 2004 & 81.436 .400 & 553 & 26,53 & 13.375 .992 & 10.328 .975 & 3.047 .017 & $22,78 \%$ & $29,50 \%$ \\
\hline 2005 & 82.392 .100 & 700 & 27,10 & 16.086 .644 & 11.871 .169 & 4.215 .475 & $26,20 \%$ & $35,51 \%$ \\
\hline 2006 & 83.311 .200 & 723 & 27,66 & 18.615 .960 & 13.481 .088 & 5.134 .872 & $27,58 \%$ & $38,09 \%$ \\
\hline 2007 & 84.218 .500 & 843 & 28,20 & 21.721 .282 & 15.913 .871 & 5.807 .411 & $26,74 \%$ & $36,49 \%$ \\
\hline 2008 & 85.118 .700 & 1.052 & 28,99 & 25.481 .039 & 18.461 .668 & 7.019 .371 & $27,55 \%$ & $38,02 \%$ \\
\hline 2009 & 86.025 .000 & 1.064 & 29,74 & 28.431 .079 & 19.914 .626 & 8.516 .453 & $29,95 \%$ & $42,76 \%$ \\
\hline 2010 & 86.947 .400 & 1.273 & 30,50 & 31.452 .503 & 21.473 .102 & 9.979 .401 & $31,73 \%$ & $46,47 \%$ \\
\hline 2011 & 87.860 .400 & 1.517 & 31,55 & 33.925 .839 & 23.998 .149 & 9.927 .690 & $29,26 \%$ & $41,37 \%$ \\
\hline 2012 & 88.809 .300 & 1.749 & 31,83 & 36.102 .943 & 26.605 .882 & 9.497 .061 & $26,31 \%$ & $35,70 \%$ \\
\hline 2013 & 89.759 .500 & 1.907 & 32,17 & 38.643 .091 & 28.588 .284 & 10.054 .807 & $26,02 \%$ & $35,17 \%$ \\
\hline 2014 & 90.728 .900 & 2.052 & 33,10 & 41.212 .965 & 30.631 .124 & 10.581 .841 & $25,68 \%$ & $34,55 \%$ \\
\hline 2015 & 91.709 .800 & 2.109 & 33,88 & 44.281 .628 & 32.355 .606 & 11.926 .022 & $26,93 \%$ & $36,86 \%$ \\
\hline 2016 & 92.692 .200 & 2.214 & 34,44 & 47.786 .134 & 34.132 .976 & 13.653 .158 & $28,57 \%$ & $40,00 \%$ \\
\hline 2017 & 93.671 .569 & 2.389 & 35,03 & 54.944 .575 & 36.619 .551 & 18.325 .024 & $33,35 \%$ & $50,04 \%$ \\
\hline 2018 & 94.670 .000 & 2.587 & 35,73 & 59.245 .062 & 38.932 .977 & 20.312 .085 & $34,28 \%$ & $52,17 \%$ \\
\hline 2019 & 95.540 .000 & 2.701 & 36,12 & 60.570 .507 & 40.779 .947 & 19.790 .561 & $32,67 \%$ & $48,53 \%$ \\
\hline 2020 & 96.517 .000 & 2.872 & 36,19 & 62.548 .596 & 43.034 .118 & 19.514 .478 & $31,20 \%$ & $45,35 \%$ \\
\hline 2021 & 97.466 .000 & 3.054 & 37,52 & 66.710 .083 & 45.142 .457 & 21.567 .626 & $32,33 \%$ & $47,78 \%$ \\
\hline 2022 & 98.326 .000 & 3.247 & 38,22 & 69.528 .383 & 47.198 .973 & 22.329 .410 & $32,12 \%$ & $47,31 \%$ \\
\hline 2023 & 99.097 .000 & 3.453 & 38,94 & 72.118 .284 & 49.139 .880 & 22.978 .404 & $31,86 \%$ & $46,76 \%$ \\
\hline 2024 & 99.793 .000 & 3.671 & 39,65 & 74.502 .136 & 50.992 .489 & 23.509 .647 & $31,56 \%$ & $46,10 \%$ \\
\hline 2025 & 100.497 .000 & 3.904 & 40,37 & 76.871 .566 & 52.903 .603 & 23.967 .962 & $31,18 \%$ & $45,30 \%$ \\
\hline 2026 & 101.198 .000 & 4.151 & 41,10 & 79.190 .589 & 54.857 .432 & 24.333 .156 & $30,73 \%$ & $44,36 \%$ \\
\hline 2027 & 101.883 .000 & 4.414 & 41,82 & 81.431 .157 & 56.834 .134 & 24.597 .023 & $30,21 \%$ & $43,28 \%$ \\
\hline 2028 & 102.573 .000 & 4.693 & 42,56 & 83.637 .998 & 58.873 .485 & 24.764 .513 & $29,61 \%$ & $42,06 \%$ \\
\hline 2029 & 103.259 .000 & 4.990 & 43,29 & 85.783 .479 & 60.963 .494 & 24.819 .985 & $28,93 \%$ & $40,71 \%$ \\
\hline 2030 & 103.923 .000 & 5.306 & 44,03 & 87.823 .346 & 63.076 .485 & 24.746 .861 & $28,18 \%$ & $39,23 \%$ \\
\hline
\end{tabular}

File: ZZa MC Number 2018

Nguồn: Nhóm nghiên cứu 
Bảng 3-40 P3-Xe máy điện từ 2015 và dự báo tổng số xe máy theo đăng ký đến năm 2030

\begin{tabular}{|c|c|c|c|c|}
\hline Năm & $\begin{array}{c}\text { Số dự báo xe máy } \\
\text { xăng theo đăng ký }\end{array}$ & $\begin{array}{c}\text { Thêm số hiệu } \\
\text { chỉnh từ 2017 }\end{array}$ & $\begin{array}{c}\text { Xe máy } \\
\text { điện }\end{array}$ & Tổng số \\
\hline 2015 & & & 152.806 & $\mathbf{4 4 . 2 8 1 . 6 2 8}$ \\
\hline 2016 & & & 654.206 & $\mathbf{4 7 . 7 8 6 . 1 3 4}$ \\
\hline 2017 & & & 881.257 & $\mathbf{5 4 . 9 4 4 . 5 7 5}$ \\
\hline 2018 & & & 1.075 .630 & $\mathbf{5 9 . 2 4 5 . 0 6 2}$ \\
\hline 2019 & 55.497 .514 & 59.130 .652 & 1.439 .856 & 60.570 .507 \\
\hline 2020 & 57.264 .890 & 60.898 .028 & 1.650 .568 & 62.548 .596 \\
\hline 2021 & 61.171 .245 & 64.804 .383 & 1.905 .700 & 66.710 .083 \\
\hline 2022 & 63.734 .414 & 67.367 .552 & 2.160 .832 & 69.528 .383 \\
\hline 2023 & 66.069 .182 & 69.702 .320 & 2.415 .964 & 72.118 .284 \\
\hline 2024 & 68.197 .902 & 71.831 .040 & 2.671 .096 & 74.502 .136 \\
\hline 2025 & 70.312 .200 & 73.945 .338 & 2.926 .228 & 76.871 .566 \\
\hline 2026 & 72.376 .091 & 76.009 .229 & 3.181 .360 & 79.190 .589 \\
\hline 2027 & 74.361 .527 & 77.994 .665 & 3.436 .493 & 81.431 .157 \\
\hline 2028 & 76.313 .235 & 79.946 .373 & 3.691 .625 & 83.637 .998 \\
\hline 2029 & 78.203 .584 & 81.836 .722 & 3.946 .757 & 85.783 .479 \\
\hline 2030 & 79.988 .319 & 83.621 .457 & 4.201 .889 & 87.823 .346 \\
\hline
\end{tabular}

File: ZZa MC Number 2018

Nguồn: Nhóm nghiên cứu 
Bảng 3-41 P4-Tỷ lệ tăng đều hàng năm

\begin{tabular}{|c|c|c|c|c|c|c|}
\hline \multirow[t]{2}{*}{ Tốc độ tăng đều hàng năm } & \multirow[t]{2}{*}{$\begin{array}{c}\text { Ký } \\
\text { hiệu }\end{array}$} & $\begin{array}{c}\text { Tỷ lệ } \\
\text { tăng đều }\end{array}$ & $\begin{array}{c}\text { Giá trị cuối } \\
\text { kỳ so với } \\
\text { dầu kỳ }\end{array}$ & $\begin{array}{l}\text { Giá trị } \\
\text { đầu kỳ }\end{array}$ & $\begin{array}{l}\text { Giá trị } \\
\text { cuối kỳ }\end{array}$ & Số năm \\
\hline & & $\mathbf{r}$ & $\mathbf{V}_{n}-V_{0}$ & $\mathbf{V}_{0}$ & $\mathbf{V}_{\mathbf{n}}$ & $\mathbf{y}$ \\
\hline \multicolumn{7}{|l|}{ Giai đoạn 1990-2018 } \\
\hline $\begin{array}{l}\text { Tốc độ tăng trưởng đều hàng năm } \\
\text { của xe máy theo đăng ký }\end{array}$ & $\mathrm{W}_{\text {reg }}$ & $14,91 \%$ & 48,98 & 1.209 .463 & 59.245 .062 & 28 \\
\hline $\begin{array}{l}\text { Tốc độ tăng trưởng đều hàng năm } \\
\text { của xe máy trong lưu thông }(*)\end{array}$ & $\mathrm{W}_{\text {cir }}$ & $13,20 \%$ & 32,20 & 1.209 .463 & 38.943 .834 & 28 \\
\hline $\begin{array}{l}\text { Tốc độ tăng đều hàng năm của } \\
\text { GDP theo đâuu người }\end{array}$ & $\mathrm{W}_{\mathrm{gdp}}$ & $12,12 \%$ & 24,64 & 105 & 2.587 & 28 \\
\hline \multicolumn{7}{|l|}{ Giai đoạn 2003-2018 } \\
\hline $\begin{array}{l}\text { Tốc độ tăng trưởng đều hàng năm } \\
\text { của xe máy theo đăng ký }\end{array}$ & $\mathrm{V}_{\text {reg }}$ & $11,63 \%$ & 5,21 & 11.379 .000 & 59.245 .062 & 15 \\
\hline $\begin{array}{l}\text { Tốc độ tăng trưởng đều hàng năm } \\
\text { của xe máy trong lưu thông }\end{array}$ & $\mathrm{V}_{\text {cir }}$ & $10,78 \%$ & 4,64 & 8.387 .565 & 38.943 .834 & 15 \\
\hline $\begin{array}{l}\text { Tốc độ tăng đều hàng năm của } \\
\text { GDP theo đầu người }\end{array}$ & $\mathrm{V}_{\text {gdp }}$ & $11,70 \%$ & 5,26 & 492 & 2.587 & 15 \\
\hline \multicolumn{7}{|l|}{ Phụ lục } \\
\hline $\begin{array}{l}\text { Tốc độ tăng đều hàng năm về dân } \\
\text { số (1990-2018) }\end{array}$ & $\mathrm{W}_{\mathrm{pop}}$ & $1,30 \%$ & 1,43 & 66.020 .000 & 94.670 .000 & 28 \\
\hline $\begin{array}{l}\text { Tốc độ đô thị hóa tăng đều hàng } \\
\text { năm (2003-2018) }\end{array}$ & $\mathrm{V}_{\text {urb }}$ & $2,21 \%$ & 1,39 & 25,76 & 35,73 & 15 \\
\hline \multicolumn{7}{|c|}{$\begin{array}{l}\text { (*) Ghi chú: Năm } 1990 \text { số xe máy còn ít. nên coi số lượng xe theo đăng ký bằng số lượng xe trong lưu thông, } \\
\text { GDP đầu người theo Tồng cục thống kê. có khác so với sồ liệu của WB }\end{array}$} \\
\hline \multicolumn{7}{|l|}{ Giai đoạn 2013-2018 } \\
\hline $\begin{array}{l}\text { Tốc độ tăng trưởng đều hàng năm } \\
\text { của xe máy theo đăng ký }\end{array}$ & $\mathrm{V}_{\text {reg }}$ & $8,92 \%$ & 1,53 & 38.643 .091 & 59.245 .062 & 5 \\
\hline $\begin{array}{l}\text { Tốc độ tăng trưởng đều hàng năm } \\
\text { của xe máy trong lưu thông }\end{array}$ & $\mathrm{V}_{\text {cir }}$ & $6,38 \%$ & 1,36 & 28.588 .284 & 38.943 .834 & 5 \\
\hline $\begin{array}{l}\text { Tốc độ tăng đều hàng năm của } \\
\text { GDP theo đâu người }\end{array}$ & $V_{\text {gdp }}$ & $6,29 \%$ & 1,36 & 1.907 & 2.587 & 5 \\
\hline \multicolumn{7}{|l|}{ Giai đoạn 2008-2013 } \\
\hline $\begin{array}{l}\text { Tốc độ tăng trưởng đều hàng năm } \\
\text { của xe máy theo đăng ký }\end{array}$ & $\mathrm{V}_{\text {reg }}$ & $8,69 \%$ & 1,52 & 25.481 .039 & 38.643 .091 & 5 \\
\hline $\begin{array}{l}\text { Tốc độ tăng trưởng đều hàng năm } \\
\text { của xe máy trong lưu thông }\end{array}$ & $\mathrm{V}_{\text {cir }}$ & $9,14 \%$ & 1,55 & 18.461 .668 & 28.588 .284 & 5 \\
\hline $\begin{array}{l}\text { Tốc độ tăng đều hàng năm của } \\
\text { GDP theo đâu người }\end{array}$ & $\mathrm{V}_{\text {gdp }}$ & $12,63 \%$ & 1,81 & 1052 & 1.907 & 5 \\
\hline \multicolumn{7}{|l|}{ Giai đoạn 2003-2008 } \\
\hline $\begin{array}{l}\text { Tốc độ tăng trưởng đều hàng năm } \\
\text { của xe máy theo đăng ký }\end{array}$ & $V_{\text {reg }}$ & $17,50 \%$ & 2,24 & 11.379 .000 & 25.481 .039 & 5 \\
\hline $\begin{array}{l}\text { Tốc độ tăng trưởng đều hàng năm } \\
\text { của xe máy trong lưu thông }\end{array}$ & $\mathrm{V}_{\text {cir }}$ & $17,09 \%$ & 2,20 & 8.387 .565 & 18.461 .668 & 5 \\
\hline $\begin{array}{l}\text { Tốc độ tăng đều hàng năm của } \\
\text { GDP theo đầu người }\end{array}$ & $\mathrm{V}_{\text {gdp }}$ & $16,42 \%$ & 2,14 & 492 & 1052 & 5 \\
\hline
\end{tabular}

File: ZZi MC flat rate 
Nguồn: Nhóm nghiên cứu

Bảng 3-42 P5-Phân bố xe máy trong lưu thông giai đoạn 2006-2017 giữa thành thị và nông thôn

\begin{tabular}{|c|c|c|c|c|c|}
\hline Năm & $\begin{array}{c}\text { Số xe } \\
\text { lưu hành }\end{array}$ & Thành thị & Nông thôn & $\begin{array}{c}\text { Thành } \\
\text { thị }\end{array}$ & $\begin{array}{c}\text { Nông } \\
\text { thôn }\end{array}$ \\
\hline $\mathbf{Y}$ & $\mathbf{M}_{\text {cir }}$ & $\mathbf{M}_{\text {urb }}$ & $\mathbf{M}_{\text {rur }}$ & urb\% & rur\% \\
\hline 2006 & $\mathbf{1 3 . 4 8 1 . 0 8 8}$ & 6.043 .122 & 7.437 .966 & $44,83 \%$ & $55,17 \%$ \\
\hline 2007 & $\mathbf{1 5 . 9 1 3 . 8 7 1}$ & 6.847 .738 & 9.066 .133 & $43,03 \%$ & $56,97 \%$ \\
\hline 2008 & $\mathbf{1 8 . 4 6 1 . 6 6 8}$ & 7.758 .454 & 10.703 .213 & $42,02 \%$ & $57,98 \%$ \\
\hline 2009 & $\mathbf{1 9 . 9 1 4 . 6 2 6}$ & 8.135 .889 & 11.778 .738 & $40,85 \%$ & $59,15 \%$ \\
\hline 2010 & $\mathbf{2 1 . 4 7 3 . 1 0 2}$ & 8.541 .053 & 12.932 .049 & $39,78 \%$ & $60,22 \%$ \\
\hline 2011 & $\mathbf{2 3 . 9 9 8 . 1 4 9}$ & 9.691 .893 & 14.306 .256 & $40,39 \%$ & $59,61 \%$ \\
\hline 2012 & $\mathbf{2 6 . 6 0 5 . 8 8 2}$ & 10.691 .589 & 15.914 .293 & $40,19 \%$ & $59,81 \%$ \\
\hline 2013 & $\mathbf{2 8 . 5 8 8 . 2 8 4}$ & 11.395 .593 & 17.192 .690 & $39,86 \%$ & $60,14 \%$ \\
\hline 2014 & $\mathbf{3 0 . 6 3 1 . 1 2 4}$ & 12.326 .606 & 18.304 .519 & $40,24 \%$ & $59,76 \%$ \\
\hline 2015 & $\mathbf{3 2 . 3 5 5 . 6 0 6}$ & 13.132 .208 & 19.223 .397 & $40,59 \%$ & $59,41 \%$ \\
\hline 2016 & $\mathbf{3 4 . 1 3 2 . 9 7 6}$ & 13.909 .476 & 20.223 .500 & $40,75 \%$ & $59,25 \%$ \\
\hline 2017 & $\mathbf{3 6 . 6 1 9 . 5 5 1}$ & 14.614 .847 & 22.004 .703 & $39,91 \%$ & $60,09 \%$ \\
\hline & $\begin{array}{c}\text { Chiều } \\
\text { hướng }\end{array}$ & & & \multirow{2}{*}{ Giảm } & Tăng \\
\hline
\end{tabular}

\begin{tabular}{|c|c|}
\hline & - Thành thị : Nông thôn \\
\hline 2017 & 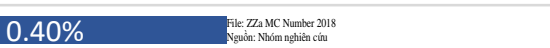 \\
\hline 2016 & 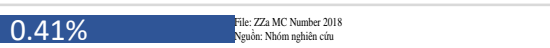 \\
\hline 2015 & 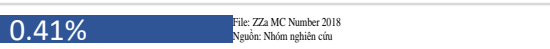 \\
\hline 2014 & 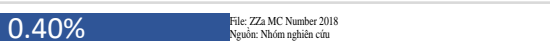 \\
\hline 2013 & $0.40 \%$ \\
\hline 2012 & 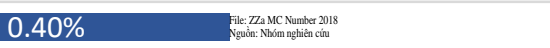 \\
\hline 2011 & 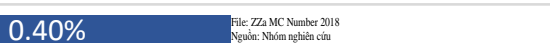 \\
\hline 2010 & 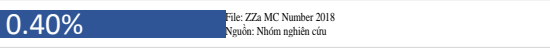 \\
\hline 2009 & 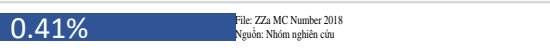 \\
\hline 2008 & 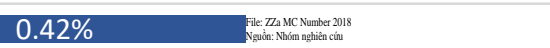 \\
\hline 2007 & $0.43 \%$ \\
\hline 2006 & $0.45 \%$ \\
\hline
\end{tabular}

File: ZZi MC flat rate

Nguồn: Nhóm nghiên cứu 
Bảng 3-43 P6-Phân bố xe máy trong lưu thông giai đoạn 2006-2017 giữa năm nhóm thu nhập

\begin{tabular}{|c|c|c|c|c|c|c|}
\hline Năm & $\begin{array}{c}\text { Số xe } \\
\text { lưu hành }\end{array}$ & & máy the & nhóm th & hập (Quin & iles) \\
\hline $\mathbf{y}$ & $\mathbf{M}_{\text {cir }}$ & Q1 & Q2 & Q3 & Q4 & Q5 \\
\hline 2006 & 13.481 .088 & 900.215 & 1.565 .704 & 2.238 .313 & 3.332 .487 & 5.444 .368 \\
\hline 2007 & 15.913 .871 & 1.210 .255 & 1.976 .568 & 2.728 .012 & 3.891 .680 & 6.107 .356 \\
\hline 2008 & 18.461.668 & 1.540 .974 & 2.406 .806 & 3.238 .945 & 4.471 .399 & 6.803 .545 \\
\hline 2009 & 19.914.626 & 1.828 .360 & 2.754 .109 & 3.629 .087 & 4.827 .301 & 6.875 .769 \\
\hline 2010 & 21.473.102 & 2.137 .821 & 3.125 .978 & 4.046 .494 & 5.210 .156 & 6.952 .653 \\
\hline 2011 & 23.998.149 & 2.385 .572 & 3.587 .687 & 4.592 .239 & 5.829 .248 & 7.603 .404 \\
\hline 2012 & 26.605 .882 & 2.644 .115 & 4.072 .844 & 5.151 .719 & 6.464 .161 & 8.273 .044 \\
\hline 2013 & 28.588.284 & 2.949 .267 & 4.425 .952 & 5.607 .336 & 6.931 .196 & 8.674 .532 \\
\hline 2014 & 30.631 .124 & 3.262 .206 & 4.791 .191 & 6.079 .735 & 7.411 .076 & 9.086 .917 \\
\hline 2015 & 32.355.606 & 3.473 .494 & 5.057 .964 & 6.464 .523 & 7.822 .774 & 9.536 .852 \\
\hline 2016 & 34.132.976 & 3.694 .634 & 5.334 .723 & 6.860 .306 & 8.244 .987 & 9.998 .326 \\
\hline 2017 & 36.619.551 & 4.058 .940 & 5.887 .091 & 7.429 .005 & 8.844 .165 & 10.400 .349 \\
\hline $\mathbf{y}$ & Mcir\% & Mq1\% & Mq2\% & Mq3\% & $\mathrm{Mq} 4 \%$ & Mq5\% \\
\hline 2006 & $100 \%$ & $6,68 \%$ & $11,61 \%$ & $16,60 \%$ & $24,72 \%$ & $40,39 \%$ \\
\hline 2007 & $100 \%$ & $7,61 \%$ & $12,42 \%$ & $17,14 \%$ & $24,45 \%$ & $38,38 \%$ \\
\hline 2008 & $100 \%$ & $8,35 \%$ & $13,04 \%$ & $17,54 \%$ & $24,22 \%$ & $36,85 \%$ \\
\hline 2009 & $100 \%$ & $9,18 \%$ & $13,83 \%$ & $18,22 \%$ & $24,24 \%$ & $34,53 \%$ \\
\hline 2010 & $100 \%$ & $9,96 \%$ & $14,56 \%$ & $18,84 \%$ & $24,26 \%$ & $32,38 \%$ \\
\hline 2011 & $100 \%$ & $9,94 \%$ & $14,95 \%$ & $19,14 \%$ & $24,29 \%$ & $31,68 \%$ \\
\hline 2012 & $100 \%$ & $9,94 \%$ & $15,31 \%$ & $19,36 \%$ & $24,30 \%$ & $31,09 \%$ \\
\hline 2013 & $100 \%$ & $10,32 \%$ & $15,48 \%$ & $19,61 \%$ & $24,24 \%$ & $30,34 \%$ \\
\hline 2014 & $100 \%$ & $10,65 \%$ & $15,64 \%$ & $19,85 \%$ & $24,19 \%$ & $29,67 \%$ \\
\hline 2015 & $100 \%$ & $10,74 \%$ & $15,63 \%$ & $19,98 \%$ & $24,18 \%$ & $29,48 \%$ \\
\hline 2016 & $100 \%$ & $10,82 \%$ & $15,63 \%$ & $20,10 \%$ & $24,16 \%$ & $29,29 \%$ \\
\hline 2017 & $100 \%$ & $11,08 \%$ & $16,08 \%$ & $20,29 \%$ & $24,15 \%$ & $28,40 \%$ \\
\hline \multicolumn{2}{|c|}{ Chiều hướng } & Tăng & Tăng & Tăng & Đều & Giảm \\
\hline
\end{tabular}

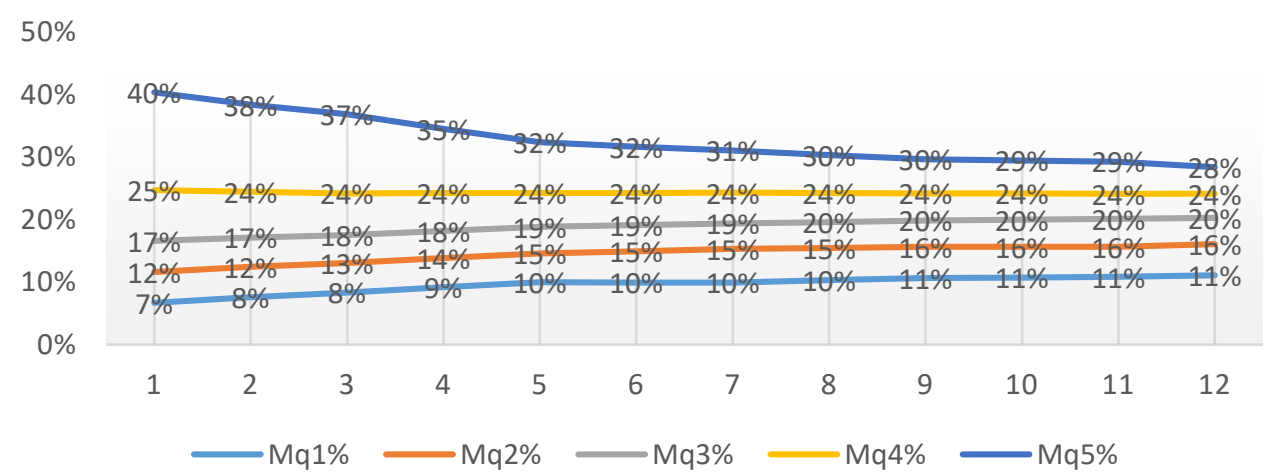

File: ZZc MC Number

Nguồn: Nhóm nghiên cứu 
Dự án: Xây dựng chiến lược an toàn giao thông đối với xe máy và kế hoạch hành động: một khởi đầu của Việt Nam

Bảng 3-44 P7- Phân bố xe máy trong lưu thông giai đoạn 2006-2017 giữa 6 vùng kinh tế xã hội

\begin{tabular}{|c|c|c|c|c|c|c|c|}
\hline \multirow{2}{*}{$\begin{array}{c}\text { Năm } \\
\text { y } \\
\end{array}$} & \multirow{2}{*}{$\begin{array}{c}\begin{array}{c}\text { Số xe lưu } \\
\text { hành }\end{array} \\
M_{\text {cir }} \\
\end{array}$} & \multicolumn{6}{|c|}{ Phân bố theo 06 vùng kinh tế-xã hội } \\
\hline & & V1 & V2 & V3 & V4 & V5 & V6 \\
\hline 2008 & 18.461 .668 & 4.097 .440 & 1.917 .960 & 3.670 .271 & 1.024 .156 & 4.932 .795 & 2.819 .046 \\
\hline 2009 & 19.914 .626 & 4.512 .480 & 2.119 .456 & 3.891 .551 & 1.117 .855 & 5.102 .402 & 3.170 .883 \\
\hline 2010 & 21.473.102 & 4.984 .372 & 2.343 .240 & 4.143 .065 & 1.221 .028 & 5.231 .949 & 3.549 .448 \\
\hline 2011 & 23.998.149 & 5.551 .290 & 2.557 .801 & 4.715 .562 & 1.401 .195 & 5.740 .077 & 4.032 .224 \\
\hline 2012 & 26.605.882 & 6.132 .771 & 2.778 .475 & 5.315 .762 & 1.592 .439 & 6.263 .179 & 4.523.256 \\
\hline 2013 & 28.588.284 & 6.507 .299 & 3.031 .472 & 5.718 .063 & 1.710 .605 & 6.680 .979 & 4.939 .866 \\
\hline 2014 & 30.631 .124 & 6.890 .713 & 3.295 .053 & 6.128 .330 & 1.830 .700 & 7.113 .448 & 5.372 .881 \\
\hline 2015 & 32.355.606 & 7.237.599 & 3.468 .036 & 6.440 .084 & 1.906 .551 & 7.561 .837 & 5.741 .498 \\
\hline 2016 & 34.132.976 & 7.540 .516 & 3.663 .723 & 6.838 .629 & 1.975 .195 & 8.045 .922 & 6.068 .992 \\
\hline 2017 & 36.619 .551 & 8.219 .097 & 3.919 .810 & 7.303 .783 & 2.185 .451 & 8.370 .079 & 6.621 .330 \\
\hline $\mathbf{y}$ & Mcir \% & Mv1\% & Mv2\% & Mv3\% & Mv4\% & Mv5\% & Mv6\% \\
\hline 2008 & $100 \%$ & $22,19 \%$ & $10,39 \%$ & $19,88 \%$ & $5,55 \%$ & $26,72 \%$ & $15,27 \%$ \\
\hline 2009 & $100 \%$ & $22,66 \%$ & $10,64 \%$ & $19,54 \%$ & $5,61 \%$ & $25,62 \%$ & $15,92 \%$ \\
\hline 2010 & $100 \%$ & $23,21 \%$ & $10,91 \%$ & $19,29 \%$ & $5,69 \%$ & $24,37 \%$ & $16,53 \%$ \\
\hline 2011 & $100 \%$ & $23,13 \%$ & $10,66 \%$ & $19,65 \%$ & $5,84 \%$ & $23,92 \%$ & $16,80 \%$ \\
\hline 2012 & $100 \%$ & $23,05 \%$ & $10,44 \%$ & $19,98 \%$ & $5,99 \%$ & $23,54 \%$ & $17,00 \%$ \\
\hline 2013 & $100 \%$ & $22,76 \%$ & $10,60 \%$ & $20,00 \%$ & $5,98 \%$ & $23,37 \%$ & $17,28 \%$ \\
\hline 2014 & $100 \%$ & $22,50 \%$ & $10,76 \%$ & $20,01 \%$ & $5,98 \%$ & $23,22 \%$ & $17,54 \%$ \\
\hline 2015 & $100 \%$ & $22,37 \%$ & $10,72 \%$ & $19,90 \%$ & $5,89 \%$ & $23,37 \%$ & $17,74 \%$ \\
\hline 2016 & $100 \%$ & $22,09 \%$ & $10,73 \%$ & $20,04 \%$ & $5,79 \%$ & $23,57 \%$ & $17,78 \%$ \\
\hline 2017 & $100 \%$ & $22,44 \%$ & $10,70 \%$ & $19,95 \%$ & $5,97 \%$ & $22,86 \%$ & $18,08 \%$ \\
\hline & ớng & $\begin{array}{l}\text { Tăng } \\
\text { giảm ít }\end{array}$ & Đều & Đều & Đều & Giảm & Tăng \\
\hline
\end{tabular}

File: ZZb MC Number 2018

Nguồn: Nhóm Nghiên cứu

\section{Vùng kinh tế- xã hội}

Nước ta có 63 tỉnh và thành phố trực thuộc Trung ương và được chia thành 6 vùng kinh tế xã hội như sau (số trước tên tỉnh là mã số theo Danh mục các đơn vị hành chính):

(1) Vùng 1, Đồng bằng sông Hồng gồm 11 tỉnh: 01, Hà Nội; 22, Quảng Ninh; 26, Vĩnh Phúc; 27, Bắc Ninh; 30, Hải Dương; 31, Hải Phòng; 33, Hưng Yên; 34, Thái Bình; 35, Hà Nam; 36, Nam Định; 37, Ninh Bình,

(2) Vùng 2, Trung du và miền núi phía Bắc gốm 14 tỉnh: 02, Hà Giang; 04, Cao Bằng; 06, Bắc Kạn; 08, Tuyên Quang; 10, Lào Cai; 11, Điện Biên; 12,Lai Châu; 14, Sơn La; 15, Yên Bái; 17, Hoà Bình; 19, Thái Nguyên; 20, Lạng Sơn; 24, Bắc Giang; 25, Phú Thọ,

(3) Vùng 3, Bắc Trung Bộ và Duyên Hải miền Trung: gồm 14 tỉnh: 38 - Thanh Hoá; 40, Nghệ An; 42, Hà Tĩnh; 44, Quảng Bình; 45, Quảng Trị; 46, Thừa Thiên Huế; 48, Đà Nẵng; 49, Quảng Nam; 51, Quảng Ngãi; 52, Bình Định; 54, Phú Yên; 56, Khánh Hoà; 58, Ninh Thuận; 60, Bình Thuận, 
(4) Vùng 4, Tây Nguyên gồm 5 tỉnh: 62, Kon Tum; 64, Gia Lai; 66, Đắk Lắk; 67, Đắk Nông; 68, Lâm Đồng,

(5) Vùng 5, Đông Nam Bộ gồm 6 tỉnh: 70, Bình Phước; 72, Tây Ninh; 74, Bình Dương; 75, Đồng Nai; 77, Bà Rịa, Vũng Tàu; 79, TP Hồ Chí Minh,

(6) Vùng 6, Đồng bằng sông Cửu Long gồm 13 tỉnh: 80, Long An; 82, Tiền Giang; 83, Bến Tre; 84, Trà Vinh; 86, Vĩnh Long; 87, Đồng Tháp; 89, An Giang; 91, Kiên Giang; 92, Cần Thơ; 93, Hậu Giang; 94,Sóc Trăng; 95, Bạc Liêu; 96, Cà Mau,

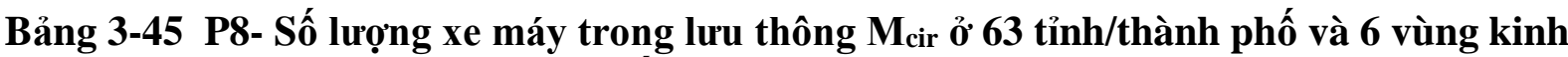
tế-xã hội năm 2017

\begin{tabular}{|c|c|c|c|c|c|}
\hline Tỉnh thành & Dân số & $\begin{array}{c}\text { Thu nhập bình } \\
\text { quân nhân } \\
\text { khẩu } 1 \text { tháng }\end{array}$ & $\begin{array}{c}\text { Mức đô thị } \\
\text { hóa }\end{array}$ & $\begin{array}{c}\text { Tổng số xe } \\
\text { máy lưu } \\
\text { thông }\end{array}$ & $\begin{array}{c}\text { Số xe máy lưu } \\
\text { thông trên } 100 \\
\text { người dân }\end{array}$ \\
\hline & pop & Inc & urb & $\mathrm{M}_{\text {cir }}$ & $\mathbf{M}_{\text {cir } 100}$ \\
\hline Toàn quốc & 93.671 .600 & 3387,12 & $35,03 \%$ & 36.619 .551 & 39,09 \\
\hline Đồng bằng sông Hồng & 21.342 .100 & $4.259,19$ & $38,18 \%$ & 8.089 .840 & 37,91 \\
\hline Hà Nội & 7.420 .100 & $5.362,18$ & $58,86 \%$ & 2.985.571 & 40,24 \\
\hline Vĩnh Phúc & 1.079 .500 & $3.060,82$ & $23,30 \%$ & 431.555 & 39,98 \\
\hline Bắc Ninh & 1.215 .200 & $4.545,63$ & $28,30 \%$ & 487.354 & 40,10 \\
\hline Quảng Ninh & 1.243 .600 & $3.966,75$ & $63,61 \%$ & 406.178 & 32,66 \\
\hline Hải Dương & 1.797 .300 & $3.432,94$ & $25,20 \%$ & 631.175 & 35,12 \\
\hline Hải Phòng & 1.997 .700 & $4.744,57$ & $46,76 \%$ & 778.540 & 38,97 \\
\hline Hưng Yên & 1.176 .300 & $2.984,01$ & $12,93 \%$ & 437.326 & 37,18 \\
\hline Thái Bình & 1.791 .500 & $3.042,62$ & $10,51 \%$ & 669.263 & 37,36 \\
\hline Hà Nam & 805.700 & $2.951,32$ & $15,76 \%$ & 263.985 & 32,76 \\
\hline Nam Định & 1.853 .300 & $3.324,05$ & $18,30 \%$ & 656.294 & 35,41 \\
\hline Ninh Bình & 961.900 & $2.996,39$ & $20,91 \%$ & 342.599 & 35,62 \\
\hline $\begin{array}{l}\text { Trung du và miền núi } \\
\text { phía Bắc }\end{array}$ & 12.148 .900 & $2.109,29$ & $18,47 \%$ & 3.930 .624 & 32,35 \\
\hline Hà Giang & 833.500 & $1.398,31$ & $15,00 \%$ & 171.430 & 20,57 \\
\hline Cao Bằng & 535.400 & $1.678,34$ & $23,18 \%$ & 176.103 & 32,89 \\
\hline Bắc Kạn & 323.200 & $1.548,58$ & $18,78 \%$ & 105.097 & 32,52 \\
\hline Tuyên Quang & 773.500 & $1.899,47$ & $13,74 \%$ & 280.146 & 36,22 \\
\hline Lào Cai & 694.400 & $1.907,20$ & $22,87 \%$ & 201.496 & 29,02 \\
\hline Yên Bái & 807.300 & $1.842,83$ & $20,56 \%$ & 257.172 & 31,86 \\
\hline Thái Nguyên & 1.255 .100 & $3.049,11$ & $35,10 \%$ & 522.289 & 41,61 \\
\hline Lạng Sơn & 778.400 & $1.811,15$ & $19,81 \%$ & 244.944 & 31,47 \\
\hline Bắc Giang & 1.674 .400 & $2.867,36$ & $11,43 \%$ & 635.467 & 37,95 \\
\hline Phú Thọ & 1.392 .900 & $2.523,37$ & $18,85 \%$ & 517.001 & 37,12 \\
\hline Điện Biên & 567.000 & $1.367,98$ & $15,10 \%$ & 130.865 & 23,08 \\
\hline Lai Châu & 446.100 & $1.327,42$ & $17,35 \%$ & 94.828 & 21,26 \\
\hline Sơn La & 1.228 .900 & $1.433,53$ & $13,63 \%$ & 323.117 & 26,29 \\
\hline Hoà Bình & 838.800 & $2.033,54$ & $14,77 \%$ & 270.669 & 32,27 \\
\hline
\end{tabular}


Dự án: Xây dựng chiến lược an toàn giao thông đối với xe máy và kế hoạch hành động: một khởi đầu của Việt Nam

Nghiên cứu hiện trạng giao thông xe máy Việt Nam

\begin{tabular}{|c|c|c|c|c|c|}
\hline Tỉnh thành & Dân số & $\begin{array}{c}\text { Thu nhập bình } \\
\text { quân nhân } \\
\text { khẩu } 1 \text { tháng }\end{array}$ & $\begin{array}{l}\text { Mức đô thị } \\
\text { hóa }\end{array}$ & $\begin{array}{c}\text { Tổng số xe } \\
\text { máy lưu } \\
\text { thông }\end{array}$ & $\begin{array}{c}\text { Số xe máy lưu } \\
\text { thông trên } 100 \\
\text { người dân }\end{array}$ \\
\hline & pop & Inc & urb & $\mathbf{M}_{\text {cir }}$ & $\mathrm{M}_{\mathrm{cir} 100}$ \\
\hline $\begin{array}{l}\text { Bắc Trung Bộ và } \\
\text { Duyên hải miền } \\
\text { Trung }\end{array}$ & 19.924 .500 & $2.574,06$ & $28,69 \%$ & 7.336.820 & 36,82 \\
\hline Thanh Hoá & 3.544 .400 & $2.224,03$ & $17,19 \%$ & 1.032.751 & 29,14 \\
\hline Nghệ An & 3.131 .300 & $2.007,40$ & $15,08 \%$ & 898.531 & 28,70 \\
\hline Hà Tĩnh & 1.272 .200 & $2.241,21$ & $18,27 \%$ & 432.537 & 34,00 \\
\hline Quảng Bình & 882.500 & $2.385,63$ & $19,69 \%$ & 291.471 & 33,03 \\
\hline Quảng Trị & 627.300 & $2.157,17$ & $29,97 \%$ & 219.250 & 34,95 \\
\hline Thừa Thiên-Huế & 1.154 .300 & $2.790,02$ & $48,81 \%$ & 505.724 & 43,81 \\
\hline Đà Nẵng & 1.064 .100 & $4.703,75$ & $87,62 \%$ & 556.140 & 52,26 \\
\hline Quảng Nam & 1.493 .800 & $2.298,03$ & $24,22 \%$ & 560.297 & 37,51 \\
\hline Quảng Ngãi & 1.261 .600 & $2.190,52$ & $15,16 \%$ & 491.624 & 38,97 \\
\hline Bình Định & 1.529 .000 & $2.852,22$ & $31,03 \%$ & 637.394 & 41,69 \\
\hline Phú Yên & 904.400 & $2.481,16$ & $29,08 \%$ & 375.182 & 41,48 \\
\hline Khánh Hoà & 1.222 .200 & $3.188,73$ & $45,03 \%$ & 562.540 & 46,03 \\
\hline Ninh Thuận & 607.000 & $2.678,82$ & $36,21 \%$ & 227.200 & 37,43 \\
\hline Bình Thuận & 1.230 .400 & $2.938,39$ & $39,31 \%$ & 546.179 & 44,39 \\
\hline Tây Nguyên & 5.778.500 & $2.595,81$ & $29,22 \%$ & 2.119.087 & 36,67 \\
\hline Kon Tum & 520.000 & $2.060,55$ & $35,54 \%$ & 173.795 & 33,42 \\
\hline Gia Lai & 1.437 .400 & $2.185,60$ & $30,10 \%$ & 449.992 & 31,31 \\
\hline Đắk Lắk & 1.896 .600 & $2.524,93$ & $24,56 \%$ & 755.926 & 39,86 \\
\hline Đắk Nông & 625.600 & $2.453,42$ & $15,20 \%$ & 207.902 & 33,23 \\
\hline Lâm Đồng & 1.298 .900 & $3.162,41$ & $39,29 \%$ & 531.472 & 40,92 \\
\hline Đông Nam Bộ & 16.739 .600 & $5.106,77$ & $62,66 \%$ & 8.632 .065 & 51,57 \\
\hline Bình Phước & 968.900 & $3.417,26$ & $19,93 \%$ & 444.664 & 45,89 \\
\hline Tây Ninh & 1.126 .200 & $3.568,09$ & $22,45 \%$ & 544.984 & 48,39 \\
\hline Bình Dương & 2.071 .000 & $5.202,85$ & $76,19 \%$ & 1.081.902 & 52,24 \\
\hline Đồng Nai & 3.027 .300 & $4.507,72$ & $35,31 \%$ & 1.574.689 & 52,02 \\
\hline Bà Rịa-Vũng Tàu & 1.101 .600 & $4.773,07$ & $51,90 \%$ & 527.293 & 47,87 \\
\hline TP. Hồ Chí Minh & 8.444 .600 & $5.649,79$ & $80,82 \%$ & 4.458.534 & 52,80 \\
\hline $\begin{array}{l}\text { Đồng bằng sông Cửu } \\
\text { Long }\end{array}$ & 17.738.000 & $\mathbf{3 . 0 0 6 , 3 7}$ & $25,52 \%$ & 6.511 .116 & 36,71 \\
\hline Long An & 1.496 .800 & $3.308,51$ & $18,03 \%$ & 622.713 & 41,60 \\
\hline Tiền Giang & 1.751 .800 & $3.313,19$ & $15,49 \%$ & 753.658 & 43,02 \\
\hline Bến Tre & 1.266 .700 & $2.630,52$ & $10,67 \%$ & 499.976 & 39,47 \\
\hline Trà Vinh & 1.045 .600 & $2.448,26$ & $18,09 \%$ & 405.109 & 38,74 \\
\hline Vĩnh Long & 1.050 .200 & $2.657,09$ & $16,97 \%$ & 394.784 & 37,59 \\
\hline Đồng Tháp & 1.690 .300 & $2.778,76$ & $17,77 \%$ & 688.888 & 40,76 \\
\hline An Giang & 2.161 .700 & $3.070,58$ & $30,75 \%$ & 785.796 & 36,35 \\
\hline
\end{tabular}


Dự án: Xây dựng chiến lược an toàn giao thông đối với xe máy và kế hoạch hành động: một khởi đầu của Việt Nam

\begin{tabular}{|l|c|c|c|c|c|}
\hline \multirow{2}{*}{ Tỉnh thành } & Dân số & $\begin{array}{c}\text { Thu nhập bình } \\
\text { quân nhân } \\
\text { khẩu 1 tháng }\end{array}$ & $\begin{array}{c}\text { Mức đô thị } \\
\text { hóa }\end{array}$ & $\begin{array}{c}\text { Tổng số xe } \\
\text { máy lưu } \\
\text { thông }\end{array}$ & $\begin{array}{c}\text { Số xe máy lưu } \\
\text { thông trên 100 } \\
\text { người dân }\end{array}$ \\
\cline { 2 - 6 } & pop & Inc & urb & M $_{\text {cir }}$ & M $_{\text {cir100 }}$ \\
\hline Kiên Giang & 1.792 .600 & $3.248,18$ & $29,48 \%$ & $\mathbf{5 3 5 . 7 6 1}$ & 29,89 \\
\hline Cần Thơ & 1.272 .800 & $3.540,80$ & $67,06 \%$ & $\mathbf{5 3 2 . 0 3 0}$ & 41,80 \\
\hline Hậu Giang & 774.600 & $2.673,95$ & $25,07 \%$ & $\mathbf{2 8 2 . 5 4 5}$ & 36,48 \\
\hline Sóc Trăng & 1.314 .300 & $2.549,08$ & $30,60 \%$ & $\mathbf{4 1 6 . 1 1 3}$ & 31,66 \\
\hline Bạc Liêu & 894.300 & $2.691,79$ & $29,29 \%$ & $\mathbf{2 6 0 . 3 4 1}$ & 29,11 \\
\hline Cà Mau & 1.226 .300 & $2.612,99$ & $22,69 \%$ & $\mathbf{3 3 3 . 4 0 1}$ & 27,19 \\
\hline
\end{tabular}

File: ZZb MC Number 2018

Nguồn: Nhóm Nghiên cứu

Bảng 3-46 P9-Các tỉnh/thành phố xếp theo số lượng xe máy trong lưu thông Mcir năm 2017

\begin{tabular}{|c|c|c|c|c|c|}
\hline Tỉnh thành xếp theo $M_{\text {cir }}$ & Dân số & $\begin{array}{c}\text { Thu nhập } \\
\text { bình quân } \\
\text { nhân } \\
\text { khẩu } 1 \\
\text { tháng } \\
\end{array}$ & $\begin{array}{l}\text { Mức đô } \\
\text { thị hóa }\end{array}$ & $\begin{array}{c}\text { Tổng số } \\
\text { xe máy } \\
\text { lưu thông }\end{array}$ & $\begin{array}{c}\text { Số xe máy } \\
\text { lưu thông } \\
\text { trên } 100 \\
\text { người dân }\end{array}$ \\
\hline & Pop & inc & urb & $\mathrm{M}_{\mathrm{cir}}$ & $\mathbf{M}_{\text {cir100 }}$ \\
\hline Toàn quốc & 93.671 .600 & 3387,12 & $35,03 \%$ & 36.619 .551 & 39,09 \\
\hline TP. Hồ Chí Minh & 8.444 .600 & $5.649,79$ & $80,82 \%$ & 4.458.534 & 52,80 \\
\hline Hà Nội & 7.420 .100 & $5.362,18$ & $58,86 \%$ & 2.985 .571 & 40,24 \\
\hline Đồng Nai & 3.027 .300 & $4.507,72$ & $35,31 \%$ & 1.574.689 & 52,02 \\
\hline Bình Dương & 2.071 .000 & $5.202,85$ & $76,19 \%$ & 1.081.902 & 52,24 \\
\hline Thanh Hoá & 3.544 .400 & $2.224,03$ & $17,19 \%$ & 1.032.751 & 29,14 \\
\hline Nghệ An & 3.131 .300 & $2.007,40$ & $15,08 \%$ & 898.531 & 28,70 \\
\hline An Giang & 2.161 .700 & $3.070,58$ & $30,75 \%$ & 785.796 & 36,35 \\
\hline Hải Phòng & 1.997 .700 & $4.744,57$ & $46,76 \%$ & 778.540 & 38,97 \\
\hline Đắk Lắk & 1.896 .600 & $2.524,93$ & $24,56 \%$ & 755.926 & 39,86 \\
\hline Tiền Giang & 1.751 .800 & $3.313,19$ & $15,49 \%$ & 753.658 & 43,02 \\
\hline Đồng Tháp & 1.690 .300 & $2.778,76$ & $17,77 \%$ & 688.888 & 40,76 \\
\hline Thái Bình & 1.791 .500 & $3.042,62$ & $10,51 \%$ & 669.263 & 37,36 \\
\hline Nam Định & 1.853 .300 & $3.324,05$ & $18,30 \%$ & 656.294 & 35,41 \\
\hline Bình Định & 1.529 .000 & $2.852,22$ & $31,03 \%$ & 637.394 & 41,69 \\
\hline Bắc Giang & 1.674 .400 & $2.867,36$ & $11,43 \%$ & 635.467 & 37,95 \\
\hline Hải Dương & 1.797 .300 & $3.432,94$ & $25,20 \%$ & 631.175 & 35,12 \\
\hline Long An & 1.496 .800 & $3.308,51$ & $18,03 \%$ & 622.713 & 41,60 \\
\hline Khánh Hoà & 1.222 .200 & $3.188,73$ & $45,03 \%$ & 562.540 & 46,03 \\
\hline Quảng Nam & 1.493 .800 & $2.298,03$ & $24,22 \%$ & 560.297 & 37,51 \\
\hline Đà Nẵng & 1.064 .100 & $4.703,75$ & $87,62 \%$ & 556.140 & 52,26 \\
\hline Bình Thuận & 1.230 .400 & $2.938,39$ & $39,31 \%$ & 546.179 & 44,39 \\
\hline Tây Ninh & 1.126 .200 & $3.568,09$ & $22,45 \%$ & 544.984 & 48,39 \\
\hline Kiên Giang & 1.792 .600 & $3.248,18$ & $29,48 \%$ & 535.761 & 29,89 \\
\hline Cần Thơ & 1.272 .800 & $3.540,80$ & $67,06 \%$ & 532.030 & 41,80 \\
\hline Lâm Đồng & 1.298 .900 & $3.162,41$ & $39,29 \%$ & 531.472 & 40,92 \\
\hline Bà Rịa-Vũng Tàu & 1.101 .600 & $4.773,07$ & $51,90 \%$ & 527.293 & 47,87 \\
\hline Thái Nguyên & 1.255 .100 & $3.049,11$ & $35,10 \%$ & 522.289 & 41,61 \\
\hline Phú Thọ & 1.392 .900 & $2.523,37$ & $18,85 \%$ & 517.001 & 37,12 \\
\hline
\end{tabular}


Dự án: Xây dựng chiến lược an toàn giao thông đối với xe máy và kế hoạch hành động: một khởi đầu của Việt Nam

\begin{tabular}{|c|c|c|c|c|c|}
\hline Tỉnh thành xếp theo $M_{\text {cir }}$ & Dân số & $\begin{array}{c}\text { Thu nhập } \\
\text { bình quân } \\
\text { nhân } \\
\text { khẩu } 1 \\
\text { tháng }\end{array}$ & $\begin{array}{l}\text { Mức đô } \\
\text { thị hóa }\end{array}$ & $\begin{array}{c}\text { Tổng số } \\
\text { xe máy } \\
\text { lưu thông }\end{array}$ & $\begin{array}{c}\text { Số xe máy } \\
\text { lưu thông } \\
\text { trên } 100 \\
\text { người dân }\end{array}$ \\
\hline & Pop & inc & urb & $\mathrm{M}_{\mathrm{cir}}$ & $\mathrm{M}_{\text {cir100 }}$ \\
\hline Thừa Thiên-Huế & 1.154 .300 & $2.790,02$ & $48,81 \%$ & 505.724 & 43,81 \\
\hline Bến Tre & 1.266 .700 & $2.630,52$ & $10,67 \%$ & 499.976 & 39,47 \\
\hline Quảng Ngãi & 1.261 .600 & $2.190,52$ & $15,16 \%$ & 491.624 & 38,97 \\
\hline Bắc Ninh & 1.215 .200 & $4.545,63$ & $28,30 \%$ & 487.354 & 40,10 \\
\hline Gia Lai & 1.437 .400 & $2.185,60$ & $30,10 \%$ & 449.992 & 31,31 \\
\hline Bình Phước & 968.900 & $3.417,26$ & $19,93 \%$ & 444.664 & 45,89 \\
\hline Hưng Yên & 1.176 .300 & $2.984,01$ & $12,93 \%$ & 437.326 & 37,18 \\
\hline Hà Tĩnh & 1.272 .200 & $2.241,21$ & $18,27 \%$ & 432.537 & 34,00 \\
\hline Vĩnh Phúc & 1.079 .500 & $3.060,82$ & $23,30 \%$ & 431.555 & 39,98 \\
\hline Sóc Trăng & 1.314 .300 & $2.549,08$ & $30,60 \%$ & 416.113 & 31,66 \\
\hline Quảng Ninh & 1.243 .600 & $3.966,75$ & $63,61 \%$ & 406.178 & 32,66 \\
\hline Trà Vinh & 1.045 .600 & $2.448,26$ & $18,09 \%$ & 405.109 & 38,74 \\
\hline Vĩnh Long & 1.050 .200 & $2.657,09$ & $16,97 \%$ & 394.784 & 37,59 \\
\hline Phú Yên & 904.400 & $2.481,16$ & $29,08 \%$ & 375.182 & 41,48 \\
\hline Ninh Bình & 961.900 & $2.996,39$ & $20,91 \%$ & 342.599 & 35,62 \\
\hline Cà Mau & 1.226 .300 & $2.612,99$ & $22,69 \%$ & 333.401 & 27,19 \\
\hline Sơn La & 1.228 .900 & $1.433,53$ & $13,63 \%$ & 323.117 & 26,29 \\
\hline Quảng Bình & 882.500 & $2.385,63$ & $19,69 \%$ & 291.471 & 33,03 \\
\hline Hậu Giang & 774.600 & $2.673,95$ & $25,07 \%$ & 282.545 & 36,48 \\
\hline Tuyên Quang & 773.500 & $1.899,47$ & $13,74 \%$ & 280.146 & 36,22 \\
\hline Hoà Bình & 838.800 & $2.033,54$ & $14,77 \%$ & 270.669 & 32,27 \\
\hline Hà Nam & 805.700 & $2.951,32$ & $15,76 \%$ & 263.985 & 32,76 \\
\hline Bạc Liêu & 894.300 & $2.691,79$ & $29,29 \%$ & 260.341 & 29,11 \\
\hline Yên Bái & 807.300 & $1.842,83$ & $20,56 \%$ & 257.172 & 31,86 \\
\hline Lạng Sơn & 778.400 & $1.811,15$ & $19,81 \%$ & 244.944 & 31,47 \\
\hline Ninh Thuận & 607.000 & $2.678,82$ & $36,21 \%$ & 227.200 & 37,43 \\
\hline Quảng Trị & 627.300 & $2.157,17$ & $29,97 \%$ & 219.250 & 34,95 \\
\hline Đắk Nông & 625.600 & $2.453,42$ & $15,20 \%$ & 207.902 & 33,23 \\
\hline Lào Cai & 694.400 & $1.907,20$ & $22,87 \%$ & 201.496 & 29,02 \\
\hline Cao Bằng & 535.400 & $1.678,34$ & $23,18 \%$ & 176.103 & 32,89 \\
\hline Kon Tum & 520.000 & $2.060,55$ & $35,54 \%$ & 173.795 & 33,42 \\
\hline Hà Giang & 833.500 & $1.398,31$ & $15,00 \%$ & 171.430 & 20,57 \\
\hline Điện Biên & 567.000 & $1.367,98$ & $15,10 \%$ & 130.865 & 23,08 \\
\hline Bắc Kạn & 323.200 & $1.548,58$ & $18,78 \%$ & 105.097 & 32,52 \\
\hline Lai Châu & 446.100 & $1.327,42$ & $17,35 \%$ & 94.828 & 21,26 \\
\hline
\end{tabular}

\begin{tabular}{|l|r|r|r|r|c|}
\hline Toàn quốc & 93.671 .600 & 3387,12 & $35,03 \%$ & 36.619 .551 & 39,09 \\
\hline Đông Nam Bộ & 16.739 .600 & $5.106,77$ & $62,66 \%$ & 8.632 .065 & 51,57 \\
\hline Đồng bằng sông Hồng & 21.342 .100 & $4.259,19$ & $38,18 \%$ & 8.089 .840 & 37,91 \\
\hline $\begin{array}{l}\text { Bắc Trung Bộ và Duyên hải miền } \\
\text { Trung }\end{array}$ & 19.924 .500 & $2.574,06$ & $28,69 \%$ & 7.336 .820 & 36,82 \\
\hline Đồng bằng sông Cửu Long & 17.738 .000 & $3.006,37$ & $25,52 \%$ & 6.511 .116 & 36,71 \\
\hline Trung du và miền núi phía Bắc & 12.148 .900 & $2.109,29$ & $18,47 \%$ & 3.930 .624 & 32,35 \\
\hline Tây Nguyên & 5.778 .500 & $2.595,81$ & $29,22 \%$ & $\mathbf{2 . 1 1 9 . 0 8 7}$ & 36,67 \\
\hline
\end{tabular}

File: ZZb MC Number 2018

Nguồn: Nhóm Nghiên cứu 
Dự án: Xây dựng chiến lược an toàn giao thông đối với xe máy và kế hoạch hành động: một khởi đầu của Việt Nam

Bảng 3-47 P10-Các tỉnh/thành phố xếp theo số lượng xe máy trong lưu thông cho 100 người dân Mcir100 năm 2017

\begin{tabular}{|c|c|c|c|c|c|}
\hline Tỉnh thành xếp theo Mcir100 & Dân số & $\begin{array}{c}\text { Thu nhập } \\
\text { bình quân } \\
\text { nhân } \\
\text { khẩu } 1 \\
\text { tháng }\end{array}$ & $\begin{array}{l}\text { Mức đô } \\
\text { thị hóa }\end{array}$ & $\begin{array}{c}\text { Tổng số } \\
\text { xe máy } \\
\text { lưu thông }\end{array}$ & $\begin{array}{c}\text { Số xe máy } \\
\text { lưu thông } \\
\text { trên } 100 \\
\text { người dân }\end{array}$ \\
\hline & pop & inc & urb & $\mathrm{M}_{\mathrm{cir}}$ & $\mathrm{M}_{\text {cir100 }}$ \\
\hline TP. Hồ Chí Minh & 8.444 .600 & $5.649,79$ & $80,82 \%$ & 4.458.534 & 52,80 \\
\hline Đà Nẵng & 1.064 .100 & $4.703,75$ & $87,62 \%$ & 556.140 & 52,26 \\
\hline Bình Dương & 2.071 .000 & $5.202,85$ & $76,19 \%$ & 1.081 .902 & 52,24 \\
\hline Đồng Nai & 3.027 .300 & $4.507,72$ & $35,31 \%$ & 1.574 .689 & 52,02 \\
\hline Tây Ninh & 1.126 .200 & $3.568,09$ & $22,45 \%$ & 544.984 & 48,39 \\
\hline Bà Rịa-Vũng Tàu & 1.101 .600 & $4.773,07$ & $51,90 \%$ & $\mathbf{5 2 7 . 2 9 3}$ & 47,87 \\
\hline Khánh Hoà & 1.222 .200 & $3.188,73$ & $45,03 \%$ & 562.540 & 46,03 \\
\hline Bình Phước & 968.900 & $3.417,26$ & $19,93 \%$ & 444.664 & 45,89 \\
\hline Bình Thuận & 1.230 .400 & $2.938,39$ & $39,31 \%$ & 546.179 & 44,39 \\
\hline Thừa Thiên-Huế & 1.154 .300 & $2.790,02$ & $48,81 \%$ & 505.724 & 43,81 \\
\hline Tiền Giang & 1.751 .800 & $3.313,19$ & $15,49 \%$ & 753.658 & 43,02 \\
\hline Cần Thơ & 1.272 .800 & $3.540,80$ & $67,06 \%$ & $\mathbf{5 3 2 . 0 3 0}$ & 41,80 \\
\hline Bình Định & 1.529 .000 & $2.852,22$ & $31,03 \%$ & 637.394 & 41,69 \\
\hline Thái Nguyên & 1.255 .100 & $3.049,11$ & $35,10 \%$ & 522.289 & 41,61 \\
\hline Long An & 1.496 .800 & $3.308,51$ & $18,03 \%$ & 622.713 & 41,60 \\
\hline Phú Yên & 904.400 & $2.481,16$ & $29,08 \%$ & 375.182 & 41,48 \\
\hline Lâm Đồng & 1.298 .900 & $3.162,41$ & $39,29 \%$ & 531.472 & 40,92 \\
\hline Đồng Tháp & 1.690 .300 & $2.778,76$ & $17,77 \%$ & 688.888 & 40,76 \\
\hline Hà Nội & 7.420 .100 & $5.362,18$ & $58,86 \%$ & 2.985 .571 & 40,24 \\
\hline Bắc Ninh & 1.215 .200 & $4.545,63$ & $28,30 \%$ & 487.354 & 40,10 \\
\hline Vĩnh Phúc & 1.079 .500 & $3.060,82$ & $23,30 \%$ & 431.555 & 39,98 \\
\hline Đắk Lắk & 1.896 .600 & $2.524,93$ & $24,56 \%$ & 755.926 & 39,86 \\
\hline Bến Tre & 1.266 .700 & $2.630,52$ & $10,67 \%$ & 499.976 & 39,47 \\
\hline Toàn quốc & 93.671 .600 & 3387,12 & $35,03 \%$ & 36.619 .551 & 39,09 \\
\hline Hải Phòng & 1.997 .700 & $4.744,57$ & $46,76 \%$ & 778.540 & 38,97 \\
\hline Quảng Ngãi & 1.261 .600 & $2.190,52$ & $15,16 \%$ & 491.624 & 38,97 \\
\hline Trà Vinh & 1.045 .600 & $2.448,26$ & $18,09 \%$ & 405.109 & 38,74 \\
\hline Bắc Giang & 1.674 .400 & $2.867,36$ & $11,43 \%$ & 635.467 & 37,95 \\
\hline Vĩnh Long & 1.050 .200 & $2.657,09$ & $16,97 \%$ & 394.784 & 37,59 \\
\hline Quảng Nam & 1.493 .800 & $2.298,03$ & $24,22 \%$ & 560.297 & 37,51 \\
\hline Ninh Thuận & 607.000 & $2.678,82$ & $36,21 \%$ & 227.200 & 37,43 \\
\hline Thái Bình & 1.791 .500 & $3.042,62$ & $10,51 \%$ & 669.263 & 37,36 \\
\hline Hưng Yên & 1.176 .300 & $2.984,01$ & $12,93 \%$ & 437.326 & 37,18 \\
\hline Phú Thọ & 1.392 .900 & $2.523,37$ & $18,85 \%$ & 517.001 & 37,12 \\
\hline Hậu Giang & 774.600 & $2.673,95$ & $25,07 \%$ & 282.545 & 36,48 \\
\hline An Giang & 2.161 .700 & $3.070,58$ & $30,75 \%$ & 785.796 & 36,35 \\
\hline Tuyên Quang & 773.500 & $1.899,47$ & $13,74 \%$ & 280.146 & 36,22 \\
\hline Ninh Bình & 961.900 & $2.996,39$ & $20,91 \%$ & 342.599 & 35,62 \\
\hline Nam Định & 1.853 .300 & $3.324,05$ & $18,30 \%$ & 656.294 & 35,41 \\
\hline Hải Dương & 1.797 .300 & $3.432,94$ & $25,20 \%$ & 631.175 & 35,12 \\
\hline Quảng Trị & 627.300 & $2.157,17$ & $29,97 \%$ & 219.250 & 34,95 \\
\hline Hà Tĩnh & 1.272 .200 & $2.241,21$ & $18,27 \%$ & 432.537 & 34,00 \\
\hline Kon Tum & 520.000 & $2.060,55$ & $35,54 \%$ & 173.795 & 33,42 \\
\hline Đắk Nông & 625.600 & $2.453,42$ & $15,20 \%$ & 207.902 & 33,23 \\
\hline
\end{tabular}




\begin{tabular}{|l|r|r|r|r|c|}
\hline \multicolumn{1}{|c|}{ Tỉnh thành xếp theo Mcir100 } & Dân số & $\begin{array}{c}\text { Thu nhập } \\
\text { bình quân } \\
\text { nhân } \\
\text { khẩu 1 } \\
\text { tháng }\end{array}$ & $\begin{array}{c}\text { Mức đô } \\
\text { thị hóa }\end{array}$ & $\begin{array}{c}\text { Tổng số } \\
\text { xe máy } \\
\text { lưu thông }\end{array}$ & $\begin{array}{c}\text { Số xe máy } \\
\text { lưu thông } \\
\text { trên 100 } \\
\text { người dân }\end{array}$ \\
\cline { 2 - 6 } Quảng Bình & 882.500 & $2.385,63$ & $19,69 \%$ & $\mathbf{2 9 1 . 4 7 1}$ & 33,03 \\
\hline Cao Bằng & 535.400 & $1.678,34$ & $23,18 \%$ & $\mathbf{1 7 6 . 1 0 3}$ & 32,89 \\
\hline Hà Nam & 805.700 & $2.951,32$ & $15,76 \%$ & $\mathbf{2 6 3 . 9 8 5}$ & 32,76 \\
\hline Quảng Ninh & 1.243 .600 & $3.966,75$ & $63,61 \%$ & $\mathbf{4 0 6 . 1 7 8}$ & 32,66 \\
\hline Bắc Kạn & 323.200 & $1.548,58$ & $18,78 \%$ & $\mathbf{1 0 5 . 0 9 7}$ & 32,52 \\
\hline Hoà Bình & 838.800 & $2.033,54$ & $14,77 \%$ & $\mathbf{2 7 0 . 6 6 9}$ & 32,27 \\
\hline Yên Bái & 807.300 & $1.842,83$ & $20,56 \%$ & $\mathbf{2 5 7 . 1 7 2}$ & 31,86 \\
\hline Sóc Trăng & 1.314 .300 & $2.549,08$ & $30,60 \%$ & $\mathbf{4 1 6 . 1 1 3}$ & 31,66 \\
\hline Lạng Sơn & 778.400 & $1.811,15$ & $19,81 \%$ & $\mathbf{2 4 4 . 9 4 4}$ & 31,47 \\
\hline Gia Lai & 1.437 .400 & $2.185,60$ & $30,10 \%$ & $\mathbf{4 4 9 . 9 9 2}$ & 31,31 \\
\hline Kiên Giang & 1.792 .600 & $3.248,18$ & $29,48 \%$ & $\mathbf{5 3 5 . 7 6 1}$ & 29,89 \\
\hline Thanh Hoán & 3.544 .400 & $2.224,03$ & $17,19 \%$ & $\mathbf{1 . 0 3 2 . 7 5 1}$ & 29,14 \\
\hline Bạc Liêu & 894.300 & $2.691,79$ & $29,29 \%$ & $\mathbf{2 6 0 . 3 4 1}$ & 29,11 \\
\hline Lào Cai & 694.400 & $1.907,20$ & $22,87 \%$ & $\mathbf{2 0 1 . 4 9 6}$ & 29,02 \\
\hline Nghệ An & 3.131 .300 & $2.007,40$ & $15,08 \%$ & $\mathbf{8 9 8 . 5 3 1}$ & 28,70 \\
\hline Cà Mau & 1.226 .300 & $2.612,99$ & $22,69 \%$ & $\mathbf{3 3 3 . 4 0 1}$ & 27,19 \\
\hline Sơn La & 1.228 .900 & $1.433,53$ & $13,63 \%$ & $\mathbf{3 2 3 . 1 1 7}$ & 26,29 \\
\hline Điện Biên & 567.000 & $1.367,98$ & $15,10 \%$ & $\mathbf{1 3 0 . 8 6 5}$ & 23,08 \\
\hline Lai Châu & 446.100 & $1.327,42$ & $17,35 \%$ & $\mathbf{9 4 . 8 2 8}$ & 21,26 \\
\hline Hà Giang & 833.500 & $1.398,31$ & $15,00 \%$ & $\mathbf{1 7 1 . 4 3 0}$ & 20,57 \\
\hline
\end{tabular}

\begin{tabular}{|l|r|r|r|r|c|}
\hline Đông Nam Bộ & 16.739 .600 & $\mathbf{5 . 1 0 6 , 7 7}$ & $\mathbf{6 2 , 6 6 \%}$ & $\mathbf{8 . 6 3 2 . 0 6 5}$ & $\mathbf{5 1 , 5 7}$ \\
\hline Toàn quốc & $\mathbf{9 3 . 6 7 1 . 6 0 0}$ & $\mathbf{3 3 8 7 , 1 2}$ & $\mathbf{3 5 , 0 3 \%}$ & $\mathbf{3 6 . 6 1 9 . 5 5 1}$ & 39,09 \\
\hline Đồng bằng sông Hồng & 21.342 .100 & $\mathbf{4 . 2 5 9 , 1 9}$ & $\mathbf{3 8 , 1 8 \%}$ & $\mathbf{8 . 0 8 9 . 8 4 0}$ & 37,91 \\
\hline $\begin{array}{l}\text { Bắc Trung Bộ và Duyên hải miền } \\
\text { Trung }\end{array}$ & 19.924 .500 & $\mathbf{2 . 5 7 4 , 0 6}$ & $\mathbf{2 8 , 6 9 \%}$ & $\mathbf{7 . 3 3 6 . 8 2 0}$ & $\mathbf{3 6 , 8 2}$ \\
\hline Đồng bằng sông Cửu Long & 17.738 .000 & $\mathbf{3 . 0 0 6 , 3 7}$ & $\mathbf{2 5 , 5 2 \%}$ & $\mathbf{6 . 5 1 1 . 1 1 6}$ & $\mathbf{3 6 , 7 1}$ \\
\hline Tây Nguyên & $\mathbf{5 . 7 7 8 . 5 0 0}$ & $\mathbf{2 . 5 9 5 , 8 1}$ & $\mathbf{2 9 , 2 2 \%}$ & $\mathbf{2 . 1 1 9 . 0 8 7}$ & $\mathbf{3 6 , 6 7}$ \\
\hline Trung du và miền núi phía Bắc & 12.148 .900 & $\mathbf{2 . 1 0 9 , 2 9}$ & $\mathbf{1 8 , 4 7 \%}$ & $\mathbf{3 . 9 3 0 . 6 2 4}$ & $\mathbf{3 2 , 3 5}$ \\
\hline
\end{tabular}

File: ZZb MC Number 2018

Nguồn: Nhóm Nghiên cứu 
Bảng 3-48 P11-Số liệu phương tiện Hà Nội 2015-2018

\begin{tabular}{|c|c|c|c|c|c|c|}
\hline \multirow{2}{*}{ Năm } & \multicolumn{7}{|c|}{ Số phương tiện quản lý } \\
\cline { 2 - 7 } & Tổng số & Ô tô & Xe máy & Xích lô & Ô tô điện & Xe máy điện \\
\hline 2015 & 5.592 .008 & 546.057 & 5.045 .672 & 209 & 70 & NA \\
\hline 2016 & 5.857 .301 & 607.227 & 5.249 .802 & 202 & 70 & 110.945 \\
\hline 2017 & 6.152 .819 & 669.216 & 5.483 .313 & 202 & 88 & 134.092 \\
\hline 2018 & 6.403 .945 & 717.172 & 5.686 .501 & 202 & 70 & 144.639 \\
\hline
\end{tabular}

\begin{tabular}{|c|c|c|c|c|c|}
\hline \multirow{2}{*}{ Năm } & \multicolumn{5}{|c|}{ So sánh cùng kỳ năm trước } \\
\cline { 2 - 6 } & $\hat{\text { Ô tô }}$ & Xe máy & Xich lô & Ô tô điện & Xe máy điện \\
\hline 2015 & $8,80 \%$ & $3,70 \%$ & $-1,90 \%$ & $40 \%$ & $0 \%$ \\
\hline 2016 & $11,20 \%$ & $4,00 \%$ & $-3,30 \%$ & $0 \%$ & $100 \%$ \\
\hline 2017 & $10,20 \%$ & $4,40 \%$ & $0 \%$ & $25,70 \%$ & $20,90 \%$ \\
\hline 2018 & $7,20 \%$ & $3,70 \%$ & $0 \%$ & $-20,50 \%$ & $7,90 \%$ \\
\hline
\end{tabular}

Nguồn: CSGT TP Hà Nội

Bảng 3-49 P12-GDP đầu người (USD/người)

\begin{tabular}{|c|c|}
\hline Năm & $\begin{array}{c}\text { Nguồn: Ngân } \\
\text { hăng thế giới }\end{array}$ \\
\hline 1985 & 230,87 \\
\hline 1986 & 421,66 \\
\hline 1987 & 573,85 \\
\hline 1988 & 389,26 \\
\hline 1989 & 94,27 \\
\hline 1990 & 94,88 \\
\hline 1991 & 137,98 \\
\hline 1992 & 138,72 \\
\hline 1993 & 181,65 \\
\hline 1994 & 220,31 \\
\hline 1995 & 275,75 \\
\hline 1996 & 322,86 \\
\hline 1997 & 346,58 \\
\hline 1998 & 346,83 \\
\hline 1999 & 361,29 \\
\hline 2000 & 388,27 \\
\hline 2001 & 402,83 \\
\hline 2002 & 427,84 \\
\hline
\end{tabular}

\begin{tabular}{|c|c|c|c|}
\hline \multirow{2}{*}{ Năm } & $\begin{array}{c}\text { Nguồn: Ngân } \\
\text { hàng thế giới }\end{array}$ & \multicolumn{2}{|c|}{$\begin{array}{c}\text { Nguồn: Niên giam } \\
\text { thống kế năm }\end{array}$} \\
\hline 2003 & 477,99 & 492 & 2007 \\
\hline 2004 & 543,87 & 553 & 2007 \\
\hline 2005 & 683,60 & 700 & 2013 \\
\hline 2006 & 779,97 & 723 & 2007 \\
\hline 2007 & 901,32 & 843 & 2010 \\
\hline 2008 & $1.143,27$ & 1.052 & 2010 \\
\hline 2009 & $1.210,69$ & 1.064 & 2010 \\
\hline 2010 & $1.310,37$ & 1.273 & 2013 \\
\hline 2011 & $1.515,48$ & 1.517 & 2013 \\
\hline 2012 & $1.722,68$ & 1.749 & 2013 \\
\hline 2013 & $1.871,33$ & 1.907 & 2013 \\
\hline 2014 & $2.012,05$ & 2.052 & 2017 \\
\hline 2015 & $2.065,17$ & 2.109 & 2017 \\
\hline 2016 & $2.170,65$ & 2.215 & 2017 \\
\hline 2017 & $2.343,12$ & 2.389 & 2017 \\
\hline Bình quân 2003-2017 & $\mathbf{1 . 3 8 3 , 4 4}$ & $\mathbf{1 . 3 7 6}$ & \\
\hline 2018 & & 2.578 & Bộ KH-ĐT \\
\hline & & \multicolumn{2}{|c|}{} \\
\hline
\end{tabular}




\section{KINH NGHIỆ QUỐC TỀ VỀ ĐẢM BẢO AN TOÀN GIAO THÔNG XE MÁY}

\subsection{Tình hình tai nạn giao thông xe máy}

Trong khi vấn đề người đi ô tô chết vì tai nạn giao thông đường bộ là vấn đề bất cập ở nhiều nơi trên thế giới thì tại khu vực Đông Nam Á và phía tây Thái Bình Dương lại đang đối mặt với những bất cập liên quan tới người đi xe máy. Trên thế giới, người đi xe máy chiếm khoảng $23 \%$ tổng số người chết vì tai nạn giao thông đường bộ (WHO, 2015). Tuy nhiên, con số cụ thể ở từng khu vực lại có sự chênh lệch. Cụ thể, tỷ lệ người đi xe máy chết ở Đông Nam Á và tây Thái Bình Dương là $34 \%$, tron gkhi tỷ lệ này ở Châu Phi chỉ là $7 \%$ và ở Châu Âu là $9 \%$. Kết quả này là dễ hiểu do xe máy ở khu vực Đông Nam Á phổ biến hơn nhiều so với các khu vực khác.

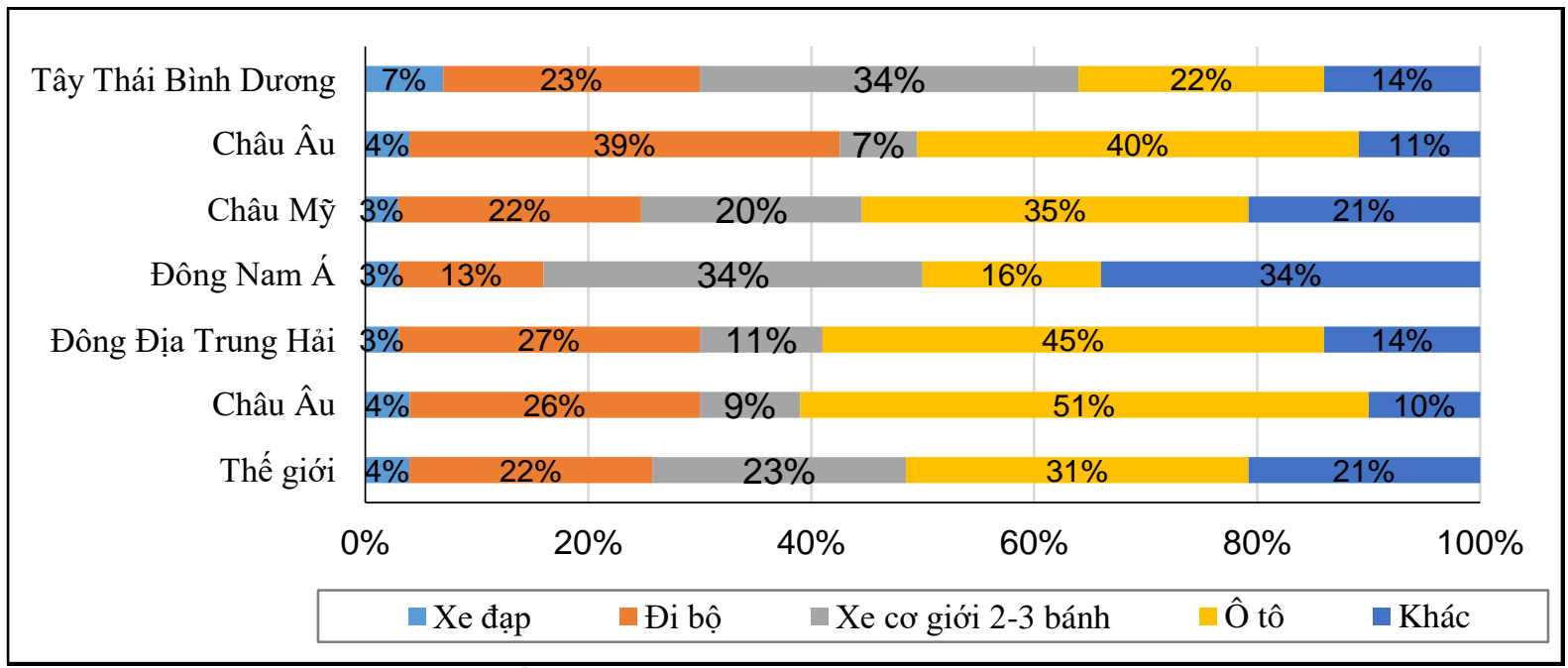

Hình 4-1 Tỷ lệ người chết vì tai nạn giao thông đường bộ theo loại phương tiện

Nguồn: (WHO, 2015)

Số người đi xe máy tử vong vì tai nạn giao thông đường bộ là vấn đề nghiêm trọng bậc nhất ở Đông Nam Á. Phần sau đây trình bày cụ thể hơn về vấn đề này ở khu vực Đông Nam Á cũng như khu vực Đông Á.

\subsubsection{Tỷ lệ người đi xe máy chết ở Đông Nam Á}

Hình sau đây cho thấy tỷ lệ người đi xe máy chết chiếm mức cao nhất ở phần lớn các nước ASEAN. Ví dụ như vào năm 2013, số người đi xe máy bị chết vì tai nạn giao thông đường bộ ở Campuchia lên tới $70,4 \%$. Tuy nhiên, cũng có thể thấy xu hướng giảm tỷ lệ tử vong của người đi xe máy ở Indonesia và Singapore, cụ thể là Indonesia đã giảm mạnh từ 61\% năm 2007 xuống còn $36 \%$ năm 2015. 


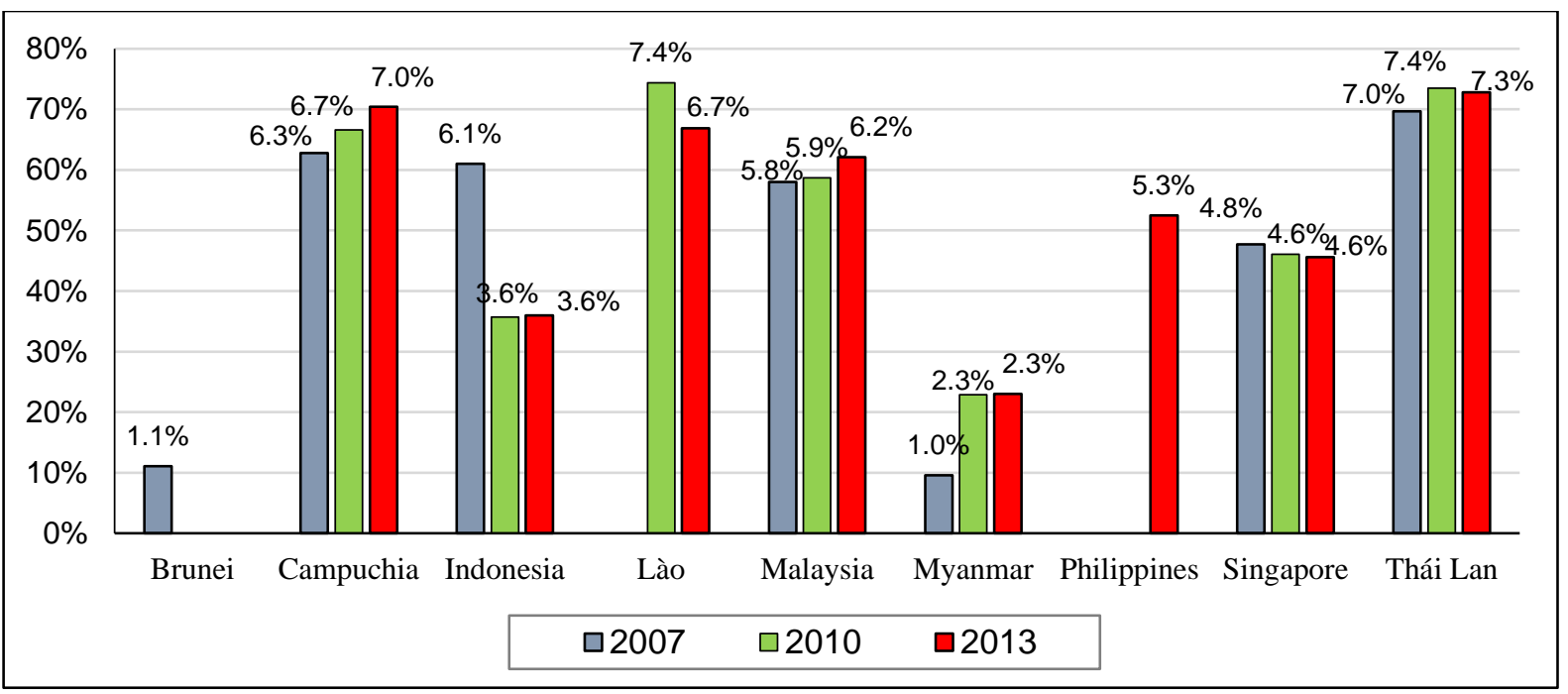

\section{Hình 4-2 Tỷ lệ tử vong của người đi xe máy tại các quốc gia ASEAN}

Nguồn: (WHO, 2009, 2013, 2015)

\subsubsection{Tỷ lệ người đi xe máy chết ở Đông Á}

Nhìn chung, lượng người đi xe máy tử vong do tai nạn giao thông đường bộ ở khu vực Đông Á đang giảm. Cụ thể ở Nhật Bản, tỷ lệ người đi xe máy tử vong do tai nạn giao thông đường bộ chiếm 34,5\% vào năm 2007, tuy nhiên tới năm 2013 con số này đã giảm xuống còn 19,7\%. Điều này là dễ hiểu vì ở các quốc gia Đông Á người dân chủ yếu sử dụng xe ô tô làm phương tiện đi lại hàng ngày.

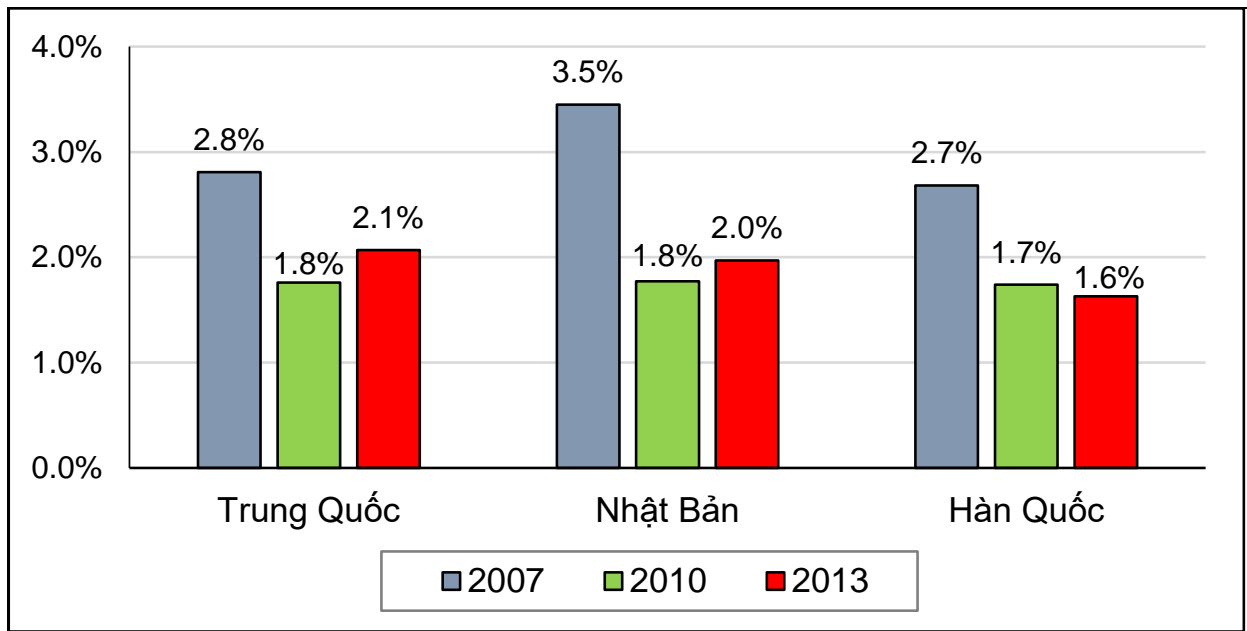

Hình 4-3 Tỷ lệ người đi xe máy tử vong ở khu vụ̣c Đông Á

Nguồn: (WHO, 2009, 2013, 2015)

4.2 Tổng quan về Kế hoạch An toàn Giao thông Đường bộ Quốc gia tại các nước ASEAN

\subsubsection{Các hướng tiếp cận khác nhau trong chiến lược an toàn giao thông}

Nhìn chung, hệ thống đường bộ gồm 3 yếu tố chính: người tham gia giao thông, mạng lưới đường và các loại phương tiện đường bộ. Tai nạn giao thông đường bộ có thể bắt nguồn từ lỗi của các yếu tố này. Cần xem xét tất cả các yếu tố này của hệ thống đường bộ để phòng tránh 
tai nạn giao thông. Nói cách khác, bất cứ nỗ lực nào nhằm phòng chống tai nạn giao thông cần được thực hiện dưới một quan điểm mang tính hệ thống. Quan điểm mang tính hệ thống này có thể được diễn giải trong 3 cách tiếp cận khác nhau, đó là $3 \mathrm{E}$ (chữ đầu của Education - giáo dục, Engineering - các biện pháp kỹ thuật và Enforcement - thực thi luật lệ), Hệ thống an toàn và hướng tiếp cận dựa vào 5 trụ cột.

\subsubsection{Hướng tiếp cận $3 E$}

Hướng tiếp cận $3 \mathrm{E}$ (giáo dục - thực thi luật lệ và các biện pháp kỹ thuật) được áp dụng để giải quyết vấn đề tai nạn giao thông đường bộ trong các chính sách và chương trình an toàn giao thông đường bộ.

Theo Sổ tay Kỹ thuật Giao thông năm 2008 của Nhật Bản, tai nạn giao thông được định nghĩa là tình huống không mong muốn xảy ra liên quan đến các yếu tố sau: con người - phương tiện và hạ tầng đường bộ (Nishiuchi, 2014). Để phòng tránh tai nạn giao thông, cần có các biện pháp tương ứng cho từng yếu tố này (xem Hình bên dưới). Trước hết, "các biện pháp kỹ thuật" sẽ tập trung vào hạ tầng đường bộ và phương tiện. Nhìn chung, các biện pháp này được thực hiện dưới hình thức quản lý giao thông và các kỹ thuật đảm bảo giao thông nhưng hầu hết đều liên quan tới việc lắp đặt các công trình an toàn giao thông. Các ủy ban an toàn công cộng thường lắp đặt các thiết bị đảm bảo an toàn giao thông như đèn tín hiệu giao thông, các biển báo quy định, sơn vạch kẻ đường và trung tâm kiểm soát giao thông. Ngoài ra, đơn vị quản lý đường bộ chịu trách nhiệm về các công trình đảm bảo an toàn như cầu đi bộ, vỉa hè, tín hiệu cảnh báo, sơn vạch kẻ đường, rào chắn, đèn đường, giải phân cách và gương an toàn giao thông. Bên cạnh đó, các biện pháp "thực thi luật lệ" và "tuyên truyền giáo dục" sẽ tập trung vào người tham gia giao thông - một trong 3 yếu tố liên quan đến tai nạn giao thông. Các biện pháp "thực thi luật lệ" có nghĩa làm đảm bảo luật được thực thi (nói cách khác là kiểm soát giao thông và thực thi luật lệ) nhưng nếu khuyến khích và duy trì các hành vi và thái độ giao thông phù hợp được xem là biện pháp giáo dục thì thực thi luật lệ cũng có thể coi là một phần của giáo dục. Các biện pháp giáo dục về an toàn giao thông chủ yếu tập trung vào các vấn đề thực thi luật lệ từ góc độ giáo dục.

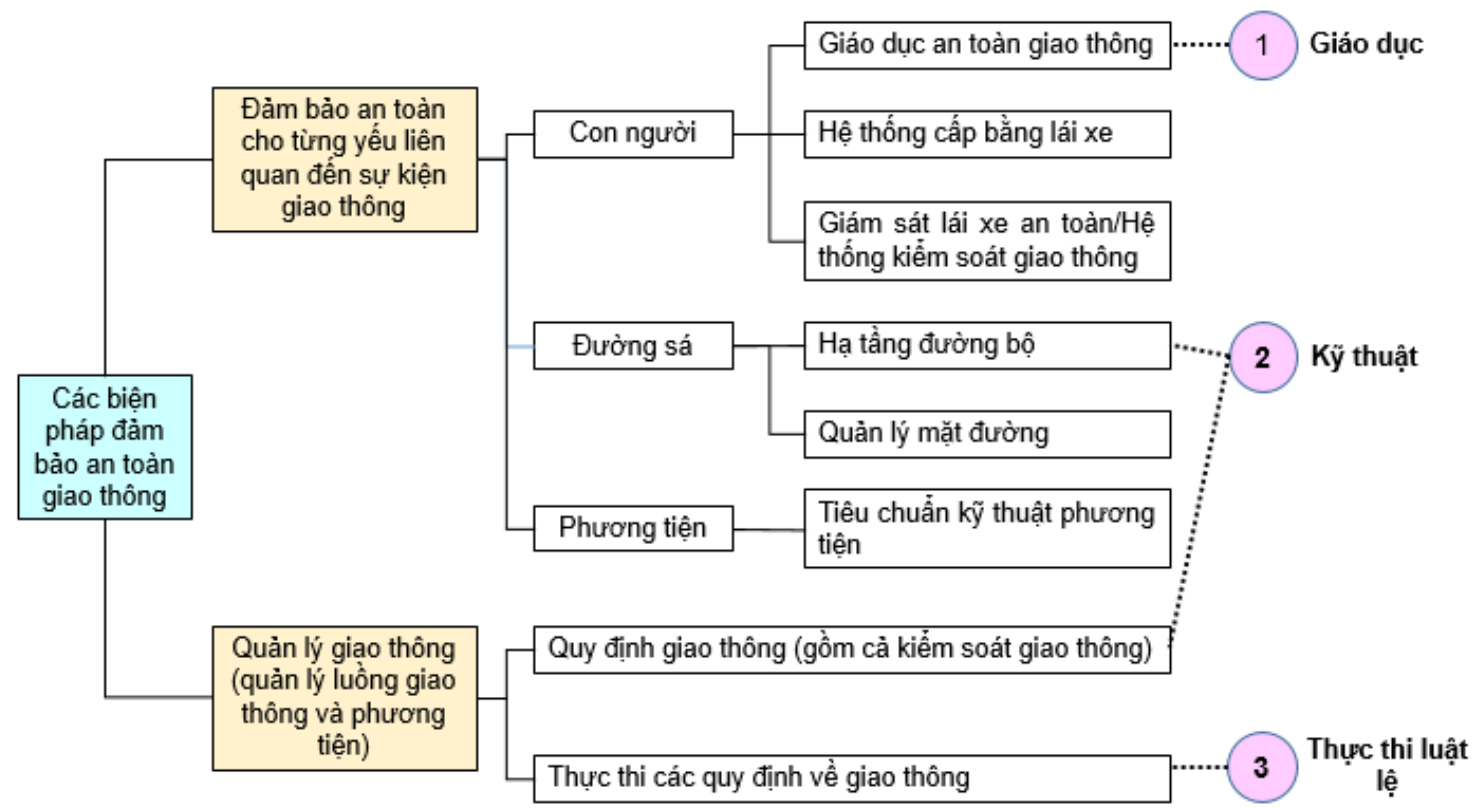

Hình 4-4 Hướng dẫn Hướng tiếp cận 3E về an toàn giao thông ở Nhật Bản

Nguồn: (Nishiuchi, 2014) 


\subsubsection{Hướng tiếp cận Hệ thống an toàn}

Phần trên đã đề cập đến $3 \mathrm{E}$ - các biện pháp kỹ thuật, thực thi luật lệ và tuyên truyền, giáo dục. Hướng tiếp cận này đã đưa ra một bộ khung hữu ích để cải thiện an toàn giao thông nhưng không xem xét chi tiết các nhóm, vấn đề và rủi ro cụ thể (DfT, 2011). Hiện tại, hướng tiếp cận để cải thiện an toàn giao thông đường bộ dựa vào kinh nghiệm của các nước đảm bảo an toàn giao thông tốt nhất (ví dụ như Hà Lan, Thụy Điển, New Zealand và Úc) là Hướng tiếp cận hệ thống an toàn (GIZ, 2017). Theo Báo cáo của Diễn đàn Giao thông Quốc tế năm 2016, "Hệ thống an toàn" là:

- Tầm nhìn hoặc mục tiêu hướng tới không có người chết và bị thương nặng do tai nạn;

- Bốn nguyên tắc hướng dẫn thiết kế, khai thác và sử dụng hệ thống đường với mục tiêu hướng tới chấm dứt tình trạng người bị chết và bị thương nặng do tai nạn giao thông;

- Thực hiện các biện pháp, công cụ và mối quan hệ giữa các yếu tố này trên các nguyên tắc để đạt mục tiêu trên.

Hướng tiếp cận Hệ thống an toàn bắt đầu được phát triển từ năm 1995 bởi Cơ quan Quản lý Đường bộ Thụy Điển (Belin et al., 2012). Kết quả được tổng hợp trong Biên bản ghi nhớ có tên gọi "Vision Zero - Ý tưởng về hệ thống giao thông đường bộ không có thiệt hại về con người". Vision Zero bao gồm hướng tiếp cận "hệ thống an toàn" để giảm thiểu khả năng dẫn đến chết người hoặc bị thương nặng khi xảy ra tai nạn (GIZ, 2017). Đây là cách tiếp cận mang tính cách mạng về an toàn cho người tham gia giao thông giúp Thuy Điển giảm mạnh số người bị chết và thương nặng do tai nạn giao thông đường bộ (Khorasani-Zavareh, 2011). Đây là chính sách an toàn giao thông đường bộ đặt trọng tâm vào việc bảo vệ những người tham gia giao thông đường bộ dễ bị tổn thương nhất.

Các hệ thống giao thông thường được thiết kế để đảm bảo công suất và khả năng cơ động tối đa chứ không phải đảm bảo an toàn tuyệt đối (GIZ, 2017). Điều này có nghĩa là người sử dụng giao thông trước đây phải chịu trách nhiệm về sự an toàn của chính họ. Sáng kiến Vision Zero có cách tiếp cận ngược lại. Trách nhiệm đảm bảo an toàn giao thông chính được xác định từ lúc thiết kế hệ thống. Mục tiêu đặt ra là không ai bị chết hoặc bị thương nặng khi tham gia giao thông do các thành phần của hệ thống được thiết kế để phòng tránh tai nạn chết người hoặc gây thương tích nghiêm trọng. Điều này có thể được thực hiện thông qua các thiết kế an toàn hơn.

Do đó, Hướng tiếp cận hệ thống an toàn có nghĩa là chuyển trách nhiệm chính từ người tham gia giao thông sang người thiết kế hệ thống giao thông đường bộ (WHO, 2011). Các bên thiết kế hệ thống, chủ yếu gồm cơ quan quản lý đường bộ, ngành công nghiệp ô tô, cảnh sát, chính trị gia và các cơ quan lập pháp. Tuy nhiên, còn có rất nhiều bên liên quan khác cũng có trách nhiệm về an toàn giao thông đường bộ như y tế, hệ thống tòa án, trường học và các tổ chức phi chính phủ. Cá nhân người tham gia giao thông cũng có trách nhiệm tuân thủ luật lệ và quy định. Đơn vị thiết kế hệ thống chịu trách nhiệm chính và kết quả do môi trường thay đổi được coi trọng hơn yếu tố con người (Khorasani-Zavareh, 2011). Hệ thống giao thông đường bộ cần xem xét những lỗi mà con người gây ra và có thể tiếp nhận lỗi trong hệ thống giao thông đường bộ nhằm phòng tránh tai nạn gây thương tích nặng hoặc chết người.

Nguyên tắc cơ bản là con người luôn có thể phạm lỗi và do đó, cần đảm bảo rằng khi tai nạn xảy ra có thể dẫn đến chết người hoặc bị thương nặng phải được giảm thiểu và thiết kế hệ thống cần xem xét đảm bảo việc giảm thiểu này $(\mathrm{GIZ}, 2017)$. Do đó, hướng tiếp cận hệ thống an toàn tìm cách xác định và điều chỉnh các nguyên nhân dẫn đến lỗi hoặc những hạn chế trong thiết kế có thể dẫn đến tai nạn chết người hoặc bị thương nặng cũng như giảm thiểu mức độ nguy hiểm và hậu quả của tai nạn. Tất cả các thành phần của một hệ thống đề phòng có lỗi khi một 
va chạm nghiêm trọng xảy ra. Mục tiêu là hiểu rõ việc con người thường hay mắc lỗi và xây dựng hệ thống quanh nhận thức này (DfT, 2011).

Có bốn nguyên tắc thuộc hệ thống an toàn (ITF, 2016):

- Mọi người có thể phạm lỗi dẫn đến tai nạn đường bộ.

- Thân thể con người có khả năng hạn chế trong việc tránh lực tác động trước khi thiệt hại xảy ra.

- Trách nhiệm chung giữa các bên thiết kế, xây dựng, quản lý và sử dụng đường, phương tiện và cung cấp dịch vụ chăm sóc sau khi tai nạn xảy ra để tránh dẫn tới bị thương nặng hoặc chết người.

- Tất cả các phần của hệ thống phải được tăng cường để tối ưu hóa tác động; và nếu 1 bộ phận bị lỗi, người tham gia giao thông vẫn được bảo vệ.

Theo Quỹ Toward-Zero Foundation, Hệ thống an toàn gồm 5 hợp phần chính như sau (xem Hình dưới):

- Đường bộ an toàn hơn: Hạ tầng đường bộ và đặc điểm đường bộ đóng vai trò then chốt trong việc giảm thiểu tai nạn và/hoặc số người bị thương trong trường hợp xảy ra tai nạn. Hạ tầng được cải thiện góp phần giảm số vụ tai nạn và số người bị thương, đây cũng là vấn đề chính trong mục tiêu giảm thiểu chấn thương lâu dài một cách bền vững.

- Phương tiện an toàn hơn: Phương tiện an toàn đóng vai trò quan trọng trong việc giảm thương chấn. Phương tiện được thiết kế tốt với các công nghệ an toàn có thể phòng chống tai nạn hoặc giảm hoặc tiếp nhận một số lực khi va chạm xảy ra, giúp giảm thiểu rủi ro về sức khỏe và thương chấn nặng.

- Người dân an toàn hơn: Do yếu tố con người là đối tượng thường để xảy ra lỗi nên người tham gia giao thông an toàn là một phần quan trọng của hệ thống đường bộ an toàn, đặc biệt là trong giai đoạn chuyển tiếp khi hệ thống đang được xây dựng. Người tham gia giao thông, với khả năng tốt nhất của mình, cần điều khiển phương tiện trong phạm vi ranh giới do đơn vị thiết kế hệ thống đường xây dựng.

- Tốc độ an toàn hơn: Để xây dựng hệ thống đường bộ an toàn, giới hạn tốc độ cần được xác định phù hợp và có hướng dẫn dựa vào hiểu biết về phản ứng của cơ thể con người trước các lực từ bên ngoài cũng như đảm bảo tuân thủ các giới hạn đã đặt ra. Giới hạn tốc độ phù hợp được xác định và tuân thủ tốt góp phần nâng cao hiệu quả của các sáng kiến thực hiện trên đường hoặc trong không gian của phương tiện.

- Chăm sóc sau tai nạn: Chăm sóc sau tai nạn là một phần quan trọng của hệ thống đường bộ an toàn. Trong trường hợp xảy ra tai nạn, chăm sóc sau tai nạn hiệu quả, bao gồm cấp cứu và chăm sóc, khôi phục sau chấn thương có thể giảm rủi ro dần đến chết người hoặc thương tật nghiêm trọng.

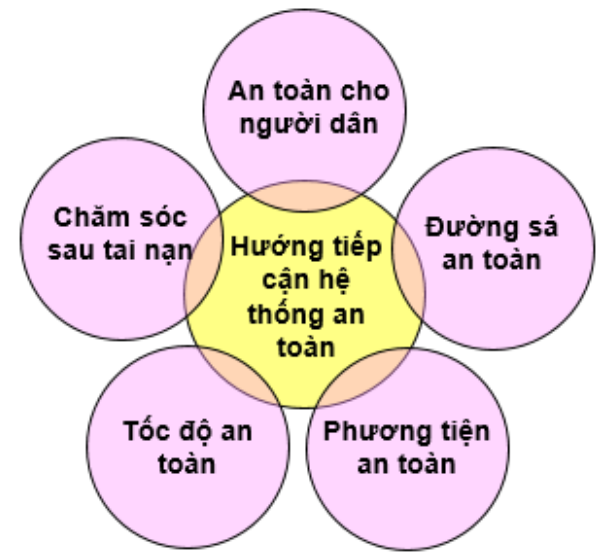

Hình 4-5 Hướng tiếp cận hệ thống an toàn đảm bảo an toàn giao thông đường bộ 
Theo báo cáo của Tổ chức Y tế Thế giới, mỗi năm có trên 1,2 triệu người chết vì tai nạn giao thông đường bộ trên thế giới (WHO, 2015). Do đó, tai nạn giao thông đường bộ được xem là nguyên nhân hàng đầu dẫn đến tử vong trên toàn cầu, đặc biệt là ở các nước có thu nhập thấp và trung bình. Cụ thể, $90 \%$ số người chết vì tai nạn giao thông đường bộ thuộc các nước có thu nhập thấp và trung bình mặc dù các nước này chỉ chiếm $54 \%$ tổng số phương tiện giao thông đăng ký trên thế giới. Hướng tiếp cận hệ thống an toàn đã được áp dụng ở các nước có mức thu nhập cao. Tuy nhiên, điều đáng chú ý là hướng tiếp cận hệ thống an toàn phù hợp cho tất cả các nước và hướng tiếp cận này có thể chuyển giao cho các nước có thu nhập trung bình và thấp (GIZ, 2017; Khorasani-Zavareh, 2011; ITF, 2008). Theo đó, ở các nước này, nếu sự an toàn vốn có của hệ thống (thiết khế đường và phương tiện an toàn) không thể thay đổi, thì cách duy nhất để giảm tai nạn giao thông đường bộ là giảm tốc độ. Nguyên tắc cơ bản của Hệ thống an toàn (hoặc Vision Zero) có thể được sử dụng trong bất cứ loại hệ thống giao thông đường bộ nào, ở bất kỳ giao đoạn phát triển nào. Ví dụ, Wegman et al. (2017) đề xuất rằng Chính phủ Myanmar cần áp dụng Hướng tiếp cận hệ thống an toàn ngay từ khi bắt đầu xây dựng chiến lược an toàn đường bộ và xây dựng các chính sách can thiệp từ hướng tiếp cận này, và đặc biệt quan trọng hơn là hướng tiếp cận này phù hợp với giai đoạn phát triển trong phát triển an toàn đường bộ của Myannmar và văn hóa của quốc gia này.

\subsubsection{Hướng tiếp cận 5 trụ cột}

Để giảm thiểu gánh nặng toàn cầu do tai nạn giao thông đường bộ gây ra, Chương trình mục tiêu toàn cầu về phát triển bền vững của Liên Hợp Quốc đã đặt mục tiêu tham vọng giảm số người chết và bị thương nặng xuống còn $50 \%$ vào năm (WHO, 2015). Mục tiêu toàn cầu cho thấy kế hoạch hành động mạnh mẽ nhất của Liên Hợp quốc nhằm thúc đẩy an toàn giao thông đường bộ và đưa ra các giải pháp cấp bách để thực hiện Kế hoạch toàn cầu cho Thập kỷ Hành động (Feest et al., 2015). Cần có cách thức mới và chiến lược mới về phòng chống tai nạn giao thông đường bộ để đạt mục tiêu tham vọng của Liên Hợp quốc. Trong những năm gần đây, WHO đã ủng hộ hướng tiếp cận hệ thống an toàn trong quản lý an toàn giao thông đường bộ (WHO, 2013, 2015).

Ban Phối hợp An toàn giao thông Đường bộ của Liên Hợp Quốc đã xây dựng Kế hoạch toàn cầu cho thập kỷ hành động về An toàn giao thông đường bộ 2011-2020. Cũng cần chú ý rằng Kế hoạch cho thập kỷ hoạt động bao hàm những nội dung được đưa ra trong Hướng tiếp cận Hệ thống an toàn (WHO, 2011). Kế hoạch đưa ra khung tổng thể cho các hoạt động có thể thực hiện trong bối cảnh một thập kỷ. Cụ thể, có 5 trụ cột hoạt động ở cấp quốc gia (xem Hình dưới) như sau:

- Trụ cột 1 (Quản lý an toàn giao thông đường bộ): Tuân thủ và/hoặc thực hiện đầy đủ các công cụ pháp lý của Liên Hợ Quốc và khuyến khích sáng tạo các công cụ an toàn của vùng;

- Trụ cột 2 (Đường bộ và di chuyển an toàn): Nâng cao chất lượng an toàn và khả năng bảo vệ của mạng lưới đường bộ vì lợi ích của tất cả mọi người tham gia giao thông, đặc biệt là các đối tượng dễ bị tổn thương (người đi bộ, người sử dụng xe đạp và xe máy);

- Trụ cột 3 (Phương tiện an toàn hơn): Khuyến khích áp dụng thống nhất các công nghệ tiên tiến trong chế tạo phương tiện để đảm bảo an toàn chủ động và thụ động thông qua việc kết hợp hài hòa các tiêu chuẩn toàn cầu, kế hoạch thông tin khách hàng và các chính sách khuyến khích thúc đẩy áp dụng các công nghệ mới;

- Trụ cột 4 (Người sử dụng đường an toàn hơn): Xây dựng các chương trình tổng thể để cải thiện hành vi của người tham gia giao thông. Thường xuyên hoặc tăng cường thực thi luật lệ, tiêu chuẩn, kết hợp với việc giáo dục/nâng cao nhận thức của cộng đồng để nâng tỷ 
lệ cài dây an toàn khi ngồi trên xe và đội mũ bảo hiểm, giảm tỷ lệ lái xe sau khi uống rượu bia, lái xe đúng tốc độ và các yếu tố rủi ro khác;

- Trụ cột 5 (Chăm sóc sau tai nạn): Nâng cao khả năng ứng phó với các trường hợp khẩn cấp sau khi tai nạn xảy ra và cải thiện năng lực của hệ thống y tế và các hệ thống khác nhằm đảm bảo cung cấp dịch vụ chăm sóc tích cực và chăm sóc phục hồi sức khỏe lâu dài cho nạn nhân của tai nạn.

Hướng tiếp cận "5 trụ cột" giống như hướng tiếp cận của "Hệ thống an toàn”.

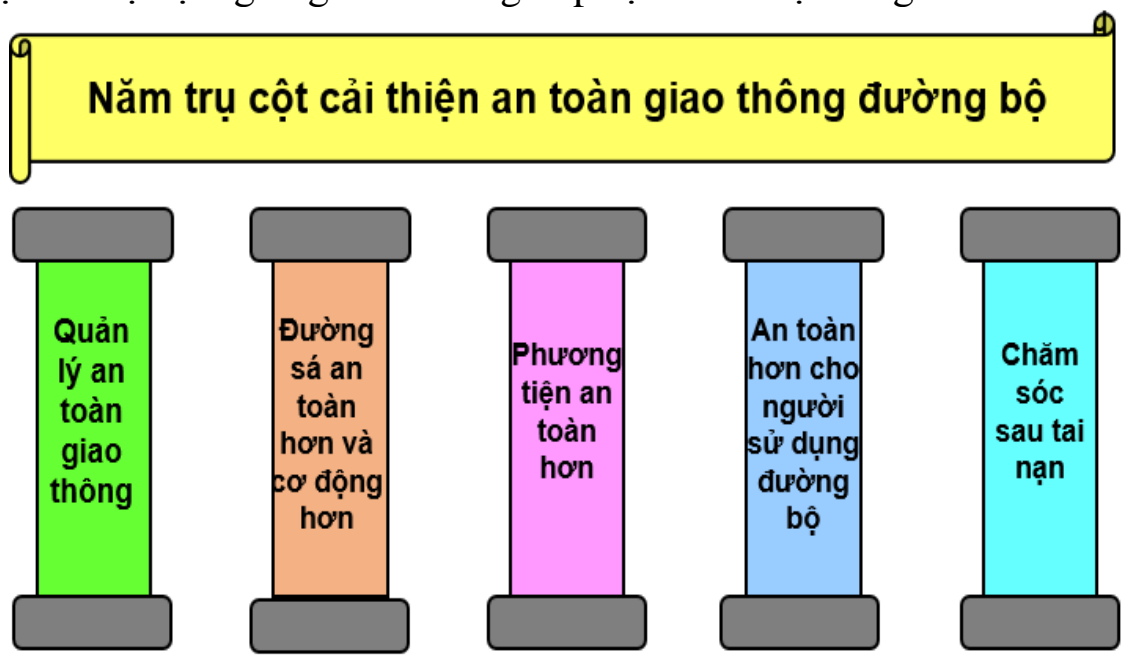

Hình 4-6 Hướng tiếp cận 5 trụ cột đảm bảo an toàn giao thông đường bộ

Trong phạm vi Chương trình một thập kỷ hành động vì an toàn đường bộ 2011-2020, các Chính phủ trên thế giới đã khuyến khích xây dựng kế hoạch quốc gia cho thập kỷ để bổ sung cho các chiến lược an toàn đường bộ quốc gia hiện có, đang thực hiện. Lý tưởng sẽ là các kế hoạch của thập kỷ hành động quốc gia phù hợp với Kế hoạch toàn cầu mặc dù cần xem xét, điều chỉnh cho phù hợp với tình hình an toàn giao thông đường bộ của từng nước.

Một số Chính phủ đã xây dựng kế hoạch quốc gia cho Thập kỷ (như Liên minh Châu Âu, Mexico, New Zealand và Panama) trong khi các chính phủ khác đang trong quá trình xây dựng kế hoạch. Một số kế hoạch bao gồm cả thời gian 10 năm trong khi một số chỉ xem xét trong khung thời gian ngắn hơn. Một số phản ánh các hoạt động ở tất cả 5 trụ cột của Kế hoạch toàn cầu trong khi một số chỉ tập trung vào một hoặc hai trụ cột. Tuy nhiên, cũng có một số triển khai kế hoạch nằm ngoài cả 5 trụ cột (WHO, 2018).

\subsubsection{Hướng tiếp cận hiện tại trong Kế hoạch an toàn giao thông của các nước ASEAN}

Phần này tổng hợp các hướng tiếp cận hiện tại trong kế hoạch đảm bảo an toàn đường bộ của các nước ASEAN và cách thức các nước ứng dụng. Chín trong tổng số mười nước đã xây dựng Kế hoạch An toàn Đường bộ riêng, ngoại trừ Singapore (xem Bảng dưới đây). Ngoài ra, hầu hết các nước ASEAN đã áp dụng hướng tiếp cận 5 trụ cột (phiên bản khác của Hướng tiếp cận hệ thống an toàn) để xây dựng kế hoạch an toàn đường bộ. 
Bảng 4-1 Kế hoạch an toàn đường bộ quốc gia của các nước ASEAN

\begin{tabular}{|c|l|c|l|}
\hline TT. & Quốc gia & $\begin{array}{c}\text { Hướng tiếp } \\
\text { cận lập kế } \\
\text { hoạch }\end{array}$ & \multicolumn{1}{c|}{ Tên kế hoạch } \\
\hline 1 & Brunei & 5 Trụ cột & Thập kỷ Dấu ảnh Hành động về An toàn Đường bộ 2011-2020 \\
\hline 2 & Cam-pu-chia & 5 Trụ cột & Chính sách An toàn Đường bộ Quốc gia tới năm 2020 \\
\hline 3 & In-đô-nê-xia & 5 Trụ cột & Quy hoạch Tồng hteer An toàn Đường bộ Quốc gia, 2011-2035 \\
\hline 4 & CHDCND Lào & 5 Trụ cột & Kế hoạch Hành động về An toàn đường bộ của Lào, 2011-2020 \\
\hline 5 & Ma-la-xia & 5 Trụ cột & Kế hoạch An toàn Đường bộ 2014-2020 \\
\hline 6 & My-an-ma & - & Kế hoạch Hành động về An toàn Đường bộ Quốc gia 2014-2020 \\
\hline 7 & Phi-lip-pin & 5 Trụ cột & Kế hoạch hành động An toàn Đường bộ, 2011-2020 \\
\hline 8 & Sin-ga-po & - & Đưa vào QHTT GVT Đường bộ 2013 \\
\hline 9 & Thái Lan & - & $\begin{array}{l}\text { Thập kỷ Hành động cho Kế hoạch Chiến lược An toàn đường bộ } \\
2012-2020\end{array}$ \\
\hline 10 & Việt Nam & - & $\begin{array}{l}\text { Chiến lược An toàn Đường bộ đến năm 2020 và tầm nhìn đến năm } \\
2030\end{array}$ \\
\hline
\end{tabular}

Nguồn: Đoàn Nghiên cứu tổng hợp từ mạng internet

Năm 2015, ASEAN đã chính thức áp dụng hướng tiếp cận 5 trụ cột trong Chiến lược An toàn Giao thông Đường bộ khu vực ASEAN (ASEAN, 2016). Chiến lược đưa ra hướng dẫn cho các kế hoạch và hoạt động đảm bảo an toàn giao thông đường bộ của các quốc gia trong Thập kỷ Hành động vì An toàn giao thông đường bộ. Hướng tiếp cận 5 trụ cột này (hay Hệ thống $\mathrm{An}$ toàn) có thể được áp dụng trong bất cứ hệ thống giao thông đường bộ nào và ở bất kỳ giai đoạn phát triển nào. Có thể chia các nước $\mathrm{ASEAN}$ thành 3 nhóm: nhóm nước có thu nhập thấp (Cambodia, Myanmar), nhóm nước có thu nhập trung bình (Indonesia, Malaysia, Thái Lan và Việt Nam), và nhóm nước có thu nhập cao (Brunei, Singapore). Phần dưới đây sẽ đưa ra cách thức áp dụng hướng tiếp cận 5 trụ cột và các bên liên quan ở một số nước ASEAN cũng như tiến độ hiện nay. Dựa vào Bảng trên, Nghiên cứu chọn 3 nước là Malaysia, Indonesia (nước có thu nhập trung bình) và Campuchia (nước có thu nhập thấp) để nghiên cứu.

\subsubsection{Malaysia}

Trong "Kịch bản theo xu hướng hiện tại/Kịch bản cơ sở”, theo đó sẽ không có sự can thiệp hoặc chương trình bổ sung nào, số người chết vì tai nạn giao thông đường bộ của Malaysia dự báo sẽ lên tới 10.716 người vào năm 2020 (RSD \& MIROS, 2014). Chiến lược đã được thông qua trong khuô khổ Kế hoạch An toàn đường bộ của Malaysia, giai đoạn 2014-2020 (dưới đây gọi tắt là RSPM 2014-2020) sẽ góp phần giảm số người chết vì tai nạn giao thông đường bộ năm 2020 xuống $50 \%$ (tức là từ 10.716 người xuống còn 5.358 người).

Tuân theo Kế hoạch toàn cầu về Thập kỷ Hành động vì an toàn giao thông đường bộ (20112020) của UN \& WHO, khung RSPM 2014-2020 gồm 5 trụ cột chiến lược (xem Hình trên). Năm trụ cột chiến lược là: 1) Quản lý an toàn đường bộ, 2) Sự di chuyển và đường bộ an toàn hơn, 3) Phương tiện an toàn hơn, 4) Người tham gia giao thông an toàn hơn và 5) Quản lý sau tai nạn. Mỗi trụ cột được xác định cụ thể hơn với các kết quả cuối cùng. Kết quả cuối cùng lại được cụ thể hóa bằng các kết quả giữa kỳ. Cụ thể, có 6 kết quả cuối cùng và 10 kết quả giữa kỳ (xem Bảng 4.2). 
Bảng 4-2 Kết quả cuối cùng và kết quả giữa kỳ của RSPM 2014-2020

\section{Kết quả cuối cùng $\quad$ Kết quả giữa kỳ}

- Hạn chế tốc độ phương tiện $\quad$ - Giảm rủi ro liên quan đến kỹ thuật thiết kế, xây dựng đường bộ

- Giảm rủi ro ho người điều - Đào tạo lái xe tốt hơn

khiển/người ngồi sau xe máy $\quad$ - Tăng tỷ lệ đội mũ bảo hiểm

- Giảm rủi ro cho người đi bộ $\quad$ - Tăng cường sự tham gia của cộng đồng

- Giảm tình trạng vượt đèn đỏ $\quad$ - Cải thiện an toàn giao thông công cộng

- Cải thiện tiêu chuẩn an toàn - Cải thiện các yêu cầu khả năng bảo vệ chủ thể bên trong khi xảy phương tiện

- Giảm rủi ro của người sử dụng xe - Cải thiện điều kiện để lưu hành ở trên đường cho các phương con tiện hiện có

- Tăng tỷ lệ cài dây an toàn khi ngồi trên xe

- Lắp đặt thiết bị giám sát tốc độ trên xe

- Cải thiện khả năng đối phó với các tình huống khẩn cấp

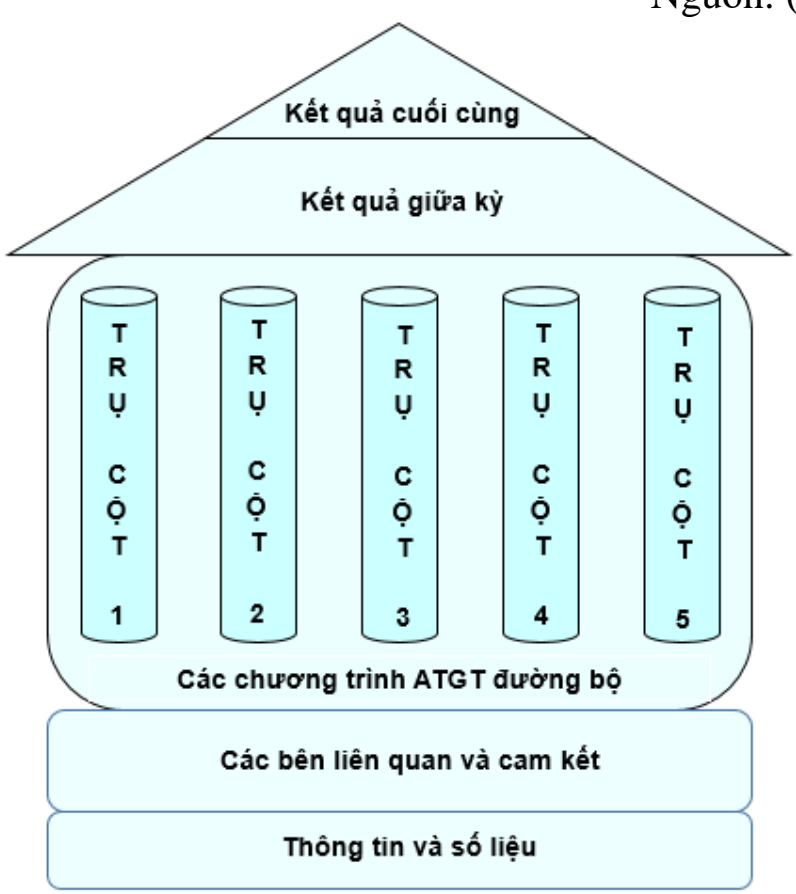

Nguồn: (RSD \& MIROS, 2014)

Trên cơ sở từng trụ cột chiến lược, rất nhiều chương trình nhằm đạt mục tiêu an toàn giao thông đường bộ sẽ được thực hiện (xem Bảng trên). Về quản lý an toàn giao thông đường bộ, 11 chương trình sẽ được thực hiện. Các chương trình này tập trung vào việc phối hợp các chương trình khác nhau, cấp vốn, hệ thống dữ liệu và đánh giá. Về sự di chuyển và đường bộ an toàn hơn, có 7 chương trình bao gồm hạn chế tốc độ trên các tuyến đường cũng như các loại phương tiện, phân luồng giao thông, tín hiệu giao thông, hạ tầng đường bộ cho xe máy, rào chắn ven đường, đánh giá tiêu chuẩn và quy định và thẩm tra an toàn giao thông đường bộ. Về phương tiện an toàn hơn, có 4 chương trình được thực hiện bao gồm: i) thực hiện các quy định của UN thông qua việc phê chuẩn loại phương tiện, ii) thực thi các tiêu chuẩn về các bộ phận của phương tiện, iii) phân tích khoảng cách giữa các quy định hiện hành và iv) đánh giá hiệu quả an toàn của phương tiện. Về trụ cột thứ 4 (người tham gia giao thông an toàn hơn), có 7 chương trình bao gồm nội dung đào tạo cho lái xe, giáo dục và nâng cao ý thức cho người dân thông qua các phương tiện thông tin đại chúng, giáo dục về an toàn giao thông đường bộ trong trường học, hệ thống xử phạt, v.v. Trong trụ cột thứ 5 , có 4 chương trình gồm cải thiện khả năng phản ứng trong trường hợp khẩn cấp hoặc tăng cường dịch vụ cấp cứu trước khi đển bệnh viện, v.v. 
Có hơn 40 bên liên quan tham gia xây dựng Kế hoạch RSPM, trong đó có 10 bộ ngành khác nhau (RSD \& MIROS, 2014). Các bên liên quan xây dựng chương trình an toàn đường bộ của mình và xác định ngân sách để thực hiện. Các chương trình được thiết kế với khung và mốc thời gian phù hợp. Mặc dù Vụ An toàn Giao thông Đường bộ của Malaysia chịu trách nhiệm chung trong việc thực hiện Kế hoạch An toàn giao thông đường bộ của Malaysia giai đoạn 2014-2020, các bên liên quan làm chủ và chịu trách nhiệm thực hiện các kế hoạch và chiến lược của mình. Họ cũng chịu trách nhiệm về sự thành công của chương trình an toàn giao thông đường bộ trong lĩnh vực mà mình quản lý. Tuy nhiên, sự tham gia của nhiều cơ quan trong quá trình thực hiện RSPM và thiếu cơ quan đứng đầu trong việc thực hiện từng trụ cột chiến lược có thể dẫn đến các vấn đề liên quan đến sự phối hợp giữa các cơ quan. Các vấn đề này bao gồm thiếu quyền làm chủ, trách nhiệm và thẩm quyền rõ ràng về an toàn giao thông đường bộ. Ngoài ra, các hoạt động có thể bị trùng lặp và các nỗ lực có thể bị chồng chéo. Kết quả là không tối ưu hóa được các nguồn lực và làm giảm hiệu quả của sáng kiến an toàn giao thông đường bộ.

\section{Bảng 4-3 Chương trình an toàn giao thông đường bộ theo các trụ cột của RSPM 2014 -}

\section{0}

\begin{tabular}{|c|c|c|c|c|}
\hline $\begin{array}{c}\text { Quản lý an toàn giao } \\
\text { thông }\end{array}$ & $\begin{array}{l}\text { Sự di chuyển và } \\
\text { đường bộ an } \\
\text { toàn hơn }\end{array}$ & $\begin{array}{l}\text { Phương tiện } \\
\text { an toàn hơn }\end{array}$ & $\begin{array}{c}\text { Người tham gia GT } \\
\text { an toàn hơn }\end{array}$ & $\begin{array}{c}\text { Quản lý sau tai } \\
\text { nạn }\end{array}$ \\
\hline $\begin{array}{l}\text { - Phối hợp liên ngành } \\
\text { giữa các chương trình } \\
\text { an toàn giao thông } \\
\text { đường bộ } \\
\text { - Gắn kêt các chương } \\
\text { trình thực thi luật lệ } \\
\text { an toàn giao thông } \\
\text { đường bộ } \\
\text { - Chương trình đào tạo } \\
\text { cho các bộ thực thi } \\
\text { luật lệ } \\
\text { - Chương trình quy } \\
\text { hoạch nguồn lực tông } \\
\text { thể } \\
\text { - Quản lý cơ sở dữ liệu } \\
\text { an toàn đường bộ tập } \\
\text { trung ch cáng } \\
\text { - Cấp vốn cho các } \\
\text { chương trình an toàn } \\
\text { giao thông đường bộ } \\
\text { - Các chương trình của } \\
\text { cộng đồng địa phương } \\
\text { - Các chương trình } \\
\text { khuyến khích sử dụng } \\
\text { phương tiện VTCC } \\
\text { - Chương trình gắn kết } \\
\text { liên ngành về số liệu } \\
\text { điều tra tai nạn giao } \\
\text { thông } \\
\text { - Chương trình nghiên } \\
\text { cứu an toàn giao } \\
\text { thông } \\
\text { - Đánh giá lại và hoàn } \\
\text { thiện các quy định về } \\
\text { an toàn giao thông } \\
\text { đường bộ }\end{array}$ & $\begin{array}{l}\text { - Rà soát hạn } \\
\text { chế tốc độ cho } \\
\text { các loại đường } \\
\text { và loại phương } \\
\text { tiện } \\
\text { - Thực hiện các } \\
\text { biện pháp kiểm } \\
\text { soát tốc độ } \\
\text { (điều tiết giao } \\
\text { thông) } \\
\text { - Quản lý tín } \\
\text { hiệu giao thông } \\
\text { (đồng bộ và tôi } \\
\text { ưu hóa tín hiệu } \\
\text { giao thông) } \\
\text { - Xây dựng làn } \\
\text { dành riêng cho } \\
\text { xe máy và vai } \\
\text { đường được } \\
\text { thảm nhựa } \\
\text { - Các chương } \\
\text { trình xây dựng } \\
\text { rào chắn bên } \\
\text { đường đảm } \\
\text { bảo an toàn } \\
\text { - Các chương } \\
\text { trình đánh giá } \\
\text { tiêu chuẩn và } \\
\text { quy định } \\
\text { - Chương trình } \\
\text { thẩm tra an } \\
\text { toàn đường bộ }\end{array}$ & $\begin{array}{l}\text { - Thực hiện các } \\
\text { quy định của } \\
\text { Liên Hợp quốc } \\
\text { thông qua việc } \\
\text { phê chuẩn loại } \\
\text { phương tiện } \\
\text { - Thực thi các } \\
\text { tiêu chuẩn về } \\
\text { các bộ phận của } \\
\text { phương tiện } \\
\text { trên thị trường } \\
\text { - Phân tích } \\
\text { khoảng cách } \\
\text { thiếu hụt các } \\
\text { quy định hiện } \\
\text { hành } \\
\text { - Chương trình } \\
\text { đánh giá hiệu } \\
\text { quả an toàn của } \\
\text { phương tiện }\end{array}$ & $\begin{array}{l}\text { - Tăng cường nội } \\
\text { dung đào tạo lái xe } \\
\text { hiện hành } \\
\text { - Chương trình giáo } \\
\text { dục nâng cao nhận } \\
\text { thức của người dân } \\
\text { thông qua các } \\
\text { phương tiện thông } \\
\text { tin đại chúng } \\
\text { - Chương trình giáo } \\
\text { dục về an toàn giao } \\
\text { thông đường bộ } \\
\text { trong trường học } \\
\text { - Hệ thống xử phạt } \\
\text { vi phạm nghiêm } \\
\text { minh hơn thông } \\
\text { qua hệ thống xử } \\
\text { phạt KEJARA } \\
\text { - Chương trình cấp } \\
\text { phép tổ chức đào } \\
\text { tạo lái xe } \\
\text { - Các chương trình } \\
\text { cho người lao } \\
\text { động, chủ doanh } \\
\text { nghiệp } \\
\text { - Các chương trình } \\
\text { tăng cường khả } \\
\text { năng dễ nhận thấy } \\
\text { của phương tiện } \\
\text { hai bánh }\end{array}$ & $\begin{array}{l}\text { - Chương trình sơ } \\
\text { cứu ở cộng đồng } \\
\text { - Cải thiện thời } \\
\text { gian đối phó với } \\
\text { tình huống khẩn } \\
\text { cấp } \\
\text { - Thiết lập hệ } \\
\text { thống điều trị } \\
\text { thương chấn } \\
\text { quốc gia } \\
\text { - Tăng cường dịch } \\
\text { vư cấp cứu trước } \\
\text { khi đưa tới bệnh } \\
\text { viện }\end{array}$ \\
\hline
\end{tabular}

Nguồn: (RSD \& MIROS, 2004) 


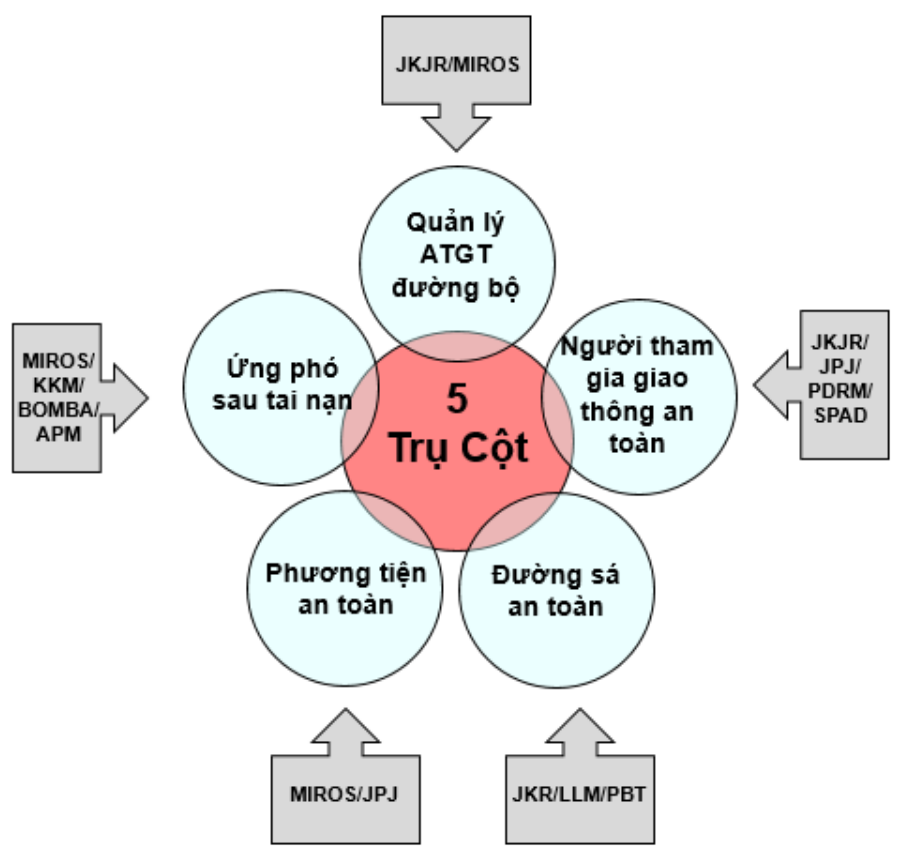

Hình 4-7 Các bên liên quan tới RSPM 2014-2020

Nguồn: (Syazana, 2018)

\subsubsection{Cambodia}

Trong "Kịch bản theo xu hướng hiện tại/Kịch bản nền" - không có các biện pháp hoặc chương trình can thiệp bổ sung, số người chết vì tai nạn giao thông đường bộ ở Cam-pu-chia dự báo sẽ lên tới 3.200 người vào năm 2020 (RCVIS, 2017). Chiến lược áp dụng ở Campuchia - Chính sách an toàn giao thông đường bộ quốc gia Cam-pu-chia đển năm 2020 (dưới đây gọi tắt là CNRSP 2020) sẽ góp phần giảm 50\% số người chết vì tai nạn giao thông đường bộ (từ 3.200 người xuống 1.600 người).

Bộ khung của CNRSP 2020 gồm 8 trụ cột (xem Hình dưới). So với Kế hoạch toàn cầu về thập kỷ hành động vì an toàn giao thông đường bộ (2011-2020), Trụ cột 4 (Người tham gia giao thông an toàn hơn) được chia thành 3 trụ cột khác nhau là: i) hành vi của người tham gia giao thông an toàn (Trụ cột 4), ii) Sửa đổi và thực thi luật pháp (Trụ cột 6) và iii) Cấp phép lái xe (Trụ cột 7). Ngoài ra, Campuchia cũng bổ sung trụ cột thứ 8 (đánh giá và quản lý dịch vụ vận tải). 


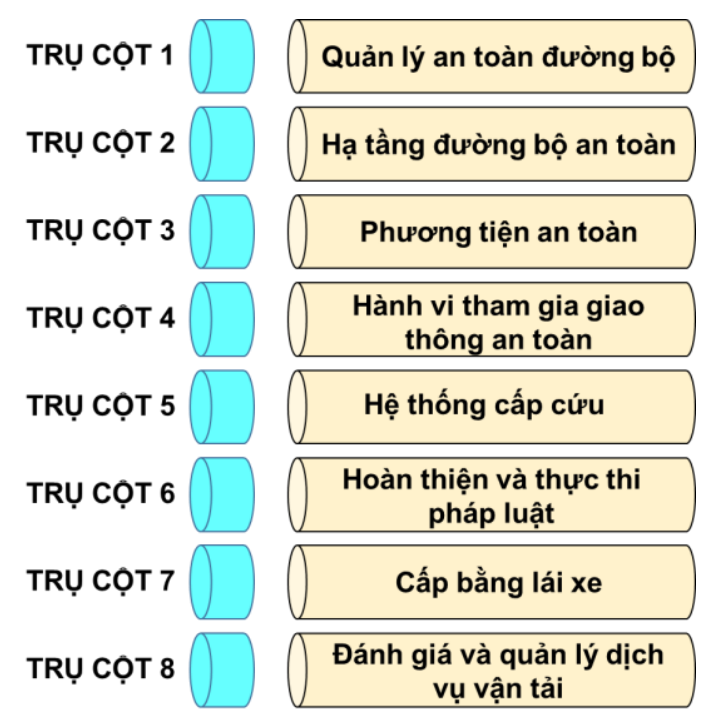

Hình 4-8 Khung CRSAP 2011-2020

Theo các trụ cột chiến lược này, hàng loạt hoạt động hoặc chương trình nhằm đạt mục tiêu an toàn giao thông đường bộ sẽ được thực hiện (xem Bảng). Thứ nhất, các hoạt động quản lý an toàn giao thông đường bộ sẽ tập trung vào hỗ trợ tài chính và xây dựng năng lực cho cán bộ đảm bảo an toàn giao thông đường bộ, các hoạt động nghiên cứu và xây dựng hệ thống dữ liệu. Việc thực hiện trụ cột thứ nhất sẽ được giám sát và đánh giá chặt chẽ nhằm đảm bảo thực hiện mục tiêu chung và mục tiêu cụ thể. Ử ban An toàn Giao thông Đường bộ Quốc gia chịu trách nhiệm phối hợp, giám sát và đánh giá. Thứ hai, kế hoạch hành động về hạ tầng đường bộ an toàn sẽ tập trung vào vấn đề kiểm soát tốc độ thông qua các biện pháp điều tiết giao thông và quản lý tốc độ cũng như chương trình cải tạo các điểm đen về giao thông. Bên cạnh đó, chương trình thẩm tra an toàn giao thông đường bộ sẽ được tích hợp trong thiết kế đường, dự án đường bộ cũng như các kỹ sư đường bộ sẽ được đào tạo kỹ năng thẩm tra an toàn giao thông đường bộ. Thứ ba, các hoạt động của trụ cột phương tiện an toàn sẽ tập trung xây dựng hệ thống tiêu chuẩn kỹ thuật phương tiện và mạng lưới trung tâm kiểm định phương tiện. Thứ tư, các hoạt động của trụ cột cải thiện hành vi của người tham gia giao thông đường bộ an toàn sẽ tập trung vào các chiến dịch tuyên truyền giáo dục nâng cao ý thức về an toàn đường bộ qua các phương tiện thông tin đại chúng, giáo dục ở trường học, đào tạo thí điểm và các hướng tiếp cận khác. Kế hoạch hành động của trụ cột thứ 5 tập trung vào việc cải thiện dịch vụ cấp cứu trong cả nước. Bộ Y tế đã xây dựng chính sách quốc gia về dịch vụ sơ cứu trước khi tới bệnh viện và dịch vụ chăm sóc tại bệnh viện. Các hoạt động của trụ cột thứ 6 nhằm đảm bảo cảnh sát giao thông sẽ có đủ năng lực, trang thiết bị và được đào tạo để phát triển chuyên môn. Ngoài ra, luật giao thông cũng sẽ được sửa đổi nếu cần thiết nhằm giải quyết tình hình thực tế. Kế hoạch hành động của trụ cột thứ 7 sẽ cải thiện các chương trình tập huấn ở các trường đào tạo lái xe. Ngoài ra, kết nối dữ liệu giữa hệ thống của cảnh sát, tòa án và Bộ Giao thông cũng sẽ được triển khai.

Cuối cùng, các hoạt động của trụ cột thứ 8 sẽ tập trung vào sự an toàn của các dịch vụ giao thông cũng như nâng cao ý thức của các đơn vị cung cấp dịch vụ vận tải về an toàn giao thông đường bộ.

\section{Bảng 4-4 Các hoạt động/chương trình an toàn giao thông đường bộ thuộc 8 trụ cột của CNRSP 2020}

\begin{tabular}{|c|l|l|l|}
\hline TT & \multicolumn{1}{|c|}{ Trụ cột } & \multicolumn{1}{c|}{ Hoạt động/chương trình } \\
\hline 1 & $\begin{array}{l}\text { Quản lý an toàn } \\
\text { giao thồng chơơng trình trao đổi và } \\
\text { đường bộ }\end{array}$ & $\bullet \begin{array}{l}\text { Xây dựng năng lực thông qua các khóa đào tạo, các chự kinh nghị̂m. } \\
\text { học tập kinh }\end{array}$ \\
\hline
\end{tabular}




\begin{tabular}{|c|c|c|}
\hline TT & Trụ cột & Hoạt động/chương trình \\
\hline & & 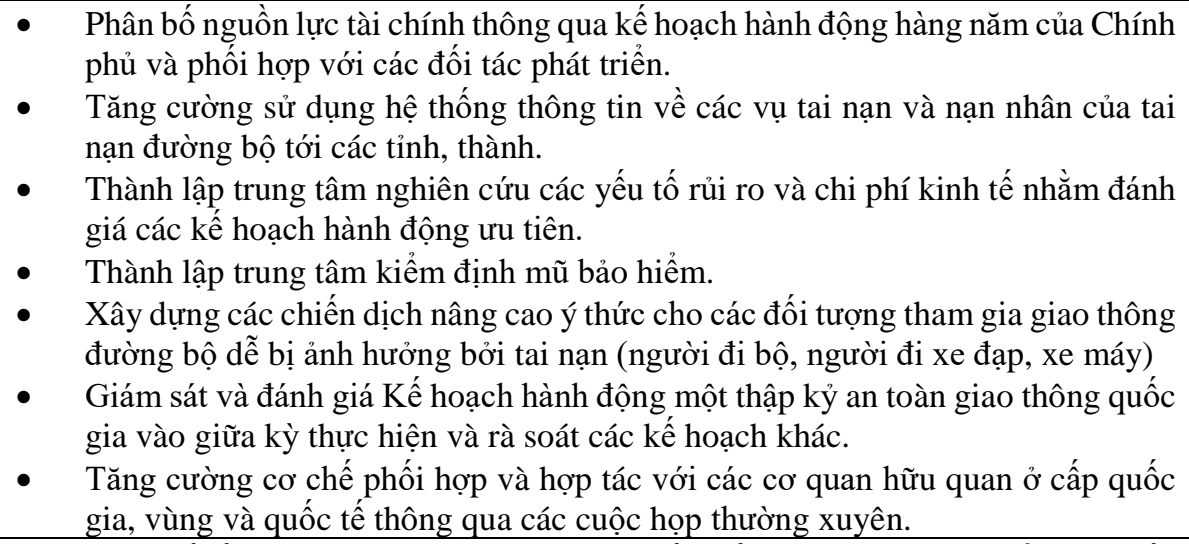 \\
\hline 2 & $\begin{array}{l}\text { Hạ tầng đường } \\
\text { bộ an toàn }\end{array}$ & 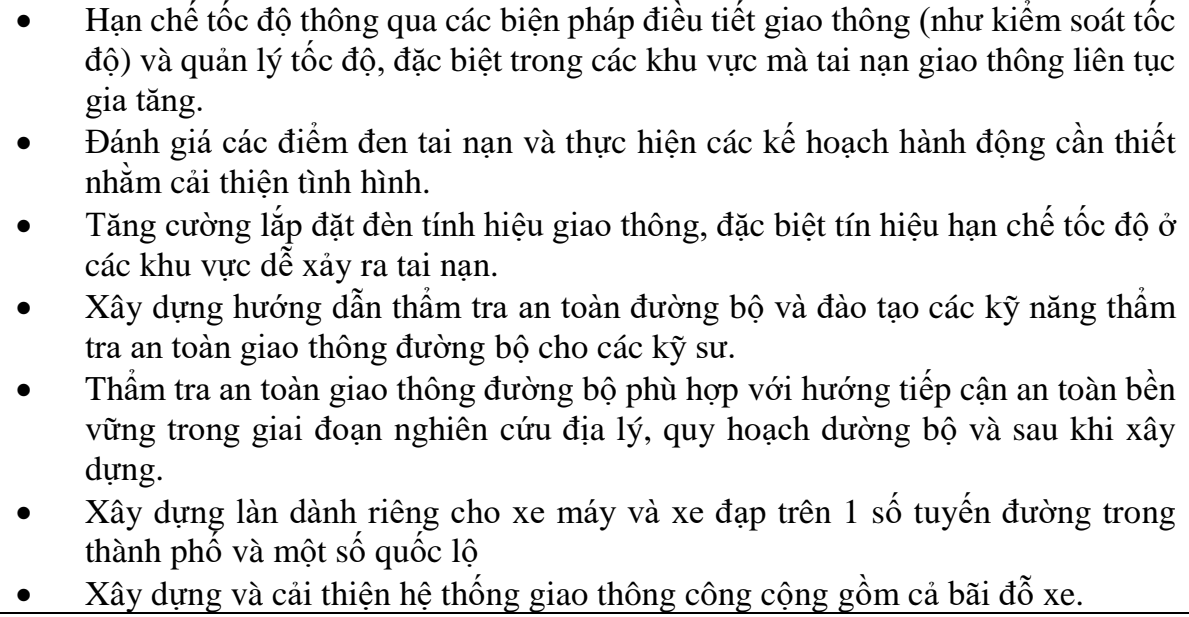 \\
\hline 3 & $\begin{array}{l}\text { Phương tiện an } \\
\text { toàn }\end{array}$ & $\begin{array}{l}\text { - Xây dựng hệ thống tiêu chuẩn kỹ thuật phương tiện cho xe nhập khẩu và sản } \\
\text { xuất trong nước. } \\
\text { - Nâng cao ý thức của người tham gia giao thông về phương tiện an toàn. } \\
\text { - Xây dựng thêm các trung tâm kiểm định ở } 24 \text { tỉnh thành cũng như cải thiện chất } \\
\text { lượng của các trung tâm này dựa trên các tiêu chuẩn quốc tế đã được công nhận }\end{array}$ \\
\hline 4 & $\begin{array}{l}\text { Hành vi của } \\
\text { người tham gia } \\
\text { giao thông } \\
\text { đường bộ an } \\
\text { toàn }\end{array}$ & $\begin{array}{l}\text { - Xây dựng chiến lược giáo dục và nâng cao ý thức về luật lệ giao thông. } \\
\text { - Xây dựng kế hoạch hành động toàn diện về giáo dục an toàn giao thông đường } \\
\text { - } \quad \text { bộ. } \\
\text { Giáo dực người điều khiển phương tiện về mối nguy hiểm khi không đội mũ } \\
\text { bảo hiếm, chạy quá tốc độ, lái xe sau khi uống rượu bia, không cài dây an toàn } \\
\text { và chở quá tải. } \\
\text { - Lắp đặt cầu cho người đi bộ ở các khu đô thị } \\
\text { - Giáo dụng nâng cao ý thức của người tham gia giao thông, gồm cả các công ty } \\
\text { vận tải về tham gia giao thông an toàn }\end{array}$ \\
\hline 5 & $\begin{array}{l}\text { Hệ thống cấp } \\
\text { cứu }\end{array}$ & $\begin{array}{l}\text { - Cải thiện dịch vụ cấp cứu trước khi tới bệnh viện. } \\
\text { - Xây dựng năng lực của cảnh sát giao thông, quân đội và cộng đồng về các kỹ } \\
\text { năng cấp cứu sơ bộ. } \\
\text { - Tăng cường chất lượng các dịch vụ cấp cứu và quản lý điều trị trong bệnh viện. } \\
\text { - Cải thiện mạng lưới thông tin của các trung tâm thông tin tai nạn giao thông } \\
\text { đường bộ. } \\
\text { - Tăng cương dịch vụ cấp cứu, cũng như lắp đặt thiết bị tiêu chuẩn và phát triển } \\
\text { nguồn nhân lực. } \\
\text { - Khuyến khích sử dụng hệ thống phục hồi chức năng cho nạn nhân của các vụ } \\
\text { tai nạn giao thông đường bộ. }\end{array}$ \\
\hline 6 & $\begin{array}{l}\text { Hoàn thiện và } \\
\text { thực thi pháp } \\
\text { luật }\end{array}$ & $\begin{array}{l}\text { - Sửa đổi, bổ sung luật giao thông đường bộ. } \\
\text { - } \quad \text { Rà soát việc thực thi luật lệ và các kế hoạch hành động. } \\
\text { - Tổ chức các khóa đào tạo phát triển năng lực chuyên môn cho cảnh sát giao } \\
\text { thông về thực thi luật lệ. }\end{array}$ \\
\hline
\end{tabular}




\begin{tabular}{|c|c|c|}
\hline TT & Trụ cột & Hoạt động/chương trình \\
\hline & & $\begin{array}{l}\text { - Cung cấp trang thiết bị, công cụ hiện đại cho công việc thực thi luật lệ. } \\
\text { - Thực thi luật giao thông thống nhất, đậc biệt các quy định về đội mũ bảo hiểm, } \\
\text { chạy xe quá tốc độ, lái xe sau khi uống rượu bia, đỗ xe trái quy định và lái xe } \\
\text { đi thẳng trên làn đường rẽ trái }\end{array}$ \\
\hline 7 & Cấp phép lái xe & 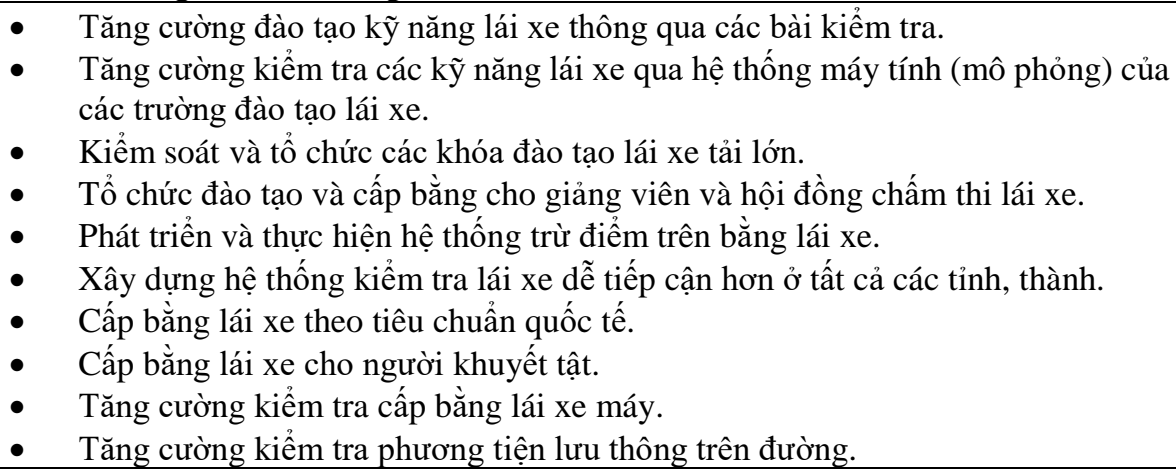 \\
\hline 8 & $\begin{array}{l}\text { Đánh giá và } \\
\text { quản lý dịch vụ } \\
\text { vận tải }\end{array}$ & $\begin{array}{l}\text { - Tăng cường kỹ năng lãnh đạo, quản lý và trách nhiệm của các cơ quan vận tải } \\
\text { thông qua các hướng dần nội bộ về an toàn giao thông đường bộ, lập kế hoạch } \\
\text { hoạch và thực hiện quản lý rủi ro. } \\
\text { - Thúc đẩy công tác đào tạo và phổ biến hướng dẫn quản lý an toàn đường bộ } \\
\text { cho hành khách, các công ty vận tải hàng hóa và lái xe. } \\
\text { - Giám sát và đánh giá sự an toàn trong vận tải hành khách và hàng hóa thông } \\
\text { qua thực thi luật lệ và thu thập số liệu về tai nạn giao thông. }\end{array}$ \\
\hline
\end{tabular}

Nguồn: (NSCR, 2014)

Bên cạnh đó, Ủy ban An toàn Giao thông Quốc gia (NSCR) sẽ chịu trách nhiệm điều phối, giám sát và đánh giá việc thực hiện CNRSP 2020. Ngoài ra, từng hoạt động của chương trình sẽ được giao cho các bên liên quan (xem Bảng). Thiếu cơ quan chịu trách nhiệm đứng đầu trong quá trình thực hiện của từng trụ cột chiến lược có thể dẫn đến các vấn đề liên quan đến công tác phối kết hợp liên ngành.

Bảng 4-5 Chương trình và các bên liên quan của CNRSP 2020

\begin{tabular}{|c|c|c|c|}
\hline TT & Trụ cột & Chương trình & Các bên liên quan \\
\hline \multirow[t]{7}{*}{1} & \multirow[t]{7}{*}{$\begin{array}{l}\text { Quản lý an } \\
\text { toàn giao } \\
\text { thông đường } \\
\text { bộ }\end{array}$} & Xây dựng năng lực & $\begin{array}{l}\text { NRSC; Bộ Giao thông Công chính (MPWT); Bộ Thông } \\
\text { tin (MOI), Bộ Y tế (MOH); Bộ Giáo dục, Thanh thiếu } \\
\text { niên và Thể thao (MOEYS); Bộ Phát triển Nông thôn } \\
\text { (MRD); CRC và các đối tác phát triển }\end{array}$ \\
\hline & & Hỗ trợ tài chính và nguồn lực & MPWT, NRSC, Ban thư ký PRSC, MOI, MOH, MOEYS \\
\hline & & $\begin{array}{l}\text { Hệ thống thông tin tai nạn } \\
\text { giao thông và nạn nhân }\end{array}$ & $\begin{array}{l}\text { MPWT, NRSC, Ban thư ký PRSC, MOI, MOH, MOEYS } \\
\text { và đối tác phát triển }\end{array}$ \\
\hline & & Nghiên cứu & $\begin{array}{l}\text { MPWT, NRSC, Ban thư ký PRSC, MOI, MOH, MOEYS } \\
\text { và đối tác phát triển }\end{array}$ \\
\hline & & $\begin{array}{l}\text { Các chiến dịch nâng cao nhận } \\
\text { thức }\end{array}$ & $\begin{array}{l}\text { NRSC, Ban Thư ký PRSC, MOI, các đối tác phát triển, tổ } \\
\text { chức phi chính phủ và cộng đồng }\end{array}$ \\
\hline & & Giám sát và đánh giá & $\begin{array}{l}\text { NRSC, Ban Thư ký PRSC, MOI, Bộ Kinh tế và Tài chính } \\
\text { (MOEF) }\end{array}$ \\
\hline & & Phối hợp với đối tác & NRSC, Ban Thư ký PRSC \\
\hline 2 & $\begin{array}{l}\text { Hạ tầng } \\
\text { đường bộ an } \\
\text { toàn }\end{array}$ & $\begin{array}{l}\text { Xây dựng và nghiên cứu phát } \\
\text { triển đường bộ }\end{array}$ & $\begin{array}{l}\text { NSCR, MPWT, MOI, MOH, MOEYS, MRD, chính } \\
\text { quyền địa phương, CRC, đối tác phát triển }\end{array}$ \\
\hline 3 & $\begin{array}{l}\text { Phương tiện } \\
\text { an toàn }\end{array}$ & $\begin{array}{l}\text { Tiêu chuẩn và quy trình kỹ } \\
\text { thuật }\end{array}$ & $\begin{array}{l}\text { MPWT, MOI, nhà sản xuất phương tiện, công ty bảo } \\
\text { hiểm, trường đạo tạo lái xe, Bộ Công nghiệp (MOID) }\end{array}$ \\
\hline \multirow[t]{3}{*}{4} & \multirow{3}{*}{$\begin{array}{lr}\text { Hành } & \text { vi } \\
\text { tham } & \text { gia }\end{array}$} & Giáo dục cộng đồng & MPWT, MOEYS, MOI, NSCR, đối tác phát triển \\
\hline & & Trẻ em & MOEYS, MPWT, MOI, đối tác phát triển \\
\hline & & Người đi xe đạp & MOEYS, MOI, đối tác phát triển \\
\hline
\end{tabular}




\begin{tabular}{|c|c|c|c|}
\hline TT & Trụ cột & Chương trình & Các bên liên quan \\
\hline & $\begin{array}{l}\text { giao thông } \\
\text { an toàn }\end{array}$ & Người khuyết tập & $\begin{array}{l}\text { MOEYS; MOI; Bộ An sinh Xã hội (MOSA), Bộ thanh } \\
\text { thiếu niên, thương binh và xã hội (MOSVR); Bộ Lao } \\
\text { động và Đào tạo nghề (MOLVT), NSCR, Ban thư ký } \\
\text { PRSC, đối tác phát triển }\end{array}$ \\
\hline \multirow[t]{4}{*}{5} & \multirow[t]{4}{*}{$\begin{array}{l}\text { Hệ thống } \\
\text { cấp cứu }\end{array}$} & $\begin{array}{l}\text { Chăm sóc trước khi chuyển } \\
\text { tới bệnh viện }\end{array}$ & MOH, MOI, Bộ Quốc phòng (MONF), đối tác phát triển \\
\hline & & Điều trị tại bệnh viện & MOH, đối tác phát triển \\
\hline & & $\begin{array}{l}\text { Mạng lưới thông tin và điều } \\
\text { vận }\end{array}$ & $\begin{array}{l}\text { Hội đồng Bộ trưởng, Bộ Bưu chính Viễn thông (MOPC), } \\
\text { MOH, MOI, MONF, đối tác phát triê̂n }\end{array}$ \\
\hline & & Phục hồi chức năng & MOH, đối tác phát triển \\
\hline \multirow[t]{2}{*}{6} & \multirow{2}{*}{$\begin{array}{l}\text { Hoàn thiện } \\
\text { và thực thi } \\
\text { pháp luật }\end{array}$} & Xây dựng năng lực & MOI, MPWT, NSCR, đối tác phát triển \\
\hline & & Thực thi pháp luật & MOI, MONF, MPWT, MOEF, đối tác phát triển \\
\hline 7 & $\begin{array}{l}\text { Cấp phép lái } \\
\text { xe }\end{array}$ & $\begin{array}{l}\text { Các khóa đào tạo và trường } \\
\text { đào tạo }\end{array}$ & $\begin{array}{l}\text { MPWT, MOI, MOEYS, MOH, MOSA, trường đào tạo } \\
\text { lái xe, đối tác phát triến }\end{array}$ \\
\hline 8 & $\begin{array}{l}\text { Quản lý dịch } \\
\text { vụ vận tải }\end{array}$ & $\begin{array}{l}\text { Các hướng dẫn và chiến dịch } \\
\text { nâng cao nhận thức }\end{array}$ & $\begin{array}{l}\text { MPWT, MOI, Bộ Du lịch (MOT), Hiệp hội Vận tải hàng } \\
\text { hóa }\end{array}$ \\
\hline
\end{tabular}

Nguồn: (NSCR, 2014)

\subsubsection{Indonesia}

Tuân theo Kế hoạch Toàn cầu về thập kỷ hành động vì an toàn đường bộ (2011-2020) của UN \& WHO, bộ khung kế hoạch quốc gia của Indonesia về an toàn giao thông đường bộ 2011-2035 (sau đây gọi tắt là INRSP 2011-2035) gồm 5 trụ cột chiến lược (xem Hình). Năm trụ cột chiến lược gồm: 1) Quản lý an toàn giao thông đường bộ, 2) Đường bộ an toàn hơn, 3) Phương tiện an toàn hơn, 4) Người tham gia giao thông an toàn hơn và 5) Quản lý sau tai nạn. So với mốc cơ sở (2010), chiến lược áp dụng trong INRSP 2011-2035 sẽ giảm tỷ lệ người chết vì tai nạn giao thông đường bộ từ 3,93 người/ 10.000 phương tiện năm 2010 xuống còn 1,96 người năm 2020 và 0,79 người năm 2035. Nói cách khác, tỷ lệ số người chết vì tai nạn giao thông đường bộ sẽ giảm $50 \%$ vào năm 2020 và $80 \%$ vào năm 2030 .

Trên cơ sở các trụ cột chiến lược, các hoạt động và chương trình sẽ được thực hiện (xem Bảng). Mục tiêu của trụ cột thứ nhất là thúc đẩy thành lập đối tác liên ngành để phát triển và xây dựng chiến lược, kế hoạch an toàn giao thông đường bộ quốc gia. Mục tiêu được củng cố bởi các số liệu thu thập và bằng chứng nghiên cứu nhằm đánh giá thiết kế phương án phòng chống và giám sát thực hiện cũng như hiệu quả. Trụ cột thứ hai nhằm cải thiện chất lượng bảo vệ an toàn cho mạng lưới đường bộ và lợi ích của tất cả các đôi tượng tham gia giao thông đường bộ (đặc biệt là các đối tượng sử dụng đường bộ dễ bị tổn thương nhất như người đi bộ, người đi xe đạp và xe máy). Điều này có thể đạt được thông qua việc thực hiện đánh giá cải thiện công tác quy hoạch, thiết kế, xây dựng và khai thác hạ tầng đường bộ an toàn hơn. Các chương trình của trụ cột thứ 3 tập trung vào sự an toàn của công nghệ chế tạo phương tiện nhằm đảm bảo sự an toàn chủ động và thụ động thông qua việc kêt hợp thống nhất các tiêu chuẩn toàn cầu liên quan, thông tin người sử dụng và các chương trình ưu đãi thúc đẩy áp dụng công nghệ mới. Trọng tâm của trụ cột thứ tư là sự bền vững trong thực thi luật lệ và tiêu chuẩn giao thông đường bộ kết hợp với các hoạt động giáo dục, nâng cao nhận thức của người dân. Trụ cột thứ năm nhằm đảm bảo tăng cường khả năng phản ứng trong các trường hợp khẩn cấp và năng lực của hệ thống $\mathrm{y}$ tế nhằm cung cấp dịch vụ cấp cứu và điều trị lâu dài. 


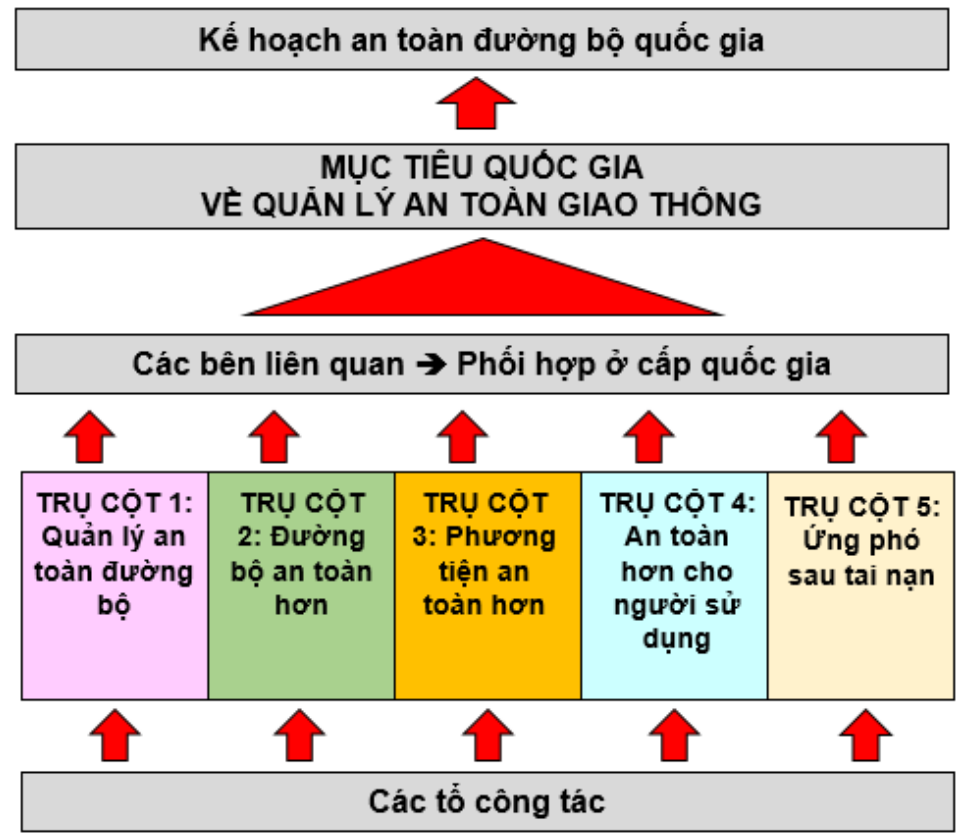

Hình 4-9 Sự phối họ̣p giữa 5 trụ cột nhằm đạt mục tiêu quốc gia của In-đô-nê-xia

Nguồn: (Cộng hòa In-đô-nê-xia, 2011)

Bảng 4-6 Các chương trình và các bên liên quan của INRSP 2011-2035

\begin{tabular}{|c|c|c|c|c|}
\hline TT & Trụ cột & Chương trình & $\begin{array}{l}\text { Co' quan } \\
\text { chủ trì }\end{array}$ & Cơ quan hỗ trọ’, phối họ̣p \\
\hline \multirow[t]{8}{*}{1} & \multirow[t]{8}{*}{$\begin{array}{l}\text { Quản lý an } \\
\text { toàn giao } \\
\text { thông đường } \\
\text { bộ }\end{array}$} & $\begin{array}{l}\text { 1.1. Thống nhất và phối hợp về } \\
\text { an toàn giao thông đường bộ }\end{array}$ & $\begin{array}{l}\text { Cơ quan } \\
\text { Quy hoạch } \\
\text { Phát triển } \\
\text { Quốc gia } \\
\text { (NDPA) }\end{array}$ & $\begin{array}{l}\text { Bộ GTVT (MOT); Cảnh sát Quốc gia } \\
\text { (NP); Bộ Công chính (MOPW); Bộ } \\
\text { Y tế (MOH); Bộ Công nghệ, Thông } \\
\text { tin (MOCI); Bộ Nghiên cứu và Công } \\
\text { nghệ (MORT); Bộ Giáo dục (MOE); } \\
\text { Bộ Công nghiệp (MOID); cộng đồng }\end{array}$ \\
\hline & & $\begin{array}{l}\text { 1.2. Quy định giao thông áp dụng } \\
\text { cho phương tiện cứu hộ, cứu } \\
\text { nạn }\end{array}$ & MOT & NP, MOPW, MOH, MOCI \\
\hline & & $\begin{array}{l}\text { 1.3. Nghiên cứu về an toàn giao } \\
\text { thông đường bộ }\end{array}$ & MORT & MOT, NP, MOPW, MOH, Cộng đồng \\
\hline & & $\begin{array}{l}\text { 1.4. Hệ thống giám sát và thông } \\
\text { tin tai nan tổng hơp }\end{array}$ & NP & $\begin{array}{l}\text { MOT, MOPW, MOH, Các công ty } \\
\text { bảo hiểm, MOCI, }\end{array}$ \\
\hline & & $\begin{array}{l}\text { 1.5. Quỹ an toàn giao thông } \\
\text { đường bộ }\end{array}$ & NDPA & $\begin{array}{l}\text { MOF, MOT, NP, MOPW, MOH, } \\
\text { MOCI, MORT, MOE, MOID, Các } \\
\text { công ty bảo hiểm, Cộng đồng }\end{array}$ \\
\hline & & $\begin{array}{l}\text { 1.6. Đối tác an toàn giao thông } \\
\text { đường bộ }\end{array}$ & NDPA & $\begin{array}{l}\text { MOT, NP, MOPW, MOID, MOF, } \\
\text { MOCI, MORT, MOE, MOID }\end{array}$ \\
\hline & & $\begin{array}{l}\text { 1.7. Hệ thống quản lý an toàn cho } \\
\text { vận tải công cộng }\end{array}$ & MOT & $\begin{array}{l}\text { Bộ Lao động (MOL), chính quyền địa } \\
\text { phương, cá tồ chức, SBAJ, Các công } \\
\text { ty bảo hiểm }\end{array}$ \\
\hline & & $\begin{array}{l}\text { 1.8. Hoàn thiện các quy định về } \\
\text { an toàn giao thông đường bộ }\end{array}$ & MOT & $\begin{array}{l}\text { NDPA, NP, MOPW, MOH, MOCI, } \\
\text { MORT, MOE, MOID, chính quyền } \\
\text { địa phương, cộng đồng }\end{array}$ \\
\hline \multirow[t]{2}{*}{2} & \multirow[t]{2}{*}{$\begin{array}{l}\text { Đường bộ an } \\
\text { toàn hơn }\end{array}$} & $\begin{array}{l}\text { 2.1. Xây dựng các tuyến đường } \\
\text { an toàn hơn }\end{array}$ & MOPW & MOT, chính quyền địa phương \\
\hline & & $\begin{array}{l}\text { 2.2. Quy hoạch và xây dựng } \\
\text { đường bộ an toàn hơn (gồm } \\
\text { cả trang thiết bị đường bộ) }\end{array}$ & MOPW & MOT, NP, chính quyền địa phương \\
\hline
\end{tabular}


Dự án: Xây dựng chiến lược an toàn giao thông đối với xe máy và kế hoạch hành động: một khởi đầu của Việt Nam

“Nghiên cứu hiện trạng giao thông xe máy Việt Nam"

\begin{tabular}{|c|c|c|c|c|}
\hline TT & Trụ cột & Chương trình & $\begin{array}{c}\text { Cơ quan } \\
\text { chủ trì }\end{array}$ & Cơ quan hỗ trọ̆, phối hợp \\
\hline & & $\begin{array}{l}\text { 2.3. Cải thiện các tiêu chuẩn về } \\
\text { điều kiện đường bộ cho phép } \\
\text { xe lưu hành an toàn hơn }\end{array}$ & MOPW & MOT, chính quyền địa phương \\
\hline & & $\begin{array}{l}\text { 2.4. Môi trường đường bộ an } \\
\text { toàn hơn }\end{array}$ & MOPW & $\begin{array}{l}\text { MOT, Bộ Nội vụ (MOIA), Bộ Môi } \\
\text { trường (MOEN) }\end{array}$ \\
\hline \multirow[t]{8}{*}{3} & \multirow[t]{8}{*}{$\begin{array}{l}\text { Phương tiện } \\
\text { an toàn hơn }\end{array}$} & $\begin{array}{l}\text { 3.1. Các quy định về vận hành } \\
\text { phương tiện }\end{array}$ & NP & MOT \\
\hline & & $\begin{array}{l}\text { 3.2. Thực hiện và cải thiện quy } \\
\text { trình kiểm tra đánh giá định } \\
\text { kỳ và loại kiểm tra, đánh giá }\end{array}$ & MOT & MOID, NP, chính quyền địa phương \\
\hline & & 3.3. Giới han tốc đô phương tiện & MOT & MORT, NP, chính quyền đia phương \\
\hline & & 3.4. Giải quyết vấn đề quá tải & MOT & $\begin{array}{l}\text { MOPW, NP, MOCI, NDPA, MORT, } \\
\text { chính quyền địa phương, cộng đồng }\end{array}$ \\
\hline & & $\begin{array}{l}\text { 3.5. Xứ lý phương tiện hết hạn sử } \\
\text { dung }\end{array}$ & MOT & MOID, chính quyền địa phương \\
\hline & & $\begin{array}{l}\text { 3.6. 3.6. Tiêu chuẩn an toàn trong } \\
\text { VTCC }\end{array}$ & MOT & NP, MOID \\
\hline & & $\begin{array}{l}\text { 3.7. Cải thiện quy trình kiểm tra } \\
\text { phương tiện đã qua sử dụng } \\
\text { nhập khẩu và phương tiện } \\
\text { chuyển đổi }\end{array}$ & MOT & MOID \\
\hline & & $\begin{array}{l}\text { 3.8. Nghiên cứu phát triển và } \\
\text { thiết kế phương tiện cơ giới }\end{array}$ & MORT & MOT \\
\hline \multirow[t]{8}{*}{4} & \multirow{8}{*}{$\begin{array}{l}\text { Người } \\
\text { gia } \quad \text { giao } \\
\text { thông an } \\
\text { toàn hơn }\end{array}$} & $\begin{array}{l}\text { 4.1. Giám sát điều kiện tiêu } \\
\text { chuẩn của lái xe }\end{array}$ & NP & $\mathrm{MOH}$ \\
\hline & & $\begin{array}{l}\text { 4.2. Cải thiện hạ tầng hệ thống } \\
\text { kiểm tra cấp bằng lái xe }\end{array}$ & NP & $\begin{array}{l}\text { MOT, MORT, chính quyền địa } \\
\text { phương, cộng đồng }\end{array}$ \\
\hline & & $\begin{array}{l}\text { 4.3. Cải thiện quy trình kiểm tra } \\
\text { cấp bằng lái }\end{array}$ & NP & $\begin{array}{l}\text { Bộ Luật pháp và Quyền con người } \\
\text { (MOLHR) }\end{array}$ \\
\hline & & $\begin{array}{l}\text { 4.4. Hướng dẫn kỹ thuâat cho các } \\
\text { trường đào tạo lái xe }\end{array}$ & $\mathrm{NP}$ & MOT, MOL, chính quyền địa phương \\
\hline & & $\begin{array}{l}\text { 4.5. Giải quyết } 5 \text { yếu tố rủi ro } \\
\text { chính }\end{array}$ & $\mathrm{NP}$ & $\begin{array}{l}\text { MOLHR, MOT, chính quyền địa } \\
\text { phương }\end{array}$ \\
\hline & & $\begin{array}{l}\text { 4.6. Thực thi luật lệ bằng công } \\
\text { nghệ điện tử }\end{array}$ & NP & MOLHR, MORT \\
\hline & & $\begin{array}{l}\text { 4.7. Giáo dục về an toàn đường } \\
\text { bộ chính thức và phi chính } \\
\text { thức }\end{array}$ & MOE & NP, MOT, MOL \\
\hline & & $\begin{array}{l}\text { 4.8. Các chiến dịch an toàn giao } \\
\text { thông đường bộ về: i) } 5 \text { yếu } \\
\text { tố rủi ro chính đối với các đối } \\
\text { tượng dễ bị tổn thương khi } \\
\text { tham gia giao thông đường } \\
\text { bộ (đội mũ bảo hiềm, cài dây } \\
\text { an toàn, tốc độ phương tiện, } \\
\text { điều khiến phương tiện sau } \\
\text { khi uống rượu bia, sử dụng } \\
\text { điện thoại di động khi lái xe), } \\
\text { 2) Hành vi an toàn trên } \\
\text { đường }\end{array}$ & MOT & $\begin{array}{l}\text { NP, MOE, MOH, MOIA, Bộ Tôn } \\
\text { giáo (MOR), cộng đồng, chính quyền } \\
\text { địa phương }\end{array}$ \\
\hline \multirow[t]{3}{*}{5} & \multirow{3}{*}{$\begin{array}{l}\text { Phản ứng sau } \\
\text { khi có tai nạn } \\
\text { xảy ra }\end{array}$} & $\begin{array}{l}\text { 5.1. Hệ thống chăm sóc y tế sau } \\
\text { tai nạn }\end{array}$ & $\mathrm{MOH}$ & $\begin{array}{l}\text { NP, MOT, MOPW, chính quyền địa } \\
\text { phương, cộng đồng }\end{array}$ \\
\hline & & $\begin{array}{l}\text { 5.2. Hệ thống thông tin cấp cứu } \\
\text { (một mã truy cập) }\end{array}$ & MOCI & MOH, NP, MOT, MOPW, cộng đồng \\
\hline & & $\begin{array}{l}\text { 5.3. Bảo hiểm cho nạn nhân tai } \\
\text { nạn tại các bệnh viện }\end{array}$ & MOF & $\begin{array}{l}\text { MOH, NP, Các công ty bảo hiểm, } \\
\text { chính quyền địa phương }\end{array}$ \\
\hline
\end{tabular}


Dự án: Xây dựng chiến lược an toàn giao thông đối với xe máy và kế hoạch hành động: một khởi đầu của Việt Nam

\begin{tabular}{|c|c|c|c|c|}
\hline TT & Trụ cột & Chương trình & $\begin{array}{l}\text { Co quan } \\
\text { chủ trì }\end{array}$ & Cơ quan hỗ trọ’, phối hợp \\
\hline & & $\begin{array}{l}\text { 5.4. Bảo hiểm trách nhiệm bên } \\
\text { thứ ba }\end{array}$ & MOF & Các công ty bảo hiểm \\
\hline & & $\begin{array}{l}\text { 5.5. Phân bổ quỹ an toàn đường } \\
\text { bô cho các công ty bảo hiểm }\end{array}$ & NDPA & MOF, Các công ty bảo hiểm. \\
\hline & & $\begin{array}{l}\text { 5.6. Chương trình điều trị sau tai } \\
\text { nạn }\end{array}$ & $\mathrm{MOH}$ & $\begin{array}{l}\text { Bộ An sinh xã hội (MOSA), chính } \\
\text { quyền địa phương, cộng đồng }\end{array}$ \\
\hline & & $\begin{array}{l}\text { 5.7. Nghiên cứu về vấn đề điều trị } \\
\text { cho nạn nhân bị TNGT }\end{array}$ & $\mathrm{MOH}$ & Cộng đồng, trường cao đẳng, đại học \\
\hline
\end{tabular}

Nguồn: (Cộng hòa In-đô-nê-xia, 2011)

Có nhiều bên liên quan thực hiện INRSP 2011-2035. Tuy nhiên, In-đô-nê-xia có thể giải quyết các vấn đề phối hợp liên ngành bằng cách chỉ định cơ quan chủ trì cho từng chương trình hoặc hoạt động (xem Bảng trên). Với Trụ cột 1 (Quản lý an toàn đường bộ), Cơ quan Quy hoạch Phát triển Quốc gia và Bộ GTVT chia sẻ vai trò của cơ quan chủ trì. Đối với Trụ cột 2 (Đường bộ an toàn hơn), chỉ có Bộ GTVT đóng vai trò là cơ quan chủ trì. Tương tự, Bộ GTVT chịu trách nhiệm chính về Trụ cột 3 (Phương tiện an toàn hơn) và Trụ cột 4 (Người tham gia giao thông an toàn hơn); Cảnh sát Quốc gia chịu trách nhiệm chính về các chương trình của Trụ cột 6 và 8 . Với trụ cột cuối cùng, Bộ Y tế và Bộ Tài chính là cơ quan chủ trì của 5 trong 7 chương trình.

\subsection{Các chính sách cấm xe máy và hạn chế ô tô trên thế giới}

Mục tiêu quản lý xe máy của nhà nước chủ yếu nhằm: (1) đảm bảo an toàn giao thông và bảo vệ môi trường và (2) kiểm soát tăng trưởng xe máy. Việt Nam là một trong những nước cần kiểm soát tăng trưởng xe máy nhanh và đã nỗ lực rất nhiều để thực hiện. Tuy nhiên, rất ít nỗ lực thành công. Ở các nước khác, trong một số khu vực, xe máy bị cấm lưu thông. Đó là lý do các điển hình nghiên cứu sẽ hữu ích cho việc xem xét, đề xuất chính sách. Đặc biệt là đối với trường hợp của Trung Quốc và Myanmar như tổng hợp trong phần dưới đây.

\subsubsection{Các chính sách cấm và hạn chế xe máy của Trung Quốc}

\subsubsection{Cấm theo vùng hay khu vụ̣c của một tỉnh/thành phố, không cấm toàn quốc}

Yang (2010) tổng hợp một số chính sách cấm/hạn chế xe máy ở Trung Quốc như sau:

- Một số thành phố ngừng cấp phép đăng ký xe máy mới;

- Một số thành phố cấm xe máy và xe 2 bánh lưu thông trên một số khu vực trung tâm hoặc một số tuyến đường chính.

- Một số thành phố cho phép số lượng xe máy được cấp đăng ký nhất định và tổ chức đấu giá biển số.

Cụ thể, 3 siêu đô thị cấm hoặc hạn chế xe máy là Bắc Kinh, Thiên Tân và Thượng Hải. Chính sách được cả chính quyền trung ương và địa phương đưa ra. Tuy nhiên, chính sách cấm/hạn chế xe máy này được thực hiện ở cấp quản lý thấp hơn. Trong các trường hợp này, đây là những quyết định rõ ràng của chính quyền địa phương được cấp cao hơn thông qua. Cấp địa phương có thể là dưới tỉnh, quận hoặc cấp thành phố trong địa hạt (xem Bảng dưới). Do đó, có thể thấy điểm đầu tiên trong chính sách cấm/hạn chế là không cấm/hạn chế xe máy trong cả nước mà chỉ thực hiện ở một số khu vực. Ở các khu vực không cấm/hạn chế, vì tiện ích của xe máy và điều kiện sử dụng, xe máy vẫn được phép lưu hành. 


\section{Bảng 4-7 Cấm/hạn chế xe máy ở một số đô thị của Trung Quốc}

Xe máy bị cấm/hạn chế sử dụng ở các khu vực sau của Trung Quốc:

Cấp tỉnh/thành phố: Bắc Kinh, Thiên Tân và Thượng Hải

Ở cấp thấp hơn (thành phố trực thuộc tỉnh, quận và hạt)

Quảng Châu, Trung Sơn, Thiều Quan, Châu Hải, Đông Hoản, Sán Đầu, Thâm Quyến (tỉnh Quảng Đông);

Thẩm Dương, Đan Đông, Đại Liên, Tieling, Benxi, Anshan (Tỉnh Liên Ninh);

Nam Kinh, Tô Châu, Vô Tích, Thường Châu, Trấn Giang, Nam Thông, Dương Châu, Diêm Thành, Huai'an,

Từ Châu, Chiến Giang, Giang Tô, Zhangjiagang, Giang Âm, Liên Vân Cảng, Côn Sơn (Tỉnh Giang Châu);

Phúc Châu, Tuyền Châu, Chương Châu, Longyan, Hạ Môn (tỉnh Phúc Kiến);

Hàng Châu, Ôn Châu, Ninh Ba, Gia Hưng, Shaoxing, Yiwu (tỉnh Chiết Giang);

Yên Đài, Thanh Đảo, Tế Nam (tỉnh Sơn Đông);

Thạch Gia Trang, Đường Sơn, Trương Gia Khẩu, Qinhuangdao (tỉnh Hà Bắc);

Lạc Dương, Trịnh Châu, Xinxiang, Nanyang, Linzhou, Jiaozou, Anyang (tỉnh Hồ Nam);

Harbin (tỉnh Hắc Long Giang);

Quý Dương, An Thuận, Tongren, Duyun, Zunyi (tỉnh Quý Châu);

Hợp Phì (tỉnh An Huy);

Nam Dương, Cửu Giang (tỉnh Giang Tây);

Trường Sa, Tương Đàm, Nhạc Dương, Trương Gia Giới, Hành Dương (tỉnh Hứa Nam);

Thành Đô, Miên Dương, Deyang, Nghi Tân (tỉnh Tứ Xuyên);

Kôn Minh, Yuxi, Qujing, Mengzi (tỉnh Vân Nam);

Hải Khẩu (tỉnh Hải Nam);

Nam Ninh (khu tự trị của Người Choang ở Quảng Tây);

Vũ Hán, Dương Dương, Nghi Xương, Zhongxiang (tỉnh Hồ Bắc);

Tây An (tỉnh Thiểm Tây);

Thái Nguyên (tỉnh Sơn Tây)

Bao Đầu, Ordos, Dongsheng, Hohhot (khu tự trị Nội Mông);

Trường Xuân (tỉnh Cát Lâm);

Ngân Xuyên (khu tự trị Ninh Hạ Hồi);

Lan Châu (tỉnh Cam Túc);

Tân Cương (khu tự trị Tân Cương).

Nguồn: (Yang, 2010)

Những nhà hoạch định chính sách của các địa phương ở Trung Quốc tin rằng xe máy gây cản trở giao thông và dễ xảy ra tai nạn. Do đó, chính sách cấm áp dụng với tất cả các loại xe máy, dù sử dụng nguồn năng lượng gì. Tuy nhiên, có một điểm đáng chú ý là xe đạp điện được phân loại là xe phi cơ giới và do đó, không thuộc diện bị cấm. Có rất nhiều loại "xe đạp" điện giống như xe cơ giới hai bánh nhưng được trang bị (trang trí) với bàn đạp để được xem là "xe đạp". Do các tiêu chuẩn về xe đạp điện chưa được thực thi nghiêm nên xe đạp điện và xe máy điện đã lấp vào chỗ trống của thị trường do lệnh cấm xe máy tạo ra. Kết quả thực thi quy định không nghiêm dẫn đến chính sách của chính quyền địa phương không hiệu quả chứ không phải quyết định có chủ ý nhằm hỗ trợ giao thông bằng xe điện. Thực tế, sự phát triển nhanh của thị trường xe đạp điện là một "tai nạn” chính sách hơn là một thành công của chính sách (Yang, 2010).

Trong những năm gần đây, việc hạn chế xe đạp điện đã dần được áp dụng rộng rãi hơn. Ví dụ, tỉnh Vũ Hán cấm xe đạp điện lưu thông trên các tuyến đường trong thành phố từ năm 2001 hoặc Phật Sơn cấm xe đạp điện trong khu vực trung tâm thành phố từ năm 2008.

\subsubsection{Kinh nghiệm về chính sách cấm xe máy ở một số tỉnh}

a) Quy trình từng bước một

Chính sách cấm xe máy có tác động xã hội rất lớn. Đó là lý do cần có lộ trình dài hạn. Lộ trình thực hiện chính sách cấm xe máy ở Quảng Châu và Thượng Hải được tổng hợp trong Bảng bên dưới. Có thể thấy Quảng Châu cần 8 năm để thực hiện chính sách theo từng giai đoạn. Tuy 
nhiên, 8 năm không phải là khoảng thời gian quá dài để thực hiện một chính sách có tác động rất lớn tới xã hội.

\section{Bảng 4-8 Quá trình thực hiện chính sách cấm xe máy ở Quảng Châu và Thượng Hải}

- 1991: Hạn chế xe máy không mang biển Quảng Châu vào ban ngày (tất cả xe máy không đăng ký ở Quảng Châu bị cấm lưu hành trong nội đô từ 7 giờ sáng đến 7 giờ tối). Số xe máy mới đăng ký bị hạn chế ở 500 xe/tháng;

- 1995: Cấm đăng ký xe máy mới;

- 1998: Dừng xử lý xe máy hết hạn sử dụng, cập nhật thông tin đăng ký hoặc khiếu kiện cho việc mất giấy đăng ký;

- 1999: Cấm tất cả các loại xe máy mà không đăng ký ở trung tâm Quảng Châu;

- 11/2000: Xe máy và xe 3 bánh đăng ký ở ngoài khu vực nhất định bị cấm ở các quận xung quanh Panyu, Huadu, TP Zengcheng và TP Conghua;

- 2001: Lập tổ công tác về cấm xe máy

- 1/2002: Quy định quản lý tiêu hủy xe máy cũ của Quảng Châu có hiệu lực. Xe máy hoạt động trên 15 năm được coi là xe hết hạn sử dụng, trừ xe đáp ứng được tiêu chuẩn khí thải hiện hành.

- 12/2002: Dừng cấp đăng ký xe máy mới ở 2 quận lân cận (Panyu và Huadu) và các thành phố (Conghua và Zengcheng);

- 2/2003: Quy định về tiêu hủy xe máy và xe 3 bánh được điều chỉnh xuống tương ứng còn 10 năm và 8 năm;

- 4/2003: Bất cứ xe máy nào đăng ký trước $1 / 1 / 1990$ đều hết hạn sử dụng ngay lập tức. Xe máy đăng ký trong giai đoạn 1990 - 1993 sẽ hết hạn sử dụng vào ngày 1/10/2003.

- 3/2004: "Tuyên bố hạn chế xe máy lưu thông trên các tuyến đường của một số khu đô thị" - hạn chế xe máy trong khu vực trung tâm, áp dụng theo 3 giai đoạn.

- 5/2004: Cấm xe máy lưu hành hàng ngày từ 9 giờ sáng đến 4:30 chiều và từ 8:30 sáng đến $5 \mathrm{~h}$ chiều ngày tiếp theo trên một số tuyến hướng tâm ;

- 1/2006: Cấm xe máy lưu hành trên đường Dongfeng 24 giờ/ngày (xe đạp cũng bị cấp lưu thông trên tuyến đường này trước đây)

- 1/2007: Cấm tất cả các loại xe máy trong khu vực đô thị, 24 giờ/ngày.

Nguồn: (Hook và cộng sự, 2009)

Quá trình thực hiện cấm xe máy ở Thượng Hải được thực hiện như sau:

- 7/2002: Cấm lưu hành xe mô tô hai bánh (gồm cả xe đạp gắn máy) trên các tuyến đường chính nằm trong phạm vi đường vành đai Thượng Hai, khu vực tiểu Lujiazui của khu đô thị mới Pudong, trung tâm hành chính Huamu và khu thương mại Zhuyuan trong cả ngày, mở rộng lệnh cấm xe máy 2 bánh (cả xe đạp máy) có biển số nước ngoài trong thành phố.

- 2003: Ủy ban Kinh tế Đô thị Thượng Hải, Ban Quy hoạch, Cục An ninh đô thị và Cục bảo vệ môi trường đô thị cùng ban hành quy định nhằm làm rõ tiêu chuẩn để tiêu hủy xe ba bánh, xe máy các loại đã đăng ký tại thành phố. Quy định: xe sẽ bị thải bỏ nếu theo các tiêu chuẩn như xe đã đăng ký được 8 năm, cự ly vận hành trên $100.000 \mathrm{~km}$, xe bị hưu hại nặng và lượng nhiên liệu tiêu thụ vượt quá tiêu chuẩn quốc gia $20 \%$.

- 2008: Ngừng đăng ký xe máy mới từ ngày 1 tháng 1 .

- 2010: Cục An ninh Đô thị quyết định thực hiện các biện pháp kiểm soát giao thông để cấm xe máy (gồm cả xe đạp điện) lưu thông trên đường quanh khu Triển lãm từ 15 tháng 4 đến 31/10.

- 2011: Từ 15.9, xe máy 2 bánh bị cấm trên 1 số tuyến đường và bị hạn chế trên một số tuyến đường khác. Xe máy các loại mang biển số nước ngoài cấm đi vào khu cao tốc vành đai Thượng Hải G1501 (trước đây là vành đai ngoại ô $\mathrm{A} 30$ ) và khu đô thị Qingpu.

- 2013: Cảnh sát Thượng Hải công bố đợt kiểm tra các loại phương tiện như xe máy của tỉnh và thành phố, tập trung vào việc khảo sát xe máy trong tỉnh và thành phố.

Nguồn: (“Chính sách cấm xe máy ở Thượng Hải, Trung Quốc”, 2016)

\section{b) Sự cần thiết của các chính sách hỗ trợ}

Hook và cộng sự (2009) tổng hợp các biện pháp nhằm hạn chế tác động xã hội của lệnh cấm xe máy ở Quảng Châu. Các chính sách này gồm:

1) Người dân phải trả khoảng 180 USD để tiêu hủy xe hết hạn sử dụng. Mức phí dựa trên tuổi sử dụng của phương tiện. 
2) Hỗ trợ việc làm cho người lái xe máy bị chuyển đổi. Một số loại trợ cấp lao động được ban hành để hỗ trợ người trước đây là lái xe ôm hoặc xe taxi hoặc làm việc trong lĩnh vực vận chuyển bằng xe máy để giúp người lao động tìm việc làm mới.

c) Đánh giá tác động của chính sách cấm xe máy

Chính sách "cấm xe máy” của Quảng Châu có tác động rất lớn tới việc đi lại của người dân cũng như hoạt động của giao thông đô thị cùng với những ảnh hưởng tới môi trường sinh thái, an sinh và trật tự xã hội và chi phí giao thông của thành phố (Deng và cộng sự, 2009). Tác động đầu tiên theo Deng và cộng sự là sự thay đổi trong tỷ phần đảm nhận phương thức trước và sau khi thực hiện. Tỉnh Quảng Châu trước đây gồm 8 quận và sau khi thực hiện lệnh cấm, tỷ lệ đi lại bằng xe máy đã giảm $5,1 \%$ trong khi tỷ lệ đi lại bằng phương tiện công cộng và xe đạp đã tăng $2 \%$, tỷ lệ đi lại bằng xe con tăng nhẹ. Số liệu thống kê về việc chuyển đổi phương thức của người điều khiển xe máy tháng 5 năm 2008 cho thấy tỷ lệ chuyển sang sử dụng phương tiện công cộng và xe đạp tương ứng là $50 \%$ và $19 \%$, số còn lại chuyển sang sử dụng xe con, tàu điện ngầm và taxi với tỷ lệ tương ứng là $11 \%, 10 \%$ và $4 \%$.

Thực hiện thành công chính sách cấm xe máy góp phần tối ưu hóa cơ cấu phương thức giao thông nói chung của Quảng Châu cũng như tác động tới tình hình khai thác hệ thống tàu điện ngầm. Ví dụ, các phương thức vận tải công cộng phải đảm nhận chuyên chở lượng hành khách lớn hơn, dẫn tới tình trạng ùn tắc trong giờ cao điểm. Đó là lý do cần phân tích xem tỷ lệ người sử dụng xe máy chuyển đổi sang các phương thức khác như thế nào và mức độ khai thác và dịch vụ của hệ thống giao thông có ảnh hưởng tới việc chuyển đổi này như thế nào. Vì thế, Deng và cộng sự cho thấy tác động của lệnh cấm xe máy tới từng phương thức vận tải.

1) Tác động tới tàu điện ngầm: Khoảng 96.700 người đi xe máy chuyển sang sử dụng tàu điện ngầm hàng ngày do lệnh cấm xe máy. Lượng người đi xe máy này chiếm khoảng $10,5 \%$ lượng hành khách đi tàu điện ngầm năm 2007.

2) Tác động tới xe buýt: Khoảng 513.800 người đi xe máy chuyển sang đi xe buýt hàng ngày do lệnh cấm xe máy. Lượng người này chiếm $11,4 \%$ lượng hành khách đi xe buýt năm 2007, và chấm dứt chuỗi các năm mà lượng hành khách đi xe buýt giảm. Trong cùng giai đoạn này, năng lực vận tải công cộng trong khu đô thị đã tăng từ 8.456 xe lên 9.424 xe, hay nói cách khác số lượng xe tăng 11,4\%.

3) Tác động tới taxi: 40.300 hành khách đi taxi hàng ngày là chuyển từ đi xe máy sang do lệnh cấm. Lượng người này chiếm $2,1 \%$ lượng hành khách đi taxi hàng ngày năm 2007 . Số lượng xe taxi tăng 2,8\% từ 16.892 lên 17.695 xe, tăng chậm hơn tốc độ tăng số lượng hành khách.

4) Tác động tới xe con: Số người sử dụng xe con tăng lên 680.100 năm 2007, trong đó khoảng 110.800 người là chuyển từ xe máy sang do lệnh cấm. Giả định mỗi xe con chở trung bình 2,2 người, con số trên tương ứng với 50.400 xe con, chiếm 5,2\% số xe lưu thông hàng ngày (hay lưu lượng giao thông) năm 2007 và $16,3 \%$ số xe mới trong những năm gần đây. Do số lượng xe máy lưu hành trong thành phố là 326.000 xe nên lệnh cấm xe máy ở Quảng Châu đã góp phần giải phóng năng lực đường vào khoảng 97.800 xe con, đương đương với 5,8\% năng lực đường ước tính (1,7 triệu xe con) ở khu vực đô thị vào năm 2010. Để dễ hình dung, con số này tương ứng với tăng số xe con bình quân hàng năm từ năm 2005 tới năm 2007 là 97.200 xe.

5) Tác động tới xe đạp: Bình quân, có khoảng 187,400 người chuyển từ sử dụng xe máy sang sử dụng xe đạp do lệnh cấm, chiếm 16,5\% lưu lượng xe đạp bình quân hàng ngày năm 2005 . Sau khi có lệnh cấm, lưu lượng xe đạp trên các tuyến đường chính ban đầu tăng nhưng sau đó giảm dần. Đến tháng 5 năm 2008, lưu lượng xe đạp trên 39 đoạn đường đô thị chính trong giờ cao điểm đã giảm tới $122,8 \%$ so với con số trước khi thực hiện lệnh cấm và trong khu vực trung tâm thì giảm tới $97,5 \%$ so với trước lệnh cấm. Mặc dù chính sách cấm đã từng bước làm giảm vai trò của xe máy, củng cố vai trò của vận tải công cộng (tàu điện 
ngầm và xe buýt) trong việc đáp ứng nhu cầu đi lại của người dân và giúp người dân nhận thức tốt hơn về phương thức thân thiện với môi trường như xe đạp, nhưng tỷ lệ người sử dụng xe máy chuyển sang các phương thức vận tải khác vẫn lớn hơn. Kết quả là nhiều người chuyển sang lựa chọn vận tải công cộng, đem lại cơ hội lớn nhưng cũng không ít thách thức cho phát triển vận tải công cộng và cho các phương thức khác tăng trưởng trong giai đoạn hiện nay.

Tiếp đó, Deng và cộng sự cũng chỉ ra một số tồn tại của chính sách trong việc đáp ứng nhu cầu đi lại của người dân như sau:

1) Vận tải công cộng: Mạng lưới vận tải công cộng chưa hoạt động rộng khắp mà mới chỉ tập trung ở khu vực trung tâm thành phố. Xe buýt chưa hoạt động ở một số đoạn tuyến trong một số khung giờ nhất định. Các tuyến xe buýt quy mô vừa và nhỏ và các tuyến xe buýt gom khách cho tàu điện không hấp dẫn hành khách do khoảng giãn cách giữa các chuyến lớn. Khảo sát hoạt động của xe buýt cho thấy khoảng giãn cách giữa các chuyến là 24 phút và lớn nhất lên tới 60 phút/chuyến trên 9 tuyến vận tải công cộng. Hầu hết các tuyến đều dừng khai thác sớm trong khoảng thời gian 20 giờ-21 giờ hàng ngày, khiến người dân dọc các tuyến này cảm thấy không thuận tiện khi đi lại vào buổi tối. Bên cạnh đó, xe buýt phục vụ các tuyến hoạt động vào ban đêm lại không đủ, có mức phí cao.

2) Vận tải hàng hóa: Lệnh cấm làm tăng chi phí vận chuyển hàng hóa của các ngành kinh doanh và công nghiệp mà xe máy là phương tiện vận chuyển chính trước đây. Kết quả là xe ba gác và xe buýt nhỏ trở thành loại phương tiện vận tải hàng hóa quan trọng trong và quanh các chợ đầu mối.

3) Taxi: Nhiều xe taxi đưa vào hoạt động vẫn không đáp ứng được nhu cầu tăng thêm phát sinh do lệnh cấm xe máy nên người dân càng gặp khó khăn hơn trong việc gọi taxi. Đến cuối năm 2007, Quảng Châu có 17.695 xe taxi đang hoạt động, tương đương với 18 taxi/10.000 dân, thấp hơn rất nhiều so với con số của Bắc Kinh là 41 taxi và Thượng Hải là 26 taxi do từ cuối năm 1998, Quảng Châu đã không mở rộng năng lực vận tải bằng taxi. Việc khó tiếp cận taxi còn là nguyên nhân của lệnh cấm hoạt động trong trung tâm, mở rộng khu vực đô thị và tăng dân số cơ học và tự nhiên cũng như mở rộng Hội chợ Xuất - Nhập khẩu Trung Quốc (Hội chợ Quảng Châu).

\subsubsection{Chính sách hạn chế sở hữu phương tiện tại thành phố Bắc Kinh}

\subsubsection{Các quy định về bốc thăm đăng ký xe con tại Bắc Kinh}

Yang và cộng sự (2014) đã có một bài viết chuyên sâu về kinh nghiệm của Trung Quốc trong việc sử dụng hệ thống bốc thăm cấp phép đăng ký biển số phương tiện. Chi tiết bài viết của Yang và cộng sự được tổng hợp trong phần dưới đây.

Từ tháng 1 năm 2001, Bắc Kinh bắt đầu hạn chế người dân mua xe con bằng cách phân bổ biển số mới thông qua việc bốc thăm được tổ chức công khai. Mặc dù khái niệm hạn chế cấp biển số không phải là mới nhưng trường hợp của Bắc Kinh khá đặc biệt khi sử dụng hệ thống bốc thăm thay vì sử dụng hệ thống đấu giá.

Yang và cộng sự nêu rõ 3 điểm khác biệt chính trong việc sử dụng hệ thống bốc thăm thay vì hệ thống đấu giá để phân bổ số lượng xe ô tô khi hạn chế lượng cung như sau:

1) Thứ nhất, đấu giá giúp tăng nguồn thu trong khi hệ thống bốc thăm thì không. Khoảng 5 tỷ RMB đã thu được thông qua đấu giá ở Thượng Hải năm 2001; hệ thống bốc thăm của Bắc Kinh không đem lại nguồn thu nào. Ở Thượng Hải, nguồn thu này được phân bổ để phát triển đường sá và hệ thống vận tải công cộng. 
2) Thứ 2, ở Bắc Kinh, nhiều người bốc thăm trúng biển số không sử dụng hạn mức mua xe của họ (giấy phép cho phép mua xe), thay vào đó, để giấy phép hết hạn mà không mua xe; số liệu thống kê cho thấy có nhiều tháng, khoảng $10 \%$ số người trúng thăm mua xe để giấy phép hết hạn. Khó có thể tưởng tượng trường hợp những người tham gia đấu giá với giấp phép đắt đỏ sau đó lại để giấy phép hết hạn mà không mua xe. Kết quả là số phương tiện tăng chậm hơn số giấy phép cấp theo hệ thống bốc thăm.

3) Thứ 3 , trong hệ thống đấu giá, những người có nhu cầu mua xe cao nhất sẽ trả tiền để được mua xe. Ngược lại, trong hệ thống bốc thăm, người nhận xe được chọn ngẫu nhiên từ những người đăng ký. Do đó, hệ thống bốc thăm sẽ phân bổ số phương tiện cho những người không hẳn có nhu cầu. Kết quả cho thấy chính sách bốc thăm của Bắc Kinh làm thiệt hại 36 tỷ RMB năm 2012. Một hậu quả khác trong phân bổ biển số cho những người không có nhu cầu mua xe là giá mua giấy phép trên chợ đen tăng.

Không có công bố hoặc tài liệu nào nói về nguyên nhân tại sao Bắc Kinh chọn hệ thống bốc thăm thay vì đấu giá để hạn chế tăng trưởng phương tiện. Nhiều năm trước khi thực hiện chính sách của Bắc Kinh, Singapore và Thượng Hải đã hạn chế thành công số lượng xe hơi thông qua đấu giá. Theo Yang và cộng sự, có thể có 2 nguyên nhân như sau:

1) Thứ nhất, hệ thống bốc thăm có vẻ công bằng hơn. Người dân với mức thu nhập trung bình có cơ hội lớn hơn để có được phép cấp biển số nhờ bốc thăm thay vì đấu giá. Công bằng giữa các nhóm có mức thu nhập khác nhau ngày càng trở thành vấn đề quan trọng ở Trung Quốc, đặc biệt là đối với người dân đô thị. Sở hữu xe con không chỉ là đặc quyền của người giàu mà là biểu tượng gia nhập tầng lớp thu nhập trung bình.

2) Thứ hai, Bắc Kinh đã sử dụng cách thức bốc thăm để phân bổ nhà phù hợp với thu nhập của người dân. Chính sách này được xem là khá thành công nên đã khuyến khích chính quyền sử dụng để phân bổ quyền mua phương tiện.

Ngày 13/12/2010, lần đầu tiên Bắc Kinh ban hành kế hoạch hạn chế đăng ký phương tiện để người dân biết. Kế hoạch cũng bao gồm tăng phí đô̂ xe, mở rộng dịch vụ vận tải công cộng và xây dựng các tuyến đường mới. Từ 24/12/2010, hệ thống đăng ký xe mới bị tạm dừng và người dân được thông báo về việc muốn đăng ký biển số mới, các cá nhân và các công ty phải là người chiến thắng trong cuộc bốc thăm được tổ chức công khai bởi Ủy ban Giao thông Đô thị Bắc Kinh.

Việc bốc thăm được tổ chức vào ngày 26 hàng tháng. Người dân cạnh tranh để may mắn bốc trúng 1 trong 17.600 biển số mỗi tháng. Để được bốc thăm, người dân đăng ký trực tuyến trên trang mạng của thành phố mà không phải nộp phí. Người đăng ký phải trả lời 10 câu hỏi gồm số đăng ký, địa chỉ và thông tin liên hệ. Sau đó, thành phố xem xét lựa chọn đơn đủ điều kiện. Chỉ có người dân có hộ khẩu ở Bắc Kinh hoặc người dân làm việc đã đóng thuế ở Bắc Kinh trên 5 năm mới được chọn tham gia. Ngoài ra, người dân đã có phương tiện sẽ không được tham gia. Tuy nhiên, người lái xe thứ 2 trong hộ gia đình đã có xe con có thể được tham gia bốc thăm quyền mua xe thứ 2 cho hộ gia đình.

Các doanh nghiệp cũng có cơ hội có quyền cấp biển số mua xe thông qua một cuộc bốc thăm khác với 2.400 biển số cấp/tháng; trong đó 400 biển số dành riêng cho doanh nghiệp kinh doanh trong lĩnh vực vận tải như công ty cho thuê xe và công ty taxi. Các doanh nghiệp phải trả thuế giá trị gia tăng và thuế bán hàng với mức thấp nhất là 50.000 RMB áp dụng cho doanh nghiệp may mắn bốc được quyền mua xe mỗi năm và có thể tăng cơ hội mua thêm xe với khoản thuế tăng thêm là 500.000. Tuy nhiên, doanh nghiệp không được phép mua quá 8 xe/năm. Các cơ quan nhà nước, tổ chức xã hội và các tổ chức khác cũng tham gia bốc thăm để giành quyền mua sắm xe. 
Việc tổ chức bốc thăm được thực hiện bởi 6 đại diện là thành viên của Hội đồng Nhân dân hoặc UBND Thành phố Bắc Kinh. Theo đó, tại mỗi cuộc bốc thăm, người tham gia viết 1 số có 6 chữ số bất kỳ. Dưới sự giám sát của các công chứng viên và nhân viên của Ủy ban Thanh tra và Giám sát Kỷ luật, 1 kỹ thuật viên nhập tất cả các số có dấu của văn phòng công chứng vào máy tính cấp biển số để chọn. Kỹ thuật viên ghi lại các biển số được chọn trên đĩa và gửi bản sao đến phòng công chứng, Ủy ban Giám sát của TP Bắc Kinh và Văn phòng Kiểm soát Hạn mức và quản lý xe con của Bắc Kinh. Các số được chọn được công bố trên hệ thống trang web bốc thăm cấp biển số.

Người may mắn sẽ nhận được hạn mức mua xe dưới dạng một chứng chỉ mà có thể tải về từ trang web, bằng này chính là giấy phép cho phép người may mắn có quyền mua xe mới hoặc xe đã qua sử dụng. Người có hạn mức có thể mua biển số với mức phí $125 \mathrm{RMB}$. Hạn mức không được chuyển đổi và bán. Mỗi người may mắn có 6 tháng để mua xe trước khi giấy phép hết hạn. Nếu không mua xe trong khoảng thời gian này, giấy phép sẽ hết hạn sử dụng và được nhập lại vào hạn mức cho lần bốc thăm tiếp theo.

Những người đã có xe không được quyền tham dự trong cuộc bốc thăm, thay vào đó, họ được quyền giữ đăng ký xe hiện có. Nếu người hiện đang sở hữu xe phá hủy hoặc bán xe đã qua sử dụng cho đại lý bán xe, họ có thể giữ lại biển số được cấp để mua xe mới.

\subsubsection{Kinh nghiệm: Thực thi nghiêm ngặt để đảm bảo sự thành công của hệ thống bốc thăm quyền có giấy phép mua xe}

Hệ thống bốc thăm được thực hiện rất nghiêm (Yang và cộng sự, 2014). Người dân muốn tìm cách để tránh hệ thống nghiêm ngặt này, ví dụ như mua xe từ tỉnh khác. Để đối phó với việc người dân mua xe từ thành phố khác và vận hành ở Bắc Kinh, thành phố ban hành quy định hạn chế phương tiện lưu thông bằng cách yêu cầu tất cả xe mang biển số không phải biển số của Bắc Kinh phải có giấy phép lưu thông chính thức trước khi lái xe vào khu vực bên trong đường vành đai 5 . Hơn nữa, chỉ có xe mang biển số của Bắc Kinh mới được hoạt động trong khu vực nằm trong vành đai 5 trong khoảng thời gian giờ cao điểm từ $7 \mathrm{~h}$ đến $9 \mathrm{~h}$ sáng và $5 \mathrm{~h}$ đến 8 giờ tối các ngày làm việc trong tuần. Chủ sở hữu xe có biển ngoại tỉnh nếu cố tình vi phạm sẽ bị phạt 100 RMB cho mỗi lần vi phạm.

\subsubsection{3 Đánh giá tác động của hệ thống bốc thăm}

Yang và cộng sự (2014) thấy rằng hệ thống bốc thăm của Bắc Kinh có tác động rất lớn như sau:

1) Tác động tới nhu cầu về giấy phép cấp biển số: Hệ thống bốc thăm dường như làm tăng nhu cầu của số người muốn tham gia. Ứng viên đủ tiêu chuẩn có thể đăng ký bốc thăm mà không mất phí bằng cách điền đơn rất ngắn trên mạng. Do quy trình đăng ký đơn giản và miễn phí nên thường tất cả các thành viên của gia đình cùng tham gia bốc thăm với hy vọng 1 người trong gia đình sẽ là người may mắn đem lại cơ hội mua xe cho gia đình. Ngoài ra, hộ gia đình chưa có nhu cầu mua sắm xe ngay cũng thường giam gia với ý nghĩ họ có thể có nhu cầu mua xe khi họ là người may mắn. Kết quả là nhiều người may mắn lại không mua xe trong thời giạn 6 tháng, để hạn mức hết hạn. Thống kê cho thấy tháng 6 năm 2012, 10,9 \% cá nhân may mắn không mua xe trong thời gian cho phép. Đối với các doanh nghiệp may mắn, tỷ lệ không mua xe trong thời hạn cho phép lên tới $22,8 \%$. Việc có rất ít cơ hội may mắn cho thấy nhiều người thực sự có nhu cầu tham gia lại có rất ít cơ hội may mắn để mua xe. Bên cạnh đó, nhiều hạn mức lại để hết hạn mà không được sử dụng. Điều này là một điểm tất yếu xảy ra dưới hệ thống bốc thăm của Bắc Kinh. Người đăng ký may mắn được 
quyền chọn mua xe mà không phải trả thêm phí nếu để hạn mức hết hạn. Nếu để hạn mức hết hạn, họ chỉ cần đăng ký tham gia bốc thăm lần khác mà không phải trả phí phạt. Hệ thống này được xây dựng để đảm bảo việc tham dự vào hệ thống bốc thăm sẽ tạo ra giá trị tích cực cho người tham dự dưới hình thức là họ có một cơ hội để chiến thắng trong việc mua xe ô tô. Do đó, Bắc Kinh đã sửa đổi chính sách vào năm 2012 nhằm giải quyết vấn đề này. Thời hạn hiệu lực để đăng ký bị hạn chế: sau mỗi 3 tháng, những người tham gia bốc thăm quyền mua xe phải sử dụng trang web để xác nhận rằng họ thực sự có nhu cầu mua xe, nếu không, đơn của họ sẽ bị loại bỏ.

2) Tác động tới số lượng xe: Việc bốc thăm giành quyền mua xe có tác động rất lớn tình hình đăng ký xe. Lượng đăng ký xe mới đã giảm 75\% trong giai đoạn 2010-2011. Tương tự tăng trưởng tổng số xe đăng ký mới cũng giảm mạnh. Tổng số xe mới bán ở Bắc Kinh giảm mạnh từ 920.000 xe năm 2010 xuống còn 400.000 xe năm 2011 , giảm $57 \%$. Doanh thu bán xe của Bắc Kinh giảm từ 155,7 tỷ RMB xuống còn 86,8 tỷ RMB, giảm $44 \%$. Thị trường xe con đã qua sử dụng cũng bị ảnh hưởng mạnh bởi chính sách này: số xe đã qua sử dụng bán được giảm từ 520.000 xe năm 2010 xuống 400.000 xe năm 2011 .

3) Cải thiện ùn tắc giao thông: Hiệu quả của chính sách bốc thăm quyền mua xe có tác động cải thiện tình hình giao thông ngay lập tức. Ùn tắc giao thông giảm đáng kể từng tháng trong năm 2011, cho thấy việc thực thi chính sách có hiệu quả rất lớn. Theo Báo cáo Giao thông hàng năm của Bắc Kinh năm 2011, tốc độ của phương tiện đã tăng từ 22,6 km/h năm 2010 lên $25,3 \mathrm{~km} / \mathrm{h}$ năm 2011. Tóm lại, hạn chế cấp biển số có tác động trực tiếp tới sự tăng trưởng số lượng xe con, góp phần nâng cao hiệu quả của các biện pháp khác. Hạn chế cấp phép biển số lưu hành giảm tăng trưởng trong nhu cầu sử dụng đường bộ, cho phép tăng năng lực đường bộ và các phương tiện thay thế, qua đó góp phần giảm ùn tắc giao thông. Tuy nhiên, còn quá sớm để đánh giá tác động này trong giai đoạn trung và dài hạn.

\subsubsection{Chính sách cấm xe máy ở Yangon (Myanmar)}

\subsubsection{Thay đổi trong chính sách}

Chính quyền trung ương đã ban hành lệnh cấm xe máy từ năm 2003 ở Yangon theo lộ trình từng bước với những thay đổi trong các quy định. Lộ trình thực hiện như sau:

- Giai đoạn 1 (2003-2007): Cấm xe máy trong toàn thành phố.

- Giai đoạn 2 (2007-8/2008): Nới lỏng lệnh cấm, cho phép xe máy hoạt động ở 14 khu vực ngoại thành.

- Giai đoạn 3 (2009- đến nay): Chính quyền quyết định cấm hoàn toàn xe máy ở Yangon do xe máy thường vi phạm luật giao thông và thường xuyên gây tai nạn.

Không giống như các thành phố của Trung Quốc, TP Yangon cấm xe máy khi xe máy không được sử dụng rộng rãi do chi phí cao. Thuế nhập khẩu rất cao trong khi thu nhập của người dân thấp. Tuy nhiên, trong 15 năm qua, tình hình đã thay đổi. Những cải cách của chính quyền Thein Sein khiến giá xe máy giảm mạnh cho cả xe cần cấp phép và xe không cần cấp phép. Xe không cần cấp phép, xe Trung Quốc hiện được bán với giá khoảng $350.000 \mathrm{~K}$ trong khi xe cần cấp phép vào khoảng $450.000 \mathrm{~K}$, giảm một nửa so với giá bán năm 2008 , không tính đến lạm pháp và biến động tỷ giá. Kết quả là nhiều người dân cho rằng lợi ích do sở hữu xe máy mang lại lớn hơn hậu quả của việc bị bắt giữ khi sử dụng ${ }^{69}$.

\subsubsection{Lý do chính quyền áp đặt lệnh cấm}

${ }^{69} \mathrm{https}$ ://frontiermyanmar.net/en/yangons-two-wheeled-conundrum 
Lý do cấm xe máy theo giải thích của chính quyền địa phương đưa ra là Yangon rất đông đúc và tai nạn thường xuyên xảy ra. Một bộ trưởng còn khẳng định: Nguyên nhân cấm xe máy là

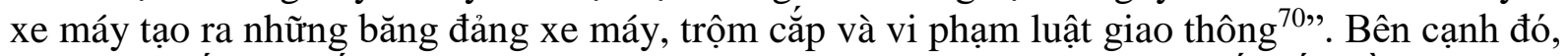
Yangon thiếu hệ thống vận tải công cộng tin cậy nên người dân giải quyết vấn đề này thông qua việc sử dụng xe máy, khiến số lượng xe máy tăng mạnh.

\subsubsection{Các tác động của chính sách cấm xe máy}

Chính quyền Yangon phải đối mặt với tình trạng ùn tắc ngày càng nghiêm trọng. Không giống như các thành phố Tokyo hay Bangkok, nơi ùn tắc giao thông đã trở nên nổi tiếng, ùn tắc giao thông ở Yangon xảy ra không chỉ trên các tuyến đường chính mà ở cả các tuyến phố trong các khu dân cư. Tình trạng đó gây khó chịu không chỉ cho người sử dụng xe máy mà còn cả người dân trong khu vực.

Mật độ xe con (tỷ lệ số xe con/số dân) ở Tokyo và Băng Cốc cao hơn nhiều so với tỷ lệ này của Yangon. Do đó, dễ hiểu tại sao ùn tắc giao thông lại xảy ra. Mặc dù ùn tắc giao thông diễn ra thường xuyên ở Băng Cốc hay Tokyo, người đi xe máy và người đi bộ đều có kỷ luật khá tốt. Ngược lại ở Yangon, nơi có mật độ xe con thấp hơn nhiều, ùn tắc giao thông thường xảy ra do người đi xe máy và người đi bộ thiếu kỷ luật và ý thức. Hầu hết người đi xe máy không tuân thủ luật lệ giao thông hoặc thiếu ý thức khi lái xe. Họ không chú ý tới người đi bộ cũng không tuân thủ luật lệ.

Các nguyên nhân chính dẫn đến ùn tắc giao thông ở Yangon là: hệ thống đường bộ chưa được đầu tư phát triển đáp ứng nhu cầu của người dân; chưa phát triển hệ thống vận tải khối lượng lớn phù hợp, thiếu không gian bãi đỗ xe công cộng dẫn tới việc đỗ xe tràn lan dọc các tuyến đường, tuyến phố. Không có xe máy, người dân phải sử dụng xe con nhưng do chi phí mua xe mới cao, người dân thường mua xe đã qua sử dụng, không đáp ứng các tiêu chuẩn về an toàn và bảo vệ môi trường.

Một vấn đề khác là thực thi luật lệ. Xe máy bị cấm lưu thông trong khu vực trung tâm Yangon trong khi vẫn được sử dụng rộng rãi ở khu vực ngoại vi thành phố, nơi vận tải công cộng còn kém phát triển. Kết quả là vẫn xảy ra tình trạng xe máy đi vào trung tâm thành phố. Cảnh sát đã thực hiện một số biện pháp để tăng cường thực thi pháp luật như bắt giữ người điều khiển và giữ phương tiện. Xe không có giấy phép sẽ được đem ra đấu giá hoặc bị tiêu hủy nếu người chủ sở hữu không đăng ký xe trong vòng 6 tháng, trong khi đó, xe có giấy phép - thường là xe có đăng ký ở các bang hoặc vùng khác - có thể được trả lại sau khi trả khoảng tiền phạt $51.500 \mathrm{~K}$ (42 đô la Mỹ). Tuy nhiên, hiện cảnh sát đang phải đối mặt với vấn đề giữ xe vi phạm bắt được ở đâu. Thành phố không đủ chỗ để tất cả các xe vi phạm thu giữ được.

\subsection{Tổ chức giao thông cho xe máy và xe đạp điện ở Châu Á}

Các phương tiện cơ giới hai bánh (xe máy, xe đạp điện) được sử dụng làm phương tiện đi lại chính hàng ngày tại nhiều đô thị ở châu Á. Có nhiều lý do khiến người dân thích sử dụng các loại xe này. Ví dụ như các phương tiện này tiện lợi, rẻ và linh hoạt. Tuy nhiên, dù một mặt việc sử dụng các loại xe đó cũng mang lại lợi ích nhất định, nhưng mặt khác, người điều khiển các phương tiện cơ giới hai bánh lại phải hứng chịu nhiều rủi ro. Theo các Báo cáo của Tổ chức $\mathrm{Y}$

${ }^{70} \mathrm{http}: / /$ elevenmyanmar.com/local/6329 
tế Thế giới về Hiện trạng An toàn Đường Bộ trên toàn cầu (WHO, 2013, 2015) thì các đối tượng điều khiển phương tiện cơ giới hai bánh thường chịu nhiều rủi ro nhất trên đường bộ, nhất là tại khu vực Đông Nam Á. Cụ thể, người điểu khiển phương tiện cơ giới 2-3 bánh chiếm tới $33 \%$ tỷ lệ tử vong do tai nạn giao thông ở Đông Nam Á. Do đó, đảm bảo an toàn cho người điều khiển phương tiện cơ giới hai bánh được coi là nhiệm vụ trọng yếu của các cơ quan quản lý giao thông ở nhiều quốc gia.

Các biện pháp tổ chức giao thông đóng vai trò then chốt trong việc đảm bảo giao thông an toàn và thông suốt trên đường bộ, nhất là ở khu vực Đông Nam Á nơi chủ yếu là dòng giao thông hỗn hợp. Các biện pháp tổ chức giao thông chỉ tập trung vào việc tách riêng luồng xe cơ giới hai bánh khỏi dòng giao thông hỗn hợp để giảm việc sử dụng cũng như hạn chế quyền của người sử dụng xe. Cụ thể, các biện pháp tổ chức giao thông liên quan tới xe cơ giới hai bánh bao gồm rẽ theo hai bước tại nút giao, vạch dừng dành riêng cho xe hai bánh, làn đường cho xe hai bánh. Những biện pháp đó đã được triển khai ở nhiều nền kinh tế khác nhau, cả ở những nơi có thu nhập cao (Đài Loan - Trung Quốc), thu nhập trung bình-cao (Malaysia và Trung Quốc), và thu nhập trung bình-thấp (Indonesia).

\subsubsection{Các biện pháp tổ chức giao thông liên quan tới xe máy}

\subsubsection{Làn xe máy}

a) Đài Loan: Làn ưu tiên/dành riêng cho xe máy

Giao thông hỗn hợp ô tô và xe máy là hình thái giao thông chính ở Đài Loan (Hsu và cộng sự., 2003). Giao thông hỗn hợp ô tô và xe máy sẽ trở nên ngày càng nguy hiểm hơn do xe máy làm cản trở. Thực tế quan sát cho thấy, xe máy có kích thước khá nhỏ, tạo điều kiện linh hoạt khi di chuyển, có thể dừng đỗ ở mọi nơi. Ngoài ra, xe máy có thể dễ dàng len lỏi vào hàng xe ô tô ở những khu vực ùn tắc. Do đó, mô hình phân tách các loại xe đã được áp dụng ở Đài Loan. Năm 1999, Đài Bắc đã có thiết kế mới cho làn dành riêng cho xe máy ở khu vực trung tâm thành phố. Đài Loan là một trong số ít vùng lãnh thổ trên thế giới đã xây dựng hạ tầng riêng cho xe máy và đã nghiên cứu tác động từ đó (Hook và cộng sự, 2009). Trên phần lớn lãnh thổ Đài Loan, làn xe máy được tách khỏi dòng xe ô tô chỉ bằng vạch sơn kẻ. Dải phân cách cứng tách làn xe máy chỉ được bố trí ở một số cầu nhất định, một số đoạn đường ngắn dẫn lên cầu.

Hsu và cộng sự (2009) đã định nghĩa một tham số mới, "tỷ lệ hỗn loạn", để mô tả tình trạng giao thông hỗn loạn của xe máy trong làn giao thông hỗn hợp. Tỷ lệ hỗn loạn này có giá trị càng cao thì xu hướng giao thông xe máy càng hỗn loạn hơn. Nói cách khác, tỷ lệ này cho thấy rằng xe máy tự loại bỏ bản thân và sẽ làm tăng nguy cơ xung đột. Nếu tỷ lệ hỗn loạn nhỏ, trật tự trên luồng giao thông là tốt. Giá trị của tỷ lệ hỗn loạn này phụ thuộc vào tốc độ, lưu lượng xe và chiều rộng làn xe (Hsu \& Li, 2007; Hsu và cộng sự, 2009). Tỷ lệ hỗn loạn cần được cân nhắc tới trước khi triển khai làn xe máy. Căn cứ vào tỷ lệ hỗn loạn này, Hook và cộng sự (2009) đã tổng hợp các nguyên tắc sơ bộ sau đây đối với việc tách làn xe máy:

- Trên các đoạn đường nơi xe máy và các loại xe ba bánh chiếm tỉ trọng phương thức trên $50 \%$ thì việc tách làn xe không có ý nghĩa;

- Có thể bố trí làn xe máy riêng nếu có trên 1.000 xe máy di chuyển mỗi giờ và nếu tỷ trọng xe máy từ $10 \%$ đến $60 \%$ lượng xe.

- Cần tính toán chiều rộng đường và tốc độ cho phép từ $40 \mathrm{~km} / \mathrm{h}$ trở xuống để đảm bảo dòng giao thông hỗn hợp an toàn ở tốc độ thấp thay cho việc chia dòng giao thông thành các làn xe đặc biệt. 
Về việc tách xe máy khỏi dòng xe di chuyển nhanh, có hai loại làn xe máy là làn ưu tiên và làn dành riêng cho xe máy (Wang, 2014; Yeh, 2012). Làn dành riêng cho xe máy tạo một không gian làn đường tách riêng mà dành chủ yếu cho người đi xe máy trừ khi ô tô phải đi qua để đỗ cạnh lề đường hoặc để rẽ phải tại nút giao kế tiếp. Trong phần lớn trường hợp, việc bố trí làn xe dành riêng/ưu tiên xe máy đi kèm với các làn cấm xe máy (xem Hình bên dưới). Việc kết hợp này là nhằm tập trung xe máy vào khu vực làn đường dành riêng/ưu tiên xe máy (Wang, 2014). Trên phần lớn các tuyến đường đô thị, các làn dành riêng/ưu tiên xe máy thường bị dùng làm nơi đỗ, dừng xe. Hậu quả là xe máy bị buộc phải di chuyển trên các làn cấm xe máy hoặc trên các làn xe tốc độ cao. Tai nạn đường bộ có nguy cơ xảy ra trong thời gian chuyển làn khi xe máy bị buộc phải rời khỏi làn dành riêng/ưu tiên xe máy. Nhìn chung, làn dành riêng/ưu tiên xe máy thường ít khi được bố trí hơn so với biện pháp khu vực dừng chờ dành riêng cho xe máy ở phía sau vạch dừng vì không có đủ không gian đường (Yeh, 2012).

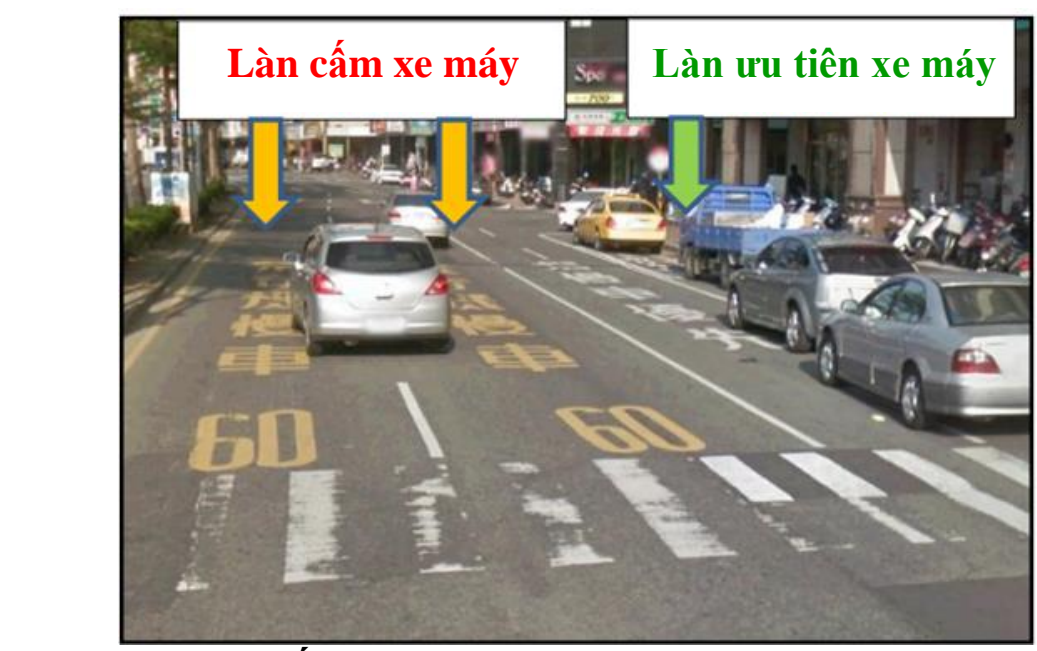

Hình 4-10 Làn cấm xe máy (MBL) và Làn ưu tiên xe máy (MPL)

Nguồn: (Wang, 2014)

\section{b) Malaysia: Làn ưu tiên/dành riêng cho xe máy}

Theo một báo cáo của MIROS về hạ tầng dành cho xe máy, ở Malaysia có hai loại công trình hạ tầng cho xe máy là: 1) Làn dành riêng cho xe máy (xem Hình trên); và 2) Làn ưu tiên cho xe máy (xem Hình dưới). Các công trình hạ tầng này nhằm tách xe máy khỏi dòng giao thông hỗn hợp. Làn dành riêng cho xe máy $(\mathrm{EMCL})$ được bố trí trên đường có trải mặt và tách biệt hoàn toàn khỏi phần đường xe cơ giới khác. Loại hạ tầng này chỉ có thể triển khai trên các đoạn đường có chỉ giới lớn. Trên thực tế, làn dành riêng cho xe máy được bố trí ở đường liên bang (F02), cao tốc Sha Alam (KESAS), tuyến sân bay Subang (FT15), Putrajaya, cao tốc Butterworth-Kulim (BKE), cao tốc hành lang Guthrie và đường Cảng Tanjung Pelepas.

Làn dành riêng cho xe máy đầu tiên được bố trí trên đường liên bang F02 vào đầu thập kỷ 70 với sự hỗ trợ của Ngân hàng Thế giới. Tuyến đường này nối thành phố Kuala Lumpur với sân bay quốc tế Subang, tổng chiều dài $16 \mathrm{~km}$. Về sau, vào đầu năm 1992, việc kéo dài làn xe máy được thực hiện trong khuôn khổ dự án Lebuhraya Utara Selatan (PLUS) từ sân bay quốc tế Subang tới Shah Alam và Klang. Do đó, tổng chiều dài làn dành riêng cho xe máy trên trục F02 lên tới khoảng 30 km mỗi hướng (Kuala Lumpur-Klang và Klang-Kuala Lumpur). Các đoạn chính của làn dành riêng cho xe máy đều được hoàn tất trước thời hạn và đã thông xe vào tháng 11 năm 1993. 


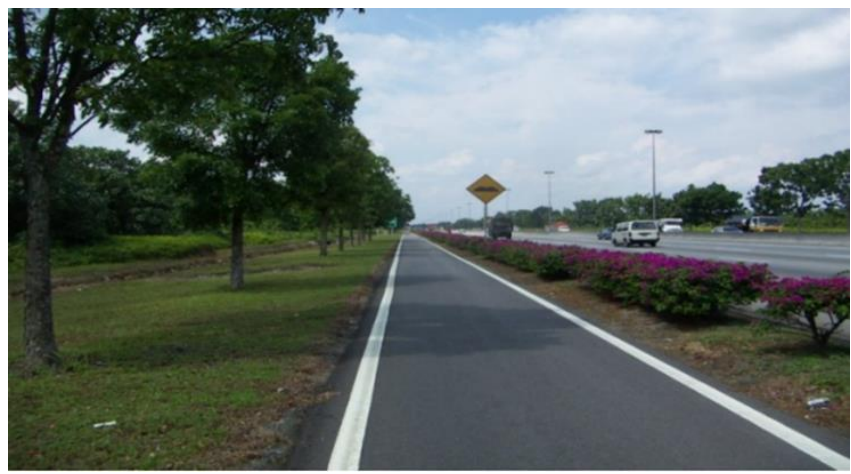

Hình 4-11 Làn dành riêng cho xe máy (EMCL)

Nguồn: (MIROS, 2017)

Làn ưu tiên xe máy (NEMCL) được 'cải tạo' từ các trục đường liên bang hiện hữu, nằm trong phần đường chính, để tạo không gian di chuyển riêng cho người đi xe máy song song với dòng xe cơ giới khác. Làn ưu tiên xe máy được chia thành hai loại, là làn có đánh dấu trên mặt đường thể hiện rằng đó là hành lang bố trí cho người đi xe máy và làn không có sơn kẻ mặt đường riêng, cũng là loại tận dụng từ vai đường. Phần vai đường có vai trò hỗ trợ cho phần mặt đường chính trên tất cả các đường quốc lộ và liên bang. Chiều rộng của vai đường có thể thay đồi khoảng $1,5 \mathrm{~m}$ tới $2,0 \mathrm{~m}$, tuỳ thuộc vào chức năng của tuyến đường. Người đi xe máy có thể di chuyển trên phần vai đường, còn các loại xe cơ giới khác không đường đi vào phần đường này trừ phi có trường hợp khẩn cấp, hư hỏng xe. Hiện tại, làn ưu tiên xe máy được bố trí trên toàn lãnh thổ Malaysia.
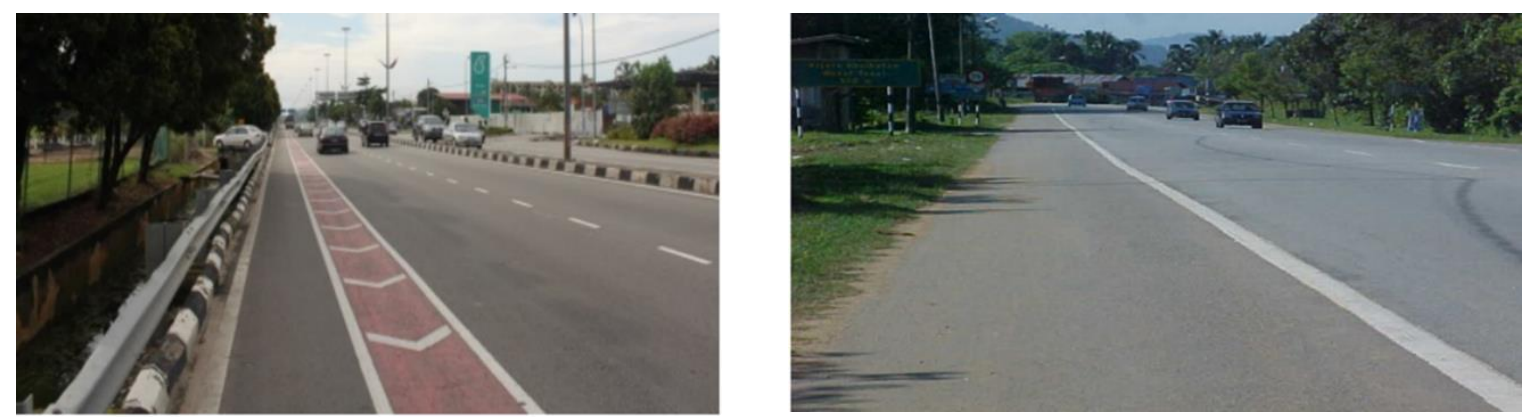

Hình 4-12 Làn ưu tiên xe máy (NEMCL)

Nguồn: (MIROS, 2017)

Thực tế tại Malaysia cho thấy rằng làn xe máy, như đã bố trí ở nhiều nơi, tỏ ra hữu hiệu khi giảm các vụ va chạm và tai nạn cùng chiều (Hook \& Fabian, 2009). Làn đầu tiên được bố trí vào thập kỷ 1970, và kể từ đó Malaysia đã luôn chủ động xây dựng các chiến lược để kiểm soát dòng giao thông xe máy. Malaysia đã áp dụng cả làn 'dành riêng' và làn 'ưu tiên' (sử dụng vai đường). Nghiên cứu của Law và Radin Sohadi (2005) cho thấy rằng làn dành riêng cho xe máy cần chiều rộng hữu hiệu là $3,81 \mathrm{~m}$ (tính cả phần $0,38 \mathrm{~m}$ tại hai rìa đường) để hai xe máy di chuyển song song thoải mái ở tốc độ $70 \mathrm{~km} / \mathrm{h}$. Giá trị này cao hơn mức $3,5 \mathrm{~m}$ mà Bộ Hạ tầng đang áp dụng (Hook \& Fabian, 2009). Theo Chương trình Tiếp cận Đường bộ Quốc tế, chiều rộng làn xe máy cần rộng tối thiểu $1,8 \mathrm{~m}$ (mỗi hướng).

Ngoài ra, Hook và Fabian (2009) cũng đã tổng hợp một nội dung của Hướng dẫn Thiết kế Malaysia (Arahan Teknik Jalan8/86, 1986.A Guide On Geometric Design of Roads, Jabatan 
Kerja Raya (JKR), Malaysia) như sau: “Tại những khu vực thường xuyên có tỷ lệ cao người đi xe máy, lưu lượng có thể tác động đến dòng giao thông cơ giới. Trong các trường hợp đó, cần cân nhắc bố trí làn xe máy tách riêng. Những tiêu chí chung để xác định sự cần thiết của làn dành riêng cho xe máy là: (i) tổng lưu lượng giao thông vượt quá năng lực của làn xe, và (ii) lưu lượng xe máy vượt quá $20 \%$ tổng lưu lượng giao thông."

Theo Hook và Fabian, Hướng dẫn Thiết kế Malaysia cũng đề xuất: "Khi lưu lượng xe máy vượt quá $30 \%$ tổng lưu lượng giao thông tại nút giao vào giờ cao điểm hoặc việc bố trí nút giao đồng mức không đảm bảo lưu thông thông suốt, hay không đảm bảo an toàn cho người đi xe máy, thì cần cân nhắc bố trí nút giao khác mức. Biện pháp này có thể dễ dàng triển khai tại nút có vòng xuyến hoặc các nút có bố trí hầm chui. Hầm chui phải có tĩnh không $2,5 \mathrm{~m}$, độ dốc tối đa $10 \%$, cần có chiếu sáng để đảm bảo tầm nhìn và an toàn vào ban đêm."

Không còn nghi ngờ gì nữa, việc tách xe máy khỏi dòng xe cơ giới khác là việc làm lý tưởng để đảm bảo an toàn cho người đi xe máy trên các tuyến đường lưu lượng lớn (MIROS, 2017).

Tuy nhiên, làn xe máy ở Malaysia cũng có một số vấn đề, cụ thể như sau:

1) Hiệu quả sử dụng làn xe máy: Việc sử dụng làn xe máy cũng là một vấn đề ở Malaysia. Ở một số nơi, có vẻ như làn xe máy chưa thực sự phát huy hiệu quả. Tuy nhiên, nhận định này không có số liệu cụ thể để chứng minh và cũng chưa có nghiên cứu quy mô nào triển khai để xác định tại sao người đi xe máy lại tỏ ra lưỡng lự khi sử dụng hạ tầng dành cho mình.

2) Điểm vào và ra của làn xe máy dành riêng cũng là một trong những điểm nguy hiểm nhất, do ở nơi này người đi xe máy phải có những quyết định quan trọng về việc nhập vào hay rời khỏi dòng giao thông cơ giới chung. Vấn đề đầu tiên là có nhiều dạng và thiết kế không hợp lý tại các điểm vào, ra làn dành riêng cho xe máy. Quan sát thực tế cho thấy những nhược điểm của các điểm vào, ra này là: $i)$ thiếu biển cảnh báo cho người đi xe máy biết sự hiện diện của điểm vào, ra; ii) vị trí bất hợp lý của điểm vào, ra tại các đoạn cong, đoạn dốc, gần nút giao hay hầm chui, làm hạn chế tầm nhìn, khả năng quan sát và tiềm ẩn rủi ro; iii) cự ly gần giữa điểm vào, ra và nút giao trên đường chính có thể gây xung đột với các phương tiện cơ giới đường bộ.

3) Vấn đề không hợp chuẩn và sử dụng sai mục đích làn ưu tiên xe máy: Mặt bằng của làn ưu tiên xe máy, theo quan sát trên cả nước Malaysia, là thiếu nhất quán. Sự nhiếu nhất quán có ở chiều rộng làn, thiết kế vạch phân làn, bố trí góc phản quang, chiều rộng hành lang an toàn. Có lý do để tin rằng chính những sự thiếu nhất quán này dẫn tới việc phát huy thiếu hiệu quả phần hạ tầng đã bố trí riêng đó.

4) Rủi ro va chạm tại các đoạn có làn ưu tiên xe máy, và

5) Những khoảng trống trong hướng dẫn thiết kế: Trong giai đoạn xây dựng ban đầu làn dành riêng cho xe máy, tiêu chuẩn thiết kế cho xe máy còn rất hạn chế hoặc chưa có. Vào năm 2011, Hiệp hội Kỹ thuật Đường bộ Malaysia (REAM) phối hợp với Jabatan Kerja Raya (JKR) Malaysia xây dựng hướng dẫn thiết kế cho công trình phục vụ xe máy.

\subsubsection{Rẽ theo hai bước cho xe máy}

\section{a) Đài Loan: Ô rẽ trái dành cho xe máy \& Làn cấm xe máy}

Hook và Fabian (2009) đã tổng hợp hai dạng tai nạn xe máy chính ở Đài Bắc (Trung Quốc) như sau: 1) va chạm bên sườn trên đường khi chuyển làn xe, và 2) va chạm đối đầu và va chạm bên sườn tại nút giao có sự liên quan tới xe máy rẽ trái. Để đối phó với vấn đề tai nạn tại nút giao khi xe rẽ trái, quy định rẽ trái theo hai bước/giai đoạn đã có hiệu lực từ năm 1984 (Wang, 2014). Quy định này bắt đầu áp dụng ở Đài Bắc, rồi dần dần triển khai trên cả nước. Theo đó, xe máy dưới $250 \mathrm{cc}$ bị cấm rẽ trái trực tiếp trên đường có hai làn xe trở lên (Everington, 2018). Xe máy chuyển hướng tại nút giao có đèn tín hiệu phải tuân thủ quy định sau đây về rẽ trái theo hai 
bước. Xe máy rẽ trái phải đi thẳng qua nút giao tới ô sơn kẻ dành cho xe máy chờ (ô chờ rẽ cho xe máy rẽ trái theo hai bước) và chờ cho đến khi tín hiệu chuyển đèn xanh. Nếu làn bên trong có biển hoặc có vạch kẻ chỉ dẫn "cấm xe máy", thì người đi xe máy phải thực hiện rẽ trái theo hai giai đoạn (xem Hình dưới).
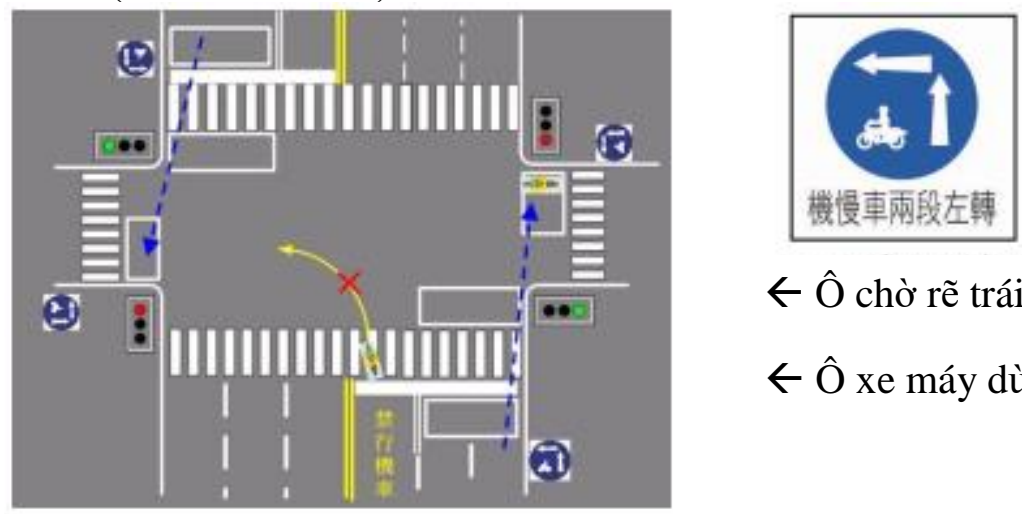

$\leftarrow$ Ô chờ rẽ trái

$\leftarrow$ Ô xe máy dừng, chờ

\section{Hình 4-13 Co chế chuyển hướng 2 bước ở Đài Loan}

Nguồn: (Wang, 2014)

Quy trình này thực tế đã chia việc rẽ trái thành hai giai đoạn với hai pha đèn giao thông khác nhau. Ý tưởng ở đây là xe máy thường di chuyển ở phía bên phải của đường, nên việc rẽ trái trực tiếp cắt ngang nhiều làn đường được coi là hành vi nguy hiểm, do đó cần phải tách thành những bước nhỏ hơn. Người đi xe máy có xu hướng đi vào phần không gian giữa làn xe sát lề và làn xe hỗn hợp liền kề, cho dù làn xe đó có được đánh dấu là làn xe máy hay không. Khi xe máy tới nút giao thì sẽ đi thẳng cho tới khi đến ô chờ rẽ trái. Nhờ biện pháp này, số vụ tai nạn giao thông do rẽ trái gây ra có thể giảm xuống. (Hook \& Fabian, 2009).

Thông thường, xe máy bị cấm rẽ trái trực tiếp nếu như đã có ô chờ rẽ trái bố trí tại nút giao có đèn tín hiệu. Người đi xe máy muốn rẽ trái phải đi thẳng qua nút giao vào pha đèn xanh rồi đợi tại khu vực đã chỉ định sẵn phía trước vạch sang đường cho người đi bộ, phía trước dòng giao thông theo hướng vuông góc tới. Do đó, vạch sang đường và vạch dừng cần dịch lùi xa nút giao hơn, để tạo không gian cho ô chờ rẽ trái. Kích thước của ô chờ rẽ trái theo quy trình hai bước này phụ thuộc vào không gian có được tại từng nút giao cụ thể. Thông thường, diện tích chờ rẽ trái có kích thước $0,8 \mathrm{~m}$ x 2,3m cho mỗi xe chờ rẽ trái (Hook \& Fabian, 2009).

Có hai nguyên tắc sơ bộ khi bố trí ô rẽ trái (hay ô xe máy chờ), bao gồm: 1) mặt bằng của nút giao và 2) lượng xe máy rẽ trái. Về mặt bằng nút giao, ô chờ rẽ trái thường được bố trí ở hướng nhập của đường chạy cắt ngang có hai làn xe trở lên (Yeh, 2012). Ngoài ra, thường bố trí tại ngã tư, ít khi bố trí tại ngã ba (dạng hình chữ $\mathrm{T}$ hay chữ $\mathrm{Y}$ ). Đối với nút giao hình chữ $\mathrm{T}$, do hạn chế về không gian, việc triển khai vùng chờ rẽ theo quy trình hai bước cho xe máy là khá khó khăn. Tại nút giao hình chữ $\mathrm{T}$, việc xung đột giữa xe máy rẽ trái và xe đi thẳng diễn ra thường xuyên (Wang, 2014). Về lưu lượng xe máy, nên bố trí ô chờ rẽ trái cho xe máy khi có trên 200 xe máy rẽ trái mỗi giờ tại nút giao có đèn tín hiệu (Hook \& Fabian, 2009). 


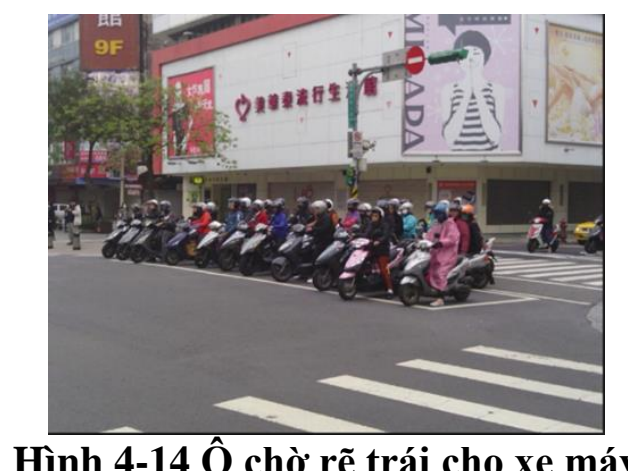

Nguồn: (Everington, 2018)

Tuy nhiên, việc triển khai quy trình rẽ trái theo hai bước cũng có nhiều hạn chế. Everington (2018) đã liệt kê nhiều vấn đề bất cập liên quan tới ô chờ rẽ trái ở Đà Loan:

- Không lường trước được hành vi của lái xe: Người đi xe máy rẽ phải thường đến sát hoặc lấn vào chỗ xe máy đang chờ thực hiện chu kỳ rẽ trái, nên nếu như đèn tín hiệu không thuận lợi thì có thể xảy ra xung đột.

- Hiệu quả chuyển hướng kém: Tại giờ cao điểm, số lượng xe máy chờ rẽ trái sẽ vượt quá diện tích của ô chờ rẽ, do đó tràn vào các làn xe khác. Điều này khiến lường lưu thông trở nên kém hiệu quả, không chỉ làm tăng tắc nghẽn giao thông mà còn gây nguy hiểm cho người đi bộ đi trên vạch sang đường.

- Vi phạm luật giao thông: Một vấn đề khác nữa là việc muốn chiếm lấy chỗ trong ô chờ để có được vị trí dẫn đầu trong dòng giao thông khi đèn tín hiệu chuyển xanh. Những người lợi dụng cơ chế theo cách này sẽ làm giảm chỗ dành cho những người thực sự muốn rẽ trái, khiến gây thêm ùn tắc và như vậy, có thể nói là mục đích ban đầu của việc tạo ra ô chờ rẽ trái đó đã không đạt được.

- Vị trí của ô chờ rẽ trái có thể gây ra xung đột giữa xe máy rẽ trái và xe máy đi thẳng. Ngoài ra, vạch sang đường và vạch dừng phải lùi lại để tạo không gian cho ô chờ rẽ trái, khiến làm tăng chiều dài vượt nút giao và làm giảm tầm nhìn tại nút giao.

Chính từ các bất cập trên, thành phố Taoyuan ở phía bắc Đài Loan đã có thí tổ chức thí điểm bỏ áp dụng ô chờ rẽ trái cho xe máy, thay vào đó là cho phép xe máy rẽ trái trực tiếp, và thực tế đã dần tới ít tai nạn hơn. Từ năm 2016, tỷ lệ tai nạn xe máy đã giảm mạnh (30\%-40\%) tại 17 nút giao nơi bỏ áp dụng quy định cấm xe máy rẽ trái trực tiếp.

b) Nhật Bản: Quy định rẽ phải theo hai bước dành cho xe máy phân khối nhỏ

Quy định chuyển hướng hai bước áp dụng với xe máy không phải chỉ có ở Đài Loan. Trên thực tế, quy định này cũng được áp dụng ở Nhật Bản. Ở Nhật Bản, dòng phương tiện di chuyển ở bên trái đường và có nhiều người sử dụng xe máy để đi lại trong đô thị. Xe đạp cũng được sử dụng trên đường phố, cùng với các loại xe cơ giới. Mặc dù người dân Nhật Bản nhìn chung kiên nhẫn, lái xe cẩn trọng, nhưng những tai nạn có liên quan tới xe đạp và xe máy vẫn thường xuyên xảy ra. Do đó, quy định rẽ phải hai bước được áp dụng từ thập kỷ 1960 (Moto Japan, 2017).

Quy định về chuyển hướng hai bước như sau: Khi muốn rẽ phải, xe máy phải bám theo phía bên trái của làn đường và đi vào nút giao cùng với luồng xe (xem Hình dưới). Xe máy sẽ dừng lại phía trước dòng xe đang xếp hàng chờ tín hiệu đèn ở phía đó chuyển sang xanh. Khi đó, xe máy có thể đi thẳng để có được hướng di chuyển như mong muốn. 

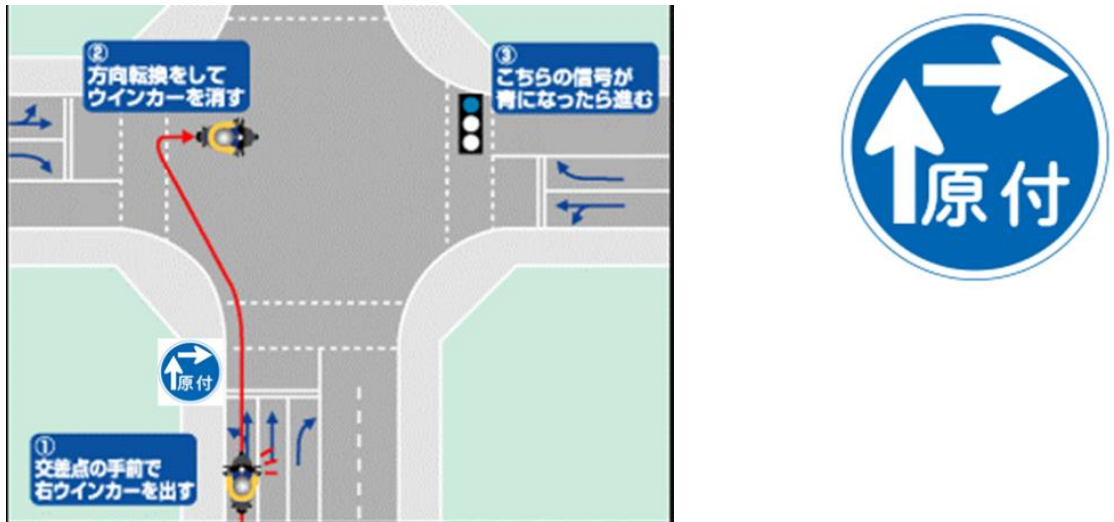

Hình 4-15 Minh hoạ quy trình rẽ phải theo hai bước ở Nhật Bản

Nguồn: (Moto Japan, 2017)

Theo Luật Giao thông Đường bộ năm 1960, các phương tiện cơ giới hạng nhẹ và xe gắn máy buộc phải tuân thủ quy trình rẽ phải theo hai bước tại tất cả các nút giao. Luật Giao thông Đường bộ điều chỉnh năm 1964 quy định xe đạp có động cơ loại 1 không phải theo quy định chuyển hướng hai bước, và sau đó, chỉ có các phương tiện hạng nhẹ mới phải áp dụng quy định chuyển hướng hai bước tại tất cả các nút giao. Để bảo vệ tốt hơn cho các phương tiện giao thông cơ giới, Luật Giao thông Đường bộ lại được điều chỉnh năm 1986. Theo đó, xe đạp gắn động cơ buộc phải thực hiện rẽ phải theo hai bước trên đường có nhiều làn xe.

Theo Luật Giao thông Đường bộ (Trang dịch Luật tiếng Nhật, 2016), Đoạn 3, Điều 34 có quy định rằng "Khi muốn rẽ phải, người điều khiển phương tiện giao thông đường bộ hạng nhẹ phải trước tiên đưa xe về phía lề phải của đường, sau đó đi thẳng vào trong nút giao men theo rìa ngoài cùng và ở tốc độ đã giảm." Ngoài ra, Đoạn 5 , Điều 34 có quy định rằng, "Căn cứ vào quy định tại Đoạn 2 và đoạn trên, khi xe đạp có động cơ muốn rẽ phải trên đường có biển báo hoặc dấu hiệu yêu cầu di chuyển theo mép của nút giao có đèn tín hiệu khi rẽ phải, hoặc trên bất kỳ tuyến đường nào có ba làn xe trở lên ở phía trái của đường (hoặc trên đường đó, nếu đó là đường một chiều) (gọi tắt về sau là 'đường có nhiều làn xe') (nhưng chỉ trong trường hợp xe đạp có gắn động cơ chuyển hướng tại nút giao có đèn tín hiệu), thì người điều khiển phải đưa xe đạp có gắn động cơ đó về càng gần gàng tốt rìa trái của đường, di chuyển với tốc độ đã giảm theo mép ngoài của nút giao; tuy nhiên điều này không áp dụng khi xe đạp có gắn động cơ, theo yêu cầu của biển báo hoặc vạch kẻ trên đường có nhiều làn xe, phải di chuyển về phía giữa hoặc rìa phải của đường trước khi chuyển hướng sang phải tại nút giao có đèn tín hiệu."

Tại bất kỳ nút giao có bố trí đèn hiệu nào, nếu có biển báo "xe máy hạng nhẹ rẽ phải hai bước" (xem Hình), thì việc rẽ phải hai bước là bắt buộc, và ngược lại. Để đảm bảo giao thông thông suốt trên tuyến đường thường xuyên có ùn tắc do lượng xe đông hoặc có tàu điện, thì người điều khiển giao thông có thể điều khiển các lái xe tuân thủ các quy định giao thông khác. Không giống như ở Đài Loan, tỷ lệ giao thông hỗn hợp ở Nhật Bản khá thấp. Ngoài ra, người dân Nhật Bản cũng tuân thủ tốt quy tắc giao thông nên việc triển khai quy định chuyển hướng hai bước ở Nhật Bản diễn ra thuận lợi.

\subsubsection{3 Ô dừng chờ đèn đỏ dành riêng cho xe máy tại Đài Loan}

Hsu và cộng sự (2003) đã chỉ ra đặc điểm của dòng giao thông xe máy tại nút giao như sau: 
- Xe máy sẽ tràn lên phía trước dòng xe tại nút giao, kết quả là sẽ có nhiều xe cùng xuất phát trong một thời gian ngắn khi tín hiệu đèn chuyển sang xanh. Hiện tượng này tạo ra sóng xe máy sau nút giao có đèn tín hiệu.

- Nhiều xe máy dừng quá vạch dừng và đợi đèn xanh ngay trên vạch sang đường cho người đi bộ.

- Khả năng tăng tốc của xe máy cao hơn xe ô tô khi ở trạng thái đứng im, nhưng kém hơn ô tô khi di chuyển trên $40 \mathrm{~km} / \mathrm{h}$.

- Dòng bão hoà xe máy phụ thuộc vào hành vi chờ tại gần vạch dừng (Hsu, 1996). Do hiện tượng xuất phát tập thể của xe máy tại nút giao, nên bố trí không gian cho xe máy xuất phát trước có thề giúp tăng năng lực thông qua của các nút giao có đèn tín hiệu.

Từ năm 2000, các khu vực dừng chờ cho xe máy (MWZ) đã được chính thức triển khai phía trên vạch dừng tại các nút giao có đèn tín hiệu, nơi tốc độ tối đa quy định dưới $60 \mathrm{~km} / \mathrm{h}$, ở Đài Loan. Mục đích chính của MWZ là tăng tốc độ xe thoát qua tại các nút giao có đèn tín hiệu. Với thiết kế này, người đi xe máy được khuyến khích vượt các xe đi chậm hoặc dừng bằng cách di chuyển hay lách giữa các làn xe, để tới vị trí dừng chờ tại $\mathrm{MWZ}$ khi đèn còn đỏ (Wang, 2014).

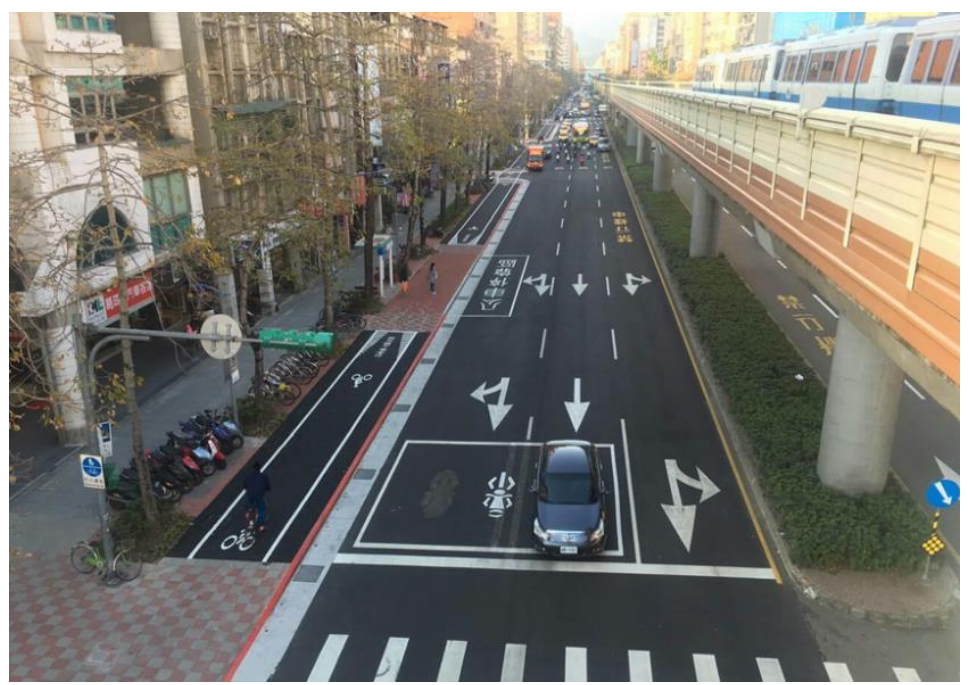

Hình 4-16 Khu vực xe máy chò̀ (MWZ) ở Đài Loan

Nguồn: (Guardian News, 2016)

Cần cân nhắc triển khai MWZ nếu như số lượng xe máy chờ mỗi pha đèn tín hiệu là lớn hơn 10 , hoặc 800 xe máy mỗi giờ. Lý do là vì xe máy có thể khởi động và xuất phát nhanh hơn xe ô tô thông thường, nên sẽ giúp thoát xe tại nút giao nhanh hơn các xe khác. Diện tích chỗ chờ phải có kích thước $0,8 \mathrm{~m}$ x $2,0 \mathrm{~m}$ cho mỗi xe chờ theo chu kỳ pha đèn. Khu vực xe máy chờ có thể tràn sang các làn xe khác, miễn là không cản trở chức năng của các dòng xe rẽ trái, phải được phép. Khi cho phép xe máy di chuyển lên trên dòng xe ô tô thì tính hiệu quả của nút giao cũng được cải thiện. Thử nghiệm trên các trục đường có bố trí khu vực xe máy chờ ở Đài Bắc cho thấy mức giảm trung bình đối với trì hoãn là 4,8 giây mỗi xe máy và 4,3 giây mỗi xe ô tô (Hook \& Fabian, 2009).

Quy định về khu vực xe máy chờ có cả ưu và nhược điểm (Wang, 2014).

- Uu điểm: Việc bố trí khu vực dừng chờ cho xe máy (MWZ) đã được chứng minh là có thể làm giảm tổng thời gian trì hoãn và tăng tỷ lệ dòng xe bão hoà tại các nút giao có đèn tín hiệu. MWZ có thể giúp giảm mức độ hỗn hợp của dòng giao thông ở phía sau các vùng xe máy chờ. Tuy nhiên, xung đột giữa xe máy và các loại xe cơ giới khác không có sự khác 
biệt đáng kể nào. Chưa có một nghiên cứu nào được thực hiện để phân tích tình hình va chạm trước và sau khi thực hiện các khu vực dành chờ dành cho xe máy.

- Nhược điểm: Một trong những vấn đề chính của MWZ chính là vùng lưỡng lự (hay khu vực phải ra quyết định, tức là khu vực nơi người điều khiển xe phải cân nhắc xem nên dừng hay vượt qua lằn ranh vàng) sẽ thay đổi và thời gian giải toả cho mỗi pha đèn cũng cần phải điều chỉnh lại vì vạch dừng xe bị đẩy xa khỏi nút giao. Vấn đề này chưa được giải quyết tại phần lớn các nút giao nơi đã bố trí vùng xe máy chờ.

Một vấn đề khác là chưa có quy định chính thức nào cho phép xe máy được phép di chuyển giữa hai làn xe. Theo quy định giao thông đường bộ ở Đài Loan (Số 56) (53), việc lách làn khi xe ô tô dừng theo hàng chờ đèn đỏ là hành vi bị cấm. Tuy nhiên, cũng không có quy định cụ thể hoặc điều khoản nào làm rõ liệu việc cấm hành vi lách làn như vậy có áp dụng đối với xe máy hay không.

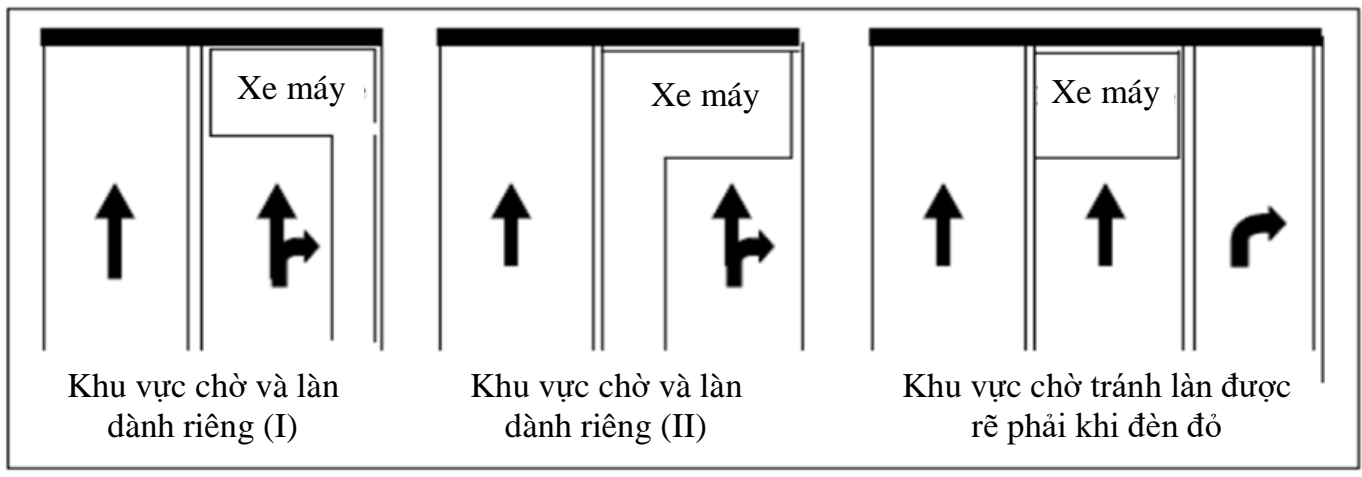

Hình 4-17 Các cách bố trí làn xe máy

Nguồn: (Hook \& Fabian, 2009)

Nhìn chung, MWZ thường được bố trí tại hướng nhập nút giao của đường giao nhau có hai làn xe trở lên (xem Hình). Ngoài ra, MWZ thông thường đi kèm với một làn xe máy hướng về nút giao. Tuy nhiên, vị trí của làn xe máy so với dòng giao thông hỗn hợp vẫn còn là một chủ đề gây tranh cãi. Hướng dẫn Thiết kế Đài Bắc (Trung Quốc) đưa ra ba phương án lựa chọn (xem Hình). Theo đó, xe máy có thể (i) có làn xe dành riêng sát vỉa hè, (ii) có làn xe dành riêng giữa vỉa hè và làn xe ô tô, (iii) sử dụng chung làn đường rộng hơn sát lề với ô tô. Thiết kế theo Phương án II nhìn chung là phương án được chọn nhiều hơn vì có ưu điểm là tránh được xung đột với xe rẽ phải, xe dừng đỗ như xe buýt hay taxi, người đi bộ và đi xe đạp ở trong làn sát lề (Hook \& Fabian, 2009).

\subsubsection{Các biện pháp tổ chức giao thông liên quan tới xe đạp điện}

Nhìn chung, xe đạp điện và xe máy điện có một số điểm chung. Khác với xe đạp truyền thống, xe đạp điện hay xe máy điện có gia tốc lớn hơn, tốc độ cao hơn và có hệ thống trợ lực (Du và cộng sự, 2013). Do đó các biện pháp tổ chức giao thông cho xe máy cũng có thể áp dụng cho xe máy điện, xe đạp điện. Hiện nay, xe máy điện đã trở nên phổ biến ở nhiều đô thị, nhất là ở Trung Quốc do xe máy bị cấm ở nhiều thành phố lớn. Ở Trung Quốc, xe đạp điện được xếp vào nhóm xe phi cơ giới do đó không bị cấm. Có nhiều mẫu "xe đạp" điện khác nhau và thực tế xe đạp điện không khác các loại xe tay ga hạng nhẹ thông thường, nhưng chúng được lắp đặt thêm các đôi bàn đạp (có tính chất trang trí) để được coi là "xe đạp". Do chế tài quản lý tiêu chuẩn xe đạp điện còn lỏng lẻo nên xe đạp điện và các loại xe máy điện trên thực tế đã lấp vào chỗ trống trên thị trường do lệnh cấm xe máy tạo ra (C. J. Yang, 2010). Trong hai thập kỷ qua, số lượng xe đạp điện sử dụng tại các khu vực đô thị tại Trung Quốc đã tăng mạnh, từ 58.000 chiếc 
trong năm 1998 lên 140 triệu chiếc vào năm 2012 (Guo và cộng sự, 2014). Với thực tế đó, các biện pháp kiểm soát xe đạp điện ở Trung Quốc đã được rà soát lại.

\subsubsection{Mái che nắng cho xe đạp điện ở Trung Quốc}

Một trong những bất lợi của người đi xe hai bánh là phải chịu nắng và nhiệt độ cao vào mùa hè. Thông thường, người đi xe đạp điện, xe máy điện thường có xu hướng vượt đèn đỏ vào ngày trời nắng nóng do mất kiên nhẫn khi đứng dưới ánh nắng chói chang. Vì vậy, nhiều đô thị ở Trung Quốc đã bố trí mái che nắng tại làn dành cho xe đạp điện, xe máy điện. Biện pháp này được kỳ vọng sẽ giúp làm giảm tỷ lệ người vượt đèn đỏ. Chức năng chính của mái che nắng (mưa) là tạo trật tự giao thông, cải thiện an toàn giao thông, là nơi tránh mưa nắng cho người tham gia giao thông, cải thiện môi trường đi lại, cải thiện hạ tầng dịch vụ đô thị, cải thiện môi trường đô thị, cải thiện cảnh quan đô thị. Mái che mưa nắng này đã được triển khai tại trên 80 đô thị lớn, trong đó có Thượng Hải, Nam Ninh, Vũ Hán, Thái Nguyên, Hợp Phì và Trường Sa, ở các mức độ khác nhau và đã đạt được những thành tựu xã hội nhất định (Sina Henan, 2014).

Hàng Châu là thành phố đầu tiên thử nghiệm bố trí mái che mưa nắng cho các làn xe phi cơ giới vào năm 2007 với bốn mái che lắp tại nút giao Zhonghe-Tiyuchang. Vào năm 2009, 450 mái che dễ tháo lắp đã được chọn làm mẫu thiết kế cuối cùng, được lắp đặt tại 127 tuyến đường chính tại Hàng Châu. Đồng thời, Hàng Châu - với tư cách là thành phố đầu tiên phát triển và áp dụng mái che mưa nắng cho xe phi cơ giới (trong khi còn hiếm thấy ở các đô thị khác ở Trung Quốc và các quốc gia khác) - đã được chọn là thành phố thí điểm. Đơn giá của một hệ thống mái che là khoảng USD 400 - 500. Điều đó cho thấy hệ thống này là một phương án dễ triển khai, chi phí thấp cho các quốc gia có làn xe đạp giống như Trung Quốc (Zhang \& Wu, 2013).

Có hai dạng mái che mưa nắng cơ bản (xem Hình). Loại đầu tiên là hai bên mái che được cố định trên cột thép. Loại thứ hai là chỉ một bên mái che được cố định vào cột thép. Tấm che có dạng cong lồi, diện tích khoảng $20-30 \mathrm{~m}^{2}$, cách mặt đất khoảng $3 \mathrm{~m}$, đỉnh mái được treo vào tay đòn nối chéo vào cột thép hình vuông. Lý do cho việc mái che mưa nắng bố trí xa hàng xe đang đỗ là vì nút giao có một độ cong, hoặc nó bị ảnh hưởng tởi các công trình đường ống ngầm. Khi lắp đặt mái che mưa nắng, chỉ có thể lùi lại. Khoảng cách từ 1 đến $2 \mathrm{~m}$ không hợp lý. Đặt xa thì không gây ùn tắc.

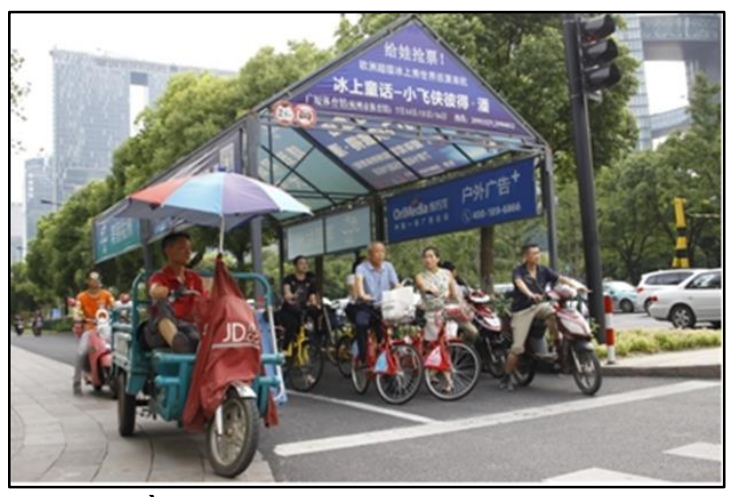

Nguồn: (Nhân dân Nhật báo, 2017)

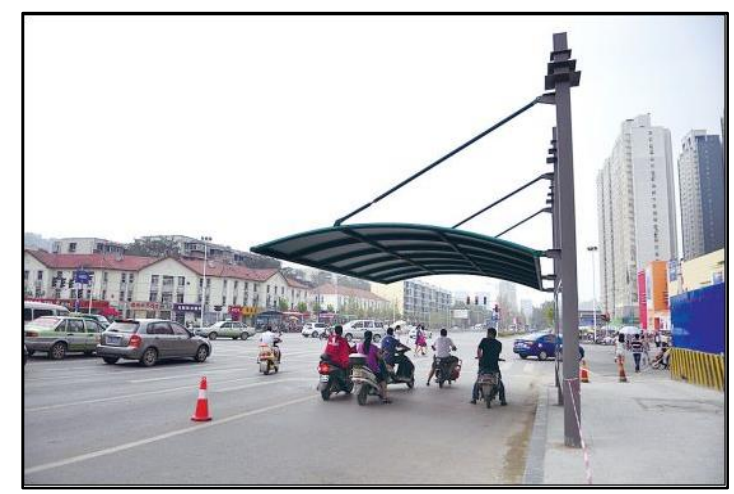

Nguồn: (Sina Henan, 2014)

Hình 4-18 Hai loại mái che mưa nắng cơ bản ở Trung Quốc

Nói chung, có hai nguyên tắc sơ bộ phải cân nhắc khi bố trí mái che mưa nắng, như sau: 
1) Áp dụng đối với các nút giao lớn trên đường đô thị lớn nơi chu kỳ đèn tín hiệu có thể dài hơn 90 giây. Kết quả là người đi xe đạp, xe đạp điện có thể sẵn sàng chờ đợi lâu trong điều kiện thời tiết nắng nóng.

2) Áp dụng khi có làn dành riêng cho xe đạp và xe đạp điện.

Trên thực tiễn, mái che mưa nắng được bố trí phía trước vạch dừng trên làn dành cho xe đạp điện. Mái che mưa nắng có một số ưu điểm như sau:

- Nút giao có bố trí mái che mưa nắng có tỷ lệ người vượt đèn đỏ thấp hơn hẳn so với những nút giao không có mái che;

- Tại các nút giao có mái che mưa nắng, người đi xe đạp, xe đạp điện có xu hướng dừng trước vạch dừng.

\subsubsection{Làn xe đạp điện ở Trung Quốc}

Trong những năm gần đây, do chính sách cấm xe máy, các loại xe đạp điện giá rẻ, thuận tiện, tương đối hiệu quả năng lượng đã trở thành phương tiện giao thông phi cơ giới chủ đạo ở Trung Quốc. Số lượng xe đạp điện ở Trung Quốc đã lên tới gần 200 triệu chiếc vào năm 2013. Do xe đạp và xe đạp điện được xếp chung vào một nhóm, sự thiếu đồng nhất về tốc độ di chuyển giữa xe đạp điện và xe đạp truyền thống nên dòng giao thông hỗn hợp giữa hai phương tiện này trên làn dành cho xe đạp truyền thống đang trở nên phổ biển ở các đô thị Trung Quốc. Dòng giao thông với tốc độ chênh lệch gồm xe đạp và xe đạp điện này sẽ gây ra các vấn đề về hiệu quả và an toàn.

Hướng dẫn Thiết kế Trung Quốc khuyến nghị tách riêng các làn xe đạp. Những hướng dẫn này bao gồm mật độ đường xe đạp là $1 \mathrm{~km}$ tới $3 \mathrm{~km}$ đường, làn dành riêng cho xe đạp là $400-600 \mathrm{~m}$, cứ $150-200 \mathrm{~m}$ phải có lối đi xe đạp tới các khu chung cư. Hướng dẫn còn khuyến nghị rằng làn xe đạp có chiều rộng $1 \mathrm{~m}$, cộng thêm $0,25 \mathrm{~m}$ ở làn sát vỉa hè hoặc giải phân cách. Đối với đường xe đạp hai chiều, chiều rộng tối thiểu là $3,5 \mathrm{~m}$. Đối với các loại hình giao thông phi cơ giới khác, chiều rộng tối thiểu mỗi hướng là 4,5 m (Qilu Evening News, 2011). Hướng dẫn Quy hoạch giả định rằng làn xe đạp phục vụ 1.500 xe theo mỗi mét chiều rộng của làn và 1.000 xe mỗi giờ tại nút giao, mặc dù các tham số này hiếm khi được sử dụng khi thiết kế hạ tầng xe đạp thực tế.

Hiện nay có một số nguyên tắc sơ bộ đối với việc bố trí làn xe đạp như sau: i) áp dụng tại trục đường đô thị lớn có 2 làn xe mỗi hướng; ii) lưu lượng thực tế xe đạp và xe đạp điện.

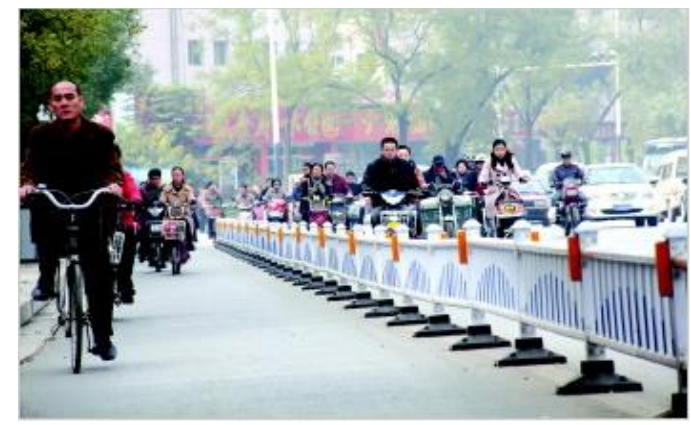

Hình 4-19 Làn xe đạp điện ở Trung Quốc

Nguồn: (Qilu Evening News, 2011)

Bộ Nhà ở và Phát triển Đô thị-Nông thôn Trung Quốc (MOHURD) kiến nghị tiêu chuẩn chiều rộng làn xe đạp là $1,0 \mathrm{~m}$, lối đi xe đạp phải có hai 1 àn xe và không được dưới $2,5 \mathrm{~m}$. MOHURD 
cũng kiến nghị năng lực của lối đi xe đạp một chiều là 1600 - 1800 xe mỗi giờ, với điều kiện phân tách riêng, và 1400 - 1600 xe/h khi không có phân cách riêng (Zhou và cộng sự, 2015).

Trên thực tế, việc bố trí làn xe đạp điện cũng có một số vấn đề do các làn xe phi cơ giới có chiều rộng khá hẹp, nhiều xe va chạm với thanh chắn, gây xước xe, và cũng gây khó chịu cho người dân.

\subsection{Kiểm tra độ tỉnh táo của người lái xe máy}

\subsubsection{Tổng quan về kiểm tra độ tỉnh táo}

\section{Khái niệm DUI và DWI}

Trong việc phòng chống vi phạm về nồng độ cồn và/hoặc ma túy, có hai khái niệm rất phổ biến trên thế giới, nhưng ít biết ở Việt Nam. Đó là DUI và DWI.

- Sự khác biệt chính: DUI (Driving Under the Influence) chỉ trường hợp lái xe dưới ảnh hưởng (có hại) có thể là do rượu hoặc ma túy hoặc cả hai. Có thể coi DUI là "lái xe khi (sức khỏe) đang bị ảnh hưởng (xấu)", trong khi DWI (Driving While Intoxicated) dùng để chỉ "lái xe trong khi say rượu".

- Cả hai DUI và DWI đều là hành vi trái pháp luật của lái xe do họ điều khiển phương tiện giao thông trong lúc đang chịu ảnh hưởng (xấu) do nồng độ cồn và / hoặc ma túy.

- Một số quốc gia coi hai hành vi này như nhau nhưng một số lại phân loại chúng như hai loại vi phạm riêng biệt.

- Tại nơi có phân loại chúng một cách riêng biệt, DUI là tội nhẹ hơn. DUI biểu thị một lái xe với sức khỏe đang bị ảnh hưởng của nồng độ cồn/ma túy nhưng có thể chưa say, còn DWI là để chỉ người lái bị buộc tội uống rượu say mà vẫn lái xe. Mức độ nghiêm trọng được xác định bởi nồng độ rượu trong máu của lái xe $(\mathrm{BAC})$ tại thời điểm bị bắt.

Đây không chỉ là cách viết tắt, mà ngày nay "DUI" và 'DWI", như vừa nêu, đã trở thành một khái niệm, thành một danh từ riêng. Vì vậy, ở các nước, ta có thể thấy chúng được dùng rất phổ biến, như một danh từ riêng (xem hình bên). Dùng khái niệm này có lợi gì? Đây không chỉ là cách nói gọn; đó là một khái niệm được công nhận trong các văn bản pháp lý của những quốc gia sử dụng chúng, trong đó bao gồm cả các vi phạm do ma túy, chất kích thích khác chứ không chỉ do rượu bia. Ý nghĩa thực tiễn quan trọng của vi phạm DUI là ở chỗ: có thể không cần đo nồng độ cồn nhưng nếu xác định được sức khỏe đang bị ảnh hưởng xấu (ở mức nào đó) là cơ quan công quyền có thể xử lý được.

Vì vậy, khái niệm "DUI" được sử dụng rất rộng rãi trên thế giới. Nhưng việc dùng từ "DUI" hay "DWI" trong tiếng Việt có thể không được thuận lợi do đặc điểm riêng của ngôn ngữ.

Lái xe trong tình trạng bị ảnh hưởng của chất kích thích (DUI) hoặc lái xe trong tình trạng say rượu (DWI) nghĩa là hành vi điều khiển hay lái xe máy trong khi bị tác động từ rượu hoặc các loại chất kích thích khác tới ngưỡng khiến cho người lái xe đó không có khả năng điều khiển xe máy một cách an toàn. DUI hiện đang là vấn đề bất cập phổ biến trên cả thế giới. Nếu không có kiểm tra y tế thì có những trường hợp khó có thể xác định xem người điều khiển xe bị dừng đó có say hay bị tác động từ chất kích thích hay không. Do đó, cảnh sát giao thông ở các nước phát triển (v.d. Hoa Kỳ và Canada) thường sử dụng nhiều hình thức kiểm tra độ tỉnh táo ngay tại hiện trường. Cần lưu ý rằng trước khi áp dụng các bài kiểm tra này thì cảnh sát phải có đủ lý do để dừng phương tiện đang lưu thông. Cảnh sát chỉ được phép yêu cầu dừng xe chỉ vì lái 
xe điều khiển xe một cách khác thường hoặc vi phạm các quy định giao thông. Nếu cảnh sát giao thông phát hiện ra mùi rượu hoặc có lý do để tin rằng người lái xe đang say hoặc đang bị thuốc làm ảnh hưởng thì có quyền yêu cầu lái xe thực hiện một số bài kiểm tra (Lawyerahead, 2009).

Xét về vị trí và phương pháp, kiểm tra độ tỉnh táo được chia thành hai nhóm: kiểm tra tại hiện trường (hoặc tại hiện trường) và kiểm tra tại phòng thí nghiệm (xem Hình). Các bài kiểm tra tại hiện trường được gọi là các bài kiểm tra "phân tán sự tập trung". Những bài kiểm tra này, về lý thuyết, xác định xem lái xe có khả năng thực hiện những hành vi tổng hợp về tinh thần và cơ thể cần có khi điều khiển xe cơ giới hay không. Cảnh sát thường áp dụng kiểm tra độ tỉnh táo tại hiện trường vì tính đơn giản và không tốn nhiều thời gian. Nội dung kiểm tra phổ biến nhất là kiểm tra rung giật nhãn cầu (HGN), đi và xoay (WAT), đứng một chân (OLS). Kiểm tra khí thở cũng có lúc được xếp vào nhóm kiểm tra độ tỉnh táo tại hiện trường, mặc dù đây không thuộc tập hợp các bài kiểm tra khả năng đáp ứng của lái xe. Loại hình kiểm tra này sử dụng thiết bị kiểm tra khí thở cầm tay, nhưng mục đích sử dụng chính của nó là sàng lọc và thiết lập cơ sở tiến hành bắt giữ. Đối với kiểm tra tại phòng thí nghiệm, lái xe được yêu cầu cung cấp mẫu máu và mẫu nước tiểu để xét nghiệm khoa học. Do đó, kết quả xét nghiệm có độ tin cậy cao hơn nhưng cũng phức tạp và tốn nhiều thời gian hơn. Mặc dù một phần nội dung kiểm tra này được thực hiện tại hiện trường, nhưng vẫn không được xếp vào nhóm kiểm tra độ tỉnh táo tại hiện trường.

Xét về sự thi hành, kiểm tra độ tỉnh táo tại hiện trường được chia thành hai nhóm là nhóm đã chuẩn hoá và chưa chuẩn hoá (xem Hình). Nội dung kiểm tra độ tỉnh táo chuẩn hoá nghĩa rằng cho dù ai là người yêu cầu kiểm tra thì các bước hướng dẫn thực hiện và cách ghi kết quả cũng phải như nhau (Báo cáo về thực hiện Kiểm tra độ tỉnh táo tại hiện trường, 2018b). Các nội dung kiểm tra chưa chuẩn hoá thì có thể khác nhau về quy trình, các bước hướng dẫn triển khai, cũng như cách ghi nhận kết quả. Ví dụ, số lượng bài kiểm tra để đánh giá mức độ tác động được áp dụng ở Hoa Kỳ trước đây bao gồm 'đặt ngón tay lên mũi', 'đếm ngược', 'đọc bảng chữ cái'. Do có nhiều loại hình kiểm tra được áp dụng, nên Cơ quan Kiểm soát An toàn Giao thông Quốc lộ Quốc gia (NHTSA) đã tổ chức nghiên cứu các nội dung này để xác định xem đâu là hình thức đáng tin cậy nhất. Trong tất cả những loại hình kiểm tra được nghiên cứu, có ba loại hình đã chứng minh được có sự liên hệ mật thiết nhất với việc bị say rượu khi áp dụng cùng nhau: 'rung giật nhãn cầu', ‘đi rồi xoay người' và ‘đứng một chân'. Sau khi xác định được những bài kiểm tra này, NHTSA đã xây dựng quy trình nghiêm ngắt buộc phải theo khi thực hiện. Ba bài kiểm tra này cũng được gọi là các bài kiểm tra độ tỉnh táo tại hiện trường chuẩn hoá. 


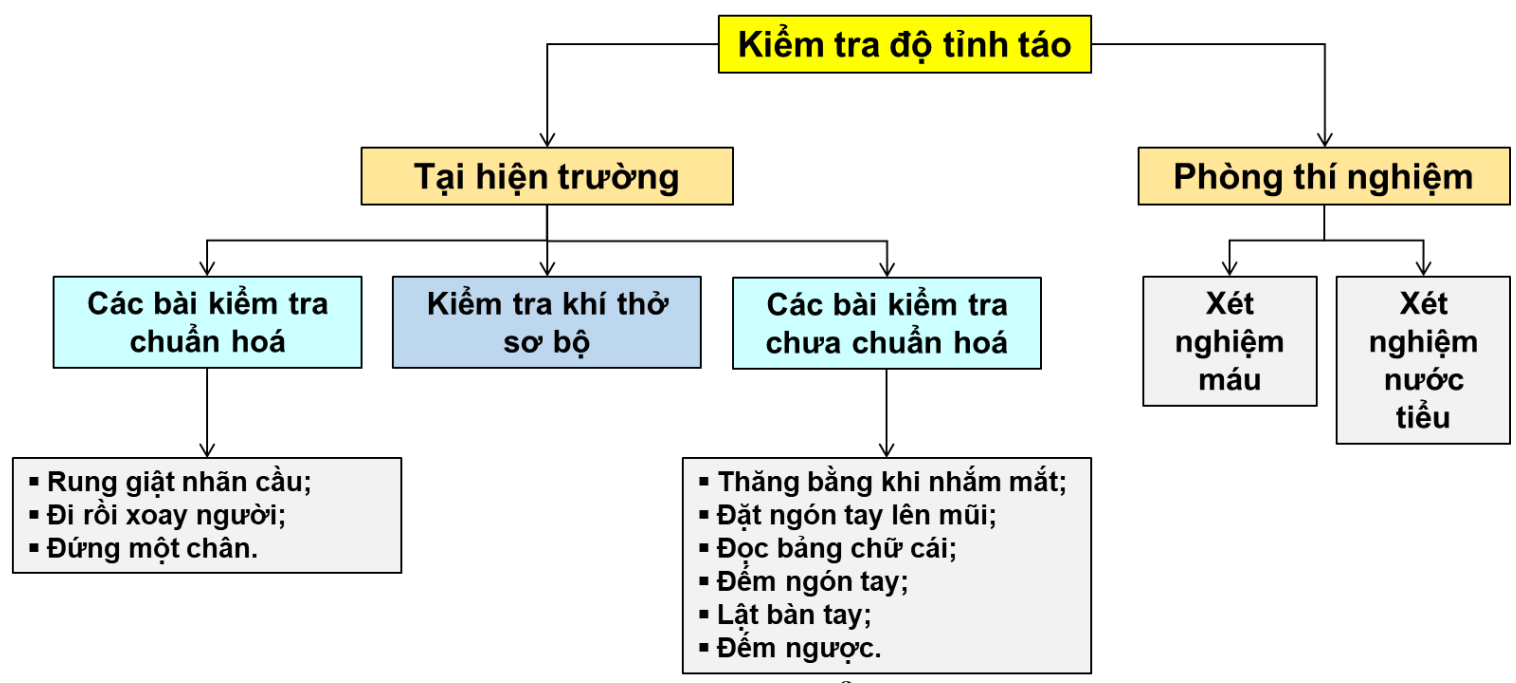

Hình 4-20 Các loại hình kiểm tra độ tỉnh táo

Nguồn: Đoàn Nghiên cứu kết hợp với thông tin từ Internet

Bảng dưới tổng hợp nội dung và những vấn đề liên quan tới các bài kiểm tra độ tỉnh táo đã chuẩn hoá và chưa chuẩn hoá.

\section{Bảng 4-9 Tổng hợp các bài kiểm tra độ tỉnh táo tại hiện trường}

\begin{tabular}{|c|c|c|c|}
\hline STT & Bài kiểm tra & Nội dung & Vấn đề, khó khăn \\
\hline \multicolumn{4}{|c|}{$\begin{array}{l}\text { Lưu ý chung: Từng bài kiểm tra sau đây, đứng riêng biệt thì độ chính xác chưa thật sự đảm bảo. Tuy nhiên, } \\
\text { bằng cách kết hợp 2-3 bài kiểm tra, độ chính xác sẽ đạt (xem phần dưới) }\end{array}$} \\
\hline 1 & $\begin{array}{ll}\text { Rung } & \text { giật } \\
\text { nhãn } & \text { cầu } \\
(\mathrm{HGN}) & \end{array}$ & $\begin{array}{l}\text { Đây là bài kiểm tra mắt đơn giản. Người } \\
\text { bị dừng xe (hay đối tượng) phải nhìn theo } \\
\text { một vật di chuyển để xác định những đặc } \\
\text { điểm của rung giật nhãn cầu. }\end{array}$ & $\begin{array}{l}\text { Vấn đề của bài kiểm tra này là độ chính } \\
\text { xác khi xác định xem đối tượng có trong } \\
\text { tình trạng bị ảnh hưởng bởi rượu hay chất } \\
\text { kích thích hay không. Ở Hoa Kỳ, tỷ lệ } \\
\text { chính xác của bài kiểm tra này chỉ là } 77 \% \\
\text { (NHTSA, 2015). Có rất nhiều các yếu tố } \\
\text { (ví dụ như thần kinh, tình trạng mắt) có } \\
\text { thể gây ra những cử động của nhãn cầu - } \\
\text { vấn đề này chỉ có bác sĩ mới có thể xác } \\
\text { định được, cảnh sát giao thông thì không. }\end{array}$ \\
\hline 2 & $\begin{array}{lr}\text { Kiểm } & \text { tra 'đi } \\
\text { rồi } & \text { xoay } \\
\text { người' } & (\text { WAT) }\end{array}$ & $\begin{array}{l}\text { Đối tượng phải đi bộ sao cho gót chân } \\
\text { trước chạm ngón chân sau trên một } \\
\text { đường thẳng }\end{array}$ & $\begin{array}{l}\text { Cũng giống như kiểm tra HGN, vấn đề } \\
\text { của bài kiểm tra này là độ chính xác. Theo } \\
\text { NHTSA, ở Hoa Kỳ, độ chính xác của bài } \\
\text { kiểm tra này chỉ đạt } 66 \% \text { khi thực hiện } \\
\text { theo đúng hướng dẫn của NHTSA. Có } \\
\text { nhiều yếu tố ảnh hưởng tới khả năng giữ } \\
\text { thăng bằng của con người khi bước đi } \\
\text { ngón chạm gót, ví dụ như độ tuối, giới } \\
\text { tính, tình trạng thể chất, buồn ngủ, mệt } \\
\text { mỏi, lo lắng/sợ hãi vì bị cảnh sát dừng xe } \\
\text { (Rubenzer, 2008). }\end{array}$ \\
\hline 3 & $\begin{array}{l}\text { Đứng một } \\
\text { chân }\end{array}$ & $\begin{array}{l}\text { Đối tượng phải đứng trên một chân trong } \\
\text { một khoảng thời gian nhất định. }\end{array}$ & $\begin{array}{l}\text { Giống như kiểm tra HGN và WAT, vấn } \\
\text { đề nảy sinh khi kiểm tra đứng một chân là } \\
\text { độ chính xác. Ở Hoa Kỳ, độ chính xác của } \\
\text { bài kiểm tra này chỉ là } 66 \% \text { (NHTSA, } \\
\text { 2015). Kết quả của bài kiểm tra này chịu } \\
\text { ảnh hưởng từ nhiều yếu tố. }\end{array}$ \\
\hline 4 & $\begin{array}{l}\text { Thăng bằng } \\
\text { khi nhắm mắt }\end{array}$ & $\begin{array}{l}\text { Đối tượng phải đứng chụm chân vào } \\
\text { nhau, nhắm mắt, đầu hơi ngả về phía } \\
\text { sau. }\end{array}$ & $\begin{array}{l}\text { Bài kiểm tra này có hai vấn đề. Thứ nhất, } \\
\text { bài kiểm tra này chưa được chuấn hoá. } \\
\text { Nói cách khác là chưa có hướng dẫn chính }\end{array}$ \\
\hline
\end{tabular}




\begin{tabular}{|c|c|c|c|}
\hline STT & Bài kiểm tra & Nội dung & Vấn đề, khó khăn \\
\hline & $\begin{array}{l}\text { (Thăng bằng } \\
\text { Romberg) }\end{array}$ & & $\begin{array}{l}\text { thức về cách thực hiện, các bước thực hiện } \\
\text { và cách ghi kết quả. Mối người cảnh sát } \\
\text { giao thông có thể có các cách thức riêng } \\
\text { thực hiện bài kiểm tra này. Điều đó dẫn } \\
\text { tới vấn đề thứ hai, đó là độ chính xác. }\end{array}$ \\
\hline 5 & $\begin{array}{l}\text { Đặt ngón tay } \\
\text { lên mũi (FTN) }\end{array}$ & $\begin{array}{l}\text { Đối tượng phải nhắm mắt, hơi ngả đầu } \\
\text { về phía sau và dùng ngón trỏ đặt lên } \\
\text { mũi. Thông thường sẽ phải thực hiện } \\
\text { động tác này ba lần mỗi tay, tồng cộng } \\
\text { sáu lần. }\end{array}$ & $\begin{array}{l}\text { Giống như bài kiểm tra Romberg, vấn đề } \\
\text { đối với FTN là thiếu hướng dần chính } \\
\text { thức và độ chính xác. Bài 'đặt ngón tay } \\
\text { lên mũi' lúc đầu là nhằm đánh giá chức } \\
\text { năng hệ thần kinh, khả năng phối hợp } \\
\text { động tác. Do cảnh sát không phải là bác sĩ } \\
\text { nên không thể xác định xem lái xe có qua } \\
\text { hay không qua bài kiểm tra này do đã } \\
\text { uống chất có cồn hoặc đang trong tình } \\
\text { trạng bệnh lý (Báo cáo về thực hiện kiểm } \\
\text { tra độ tỉnh táo tại hiện trường, 2018a). }\end{array}$ \\
\hline 6 & $\begin{array}{l}\text { ABC (đọc } \\
\text { bảng chữ cái) }\end{array}$ & $\begin{array}{l}\text { Đối tượng phải đọc được toàn bộ hay } \\
\text { một phần của bảng chữ cái. } \\
7 Y X W V U \text { T S R } \\
\text { Q P O N L K I } \\
\text { H G F E C B A }\end{array}$ & $\begin{array}{l}\text { Thiếu hướng dẫn chính thức và độ chính } \\
\text { xác cũng là những vấn đề của bài kiềm tra } \\
\text { ABC. Theo cách hiểu thông thường thì } \\
\text { đối tượng phải đọc ngược bảng chữ cái; } \\
\text { tuy nhiên thì việc đó chưa bao giờ được } \\
\text { thực hiện vì ngay cả những người tỉnh táo } \\
\text { cũng có lúc không làm được điều đó. Có } \\
\text { nhiếu yếu tố tác động tới trí nhớ, ví dụ như } \\
\text { độ tuổi, sợ hãi khi bị cảnh sát dừng xe. }\end{array}$ \\
\hline 7 & Đếm ngón tay & $\begin{array}{l}\text { Đối tường phải duỗi thẳng một cánh tay, } \\
\text { lòng bàn tay hướng ra phía trước. Sau đó, } \\
\text { đối tượng dùng đầu ngón tay cái chạm } \\
\text { vào các ngón còn lại và đếm mối khi ngón } \\
\text { cái chạm vào ngón kia. }\end{array}$ & $\begin{array}{l}\text { Cũng như các bài kiểm tra độ tỉnh táo tại } \\
\text { hiện trường chưa được chuẩn hoá khác, độ } \\
\text { tin cậy của bài kiểm tra đếm ngón tay } \\
\text { cũng gây tranh cãi. Trên thực tế, kết quả } \\
\text { của bài kiểm tra này phụ thuộc vào người } \\
\text { thực hiện bài kiểm tra đó. Ngoài ra, cũng } \\
\text { không có hướng dẫn cụ thể vì chưa được } \\
\text { chuẩn hoá. }\end{array}$ \\
\hline 8 & Lật bàn tay & $\begin{array}{l}\text { Đối tượng duỗi cánh tay, lòng bàn tay } \\
\text { hướng lên phía trên. Sau đó đối tượng } \\
\text { phải xoay bàn tay phía trên } 180 \text { độ để } \\
\text { chạm xuống tay bên dưới bằng mu bàn } \\
\text { tay, đồng thời đếm "1" trước khi xoay trở } \\
\text { lại như cũ. }\end{array}$ & $\begin{array}{l}\text { Bài kiểm tra này chưa được chuẩn hoá, do } \\
\text { đó không có hướng dẫn chính thức cho } \\
\text { cảnh sát. Ngoài ra, có một số yếu tố có thể } \\
\text { dẫn tới kết quả kém của bài kiểm tra lật } \\
\text { bàn tay này, bao gồm những vấn đề về } \\
\text { phối hợp cử động (có thể do chân thương, } \\
\text { viêm khớp, hay bệnh lý), hướng dẫn sai tữ } \\
\text { phía cảnh sát, hay những yếu tố xao nhãng } \\
\text { bên ngoài (Báo cáo về thực hiện kiểm tra } \\
\text { độ tỉnh táo tại hiện trường, 2018a). }\end{array}$ \\
\hline 9 & Đếm ngược & $\begin{array}{l}\text { Đối tượng phải đếm ngược theo yêu cầu. } \\
\text { Ví dụ, cảnh sát có thể yêu cầu đếm ngược } \\
\text { từ } 50 \text { về } 1 . \\
\qquad \begin{array}{l}100, \\
50, \longrightarrow 1 \\
30\end{array}\end{array}$ & $\begin{array}{l}\text { Do không có hướng dẫn tiêu chuẩn cho } \\
\text { bài kiểm tra này, mỗi người cảnh sát đều } \\
\text { có thể thực hiện theo cách của mình. Điều } \\
\text { đó dẫn tới tranh cãi về độ chính xác của } \\
\text { kết quả thu được. Ngoài ra, còn có một số } \\
\text { yếu tố có thể tác động tới năng lực đếm } \\
\text { ngược của một cá nhân. }\end{array}$ \\
\hline
\end{tabular}

Nguồn: Nhóm nghiên cứu kết hợp với thông tin từ Internet 


\subsubsection{Bài học kinh nghiệm từ Hoa Kỳ}

Các bài kiểm tra độ tỉnh táo tại hiện trường được áp dụng ở nhiều bang tại Hoa Kỳ. Do có nhiều bài kiểm tra khác nhau, nên NHTSA đã chuẩn hoá quy trình xác định DUI/DWI và ba bài kiểm tra độ tỉnh táo tại hiện trường (HGN, WAT và OLS). Nhưu, độ chính xác của kết quả các bài kiểm tra độ tỉnh táo tại hiện trường đã chuẩn hoá này vẫn còn là chủ đề gây tranh cãi, cho dù đã có những tiêu chuẩn/hướng dẫn thực hiện những bài kiểm tra đó. Kết quả là phát sinh một số vấn đề pháp lý khi cảnh sát xác định nồng độ cồn theo kết quả kiểm tra độ tỉnh táo tại hiện trường. Phần sau đây trình bày về quy trình xác định DUI/DWI, ba bài kiểm tra độ tỉnh táo tại hiện trường đã chuẩn hoá và vấn đề pháp lý nói trên.

\subsubsection{Quy trình xác định DUI/DWI}

Theo NHTSA (2015), toàn bộ quy trình tìm và thu thập bằng chứng là nhằm xác định xem liệu có nên bắt giữ đối tượng vì vi phạm quy định DWI hay không. Quy trình xác định DWI bao gồm ba giai đoạn: i) xe đang lưu thông, ii) tiếp xúc cá nhân, và iii) sàng lọc trước khi bắt giữ.

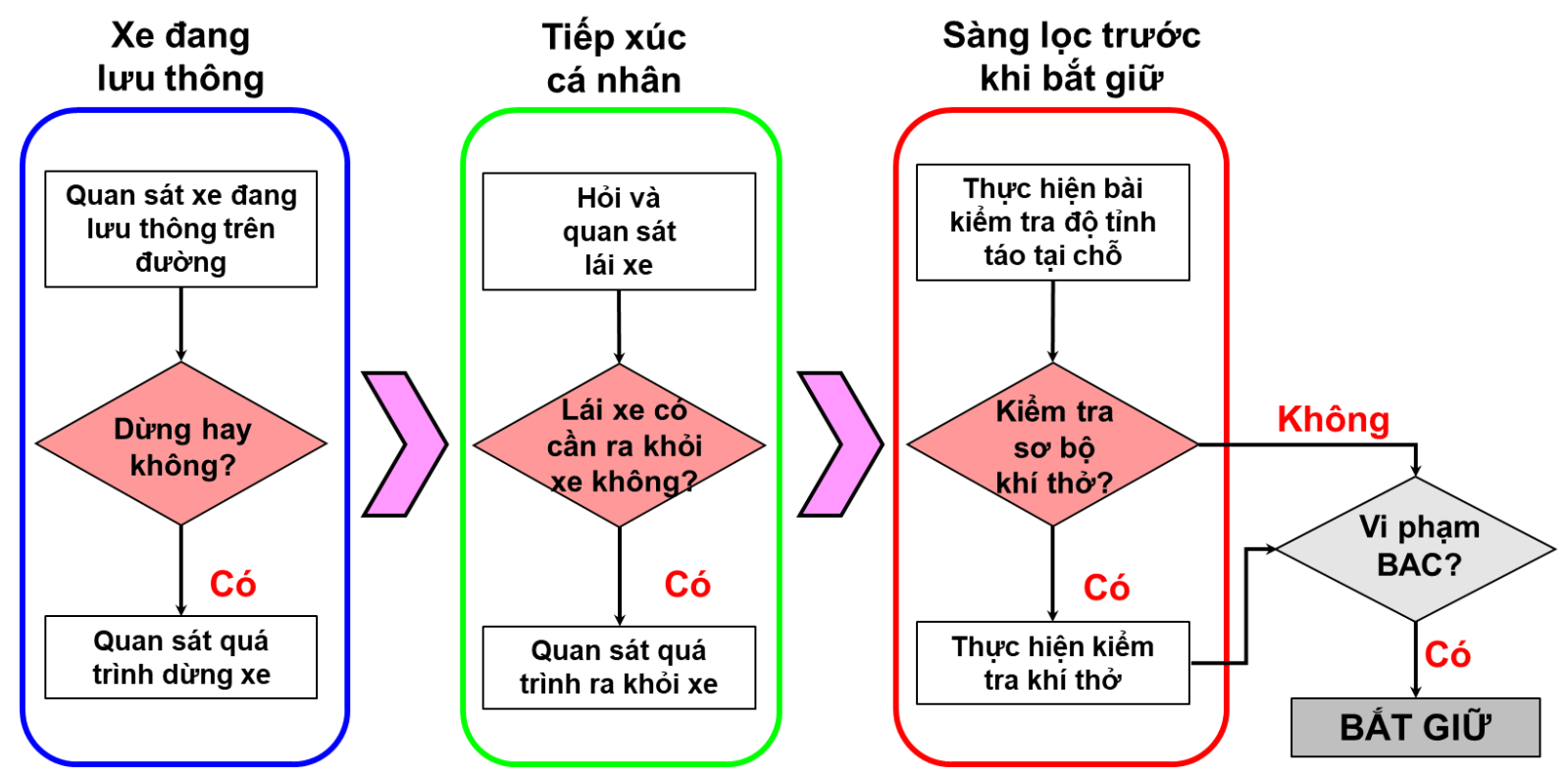

Hình 4-21 Quy trình xác định DWI ở Hoa Kỳ

Nguồn: Đoàn Nghiên cứu tổng hợp thông tin từ NHTSA (2015)

\section{a) Giai đoạn I: Xe đang lưu thông}

Như mô tả trong Hình trên, cảnh sát giao thông có hai nhiệm vụ trong giai đoạn I, đó là i) quan sát xe đang lưu thông trên đường, và ii) quan sát quá trình dừng xe. Bên cạnh đó, quyết định quan trọng phải đưa ra là dừng xe hay không. Với nhiệm vụ đầu tiên, cảnh sát giao thông quan sát xe đang lưu thông để ghi nhận những dấu hiệu về khả năng vi phạm DWI. Cảnh sát giao thông có thể chú ý tới xe, lái xe hoặc cả hai. Có một số dấu hiệu về vi phạm DWI:

- vi phạm quy tắc giao thông;

- vi phạm về phương tiện;

- nhãn dán kiểm định hết hạn;

- hành vi điều khiển xe bất thường, ví dụ như đánh võng trong một làn hoặc di chuyển chậm hơn tốc độ bình thường;

- có bằng chứng về đồ uống hoặc thuốc kích thích trong xe. 
Đối với người đi xe máy, NHTSA đã giới thiệu Hướng dẫn Quan sát Xác định Người đi xe máy vi phạm DWI (NHTSA, 2013). Bản hướng dẫn này gồm một tập hợp những dấu hiệu hành vi giúp xác định xem người điều khiển xe máy nào đang lái xe trong tình trạng bị suy rượu. Cảnh sát giao thông có thể sử dụng những dấu hiệu này ban ngày lẫn ban đêm. Những dấu hiệu đó được xếp theo nhóm "Rất rõ ràng" và "Rõ" (xem Bảng bên dưới).

\section{Bảng 4-10 Tổng hợp dấu hiệu người đi xe máy bị suy nhược}

Rất rõ ràng (xác suất $50 \%$ trở lên)

- Rê bánh xe khi vào đoạn cong hoặc lối rẽ

- Khó khăn khi xuống xe

- Khó giữ thăng bằng khi dừng xe

- Khó khăn khi chuyển hướng (không ổn định, chỉnh hướng đột ngột, phanh chậm, góc nghiêng không thích hợp)

- Không quan sát xung quanh

- Hành vi không thích hợp hoặc bất thường (v.d cầm hoặc làm rơi đồ vật, tiểu tiện ở vệ đường, gây mất trật tự, v.v.)

- Lạng lách

Rõ (xác suất 30\%-50\%)

- Động tác thất thường khi đang đi thẳng

- Xe không bật đèn vào ban đêm

- Cẩu thả

- Đi quá gần xe trước

- Bỏ qua tín hiệu đèn hoặc biển báo

- Lẩn tránh

- Nhầm đường

Nguồn: (NHTSA, 2013)

Từ những quan sát sơ bộ này khi xe đang lưu thông, cảnh sát giao thông phải ra quyết định có dừng phương tiện hay không. Tại thời điểm này, có ba lựa chọn: 1) dừng phương tiện, 2) tiếp tục quan sát phương tiện, và 3) bỏ qua phương tiện.

Nhiệm vụ thứ hai trong giai đoạn này là quan sát hành vi của lái xe khi phản ứng với tín hiệu yêu cầu dừng xe của cảnh sát giao thông, đồng thời lưu ý bất kỳ dấu yệu bổ sung nào về vi phạm DWI. Có nhiều dấu hiệu cần chú ý khi đối tượng dừng xe:

- Dừng xe quá xa vỉa hè hoặc ở một góc không thích hợp;

- Dừng quá sát hoặc vượt vạch giới hạn;

- Dừng gấp, đột ngột;

- Tăng, giảm tốc không cần thiết;

- Tốc độ không đều;

- Chậm hơn giới hạn tốc độ $10 \mathrm{mph}$ trở lên.

Ngoài ra, NHTSA (2015) cũng đã tổng hợp 10 dấu hiệu sau khi dừng như sau:

- Khó khăn khi kiểm soát xe

- Lục tìm giấy phép lái xe, giấy tờ xe

- Khó khăn khi ra khỏi xe

- Lặp lại câu hỏi hay lời nới của cảnh sát

- Cơ thể đung đưa, thiếu ổn định, mất cân bằng

- Tỳ người lên xe hoặc vật khác

- Nói líu lưỡi

- Chậm phản ứng với yêu cầu của cảnh sát khiến cảnh sát phải nhắc lại

- Cung cấp thông tin sai, thay đổi câu trả lời

- Có mùi đồ uống có cồn

\section{b) Giai đoạn II: Tiếp xúc cá nhân}

Cũng giống như giai đoạn I, giai đoạn II bao gồm hai nhiệm vụ chính về thu thập bằng chứng và một quyết định quan trọng (xem Hình). Nhiệm vụ đầu tiên của cảnh sát giao thông là tiếp cận, quan sát và thẩm vấn lái xe khi lái xe vẫn ở trong xe. Mục đích của nhiệm vụ này là ghi nhận trực diện những dấu hiệu, bằng chứng sử dụng đồ uống có cồn hay chất kích thích. Từ quá trình trao đổi và quan sát trực diện lái xe, kết hợp với những quan sát trong giai đoạn I, 
cảnh sát giao thông phải ra quyết định xem có đủ lý do để yêu cầu lái xe ra khỏi xe hay không. Cần lưu ý rằng ở mỗi bang tại Hoa Kỳ đều có các quy định riêng về việc yêu cầu ra khỏi xe. Ở một số bang, có quy định rằng lái xe luôn bị yêu cầu phải ra khỏi xe, bất kể lý do dừng xe. Ở các bang khác thì cảnh sát giao thông không nhất thiết phải yêu cầu lái xe rời khỏi xe mà việc ra quyết định là căn cứ vào kết quả quan sát và thẩm vấn lái xe. Nếu cảnh sát giao thông quyết định yêu cầu lái xe ra khỏi xe thì nhiệm vụ thứ hai là quan sát kỹ càng hành vi của lái xe khi rời xe, ghi nhận những dấu hiệu cho thấy sự sử dụng đồ uống có cồn hay chất kích thích.

Đối với nhiệm vụ đầu tiên của giai đoạn II, NHTSA (2015) đã có khuyến nghị về dấu hiệu điều tra đặc trưng đối với lái xe trong khi quan sát và thẩm vấn (xem Bảng dưới). Những dấu hiệu đó có thể nhận ra bằng thị giác, thính giác và khứu giác.

\section{Bảng 4-11 Dấu hiệu điều tra đặc trưng đối với lái xe khi thẩm vấn}

\begin{tabular}{|c|c|c|}
\hline Dấu hiệu thị giác & Dấu hiệu thính giác & Dấu hiệu khứu giác \\
\hline $\begin{array}{l}\text { - } \quad \text { Mắt có vằn máu } \\
\text { - } \quad \text { Trang phục bẩn } \\
\text { - Ngón tay run rẩy } \\
\text { - } \quad \text { Có lưu trữ rượu } \\
\text { - Có chất gây nghiện, đồ tiêm } \\
\text { - chích } \\
\text { - } \quad \text { Trầy xước, sung trên cơ thể } \\
\text { - Hành vi bất thường }\end{array}$ & $\begin{array}{ll}\text { - } & \text { Nói líu lưỡi } \\
\text { - } & \text { Thú nhận có uống rượu } \\
\text { - } & \text { Câu trả lời không nhất quán } \\
\text { - } & \text { Phát ngôn lạ thường } \\
\text { - } & \text { Ngôn ngữ tục tĩu } \\
\text { - } & \text { Các dấu hiệu khác }\end{array}$ & 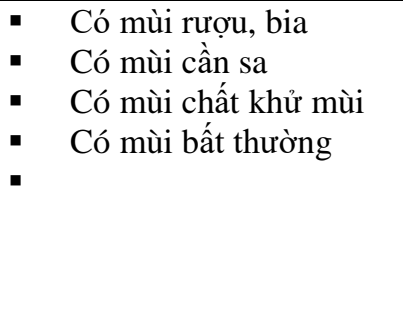 \\
\hline
\end{tabular}

Nguồn: Tổng hợp từ NHTSA (2015)

Ngoài ra, NHTSA đã hướng dẫn cảnh sát giao thông sử dụng ba kỹ thuật thẩm vấn để có thể đánh giá mức độ suy nhược khi lái xe vẫn còn ngồi sau tay lái. Những kỹ thuật đó áp dụng nguyên tắc phân tán sự tập trung. Cảnh sát yêu cầu lái xe cùng một lúc tập trung vào hai việc trở lên. NHTSA lưu ý rằng những kỹ thuật này không đáng tin cậy như các bài kiểm tra độ tỉnh táo tại hiện trường đã chuẩn hoá (SFST) nhưng lại hữu ích khi thu thập bằng chứng về việc sử dụng đồ uống có cồn hay chất kích thích. Nói cách khác, những kỹ thuật này không thay thế cho SFST. Ba kỹ thuật thẩm vấn đó là:

- Đặt những câu hỏi về hai vấn đề cùng một lúc

- Đặt những câu hỏi gây xao lãng, gián đoạn

- Đặt những câu hỏi bất thường.

Về kỹ thuật đầu tiên, ví dụ điển hình là cảnh sát giao thông yêu cầu lái xe trình cả giấy phép lái xe và giấy tờ xe. Khi lái xe đang tìm những giấy tờ này thì cảnh sát giao thông có thể áp dụng kỹ thuật thứ hai để đặt những câu hỏi gây xao lãng, gián đoạn. Ví dụ, những câu hỏi không liên quan như "Hôm nay là thứ mấy?" hoặc "Anh là người ở đâu đến?" Sau khi đã nhận giấy phép lái xe và giấy tờ xe, cảnh sát giao thông có thể sử dụng những câu hỏi bất thường (kỹ thuật thứ ba). Với kỹ thuật thứ ba, cảnh sát giao thông có thể xác nhận thông tin thông qua những câu hỏi bất thường. Ví dụ, khi đang cầm giấy giép lái xe của lái xe, cảnh sát giao thông có thể hỏi "Tên đệm của anh là gì?" Dấu hiệu của việc sử dụng đồ uống có cồn hay chất kích thích của lái xe có thể xuất hiện trong hành vi sau khi câu hỏi đó xuất hiện. Bảng dưới tổng hợp những hành vi thể hiện dấu hiệu sử dụng đồ uống có cồn hay chất kích thích mà cảnh sát giao thông nên chú ý tới.

Bảng 4-12 Tổng hợp các kỹ thuật thẩm vấn

\begin{tabular}{|l|l|l|l|}
\hline STT & Kỹ thuật thẩm vấn & Ví dụ câu hỏi đặc trưng & Dấu hiệu sử dụng rượu hay chất kích thích \\
\hline
\end{tabular}




\begin{tabular}{|c|c|c|c|}
\hline 1 & $\begin{array}{l}\text { Đặt những câu hỏi về } \\
\text { hai vấn đề cùng một } \\
\text { lúc }\end{array}$ & $\begin{array}{l}\text { Anh vui lòng xuất trình } \\
\text { bằng lái xe, giấy tờ xe? }\end{array}$ & $\begin{array}{l}\text { - Quên trình cả hai loại giấy tờ } \\
\text { - Trình nhầm giấy tờ } \\
\text { - Không tìm thấy giấy phép lái xe, giấy tờ xe } \\
\text { hoặc cả hai } \\
\text { - } \quad \text { Run rẩy, làm rơi ví, giấy phép lái xe hay } \\
\text { giấy tờ xe } \\
\text { - Không thể dùng ngón tay nhận lại giấy tờ }\end{array}$ \\
\hline 2 & $\begin{array}{l}\text { Đặt những câu hỏi } \\
\text { gây xao lãng, gián } \\
\text { đoạn }\end{array}$ & $\begin{array}{l}\text { - Hôm nay ngày gì nhi? } \\
\text { - } \quad \text { Anh người ở đâu? }\end{array}$ & $\begin{array}{l}\text { - } \quad \text { Bỏ qua câu hỏi, chỉ tập trung vào tìm giấy } \\
\text { phép lái xe, giấy tờ xe } \\
\text { - } \quad \text { Quên tìm kiếm, sau khi trả lời câu hỏi } \\
\text { - } \quad \text { Trả lời không ăn nhập gì với câu hỏi }\end{array}$ \\
\hline 3 & $\begin{array}{l}\text { Đặt những câu hỏi bất } \\
\text { thường }\end{array}$ & $\begin{array}{l}\text { - } \quad \text { Tên đệm của anh là gì? } \\
\text { - Những câu hỏi về gia } \\
\text { đình, công việc }\end{array}$ & - Như trên \\
\hline
\end{tabular}

Nguồn: Tổng hợp từ NHTSA (2015)

\section{c) Giai đoạn III: Sàng lọc trước khi bắt giữ}

Ở giai đoạn ba này, nhiệm vụ chính của cảnh sát giao thông là thực hiện các bài kiểm tra độ tỉnh táo tại hiện trường. Quá trình thực hiện kiểm tra độ tỉnh táo tại hiện trường được mô tả chi tiết ở phần sau đây. Từ kết quả kiểm tra này, cảnh sát giao thông phải quyết định xem lái xe có vi phạm quy định $\mathrm{BAC}$ hay không. Tuỳ theo chính sách của địa phương mà cảnh sát giao thông có thể tiến thành thêm hoặc thu xếp kiểm tra sơ bộ khí thở (PBT). PBT sử dụng thiết bị đo khí thở cầm tay để xác định nồng độ cồn trong máu (BAC) của người được đo. Vấn đề pháp lý sẽ nảy sinh nếu như cảnh sát giao thông xác định lái xe vi phạm $\mathrm{BAC}$ mà không có $\mathrm{PBT}$.

\subsubsection{Các bài kiểm tra độ tỉnh táo tại hiện trường đã chuẩn hoá (SFST)}

Nhìn chung, độ chính xác của các bài kiểm tra độ tỉnh táo tại hiện trường chịu tác động từ nhiều yếu tố, nhất là kiến thức của cảnh sát giao thông cũng như các bước thực hiện. Để tăng độ chính xác của kết quả kiểm tra, cơ quan NHTSA Hoa Kỳ đã chuẩn hoá ba bài kiểm tra độ tỉnh táo tại hiện trường chính, bao gồm Rung giật nhãn cầu (HGN), Đi và xoay người (WAT), Đứng một chân (OLS). Từ kết quả của một loạt các nghiên cứu tại phòng thí nghiệm có kiểm soát, đã xác định được những dấu hiệu được kiểm chứng khoa học về sự tác động của đồ uống có cồn từ ba bài kiểm tra này (NHTSA, 2015). Quy trình và dấu hiệu của từng bài kiểm tra cụ thể như sau.

\section{a) Kiểm tra rung giật nhãn cầu (HGN)}

Theo NHTSA, HGN là động tác không tự nguyện của mắt khi phải di chuyển sang hai bên. Bài kiểm tra này đưa ra kết quả đầu tiên và chính xác nhất trong SFST. Loại kiểm tra cử động nhãn cầu này hữu ích cho việc xác định mức độ ảnh hưởng của rượu cũng như việc đối tượng có sử dụng chất kích thích. Khi có người bị ảnh hưởng do tác động từ rượu hoặc chất kích thích, một số cử động rung giật nhãn cầu có thể quan sát được nếu như mắt di chuyển quá sang một bên. Trước khi thực hiện HGN, phải đảm bảo hai mắt có kích thước đồng tử bằng nhau, cho nhãn cầu nghỉ, cử động đều nhau (có thể cùng bám theo một vật). Nếu hai mắt không đồng thời bám theo cùng nhau, hoặc nếu như đồng tử có kích thước chênh lệch dễ thấy, thì có khả năng là đã có rối loạn y tế hoặc thương tổn gây ra rung giật nhãn cầu.

Có thể quan sát được trực tiếp HGN mà không cần có thiết bị chuyên dụng nào. Cảnh sát giao thông chỉ cần một vật có tính tương phản để lái xe có thể dõi theo bằng mắt. Thông thường, có thể sử dụng đèn pin nhỏ hoặc bút. Cảnh sát giao thông cần giữ vật kích thích hơi cao hơn tầm mắt lái xe, sao cho mắt lái xe mở to khi nhìn thẳng vào đó. Nên giữ vật đó cách mũi của lái xe khoảng 12-15 inch.

Theo NHTSA (2015), quy trình thực hiện HGN gồm có chín bước như sau: 
1) Bước 1: Kiểm tra xem có đeo kính không. Cảnh sát giao thông, đầu tiên, hướng dẫn lái xe tháo bỏ kính. NHTSA có lưu ý rằng cảnh sát giao thông cần kiểm tra xem lái xe có đeo kính áp tròng, nhất là loại có màu, hay không. Những loại mắt kính này có thể tác động tới việc so sánh kích thước đồng tử.

2) Bước 2: Hướng dẫn bằng lời. Cảnh sát giao thông phải hướng dẫn cụ thể bằng lời cho lái xe. Những điểm chính trong lời hướng dẫn bao gồm:

- Khép hai chân chạm nhau, hai tay buông hai bên.

- Giữ vững đầu

- Nhìn vào vật thể

- Chỉ dùng mắt dõi theo chuyển động của vật thể

- Tiếp tục nhìn vào vật thể cho đến khi được thông báo đã xong

3) Bước 3: Đưa vật thể vào vị trí. Cảnh sát giao thông cần giữ vật thể phía trước mũi lái xe khoảng 12-15 inch (30-38 cm), hơi cao hơn tầm mắt của lái xe rồi bắt đầu bài kiểm tra.

4) Bước 4: Kiểm tra kích thước của đồng tử, kiểm tra cử động nghỉ của nhãn cầu.

5) Bước 5: Kiểm tra khả năng đồng thời dõi theo vật thể.

6) Bước 6: Tìm kiếm dấu hiệu không dõi theo liên tục được (Dấu hiệu 1). Mục đích của bước này là kiểm tra cả mắt trái và phải để tìm kiếm Dấu hiệu 1 . Cả hai mắt có thể đều rung giật khi dõi theo chuyển động đều của vật thể-ví dụ như bút chì hoặc đèn pin nhỏ. Mắt của người bị ảnh hưởng bởi đồ uống có cồn hay chất kích thích không di chuyển một cách liên tục được.

7) Bước 7: Tìm kiếm dấu hiệu rung giật rõ ràng và ổn định ở độ chênh lệch tối đa (Dấu hiệu 2). Mục đích của bước 7 này là kiểm tra cả mắt trái và mắt phải xem có dấu hiệu 2 hay không. Hiện tượng rung giật nhãn cầu rõ ràng và ổn định rõ rệt nhất khi mắt bị giữ ở vị trí lệch tối đa trong thời gian tối thiểu là bốn giây và tiếp tục rung giật về hai bên.

8) Bước 8: Tìm kiếm dấu hiệu rung giật nhãn cầu trước góc 45 độ (Dấu hiệu 3). Mục đích của bước này là kiểm tra xem mắt trái và mắt phải có Dấu hiệu 3 không. Nếu hiện tượng rung giật xảy ra trước góc 45 độ thì rõ ràng người đó ở tình trạng bị ảnh hưởng bởi đồ uống có cồn hay chất kích thích.

9) Bước 9: Tổng hợp dấu hiệu. Số dấu hiệu tối đa mỗi mắt là 3 , do đó tổng số dấu hiệu là 6 . Về việc đọc kết quả kiểm tra, NHTSA khuyến nghị rằng $\mathrm{BAC}$ của lái xe ở mức 0,08 trở lên nếu như cảnh sát giao thông ghi nhận bốn dấu hiệu trở lên. Độ chính xác của kiểm tra HGN là $88 \%$.

\section{b) Kiểm tra Đi-và-Xoay người (WAT)}

Kiểm tra WAT bao gồm hai bước là i) hướng dẫn và ii) thực hiện. Khi hướng dẫn, cảnh sát giao thông nên tập trung vào điều kiện kiểm tra. WAT cần thực hiện trên bề mặt khô ráo, cứng, bằng phẳng, không trơn trượt. Cần bố trí đủ chỗ cho đối tượng hoàn tất được 9 bước nối gót (xem Hình). Sau đó, cảnh sát giao thông hướng dẫn cho lái xe cách thực hiện WAT. Bước tiếp theo là lái xe thực hiện bài kiểm tra theo hướng dẫn của cảnh sát giao thông.

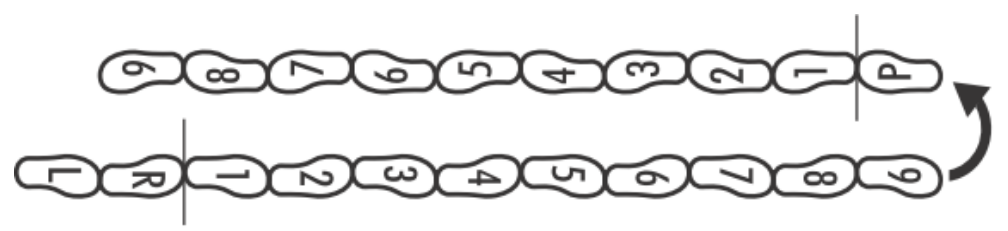

Hình 4-22 Kiểm tra WAT

Khi thực hiện bài kiểm tra WAT, cảnh sát giao thông có thể để ý tám dấu hiệu sau đây:

- Không giữ được thăng bằng khi nghe hướng dẫn. Lái xe phải giữ thăng bằng khi hai bàn chân xếp nối gót trên một đường thẳng, và đồng thời, lắng nghe lời hướng dẫn. Về cơ bản, 
người bị ảnh hưởng bởi đồ uống có cồn hay chất kích thích chỉ có thể làm một trong hai việc đó; đã nghe hướng dẫn thì không thể giữ thăng bằng.

- Bắt đầu quá sớm. Đối tượng giữ được thăng bằng, nhưng không lắng nghe lời hướng dẫn. Cảnh sát giao thông đã yêu cầu cụ thể là lái xe không bước đi khi chưa nghe thấy hiệu lệnh.

- Vừa đi vừa dừng. NHTSA có lưu ý rằng cảnh sát giao thông không ghi lại dấu hiệu này nếu đơn giản là đối tượng đang đi chậm.

- Không nối gót. Đối tượng tạo khoảng trống rộng hơn một nửa inch từ gót chân trước tới ngón chân sau ở bất kỳ bước nào.

- Bước lệch hàng. Đối tượng bước hoàn toàn ra bên ngoài đường chỉ dẫn.

- Dùng tay để giữ thăng bằng. Đối tượng nhấc một hoặc cả hai tay nhiều hơn 6 inch từ sát người để duy trì thăng bằng cơ thể.

- Xoay không đúng. Đối tượng nhấc chân trước khỏi hàng khi quay người. NHTSA có lưu ý rằng cảnh sát giao thông có thể ghi lại dấu hiệu này nếu lái xe không tuân thủ lời hướng dẫn đổi hướng.

- Nhầm số bước chân. Đối tượng bước nhiều hoặc ít hơn 9 bước trong chiều đi hay chiều về.

Về đọc kết quả kiểm tra, NHTSA khuyến nghị BAC của lái xe ở mức 0,08 trở lên nếu cảnh sát giao thông xác định được hai dấu hiệu trở lên trong bài kiểm tra WAT. Độ chính xác của kiểm tra WAT là $79 \%$.

\section{c) Kiểm tra đứng một chân (OLS)}

Giống như kiểm tra WAT, kiểm tra OLS gồm hai bước, đó là i) hướng dẫn và ii) thực hiện giữ thăng bằng và đếm. Ở bước đầu, cảnh sát giao thông cần đảm bảo được điều kiện kiểm tra, sau đó hướng dẫn cho lái xe. Ở bước tiếp theo, lái xe sẽ thực hiện bài kiểm tra OLS theo hướng dẫn của cảnh sát. Lái xe cần đếm chậm và đứng một chân trong thời gian lâu hơn 30 giây. Cảnh sát giao thông sẽ kết thúc bài kiểm tra khi đã quá 30 giây. Khi thực hiện bài kiểm tra OLS, cảnh sát giao thông cần chú ý tới bốn dấu hiệu sau đây:

- Chao đảo người khi giữ thăng bằng. Chao đảo nghĩa là thân người lái xe chuyển động sang hai bên, trước sau khi giữ thăng bằng ở tư thế đứng một chân.

- Dùng tay để giữ thăng bằng: Lái xe nhấc tay cao 6 inch trở lên từ vị trí sát thân để giữ thăng bằng.

- Nhảy lò cò. Lái xe co được một chân không chạm đất nhưng lại phải nhảy lò cò mới giữ được thăng bằng.

- Chân co chạm đất. Lái xe không thể giữ tư thế đứng một chân nên để chân co chạm đất từ một lần trở lên trong thời gian 30 giây.

Về việc đọc kết quả kiểm tra, NHTSA khuyến nghị BAC của lái xe ở mức 0,08 trở lên nếu cảnh sát giao thông ghi nhận hai dấu hiệu trở lên khi thực hiện kiểm tra OLS. Độ chính xác của kiểm tra OLS là $83 \%$.

\subsubsection{Các vấn đề pháp lý: Độ chính xác}

Phần lớn các địa phương ở Hoa Kỳ hiện nay có loại quy định về DWI trở lên (Rubenzer, 2008). Loại đầu tiên yêu cầu bằng chứng về suy nhược tinh thần, thể chất hay khả năng lái xe do sử dụng chất có cồn. Theo loại quy định này, những ghi nhận về lỗi điều khiển phương tiện và hành vi của người điều khiển, khả năng thực hiện những động tác giản (ví dụ như trình giấy phép lái xe) và kết quả SFTS là những bằng chứng quan trọng. Loại quy định về DWI thứ hai quy định rằng kết quả xét nghiệm khí thở và máu cho thấy nồng độ cồn trong máu $(\mathrm{BAC})$ vượt ngưỡng quy định tạo ra giả định về việc say rượu. 
Sau khi xem xét các nghiên cứu về SFTS có liên quan tới ngộ độc do chất có cồn, Rubenzer cũng thấy rằng SFTS có thể coi là hiệu quả trong việc tìm dấu vết cần sa và các chất an thần gây nghiện, nhưng có lẽ chỉ với liều lượng lớn amphetamine. Theo số liệu của Cơ quan Kiểm soát An toàn Giao thông Quốc lộ Quốc gia Hoa Kỳ, độ chính xác của HGN là 88\%, WAT 79\% và OLS $83 \%$. Như vậy sai số của từng phép thử riêng rẽ là $12 \%, 21 \%$ và $17 \%$, mức khá cao.

Tuy nhiên, nếu dùng cả ba phép thử thì sai số sẽ chỉ là $0,4284 \%(=12 \%$ x $21 \%$ x $17 \%)$, nghĩa là độ chính xác tới 99,5716\%, gần như tuyệt đối. Vì vậy, CSGT ở các nước thường quy định sử dụng cả gói 3 phép thử chuẩn hóa này.

Hiện tại cũng có tranh cãi về cơ sở pháp lý của SFTS nếu cảnh sát giao thông bắt giữ nghi phạm mà chỉ dựa vào đánh giá kết quả SFTS. Kết quả SFST đã được gắn liền với mức độ $\mathrm{BAC}$ như một tiêu chí (Rubenzer, 2008). Đối với WAL và OLS, hai bài kiểm tra này thường được coi là "bài kiểm tra phân tán sự tập trung" trong các ấn phẩm của NHTSA, mặc dù chưa hề có phân tích thực nghiệm để chứng thực điều đó. Ngoài ra cũng còn một vấn đề về hiệu chuẩn: Mức độ suy nhược tâm lý ở mức độ nào thì SFST chuyển thành suy giảm khả năng điều khiển phương tiện giao thông?

Đã có nhiều tranh cãi pháp lý về SFST. Liệu HGN có phải là bằng chứng khoa học, kỹ thuật hay có trọng lượng? Các SFST khác có tính khoa học không? Cảnh sát giao thông có được coi là chuyên gia kỹ thuật không? Cảnh sát có thể chứng nhận mối tương quan giữa HGN và BAC không? Khi coi HGN là có tính khoa học, một số tranh luận mơ hồ cũng đã được nêu lên: rằng HGN có tính khoa học vì nhiều lý do. Thứ nhất, tên đó mang tính khoa học. Thứ hai, nội dung mô tả nghe có vẻ chi tiết và phức tạp. Thứ ba là bài kiểm tra này do chuyên viên y tế thực hiện. Lý do cuối cùng là bài kiểm tra này được xây dựng và nghiên cứu trong cơ sở y khoa. Những lời tranh biện cho rằng $\mathrm{HGN}$ không có tính khoa học thì cho rằng bài kiểm tra này kéo theo những ghi nhận về chỉ dấu khách quan về sử dụng đồ uống có cồn hay chất kích thích, cụ thể là rung giật mắt, mà không cần có thiết bị chuyên dụng.

\subsubsection{Thực tế kiểm tra độ tỉnh táo ở châu Á}

\subsubsection{Chính sách về nồng độ cồn khi lái xe}

SFST chủ yếu được áp dụng ở Hoa Kỳ, nhưng những bài kiểm tra này chưa được áp dụng ở nhiều nước Đông Nam Á và Đông Á. Thực tế cho thấy kiểm tra khí thở là bài kiểm tra độ tỉnh táo phổ biến nhất ở châu Á. Tính tới năm 2016, tất cả các quốc gia Đông Nam Á và Đông Á đều đã có các luật quy định về nồng độ cồn khi điều khiển phương tiện tham gia giao thông (xem Bảng dưới). Indonesia là nước duy nhất không có giới hạn rõ ràng về nồng độ cồn trong máu (BAC). Các điều luật về uống rượu bia trước khi lái xe ở khu vực ASEAN thường có ngưỡng BAC trong khoảng 0,05\%-0,08\%, bất kể loại giấy phép lái xe hay loại xe. Cụ thể, ngưỡng $\mathrm{BAC}$ cho phép tại Campuchia, Lào, Philipin và Thái Lan là $0,05 \%$, trong khi các nước ASEAN khác áp dụng ngưỡng BAC là $0,08 \%$. Ở khu vực Đông Á, Trung Quốc và Nhật Bản đều áp dụng ngưỡng BAC thấp hơn, cụ thể Trung Quốc $0,02 \%$ và Nhật Bản $0,03 \%$.

\begin{tabular}{|c|c|c|c|c|}
\hline \multirow{3}{*}{ STT } & Bảng 4-1? & $\operatorname{ng} \mathrm{BAC} \mathrm{cl}$ & o tai Đông $\mathrm{Na}$ & Á và Đông Á \\
\hline & \multirow[t]{2}{*}{ Quốc gia } & \multicolumn{3}{|c|}{ Nồng độ cồn trong máu (BAC) cho phép } \\
\hline & & Toàn dân & Lái xe trẻ/mới & $\begin{array}{c}\text { Lái xe chuyên } \\
\text { nghiệp/kinh doanh }\end{array}$ \\
\hline 1 & Brunei & $\begin{array}{l}35 \mathrm{mg} \text { cồn trol } \\
80 \mathrm{mg} \text { cồn trol }\end{array}$ & $\begin{array}{l}\text { khí thở; hoặc } \\
\text { máu }\end{array}$ & \\
\hline
\end{tabular}




\begin{tabular}{|c|l|c|c|c|}
\hline \multirow{2}{*}{ STT } & \multirow{2}{*}{ Quốc gia } & \multicolumn{3}{|c|}{ Nồng độ cồn trong máu (BAC) cho phép } \\
\cline { 3 - 5 } & & Toàn dân & Lái xe trẻ/mới & $\begin{array}{c}\text { Lái xe chuyên } \\
\text { nhiệp/kinh doanh }\end{array}$ \\
\hline 2 & Campuchia & $0,05 \%$ & $0,05 \%$ & $0,05 \%$ \\
\hline 3 & Indonesia & None & None & None \\
\hline 4 & Lào & $0,05 \%$ & $0,05 \%$ & $0,05 \%$ \\
\hline 5 & Malaysia & $0,08 \%$ & $0,08 \%$ & $0,08 \%$ \\
\hline 6 & Myanmar & $0,08 \%$ & $0,08 \%$ & $0,08 \%$ \\
\hline 7 & Philippines & $0,05 \%$ & $0,05 \%$ & $0,05 \%$ \\
\hline 8 & Singapore & $0,08 \%$ & $0,08 \%$ & $0,08 \%$ \\
\hline 9 & Thái Lan & $0,05 \%$ & $0,05 \%$ & $0,05 \%$ \\
\hline 10 & Trung Quốc & $0,02 \%$ & $0,02 \%$ & $0,02 \%$ \\
\hline 11 & Nhật Bản & $0,03 \%$ & $0,03 \%$ & $0,03 \%$ \\
\hline 12 & Hàn Quốc & $0,05 \%$ & $0,05 \%$ & $0,05 \%$ \\
\hline
\end{tabular}

Nguồn: Tổng hợp từ số liệu của WHO (2016) và các nguồn khác

Về ngưỡng BAC ở Trung Quốc, Wang và cộng sự (2015) đã tổng hợp những thay đổi về chính sách về uống rượu bia trước khi lái xe như sau:

- 1/10/1955: Luật giao thông đầu tiên của Trung Quốc, "Các quy định về giao thông đô thị" (mục 46) được ban hành: "Cấm lái xe trong tình trạng say rượu bia".

- 1/08/1988: "Quy tắc giao thông” thay thế cho "Các quy định về giao thông đô thị”. Các quy định chi tiết hơn bao gồm: Lái xe trong tình trạng say rượu bia sẽ bị xử phạt, giam giữ, hoặc tạm thời tước giấy phép lái xe cơ giới.

- 4/6/1996: Ban hành "Các quy định giao thông đường bộ đô thị”, bổ sung quy định "thu hồi giấy phép lái xe cơ giới” nếu điều khiển xe trong tình trạng say rượu bia.

- Năm 2004 có thể được coi là năm mang tính bước ngoặt trong việc xử lý hành vi lái xe trong tình trạng say rượu ở Trung Quốc. Các ngưỡng tiêu chuẩn được đưa ra trong một nghiên cứu: Lái xe sau khi có uống rượu bia, $B A C \geq 20 \mathrm{mg} / 100 \mathrm{ml}$ và $\leq 80 \mathrm{mg} / 100 \mathrm{ml}$; lái xe trong tình trạng say xỉn, $B A C \geq 80 \mathrm{mg} / 100 \mathrm{ml}$;

- 1/5/2011: Bổ sung Luật Hình sự: Người lái xe trong tình trạng say xỉn có thể bị phạt hành chính và phạt tù.

- 24/4/2011: Luật An toàn Giao thông Đường bộ sửa đổi, Điều 91 quy định như sau: lái xe sau khi uống rượu bia sẽ tịch thu giấy phép lái xe ít nhất 6 tháng, đồng thời phạt 1000 2000 RMB (156 - 313 USD). Lái xe trong tình trạng say xỉn sẽ gị giam giữ cho đến khi tỉnh, bị tước giấy phép lái xe ít nhất 5 năm, đồng thời nếu vi phạm luật hình sự thì sẽ bị truy tố theo phép luật. Lái xe say xỉn điều khiển xe kinh doanh sẽ bị giam giữ tới 15 ngày, bị tước giấy phép lái xe ít nhất 10 năm, cấm lái xe kinh doanh suốt đời, đồng thời nếu vi phạm luật hình sự thì sẽ bị truy tố theo quy định pháp luật. Người lái xe có uống rượu hoặc say xỉn mà gây tai nạn nghiêm trọng sẽ bị cấm lái xe suốt đời.

- 1/1/2013: "Quy định mới về trừ điểm khi vi phạm an toàn giao thông đường bộ": quy định chính thức "BAC $\geq 20 \mathrm{mg} / 100 \mathrm{ml}$ và $\leq 80 \mathrm{mg} / 100 \mathrm{ml}$ " là lái xe sau khi có uống rượu bia, và " $B A C \geq 80 \mathrm{mg} / 100 \mathrm{ml}$ " là lái xe trong tình trạng say xỉn. Trừ 12 điểm nếu $\mathrm{BAC} \geq 20 \mathrm{mg} / 100 \mathrm{ml}$, đồng thời người lái xe phải buộc học luật và quy định an toàn giao thông đường bộ, chỉ có thể nhận lại giấy phép lái xe sau khi đã qua bài kiểm tra.

Theo Wang và cộng sự, do thiếu nghiên cứu định lượng về tình hình giao thông ở Trung Quốc trong giai đoạn từ 1955 tới 2003 nên hầu như không có thông tin về số vụ tai nạn do lái xe có uống rượu bia. Do đó thiếu những quy định pháp luật, biện pháp chế tài không chỉ trên lý thuyết mà cả trên thực tế về ngăn ngừa lái xe sau khi uống rượu bia đều không đạt yêu cầu trong những năm đó. Tiêu chuẩn về nồng độ cồn trong máu được nghiên cứu năm 2004 đã đưa ra những gợi ý về cách sàng lọc các đối tượng lái xe sau khi uống rượu bia, nhưng thực tế áp dụng ngưỡng 
BAC không được tốt như mong đợi. Xu hướng thương vong do tai nạn giao thông không thay đổi nhiều. Điều này là do việc kiểm tra khí thở ngẫu nhiên (bên lề đường) và kiểm tra khí thở lấy bằng chứng (tại đồn cảnh sát) không được đưa vào trong quy định pháp luật, đồng thời việc kém áp dụng các tiêu chuẩn đo lường cũng ảnh hưởng tới tính hiệu quả của công tác kiểm tra. Sau khi xảy ra một loạt các vụ tai nạn nghiêm trọng có nguyên nhân từ lái xe say rượu, tác động nguy hiểm của hành vi lái xe khi say xỉn đã gây chấn động dư luận cũng như chính phủ Trung Quốc. Do đó, Luật Hình sự sửa đổi ban hành năm 2011 đã lần đầu tiên coi lái xe khi say xỉn là tội hình sự. Ngoài ra, Luật An toàn Giao thông Đường bộ cũng được ban hành trong năm này, quy định cụ thể mức phạt đối với người lái xe sau khi uống rượu bia. Cho dù đã tăng mức chế tài, nhiều vụ tai nạn do lái xe say xỉn vẫn tiếp tục diễn ra năm 2012. Cụ thể, lái xe là người nổi tiếng và những vụ tai nạn này đã tác động tiêu cực tới toàn xã hội Trung Quốc. Để giải quyết vấn vấn đề, chính phủ Trung Quốc đã tăng cường thêm các biện pháp chế tài từ ngày 1/1/2013, bao gồm các quy định chi tiết hơn về xử phạt hành vi lái xe sau khi uống rượu bia và lái xe khi say xỉn.

\subsubsection{Kiểm tra khí thở}

Kiểm tra khí thở ngẫu nhiên (RBT) và điểm kiểm tra độ tỉnh táo đã được áp dụng ở nhiều nước ASEAN. Nói chung, kiểm tra khí thở ngẫu nhiên được áp dụng ở các điểm kiểm tra thông thường của cảnh sát. Đây là hình thức phổ thông nhất về điểm kiểm tra độ tỉnh táo. Điểm kiểm tra này không chỉ dành riêng cho việc kiểm tra người lái xe có sử dụng rượu bia khi lái xe mà còn để kiểm tra giấy phép lái xe, đăng kiểm xe, tốc độ xe, việc sử dụng dây an toàn, đội mũ bảo hiểm, và các nội dung khác. Ngoài ra, còn có hai loại hình điểm kiểm tra độ tỉnh táo là: i) các điểm kiểm tra độ tỉnh táo chọn lọc (hay điểm kiểm tra khí thở chọn lọc - SBT), và ii) điểm kiểm tra độ tỉnh táo trong sự kiện đặc biệt. Ví dụ, SBT được chính thức triển khai ở Thái Lan (Ditsuwan và cộng sự, 2015). Khác với RBT, chỉ có những lái xe bị cảnh sát giao thông nghi ngờ đang say xỉn mới bị dừng xe để kiểm tra. Những điểm kiểm tra độ tỉnh táo chọn lọc thường chỉ hoạt động trong thời gian ngắn, thường là buổi đêm $(22 \mathrm{~h}-24 \mathrm{~h}$ hoặc $1 \mathrm{~h}-4 \mathrm{~h})$ ở những khu vực có rủi ro lớn, ví dụ như các khu vực giải trí ban đêm. Thực tiễn ở Thái Lan khác với ở Australia nơi cũng triển khai RBT, nhưng lại khá tương đồng so với Hoa Kỳ. Ngoài ra, hình thức điểm kiểm tra được biết tới nhiều nhất ở Thái Lan là điểm kiểm tra độ tỉnh táo theo sự kiện đặc biệt - triển khai khi có những dịp đặc biệt ví dụ như ngày lễ lớn. Khi diễn ra lễ Songkran ( 3 ngày trước và sau ngày 13 tháng 4 ) và Tết ( $2-3$ ngày trước và sau ngày 1 tháng Giêng), người Thái đi lại rất nhiều, lượng tiêu thụ đồ uống có cồn ở mức cao. Trên cả nước đều bố trí các điểm kiểm tra cố định hoặc lưu động để xác định các trường hợp vi phạm luật giao thông, nói chung là từ $2 \mathrm{~h}$ tới $22 \mathrm{~h}$, là khung thời gian hay xảy ra tai nạn giao thông.

Bảng 4-14 Kiểm tra khí thở ngẫu nhiên và các điểm kiểm tra ở Đông Nam Á, Đông Á

\begin{tabular}{|c|l|c|c|}
\hline STT & \multicolumn{1}{|c|}{ Quốc gia } & $\begin{array}{c}\text { Áp dụng Kiểm tra Khí thở Ngẫu nhiên } \\
\text { (RBT) }\end{array}$ & Điểm kiểm tra \\
\hline 1 & Brunei Darussalam & Thiếu số liệu & Thiếu số liệu \\
\hline 2 & Campuchia & Có & Có \\
\hline 3 & Indonesia & Có & Không \\
\hline 4 & Lào & Có & Có \\
\hline 5 & Malaysia & Có & Có \\
\hline 6 & Myanmar & Có & Có \\
\hline 7 & Philippin & Không & Không \\
\hline 8 & Singapore & Có & Có \\
\hline 9 & Thái Lan & Có & Có \\
\hline
\end{tabular}




\begin{tabular}{|c|l|c|c|}
\hline STT & \multicolumn{1}{|c|}{ Quốc gia } & $\begin{array}{c}\text { Áp dụng Kiểm tra Khí thở Ngẫu nhiên } \\
\text { (RBT) }\end{array}$ & Điểm kiểm tra \\
\hline 10 & Trung Quốc & Có & Có \\
\hline 11 & Nhật Bản & Có & Không \\
\hline 12 & Hàn Quốc & Không & Không \\
\hline
\end{tabular}

Nguồn: Tổng hợp từ số liệu của WHO (2016) và các nguồn khác

\subsubsection{Tự kiểm tra độ tỉnh táo}

Do đặc điểm dễ thực hiện, không tốn kém nên nhiều doanh nghiệp vận tải và cá nhân người lái xe (cả ô tô và xe máy) trên thê giới thường tự áp dụng các bài kiểm tra này để đánh giá độ tỉnh táo trước khi lái.

\subsection{Một số công cụ thể chế quản lý xe máy trên thế giới}

\section{Công cụ 1-Hệ thống gia hạn GPLX cho xe máy}

\section{- Hệ thống gia hạn GPLX xe máy cơ bản (mức 1)}

Nhiều nước quy định hệ thống gia hạn GPLX định kỳ không chỉ áp dụng cho ô tô mà còn cả cho xe máy, để bảo đảm việc quản lý hiệu quả hệ thống cấp GPLX. Họ tổ chức các lớp học bồi dưỡng trong quá trình gia hạn định kỳ về luật giao thông đường bộ, đặc điểm của TNGT, v.v., từ đó, những bài học này sẽ góp phần ngăn chặn tình trạng lái xe nguy hiểm.

\section{- Hệ thống gia hạn GPLX dựa trên vi phạm giao thông (mức 2)}

Ở mức này, nội dung của khóa học bồi dưỡng và giai đoạn gia hạn được xây dựng dựa trên những vi phạm của lái xe. Ví dụ, trong trường hợp lái xe không vi phạm, thời hạn sẽ dài hơn, thời gian khóa học bồi dưỡng ngắn hơn và lệ phí cấp GPLX ít hơn. Ngược lại, lái xe thường xuyên vi phạm sẽ phải học lâu hơn và thời gian gia hạn sẽ ngắn hơn, lệ phí cấp GPLX cũng cao hơn một cách đáng kể. Kết quả, những lái xe hay vi phạm sẽ được bài học thẩm thía. Ngoài ra, quy định một giai đoạn bắt đầu cho những lái xe trẻ.

\section{- Đặt mạch tích hợp (con chip) trong giấy phép lái xe}

Có thể sử dụng con chip gắn vào GPLX giúp tăng hiệu quả việc quản lý cơ sở dữ liệu và kiểm soát giao thông.

\section{Công cụ 2-Hệ thống cấp GPLX cho xe máy dưới 50cc}

Không ít quốc gia quy định về hệ thống cấp GPLX cho xe máy dưới 50cc. Bảng dưới đây tóm tắt quy chế đối với xe máy dưới $50 \mathrm{cc}$ ở Nhật Bản, Đài Loan, và Thái Lan. Tất cả các nước trên đều áp dụng hệ thống cấp phép cho loại xe này. Nội dung có sự khác biệt tương đối giữa các nước. Nhật Bản cho phép việc cấp phép cho học sinh phổ thông, nhưng Đài Loan và Thái Lan thì không. Nhật Bản và Thái Lan cũng có chế độ các bài giảng bắt buộc từ năm 1990, khi mọi người thi lấy bằng lái. Kết quả là. TNGT do xe máy dưới 50cc đã giảm, theo điều tra của "Hiệp hội quốc tế về khoa học ATGT”. Thái Lan cũng quy định có 2 giờ đồng hồ học bắt buộc.

Bảng 4-15 Quy chế đối với xe máy dưới 50cc ở một số quốc gia

\begin{tabular}{|c|l|c|l|}
\hline Quốc gia & \multicolumn{1}{|c|}{ Nhật Bản } & \multicolumn{1}{c|}{ Đài Loan } & \multicolumn{1}{c|}{ Thái Lan } \\
\hline Nội dung & $\begin{array}{l}\text { • Kiểm tra mắt } \\
\text { - Thi lý thuyết }\end{array}$ & $\bullet$ Thi lý thuyết (30’) & $\begin{array}{l}\text { ・ Kiểm tra mắt } \\
\bullet \text { Kiểm tra phản xạ }\end{array}$ \\
\hline
\end{tabular}




\begin{tabular}{|c|c|c|c|}
\hline & $\begin{array}{l}\text { - Khóa học kỹ năng } \\
\text { lái xe (3h) }\end{array}$ & & $\begin{array}{l}\text { - Học luật giao thông } \\
\text { và an toàn lái xe (2h) } \\
\text { - Thi lý thuyết } \\
\text { - Thi thực hành }\end{array}$ \\
\hline Độ tuổi & Trên 16 tuổi & Trên 18 tuổi & Trên 18 tuổi \\
\hline Đặc điểm & $\begin{array}{l}\text { - Gia hạn 3-5 năm } \\
\text { một lần (25-35 } \\
\text { USD) } \\
\text { - Có bài giảng (30'- } \\
\text { 2h tùy vào vi phạm) } \\
\text { - Thi thực hành áp } \\
\text { dụng từ năm 1990 }\end{array}$ & $\begin{array}{l}\text { - Gia hạn } 6 \text { năm một } \\
\text { lần (7-8 USD) } \\
\text { - Nội dung thi bao } \\
\text { gồm luật giao thông, } \\
\text { các biền báo }\end{array}$ & $\begin{array}{l}\text { - Gia hạn } 5 \text { năm } 1 \text { lần } \\
\text { (8 USD) }\end{array}$ \\
\hline
\end{tabular}

Nguồn: Nhóm nghiên cứu

\section{Công cụ 3-Hệ thống giấy phép lái xe cho người mới lái}

Theo kinh nghiệm của các nước phát triển, cần quy định một hệ thống phù hợp cho lái xe mới. Theo quy định đó, họ thực hiện chương trình câp phép tốt nghiệp cho lái xe (GDLS). Đây là một trong những chương trình hiệu quả để giảm TNGT do lái xe trẻ gây ra. Thống kê ở New Zealand cho thấy những lái xe trẻ, đặc biệt ở độ tuổi 20, có nguy cơ TNGT nghiêm trọng cao hơn ba lần. GDLS được giới thiệu để giải quyết vấn đề này ở New Zealand, Australia, và Mỹ. Chương trình này có thể giúp giảm mạnh về tai nạn trước và sau khi lấy bằng lái xe, dựa trên báo cáo nghiên cứu an toàn "Cấp phép cho lái xe mới tốt nghiệp: kinh nghiệm của New Zealand".

Luật pháp các nước này quy định một quá trình trước khi được lấy giấy phép lái xe chính thứcgồm nhiều bước:

- Ít nhất 50 giờ lái xe có giám sát trong giai đoạn có giấy phép học lái xe

- GPLX tạm thời gồm hai giai đoạn (Giấy phép tạm thời $\mathrm{P} 1$ và $\mathrm{P} 2$ )

- Một bài kiểm tra nhận thức hiểm nguy để lên hạng từ P1 sang P2

- Khen thưởng đối với người lái xe làm đúng và xử phạt đối với lái xe không làm đúng.

\section{Công cụ 4- Hệ thống thu phí lưu hành (định kỳ) cho xe máy}

Luật Giao thông ở nhiều nước quy định hệ thống thu phí lưu hành định kỳ cho xe máy (tương tự phí sử dụng đường bộ ở Việt Nam). Việc thu chi phí người sử dụng là hợp lý và phần thu được sẽ sử dụng để hỗ trợ việc xây dựng đường và các biện pháp ATGT đường bộ.

Mặt khác, bảo hiểm (trách nhiệm dân sự) mang tính bắt buộc với tất cả các chủ phương tiện, cũng như quy định ở Việt Nam. Doanh nghiệp bảo hiểm không những chỉ bồi thường cho người gây tai nạn và nạn nhân khi TNGT xảy ra, mà hệ thống bảo hiểm cũng có thể góp phần thu thập dữ liệu về các tai nạn nhẹ. Các công ty bảo hiểm trả tiền theo tình hình TNGT, do đó, họ cũng thu thập dữ liệu này.

Điểm then chốt nằm ở chỗ thực thi phối hợp hai quy định này: Ngành GTVT kiểm tra bằng chứng về bảo hiểm khi người sở hữu phương tiện đóng phí lưu hành hàng năm hoặc hai năm một lần. Ngoài ra, họ cũng kiểm tra cả tài liệu đăng ký. Do đó, phương tiện đã qua sử dụng có thể được đăng ký lại. Cuối cùng, người sở hữu phương tiện nhận được tem dán ghi nhận đã nộp 
phí lưu hành hàng năm. Kết quả là cảnh sát có thể kiểm soát người vi phạm bằng cách kiểm tra tem dán. Ngành GTVT có thể theo dõi chính xác số lượng xe máy lưu hành.

Cả Nhật Bản và Thái Lan đều đã áp dụng hệ thống này. Chi phí được thể hiện trong bảng sau đây. Ví dụ, ở Thái Lan, hàng năm phòng giao thông thu từ 3-4 USD cho mỗi xe máy. So sánh với mức phí ở Thái Lan thì ở Nhật Bản cao hơn. Vì các khoản phí này được dùng cho việc xây dựng đường xá và các biện pháp ATGT như là các quỹ riêng cho đường bộ trong thời kỳ kinh tế Nhật Bản phát triển cao, có thể kết luận rằng hệ thống này cần thiết cho cả sự phát triển của nền kinh tế và một xã hội ATGT.

Bảng 4-16 Hệ thống phí lưu hành phương tiện

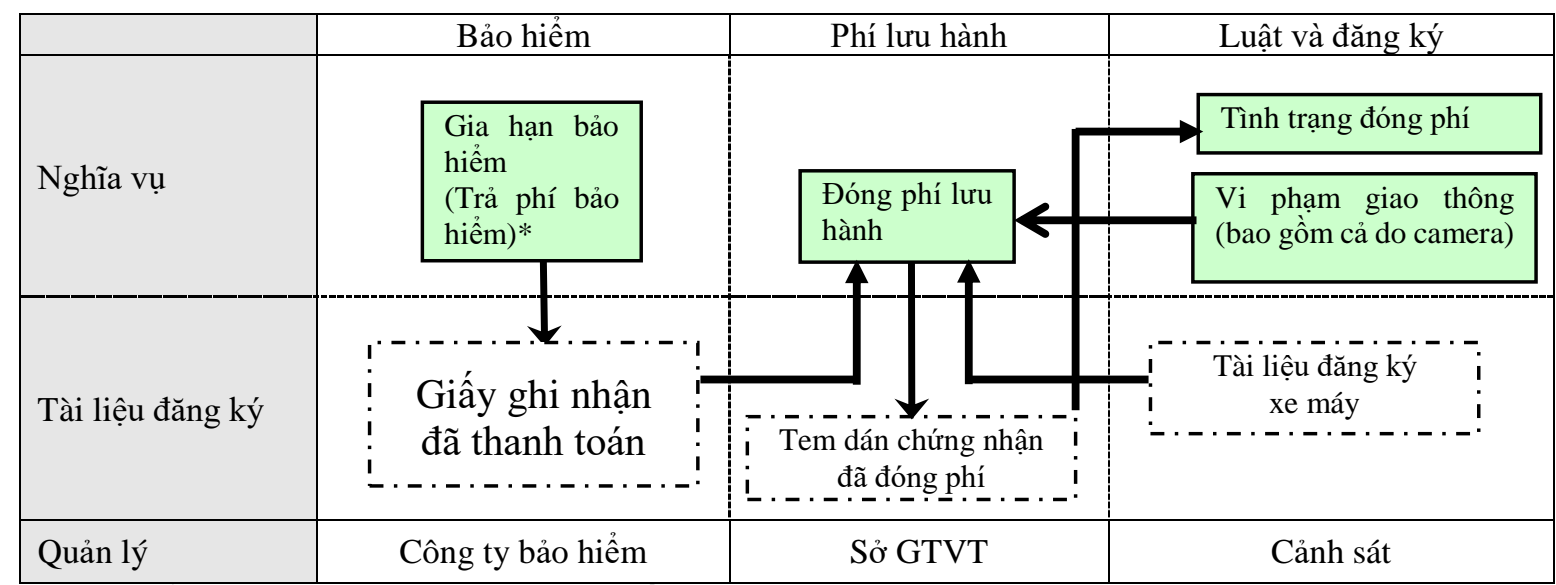

* : Bảo hiểm trách nhiệm bên thứ ba đối với phương tiện

Nguồn: JICA (2009)

Bảng 4-17 Phí lưu hành phương tiện ở Thái Lan và Nhật Bản

\begin{tabular}{|l|l|c|c|c|}
\hline \multicolumn{2}{|c|}{} & $\begin{array}{c}\text { Bảo hiểm } \\
\text { (Xấp xỉ) }\end{array}$ & $\begin{array}{c}\text { Phí lứ hành } \\
\text { (Xấp xỉ) }\end{array}$ & Luật \& Đăng ký \\
\hline \multirow{3}{*}{ Xe máy } & Thái Lan & 10 USD/năm & $3-4$ USD/năm & \multicolumn{1}{c|}{ - } \\
\cline { 2 - 5 } & Nhật Bản & $50-80$ USD/năm & 20 USD/năm & $\begin{array}{l}\text { Tối đa 2,700*_ 4,500** } \\
\text { USD (Phạt) }\end{array}$ \\
\hline
\end{tabular}

* : Chi phí mức phạt trong trường hợp lái xe không dán tem trên biển số tối đa là 2,700 USD

** : Chi phí mức phạt trong trường hợp lái xe không đóng loại phí này tối đa là 4,500 USD Nguồn: JICA (2009)

Nhật Bản và Thái Lan đã áp dụng quy chế này. Mẫu tem dán được thể hiện trong hình dưới đây. Kết quả, cảnh sát có thể dễ dàng theo dõi. 


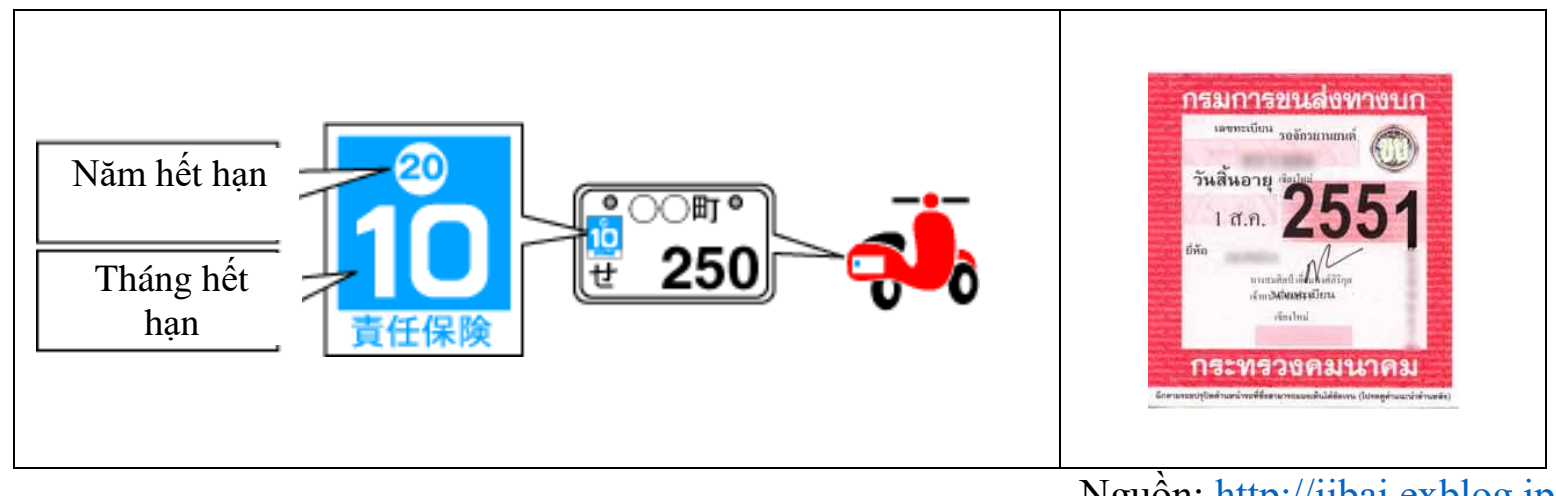

Hình 4-23 Tem chứng nhận cho xe máy

Nguồn: http://jibai.exblog.jp/

\section{Công cụ 5: Kiểm định định kỳ xe máy}

Nhiều quốc gia có hệ thống kiểm định định kỳ đối với xe máy đang lưu hành. Thông thường từ năm thứ năm sau đăng ký lần đầu, người sở hữu xe máy phải cho xe đi kiểm định tại trung tâm được chứng nhận, và xuất trình giấy chứng nhận khi đóng phí lưu hành. Tiêu chuẩn kỹ thuật và tiêu chuẩn môi trường để kiểm soát khí thải được xây dựng và phê duyệt để làm căn cứ.

Hệ thống này đã được áp dụng ở Thái Lan. Chi phí kiểm định xấp xỉ 2 USD. Ở Nhật Bản, hệ thống kiểm định chủ yếu nhằm vào đối tượng xe máy trên $250 \mathrm{cc}$. Và phương thức kiểm định cũng tương tự như ở xe hơi.

\subsection{Bài học kinh nghiệm}

\section{a) Chiến lược an toàn giao thông đường bộ}

Hướng tiếp cận 5 trụ cột (hay hướng tiếp cận Hệ thống An toàn) đã được áp dụng ở nhiều nước. Nhóm chuyên gia đã rà soát tình hình áp dụng hướng tiếp cận này tại Campuchia, Indonesia và Malaysia. Thực tiễn từ các nước này cho thấy hướng tiếp cận 5 trụ cột có thể được điều chỉnh một cách linh hoạt tuỳ theo điều kiện của từng nước. Ngoài ra, vai trò lãnh đạo và hỗ trợ của các bên cũng cần được làm rõ. Việc tham gia của nhiều ngành trong quá trình thực hiện chiến lược an toàn giao thông đường bộ mà lại thiếu một bên có vai trò phụ trách từng 'trụ cột' chiến lược cụ thể có thể dẫn tới những khó khăn khi phối hợp liên ngành do các hoạt động cụ thể có thể bị chồng chéo hay vai trò của các bên có thể bị trùng lặp. Điều đó có thể khiến không tối ưu được nguồn lực, làm giảm tính hiệu quả chung của những sáng kiến về an toàn giao thông đường bộ.

\section{b) Các chính sách về sở hữu và sử dụng xe máy}

Thực tế ở Trung Quốc và Myanmar cho thấy rằng chính sách cấm hay hạn chế xe máy có tác động xã hội rất lớn. Do đó, các cơ quan chức năng cần có quyết định chắc chắn. Quy trình thực hiện cũng cần triển khai từng bước, có những điều chỉnh phù hợp khi cần thiết. Cấm hay hạn chế xe máy chỉ nên áp dụng ở một số khu vực có mức độ đô thị hoá cao, không nên áp dụng trên phạm vi cả nước. Thực tế đã cho thấy việc cấm/hạn chế xe máy có thể dẫn tới những vấn đề khác, ví dụ như làm tăng số lượng ô tô, ùn tắc giao thông, tác động xấu tới môi trường khi sử dụng xe đã cũ. Ngoài ra, chính sách đó cũng cần có sự kiên trì thực hiện từ tất cả các bên liên quan.

\section{c) Các biện pháp kiểm soát xe máy}


Xe máy và xe máy điện là phương tiện di chuyển chính ở những đô thị Châu Á. Tuy nhiên, người đi xe cơ giới hai bánh luôn chịu nhiều nguy hiểm nhất trong các đối tượng tham gia giao thông, nhất là tại khu vực Đông Nam Á. Để đảm bảo an toàn cho các loại xe này, các quốc gia Châu Á đã thực hiện nhiều biện pháp kiểm soát, ví dụ như chuyển hướng hai bước, hệ thống hai vạch dừng (hay ô dừng cho xe máy) và làn đường cho xe hai bánh. Phần trên đã trình bày sơ bộ về các biện pháp đó ở Trung Quốc, Nhật Bản, Malaysia và Đài Loan (Trung Quốc). Về làn đường cho xe máy, thực tế ở Đài Loan cho thấy ít khi bố trí được làn dành riêng hay ưu tiên cho xe máy trên đường đô thị vì thiếu không gian đường. Những làn đường này thường được bố trí kèm với hệ thống hai vạch dừng tại các nút giao có đèn tín hiệu. Malaysia thường bố trí làn xe máy trên quốc lộ và đường cao tốc. Về chuyển hướng hai bước, thực tế áp dụng biện pháp này ở Đài Loan cho thấy rằng có thể giảm được số vụ tai nạn giao thông đường bộ liên quan tới xe máy rẽ trái tại các nút giao. Tuy nhiên, ý thức kém của người đi xe máy có thể làm suy giảm tính hiệu quả của quy định rẽ trái hai bước. Tại Nhật Bản, do ít người đi xe máy và đồng thời ý thức của người đi xe máy tốt nên biện pháp rẽ phải hai bước tỏ ra hữu hiệu. Về cơ chế hai vạch dừng, thực tế ở Đài Loan cho thấy rằng biện pháp này đã làm tăng tỷ lệ thoát xe tại các nút giao có đèn tín hiệu. Ngoài ra, cũng cần tính tới việc điều chỉnh, bổ sung các quy định giao thông. Đoàn chuyên gia cũng đã rà soát các biện pháp áp dụng cho xe máy điện ở Trung Quốc. Các biện pháp điều tiết lưu lượng xe máy điện tỏ ra hữu ích đối với các nước đang phát triển, nhất là tại các đô thị phụ thuộc vào xe máy ở Việt Nam.

\section{d) Kiểm tra độ tỉnh táo với người đi xe máy}

Các bài kiểm tra độ tỉnh táo tại chỗ được áp dụng rộng rãi như ở các bang ở Hoa Kỳ, Nhật Bản và nhiều nước khác, do đặc điểm dễ thực hiện, rất tiết kiệm, gần như không tốn kém. Do có nhiều bài kiểm tra, nên NHTSA đã chuẩn hoá quy trình xác định DUI/DWI và ba bài kiểm tra độ tỉnh táo tại chỗ (HGN, WAT và OLS). Ở các nước Châu Á, việc áp dụng các bài kiểm tra độ tỉnh táo tại chỗ là khả thi do quy trình đơn giản, không tốn thời gian. Mức chính xác của từng bài kiểm tra riêng rẽ về độ tỉnh táo tại chỗ, tuy đã chuẩn hoá, vẫn còn là chủ đề đang được tranh luận, ngay cả khi đã có tiêu chuẩn/hướng dẫn thực hiện các bài kiểm tra này. Nhưng tổ hợp cả 3 bài kiểm tra cho kết quả với độ chính xác rất cao. Đồng thời không chỉ CSGT mới sử dụng, mà các doanh nghiệp vận tải, hành khách và cá nhân lái xe có thể tự dùng để kiểm tra mức tỉnh táo cần thiết khi lái xe. 


\section{TÀI LIỆU THAM KHẢO}

ASEAN. (2016). ASEAN Regional Road Safety Strategy.

Belin, M.-Å., Tillgren, P., \& Vedung, E. (2012). Vision Zero - a road safety policy innovation. International Journal of Injury Control and Safety Promotion, 19(2), 171-179. http://doi.org/10.1080/17457300.2011.635213

Cambodia National Road Safety Committee. (2014). Cambodia National Road Safety Policy.

China People News. (2017). Installation of Sun Awnings for E-bikes in Hangzhou. Retrieved from http://paper.people.com.cn/zgcsb/html/2017-07/17/content_1791660.htm

Chính, P. M., \& Hoàng, V. Q. (2009). Kinh tế Việt Nam: Thăng trầm và đột phá. Nxb Chính trị quốc gia, Hà Nội.

Deng, X., Xu, J., \& Wang, B. (2009). Traffic Countermeasures Research for Guangzhou City in Traffic Mode Transferring Period after "Motorcycle Forbidden Ban" Effect. Journal of Transportation Systems Engineering and Information Technology, 9(4), 145-150. http://doi.org/http://dx.doi.org/10.1016/S1570-6672(08)60077-X

Department for Transport. (2011). Strategic Framework for Road Safety. Retrieved from http://www.who.int/roadsafety/decade_of_action/plan/great_britain.pdf

Everington, K. (2018). Removal of left turn boxes for scooters led to $40 \%$ fewer accidents in Taoyuan. Retrieved from https://www.taiwannews.com.tw/en/news/3396951

Feest, G., Clinton, K., Davies, D., Cooper, S., Farrer, C., Hay, G., ... Hughes, M. (2015). Making Road Safety Count: Spending Choices Which Protect Your Community.

Field Sobriety Testing Resource. (2018). Non-standardized Field Sobriety Tests.

GIZ. (2017). Urban Road Safety: A Sourcebook for Policy-makers in Developing Cities. GIZ.

Guardian News. (2016). Return of the Bicycle Kingdom? How pavement cycling is transforming Taipei. Retrieved from https://www.theguardian.com/cities/2016/mar/15/bicyclekingdom-reborn-pavement-cycling-taipei-taiwan

Guo, Y., Liu, P., Bai, L., Xu, C., \& Chen, J. (2014). Red Light Running Behavior of Electric Bicycles at Signalized Intersections in China. Transportation Research Record: Journal of the Transportation Research Board, 2468, 28-37. http://doi.org/10.3141/2468-04

Hook, W., \& Fabian, B. (2009). Regulation and Design of Motorized and non-motorized Twoand-Three-Wheelers in Urban Traffic.

Hook, W., Nadal, L., \& Fjellstrom, K. (2009). Managing Two and Three Wheeler Traffic.

Hsu, T.-P., \& Li, P.-J. (2007). Chaos Analysis of Mixed Traffic Flow With Motorcycle. In Proceedings of the Eastern Asia Society for Transportation Studies (Vol. 6).

Hsu, T.-P., Sadullah, A. F. M., \& Dao, N. X. (2003). A comparison study on motorcycle traffic development in some Asian countries - case of Taiwan, Malaysia and Vietnam.

Hsu, T.-P., Yang, F., \& Jiang-ling, S. (2009). Guideline of Lane Width of Mixed Lane for Motorcycle Traffic. In Proceedings of Eastern Asia Society for Transportation Studies (Vol. 7, pp. 1-10). 
Khorasani-Zavareh, D. (2011). System versus traditional approach in road traffic injury prevention: A call for action. Journal of Injury and Violence Research, 3(2), 1-1. http://doi.org/10.5249/jivr.v3i2.128

Law, T. H., \& Radin Sohadi, R. U. (2005). Determination of comfortable safe width in an exclusive motorcycle lane. Journal of the Eastern Asia Society for Transportation Studies, 6, 3372-3385.

Lawyerahead. (2009). What are Field Sobriety Tests.

MIROS. (2017). An Evaluation of Motorcycle Facilities : Utilisation and User Satisfaction on EMCL and NEMCL in Malaysia.

Moto Japan. (2017). 2-step road verification for mopeds in Japan. Retrieved from https://motojapan.goat.me/5OUSWwNd

Motorcycle Ban Policy in Shanghai (in Chinese). (2016). Retrieved from http://www.newmotor.com.cn/html/fdjm/80266.html

Nishiuchi, H. (2014). Traffic Safety Education and Awareness Activities in Japan.

Qilu Evening News. (2011). Guardrail for Non-motorized Vehicles. Retrieved from http://news.iqilu.com/shandong/17pic/2011/1116/1048683.shtml

Road Crash and Victim Information System. (2017). Summary Report on Road Crashes and Casualities in Cambodia.

Road Safety Department, \& Malaysian Institute of Road Safety Research. (2014). Road Safety Plan Of Malaysia 2014-2020.

Rubenzer, S. J. (2008). The Standardized Field Sobriety Tests: A review of scientific and legal issues. Law and Human Behavior, 32(4), 293-313. http://doi.org/10.1007/s10979-0079111-y

Sina Henan. (2014). Pilot Installation of Sun Awnings in Zhengzhou City. Retrieved from http://henan.sina.com.cn/news/m/2014-08-27/0731-157402.html

Syazana, N. (2018). Country Report Malaysia's Road Safety Initiatives and Programmes 2017. 9th Meeting of the ASEAN Multisector Road Safety Special Working Group, Bangkok, Thailand.

The International Transport Forum. (2008). TOWARDS ZERO: Ambitious Road Safety Targets and the Safe System Approach. OECD Publishing, Paris.

The International Transport Forum. (2016). Zero Road Deaths and Serious Injuries: Leading a Paradigm Shift to a Safe System. OECD Publishing, Paris. http://doi.org/10.1787/9789282108055-en

The Republic of Indonesia. (2011). Indonesia National Road Safety Master Plan 2011-2035.

US National Highway Traffic Safety Administration. (2013). The Detection of DWI Motorcyclists.

US National Highway Traffic Safety Administration. (2015). Instructor Guide: DWI Detection and Standardized Field Sobriety Testing. 
Wang, M. (2014). Principles for Developing Traffic Control Devices for Mixed Traffic Flow with Numerous Motor Scooters. Transportation Research Board 93rd Annual Meeting. January 12-16, Washington, D.C.

Wegman, F., Segui-Gomez, M., Wong, S. V., \& Watson, B. (2017). Road Safety in Myanmar. Recommendations of an Expert Mission invited by the Government of Myanmar and supported by the Suu Foundation. Paris, FIA.

World Health Organization. (2011). Global plan for the Decade of Action for Road Safety 20112020. World Health Organization. Retrieved from http://www.who.int/roadsafety/decade_of_action/plan/plan_english.pdf

World Health Organization. (2013). Global Status Report on Road Safety. Retrieved from http://www.who.int/violence_injury_prevention/road_safety_status/2013/en/\%5Cnhttp:// www.who.int/violence_injury_prevention/road_safety_status/2015/en/

World Health Organization. (2015). Global Status Report on Road Safety. Retrieved from $\mathrm{http}: / / w w w . w h o . i n t / v i o l e n c e$ injury_prevention/road_safety_status/2015/en/

World Health Organization. (2016). Alcohol Control Policies. Retrieved from http://apps.who.int/gho/data/node.main.A1146?lang=en

World Health Organization. (2018). National plans for the Decade of Action for Road Safety 2011-2020. Retrieved from http://www.who.int/roadsafety/decade_of_action/plan/national/en/

Yang, C. J. (2010). Launching strategy for electric vehicles: Lessons from China and Taiwan. Technological Forecasting and Social Change, 77(5), 831-834. http://doi.org/10.1016/j.techfore.2010.01.010

Yang, J., Liu, Y., Qin, P., \& Liu, A. A. (2014). A review of Beijing's vehicle registration lottery: Short-term effects on vehicle growth and fuel consumption. Energy Policy, 75, 157-166. http://doi.org/10.1016/j.enpol.2014.05.055

Yeh, T.-H. (2012). Changes in Traffic Safety Policies and Regulations in Taiwan (1950-2010). International Association of Traffic and Safety Sciences.

Zhang, Y., \& Wu, C. (2013). The effects of sunshields on red light running behavior of cyclists and electric bike riders. Accident Analysis and Prevention, 52, 210-218. http://doi.org/10.1016/j.aap.2012.12.032

Zhou, D., Xu, C., Wang, D.-H., \& Sheng, J. (2015). Estimating Capacity of Bicycle Path on Urban Roads in Hangzhou, China. 94th Annual Meeting of the Transportation Research Board, 856, 18p. Retrieved from http://docs.trb.org/prp/15-1693.pdf 